Prepared in cooperation with the

Tennessee Department of Environment and Conservation

\title{
Streamflow-Characteristic Estimation Methods for Unregulated Streams of Tennessee
}

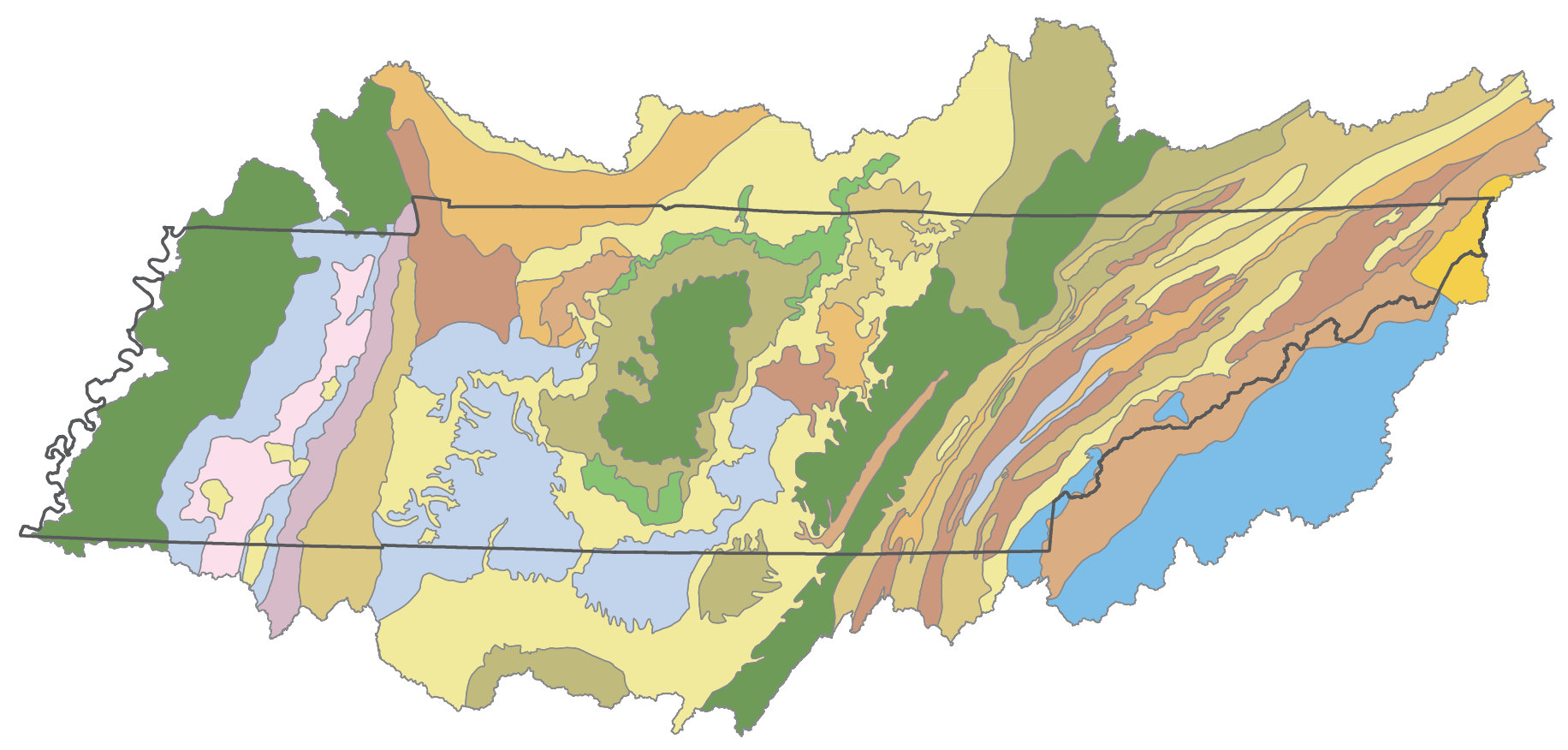

Scientific Investigations Report 2009-5159 


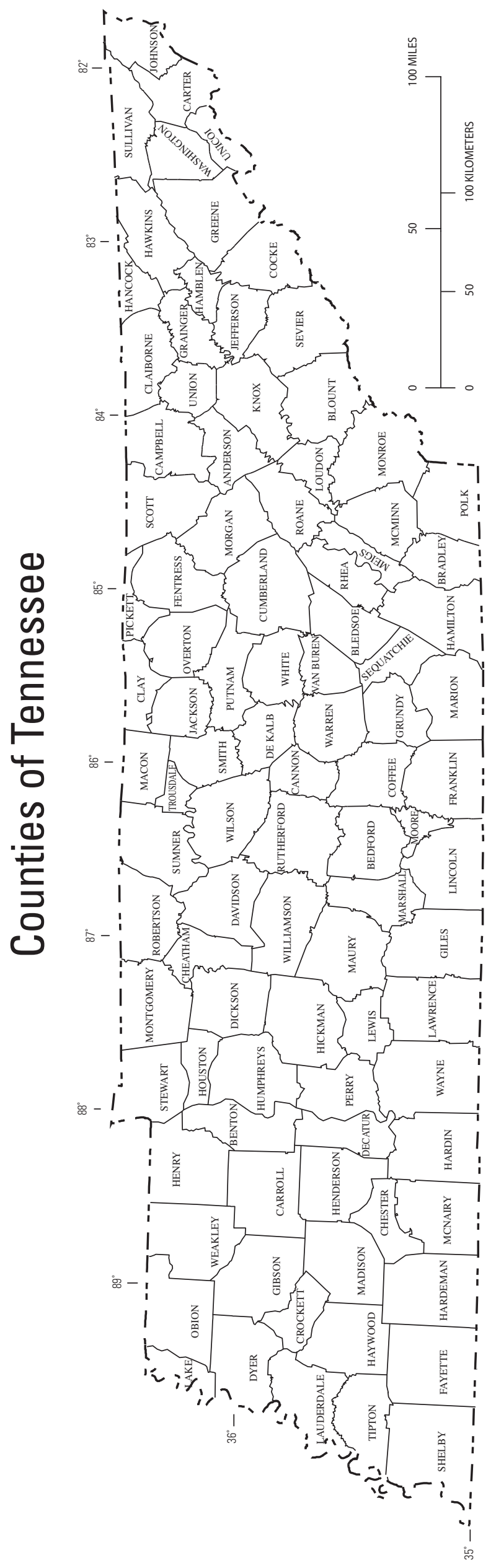

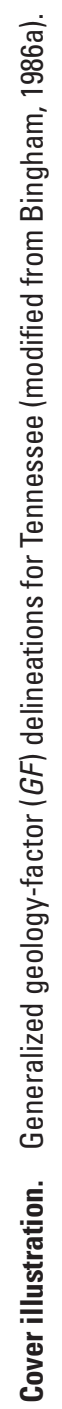




\section{Streamflow-Characteristic Estimation Methods for Unregulated Streams of Tennessee}

By George S. Law, Gary D. Tasker, and David E. Ladd

Prepared in cooperation with the

Tennessee Department of Environment and Conservation

Scientific Investigations Report 2009-5159 


\title{
U.S. Department of the Interior \\ KEN SALAZAR, Secretary \\ U.S. Geological Survey \\ Marcia K. McNutt, Director
}

\section{U.S. Geological Survey, Reston, Virginia: 2009}

\author{
For more information on the USGS — the Federal source for science about the Earth, its natural and living resources, \\ natural hazards, and the environment, visit http://www.usgs.gov or call 1-888-ASK-USGS \\ For an overview of USGS information products, including maps, imagery, and publications, \\ visit http://www.usgs.gov/pubprod \\ To order this and other USGS information products, visit http://store.usgs.gov
}

Any use of trade, product, or firm names is for descriptive purposes only and does not imply endorsement by the U.S. Government.

Although this report is in the public domain, permission must be secured from the individual copyright owners to reproduce any copyrighted materials contained within this report.

Suggested citation:

Law, G.S., Tasker, G.D., and Ladd, D.E., 2009, Streamflow-characteristic estimation methods for unregulated streams of Tennessee: U.S. Geological Survey Scientific Investigations Report 2009-5159, 212 p., 1 pl. 


\section{Acknowledgments}

The authors gratefully acknowledge the assistance and support of Dr. Sherry Wang of TDEC.

The authors gratefully acknowledge the work of the National StreamStats implementation team of the USGS. Finally, the authors thank the many hydrologic technicians of the USGS who collected and processed most of the streamflow data used in this investigation. 


\section{Contents}

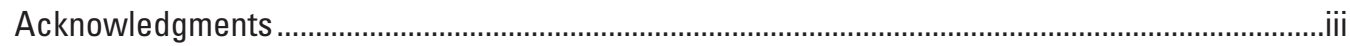

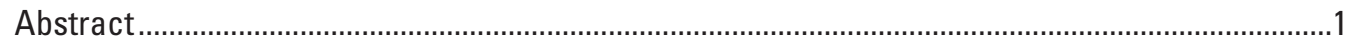

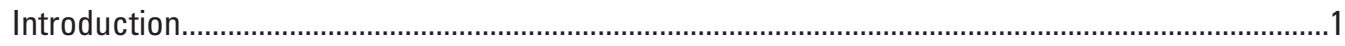

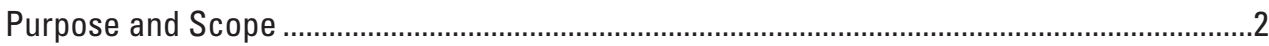

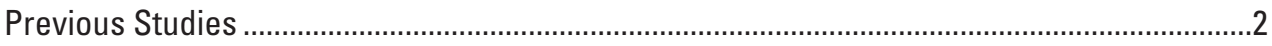

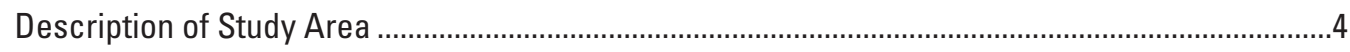

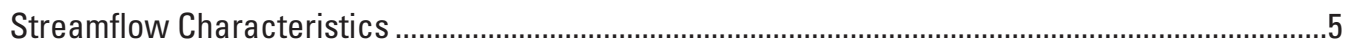

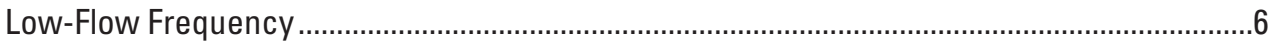

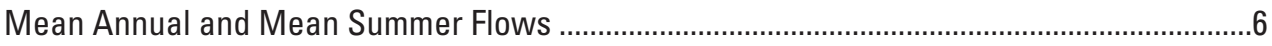

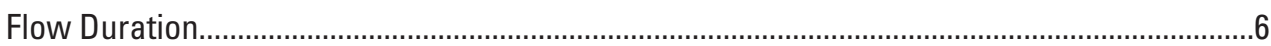

Zero Flows

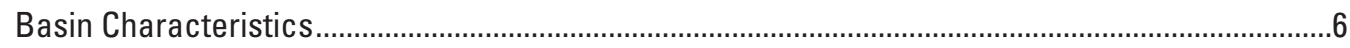

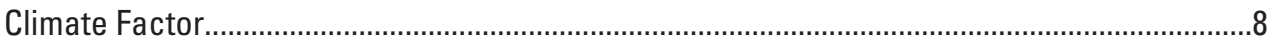

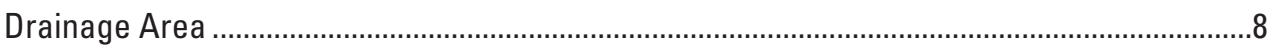

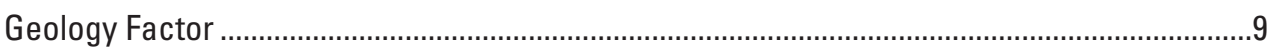

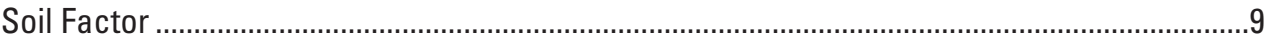

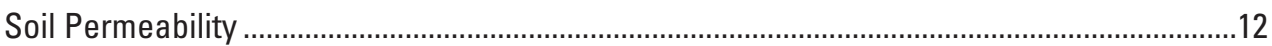

Development of Streamflow-Characteristic Datasets ..................................................................12

Continuous-Record Sites................................................................................................. 12

Low-Flow Partial-Record Sites............................................................................................ 12

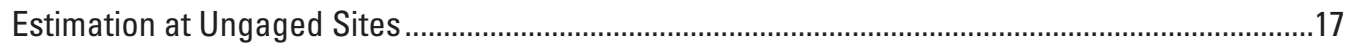

Zero Flow Estimation ........................................................................................................... 17

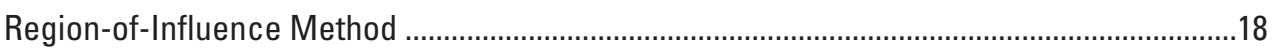

Regional Regression Equations...................................................................................................19

Comparison of Estimation by Different Methods...............................................................................21

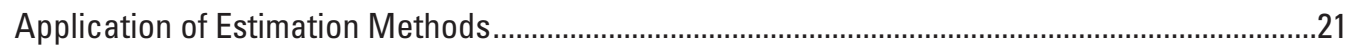

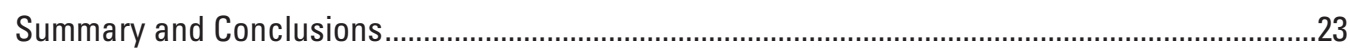

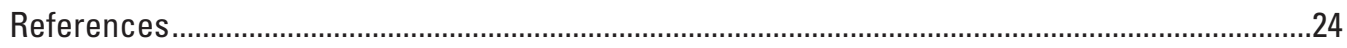

Appendix A. Basin and Streamflow Characteristics for Sites in This Report...............................31

Appendix B. Instructions for Use of the Stand-Alone Version of the Low-Flow Frequency and Flow-Duration Computer Program (TDECv301) for Tennessee ...................................................................................................201

Appendix C. Description of Output From the Stand-Alone Version of the Low-Flow Frequency and Flow-Duration Computer Program (TDECv301) for Tennessee 


\section{Plate}

[In pocket]

1. Generalized distribution of the geology factor in the study area and locations of streamflow-gaging sites with zero-flow and nonzero-flow characteristics, Tennessee and parts of Kentucky, Virginia, North Carolina, Georgia, Alabama, and Mississippi.

\section{Figures}

1-2. Maps showing-

1. Streamflow-characteristic study area, regions, and streamflow-gaging sites, Tennessee and parts of Kentucky, Virginia, North Carolina, Georgia, Alabama, and Mississippi.

2. Generalized physiographic regions of Tennessee

3. Conceptual model of the relation of streamflow in a watershed

with climate, drainage area, geology, and soil characteristics.

4. Map showing the 2-year recurrence-interval climate factor ...........................................

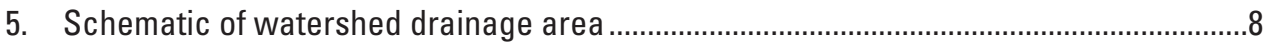

6-8. Maps showing-

6. Generalized distribution of the geology factor for Tennessee and parts of Georgia, North Carolina, Alabama, Virginia, Kentucky, and Mississippi.

7. Generalized distribution of the soil factor for Tennessee and parts of Georgia, North Carolina, Alabama, Virginia, Kentucky, and Mississippi.

8. Generalized distribution of soil permeability for Tennessee and parts of Georgia, North Carolina, Alabama, Virginia, Kentucky, and Mississippi.

9. Output from computation of 7-day low-flow frequency estimates at a continuous-record gage using U.S. Geological Survey program SWSTAT

10. Output from computation of flow duration at a continuous-record gage using U.S. Geological Survey program SWSTAT

11. Graphs showing correlation of streamflow between a long-term gage and a low-flow partial-record site where the geology factor is greater at the low-flow partial-record site, and the geology factor is greater at the long-term gage

C1. Location of stations in the region-of-influence for the West-region example given in table $\mathrm{C} 1$

C2. Location of stations in the region-of-influence for the Central+East region example given in table $\mathrm{C} 2$ 


\section{Tables}

1. Descriptions of relevant streamflow characteristics for streams in Tennessee...............5

2. Basin characteristics describing physical and climatic attributes of watersheds...........7

3. Mean standard-deviation estimation equations for mean annual flow, mean summer flow, and flow durations at short-term gages and low-flow partial-record sites.

4. Regional regression equations for the West region of Tennessee ..................................20

5. Regional regression equations for the Central+East region of Tennessee .....................20

6. Deleted-residual standard errors for the region-of-influence method and regional regression equations applied to the West region and Central+East region of Tennessee.

7. Suggested and required regional ranges for basin characteristic inputs to the low-flow frequency and flow-duration computer program for Tennessee

A1. Basin and streamflow characteristics for 196 continuous-record gaging stations in Tennessee.

A2. Basin and streamflow characteristics for 870 low-flow partial-record and short-term gaging stations in Tennessee

A3. Basin and streamflow characteristics for 158 continuous-record gaging stations in adjacent states.

C1. Low-flow frequency and flow-duration estimates for a West region site .204

C2. Low-flow frequency and flow-duration estimates for a Central+East region site.

\section{Conversion Factors and Datums}

\begin{tabular}{lcl}
\hline \multicolumn{1}{c}{ Multiply } & \multicolumn{1}{c}{ By } & \multicolumn{1}{c}{ To obtain } \\
\hline inch (in.) & Length & \\
foot (ft) & 25.4 & millimeter $(\mathrm{mm})$ \\
mile (mi) & 0.3048 & meter $(\mathrm{m})$ \\
\hline & 1.609 & kilometer $(\mathrm{km})$ \\
\hline square mile $\left(\mathrm{mi}^{2}\right)$ & Area & \\
\hline & 2.590 & square kilometer $\left(\mathrm{km}^{2}\right)$ \\
\hline cubic foot per second $\left(\mathrm{ft}^{3} / \mathrm{s}\right)$ & Flow rate & \\
million gallons per day $(\mathrm{Mgal} / \mathrm{d})$ & 0.02832 & cubic meter per second $\left(\mathrm{m}^{3} / \mathrm{s}\right)$ \\
inch per hour $(\mathrm{in} / \mathrm{h})$ & 0.04381 & cubic meter per second $\left(\mathrm{m}^{3} / \mathrm{s}\right)$ \\
inch per year $(\mathrm{in} / \mathrm{yr})$ & 0.0254 & meter per hour $(\mathrm{m} / \mathrm{h})$ \\
\hline
\end{tabular}

Temperature in degrees Fahrenheit $\left({ }^{\circ} \mathrm{F}\right)$ may be converted to degrees Celsius $\left({ }^{\circ} \mathrm{C}\right)$ as follows:

$$
{ }^{\circ} \mathrm{C}=\left({ }^{\circ} \mathrm{F}-32\right) / 1.8
$$

Vertical coordinate information is referenced to the National Geodetic Vertical Datum of 1929 (NGVD 29).

Horizontal coordinate information is referenced to the North American Datum of 1927 (NAD 27).

Elevation, as used in this report, refers to the distance above the vertical datum. 


\section{Selected Abbreviations}

CF Climate factor having a 2-year recurrence interval, dimensionless

$D A \quad$ Drainage area in square miles, includes noncontributing areas in a watershed

DEM Digital elevation model

EY Equivalent years of record for a regression estimate

GF Geology factor in days per log-cycle of declining baseflow, a watershed-weighted value

GIS Geographic information system

GIS.CF GIS-computed climate factor having a 2-year recurrence interval, dimensionless

GIS.DA GIS-computed drainage area in square miles, includes noncontributing areas

GIS.GF GIS-computed geology factor in days per log-cycle of declining baseflow, a watershedweighted value

GIS.SF GIS-computed soil factor, percentage of area underlain by a soil permeability greater than or equal to 2 inches per hour

GIS.SP GIS-computed soil permeability in inches per hour, a watershed-weighted value

LAT Latitude

LFPR Low-flow partial-record site

LNG Longitude

LT GAGE Long-term continuous-record gage used in low-flow partial-record site correlation

MA Mean annual streamflow, October through September

MNO Map number of gaged site on Plate 1

MS Mean summer streamflow, June through August

NED National Elevation Dataset

NHD National Hydrography Dataset

NRCS U.S. Department of Agriculture, Natural Resources Conservation Service

PRESS Prediction-error sum of squares

QM Instantaneous-discharge measurement

ROI Region-of-influence

RRE Regional regression

SF Soil factor, percentage of area underlain by a soil permeability greater than or equal to 2 inches per hour

$S P \quad$ Soil permeability in inches per hour, a watershed-weighted value

STANAM Station name of a gaged site

STANO Station number of a gaged site

STATSGO State Soil Geographic data base

TDEC Tennessee Department of Environment and Conservation

TDOT Tennessee Department of Transportation

USGS U.S. Geological Survey

YR Years of streamflow record

$7010 \quad$ Lowest 7-day average flow with a 10-percent probability of occurring in any given year

3005 Lowest 30-day average flow with a 20-percent probability of occurring in any given year 


\title{
Streamflow-Characteristic Estimation Methods for Unregulated Streams of Tennessee
}

\author{
By George S. Law, Gary D. Tasker, and David E. Ladd
}

\section{Abstract}

Streamflow-characteristic estimation methods for unregulated rivers and streams of Tennessee were developed by the U.S. Geological Survey in cooperation with the Tennessee Department of Environment and Conservation. Streamflow estimates are provided for 1,224 stream sites. Streamflow characteristics include the 7-consecutive-day, 10-year recurrence-interval low flow, the 30-consecutive-day, 5 -year recurrence-interval low flow, the mean annual and mean summer flows, and the 99.5-, 99-, 98-, 95-, 90-, 80-, 70-, 60-, 50-, 40-, 30-, 20-, and 10-percent flow durations. Estimation methods include regional regression (RRE) equations and the region-of-influence (ROI) method. Both methods use zero-flow probability screening to estimate zero-flow quantiles. A low flow and flow duration (LFFD) computer program (TDECv301) performs zero-flow screening and calculation of nonzero-streamflow characteristics using the RRE equations and ROI method and provides quality measures including the 90-percent prediction interval and equivalent years of record. The U.S. Geological Survey StreamStats geographic information system automates the calculation of basin characteristics and streamflow characteristics. In addition, basin characteristics can be manually input to the stand-alone version of the computer program (TDECv301) to calculate streamflow characteristics in Tennessee.

The RRE equations were computed using multivariable regression analysis. The two regions used for this study, the western part of the State (West) and the central and eastern part of the State (Central+East), are separated by the Tennessee River as it flows south to north from Hardin County to Stewart County. The West region uses data from 124 of the 1,224 streamflow sites, and the Central+East region uses data from 893 of the 1,224 streamflow sites. The study area also includes parts of the adjacent States of Georgia, North Carolina, Virginia, Alabama, Kentucky, and Mississippi. Total drainage area, a geology factor, a climate factor, and two soil factors were used as explanatory variables in the RRE equations. Average deleted-residual prediction errors for the West-region RRE equations were 18 and 123 percent for the 10-percent flow duration and 7-consecutive-day, 10 -year recurrence-interval low flow, respectively. Average deleted-residual prediction errors for RRE equations were 21 and 89 percent for the same respective flow quantiles in the Central+East region.
The ROI method calculates unique multivariable regression equations for a site of interest using the flow and basin characteristics of 45 similar streamflow-data sites selected from the same region. These 45 sites are selected using a metric that measures similarity between the site of interest and the streamflow-data sites based on total drainage area, geology factor, and climate factor. The ROI method estimates streamflow characteristics using total drainage area, geology factor, and a soil factor as explanatory variables.

Average deleted-residual prediction errors for the West-region ROI equations were 18 and 125 percent for the 10-percent duration and 7-consecutive-day, 10-year recurrence-interval low flow, respectively. Average deletedresidual prediction errors for ROI equations were 20 and 85 percent for the same respective flow quantiles in the Central+East region. In general, when compared to the RRE equations, the ROI method performs similarly in the West region and reduces streamflow-characteristic prediction errors by an average of about 7 percent in the Central+East region of Tennessee.

\section{Introduction}

Rivers and streams are the primary sources of drinking water and receptors for wastewater for citizens, businesses, and industries in the State of Tennessee. Improvement, protection, and sustainability of the flow and quality of these water resources are essential for the health of the people and environment of Tennessee.

Scientists, engineers, and water-resource managers rely on accurate and up-to-date streamflow data and estimates to characterize the natural flow of rivers and streams. Streamflow characteristics including low-flow frequencies, mean annual and mean summer flows, flow-duration characteristics of rivers and streams, and others are used in the design and maintenance of water-related structures and the study and protection of aquatic environments and ecosystems (U.S. Department of Agriculture, Forest Service, 2000; U.S. Department of Agriculture, Natural Resources Conservation Service, 2001; Tennessee Valley Authority, 2004; U.S. Fish and Wildlife Service, 2005; Association of Fish and Wildlife Agencies, 2006; National Park Service, 2006; U.S. Army Corps of Engineers, 2008, 2009). Water-quality management plans and regulatory programs need effective techniques for estimating streamflow characteristics to protect the public interest (Cleland, 2007; U.S. Environmental Protection Agency, 2008). 
Estimates of low streamflow characteristics at ungaged sites are susceptible to error because of their dependence on geology and evapotranspiration, which are difficult to describe by indices (Riggs, 1972). One persistant source of error has been the variability in precision among cartographic data sources and the difficulty of reconciling data collected at a variety of scales. Advances in computer technology, geographic information systems, and regression techniques, however, provide new means to investigate more accurate methods for statewide regionalization of low-flow characteristics at ungaged sites (Ries and others, 2004, 2007).

The U.S. Geological Survey (USGS), in cooperation with the Tennessee Department of Environment and Conservation (TDEC), assembled a low-flow frequency and flow-duration (LFFD) dataset from partial record and continuous gaging sites and developed a computer program that uses the regionof-influence (ROI) method and regional regression (RRE) equations to estimate low-flow frequencies, mean annual and mean summer flow, and flow-duration characteristics for unregulated rivers and streams in Tennessee. The overall dataset includes statistics from 1,224 stream sites, of which 1,017 sites were included in the computational program (TDECv301).

All of the 1,224 stream sites presented in Appendix A are located in rural to lightly developed areas of Tennessee and the adjacent States of Georgia, North Carolina, Virginia, Alabama, Kentucky, and Mississippi (fig. 1). Hydrologic data were collected at these sites by many Federal, State, and local government agencies including the USGS, National Park Service, U.S. Army Corps of Engineers, Tennessee Valley Authority, U.S. Forest Service, National Weather Service, TDEC, Tennessee Department of Transportation, Metropolitan Government of Nashville and Davidson County, cities of Memphis, Knoxville, Chattanooga, and others.

\section{Purpose and Scope}

This report provides basin and streamflow characteristics for 1,224 gaged sites in watersheds contributing to streams in Tennessee and documents an automated computer program that estimates streamflow characteristics for unregulated rivers and streams in Tennessee based on data from many of these sites. The program estimates nonzero streamflow characteristics using both the ROI method and an updated version of the previously published RRE method. Results of the two methods and their relative accuracy are compared. The computational algorithms used in this program deal with zero-flow characteristics using logistic-probability screening (Tasker, 1989).

Though the data included in this analysis are drawn from watersheds in other states, the estimation methods and equations presented in this report were developed explicitly for streams in Tennessee and have only been validated for Tennessee streams. Statistics for the 158 gaging stations located in other surrounding states were used solely to supplement the data available for watersheds that cross state boundaries.
Estimates of streamflow characteristics for streams located outside of Tennessee may differ from other published information for those states and should be used with caution. Complimentary estimates for other States can best be obtained from the following reports: Alabama (Atkins and Pearman, 1994), Georgia (Carter and Putnam, 1978; Carter and Fanning, 1982), North Carolina (Giese and Mason, 1991), Virginia (Hayes, 1991; Nelms and others, 1997), Kentucky (Ruhl and Martin, 1991; Martin and Ruhl, 1993; Ruhl and others, 1995; Martin, 2002), and Mississippi (Telis, 1991, 1992).

\section{Previous Studies}

Eaton (1958) computed low-flow and flow-duration statistics at 125 continuous-record streamgages using data collected through 1956. Wood and Johnson (1965) analyzed flow-duration and various consecutive-day mean-discharge characteristics for 190 continuous-record streamgages using data collected through 1960. May and others (1970) developed multivariable ordinary-least-squares estimation equations for various low-flow, high-flow, and runoff-volume characteristics at ungaged sites in Tennessee, based on data collected from 167 streamgages through the late 1960s. During this period, the Tennessee Valley Authority conducted research to correlate hydrologic conditions in watersheds with physical characteristics using factor analysis (Tennessee Valley Authority, 1965a, 1965b).

Gold (1981) produced a comprehensive report of flowduration and low-flow statistics for 204 continuous-record stations and 651 low-flow partial-record stations using data collected through 1975. Bingham (1985) updated the work of Gold (1981) by analyzing data collected through 1981 at 201 continuous-record stations and 769 low-flow partialrecord sites. Bingham (1986a, 1986b) performed two regional regression analyses using data compiled in the previously published low-flow report (Bingham, 1985) and presented two sets of regionalized low-flow equations. One set of equations applied to streams located west of the Tennessee River in the western part of the State and the other set of equations to areas east of the Tennessee River. A limitation of Bingham's regression method was the lack of a zero-streamflow characteristic testing process; consequently, Bingham's equations commonly overpredict low-flow frequencies for streams with a high probability of zero flow. Bingham (1986b) developed regression equations for estimating winter (December-April) low-flow characteristics in Tennessee.

Wetzel and Bettandorff (1986) presented techniques for estimating streamflow characteristics in the Eastern and Interior Coal Provinces, which include parts of Kentucky, Virginia, Tennessee, and Alabama. Lowery and Connell (1990) documented the regional drought that occurred across large areas of Tennessee during the period 1986-88. Their report presented discharge measurements made at more than 250 sites across the State during the summer of 1988. Many of those measurements represented low-flow conditions with a 20 -year recurrence interval. 


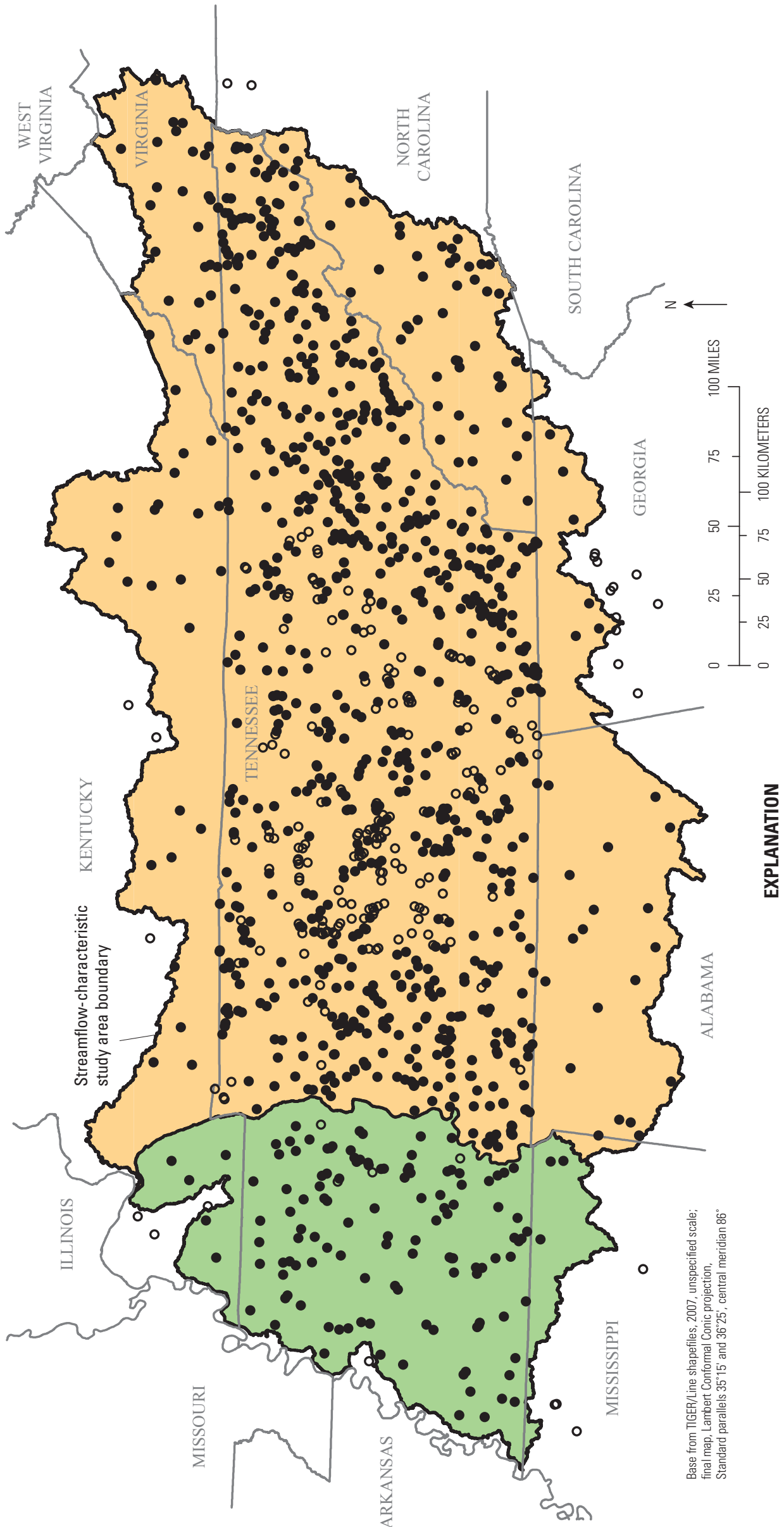


Outlaw and Weaver (1996) presented estimates of flowduration and low-flow characteristics for 215 continuousrecord and 1,216 low-flow partial-record stations in Tennessee using data collected through 1992. This study was an update of Bingham's (1985) report using low-flow estimation methods developed by Bingham (1986a, 1986b) or Wetzel and Bettandorff (1986).

\section{Description of Study Area}

The physiography of Tennessee can be represented by a transect from the Mississippi River alluvial plain to the crest of the Blue Ridge. The topography of West Tennessee includes periodically flooded valley bottoms, an extensive loess (wind-deposited silt) plateau, and deeply gullied sand hills (Fenneman, 1938, 1946; Miller, 1974; Luther, 1977). Middle Tennessee lies primarily within the Interior Low Plateau physiographic province and includes the sinkhole plains of the Nashville Basin and the rolling to dissected uplands of the Highland Rim (Fenneman, 1938, 1946). East Tennessee includes the nearly flat Cumberland Plateau, incised at its margins by numerous coves and gorges, the aptly named Valley and Ridge physiographic province, and Tennessee's highest mountains, the Unaka Range of the Blue Ridge physiographic province (fig. 2) (Fenneman, 1938, 1947; U.S. Geological Survey, 1970; Miller, 1974; Luther, 1977). Land-surface elevations in Tennessee range from about 250 feet (ft) above NGVD 29 along the Mississippi River in West Tennessee to more than $6,600 \mathrm{ft}$ in the Unaka Range.

The generalized geology of Tennessee can be described by the dominant stratigraphy and structure in the physiographic regions (Wilson, 1981). The geology of the Mississippi River Valley region is dominated by alluvial deposits of sand, silt, clay, and gravel. The Coastal Plain region is characterized by unconsolidated beds of loess, silt, clay, sand, gravel, and alluvial deposits along the major river valleys. The geology of the Western Valley region includes alluvial deposits of sand, silt, clay, and gravel on the valley floor. The adjacent uplands and ridges consist of sands and clays underlain by limestone and shale.

The geology of the Highland Rim and Central Basin physiographic regions is dominated by gently dipping beds of limestone, interbedded with minor formations of dolomite, shale, and chert, with heterogeneous alluvium along major rivers and valley floors (Wilson, 1981). The Cumberland Plateau physiographic region is a tableland, on average about 500 to $1,000 \mathrm{ft}$ higher than adjacent regions, capped by layered sandstone, shale, and conglomerate. The Sequatchie Valley physiographic region consists of a 1,000-ft deep, 4-mile (mi) wide valley where the Sequatchie River has cut through the Cumberland Plateau caprock into the underlying limestone.

The Valley and Ridge physiographic region in Tennessee is a 30- to 100-mi-wide region of elongated ridges and intervening valleys trending in a northeast-southwest direction. Geology of the region is characterized by folded and fractured beds of limestone, shale, and sandstone. Folding and fracturing that occurred 230 to 260 million years ago resulted in the northeast-southwest orientation of ridges and intervening valleys (K.E. Smith, Middle Tennessee State University, written commun., 1993). The Blue Ridge, or Unaka Range, physiographic region of East Tennessee includes the mountain ranges, valleys, and coves of the Cherokee National Forest and the Great Smoky Mountains National Park. Geology of the northern part of the region is characterized by limestone, dolomites, and shale with exposures of igneous and metamorphic rocks such as tuff, rhyolite, granite, schist, and quartzite. The mountains to the south are mainly composed of sedimentary and metamorphic rocks, including sandstone, conglomerate, arkose, and siltstone (Wilson, 1981).

The climate of Tennessee is humid subtropical. The average annual temperature for Tennessee is about 57 degrees Fahrenheit $\left({ }^{\circ} \mathrm{F}\right)$, ranging from $63^{\circ} \mathrm{F}$ in Memphis to $43^{\circ} \mathrm{F}$ in the mountains of East Tennessee (National Oceanic and Atmospheric Administration, 2006). Normal monthly mean

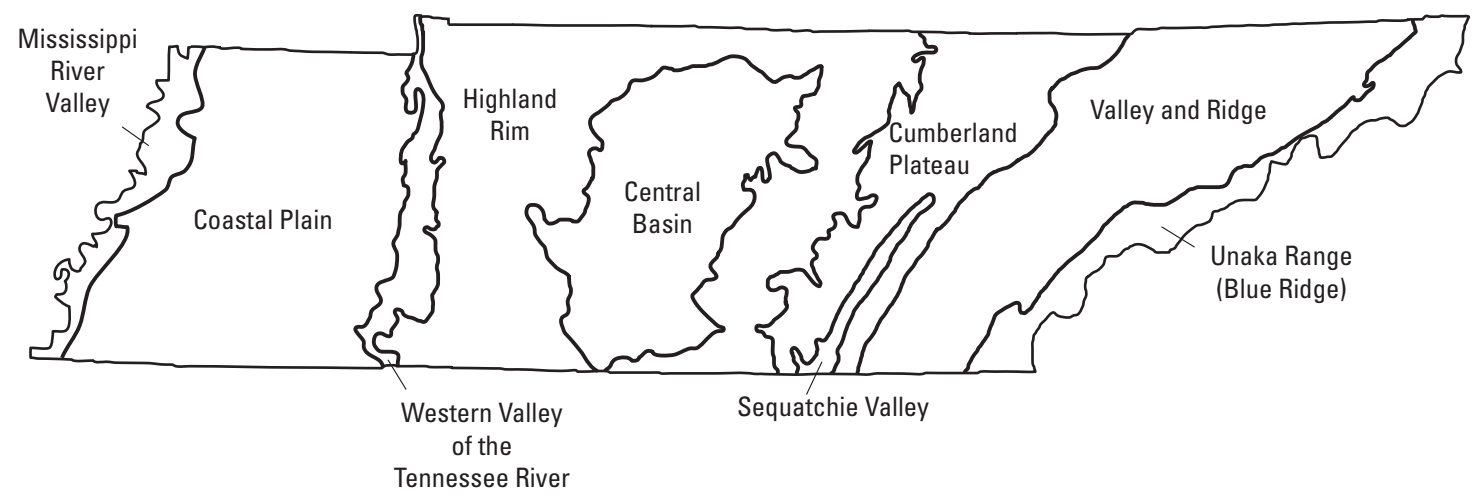

Figure 2. Generalized physiographic regions of Tennessee (modified from Fenneman, 1938, 1946; U.S. Geological Survey, 1970; Miller, 1974; and Luther, 1977). 
temperatures range from January lows of 40 to $27^{\circ} \mathrm{F}$ to July highs of 83 to $59^{\circ} \mathrm{F}$ in Memphis and the mountains of East Tennessee, respectively. Rainfall is plentiful across the State. The average annual rainfall amount for Tennessee is about 52 inches (in.) (National Oceanic and Atmospheric Administration, 2006). Annual rainfall amounts vary across the State from about 40 in. to about 80 in. (Daly, 2000). Most of Tennessee receives average annual rainfall of 50 in. to 60 in. Rainfall minima for the State occur in the northern part of the Valley and Ridge and Blue Ridge physiographic regions where average annual rainfall is about 45 in. Maxima for the State occur on the highest parts of the Cumberland Plateau and along the foothills and peaks of the Unaka Mountains where average annual rainfall totals range from 60 to 80 in.

Typically, the low-flow season in Tennessee occurs from late summer through fall. The months with the lowest flow are usually September and October (U.S. Geological Survey, 1986). Rivers and streams in the Coastal Plain physiographic region generally have sustained baseflows during dry periods whereas those on the Cumberland Plateau commonly go dry. Many streams in the Central Basin physiographic region also go dry during long periods of little or no rainfall. Streams in the Highland Rim, Valley and Ridge, and Blue Ridge physiographic regions have sustained baseflows that vary between these extremes (Tennessee Department of Conservation and Commerce, 1961; Alexander and others, 1984). Average annual runoff for Tennessee varies from approximately $18 \mathrm{in.}$ to 40 in. (U.S. Geological Survey, 1986) and evapotranspiration averages about 30 inches per year (in/yr) (Tennessee Department of Conservation and Commerce, 1961).

\section{Streamflow Characteristics}

Unregulated rivers and streams flow in predictable seasonal patterns. Free-flowing rivers and streams in Tennessee typically have their highest flows in winter and early spring and their lowest flows in late summer and fall. Many streams in Tennessee, especially the smaller streams, go dry many times throughout the year. For rivers and streams without streamgages, natural streamflow characteristics can be estimated using streamflow recorded on nearby, hydrologically similar rivers and streams as the dependent or response variable and basin characteristics at the sites as independent or explanatory variables (Riggs, 1973). The most commonly used basin characteristics for estimating low flows and flow durations are watershed drainage area and geology. Other commonly used basin characteristics include those describing watershed climate and soils.

The streamflow characteristics presented in this report are flow rates, typically given in cubic feet per second or million gallons per day, which are used to describe how much water can be expected in an unregulated river or stream under different conditions. These characteristics include selected low-flow frequencies, mean annual and mean summer flows, and flow durations (table 1).

Streamflow records used to compute flow characteristics at sites presented in this report represent unregulated-flow conditions free of the effects of large dams and reservoirs. Streamflow characteristics representing unregulated-flow conditions can be computed for continuous-record stations with at least 5 years of record using the ANNIE software package (Flynn and others, 1995). Streamflow characteristics representing unregulated-flow conditions for short-term continuous-record gages with less than 5 years of record and for low-flow partialrecord (LFPR) stations can be computed using graphical correlation techniques that relate the short-term or LFPR site to a nearby, hydrologically similar long-term continuous-record gaging station (Searcy, 1959, 1960; Riggs, 1972). For this study, only continuous-record gages having at least 10 years of record were used as long-term gages to transfer streamflow characteristics to a short-term or LFPR site.

Streamflow characteristics are typically needed at sites where no streamflow information is available. The usual method for obtaining these estimates is through regional regression analysis relating streamflow characteristics at many sites to basin characteristics such as drainage area, geology, climate, and soils at those sites.

Table 1. Descriptions of relevant streamflow characteristics for streams in Tennessee.

\begin{tabular}{|c|c|}
\hline $\begin{array}{l}\text { Streamflow } \\
\text { characteristic }\end{array}$ & Description \\
\hline 7Q10 & $\begin{array}{l}\text { Lowest } 7 \text {-day average flow with a 10-percent } \\
\text { probability of occurring in any given year }\end{array}$ \\
\hline 30Q5 & $\begin{array}{l}\text { Lowest } 30 \text {-day average flow with a } 20 \text {-percent } \\
\text { probability of occurring in any given year }\end{array}$ \\
\hline MA & Mean-annual streamflow, October through September \\
\hline MS & Mean-summer streamflow, June through August \\
\hline $\mathrm{q} 99.5$ & $\begin{array}{l}\text { Daily mean streamflow exceeded } 99.5 \text { percent of } \\
\text { the time }\end{array}$ \\
\hline q99 & Daily mean streamflow exceeded 99 percent of the time \\
\hline q98 & Daily mean streamflow exceeded 98 percent of the time \\
\hline q95 & Daily mean streamflow exceeded 95 percent of the time \\
\hline q90 & Daily mean streamflow exceeded 90 percent of the time \\
\hline q80 & Daily mean streamflow exceeded 80 percent of the time \\
\hline $\mathrm{q} 70$ & Daily mean streamflow exceeded 70 percent of the time \\
\hline $\mathrm{q} 60$ & Daily mean streamflow exceeded 60 percent of the time \\
\hline q50 & Daily mean streamflow exceeded 50 percent of the time \\
\hline $\mathrm{q} 40$ & Daily mean streamflow exceeded 40 percent of the time \\
\hline $\mathrm{q} 30$ & Daily mean streamflow exceeded 30 percent of the time \\
\hline $\mathrm{q} 20$ & Daily mean streamflow exceeded 20 percent of the time \\
\hline q10 & Daily mean streamflow exceeded 10 percent of the time \\
\hline
\end{tabular}




\section{Low-Flow Frequency}

Low-flow frequency characteristics of unregulated rivers and streams are used in planning and design of water supplies, analyzing environmental and economic impacts, modeling stream-water quality, regulating instream uses, and improving the general level of understanding of the natural and regulated stream systems (Tasker, 1987; Smakhtin, 2001). Low flow at a site is often characterized by an index of low flow computed using an adaptation of the log-Pearson Type III flood-frequency program described in Bulletin 17B of the Hydrology Subcommittee (Interagency Advisory Committee on Water Data, 1982) and implemented in the USGS computer program SWSTAT (Flynn and others, 1995).

The most widely used index of low flow in the United States is the 7-day, 10-year low flow (7Q10), which is the lowest average flow for 7 consecutive days that occurs on average once every 10 years (Riggs, 1980). Low-flow frequencies are applicable to a 1-year period. In addition to the 7Q10, the 30-day, 5-year low flow (30Q5) is presented in this report (table 1). Low-flow frequency calculations are based on dailymean flows from complete climatic years of record. For this report, a climatic year is defined as the 12-month period from April 1 to March 31 and is designated by the ending year.

\section{Mean Annual and Mean Summer Flows}

Mean annual and mean summer flows are useful for general planning and in water-quality models, such as the SPARROW model (Schwarz and others, 2006). Total maximum daily loading regulations for many waterbodies and water-quality constituents are based on the mean annual flow or mean summer flow. Mean annual and mean summer flows are determined by computing the mean of the individual daily mean discharges from the streamgage record for the specified period. Mean-annual flow is based on the water year from October 1 through September 30; mean summer flow is based on the period June 1 through August 31. Each of these streamflow characteristics represents the entire period of record from which it was computed.

\section{Flow Duration}

Flow-duration curves have been used for water-power studies and for preliminary investigations of water supply, location of industrial plants, water-quality and pollution studies, and many other purposes (Searcy, 1959; Studley, 2000, 2001). Flow-duration characteristics describe the cumulative distribution of daily mean discharges recorded at a streamgage and show the percentage of time each daily mean discharge was equaled or exceeded. Typically, a minimum of 5 complete water years of record is used to compute flow-duration characteristics using methods described by Searcy (1959, 1960) and Riggs (1972). Commonly used flow-duration characteristics include the 99.5-, 99-, 98-, 95-, 90-, 80-, 70-, 60-,
50-, 40-, 30-, 20-, and 10-percent exceedence values (table 1). For example, the 99.5-percent flow duration is the flow rate exceeded 99.5 percent of the time.

\section{Zero Flows}

Zero-flow observations are commonly recorded at many unregulated rivers and streams in Tennessee. These observations assist scientists and planners studying ecological characteristics of ephemeral, intermittent, and perennial streams. Ephemeral streams are usually dry and flow only during and immediately after rain events. An intermittent stream flows more often than it is dry. These streams will commonly have unconnected pools during summer and fall months. A perennial stream normally has flowing water in its channel at all times. Previous low flow and flow duration reports for Tennessee (Gold, 1981; Bingham, 1985; Outlaw and Weaver, 1996) did not incorporate zero-flow estimation. Such estimation is useful because of the importance of very low flows for water supply and environmental planning.

\section{Basin Characteristics}

Basin characteristics (table 2) for each site in appended tables $\mathrm{A} 1, \mathrm{~A} 2$, and $\mathrm{A} 3$ are quantities that describe the physical and climatic attributes of a watershed. Because differences in basin characteristics can be used to account for differences in streamflow characteristics of unregulated streams, these factors are used as explanatory variables in similar-group selection processes, streamflow-characteristic estimation equations, and hydrologic models. Automated techniques for measuring basin characteristics using remotely-sensed data have been used to improve estimates of streamflow characteristics since the early 1970s (Hollyday and Pluhowski, 1976).

The conceptual model (fig. 3) used for this study has five explanatory variables: (1) the 2-year recurrence-interval climate factor $(C F) ;(2)$ the total drainage area $(D A)$ of the watershed at the site of interest along a river or stream; (3) the area-weighted geology factor $(G F)$ that describes the rate of baseflow recession of the river or stream; (4) the percentage of area underlain by soil permeability of at least 2 inches per hour (in/hr) $(S F)$; and (5) the area-weighted average permeability of soil $(S P)$.

Manual procedures used to delineate basin characteristics are subject to interpretation of topography, geology, and soils descriptions, and often suffer from a lack of adequate information for precise positioning of the basin characteristic boundaries and should only be used if justified. Other than $D A$ and $C F$, the basin characteristics used as explanatory variables were not readily available for all of the sites used in the study. Automated geographic information system (GIS) methods were used to calculate basin characteristics for all of the sites. Although $D A$ and $C F$ values were available from previous analyses, these characteristics were recalculated using GIS 
Table 2. Basin characteristics describing physical and climatic attributes of watersheds.

[dd mm ss, degrees, minutes, seconds; $\mathrm{mi}^{2}$, square miles; in/hr, inches per hour; ---, dimensionless characteristic]

\begin{tabular}{|c|c|c|}
\hline $\begin{array}{l}\text { Basin } \\
\text { characteristic }\end{array}$ & Unit of measure & Definition \\
\hline \multicolumn{3}{|r|}{ Physical characteristics } \\
\hline$L N G$ & dd mm ss & Longitude, in degrees, minutes, and seconds, at a site of interest. \\
\hline$D A$ & $\mathrm{mi}^{2}$ & Drainage area of the watershed, includes noncontributing areas. \\
\hline$S F$ & percent & $\begin{array}{l}\text { Based on the maximum of the range of permeability within each soil horizon, the soil factor is the } \\
\text { percentage of area underlain by a soil permeability of at least } 2 \mathrm{in} / \mathrm{hr} \text {. }\end{array}$ \\
\hline$S P$ & in $/ \mathrm{hr}$ & $\begin{array}{l}\text { Area-weighted average of soil permeability, computed as a layer-thickness-weighted average across } \\
\text { component horizons, and as an area-weighted average across map unit components. }\end{array}$ \\
\hline
\end{tabular}

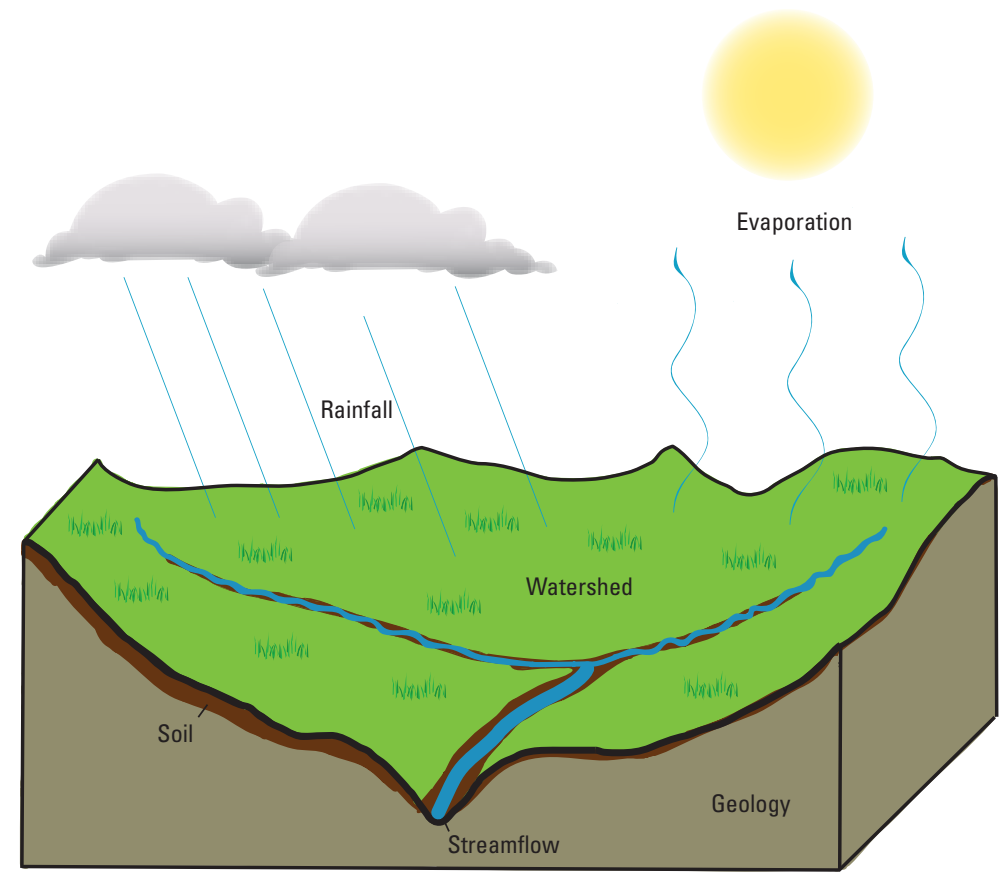

Figure 3. Conceptual model of the relation of streamflow in a watershed with climate, drainage area, geology, and soil characteristics (modified from Bingham, 1986a). 
techniques to provide a consistent method for subsequent GISbased calculations. Differences in $D A$ are shown in appended tables A1, A2, and A3 at the back of this report.

Use of GIS technology to provide streamflow statistics, basin characteristics, and other information for gaged and ungaged sites can save substantial effort and offers potentially greater precision and consistency than can be obtained by use of manual methods. The USGS, in cooperation with Environmental Systems Research Institute (ESRI), has developed a Web-enabled GIS application called StreamStats (Ries and others, 2004; Kolton and others, 2006; Ladd and Law, 2007; Ries and others, 2007), which automates the process of calculating streamflow statistics, basin characteristics, and other information for gaged and ungaged sites.

Currently, Tennessee StreamStats uses regression equations in the National Streamflow Statistics (NSS) program to calculate streamflow statistics, but it also can be used to compute the basin charactersitics for manual entry to the low-flow frequency and flow-duration computer program. Information about StreamStats and its current status is available on the World Wide Web at: http://water.usgs.gov/osw/streamstats/ ssonline.html.

\section{Climate Factor}

The primary climatic characteristics relevant to streamflow in a watershed are the intensity, duration, and amount of rainfall, as well as other meteorologic inputs that control evaporation and transpiration. Lichty and Liscum (1978) suggested the use of dimensionless regional climate factors $(\mathrm{CFs})$ for multiple recurrence intervals $(2,25$, and 100 year). The

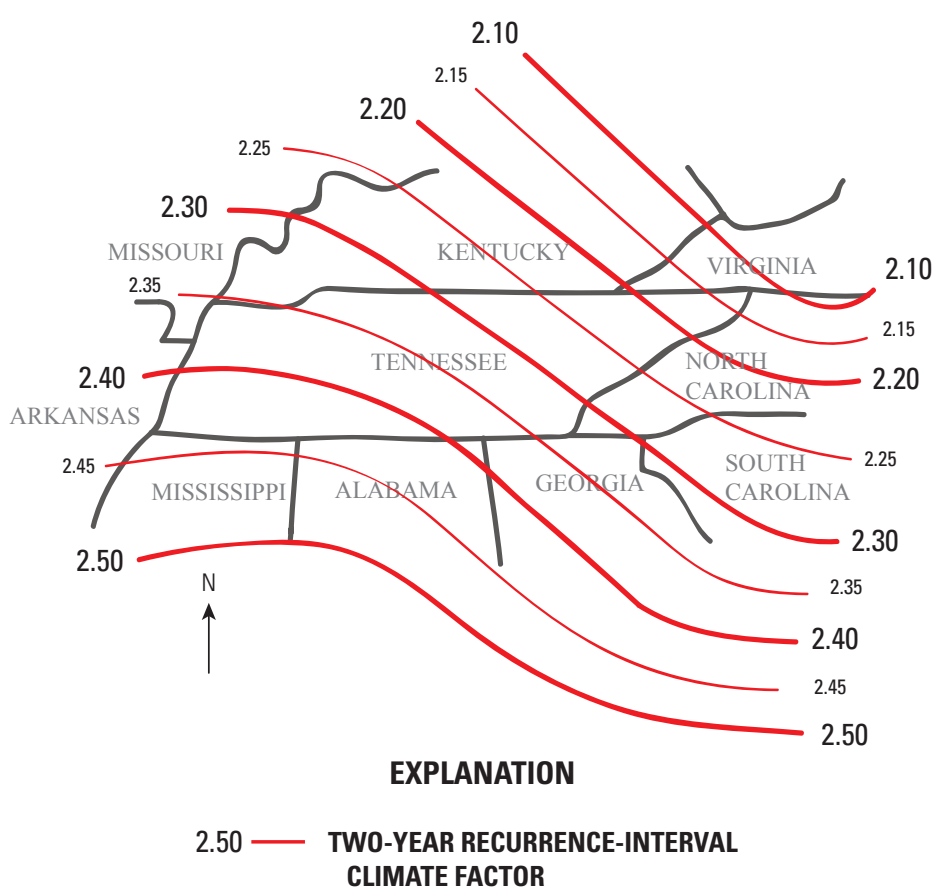

Figure 4. The 2-year recurrence-interval climate factor (modified from Lichty and Karlinger, 1990). climate factor integrates long-term rainfall and pan evaporation information and represents the effect of these climatic influences on streamflow. Point values for $C F$ were computed for 1,224 sites from isolines presented in Lichty and Karlinger (1990) (fig. 4) using a computational approach applied by Law and Tasker (2003). The point values for $C F$ were interpolated to produce a uniform grid. $C F$ values for these sites ranged from 2.307 to 2.445 for the West region and 2.056 to 2.460 for the Central+East region. Climate factors for each site presented in this study (fig. 1; plate 1) are given in appended tables $\mathrm{A} 1, \mathrm{~A} 2$, and $\mathrm{A} 3$ at the back of this report.

\section{Drainage Area}

The drainage area $(D A)$ (fig. 5) of a watershed at any given point along a river or stream is the total land area from which water drains into the river or stream above the site of interest. In the past, all drainage areas were delineated and computed using manual methods. Manually computed $D A$ values can be input to TDECv301 if justified; however, $D A$ values used in this study were computed by GIS methods incorporated in StreamStats and may differ from manually computed $D A$ values.

Tennessee's flow-duration and low-flow frequency computer program includes stream sites with drainage areas ranging from approximately 1 to $14,400 \mathrm{mi}^{2}$. $D A$ for each site used in the study was calculated using the Arc Hydro Tools extension of ArcGIS applied to the 10-meter Digital Elevation Models (DEMs) from the National Elevation Dataset (NED), the hydrologic unit code (HUC) boundary polygon feature

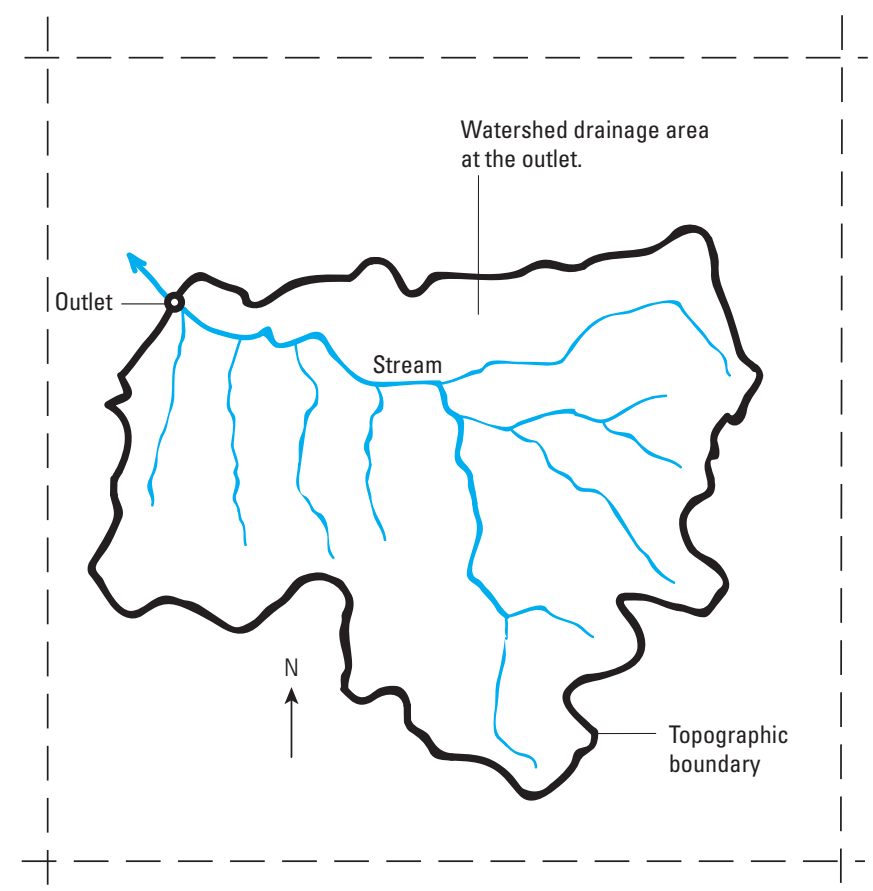

Figure 5. Schematic of watershed drainage area. 
classes (U.S. Department of Agriculture, Natural Resources Conservation Service and others, 2007), and stream-feature classes from the National Hydrography Dataset (NHD) and Tennessee Department of Transportation (TDOT). Both manually and GIS-produced drainage areas are given for each stream site for comparison to previous publications. Only the GIS-produced values, however, are used in the low-flow frequency and flow-duration dataset in this report. $D A$ values for these sites ranged from 2 to $2,405 \mathrm{mi}^{2}$ for the West region and 1.3 to $14,441 \mathrm{mi}^{2}$ for the Central+East region. Drainage areas for each stream site used in this study (fig. 1; plate 1) are given in appended tables $\mathrm{A} 1, \mathrm{~A} 2$, and $\mathrm{A} 3$ at the back of this report.

\section{Geology Factor}

Geology factor $(G F)$ is an area-weighted streamflowrecession index (Smakhtin, 2001; Konrad, 2006), in days per log cycle of declining flow (flows reduced by a factor of 10 ) at baseflow conditions, at a point of interest along a river or stream. For continuous-record gages having at least 10 years of record, a graphical computation method is used to compute $G F$. Streamflow-recession curves for each gaging station are plotted on a semilog scale (Bingham, 1986a). The baseflow recession of the hydrograph is nearly straight on a semilog plot. A large $G F$ value represents slow depletion of water from the formations and a large capacity to release water, whereas a small value represents fast depletion of water from the formations and a small capacity to release water.

$G F$ integrates effects of different geologic factors in a watershed. Bingham (1986a) gives a detailed description of the theory and development of the geology factor and generalized geology factor map. Bingham mapped geology-factor regions for Tennessee based on streamflow hydrographs, contacts between geologic formations, and the types of geologic formations at land surface. Graphically-determined $G F$ values for 109 continuous gaging stations were compared with geologic and mineral-resources maps (Hardeman and others, 1966; Tennessee Valley Authority, 1970) to delineate generalized $G F$ boundaries. Streamflow data were not available for all of the formations contributing water to streamflow within the State; however, the entire State was mapped based on the assumptions that similar types of formations contribute similar amounts of water to streamflow and that groundwater divides on the shallow aquifers correspond to topographic divides.

The updated generalized geology-factor map used for this study (fig. 6; plate 1) was based primarily on the map developed by Bingham (1986a). Published geology maps for adjacent States (Bicker, 1969 [reprint 1985]; North Carolina Geological Survey, 1985; Noger, 1988; Mancini, 1989; Virginia Division of Mineral Resources, 1993; Lawton and others, 1976 [reprint 1997]) were used to extend $G F$ regions for the updated map beyond Tennessee. $G F$ regions were refined for the updated map in a few areas of Central+East Tennessee based on additional streamflow data not used by Bingham.

For development and application of the low-flow frequency and flow-duration computer program, $G F$ is determined using GIS methods and the generalized $G F$ map (fig. 6; plate 1). The $G F$ map was scanned, georeferenced, digitized, and converted to a grid. For stream sites with watersheds that drain multiple $G F$ areas, $G F$ is determined as the area-weighted average of the sub-area $G F$ values. $G F$ values for these sites ranged from 32 to 350 days per log cycle for the West region and 32 to 175 days per log cycle for the Central+East region. $G F$ values for each site presented in this study are provided in appended tables A1, A2, and A3 at the back of this report.

\section{Soil Factor}

The soil factor $(S F)$ of a drainage basin is the percentage of area underlain by soil with a permeability of at least $2 \mathrm{in} / \mathrm{hr}$. Spatial and tabular data from the U.S. General Soil Map (U.S. Department of Agriculture, Natural Resources Conservation Service, 2006) were used to derive soil permeability values. The U.S. General Soil Map consists of georeferenced vector digital data and tabular digital data. The vector digital data are divided into map unit polygons. The tabular data include map unit subdivisions and various soil properties that can be related to the vector data. Tabular subdivisions of the map units include map unit components and map unit component horizons not shown in the vector data. The saturated hydraulic conductivity, or permeability, is reported as a range, consisting of low, representative, and high values for each component horizon.

For each component, the horizon with the lowest permeability was selected. Based on the high end of the reported permeability range, a subset of horizons with a permeability of at least $2 \mathrm{in} / \mathrm{hr}$ was selected from the set of lowest permeability horizons. Map-unit component percentages were summed for this horizon subset to calculate $S F$ for each map unit. $S F$ values for map units in the study area range from 0 to 100 percent (fig. 7). The algorithm used to calculate SF in this study is mathematically equivalent to that used by Greene and Wolfe (1998) for "restrictive permeability." The map-unit vector polygons in the study area were converted to a grid with $S F$ values, and drainage area-weighted $S F$ values were computed for each site used in the study. $S F$ values for these sites ranged from 2 to 98 percent for the West region and 2 to 100 percent for the Central+East region. $S F$ values for each site presented in this study are provided in appended tables A1, A2, and A3 at the back of this report. 


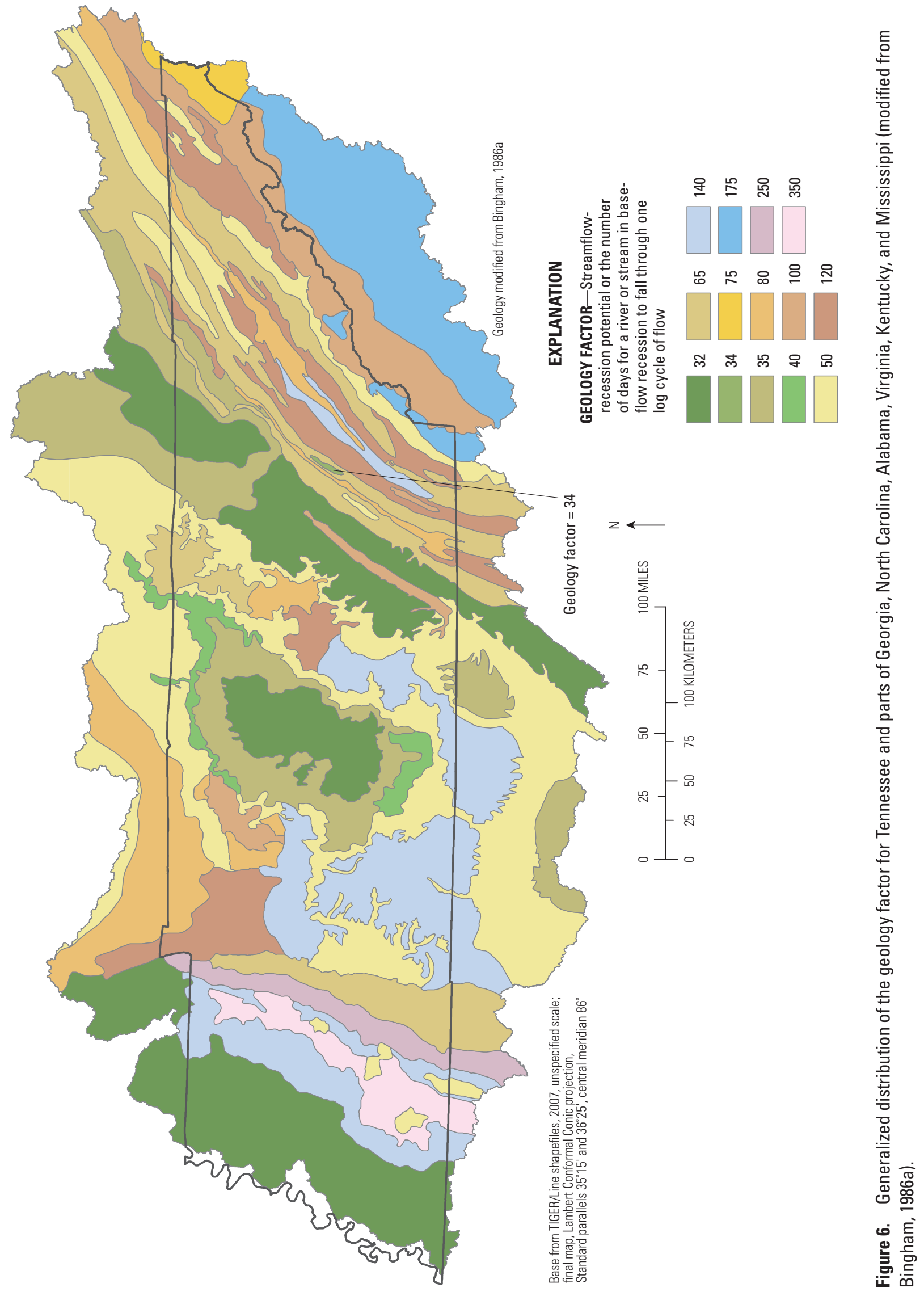




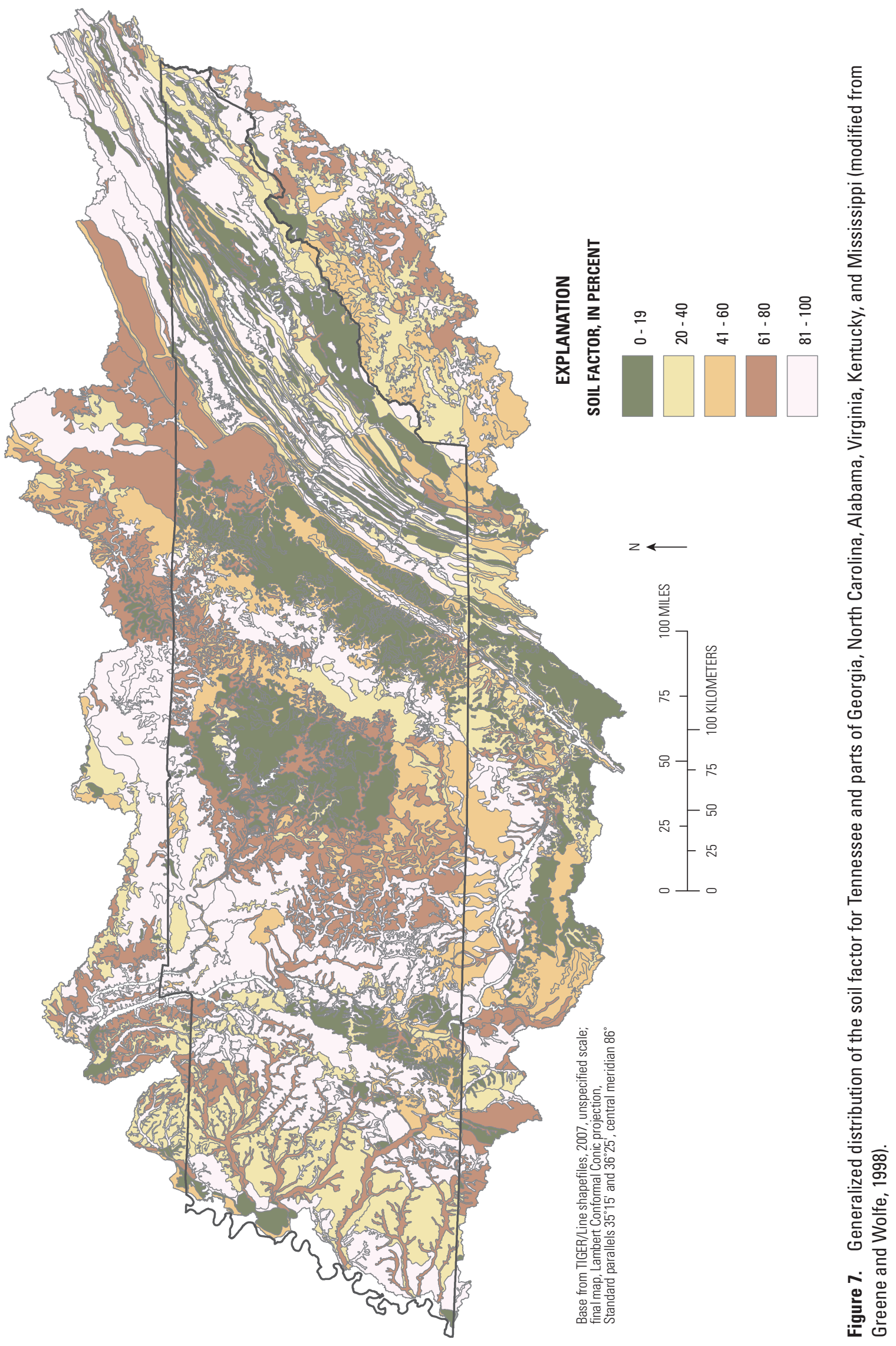




\section{Soil Permeability}

Soil permeability $(S P)$, in inches per hour, was derived from the USSOILS coverage (Schwartz and Alexander, 1995). The USSOILS coverage was developed from STATSGO data (U.S. Department of Agriculture, 1994). The USSOILS coverage includes, among other soil properties, a soil permeability value for each map unit vector polygon, which was incorporated directly into this study as $S P . S P$ was computed as a layer-thickness-weighted average across component horizons, and as an area-weighted average across map-unit components. $S P$ values for map units in the study area range from 0.15 to $9.72 \mathrm{in} / \mathrm{hr}$ (fig. 8). The map-unit vector polygons in the study area were converted to a grid with $S P$ values, and drainage area-weighted $S P$ values were computed for each site used in the study. $S P$ values for these sites ranged from 0.97 to $2.44 \mathrm{in} / \mathrm{hr}$ for the West region and 0.45 to $9.72 \mathrm{in} / \mathrm{hr}$ for the Central+East region. $S P$ values for each site presented in this study are provided in appended tables A1, A2, and A3 at the back of this report.

\section{Development of Streamflow- Characteristic Datasets}

Streamflow characteristics for unregulated rivers and streams were computed for two types of sites: (1) continuousrecord gaging stations with 5 or more years of record and (2) low-flow partial record sites (LFPR) and continuous-record sites with less than 5 years of record. At continuous-record sites with a minimum of 5 years of record, streamflow statistics were computed using standard USGS methods (Flynn and others, 1995). At LFPR and continuous-record sites with less than 5 years of record, streamflow characteristics were computed using the graphical correlation method described by Searcy $(1959,1960)$.

\section{Continuous-Record Sites}

Continuous streamflow records have been collected in the Tennessee River and Cumberland River basins since the late 1800s. Over the years, many streamflow gages were operated for a period of time and then discontinued. In this study, 354 continuous-record gaging stations with at least 5 years of record, of which 314 gages have 10 or more years of record, were identified. The median watershed area for the continuous-record gages used in this study was $125 \mathrm{mi}^{2}$. These gages are located in Tennessee and surrounding states and are listed in appended tables A1 and A3 at the back of this report. Of these sites, 196 are located in Tennessee and 158 are located in the States of Kentucky, Virginia, North Carolina, Georgia, Alabama, and Mississippi.

In general, low-flow frequency statistics at continuousrecord sites are computed using daily mean flows for all complete climatic years of record (fig. 9). Flow-duration characteristics at continuous-record gages are generally computed using daily-mean flows for all complete water years of record (fig. 10). Using the climatic year ensures that the annual low-flow period is not divided. With regard to flow-duration characteristics, the distinction among calendar, water, and climatic years is typically negligible for long records (Searcy, 1959, 1960).

The USGS has developed computer programs for computing flow-duration (Searcy, 1959, 1960) and low-flow frequency characteristics (Jennings and Benson, 1969; Riggs, 1972) for continuous-record gaging stations. The computer programs IOWDM, ANNIE, and SWSTAT (Flynn and others, 1995) were used in this study to format input data, manage and display data, and compute flow-duration and low-flow frequency characteristics at gaged sites with 5 or more years of continuous-discharge record. All of these programs and user documentation can be downloaded from the World Wide Web at http://water.usgs.gov/software/surface_water.html.

\section{Low-Flow Partial-Record Sites}

During the past 100 years, non-flood discharge measurements on unregulated rivers and streams in Tennessee and the surrounding states have been made at many sites without continuous-record streamgages. Low-flow partial-record (LFPR) sites are locations on unregulated rivers and streams where a consistent program to obtain non-flood discharge measurements, ranging from low to high baseflow, has been conducted (Gold, 1980). The median watershed area for LFPR and short-term continuous-record gages used in this study was $25 \mathrm{mi}^{2}$. These sites are located in Tennessee and are listed in appended table $\mathrm{A} 2$ at the back of this report.

Techniques for extending short-term and periodic records to produce long-term statistics from long-term continuousrecord streamgages generally involve calibrating the observed discharges at LFPR sites with at least 10 instantaneousdischarge measurements (QM) to a suitable long-term gage (Searcy, 1959, 1960; Hardison, 1971; Hardison and Moss, 1972; Riggs, 1972; Tasker, 1975, 1987; Stedinger and Thomas, 1985). For LFPR sites with fewer than 10 QM, graphical methods can be used to estimate streamflow characteristics (Searcy, 1959, 1960; Hardison and Moss, 1972; Riggs, 1972). The number of years of record for low-flow frequency estimates at an LFPR site is equal to the number of climatic years in which at least one baseflow discharge measurement was obtained at the site.

Graphical correlation (Searcy, 1959, 1960; Hardison and Moss, 1972; Riggs, 1972) and equal-yield lines were used to estimate flow-duration values and low-flow frequency values at 870 LFPR sites presented in appended table $\mathrm{A} 2$ at the back of this report. Graphical correlation involves plotting QM at LFPR sites with daily-mean discharges at a long-term continuous-record gage and interpolating a straight line that intersects the equal-yield line near the average flow at the longterm gage (fig. 11). These lines are then used to determine 


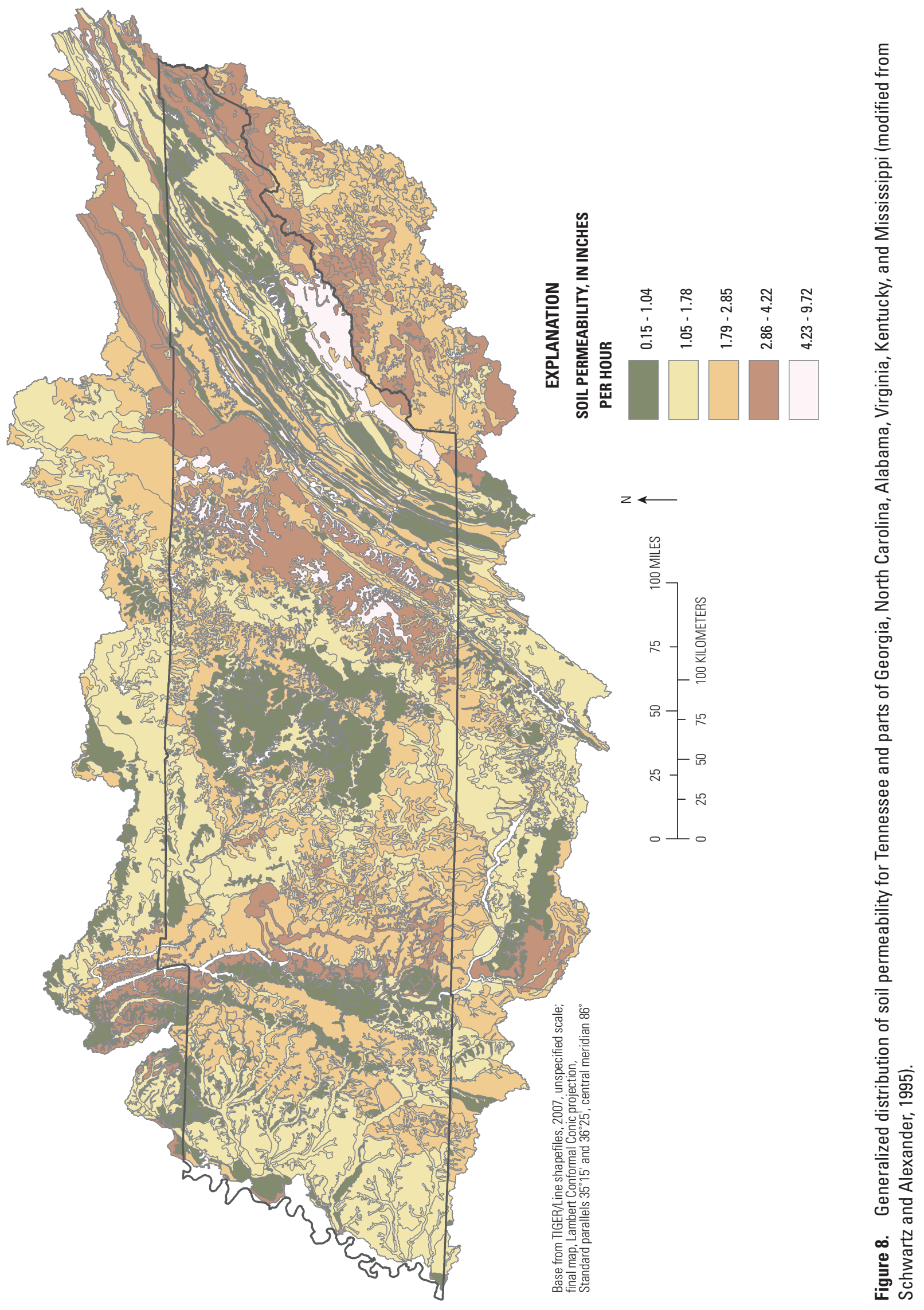




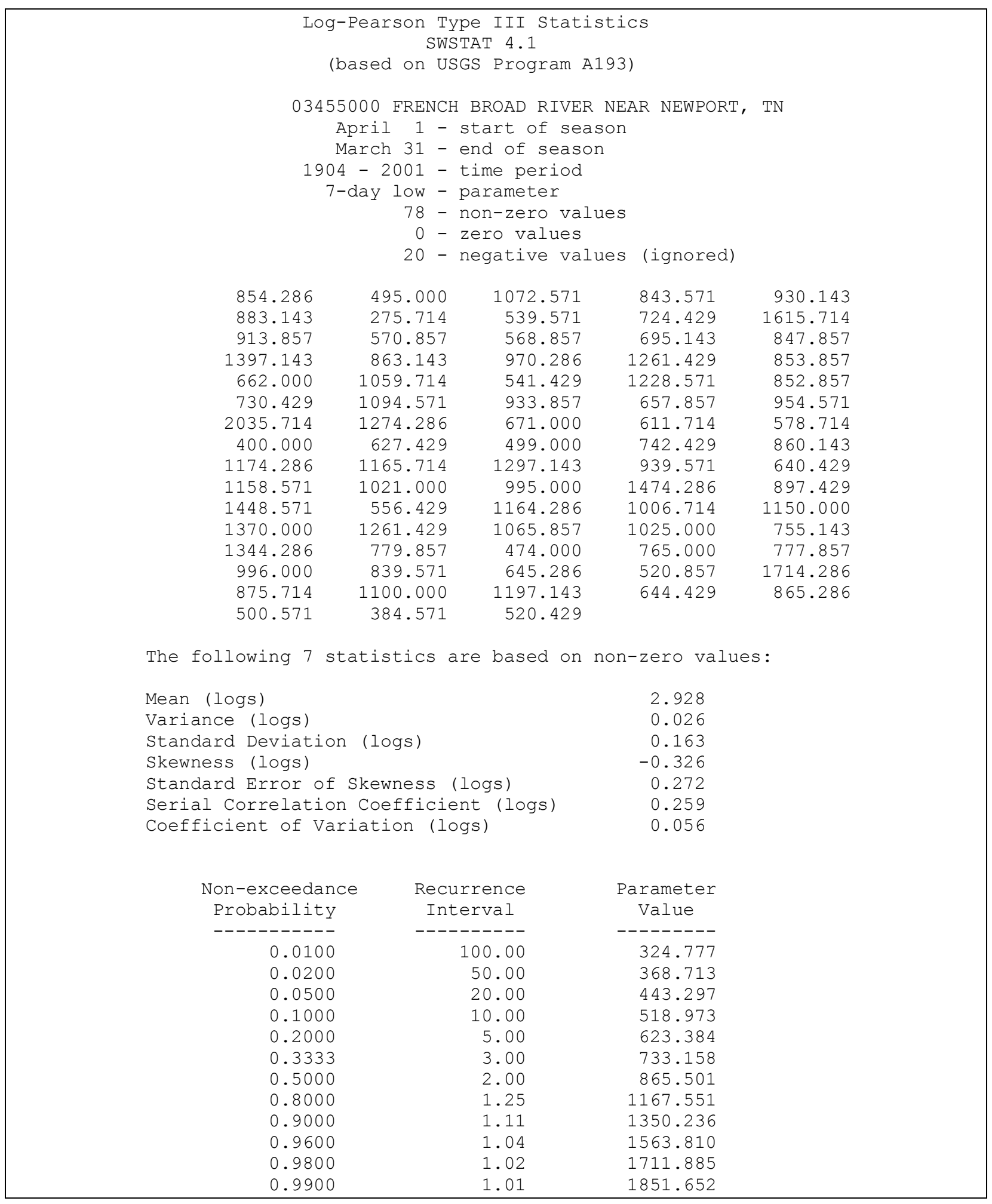

Figure 9. Output from computation of 7-day low-flow frequency estimates at a continuous-record gage using U.S. Geological Survey program SWSTAT. 


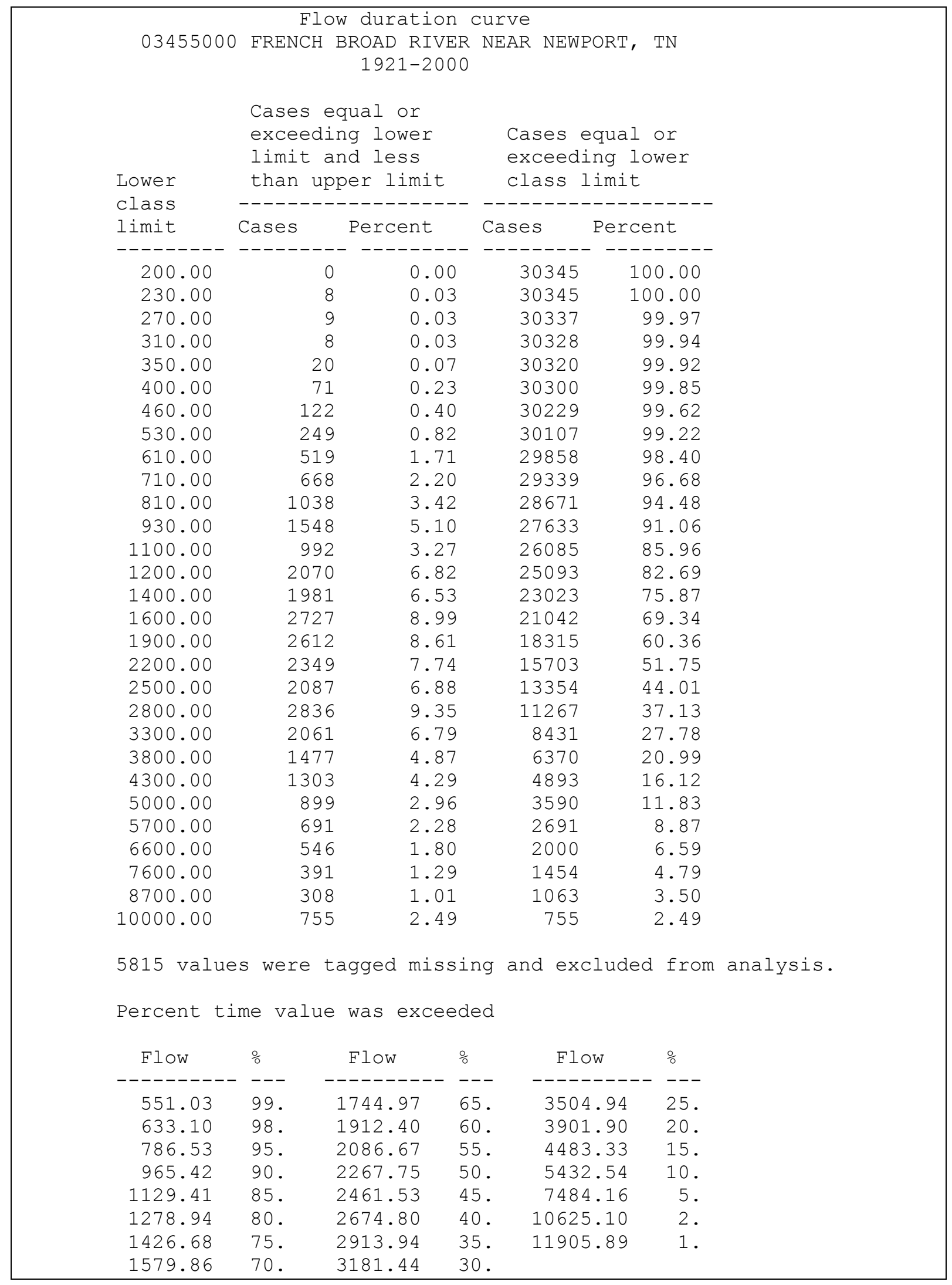

Figure 10. Output from computation of flow duration at a continuous-record gage using U.S. Geological Survey program SWSTAT. 
A.

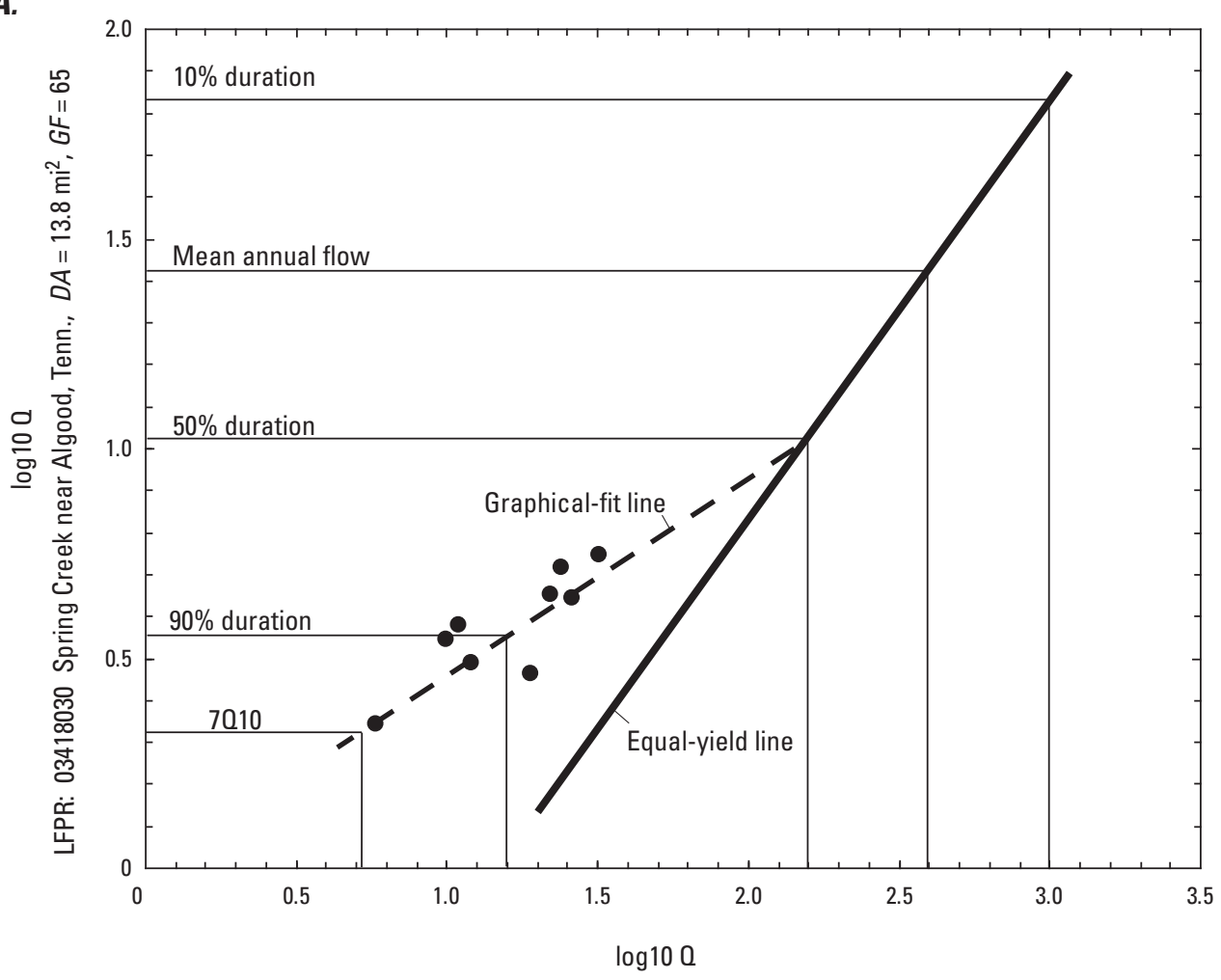

Long-term gage: 03414500 East Fork Obey River near Jamestown, Tennessee, $D A=202 \mathrm{mi}^{2}, G F=47$

B.

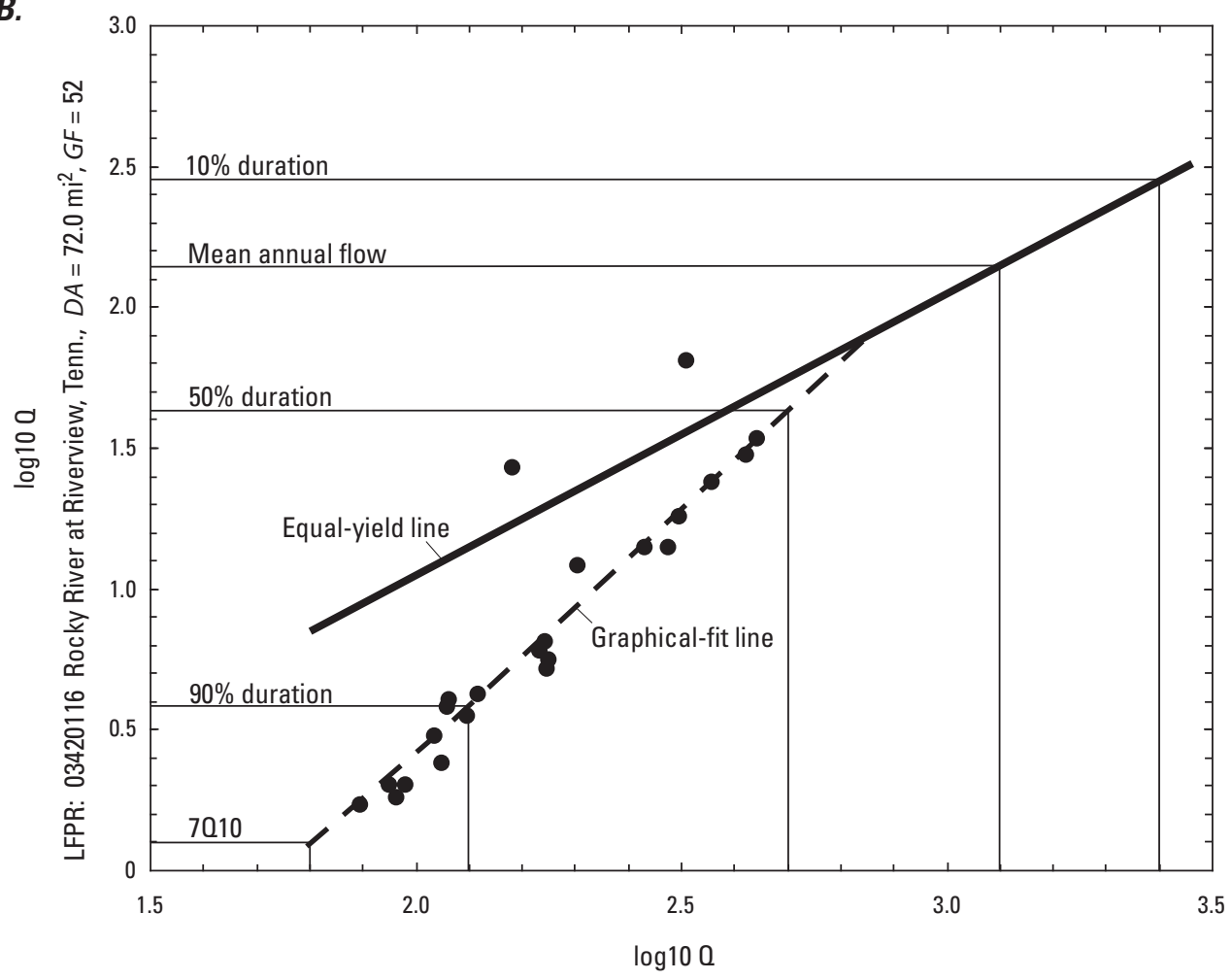

Long-term gage: 03421000 Collins River near McMinnville, Tennessee, $D A=642 \mathrm{mi}^{2}, G F=85$

Figure 11. Correlation of streamflow between a longterm gage and a low-flow partial-record site where $(A)$ the geology factor is greater at the low-flow partial-record site, and $(B)$ the geology factor is greater at the longterm gage. 
an equivalent flow at an LFPR site for a given flow at the long-term gage. The equal-yield line assumes that flows at the LFPR site and long-term gage are proportional to drainage area (Searcy, 1959, 1960) and is applied above the intersection of the low-flow line. Although multiple long-term gages can be used in LFPR correlations, in all cases for this study, only one long-term gage was used to compute equivalent streamflow characteristics at an LFPR site.

\section{Estimation at Ungaged Sites}

A site of interest is often located on an unregulated river or stream where no streamflow data are available. Streamflow characteristics at these sites in Tennessee have been estimated using multivariable ordinary least-squares regression equations developed for the West region of Tennessee and the Central+East region of Tennessee (Bingham, 1985, 1986). More recently, a procedure suggested by Tasker (1989) and applied in Arkansas uses logistic-probability equations to screen for zero-flow characteristics and multivariable ordinary least-squares regression to compute nonzero-streamflow characteristics for different regions in the State (Ludwig and Tasker, 1993; Funkhouser and others, 2008). A newer estimation method, which has been applied to flood frequency (Law and Tasker, 2003) but not to low-flow frequency and flow durations is the region-of-influence method. In this report, logistic-probability equations are used to screen for zero-flow characteristics, and both the region-of-influence method and regional regression equations are used to estimate nonzerostreamflow characteristics. Using StreamStats and the lowflow frequency and flow-duration (LFFD) computer program TDECv301, there is no difference in the amount of user effort required to apply either the region-of-influence method or the regional regression equations.

\section{Zero Flow Estimation}

Zero flows at continuous-record gages are included in streamflow characteristics estimated by the USGS computer program SWSTAT (Flynn and others, 1995). SWSTAT uses a conditional-probability adjustment in which only nonzero flows are included in the log-Pearson Type III frequency fit (Interagency Advisory Committee on Water Data, 1982). The frequency fit is then adjusted downward based on the number of years with one or more zero-flow days. Zero-flow observations at low-flow partial-record (LFPR) sites are accounted for in manual computations using hydrologic comparison and judgment (Thomas and Stedinger, 1991).

Zero-flow observations are accomodated in the flowduration and low-flow frequency (LFFD) computer program for Tennessee using logistic equations that compute the probability of a zero-flow occurrence for a given streamflow characteristic at a site of interest (Ludwig and Tasker, 1993; Helsel and Hirsch, 2002). For each gage, the number of days with zero flow is computed, and a logistic regression is performed. The logistic regression is based on the observed probability of zero flow at the site and applies to the 7Q10, 30Q5, and 99.5- to 10-percent flow durations. Logistic regression was not applied to the mean-annual and mean-summer flows because no zero flows were observed in the streamflow data for those streamflow characteristics. The resulting equations are:

$z, 7 \mathrm{Q} 10=5.73545-1.52553(\log D A)-3.42930(\log G F)$,

$z, 30 \mathrm{Q} 5=6.34833-1.56109(\log D A)-4.46114(\log G F)$, and $(4)$

$z$, duration $=0.73705-1.53054(\log D A)-1.64762(\log G F)$,

where

$$
\begin{aligned}
& z \quad \text { is the odds ratio of obtaining a zero flow for } \\
& D A \quad \text { is the drainage area of the site, and } \\
& G F \text { is the area-weighted geology factor of }
\end{aligned}
$$

The odds ratio $(z)$ is used to estimate the probability $(P)$ of a zero flow for a given streamflow characteristic as follows:

$$
P=\exp (z) /[1+\exp (z)]
$$

where

$$
z \quad \text { is defined in eqs. } 3,4 \text {, and } 5 \text {. }
$$

For stream sites anywhere in the study area, zero-flow screening is omitted for drainage areas greater than $2.5 \mathrm{mi}^{2}$ with geology factors greater than 60 . For sites in the West region, zero-flow screening is omitted for drainage areas greater than $50 \mathrm{mi}^{2}$ with geology factors greater than 40 . For sites in the Central+East region, zero-flow screening is omitted for drainage areas greater than $100 \mathrm{mi}^{2}$ with geology factors greater than 40. In any case, if the basin does not meet the second condition $(G F)$, the region-of-influence method and applicable regional regression equation are used to estimate nonzero-streamflow characteristics. A zero flow or nonzero flow is assigned to a given streamflow characteristic if:

$P, 7 Q 10 \geq 0.10$ (apply zero flow);

$P, 7 Q 10<0.10$ (compute nonzero flow);

$P, 30 Q 5 \geq 0.20$ (apply zero flow);

$P, 30 Q 5<0.20$ (compute nonzero flow);

$P, 99.5 \geq 0.005$ (apply zero flow);

$P, 99.5<0.005$ (compute nonzero flow);

$P, 99 \geq 0.01$ (apply zero flow);

$P, 99<0.01$ (compute nonzero flow);

$P, 98 \geq 0.02$ (apply zero flow);

$P, 98<0.02$ (compute nonzero flow);

$P, 95 \geq 0.05$ (apply zero flow);

$P, 95<0.05$ (compute nonzero flow);

$P, 90 \geq 0.10$ (apply zero flow); 
$P, 90<0.10$ (compute nonzero flow);

$P, 80 \geq 0.20$ (apply zero flow);

$P, 80<0.20$ (compute nonzero flow);

$P, 70 \geq 0.30$ (apply zero flow);

$P, 70<0.30$ (compute nonzero flow);

$P, 60 \geq 0.40$ (apply zero flow);

$P, 60<0.40$ (compute nonzero flow);

$P, 50 \geq 0.50$ (apply zero flow);

$P, 50<0.50$ (compute nonzero flow);

$P, 40 \geq 0.60$ (apply zero flow);

$P, 40<0.60$ (compute nonzero flow);

$P, 30 \geq 0.70$ (apply zero flow);

$P, 30<0.70$ (compute nonzero flow);

$P, 20 \geq 0.80$ (apply zero flow);

$P, 20<0.80$ (compute nonzero flow);

$P, 10 \geq 0.90$ (apply zero flow);

$P, 10<0.90$ (compute nonzero flow);

where

$P$,(stat) is the calculated probability of zero flow for a given streamflow characteristic (stat).

\section{Region-of-Influence Method}

The region-of-influence (ROI) method computes unique estimation equations for a site of interest by using streamflow and basin characteristics from a group of similar gaged sites selected from all the gaged sites in the same region (fig. 1; Appendix A). This group of sites, selected for similarity to the site of interest, is called the "region-of-influence" (Acreman and Wiltshire, 1987; Burn, 1990a,b). The similarity of a gaged site $(i)$ to the site of interest $(j)$ is based on basin characteristics rather than geographic distance. The mathematical formula for the similarity between sites $i$ and $j$ is defined by the Euclidean distance metric:

$$
d_{i j}=\left[\sum_{k=1}^{p}\left\{\left(x_{i k}-x_{j k}\right) / \operatorname{sd}\left(X_{k}\right)\right\}^{2}\right]^{1 / 2},
$$

where

$$
\begin{aligned}
& d_{i j} \text { is the Euclidian distance between sites } i \text { and } j \\
& \text { in terms of basin characteristics, } \\
& p \text { is the number of basin characteristics used to } \\
& \text { calculate } d_{i j},
\end{aligned}
$$

An important distinction exists between the two sets of basin characteristics. The first set is used to define a region-ofinfluence for a site of interest; the second set serves as explanatory variables in the predictive equations that are developed for the site. These two sets of basin characteristics may or may not be identical. In this study, the set of basin characteristics used to define the region-of-influence $(D A, G F$, and $C F)$ is different from the set of characteristics $(D A, G F$, and $S F)$ used to estimate streamflow characteristics at the site of interest.

Using $D A, G F$, and $C F$, the Euclidian distances or dissimilarities $\left(d_{i j}\right)$ between a given site of interest and all the gaged sites are computed and ranked. The group of gaging stations $(N)$ with the smallest $d_{i j}$ composes the region-ofinfluence for the site of interest. Once the region-of-influence is determined, multivariable ordinary-least-squares regression is used to develop the predictive relations between the streamflow characteristic and the basin characteristics $D A, G F$, and $S F$, and estimates of the streamflow characteristics at the site of interest are computed.

The number $(p)$ and identity of basin characteristics that are used to compute $d_{i j}$ and the $N$ gaged sites that compose the region-of-influence are specific to a given set of streamflow and basin characteristics. In addition to $p$ and $N$, a set of basin characteristics also must be chosen for use as explanatory variables in the least-squares regression equations.

The number of gaging stations $(N)$ and the basin characteristics that are used to define the region-of-influence for unregulated sites in Tennessee were selected by a computer program that computes prediction error for various combinations of $N$ and basin characteristics. A measure of the quality of a regression equation is the prediction-error sum of squares (PRESS) statistic (Helsel and Hirsch, 2002). PRESS is an estimator of uncertainty in a regression model. The PRESS statistic uses $N-1$ observations to develop the equation, then estimates the value of the observation left out. The PRESS statistic then changes the observation left out, and repeats the process for each observation. The prediction errors are squared and summed. Minimizing PRESS means that the regression equation produces the least error when making new predictions.

The PRESS statistic was used to determine the quality of the region-of-influence estimates. Various combinations of $N$ (20 to 70 by increments of 5) and basin characteristics ( $D A$, $G F, C F, S F, S P$ ) were compared to select the optimal number for inclusion in the ROI method as implemented in the LFFD computer program for Tennessee. For a given site of interest, the ROI method compares basin characteristics for 124 sites in the West region or 891 sites in the Central+East region and selects 45 sites having basin characteristics closest in similarity to the site of interest.

The accuracy of a streamflow-characteristic estimate, in equivalent years of record, is calculated by using its mean standard deviation from the sites in the LFFD dataset. For the 7Q10 and 30Q5 low-flow frequencies, mean standard deviations are computed from individual site standard deviations derived from daily-mean discharges at continuous-record sites and instantaneous discharge measurements (QM) at LFPR sites. The individual site low-flow frequency standard deviations are included in the LFFD computer program data input files. For the flow-duration, mean-annual flow, and meansummer flow estimates, the mean standard deviations are computed from regression equations (table 3 ) based on data 
from 317 continuous-record gages having at least 10 years of record. The mean standard-deviation estimation equations for mean annual flow, mean summer flow, and flow durations are included in the LFFD computer program for Tennessee.

Equivalent years of record for a streamflow characteristic at a site of interest $\left(E Y_{i}\right)$, are estimated with the equation:

$$
E Y_{i}=b^{*} \operatorname{asig}_{i}^{2} / \operatorname{sep}_{i}^{2}
$$

where

$b \quad$ is a constant that is equal to 1.8211 for the 7Q10; 1.3542 for the 30Q5; 1.0 for the mean summer and mean annual flows, and 1.57076 for each flowduration characteristic;

$\operatorname{asig}_{i}$ is the observed or estimated mean standard deviation for the streamflow characteristic from the region-ofinfluence sites; and

sep $_{i} \quad$ is the standard error of prediction for a streamflow characteristic at a site of interest from OLS regression applied to the region-of-influence sites.

The flow-duration characteristics apply to the entire period of record and are approximately equal to the median of the annual duration points. The formula for the standard error of the median $\left(S E_{m}\right)$, assuming normality, is given by Stuart and Ord (1987):

$$
S E_{m}=(1.2533 \sigma) /(n)^{1 / 2},
$$

where

$$
\begin{aligned}
& \sigma \quad \begin{array}{l}
\text { is } \begin{array}{l}
\text { the standard deviation of the annual } \\
\text { observations of a streamflow } \\
\text { characteristic, and }
\end{array} \\
n
\end{array} \\
& \text { is the equivalent years of record. }
\end{aligned}
$$

\section{Regional Regression Equations}

Multivariable ordinary-least-squares regional regression equations are the standard method for estimating streamflow characteristics and were first applied to low-flow characteristics of Tennessee streams by May and others (1970) and Bingham (1985, 1986a,b). A regional regression equation is used throughout a region to estimate a given streamflow characteristic. To evaluate the consistency of the region-of-influence (ROI) method with previous methods, new regional regression equations were developed for Tennessee using the same general form of the equations as in the past but using the regions, streamflow records, and descriptive basin characteristics used for the ROI analysis.

Bingham (1986a) established two regions in Tennessee for the development of low-flow frequency estimation equations. The regions established by Bingham (1986a) are the West region and Central+East region of Tennessee and
Table 3. Mean standard-deviation estimation equations for mean annual flow, mean summer flow, and flow durations at short-term gages and low-flow partial-record sites.

[See tables 1 and 2 for explanation of terms]

\begin{tabular}{cc}
\hline $\begin{array}{c}\text { Streamflow } \\
\text { characteristic }\end{array}$ & \multicolumn{1}{c}{ Mean standard-deviation estimation equation } \\
\hline & \multicolumn{1}{c}{ West region } \\
\hline MA & $1.0015-1.760(\log C F)-0.072(\log G F)$ \\
MS & $1.5387-2.500(\log C F)-0.156(\log G F)$ \\
q99.5 & $0.7030-0.056(\log D A)-0.194(\log G F)$ \\
q99 & $0.5983-0.206(\log G F)$ \\
q98 & $0.5958-0.206(\log G F)$ \\
q95 & $0.5626-0.191(\log G F)$ \\
q90 & $0.5360-0.179(\log G F)$ \\
q80 & $0.4741-0.151(\log G F)$ \\
q70 & $0.4410-0.134(\log G F)$ \\
q60 & $0.4352-0.128(\log G F)$ \\
q50 & $0.4270-0.119(\log G F)$ \\
q40 & $0.4173-0.110(\log G F)$ \\
q30 & $0.3068-0.097(\log G F)+0.040(\log D A)$ \\
q20 & $1.3412-0.063(\log G F)+0.038(\log D A)-2.90(\log C F)$ \\
q10 & $2.0610-4.800(\log C F)$ \\
\hline & \multicolumn{1}{c}{ Central+East region } \\
\hline MA & $0.0220-0.0457(\log G F)+0.561(\log C F)$ \\
MS & $0.6005-0.2720(\log G F)+0.530(\log C F)-0.0111(\log D A)$ \\
q99.5 & $0.6154-0.0156(\log D A)-0.211(\log G F)$ \\
q99 & $0.5580-0.2010(\log G F)$ \\
q98 & $0.5502-0.1980(\log G F)$ \\
q95 & $0.5619-0.2050(\log G F)$ \\
q90 & $0.5760-0.2100(\log G F)$ \\
q80 & $0.5891-0.2130(\log G F)$ \\
q70 & $0.5847-0.2090(\log G F)$ \\
q60 & $0.4526-0.2020(\log G F)+0.340(\log C F)$ \\
q50 & $0.3248-0.1671(\log G F)+0.480(\log C F)$ \\
q40 & $0.1683-0.1131(\log G F)+0.580(\log C F)$ \\
q30 & $0.0352-0.0818(\log G F)+0.750(\log C F)$ \\
q20 & $-0.0178-0.0610(\log G F)+0.770(\log C F)$ \\
q10 & $-0.0400-0.0485(\log G F)+0.770(\log C F)$ \\
&
\end{tabular}

are generally separated by the Tennessee River as it flows south to north from Hardin County to Stewart County. The new West-region equations (table 4) were developed using streamflow and basin characteristics from 124 data sites. The new Central+East-region equations (table 5) were developed using streamflow and basin characteristics from 891 data sites. Both sets of equations include statistically significant $(\alpha=0.95)$ explanatory variables selected from $D A, G F, C F, S P$, and $S F$. 
Table 4. Regional regression equations for the West region of Tennessee.

[See tables 1 and 2 for explanation of terms]

\begin{tabular}{cc}
\hline $\begin{array}{c}\text { Streamflow } \\
\text { characteristic }\end{array}$ & Regional regression equation \\
\hline 7Q10 & $-6.5090+1.1490(\log D A)+0.5950(\log (G F-30))+2.1800(\log S F)$ \\
\hline 30Q5 & $-5.0830+1.1080(\log D A)+0.5430(\log (G F-30))+1.5700(\log S F)$ \\
\hline MA & $-0.9615+1.0052(\log D A)+0.0233(\log (G F-30))+2.0400(\log C F)+0.1560(\log S F)$ \\
\hline MS & $-2.0017+1.0600(\log D A)+0.1130(\log (G F-30))+0.7800(\log S F)$ \\
\hline q99.5 & $-6.5290+1.1520(\log D A)+0.5950(\log (G F-30))+2.1700(\log S F)$ \\
\hline q99 & $-5.9000+1.1340(\log D A)+0.5710(\log (G F-30))+1.9000(\log S F)$ \\
\hline q98 & $-5.4330+1.1200(\log D A)+0.5560(\log (G F-30))+1.7000(\log S F)$ \\
q95 & $-4.9590+1.1040(\log D A)+0.5470(\log (G F-30))+1.5100(\log S F)$ \\
\hline q90 & $-4.5262+1.0930(\log D A)+0.5390(\log (G F-30))+1.3300(\log S F)$ \\
\hline q80 & $-4.0625+1.0880(\log D A)+0.5070(\log (G F-30))+1.1800(\log S F)$ \\
\hline q70 & $-3.4450+1.0780(\log D A)+0.4880(\log (G F-30))+0.9300(\log S F)$ \\
\hline q60 & $-4.4100+1.0870(\log D A)+0.3910(\log (G F-30))+7.2000(\log C F)+0.9100(\log S P)$ \\
\hline q50 & $-1.4200+1.0740(\log D A)+0.3490(\log (G F-30))+0.7900(\log S P)$ \\
\hline q40 & $-3.6500+1.0640(\log D A)+0.2750(\log (G F-30))+6.8000(\log C F)+0.6200(\log S P)$ \\
\hline q30 & $-3.5107+1.0310(\log D A)+0.2470(\log (G F-30))+7.7000(\log C F)$ \\
\hline q20 & $-2.5300+1.0270(\log D A)+0.0920(\log (G F-30))+6.6000(\log C F)$ \\
\hline q10 & $+0.3266+1.0340(\log D A)+0.0540(\log (G F-30))$ \\
\hline
\end{tabular}

Table 5. Regional regression equations for the Central+East region of Tennessee.

[See tables 1 and 2 for explanation of terms]

\begin{tabular}{cc}
$\begin{array}{c}\text { Streamflow } \\
\text { characteristic }\end{array}$ & Regional regression equation \\
\hline 7Q10 & $-2.5017+1.0360(\log D A)+1.0660(\log (G F-30))-2.6700(\log C F)+0.2740(\log S P)+0.2760(\log S F)$ \\
30Q5 & $-1.9755+1.0310(\log D A)+0.8700(\log (G F-30))-2.3200(\log C F)+0.2990(\log S P)+0.1950(\log S F)$ \\
\hline MA & $-0.7733+1.0142(\log D A)+2.5400(\log C F)+0.1650(\log S P)$ \\
MS & $+0.1420+1.0448(\log D A)+0.2120(\log (G F-30))-2.1400(\log C F)+0.2320(\log S P)$ \\
q99.5 & $-2.6200+1.0360(\log D A)+1.0490(\log (G F-30))-2.2600(\log C F)+0.2780(\log S P)+0.2660(\log S F)$ \\
q99 & $-2.3088+1.0360(\log D A)+0.9800(\log (G F-30))-2.4200(\log C F)+0.2560(\log S P)+0.2240(\log S F)$ \\
q98 & $-2.1383+1.0350(\log D A)+0.9180(\log (G F-30))-2.3600(\log C F)+0.2660(\log S P)+0.2130(\log S F)$ \\
q95 & $-1.8705+1.0400(\log D A)+0.8290(\log (G F-30))-2.2300(\log C F)+0.3030(\log S P)+0.1660(\log S F)$ \\
q90 & $-1.6084+1.0450(\log D A)+0.7270(\log (G F-30))-2.0500(\log C F)+0.3390(\log S P)+0.1300(\log S F)$ \\
q80 & $-0.9644+1.0510(\log D A)+0.5810(\log (G F-30))-2.1200(\log C F)+0.3360(\log S P)$ \\
q70 & $-0.6203+1.0530(\log D A)+0.4420(\log (G F-30))-2.0400(\log C F)+0.3310(\log S P)$ \\
q60 & $-0.3668+1.0510(\log D A)+0.3190(\log (G F-30))-1.7600(\log C F)+0.3140(\log S P)$ \\
q50 & $-0.2626+1.0477(\log D A)+0.2110(\log (G F-30))-1.0800(\log C F)+0.2820(\log S P)$ \\
q40 & $-0.3341+1.0394(\log D A)+0.1230(\log (G F-30))+0.2720(\log S P)$ \\
q30 & $-0.3031+1.0274(\log D A)+0.0671(\log (G F-30))+0.8600(\log C F)+0.2430(\log S P)-0.0390(\log S F)$ \\
q20 & $-0.1389+1.0145(\log D A)+1.2900(\log C F)+0.2060(\log S P)-0.0480(\log S F)$ \\
q10 & $-0.0624+1.0131(\log D A)-0.0364(\log (G F-30))+1.9600(\log C F)+0.1410(\log S P)-0.0610(\log S F)$ \\
\hline
\end{tabular}




\section{Comparison of Estimation by Different Methods}

The relative accuracy of the ROI method and the regional regression (RRE) equations was evaluated using the deletedresidual standard error $\left(S_{(-)}\right)$. $S_{(-)}$for a regression method is the square root of the average prediction error sum of squares, $(\text { PRESS } \div N)^{1 / 2}$, where $N$ is the number of residuals summed to produce the PRESS statistic. $S_{(-)}$is used to compare the predictive ability of regression methods with differing degrees of freedom. The deleted-residual standard error for a regression method in percent $\left(\% S_{(-)}\right)$is computed as follows:

$$
\% S_{(-)}=100\left(\left(\mathrm{e}^{5.3026(\text { PRESS }: N)}-1\right)^{1 / 2}\right) .
$$

The PRESS statistic was previously described in the "Region-of-Influence Method" section of this report. Comparison of the $\% S_{(-)}$values indicates that, overall, the ROI method is similar in accuracy to the RRE equations in the West region and substantially more accurate in the Central+East region (table 6). The number of sites is much less in the West region than in the Central+East region. Moreover, the degree of regional variation is less in the West region, so the advantages of a sliding "region" with $N$ equal to 45 are reduced. The total variation encompassed by 840 sites in the larger Central+East region of the State is more than the variation encompassed by 140 sites in the West region of the State, so region-of-influence groupings may be more important and significant in the Central+East region.

\section{Application of Estimation Methods}

Suggested procedures for obtaining low-flow frequencies and flow durations at sites of interest on unregulated streams and rivers in Tennessee are as follows.

- Determine the latitude ( $L A T)$ and longitude $(L N G)$, in degrees, minutes, and seconds, of the site of interest.

- Be aware of the suggested and required ranges for basin characteristics input to the low-flow and flowduration computer program (table 7).

- Go to the World Wide Web at http://water.usgs.gov/ osw/streamstats/index.html and determine basin characteristics $D A, G F, C F, S P$, and $S F$ at the site of interest using StreamStats, or manually if justified.

- Use either StreamStats or the stand-alone version of the low-flow frequency and flow-duration computer program (TDECv301) to compute streamflow statistics. Detailed instructions for the use of TDECv301 are given in Appendix B.

Table 6. Deleted-residual standard errors for the region-of-influence method and regional regression equations applied to the West region and Central+East region of Tennessee.

[Number of sites in the region-of-influence for both regions is 45; number of sites in West region is 124; number of sites in Central+East region is 891 ; Stat, streamflow characteristics, defined in table $1 ; \% S_{(-)}$, deleted-residual standard error in percent; ROI, region-of-influence method; RRE, regional-regression equations; ROI CHANGE, the percent error change when comparing the ROI method to the RRE equations]

\begin{tabular}{crrc}
\hline \multicolumn{4}{c}{ West Tennessee region } \\
\hline Stat & $\begin{array}{r}\text { ROI } \\
\% \boldsymbol{S}_{(-)}\end{array}$ & $\begin{array}{c}\text { RRE } \\
\% \boldsymbol{S}_{(-)}\end{array}$ & $\begin{array}{c}\text { ROI change } \\
\text { (percent) }\end{array}$ \\
\hline 7Q10 & 124.8 & 123.0 & -1.53 \\
30Q5 & 94.4 & 93.5 & -.87 \\
MA & 12.6 & 13.1 & +3.85 \\
MS & 38.5 & 38.3 & -.50 \\
q99.5 & 122.6 & 121.5 & -.93 \\
q99 & 105.7 & 104.7 & -.90 \\
q98 & 97.5 & 96.4 & -1.15 \\
q95 & 91.4 & 90.5 & -1.00 \\
q90 & 86.5 & 85.8 & -.86 \\
q80 & 80.8 & 79.6 & -1.43 \\
q70 & 75.9 & 75.0 & -1.19 \\
q60 & 70.0 & 69.2 & -1.25 \\
q50 & 58.2 & 57.0 & -2.17 \\
q40 & 47.9 & 46.9 & -2.12 \\
q30 & 36.9 & 36.6 & -.90 \\
q20 & 27.2 & 27.4 & +.61 \\
q10 & 17.8 & 17.7 & -.70 \\
Average & & & -.77 \\
\hline & & & \\
\hline
\end{tabular}

\begin{tabular}{cccc}
\hline \multicolumn{4}{c}{ Central+East Tennessee region } \\
\hline Stat & $\begin{array}{c}\text { ROI } \\
\% \boldsymbol{S}_{(-)}\end{array}$ & $\begin{array}{c}\text { RRE } \\
\% \boldsymbol{S}_{(-)}\end{array}$ & $\begin{array}{c}\text { ROI change } \\
\text { (percent) }\end{array}$ \\
\hline 7Q10 & 84.6 & 89.0 & +4.90 \\
30Q5 & 67.7 & 70.2 & +3.55 \\
MA & 22.3 & 25.6 & +12.84 \\
MS & 37.1 & 43.1 & +13.90 \\
q99.5 & 83.4 & 86.4 & +3.52 \\
q99 & 74.9 & 78.0 & +3.97 \\
q98 & 69.4 & 72.2 & +3.79 \\
q95 & 63.9 & 66.3 & +3.62 \\
q90 & 57.6 & 60.2 & +4.82 \\
q80 & 50.1 & 54.0 & +7.25 \\
q70 & 45.9 & 50.7 & +9.54 \\
q60 & 43.5 & 48.7 & +10.58 \\
q50 & 37.8 & 42.9 & +11.82 \\
q40 & 32.1 & 36.1 & +11.14 \\
q30 & 25.6 & 28.3 & +9.52 \\
q20 & 22.3 & 23.3 & +4.30 \\
q10 & 19.8 & 20.8 & +4.56 \\
Average & & & +7.24 \\
& & & \\
\hline
\end{tabular}


Table 7. Suggested and required regional ranges for basin characteristic inputs to the low-flow frequency and flow-duration computer program for Tennessee.

[See table 2 for description of basin characteristics]

\begin{tabular}{|c|c|c|c|c|}
\hline \multirow{2}{*}{$\begin{array}{c}\text { Basin } \\
\text { characteristic }\end{array}$} & \multicolumn{2}{|c|}{$\begin{array}{l}\text { West-region } \\
\text { ranges }\end{array}$} & \multicolumn{2}{|c|}{$\begin{array}{c}\text { Central+East-region } \\
\text { ranges }\end{array}$} \\
\hline & Lower & Upper & Lower & Upper \\
\hline \multicolumn{5}{|c|}{ Suggested ranges } \\
\hline$D A$ & 2.00 & 2,405 & 1.30 & 14,441 \\
\hline \multicolumn{5}{|c|}{ Required ranges } \\
\hline$G F$ & 32 & 350 & 32 & 175 \\
\hline$C F$ & 2.307 & 2.455 & 2.056 & 2.460 \\
\hline$S P$ & .97 & 2.44 & .45 & 9.72 \\
\hline$S F$ & 2 & 98 & 2 & 100 \\
\hline \multicolumn{5}{|c|}{ Basin characteristic units } \\
\hline$D A$ & \multicolumn{4}{|c|}{ square miles, $\mathrm{mi}^{2}$} \\
\hline$G F$ & \multicolumn{4}{|c|}{ days per log cycle of declining baseflow } \\
\hline$C F$ & \multicolumn{4}{|c|}{ dimensionless } \\
\hline$S P$ & \multicolumn{4}{|c|}{ inches per hour, in $/ \mathrm{hr}$} \\
\hline$S F$ & \multicolumn{4}{|l|}{ percent } \\
\hline
\end{tabular}

The low-flow frequency and flow-duration computer program can be applied to ungaged sites or continuous-record gages. Equivalent years of record for the regression estimate is weighted by the number of years of record at the gage to improve the accuracy of streamflow characteristics at the gage. Equivalent years of record is the number of years of gage record at a site needed to achieve an estimate of equal accuracy to the regression estimate. However, the equivalent years of record for regression estimates at a gage is usually small in comparison to the years of observed streamflow record at the gage, making the adjustment small in most cases.

Several points to consider when estimating flow durations, mean annual and mean summer flows, and low-flow frequencies of rivers and streams in Tennessee are as follows.

- Determine that the stream or river is not regulated by large dams and reservoirs. If regulated by large dams and reservoirs, streamflow-characteristic estimation methods presented in this report should not be used to make estimates of current conditions.

- Search for streamgage information at the site of interest. If present, this information should be weighted with the regression estimates.

- Search for streamgage information for nearby gages on the same stream. If present, this information should be combined with the regression estimate using the methods presented in this section.
Streamflow characteristic estimates suitable for design purposes at gaged sites can best be determined by a combined use of gaging-station data and regression estimates. The suggested procedure is to compute the desired streamflow characteristic by weighting the regression estimate with the gage estimate. The weighted value is based on the years of record at a continuous-record gage or LFPR site and the equivalent years of record for the regression estimate for the gaged site. The years of record at a gaged site and the equivalent years of record for the regression estimate at the gaged sites in Tennessee (Appendix A) are combined to compute the weighted streamflow value at the gaged site (eq. 11).

$$
Q_{t}(w)=\left(Q_{t}(g) Y R+Q_{t}(r) E Y\right) \div(Y R+E Y)
$$

where

$$
\begin{aligned}
& Q_{t}(w) \quad \text { is the weighted discharge at the gaging } \\
& \text { station or LFPR site for a given } \\
& \text { streamflow characteristic; } \\
& Q_{t}(g) \quad \text { is the streamflow characteristic determined } \\
& \text { from the streamflow record at the gaging } \\
& \text { station or LFPR site; } \\
& Y R \text { is the number of years of record at the } \\
& \text { gaging station or the number of years that } \\
& \text { discharge measurements were made at an } \\
& \text { LFPR site (appendix table A2); } \\
& Q_{t}(r) \quad \text { is the streamflow characteristic determined } \\
& \text { using the region-of-influence method at the } \\
& \text { gaging station or LFPR site; and } \\
& E Y \text { is the equivalent years of record for the } \\
& \text { regression estimate (see Appendix A if } \\
& \text { at a gaging station or LFPR site), or the } \\
& \text { computer-program (TDECv301) output } \\
& \text { (see examples provided in Appendix C). }
\end{aligned}
$$

Streamflow-characteristic estimates at an ungaged site that is on the same stream as a gaging station or LFPR site can be determined by using a combination of the regression estimate for the ungaged site and the station estimate for the nearby gaging station or LFPR site. In order to make the appropriate adjustment, first compute the ratio

$$
R=Q_{t}(w) \div Q_{t}(r)
$$

for the gaged site or LFPR site by using $Q_{t}(w)$ and $Q_{t}(r)$ as defined for equation 11 . Next, a correction factor, $R^{\prime}$, is computed as follows:

$$
R^{\prime}=R-\left(\Delta D A(R-1) \div 0.5 D A_{g}\right),
$$

where
$\triangle D A$
is the absolute value of the difference between the total drainage areas of the gaging station or LFPR site and the ungaged site, and
$D A_{g} \quad$ is the total drainage area of the gaging station or LFPR site. 
If $\triangle D A \div D A_{g}$ is less than 0.5 , then the corrected discharge for the ungaged site, $Q_{t}$ (corr), can be computed by multiplying the correction factor, $R^{\prime}$, by the regression estimate for the ungaged site $\left(Q_{t}(r)\right)$ determined by the region-of-influence method. If $\triangle D A \div D A_{g}$ is greater than 0.5 , or no streamflow data are available, then use the regression estimates from the computer program without correction.

At times, streamflow-characteristic estimates may be needed for an ungaged site that is between two gaging stations, two LFPR sites, or a gaging station and LFPR site on the same stream. In these cases, select the gaging station or LFPR site for which $\triangle D A \div D A_{g}$ is less than 0.5 , compute $R^{\prime}$, and apply as described in the previous paragraph. If $\triangle D A \div D A_{g}$ is less than 0.5 for the gaging station and the LFPR site, compute $R^{\prime}$ for each. If both correction factors are greater than 1.0, use the larger $R^{\prime}$; if both correction factors are less than 1.0, use the smaller $R^{\prime}$. If one correction factor is greater than 1.0 and the other smaller than 1.0, an average of the two correction factors should be used.

\section{Summary and Conclusions}

Streamflow characteristics of unregulated rivers and streams are used by Federal, State, regional, and local agencies for a variety of purposes. Streamflow information is required for the design and day-to-day operations of river-basin management districts, water-supply facilities, wastewatertreatment plants, and environmental planning and regulatory activities. Water-resources managers, engineers, and scientists often are called upon to estimate flow-duration, mean annual flow, mean summer flow, and low-flow frequency characteristics of unregulated rivers and streams. Commonly, the streamflow characteristics are needed at sites where streamflow has not been measured. For these sites, streamflow characteristics must be estimated using regional-regression methods or discharge measurements collected during a selected period.

A low flow and flow duration (LFFD) computer program that uses the region-of-influence (ROI) method and regional-regression (RRE) equations to estimate low-flow frequency characteristics, mean annual flow, mean summer flow, and flow-duration characteristics of unregulated rivers and streams in Tennessee has been developed by the U.S. Geological Survey, in cooperation with the Tennessee Department of Environment and Conservation. The LFFD computer program provides estimates of the 7-consecutive-day, 10-year recurrence-interval and 30-consecutive-day, 5-year recurrenceinterval low-flow frequencies, mean-annual and mean-summer flows, and the 99.5-, 99-, 98-, 95-, 90-, 80-, 70-, 60-, 50-, 40-, $30-, 20-$, and 10-percent flow durations for a site of interest. The LFFD computer program includes zero-flow probability screening and adjustment procedures for these streamflow characteristics. Methods for weighting regression estimates with gaging-station and low-flow partial-record site estimates are provided. The computer program was developed using hydrologic and basin characteristics from 1,224 sites in and near a two-region study area.
Zero-flow observations are included in the LFFD computer program for Tennessee using logistic equations that compute the probability of a zero-flow occurrence for a given streamflow characteristic at a site of interest. The logistic equations were computed using data from 102 continuousrecord streamgages with at least 10 years of record, a drainage area less than 320 square miles $\left(\mathrm{mi}^{2}\right)$, and a geology factor less than or equal to 65 . The zero-flow adjustment procedure is applied in the West region of Tennessee if drainage area is less than $50 \mathrm{mi}^{2}$ and geology factor is less than 40 or if drainage area is less than $2.5 \mathrm{mi}^{2}$ and geology factor is less than 60 . The low-flow adjustment procedure is applied in the Central+East region of Tennessee if drainage area is less than 100 and geology factor is less than 40 or if drainage area is less than 2.5 and geology factor is less than 60 . If the zero-flow probability and conditions for a given streamflow site and characteristic are not met, then the region-of-influence method and applicable regional regression equation are used to estimate the nonzero-streamflow characteristic.

The ROI method calculates unique multivariable regression equations for a site of interest using the flow and basin characteristics of 45 similar streamflow-data sites selected from the same region. These 45 sites are selected using a metric that measures similarity between the site of interest and the streamflow-data sites based on total drainage area, geology factor, and climate factor. The ROI method estimates streamflow characteristics using total drainage area, geology factor, and a soil factor as explanatory variables.

The RRE equations were computed using multivariable regression analysis. The two regions used for this study are separated by the Tennessee River as it flows south to north from Hardin County to Stewart County. The West region west of the Tennessee River uses data from 124 of the 1,224 streamflow sites, and the Central+East region uses data from 893 of the 1,224 streamflow sites. The study area also includes parts of the adjacent States of Georgia, North Carolina, Virginia, Alabama, Kentucky, and Mississippi. Total drainage area, a geology factor, a climate factor, and two soil factors are basin characteristics used as explanatory variables in the RRE equations. Average deleted-residual prediction errors for the West-region RRE equations were 18 and 123 percent for the 10-percent flow duration and 7-consecutive-day, 10 -year recurrence-interval low flow, respectively. Average deleted-residual prediction errors for RRE equations were 21 and 89 percent for the same respective flow quantiles in the Central+East region.

Average deleted-residual prediction errors for the West-region ROI equations were 18 and 125 percent for the 10-percent duration and 7-consecutive-day, 10-year recurrence-interval low flow, respectively. Average deletedresidual prediction errors for ROI equations were 20 and 85 percent for the same respective flow quantiles in the Central+East region. In general, when compared to the RRE equations, the ROI method performs similarly in the West region and reduces prediction errors by an average of about 7 percent in the Central+East region of Tennessee. 


\section{References}

Acreman, M.C., and Wiltshire, S.E., 1987, Identification of regions for regional flood frequency analysis [abs.]: EOS, v. 68 , no. 44 , p. 1262 .

Alexander, F.M., Keck, L.A., Conn, L.G., and Wentz, S.J., 1984, Drought-related impacts on municipal and major self-supplied industrial water withdrawals in TennesseeParts A and B: U.S. Geological Survey Water-Resources Investigations Report 84-4074, 16 and 398 p., respectively.

Association of Fish and Wildlife Agencies, 2006, National Fish Habitat Action Plan, accessed May 2007 at http://fishhabitat.org, $27 \mathrm{p}$.

Atkins, J.B., and Pearman, J.L., 1994, Low-flow and flowduration characteristics of Alabama streams: U.S. Geological Survey Water-Resources Investigations Report 93-4186, $264 \mathrm{p}$.

Bicker, A.R., Jr., comp., 1969 [reprint 1985], Geologic map of Mississippi: Mississippi Geological Survey, 1 sheet, scale 1:500,000.

Bingham, R.H., 1982, Low-flow characteristics of Alabama streams: U.S. Geological Survey Water-Supply Paper 2083, $27 \mathrm{p}$.

Bingham, R.H., 1985, Low flows and flow duration of Tennessee streams through 1981: U.S. Geological Survey WaterResources Investigations Report 84-4347, 325 p.

Bingham, R.H., 1986a, Regionalization of low-flow characteristics of Tennessee streams: U.S. Geological Survey WaterResources Investigations Report 85-4191, 63 p.

Bingham, R.H., 1986b, Regionalization of winter low-flow characteristics of Tennessee streams: U.S. Geological Survey Water-Resources Investigations Report 86-4007, 88 p.

Burn, D.H., 1990a, An appraisal of the "region of influence" approach to flood frequency analysis: Hydrological Science Journal, v. 35, no. 2, p. 149-165.

Burn, D.H., 1990b, Evaluation of regional flood frequency analysis with a region of influence approach: Water Resources Research, v. 26, no. 10, p. 2257-2265.

Carter, R.F., and Fanning, J.D., 1982, Monthly low-flow characteristics of Georgia streams: U.S. Geological Survey Open-File Report 82-560, 81 p.

Carter, R.F., and Putnam, S.A., 1978, Low-flow frequency of Georgia streams: U.S. Geological Survey Water-Resources Investigations Report 77-127, 104 p.

Cleland, B., 2007, TMDL development from the "bottom up"-Part IV - Connecting to storm water management programs: Seattle, WA, U.S. Environmental Protection Agency, 28 p.
Daly, Chris, 2000, United States average annual precipitation, 1961-1990, in National Atlas of the United States, accessed November 2007 at http://www.nationalatlas.gov/HELP/faq. html\#fourteen.

Daniel, J.F., 1976, Estimating ground-water evapotranspiration from streamflow records: Water Resources Research, v. 12, no. 3, p. 360-364.

Eaton, W.R., 1958, Summary of flow duration and low flow at stream-gaging stations in Tennessee: U.S. Geological Survey Open-File Report, 129 p.

Eng, Kenny, Tasker, G.D., and Milly, P.C.D., 2005, An analysis of region-of-influence methods for flood regionalization in the Gulf-Atlantic Rolling Plains: Journal of the American Water Resources Association, v. 41, no. 1, p. 135-143.

Fenneman, N.M., 1938, Physiography of the eastern United States: New York, McGraw-Hill, 714 p.

Fenneman, N.M., 1946, Physical divisions of the United States: U.S. Geological Survey special map, scale 1:7,000,000.

Ferguson, C.C., 1970, Geologic map of the Huntingdon quadrangle, Tennessee: Tennessee Department of Conservation, Division of Geology, Map GM 9-SW, scale 1:24,000.

Flynn, K.M., Hummel, P.R., Lumb, A.M., and Kittle, J.L., Jr., 1995, User's manual for ANNIE, version 2, a computer program for interactive hydrologic data management: U.S. Geological Survey Water-Resources Investigations Report 95-4085, 211 p.

Funkhouser, J.E., Eng, K., and Moix, M.W., 2008, Low-flow characteristics and regionalization of low-flow characteristics for selected streams in Arkansas: U.S. Geological Survey Scientific Investigations Report 2008-5065, 161 p.

Giese, G.L., and Mason, R.R., Jr., 1991, Low-flow characteristics of streams in North Carolina: U.S. Geological Survey Open-File Report 90-399, 2 sheets.

Gold, R.L., 1980, Low flow measurements of Tennessee streams: State of Tennessee, Department of Conservation, Division of Water Resources series no. 14, 362 p.

Gold, R.L., 1981, Low-flow frequency and flow duration of Tennessee streams: U.S. Geological Survey Open-File Report 78-807, $361 \mathrm{p}$.

Greene, D.C., and Wolfe, W.J., 1998, Superfund GIS-Soil thickness, permeability, texture, and classification in Tennessee, accessed November 2007, at http://water.usgs. gov/GIS/metadata/usgswrd/XML/statsoil.xml.

Hardeman, W.D., Miller, R.A., and Swingle, G.D., comps., 1966, Geologic map of Tennessee: Tennessee Division of Geology, 4 sheets, scale 1:250,000. 
Hardison, C.H., 1971, Prediction error of regression estimates of streamflow characteristics at ungaged sites in Geological Survey Research 1971: U.S. Geological Survey Professional Paper 750-C, p. C228-C236.

Hardison, C.H., and Moss, M.E., 1972, Accuracy of lowflow characteristics estimated by correlation of base-flow measurements: U.S. Geological Survey Water-Supply Paper 1542-B, 21 p.

Hayes, D.C., 1991, Low-flow characteristics of streams in Virginia: U.S. Geological Survey Water-Supply Paper 2374, $69 \mathrm{p}$.

Helsel, D.R., and Hirsch, R.M., 2002, Statistical methods in water resources: U.S. Geological Survey Techniques of Water-Resources Investigations, book 4, chap. A3, 510 p.

Hollyday, E.F., and Pluhowski, E.J., 1976, Improving estimates of streamflow characteristics, in ERTS-1, a new window on our planet: U.S. Geological Survey Professional Paper 929, p. 136-138.

Interagency Advisory Committee on Water Data, 1982, Guidelines for determining flood flow frequency: U.S. Geological Survey, Office of Water Data Coordination Bulletin 17B, $186 \mathrm{p}$.

Jennings, M.E., and Benson, M.A., 1969, Frequency curves for annual flood series with some zero flow events or incomplete data: Water Resources Research, v. 5, no. 1, p. 276-280.

King, P.B., 1964, Geology of the central Great Smoky Mountains, Tennessee: U.S. Geological Survey Professional Paper 349-C, 148 p., 13 pl.

Kolton, G.F., Kula, S.P., and Puskas, B.M., 2006, A streamflow statistics (StreamStats) web application for Ohio: U.S. Geological Survey Scientific Investigations Report 2006-5312, 62 p.

Konrad, C.P., 2006, Longitudinal hydraulic analysis of river-aquifer exchanges: Water Resources Research, v. 42, W08425, doi: 10.1029/2005WR004197.

Ladd, D.E., and Law, G.S., 2007, Tennessee StreamStats-A web-enabled geographic information system application for automating the retrieval and calculation of streamflow statistics: U.S. Geological Survey Fact Sheet 2007-3081, 2 p.

Law, G.S., and Tasker, G.D., 2003, Flood-frequency prediction methods for unregulated streams of Tennessee, 2000: U.S. Geological Survey Water-Resources Investigations Report 03-4176, 79 p.

Lawton, D.E., Marsalis, W.E., and others, 1976 [reprint 1997], Geologic map of Georgia: Georgia Geological Survey map, 1 sheet, scale 1:500,000.
Lichty, R.W., and Karlinger, M.R., 1990, Climate factor for small-basin flood frequency: Water Resources Bulletin, v. 26 , no. 4 , p. $577-586$.

Lichty, R.W., and Liscum, Fred, 1978, A rainfall-runoff modeling procedure for improving estimates of T-year (annual) floods for small drainage basins: U.S. Geological Survey Water-Resources Investigations Report 78-7, 44 p.

Locke, A.G.H., Stainaker, C.B., Zellmer, S.B., Williams, K., Beecher, H.A., Richards, T.A., Robertson, C.A., Wald, A.R., Paul, A.J., and Annear, T.C., 2009, Integrated approaches to riverine resource stewardship - Case studies, science, law, people, and policy: Instream Flow Council, $430 \mathrm{p}$.

Lowery, J.F., and Connell, J.F., 1990, Low flows during the 1988 drought in Tennessee: U.S. Geological Survey WaterResources Investigations Report 89-4149, 1 sheet.

Ludwig, A.H., and Tasker, G.D., 1993, Regionalization of low-flow characteristics of Arkansas streams: U.S. Geological Survey Water-Resources Investigations Report 93-4013, $19 \mathrm{p}$.

Luther, E.T., 1977, Our restless earth-The geologic regions of Tennessee: Knoxville, University of Tennessee Press, $94 \mathrm{p}$.

Mancini, E.A., 1989, Geologic map of Alabama: Geological Survey of Alabama Special Map 221, 1 sheet, scale 1:500,000.

Martin, G.R., 2002, Estimating mean annual streamflow of rural streams in Kentucky: U.S. Geological Survey WaterResources Investigations Report 02-4206, 35 p.

Martin, G.R., and Ruhl, K.J., 1993, Regionalization of harmonic-mean streamflows in Kentucky: U.S. Geological Survey Water-Resources Investigations Report 92-4173, 47 p.

May, V.J., Wood, G.H., and Rima, D.R., 1970, A proposed streamflow-data program for Tennessee: U.S. Geological Survey Open-File Report 70-219, 102 p.

McMaster, W.M., and Hubbard, E.F., 1970, Water resources of the Great Smoky Mountains National Park, Tennessee and North Carolina: U.S. Geological Survey Hydrologic Atlas 420, 2 sheets, scale 1:250,000.

Miller, R.A., 1974, The geologic history of Tennessee: Tennessee Division of Geology Bulletin 74, 63 p.

National Oceanic and Atmospheric Administration, 2006, Climatological data annual summary for Tennessee, 2006, v. 111 , no. 13,36 p.

National Park Service, 2006, Fact Sheet-Water Resources Division planning program, accessed May 2007 at http:// www.nature.nps.gpv/water/planning, 2 p. 
Nelms, D.L., Harlow, G.E., Jr., and Hayes, D.C., 1997, Baseflow characteristics of streams in the Valley and Ridge, the Blue Ridge, and the Piedmont physiographic provinces of Virginia: U.S. Geological Survey Water-Supply Paper 2457, $48 \mathrm{p} ., 1 \mathrm{pl}$.

Noger, M.C., comp., 1988, Geologic map of Kentucky: U.S. Geological Survey, 1 sheet, scale 1:500,000.

North Carolina Geological Survey, 1985, Geologic map of North Carolina: North Carolina Department of Natural Resources and Community Development, North Carolina Geological Survey, scale 1:500,000.

Outlaw, G.S., and Weaver, J.D., 1996, Flow duration and low flows of Tennessee streams through 1992: U.S. Geological Survey Water-Resources Investigations Report 95-4293, $245 \mathrm{p}$.

Parks, W.S., 1974, Geologic map of the Palmer Shelter quadrangle, Tennessee: Tennessee Department of Conservation, Division of Geology, Map GM 10-NW, scale 1:24,000.

Ries, K.G., III, Atkins, J.B., Hummel, P.R., Gray, M., Dusenbury, R., Jennings, M.E., Kirby, W.H., Riggs, H.C., Sauer, V.B., and Thomas, W.O., Jr., 2007, The National Streamflow Statistics program-A computer program for estimating streamflow statistics for ungaged sites: Techniques of Water-Resources Investigations of the U.S. Geological Survey, book 4, chap. A6, 37 p.

Ries, K.G., III, Steeves, P.A., Coles, J.D., Rea, A.H., and Stewart, D.W., 2004, StreamStats-A U.S. Geological Survey Web application for stream information: U.S. Geological Survey Fact Sheet 2004-3115, 4 p.

Riggs, H.C., 1964, The base-flow recession curve as an indicator of ground water: International Association of Scientific Hydrology Publication 63, p. 352-363.

Riggs, H.C., 1972, Low-flow investigations: Techniques of Water-Resources Investigations of the U.S. Geological Survey, book 4, chap. B1, 18 p.

Riggs, H.C., 1973, Regional analyses of streamflow characteristics: Techniques of Water-Resources Investigations of the U.S. Geological Survey, book 4, chap. B3, 15 p.

Riggs, H.C., 1980, Characteristics of low flows: Journal of the Hydraulics Division, American Society of Civil Engineers, v. 106, no. HY5, p. 717-731.

Rorabaugh, M.I., Simons, W.D., Garrett, A.A., and McMurtrey, R.G., 1966, Exploration of methods of relating ground water to surface water-Columbia River basin first phase, with a section on Direct computation of ground-water outflow by electric analog by B.H. Bermes: U.S. Geological Survey Open-File Report, 124 p.
Ruhl, K.J., Burns, R.J., Martin, G.R., and Allgeier, D.P., 1995, Flow duration of Kentucky streams through 1990Historical and monthly flow characteristics including the effects of reservoirs: U.S. Geological Survey Open-File Report 95-353, $291 \mathrm{p}$.

Ruhl, K.J., and Martin, G.R., 1991, Low-flow characteristics of Kentucky streams: U.S. Geological Survey WaterResources Investigations Report 91-4097, 50 p.

Schwarz, G.E., and Alexander, R.B., 1995, State Soil Geographic (STATSGO) data base for the conterminous United States (ed. 1.1): U.S. Geological Survey Open-File Report 95-449, Arc 7.0 coverage.

Schwarz, G.E., Hoos, A.B., Alexander, R.B., and Smith, R.A., 2006, The SPARROW surface water-quality modelTheory, application and user documentation: U.S. Geological Survey Techniques and Methods Report 6-B3, 248 p. and CD-ROM.

Searcy, J.K., 1959, Flow-duration curves: U.S. Geological Survey Water-Supply Paper 1542-A, 33 p.

Searcy, J.K., 1960, Graphical correlation of gagingstation records: U.S. Geological Survey Water-Supply Paper $1541-\mathrm{C}, 100 \mathrm{p}$.

Smakhtin, V.U., 2001, Low flow hydrology-A review: Journal of Hydrology, v. 240, p. 147-186.

Stedinger, J.R., and Thomas, W.O., Jr., 1985, Low-flow frequency estimation using base-flow measurements: U.S. Geological Survey Open-File Report 85-95, 22 p.

Stuart, Alan, and Ord, J.K., 1987, Kendall's advanced theory of statistics (5th ed.): New York, Oxford University Press, p. 332 .

Studley, S.E., 2000, Estimating flow-duration curves for selected ungaged sites in the Cimarron and Lower Arkansas River basins in Kansas: U.S. Geological Survey WaterResources Investigations Report 00-4113, 43 p.

Studley, S.E., 2001, Estimating flow-duration curves for selected ungaged sites in Kansas: U.S. Geological Survey Water-Resources Investigations Report 01-4142, 90 p.

Tasker, G.D., 1975, Combining estimates of low-flow characteristics of streams in Massachusetts and Rhode Island: Journal of Research of the U.S. Geological Survey, v. 3, no. 1, p. $107-112$.

Tasker, G.D., 1987, A comparison of methods for estimating low flow characteristics of streams: Water Resources Bulletin, v. 23, no. 6, p. 1077-1083.

Tasker, G.D., 1989, Regionalization of low flow characteristics using logistic and GLS regression, in Kavvas, M.L., ed., New directions for surface water modeling: IAHS Publication no. 181, p. 323-331. 
Tasker, G.D., Hodge, S.A., and Barks, C.S., 1996, Region of influence regression for estimating the 50-year flood at ungaged sites: Water Resources Bulletin, v. 32, no. 1, p. 163-170.

Telis, P.A., 1991, Low-flow and flow-duration characteristics of Mississippi streams: U.S. Geological Survey WaterResources Investigations Report 90-4087, 214 p.

Telis, P.A., 1992, Techniques for estimating 7-day, 10-year low-flow characteristics for ungaged sites on streams in Mississippi: U.S. Geological Survey Water-Resources Investigations Report 91-4130, 143 p.

Tennessee Department of Conservation and Commerce, 1961, Tennessee's water resources: Division of Water Resources, $128 \mathrm{p}$.

Tennessee Valley Authority, 1965a, Design of a hydrologic condition survey using factor analysis: Tennessee Valley Authority, Division of Water Control Planning, Hydraulic Data Branch, Research Paper no. 5 [variously paged].

Tennessee Valley Authority, 1965b, The Upper Bear Creek Experimental Project, 1962-1964: Knoxville, TN, Tennessee Valley Authority, 49 p.

Tennessee Valley Authority, 1970, Mineral resources of the Tennessee Valley Region: Tennessee Valley Authority, Division of Water Control Planning, Geologic Branch, map report.

Tennessee Valley Authority, 2004, Reservoir Operations Plan, accessed May 2006 at http://www.tva.gov/environment/ reports/ros_eis/index.htm [variously paged].

Thomas, W.O., Jr., and Stedinger, J.R., 1991, Estimating low-flow characteristics at gaging stations and through the use of base-flow measurements, in Kirby, W.H., and Tan, W.Y., comps., Proceedings of the United States-People's Republic of China Bilateral Symposium on Droughts and Arid-Region Hydrology, September 16-20, 1991, Tuscon, Arizona: U.S. Geological Survey Open-File Report 91-244, p. 215-219.

Trainer, F.W., and Watkins, F.A., Jr., 1975, Geohydrologic reconnaissance of the upper Potomac River basin: U.S. Geological Survey Water-Supply Paper 2035, 68 p.

U.S. Army Corps of Engineers, 2008, Value to the Nation brochure-Environment, accessed May 2009 at http://www. vtn.iwr.usace.army.mil, 5 p.

U.S. Army Corps of Engineers, 2009, Value to the Nation brochure-Lands and waters, accessed May 2009 at http://www.vtn.iwr.usace.army.mil, 5 p.

U.S. Department of Agriculture, 1994, State Soil Geographic (STATSGO) data base, CD-ROM.
U.S. Department of Agriculture, Forest Service, 2000, Water $\&$ The Forest Service: Washington, DC, $26 \mathrm{p}$.

U.S. Department of Agriculture, Natural Resources Conservation Service, 2001 (revised), Stream corridor inventory and assessment techniques, accessed May 2007 at http://www. wsi.nrcs.usda.gov, $30 \mathrm{p}$.

U.S. Department of Agriculture, Natural Resources Conservation Service, 2006, Digital General Soil Map of U.S. (version 2), tabular digital data and vector digital data, accessed June 2007 at http://datagateway.nrcs.usda.gov.

U.S. Department of Agriculture, Natural Resources Conservation Service, the U.S. Geological Survey, and the U.S. Environmental Protection Agency, 2007, Watershed Boundary Dataset (WBD), tabular digital data and vector digital data, accessed June 2007 at http://datagateway.nrcs.usda.gov.

U.S. Environmental Protection Agency, 2008, Handbook for developing watershed plans to restore and protect our waters, accessed May 2008, at http://www.epa.gov/owow/ nps/watershed_handbook, 400 p.

U.S. Fish and Wildlife Service, 2005, Wetlands status and trends-A step-down strategic plan, accessed May 2007 at http://www.fws.gov/wetlands/StatusAndTrends/index.html, $16 \mathrm{p}$.

U.S. Geological Survey, 1970, The national atlas of the United States of America: Washington, DC, U.S. Geological Survey, p. 59.

U.S. Geological Survey, 1986, National water summary 1985-Hydrologic events and surface-water resources: U.S. Geological Survey Water-Supply Paper 2300, 506 p.

Virginia Division of Mineral Resources, 1993, Geologic map of Virginia: Commonwealth of Virginia, Department of Mines, Minerals, and Energy, Division of Mineral Resources, 1 sheet, scale 1:500,000.

Wetzel, K.L., and Bettandorff, J.M., 1986, Techniques for estimating streamflow characteristics in the Eastern and Interior Coal Provinces of the United States: U.S. Geological Survey Water-Supply Paper 2276, 80 p., 1 pl.

Wilson, R.L., 1981, Guide to the geology along the interstate highways in Tennessee: Tennessee Division of Geology Report of Investigations 39, 79 p.

Wood, G.H., and Johnson, A.M.F., 1965, Flow characteristics of Tennessee streams, part A, summaries of flow duration and of low and high flows at gaging stations in Tennessee: Tennessee Division of Water Resources, 326 p. 



\section{Appendixes A-C}

A. Basin and streamflow characteristics for sites in this report .........................................31

B. Instructions for use of the stand-alone version of the low-flow frequency and flow-duration computer program (TDECv301) for Tennessee .................................201

C. Description of output from the stand-alone version of the low-flow frequency and flow-duration computer program (TDECv301) for Tennessee ……...................................203 



\title{
Appendix A. Basin and Streamflow Characteristics for Sites in This Report
}

Basin and streamflow characteristics for sites given in this report are presented in this appendix. This appendix contains three tables containing selected groupings of sites. The first table (table A1) presents basin and streamflow characteristics for 196 continuous-record gaging stations in Tennessee. The second table (table A2) presents basin and streamflow characteristics for 870 low-flow partial-record and short-term gaging stations in Tennessee. The third table in this appendix (table A3) presents basin and streamflow characteristics for 158 continuous-record gaging stations in adjacent states.

\author{
Abbreviations used in tables A1-A3 \\ DA Drainage area in square miles, includes noncontributing areas in a watershed \\ GIS Geographic information system \\ GIS.CF GIS-computed climate factor having a 2-year recurrence interval, dimensionless \\ GIS.DA GIS-computed drainage area in square miles, includes noncontributing areas \\ GIS.GF GIS-computed geology factor in days per log-cycle of declining baseflow, a watershed-weighted value \\ GIS.SF GIS-computed soil factor, percentage of area underlain by a soil permeability greater than or \\ equal to 2 inches per hour \\ GIS.SP GIS-computed soil permeability in inches per hour, a watershed-weighted value \\ LAT Latitude \\ LNG Longitude \\ MA Mean annual streamflow, October through September \\ MNO Map number of gaged site on Plate 1 \\ MS Mean summer streamflow, June through August \\ STANAM Station name of a gaged site \\ STANO Station number of a gaged site \\ YR Years of streamflow record \\ 7Q10 Lowest 7-day average flow with a 10-percent probability of occurring in any given year \\ 30Q5 Lowest 30-day average flow with a 20-percent probability of occurring in any given year
}




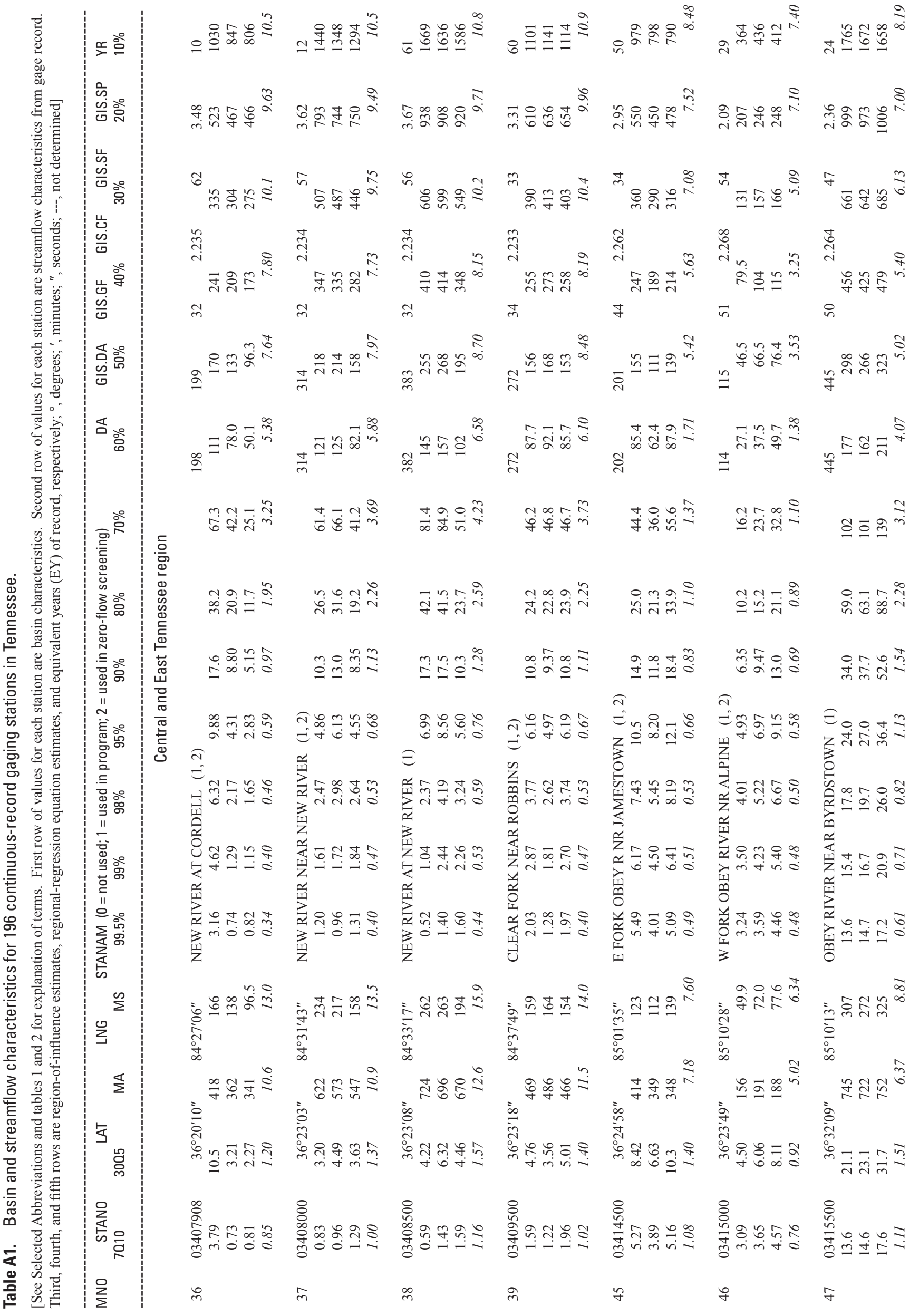




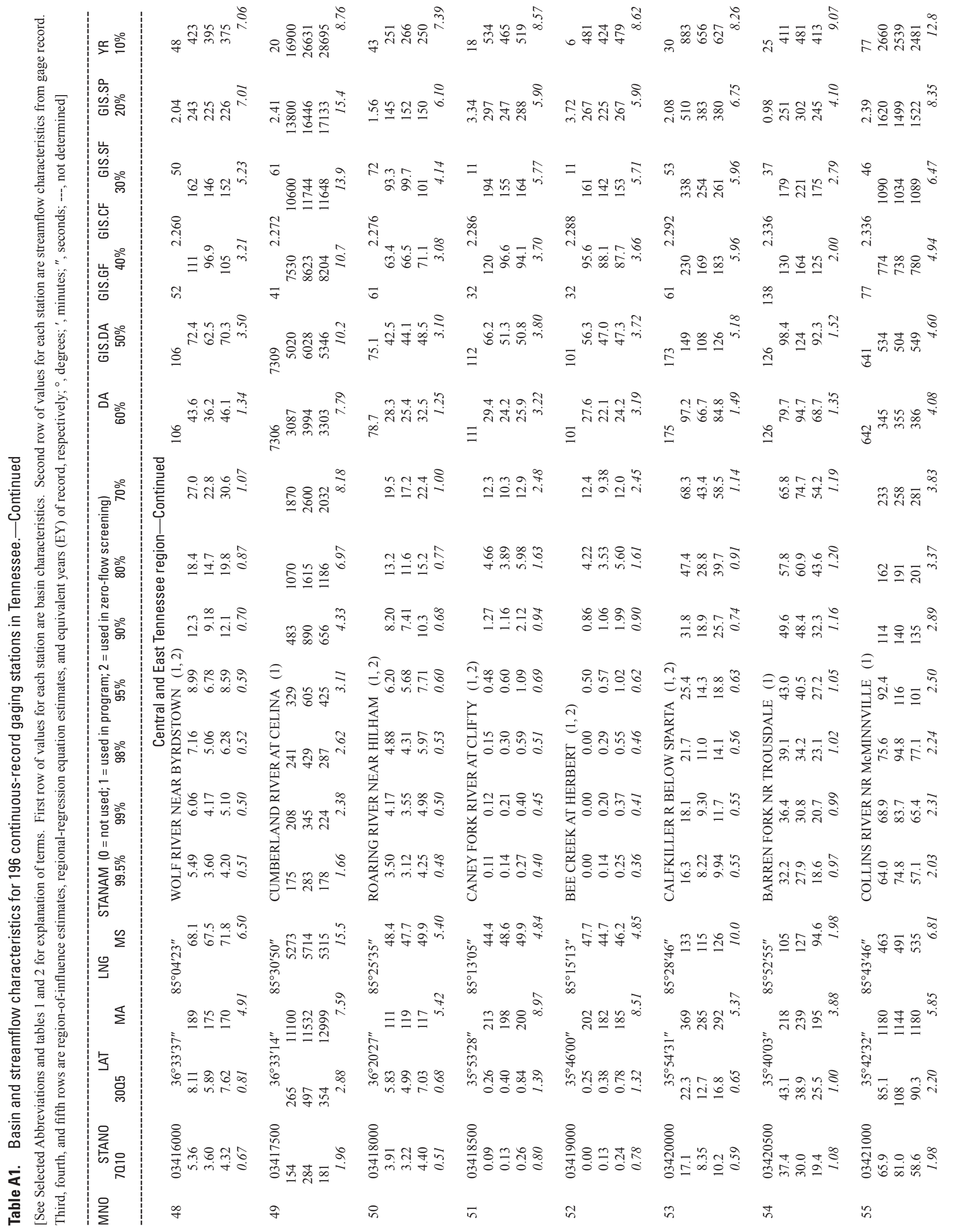




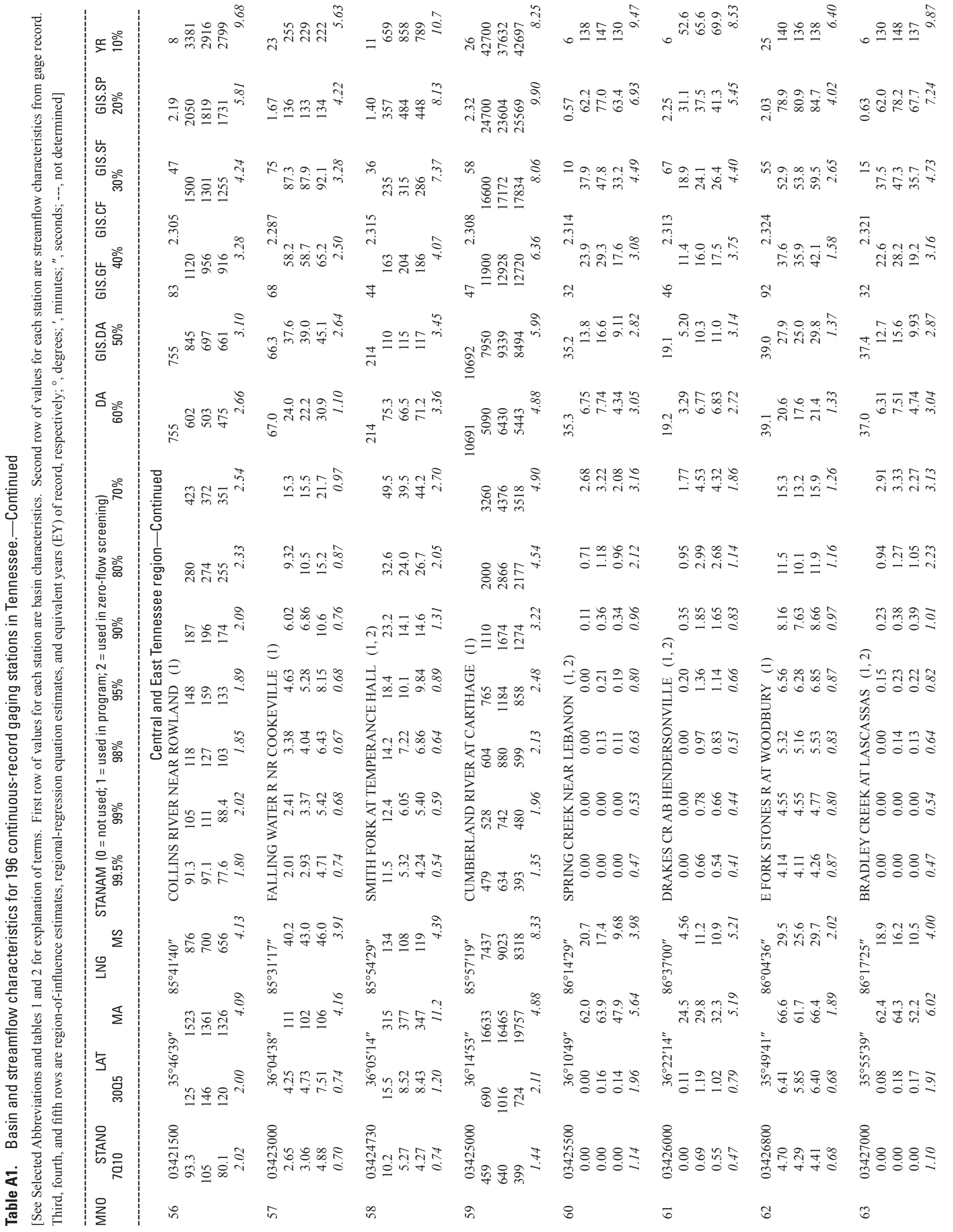




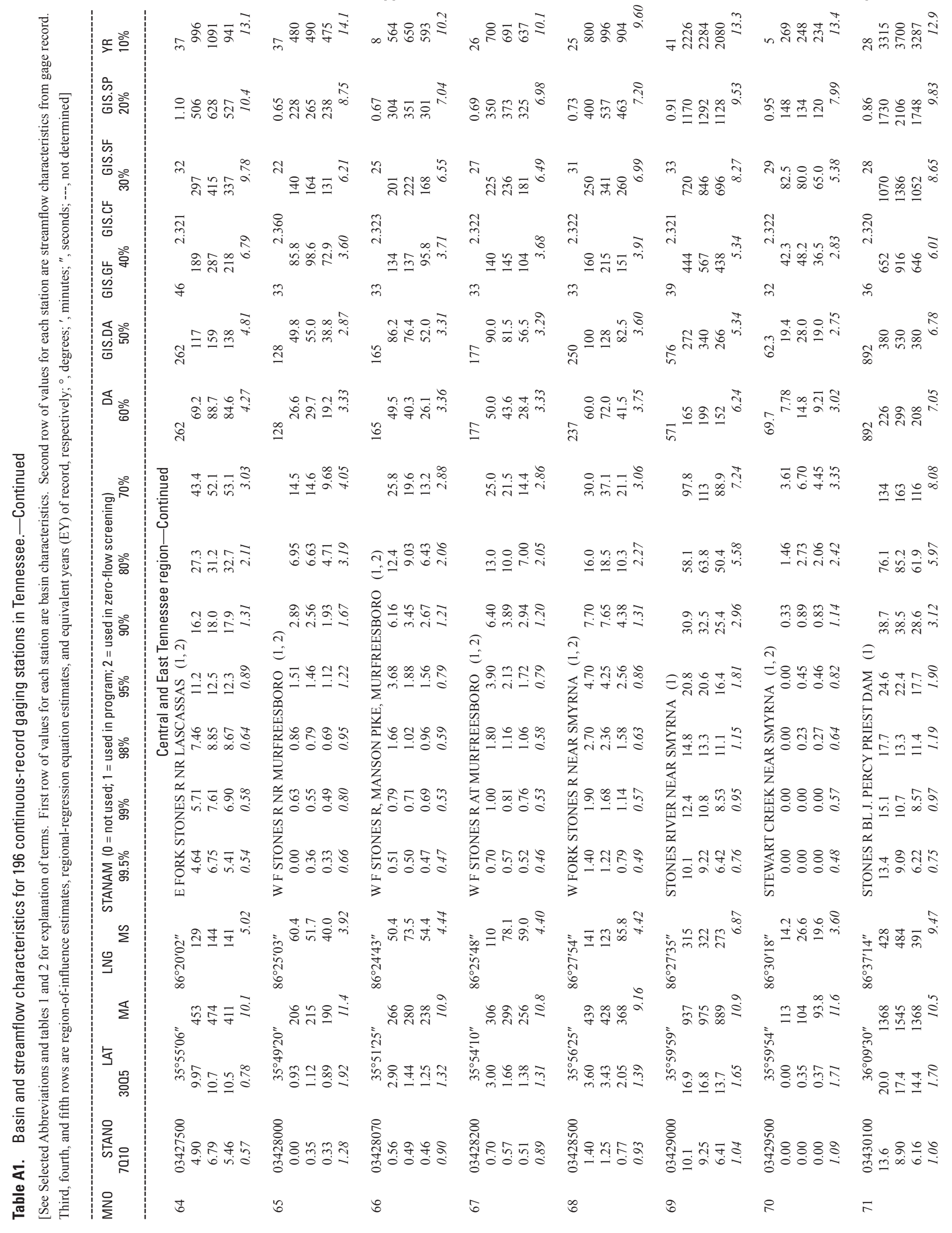




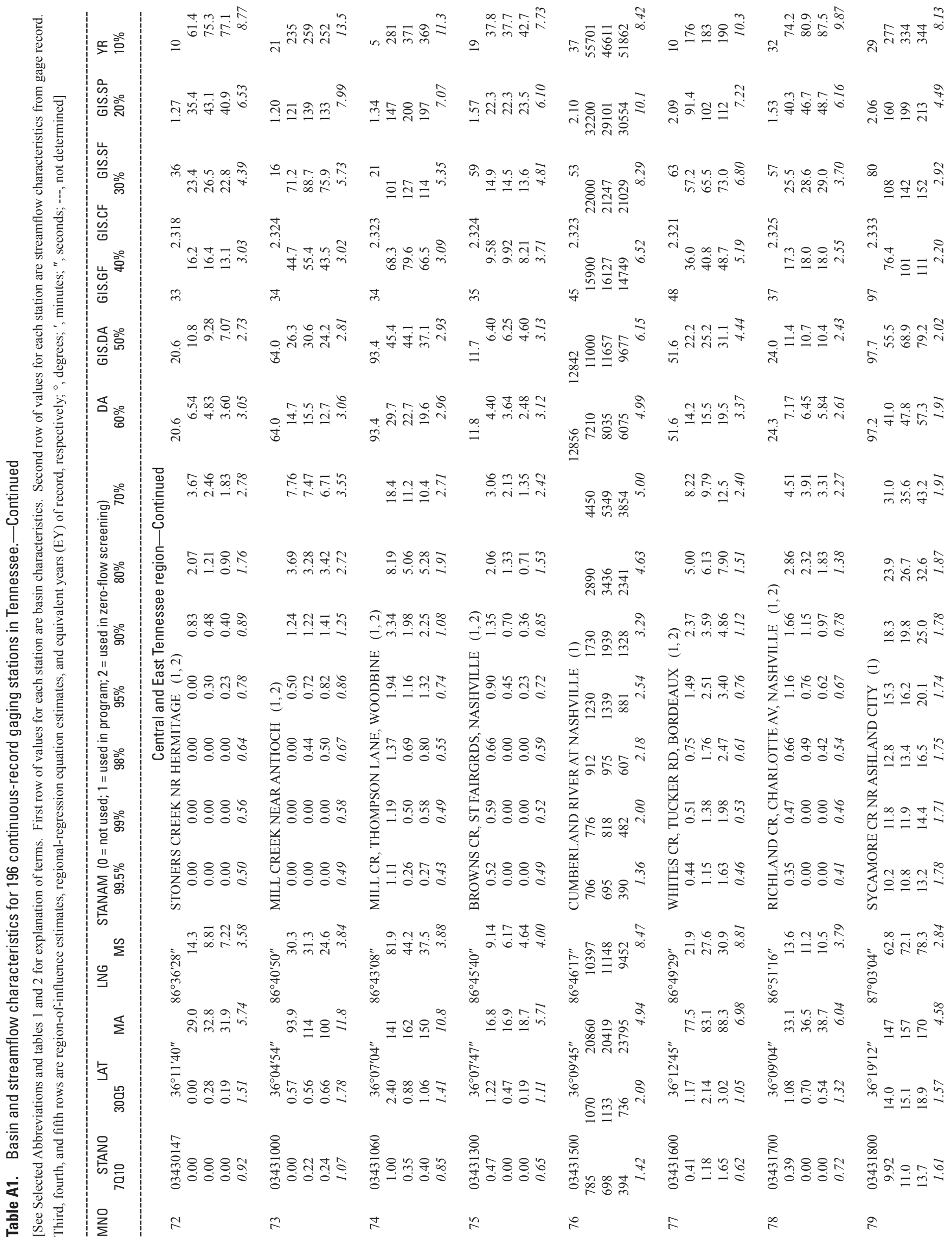




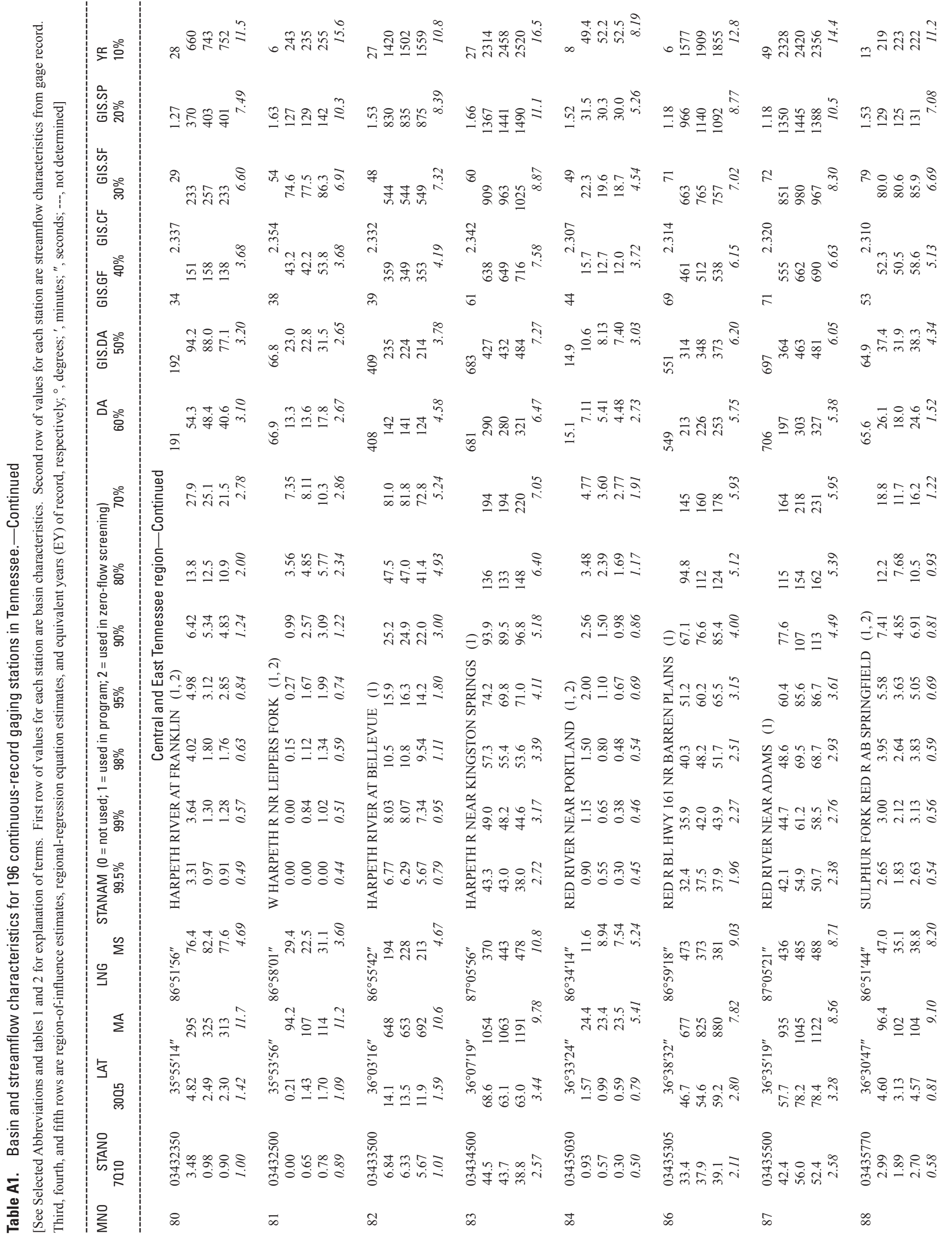




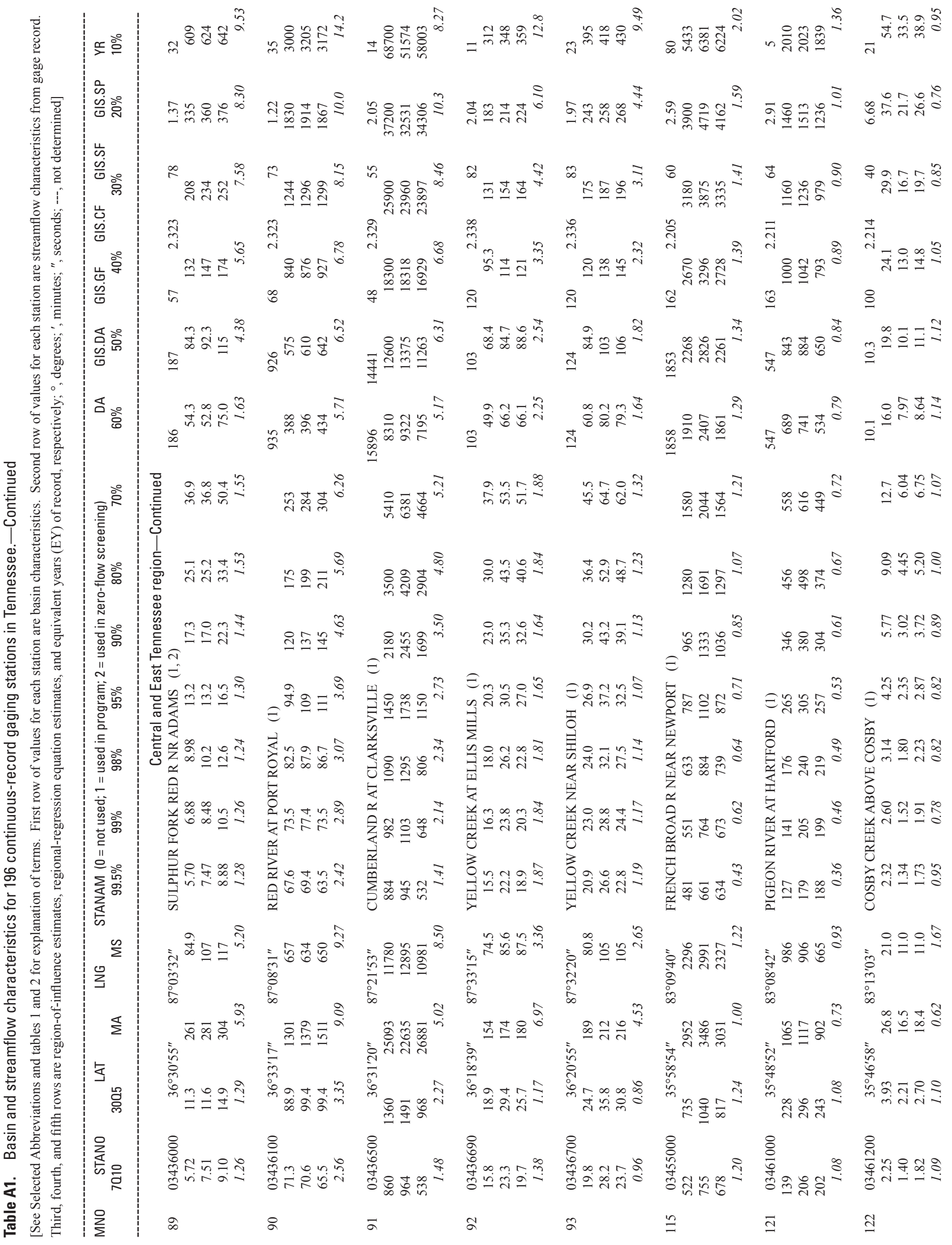




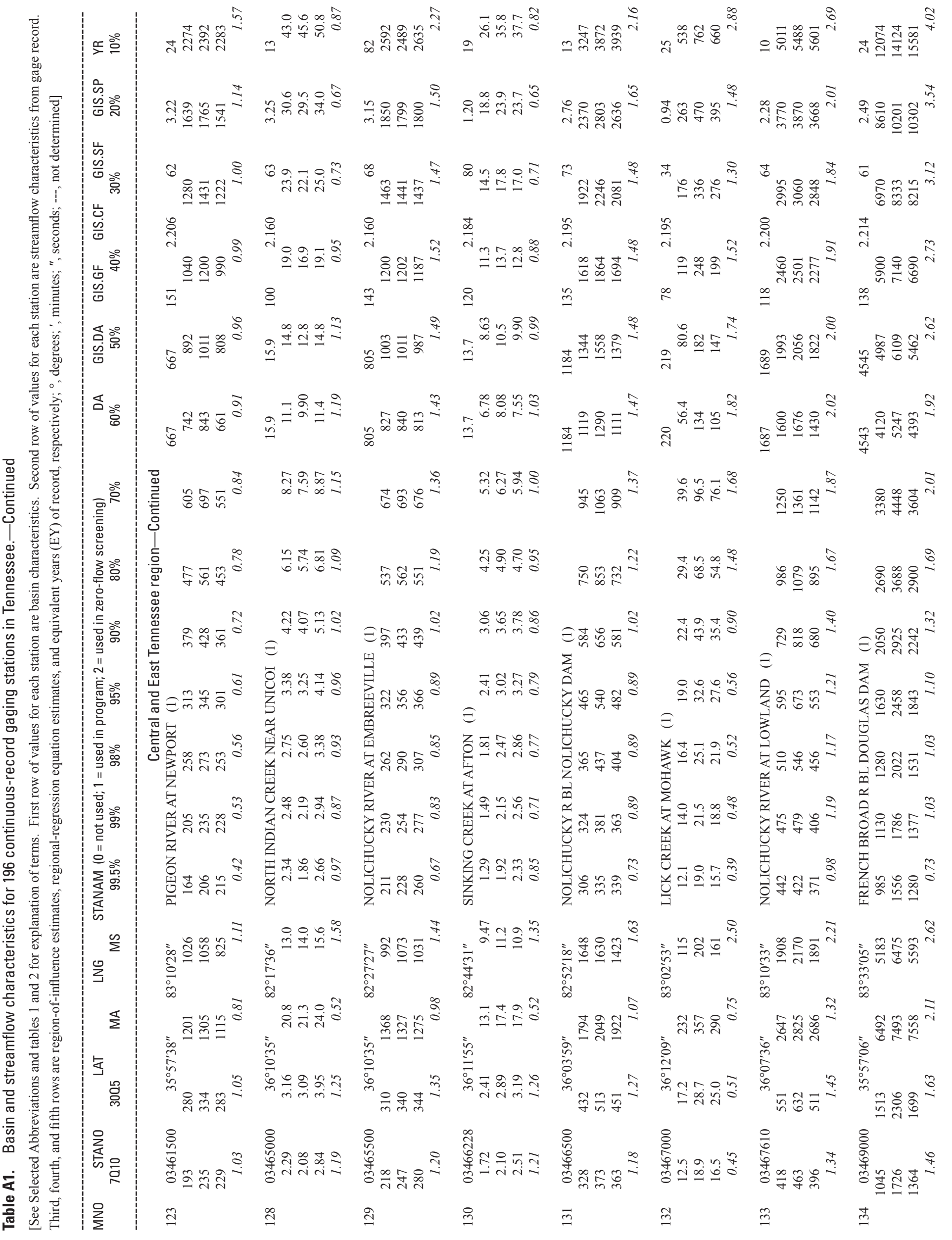




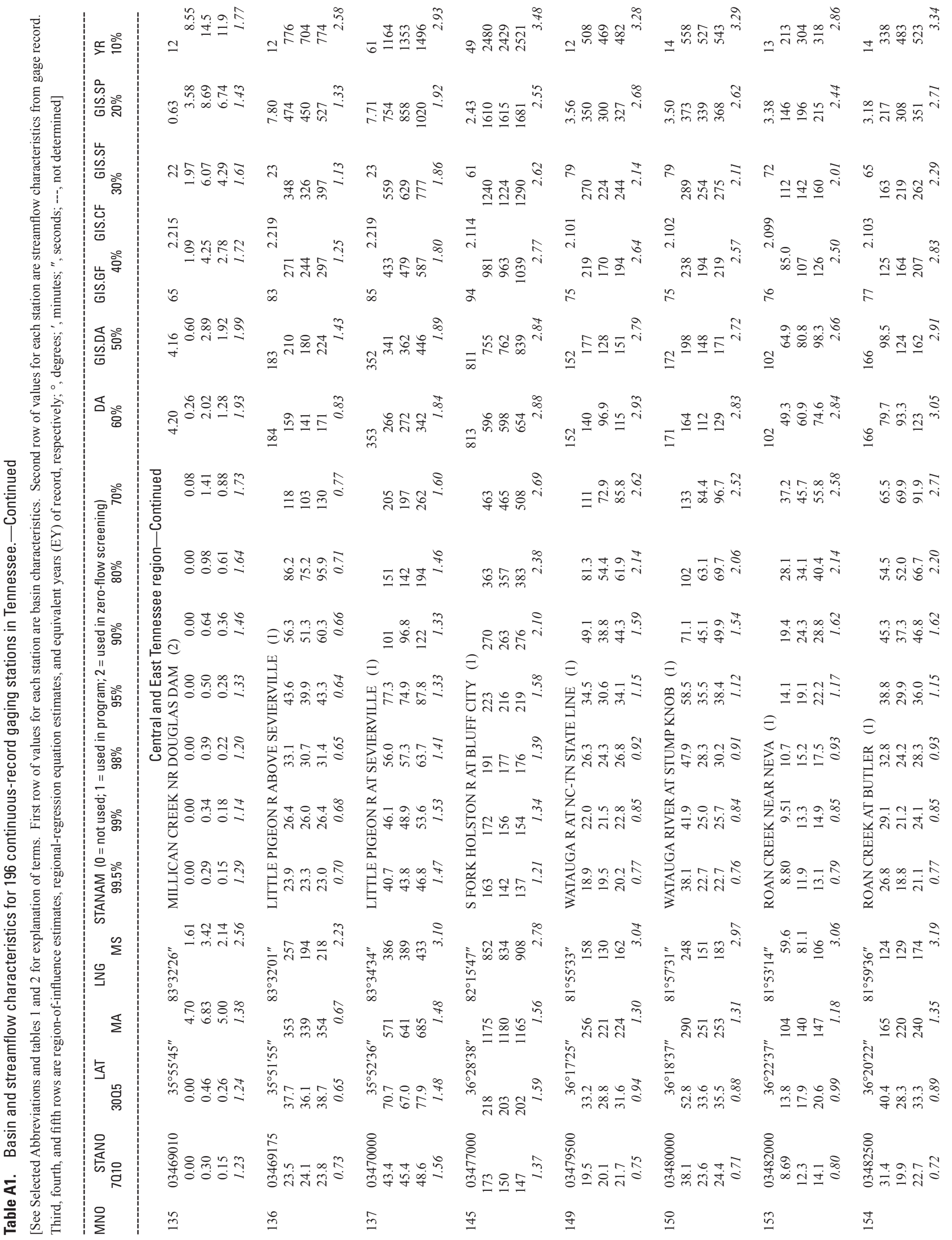




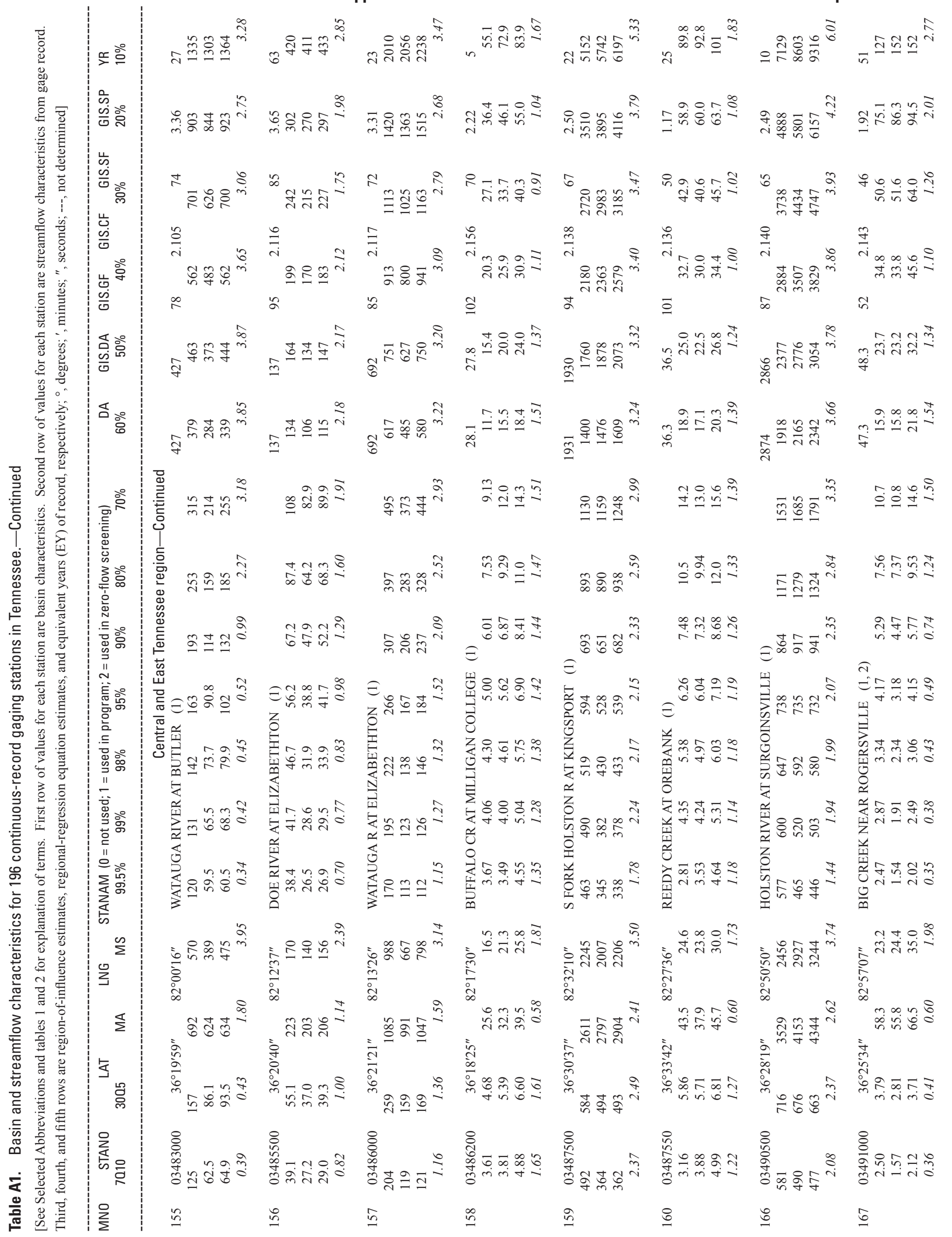




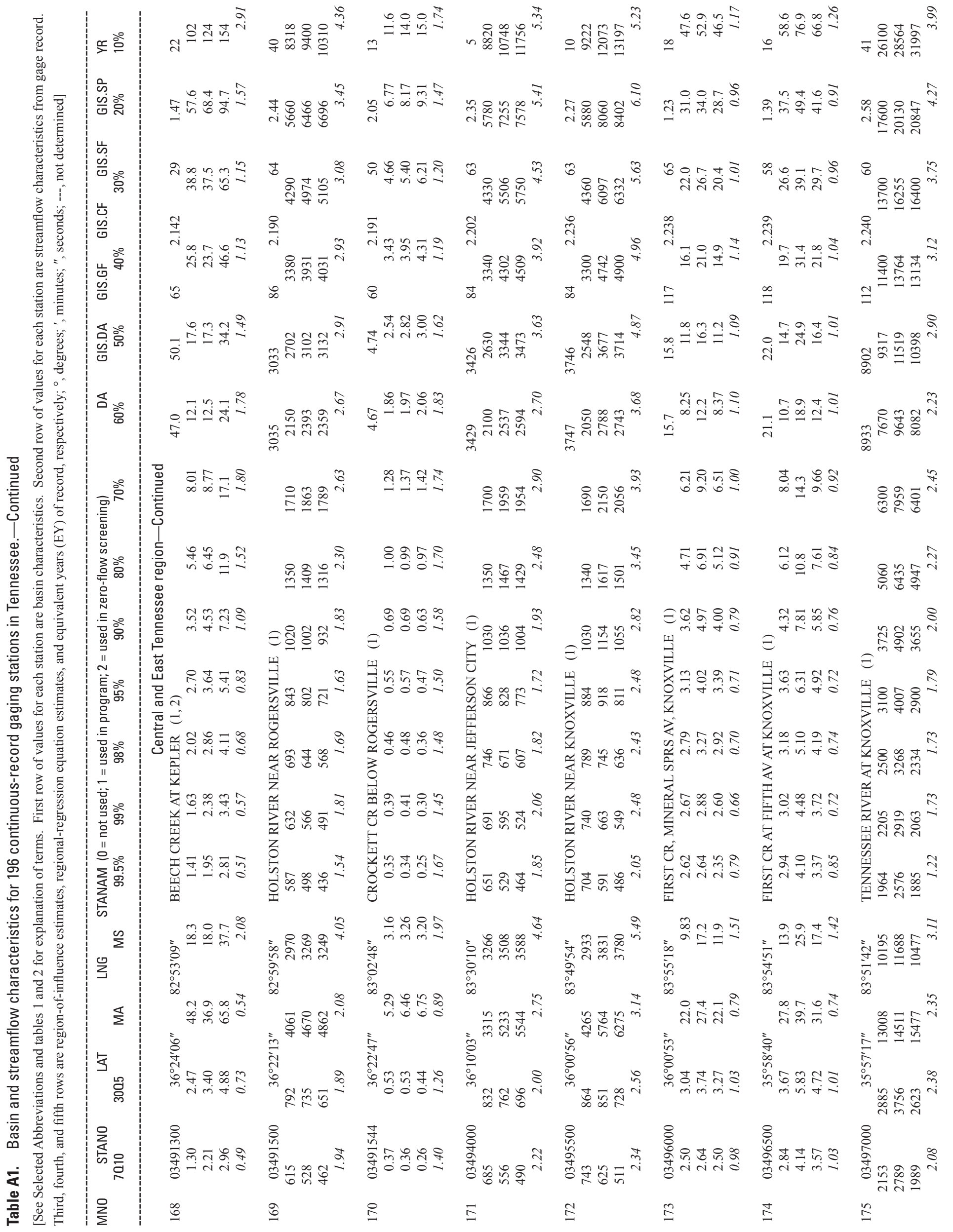




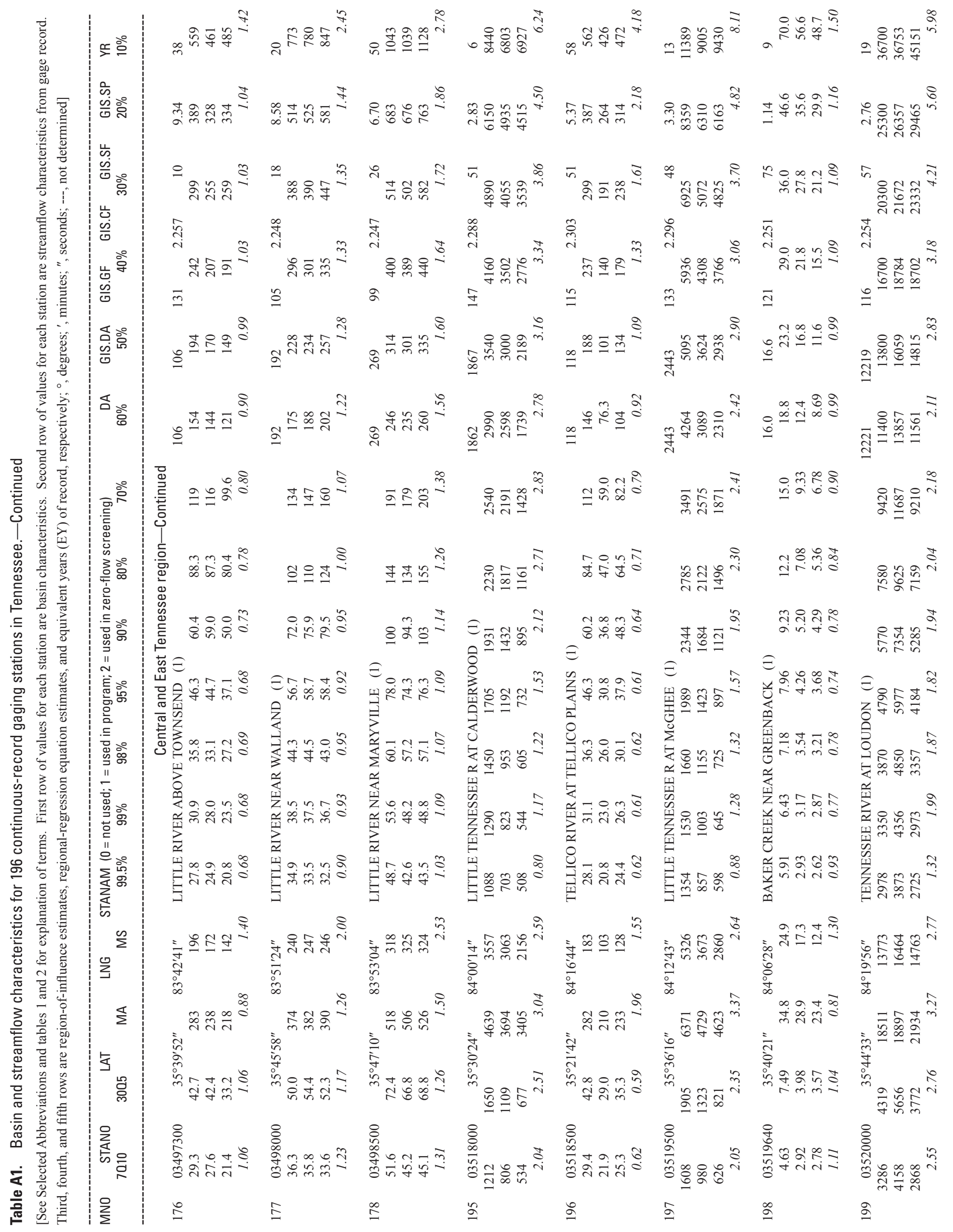




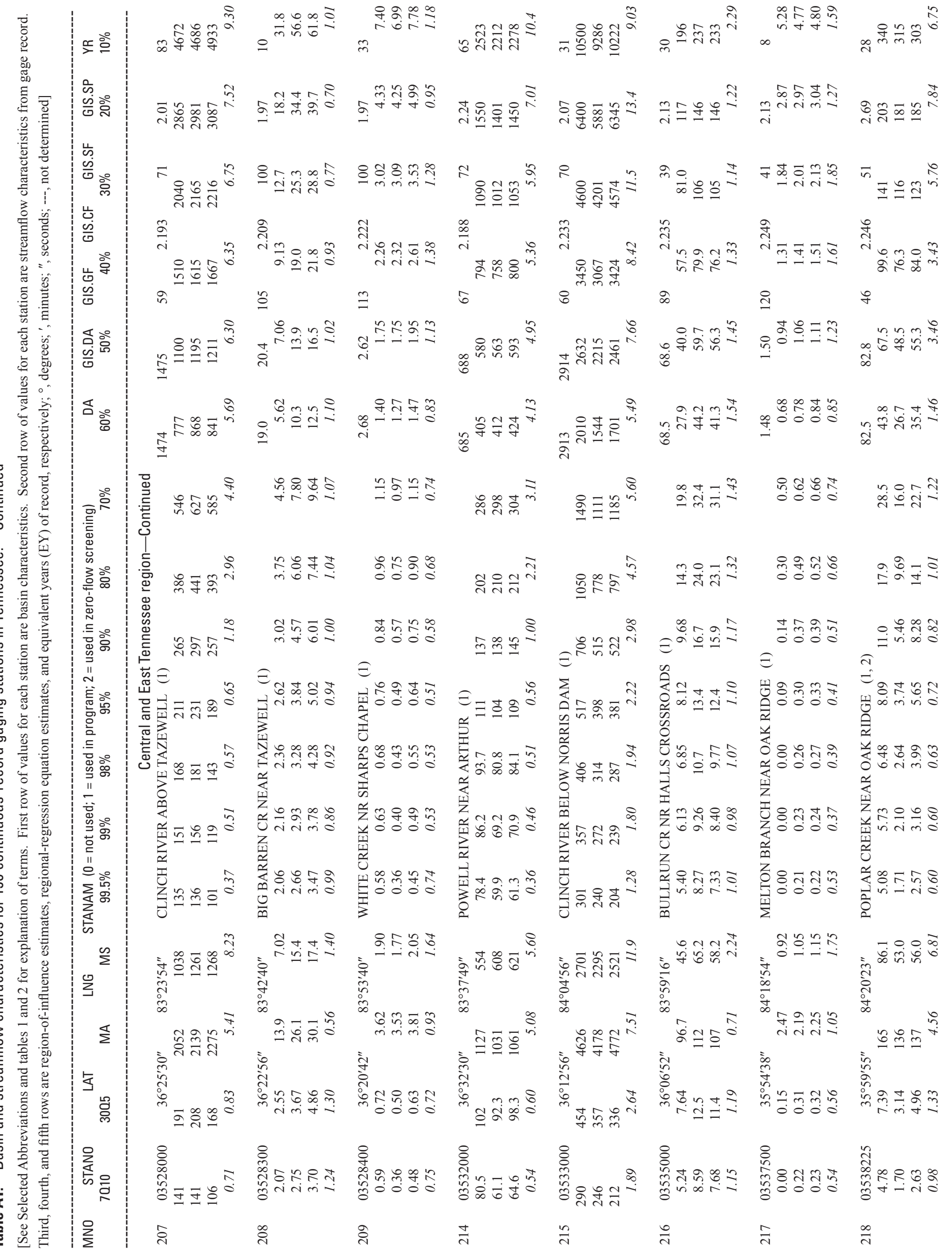




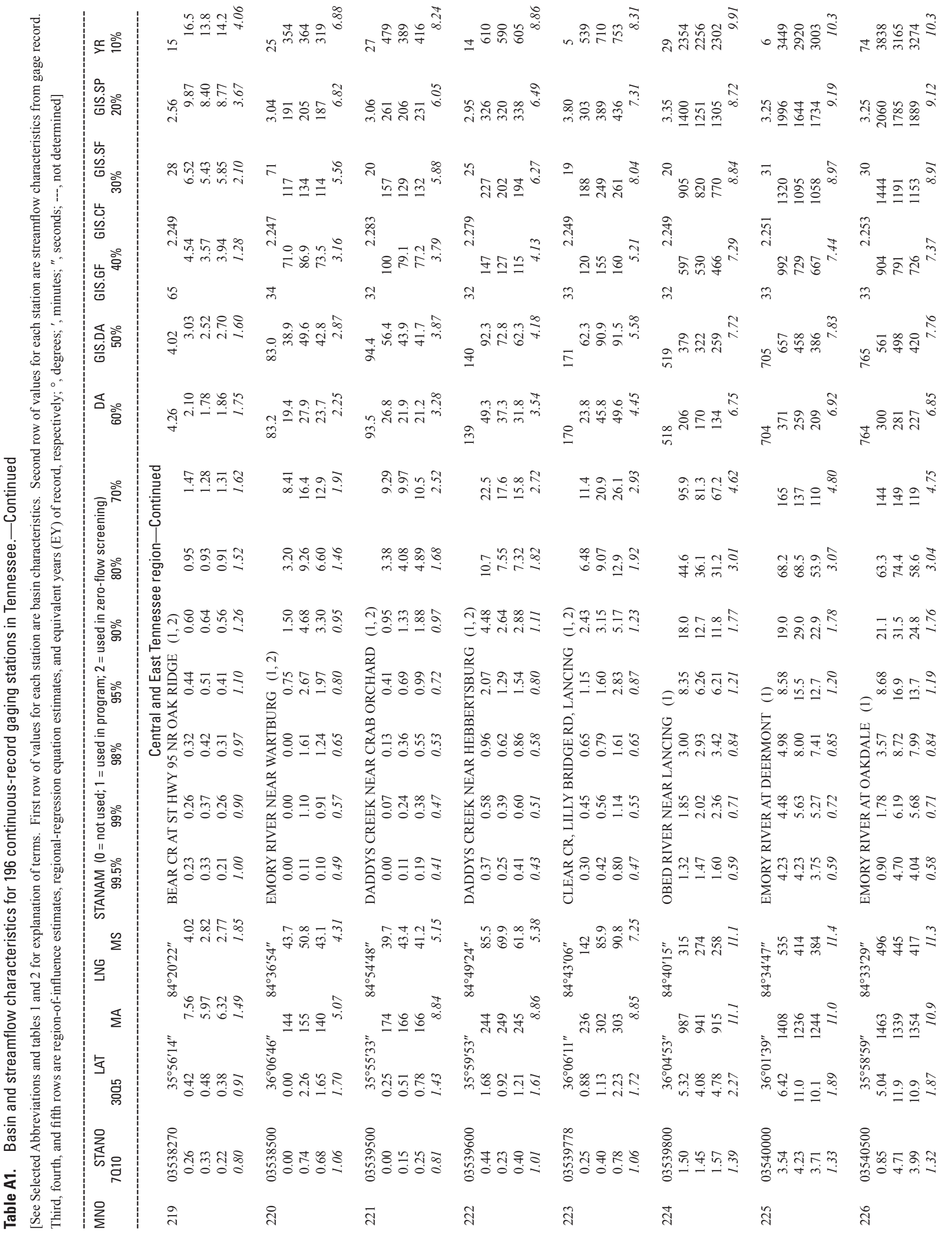




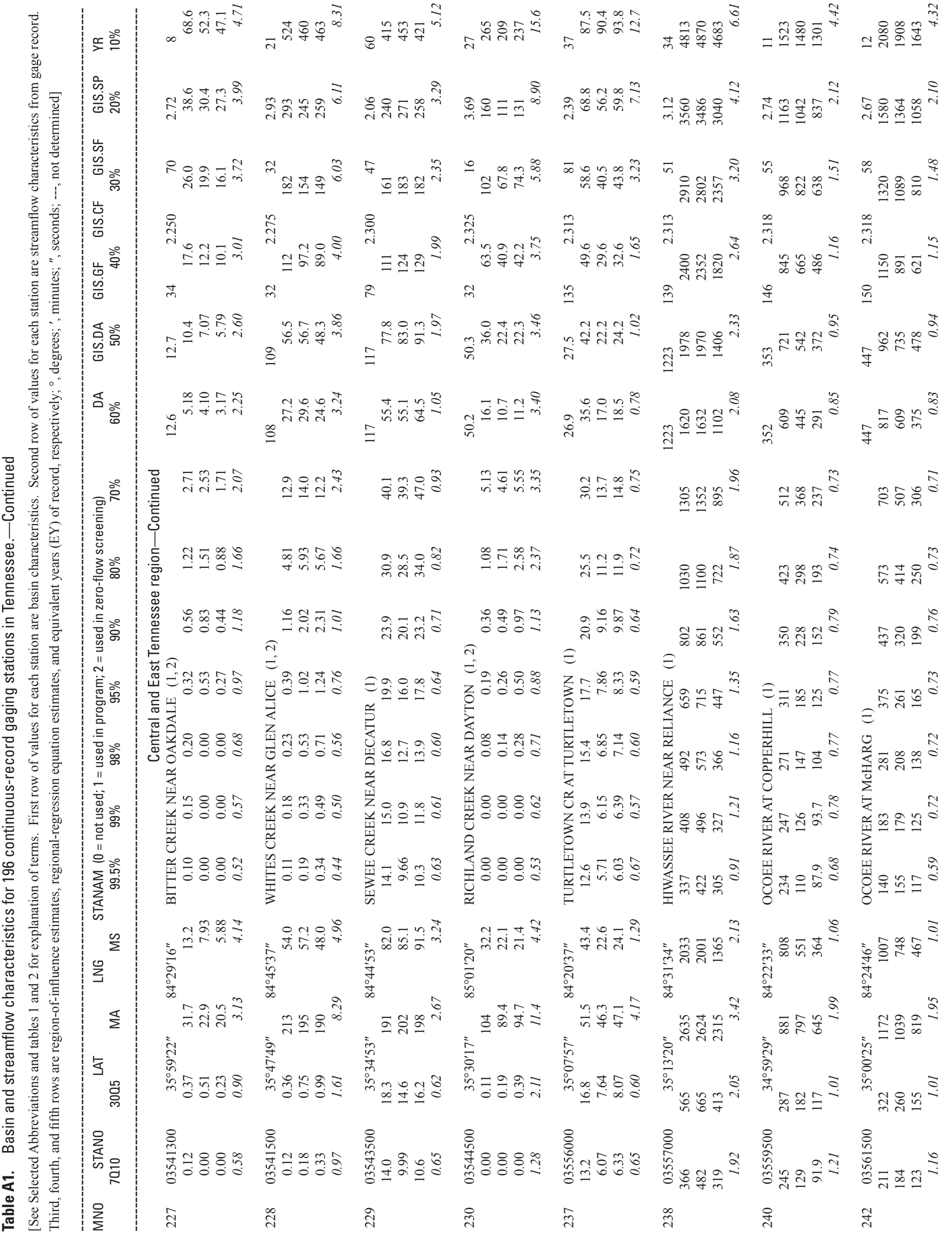




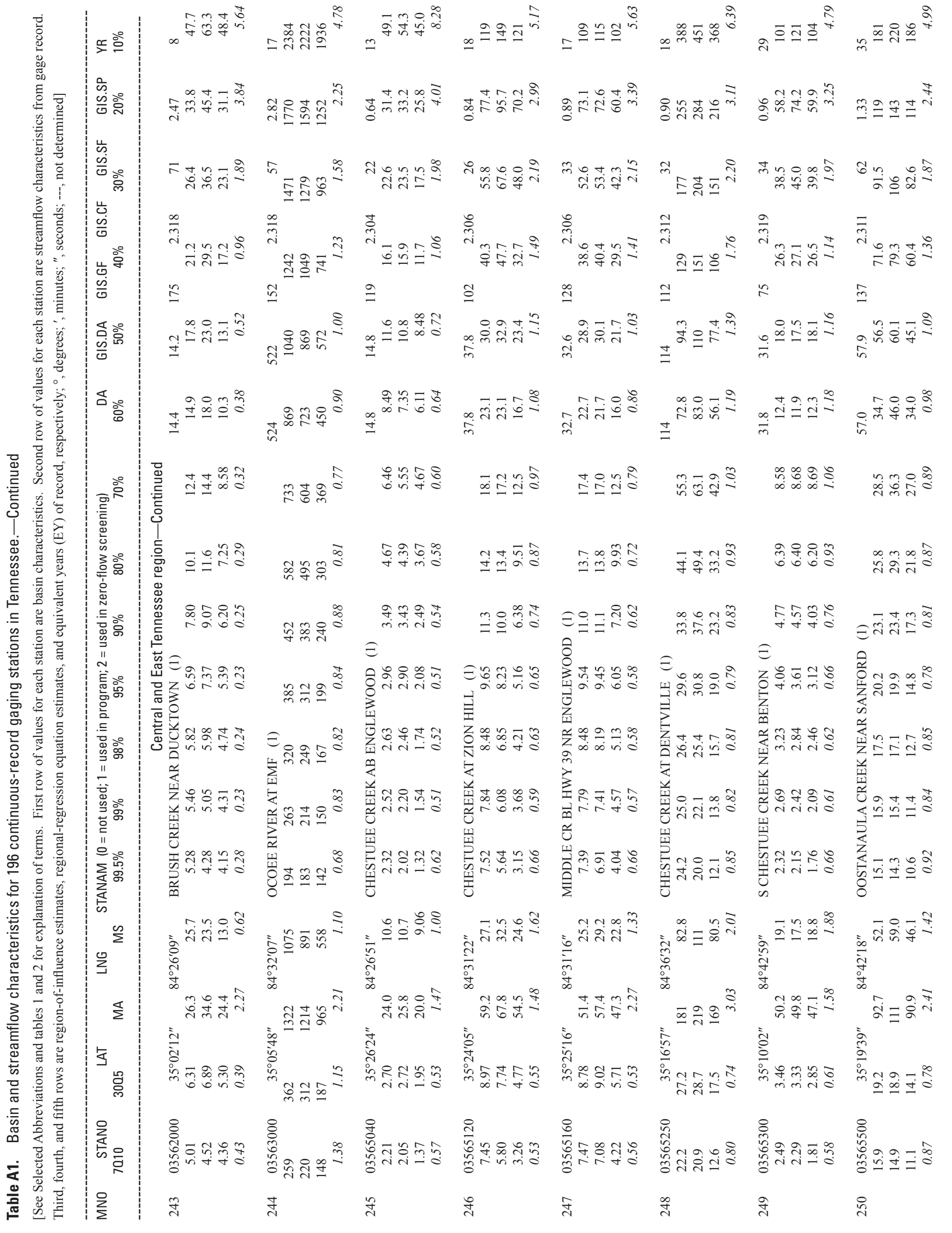




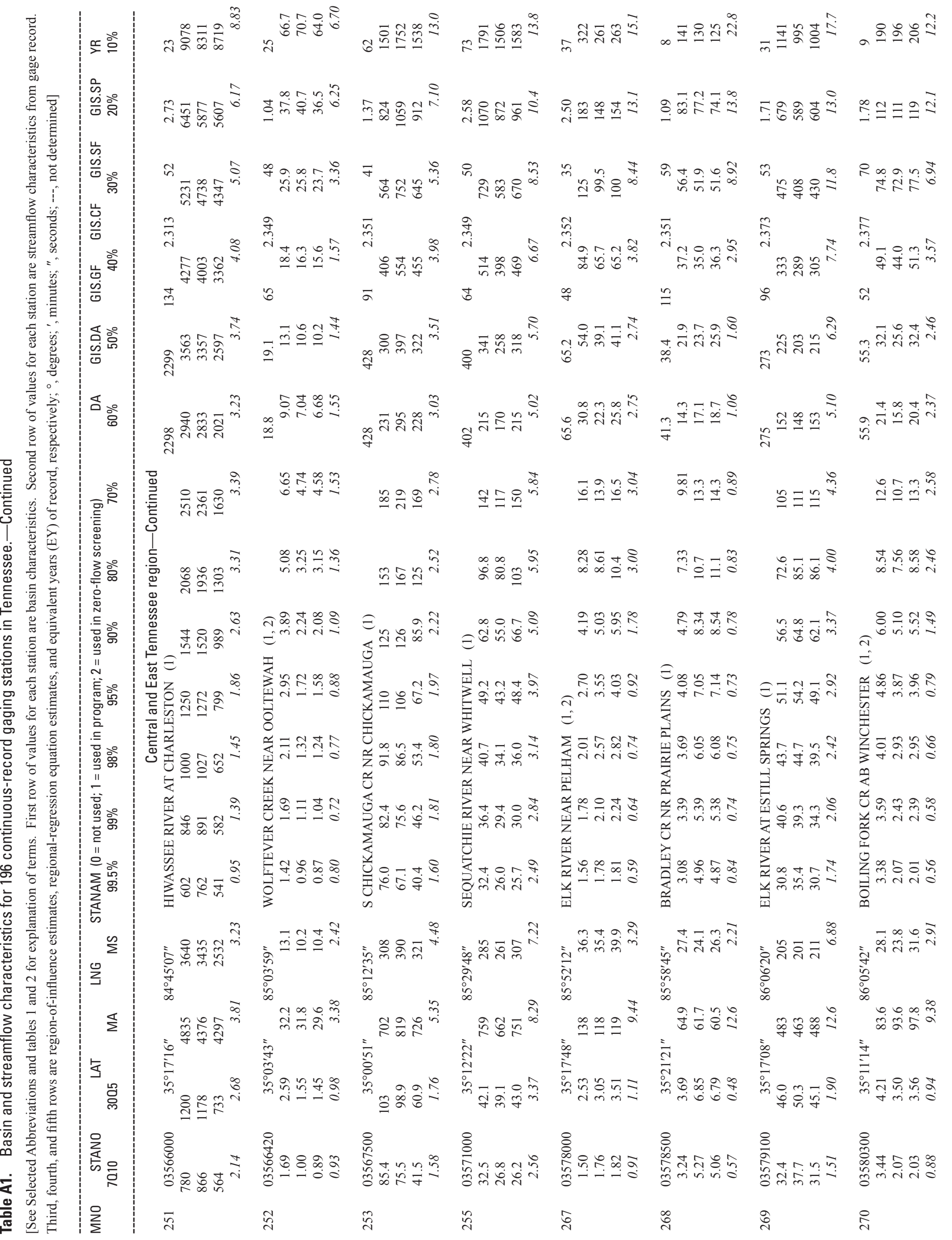




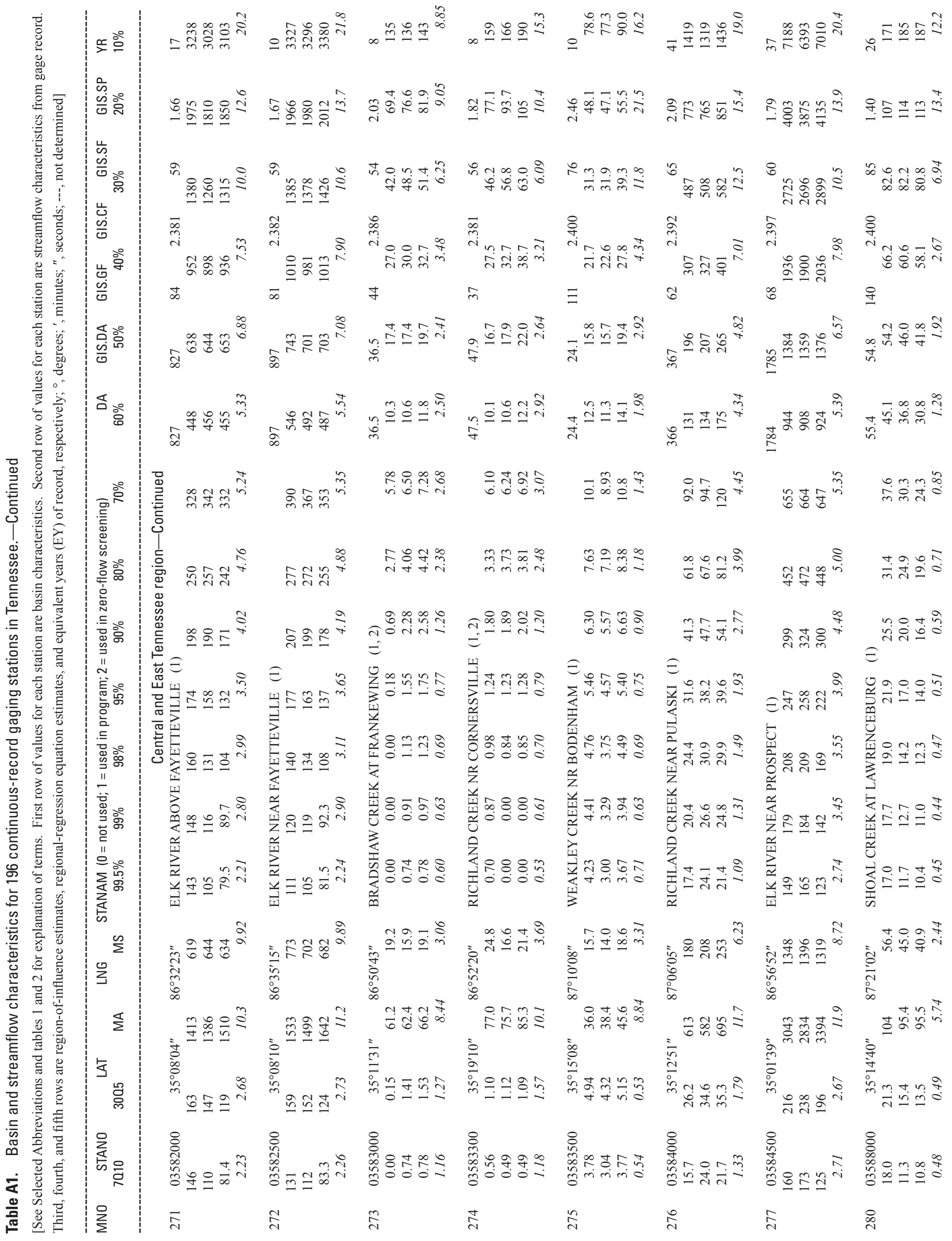




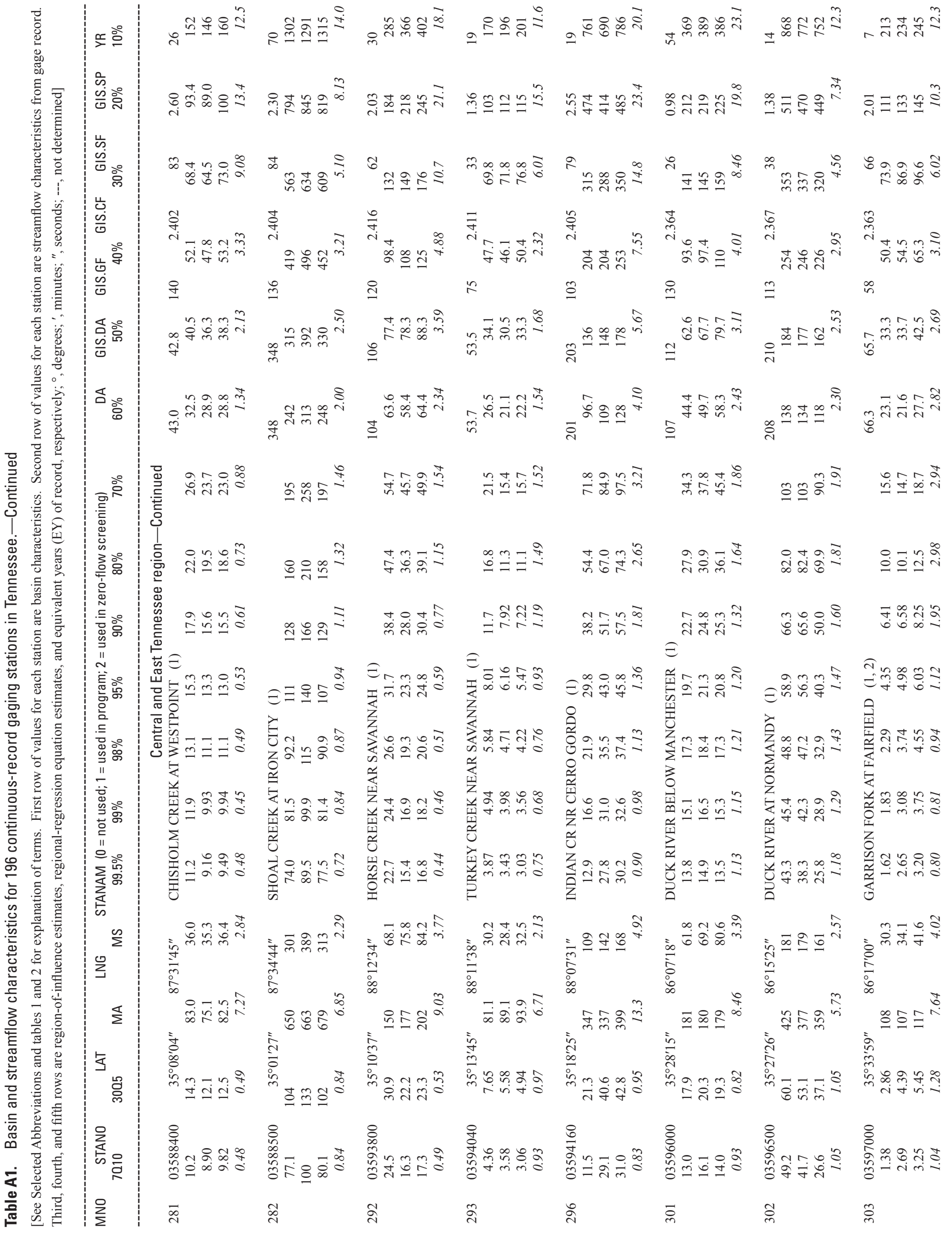


Appendix A. Basin and Streamflow Characteristics for Sites in This Report

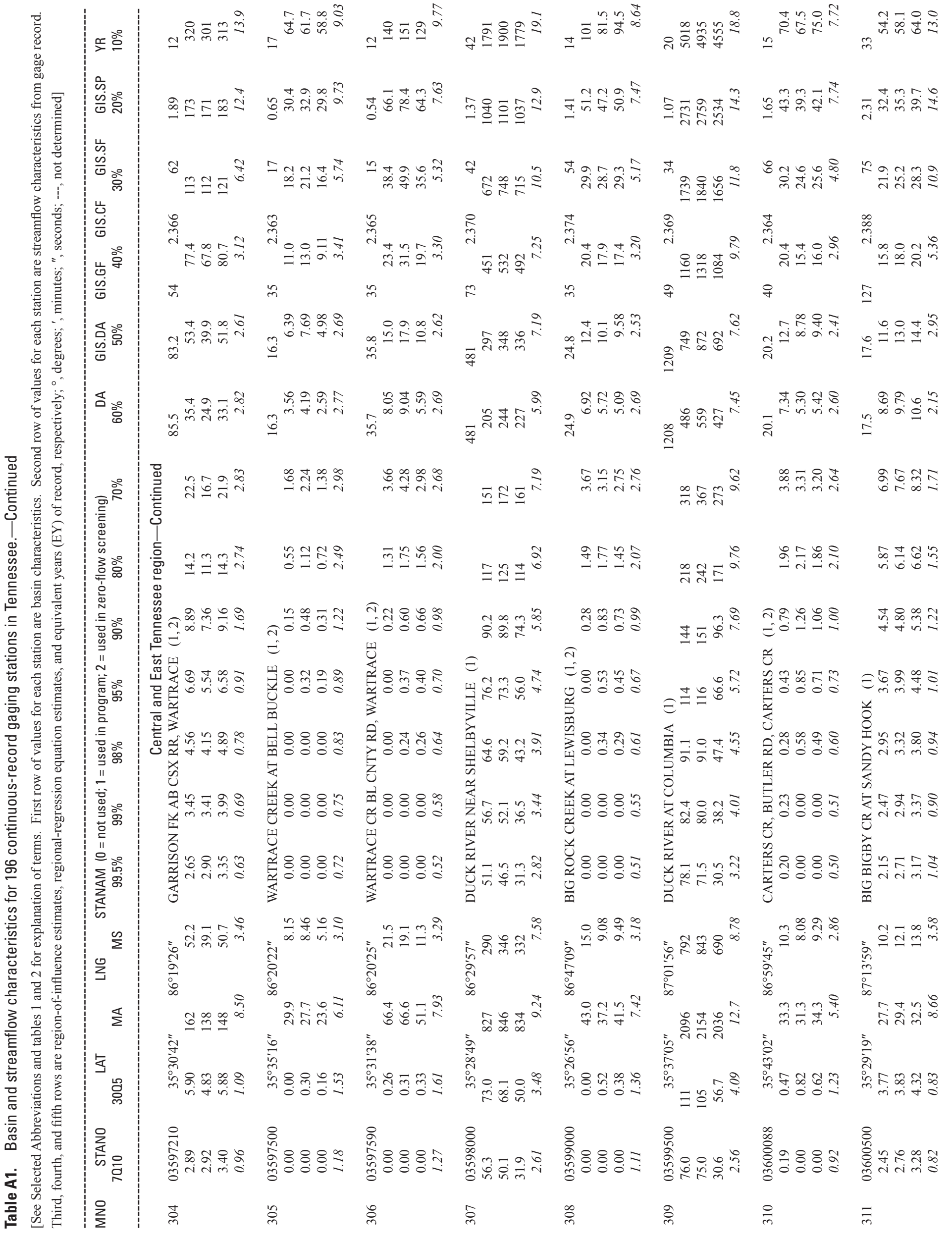




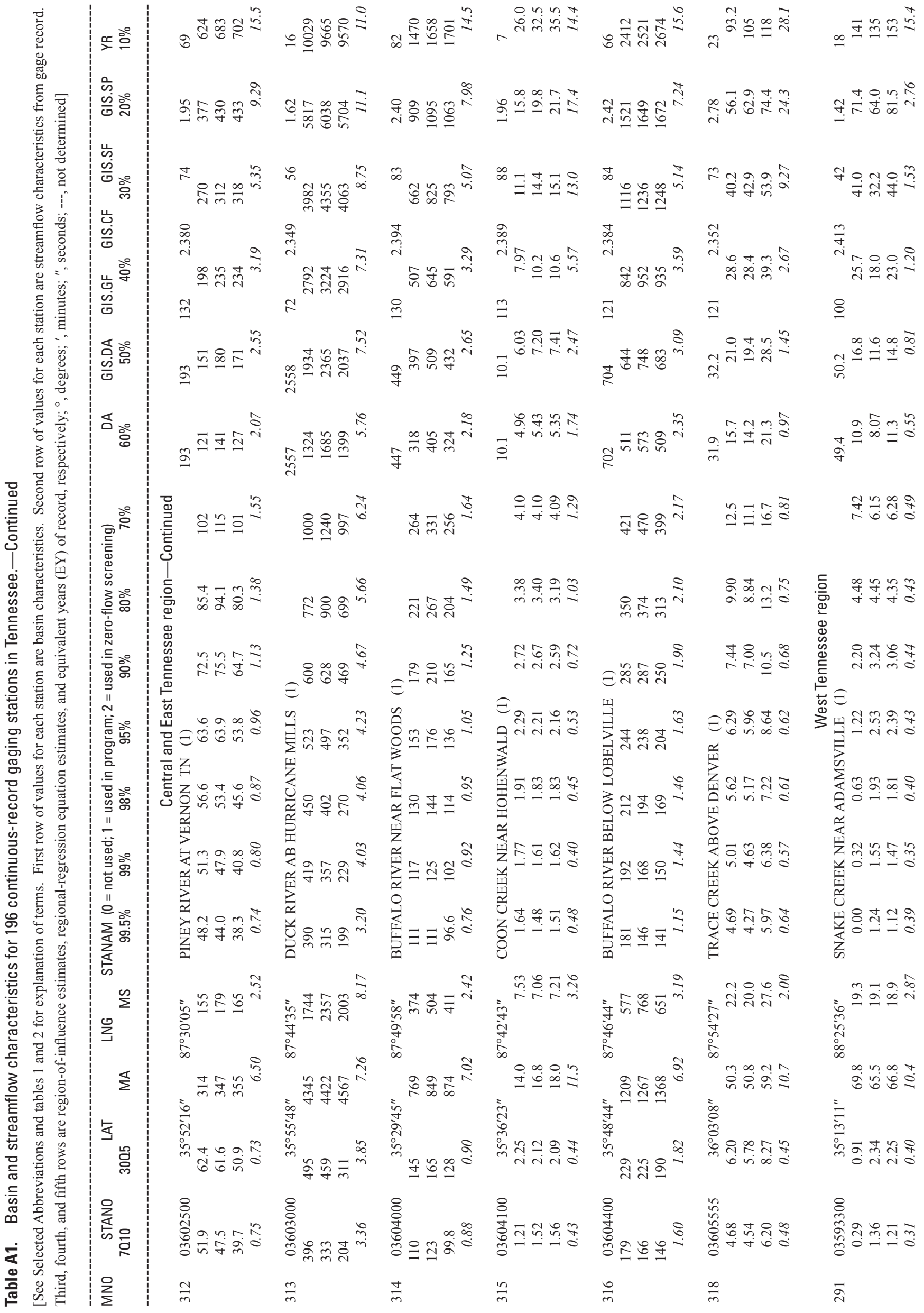




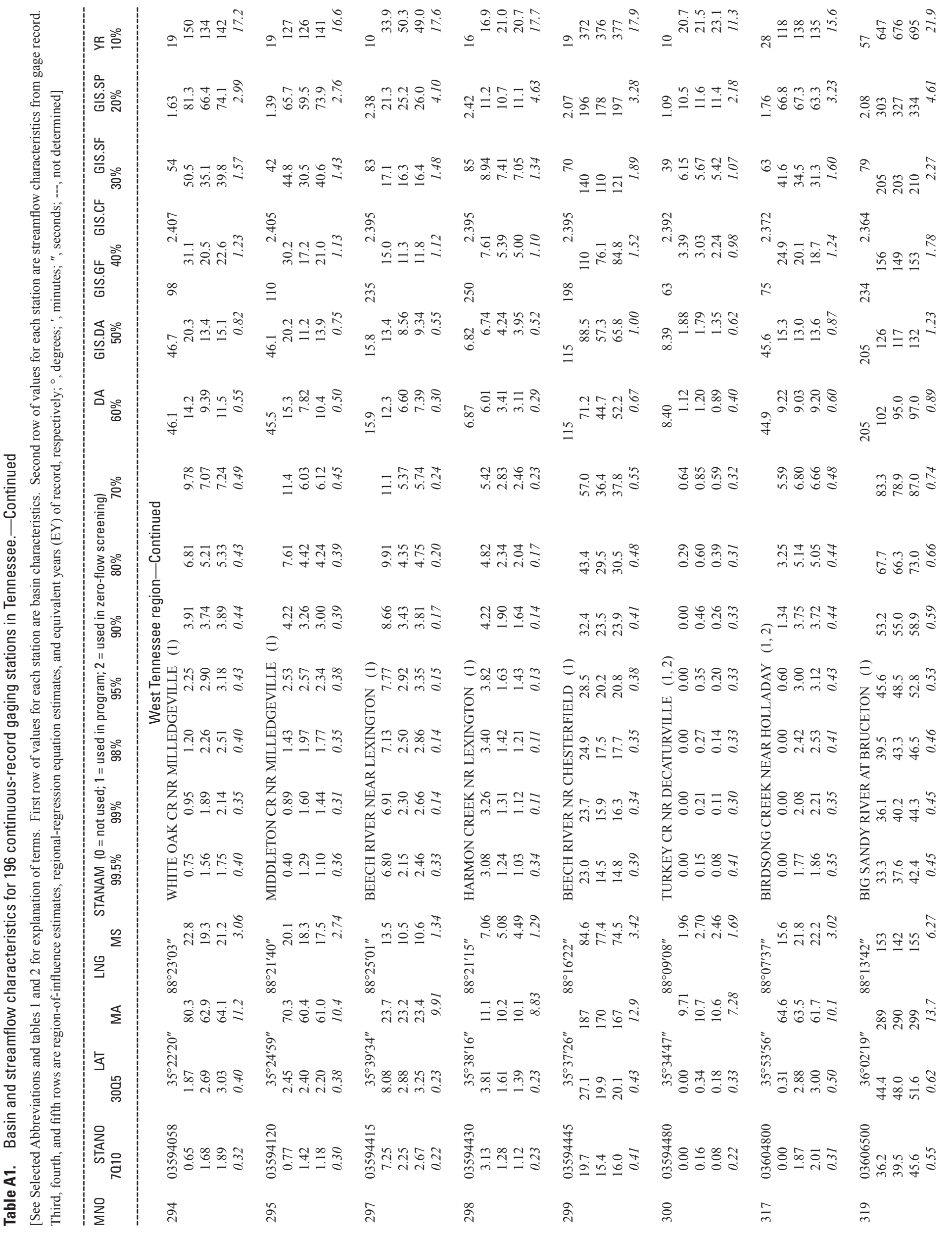




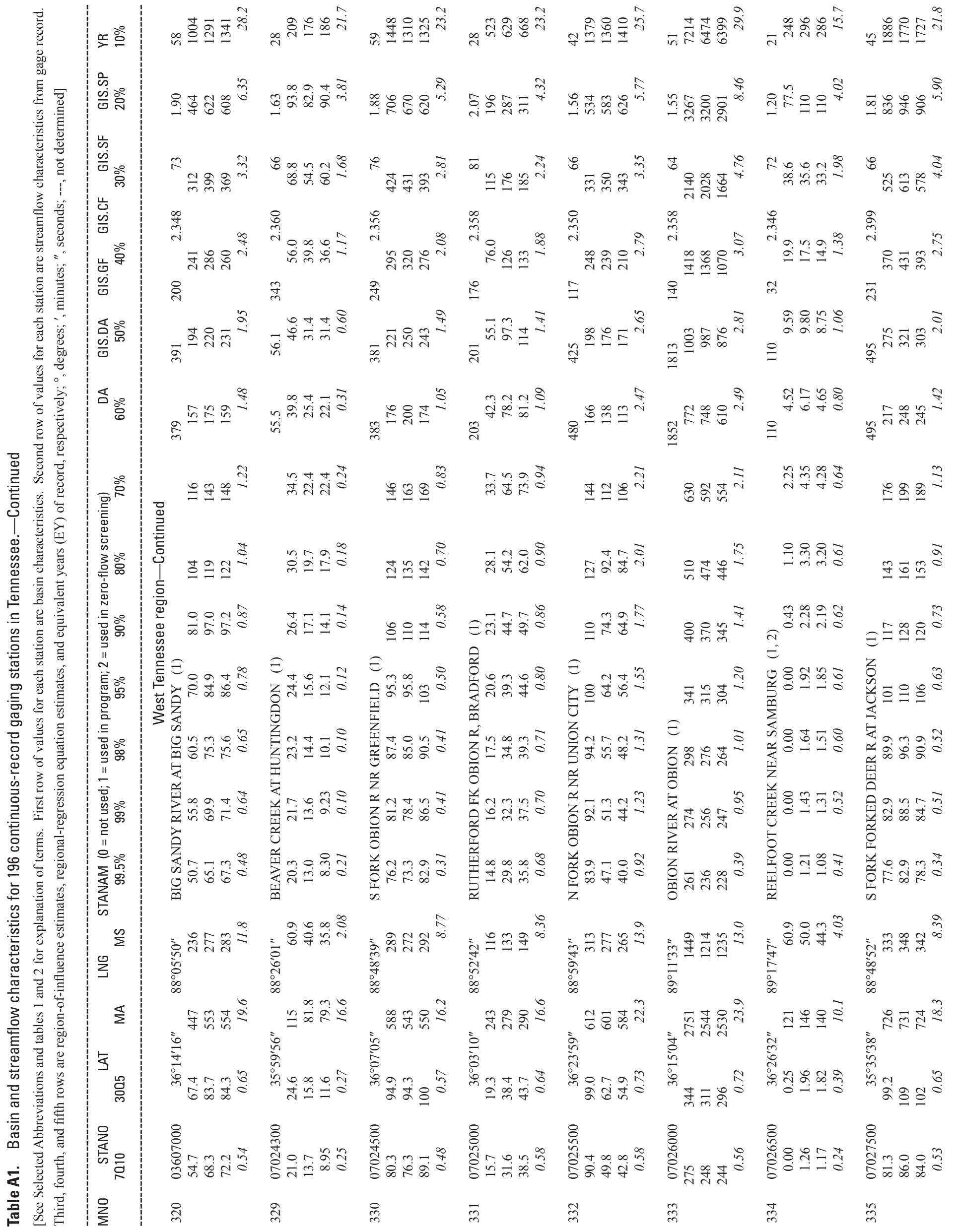




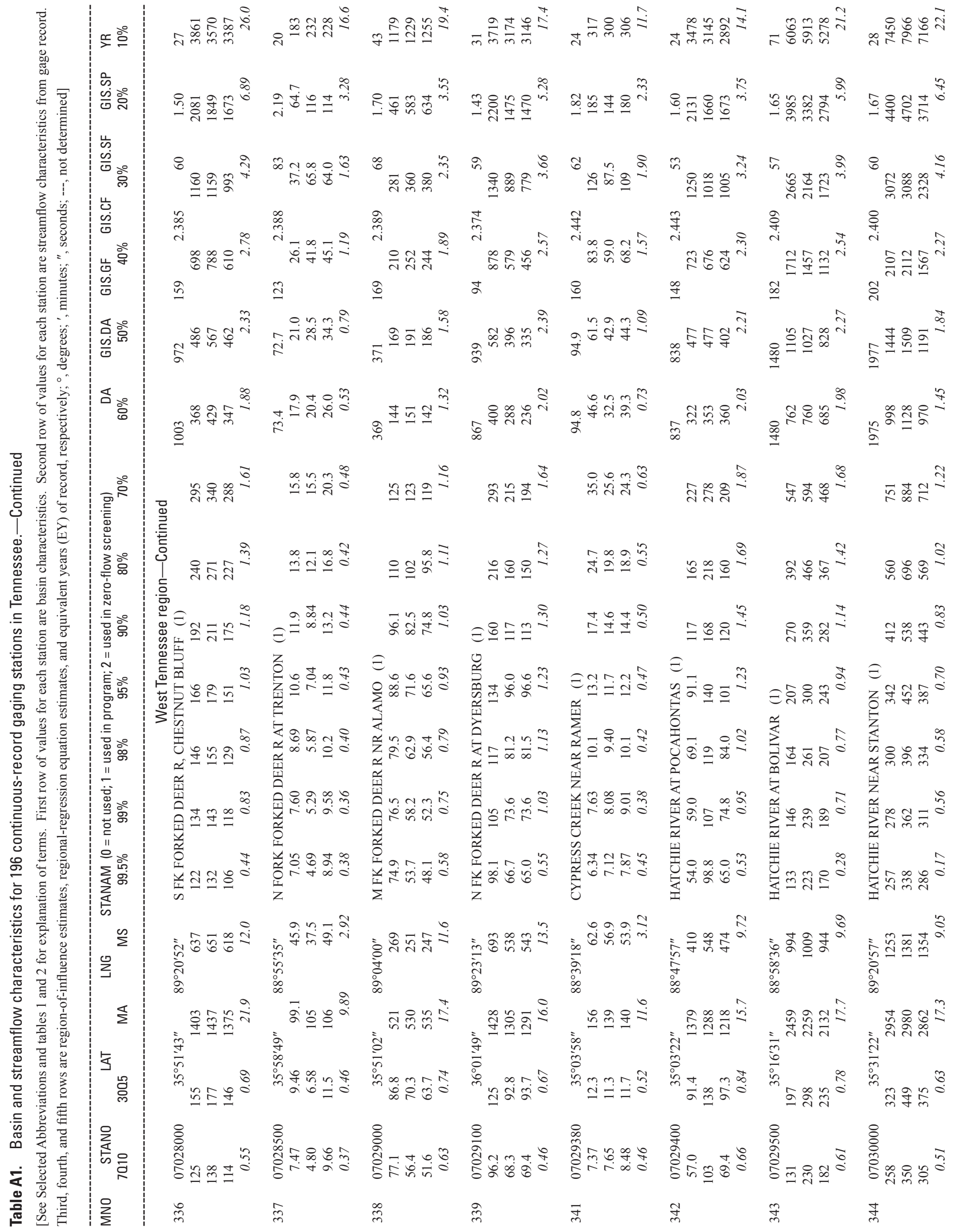




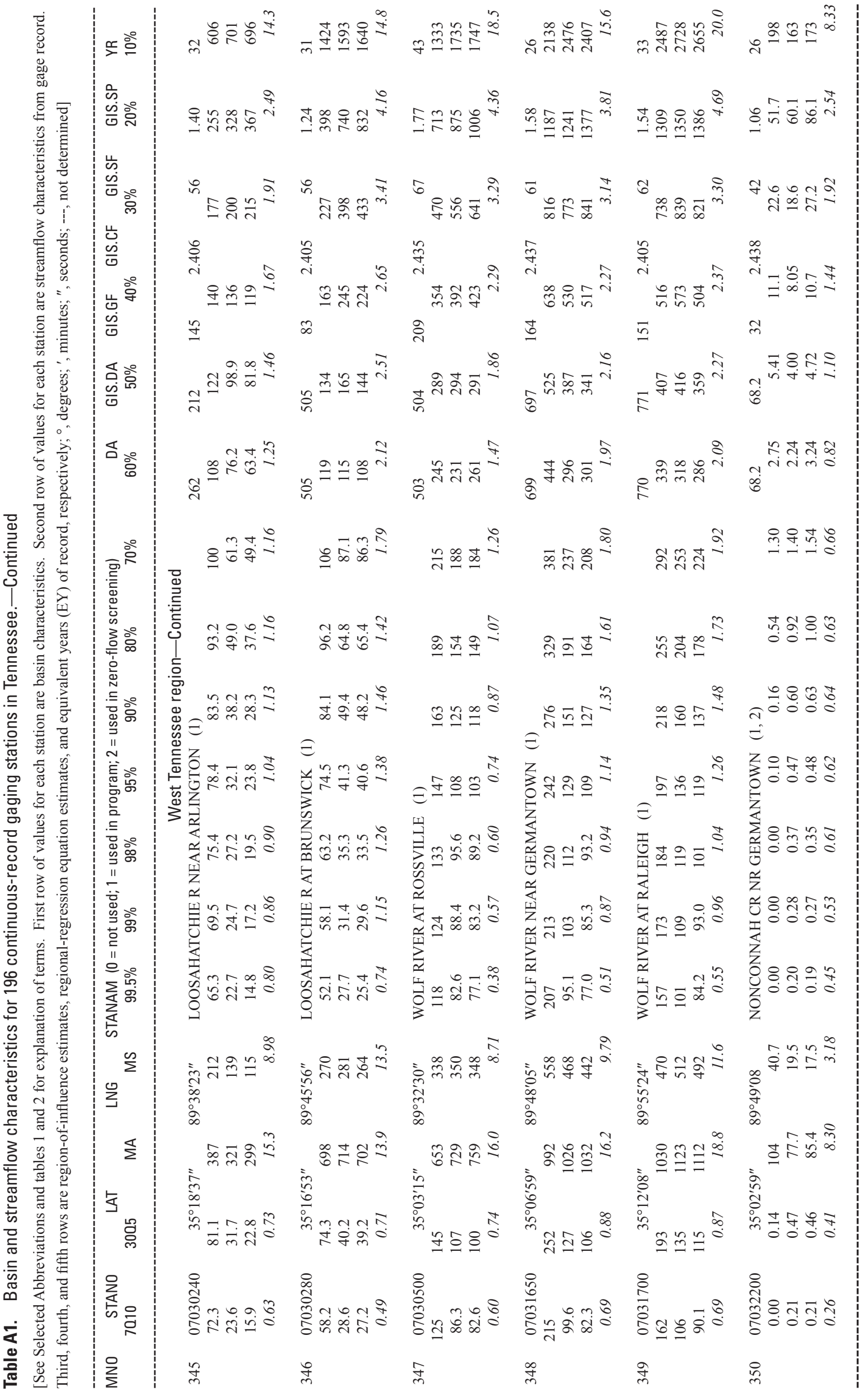




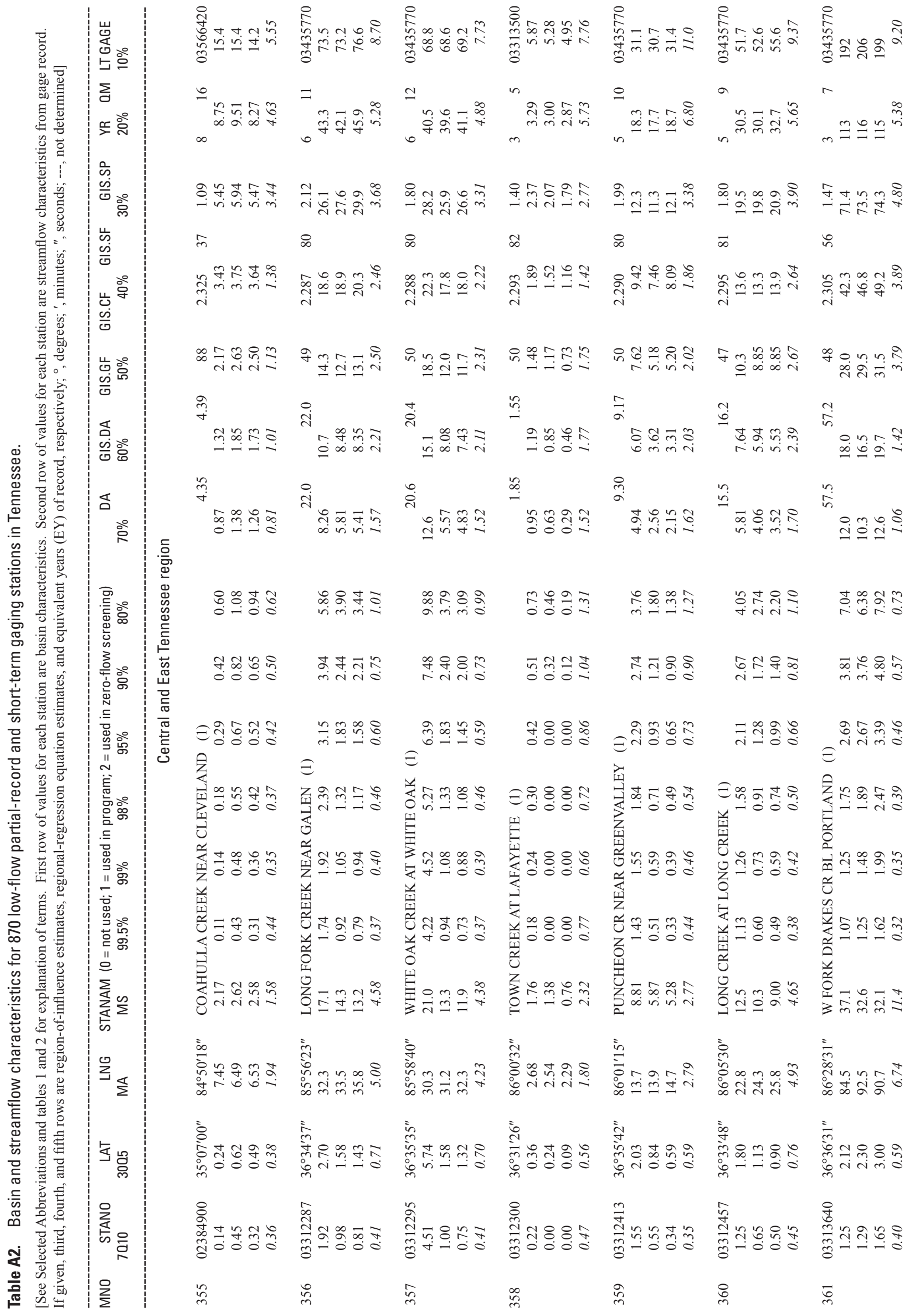




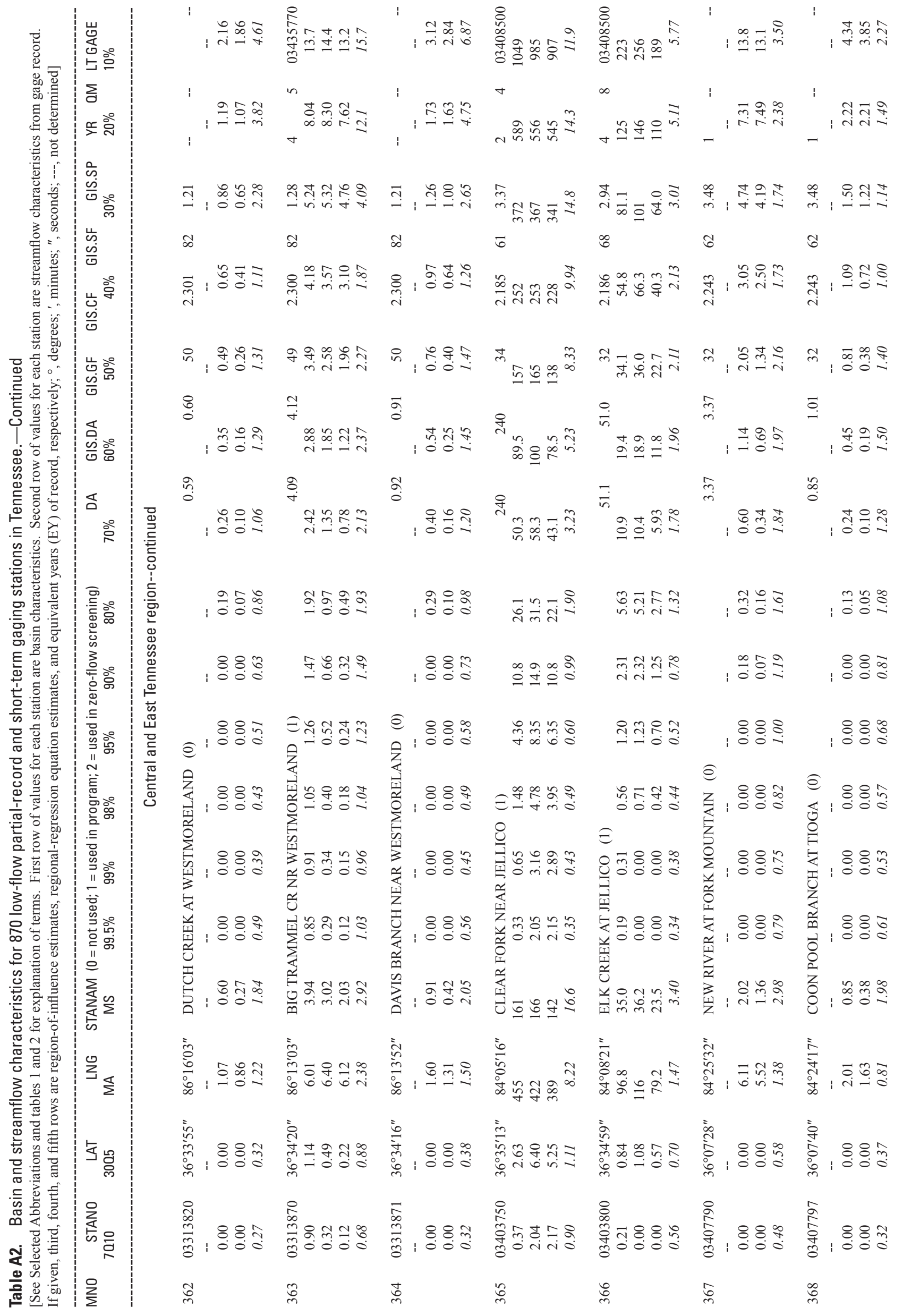




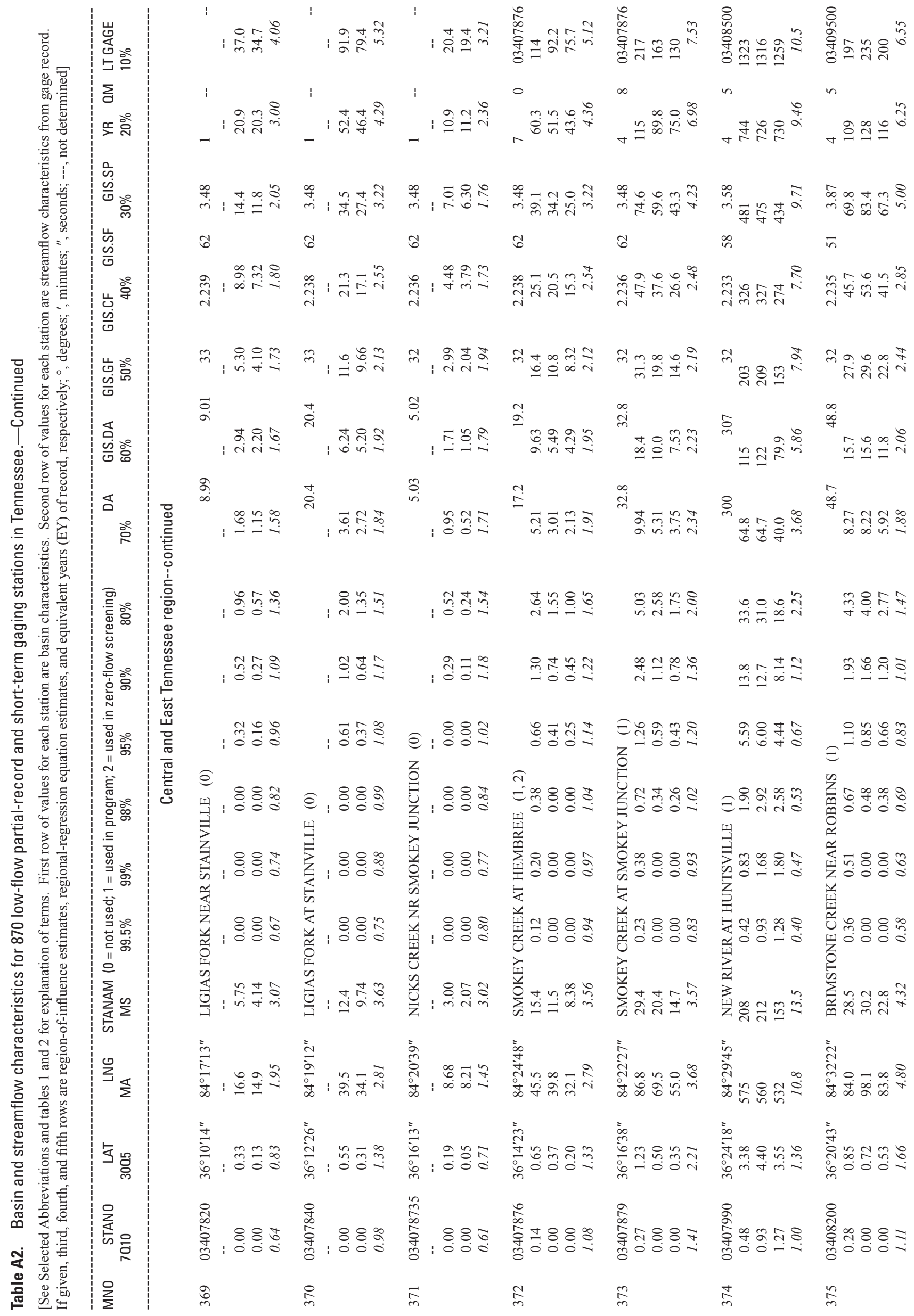




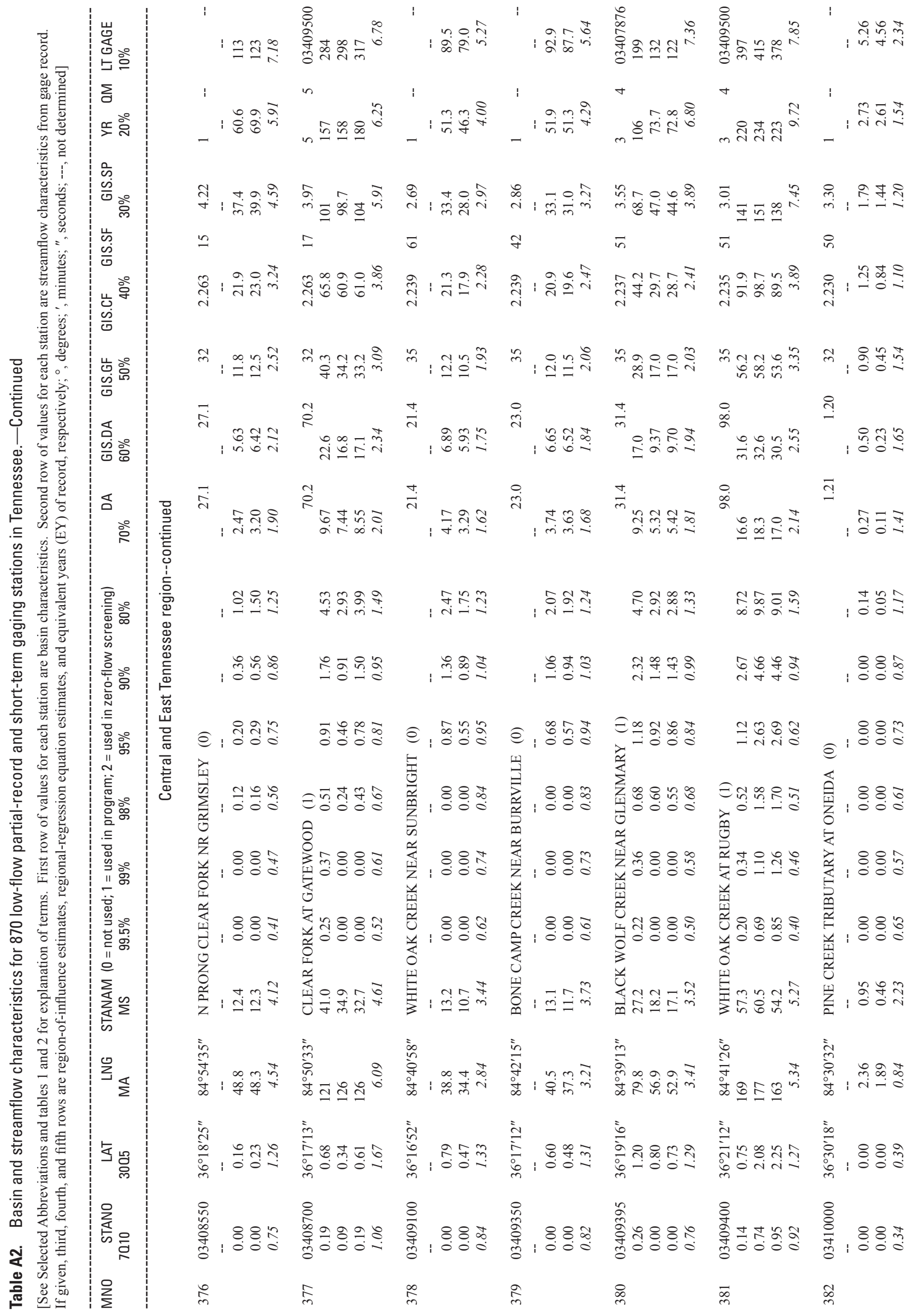


Appendix A. Basin and Streamflow Characteristics for Sites in This Report

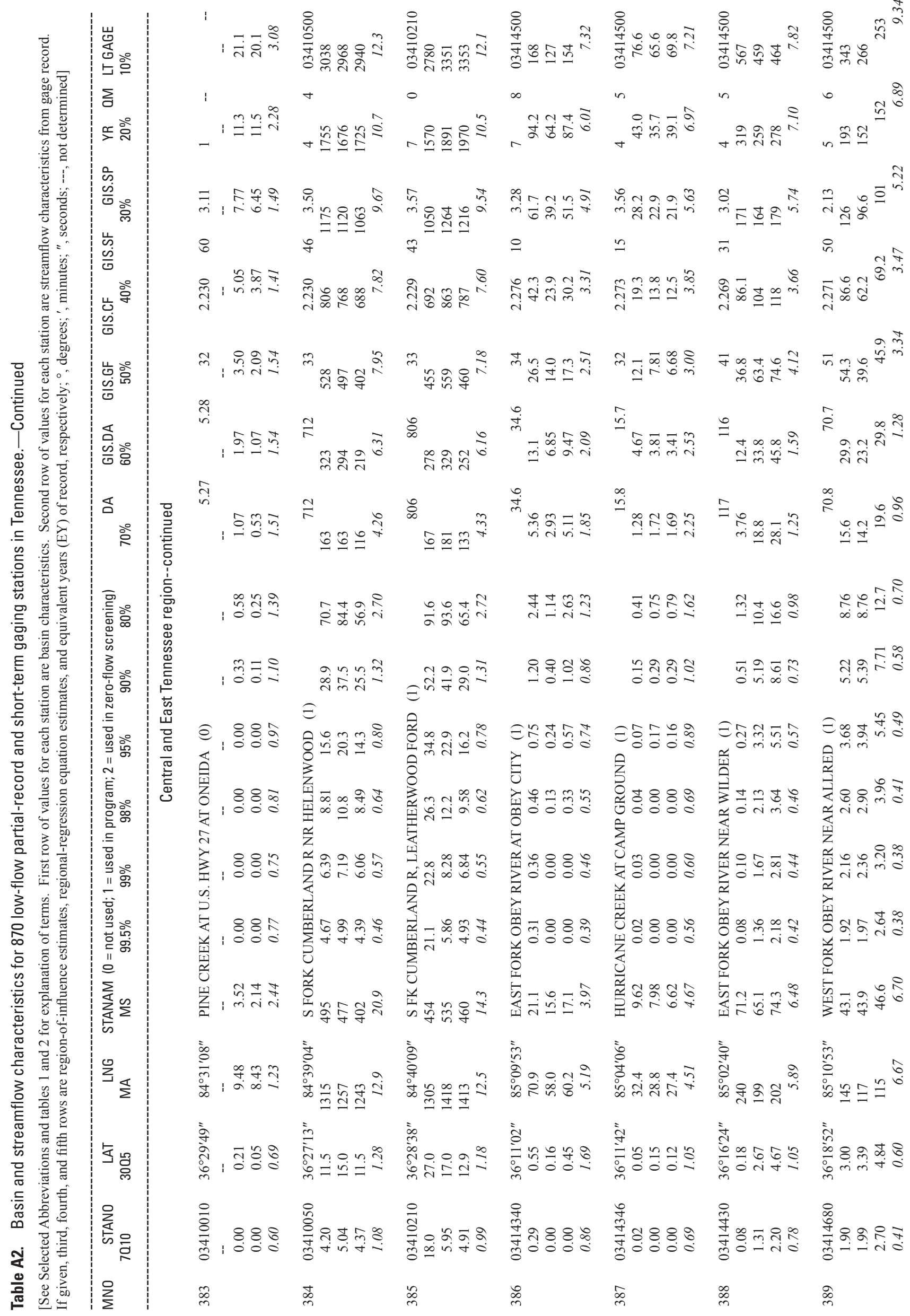




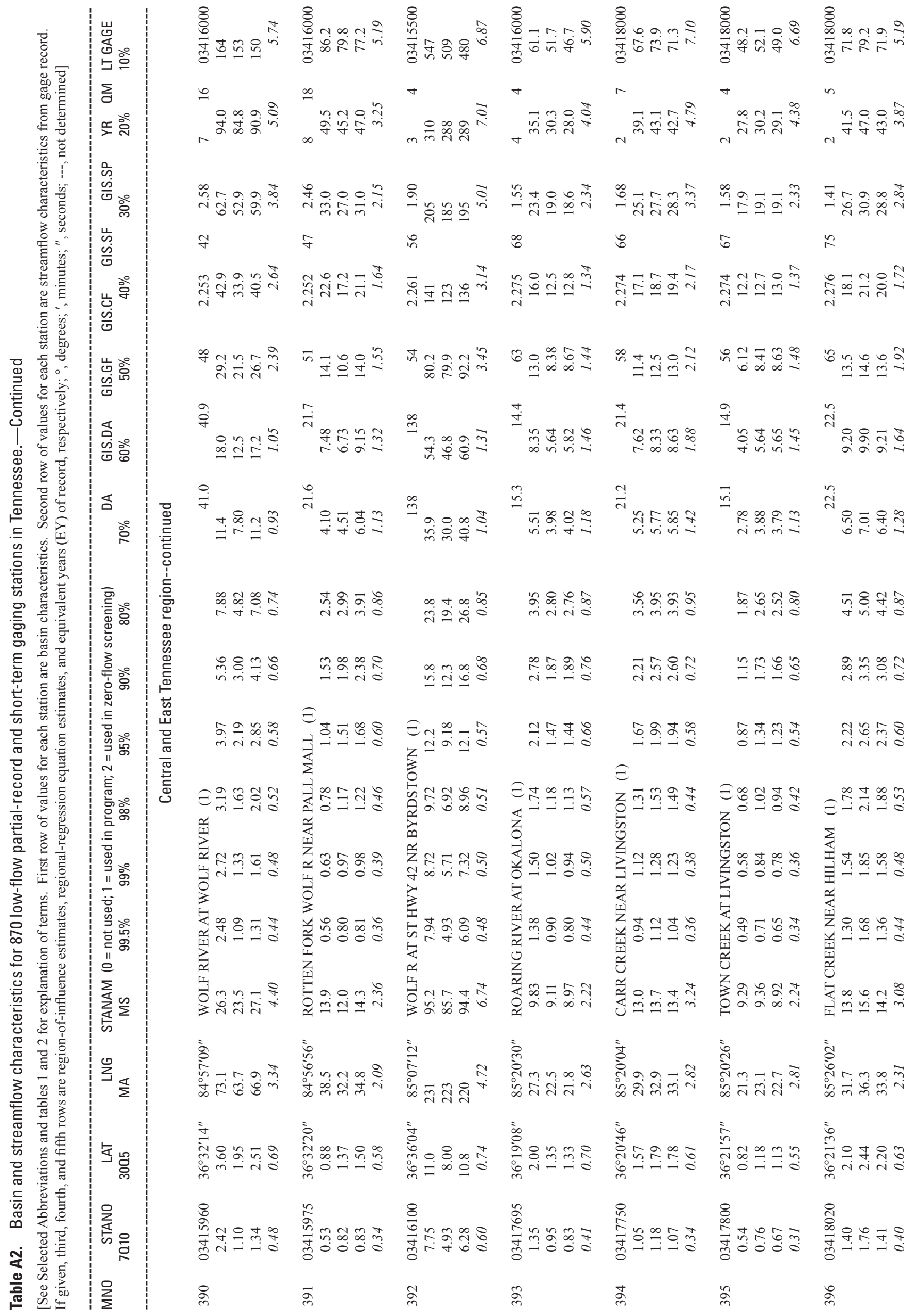




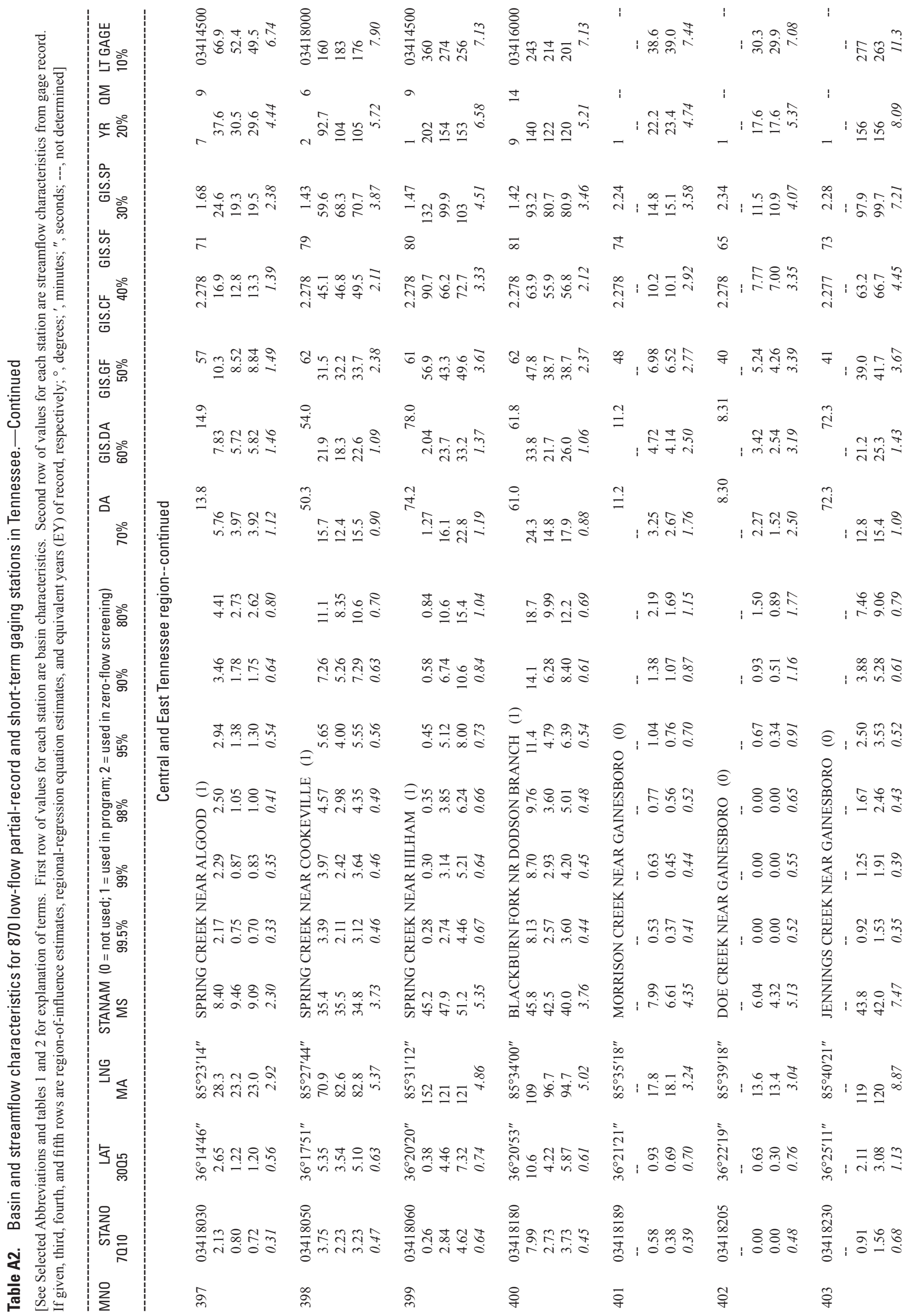




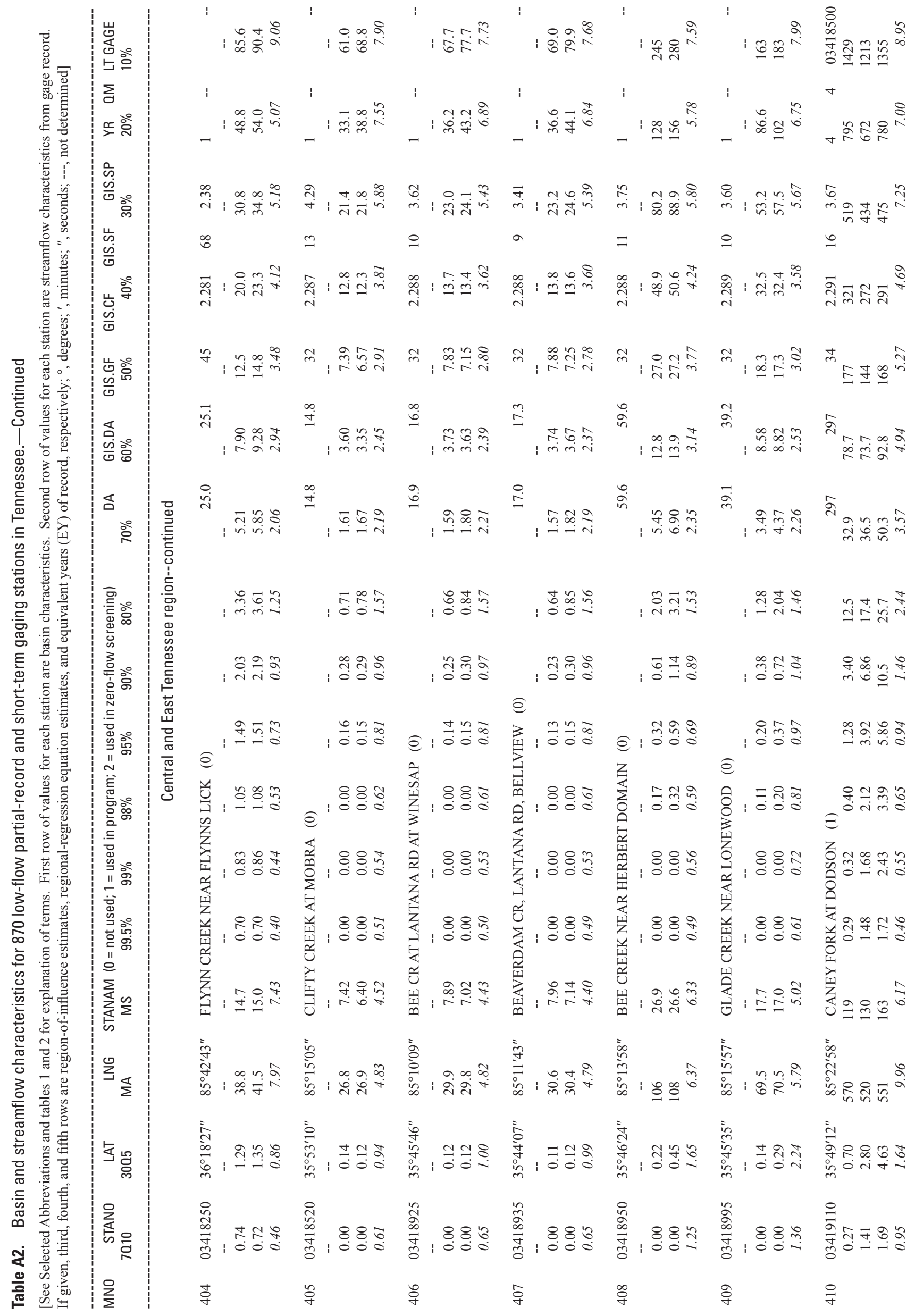




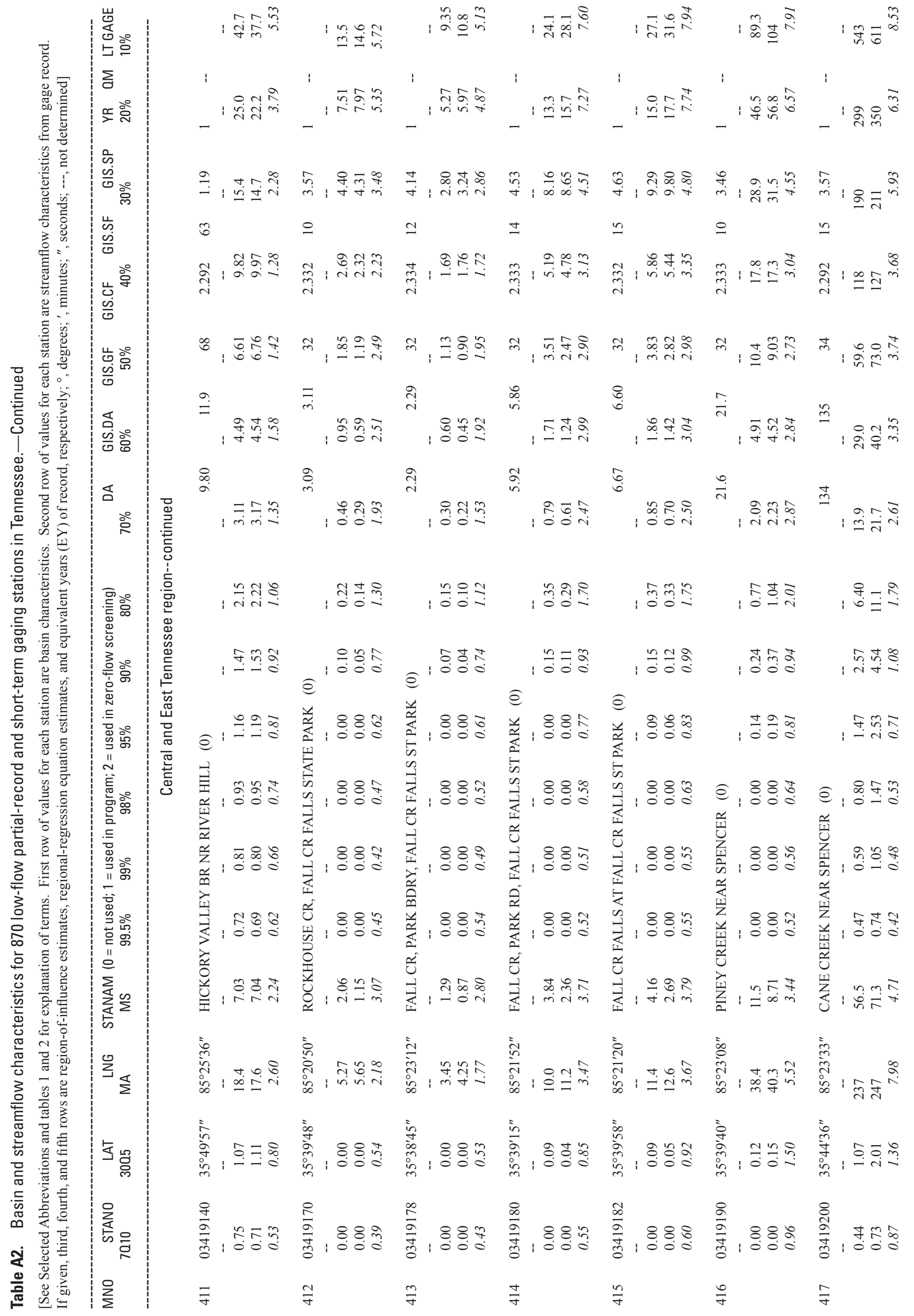




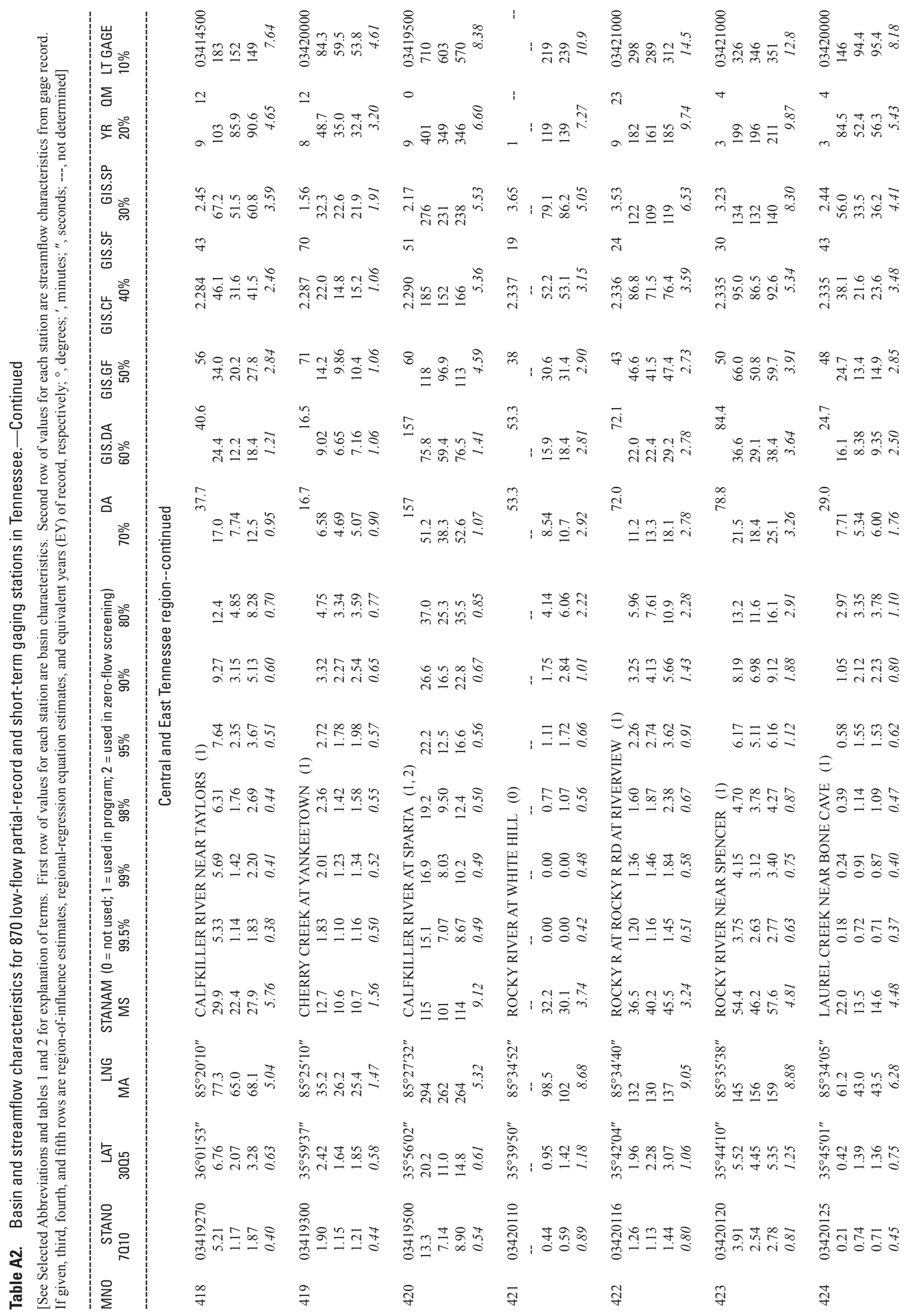




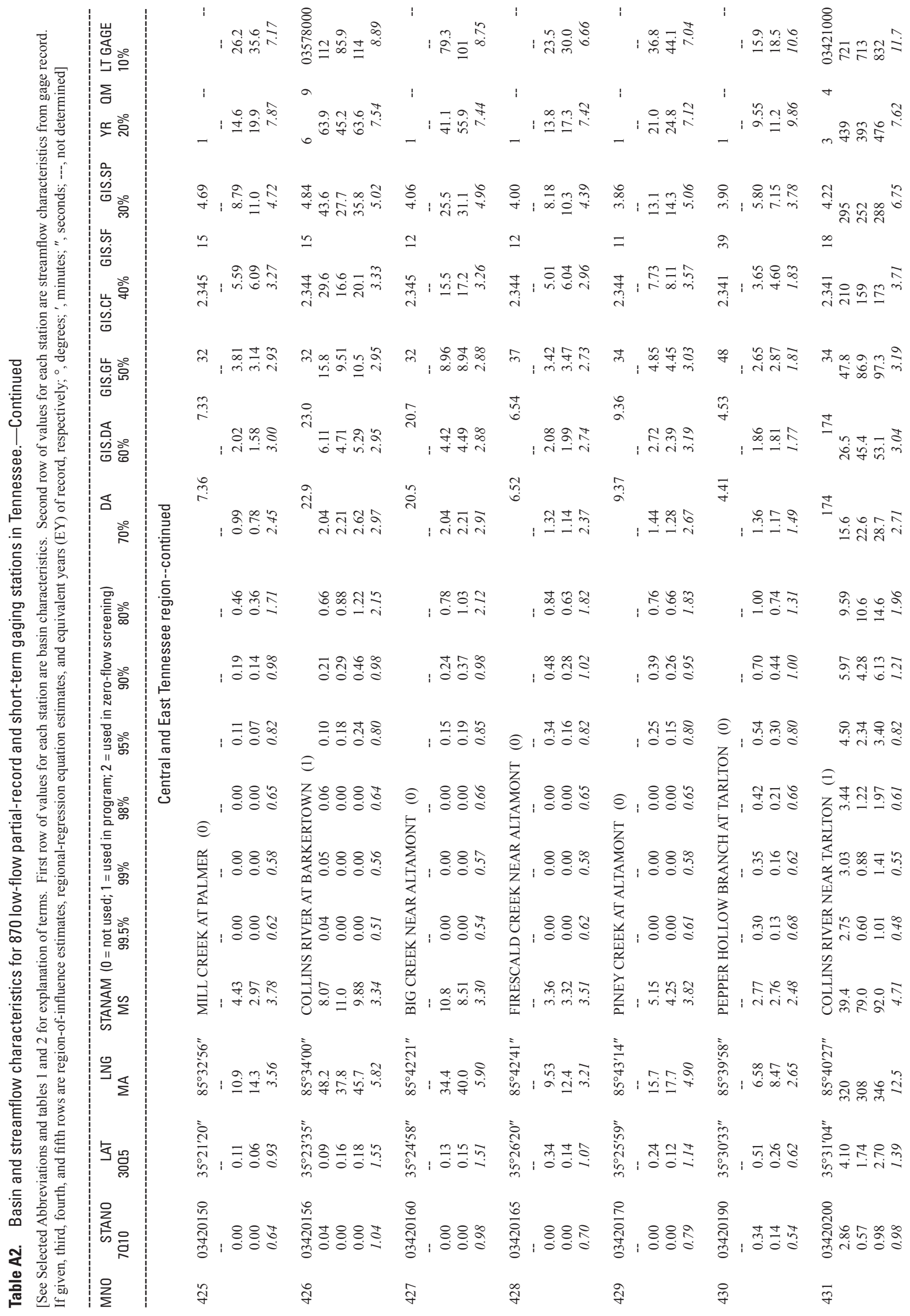




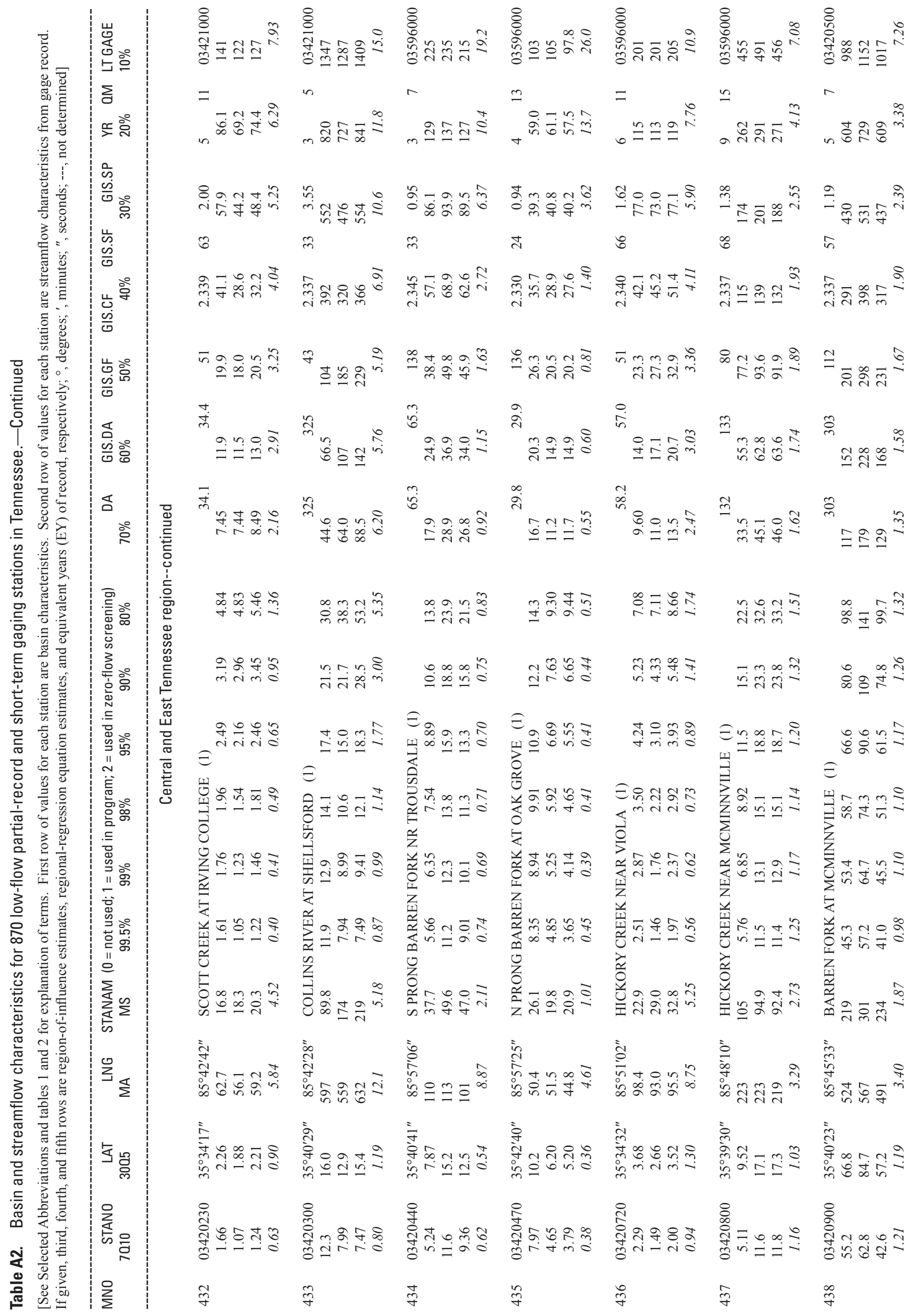




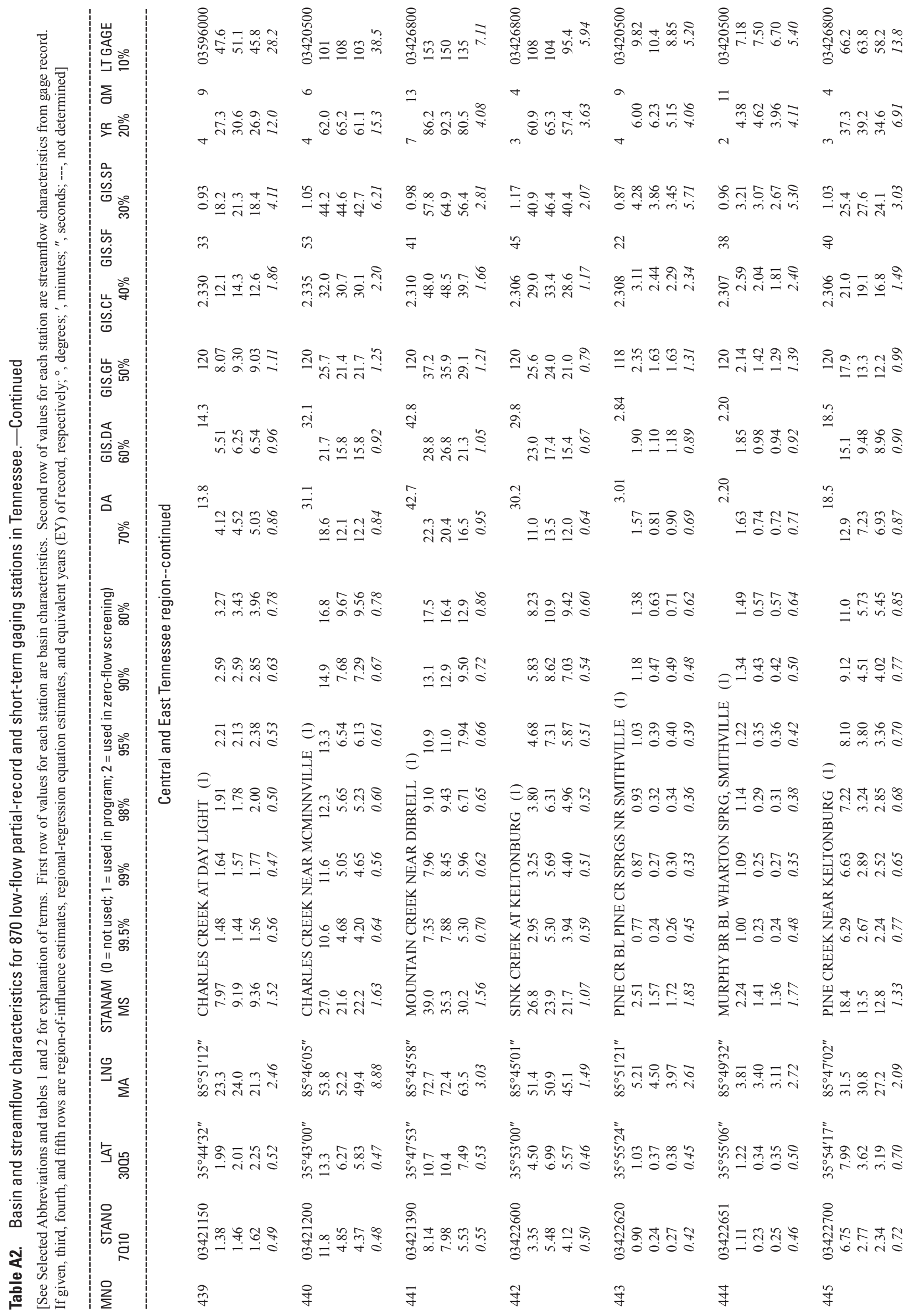




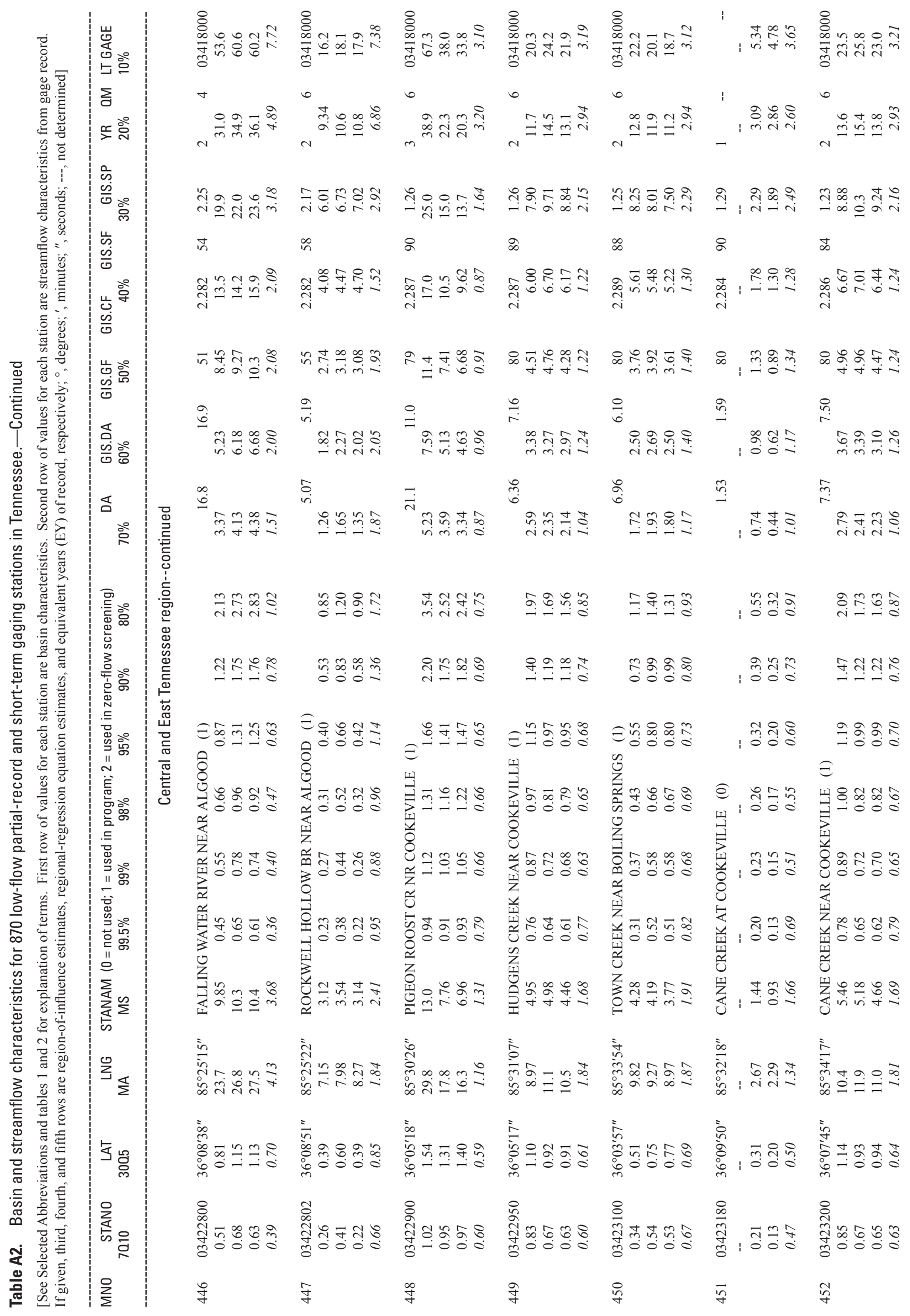




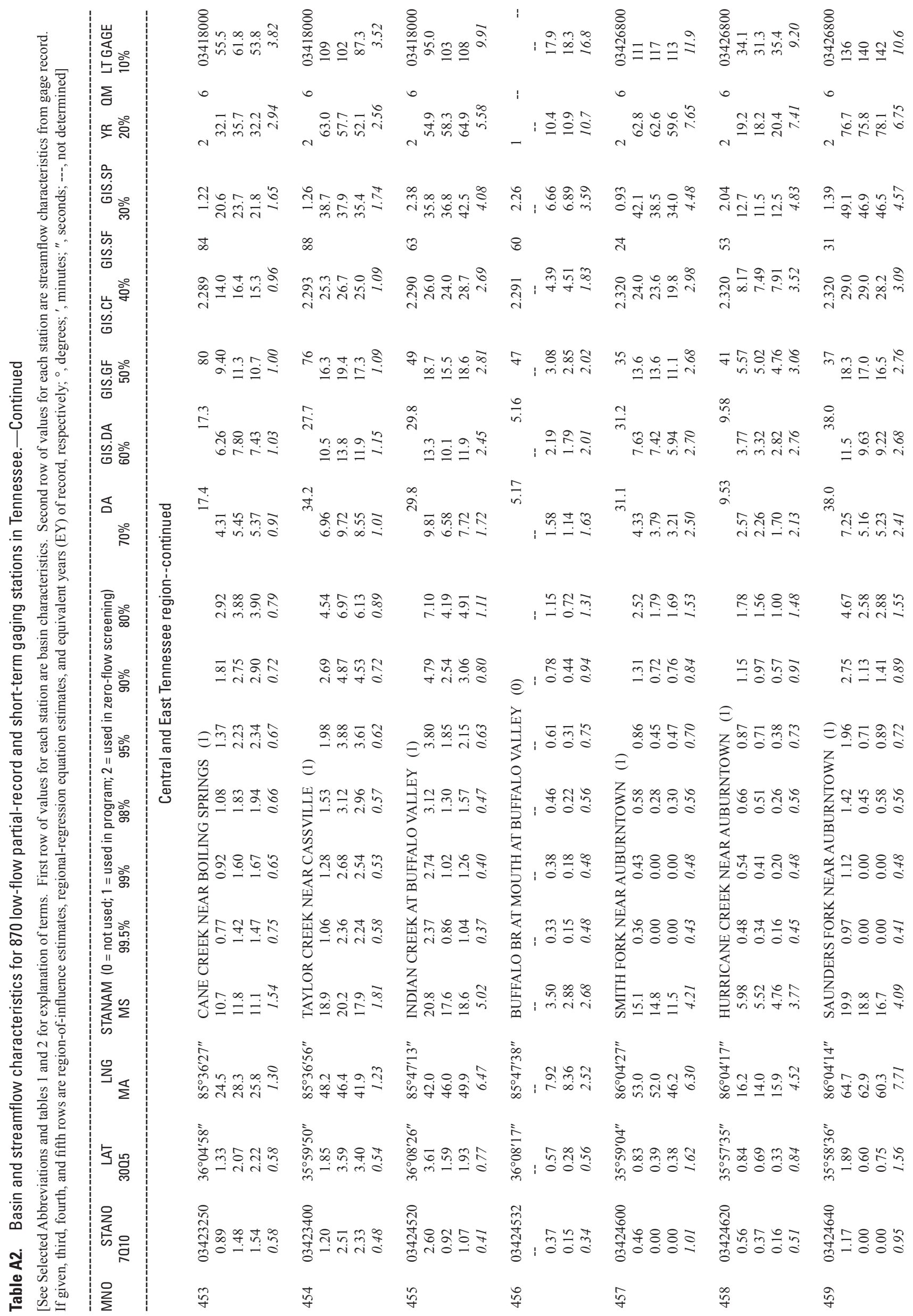




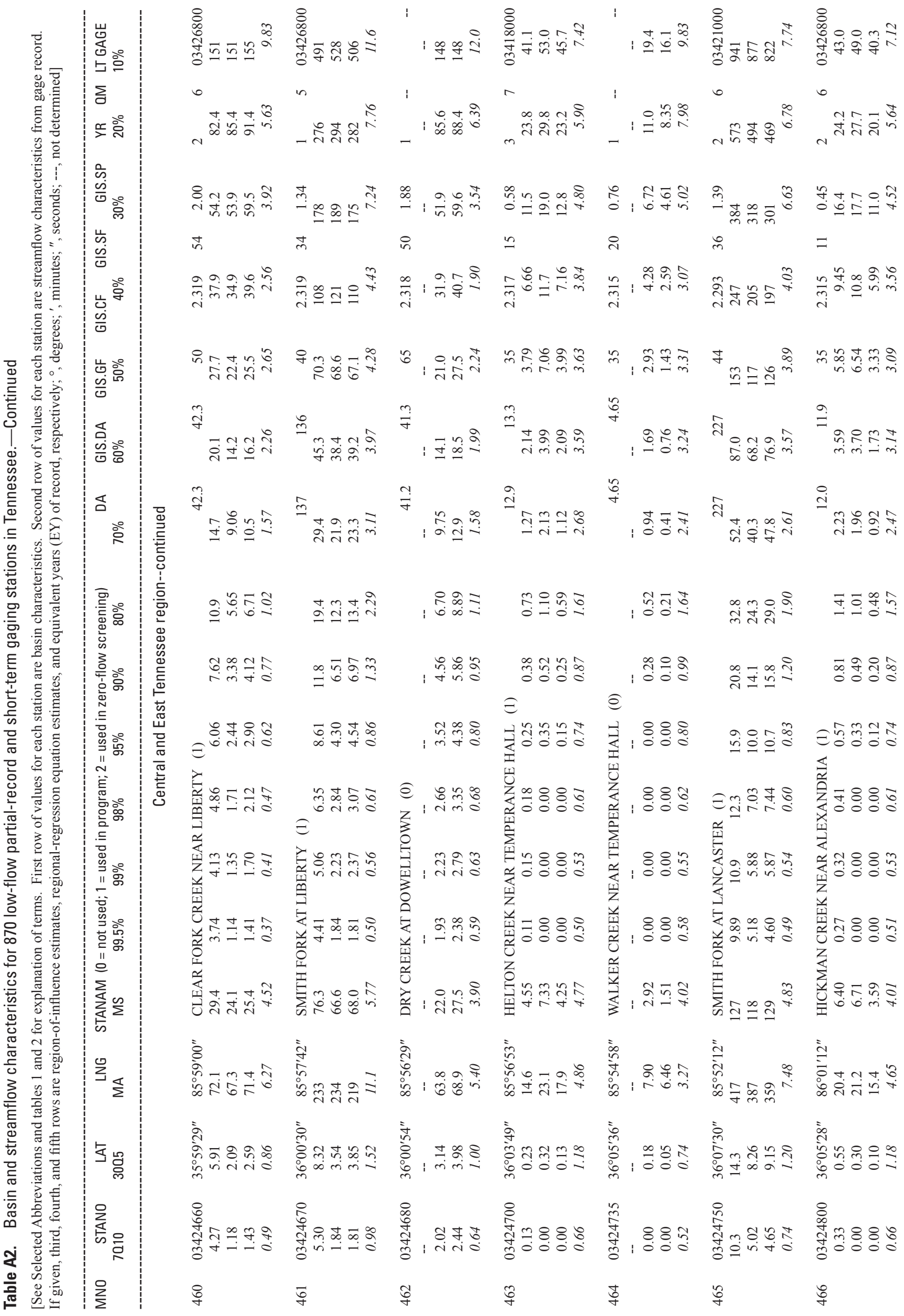


Appendix A. Basin and Streamflow Characteristics for Sites in This Report

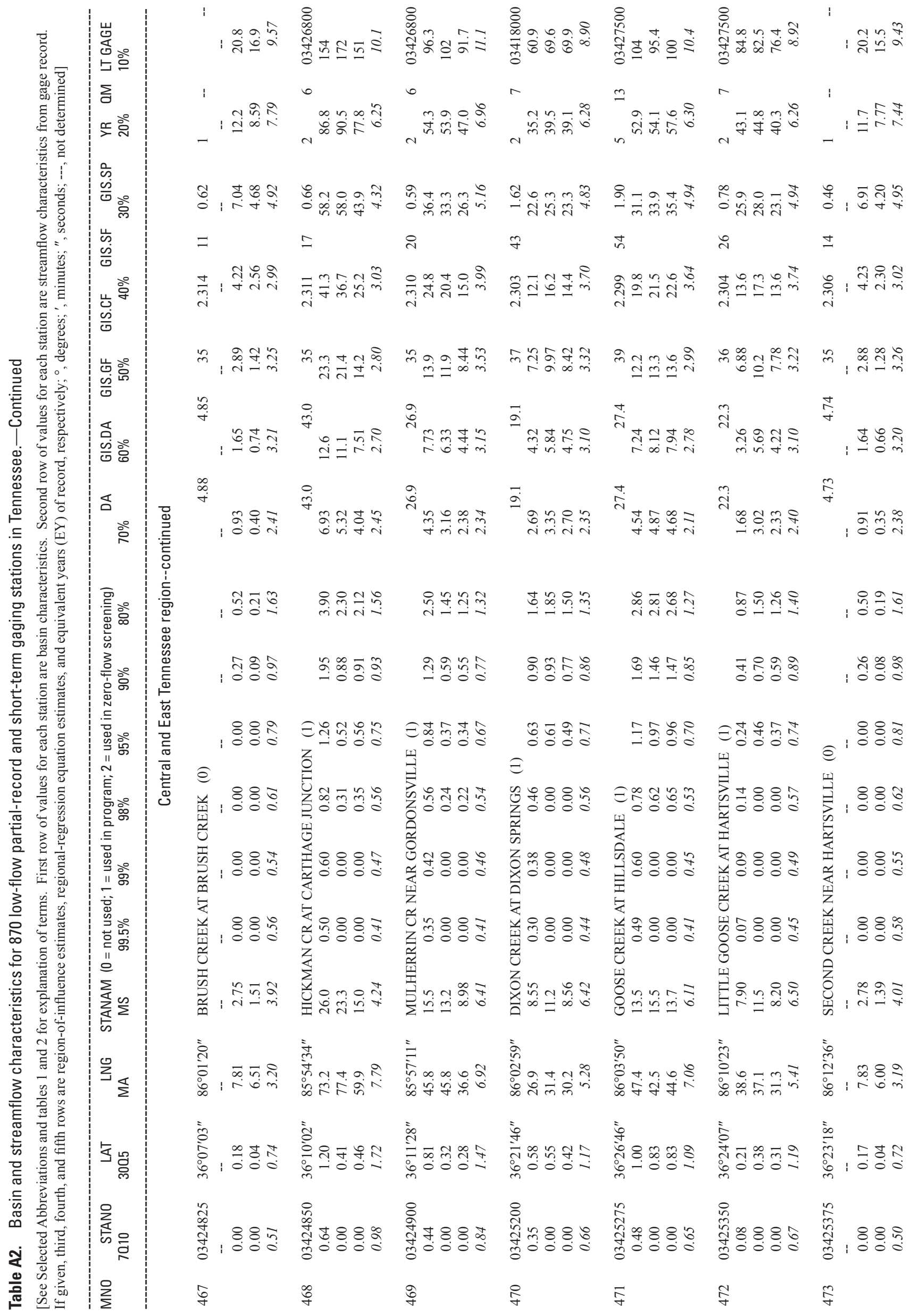




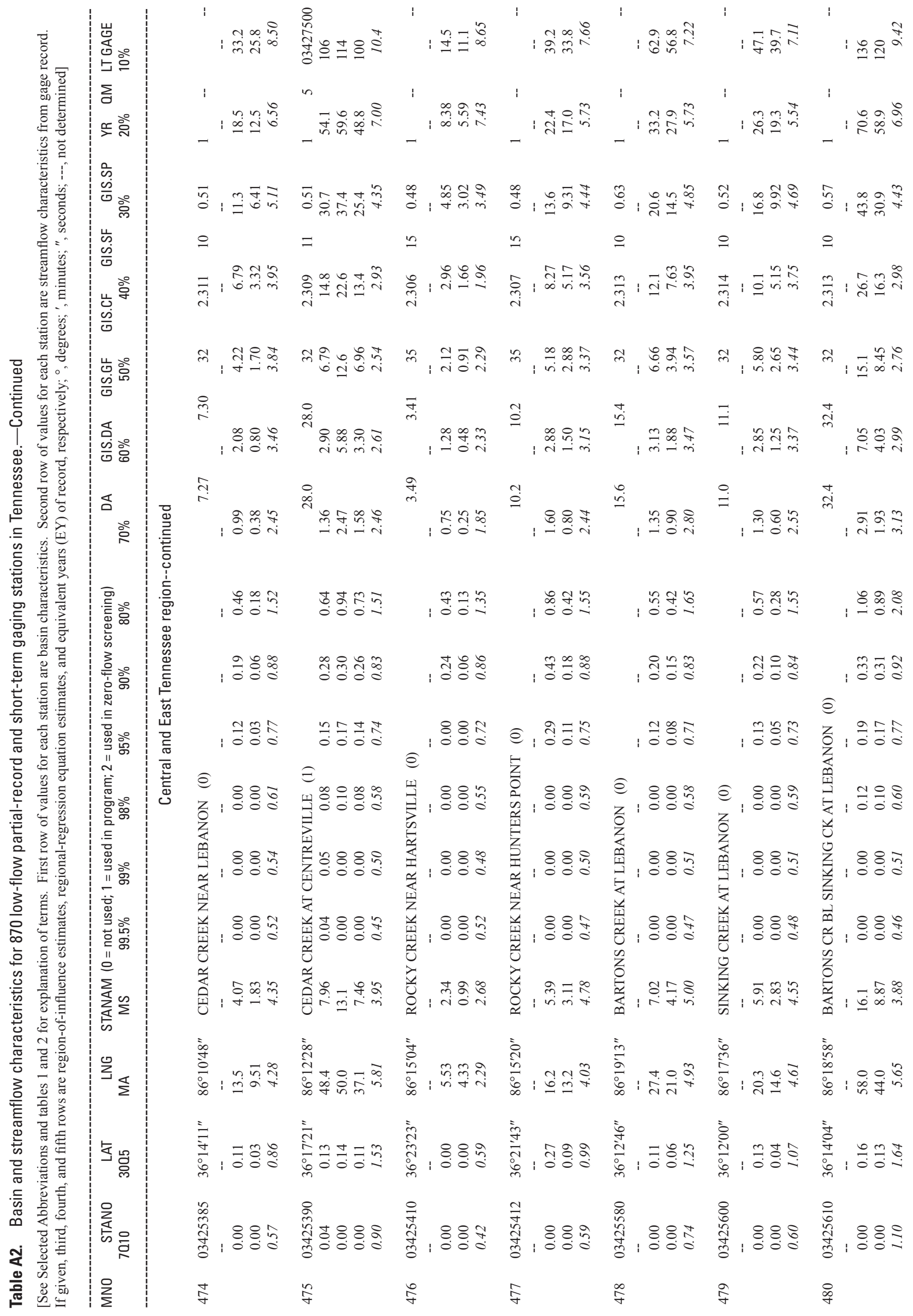




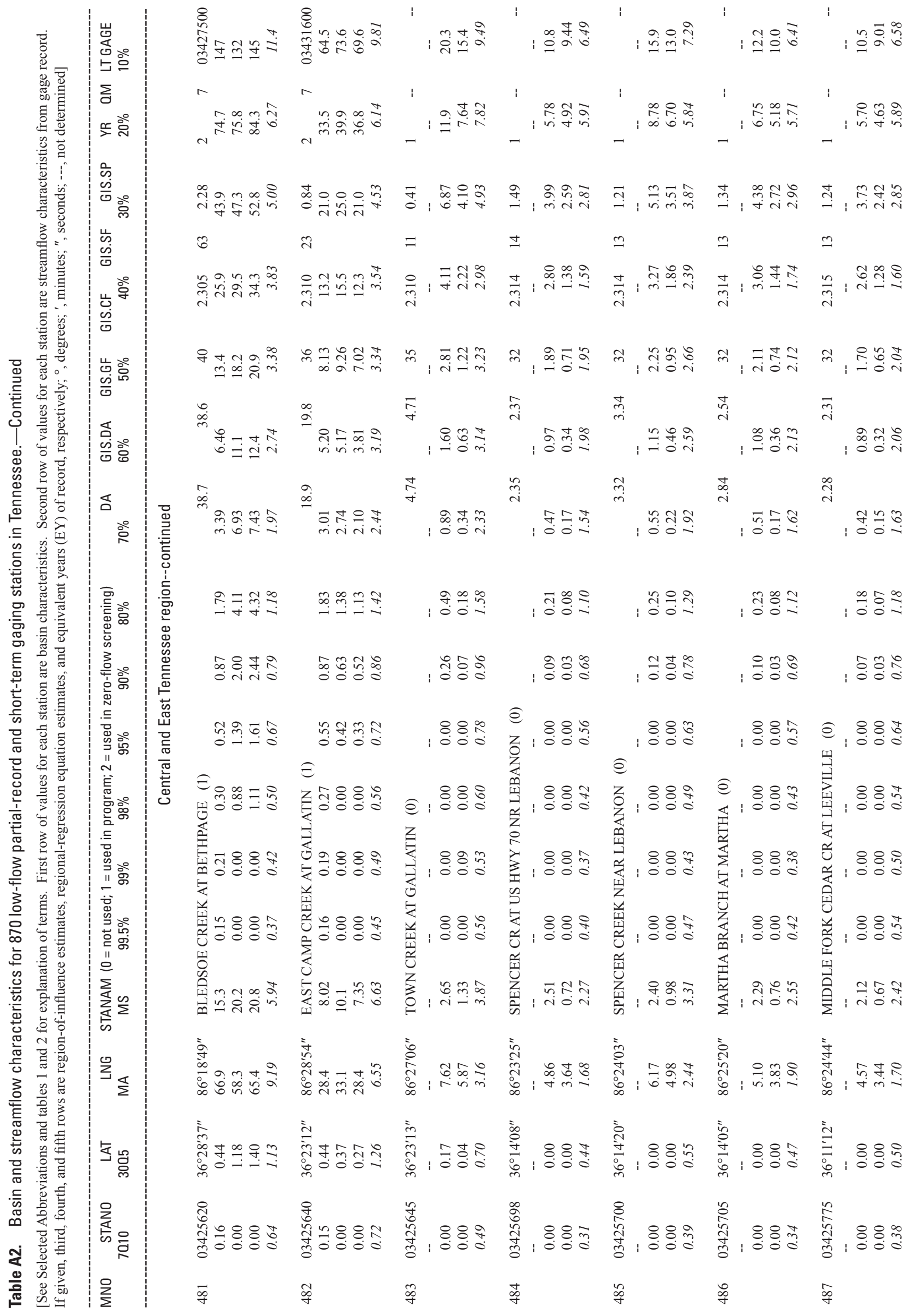




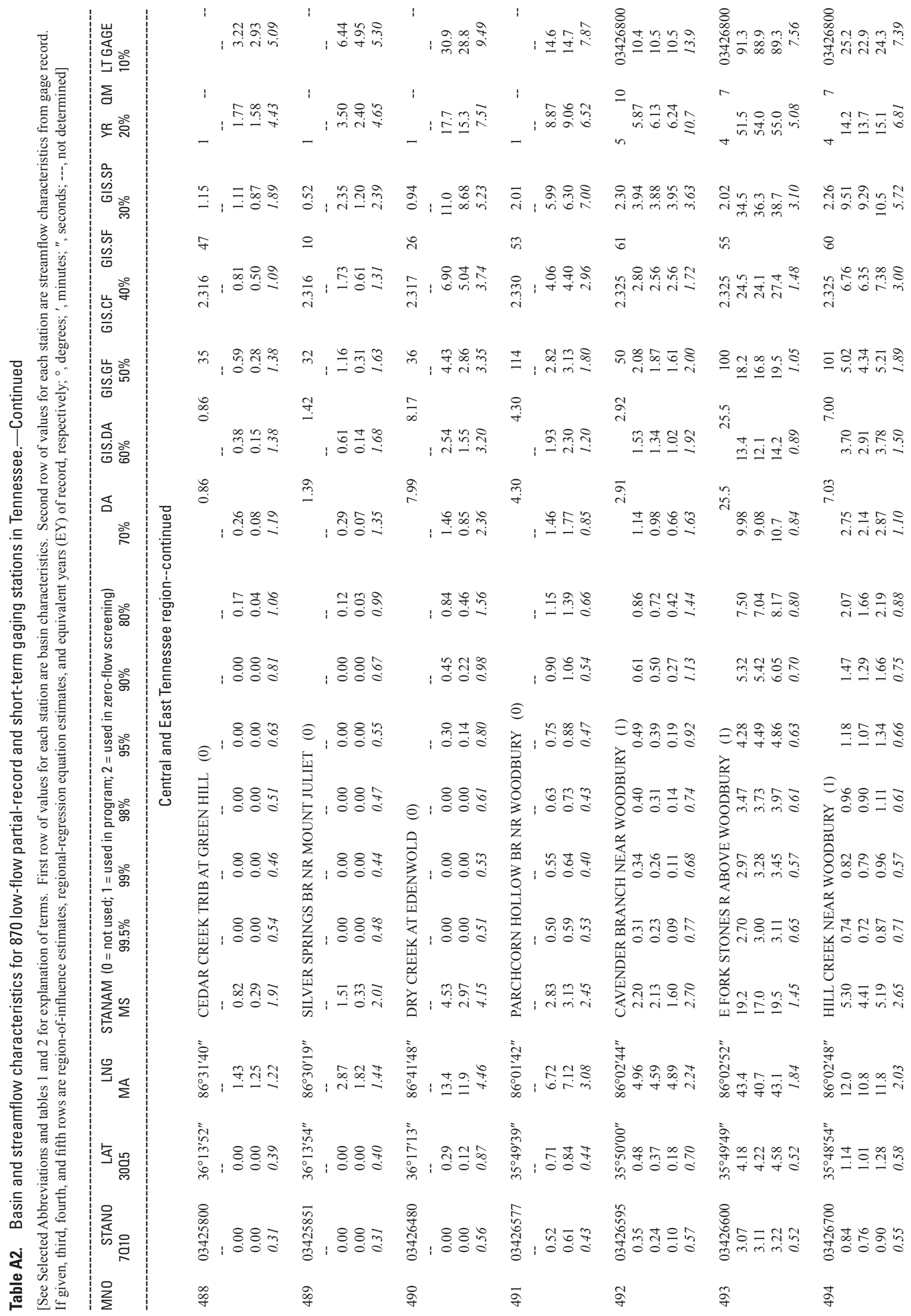




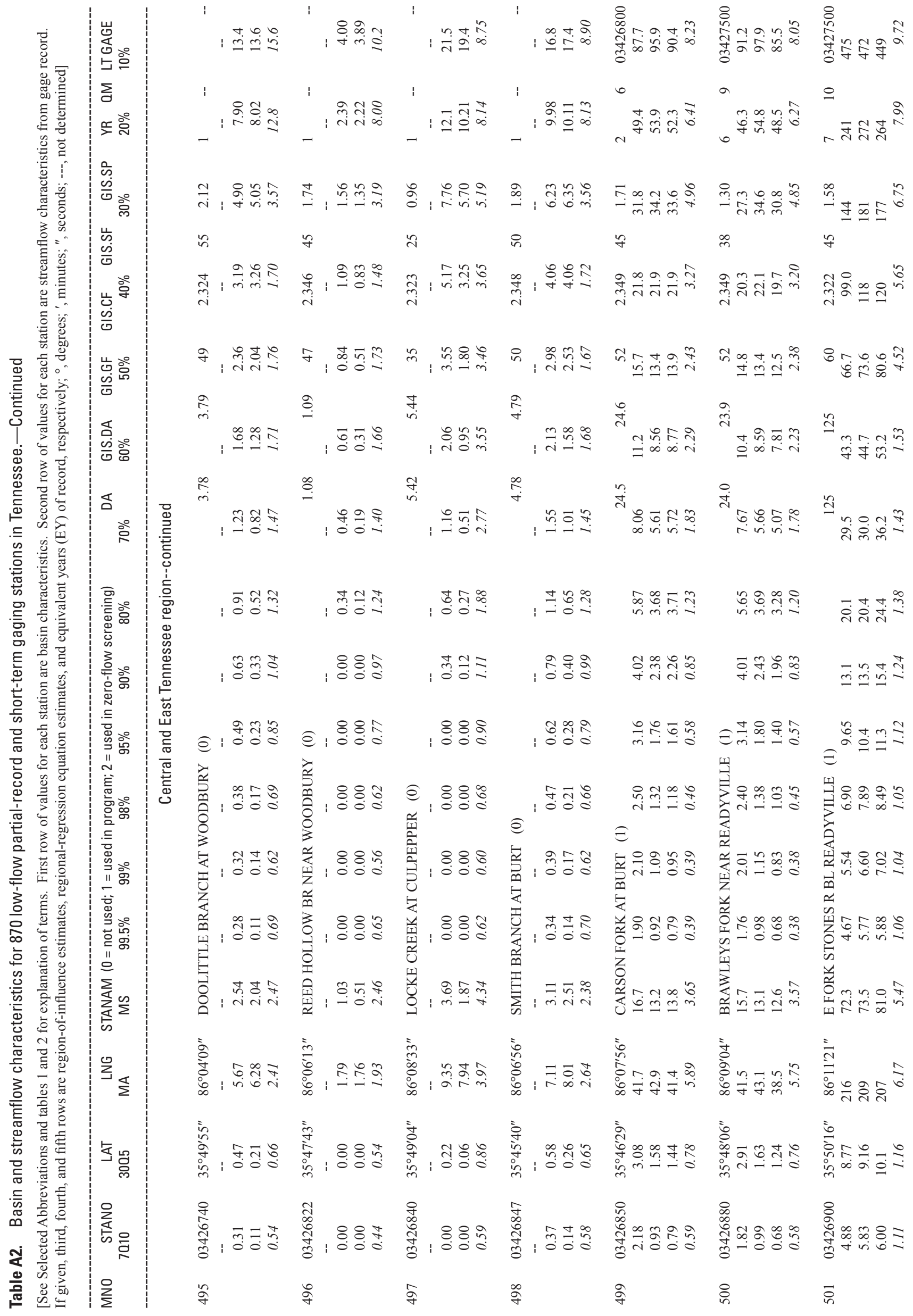




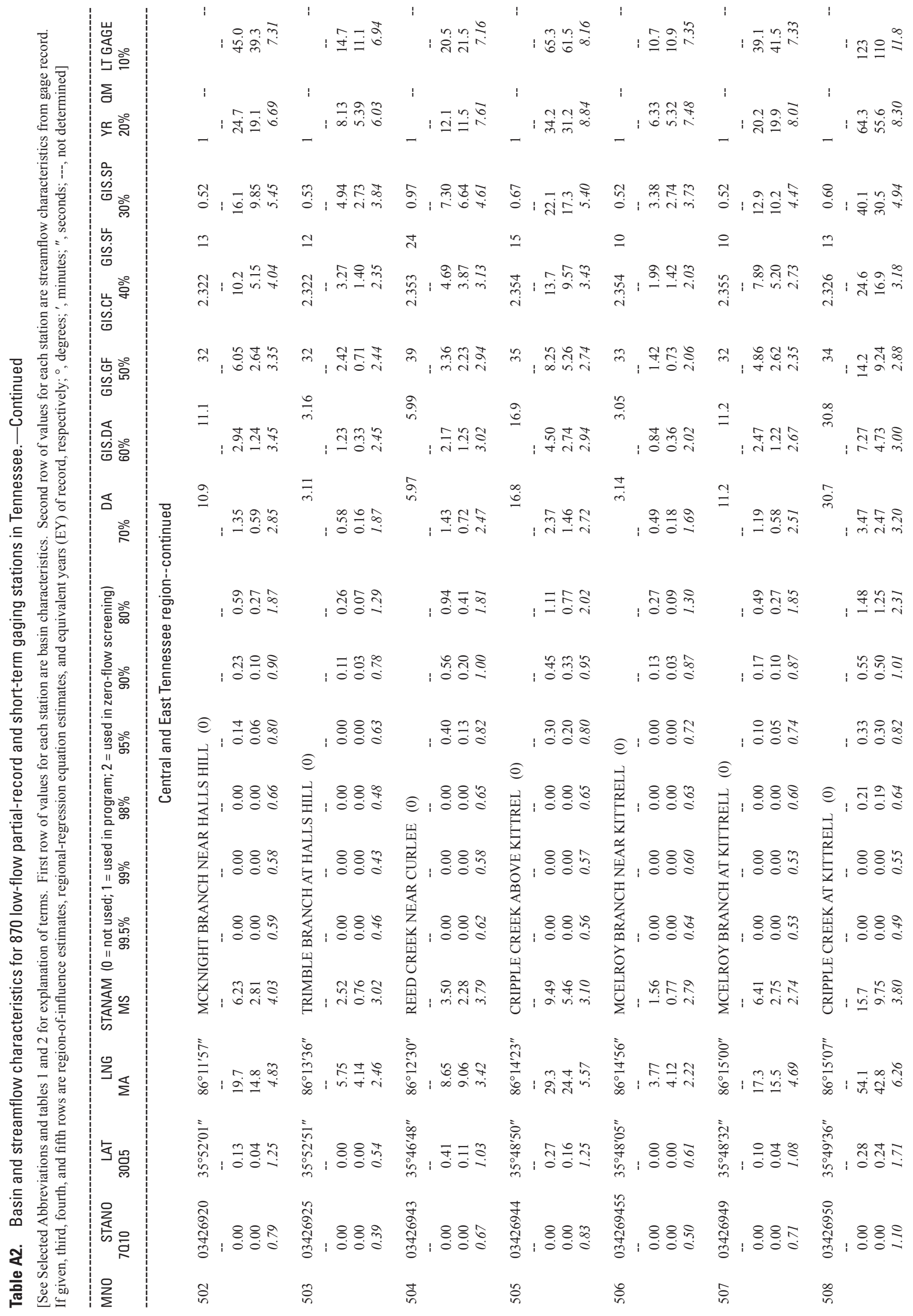




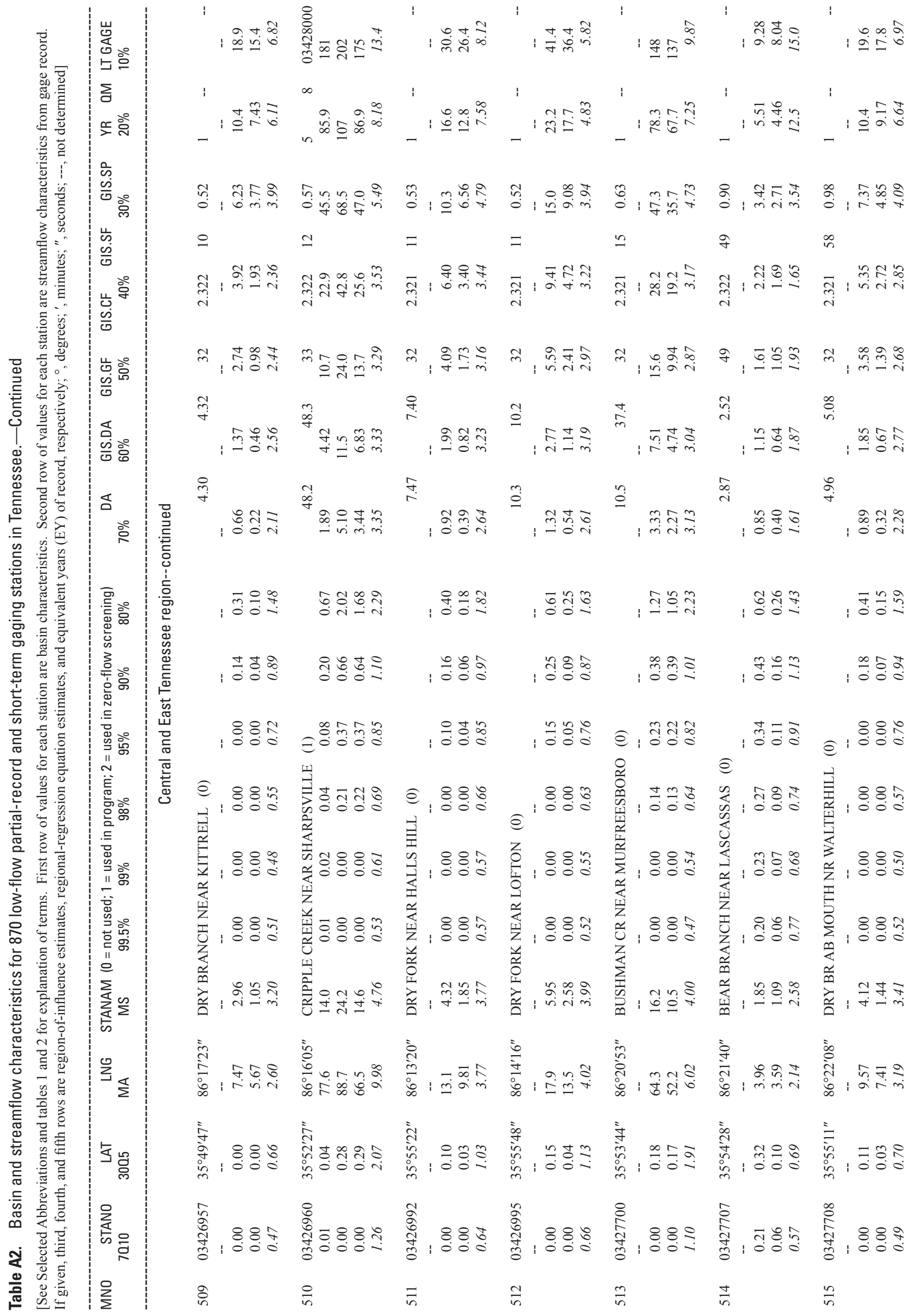




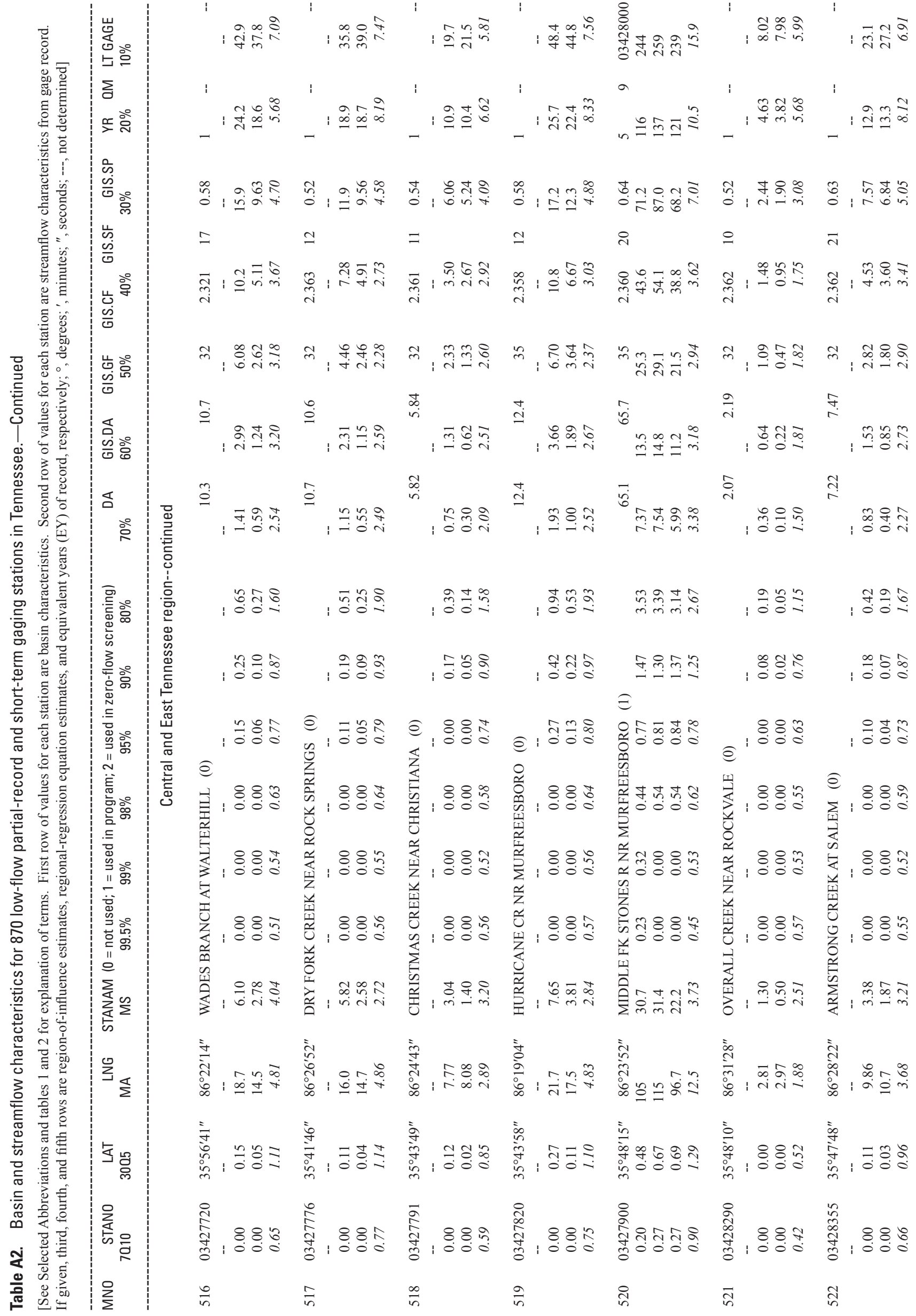




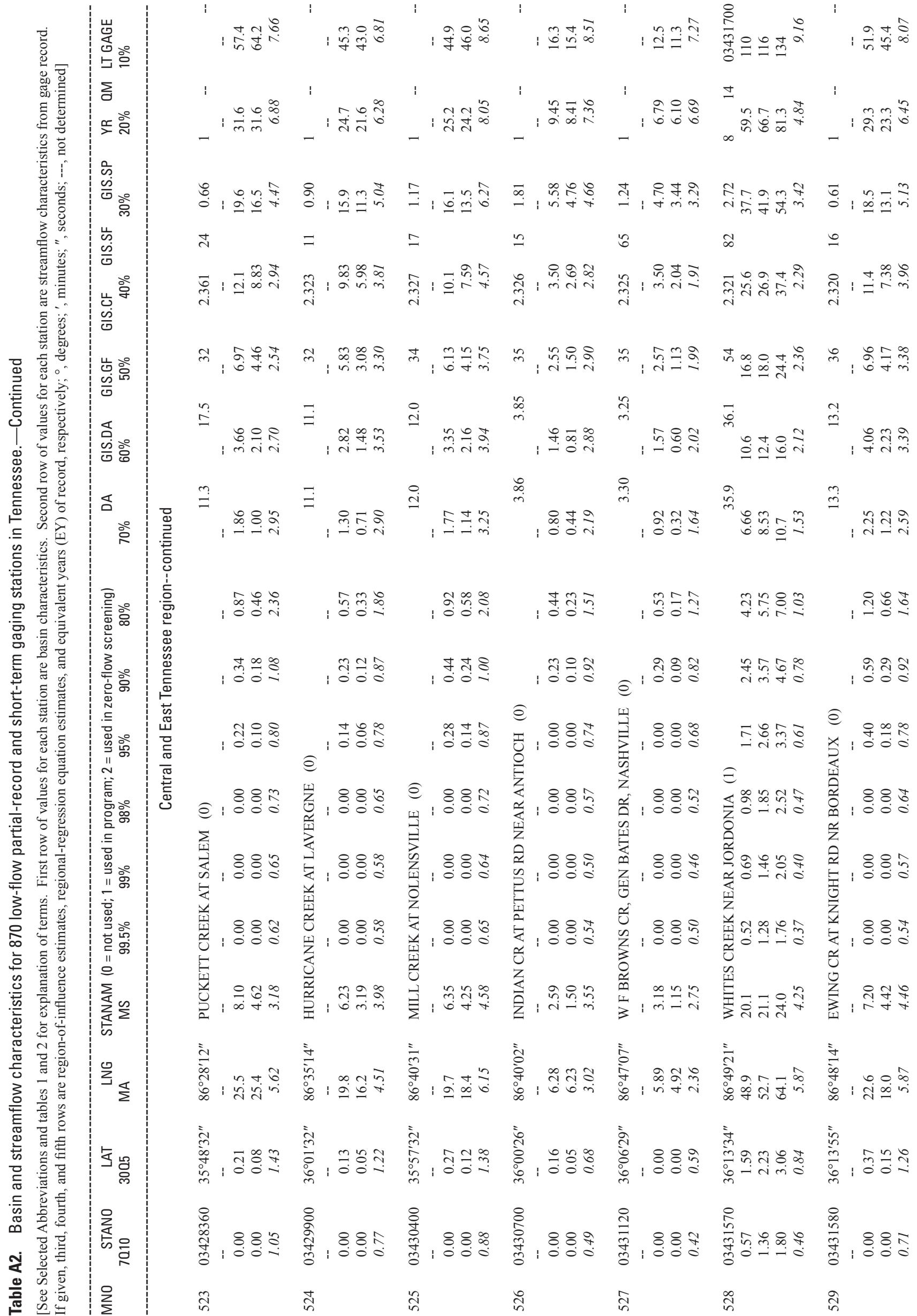




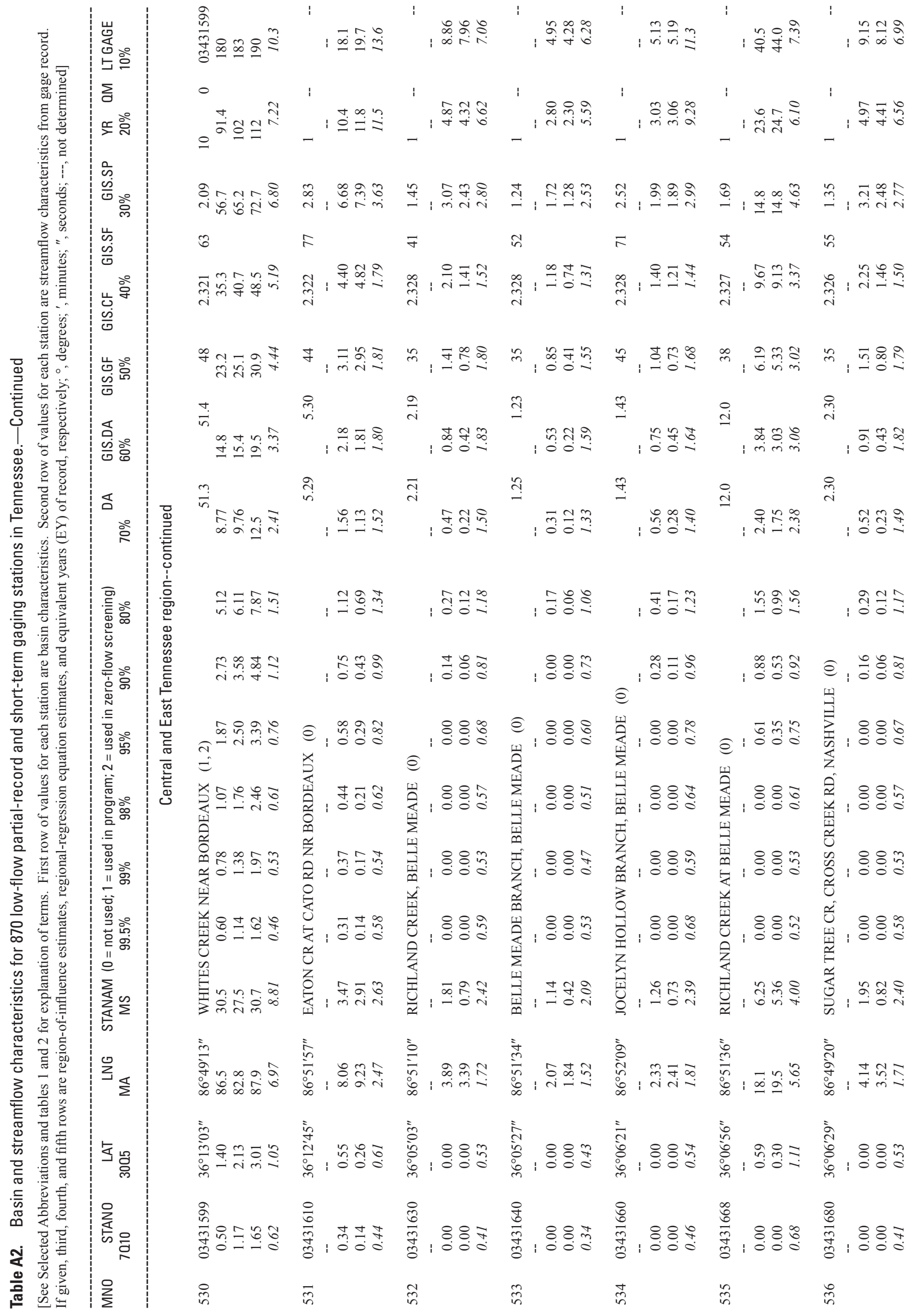




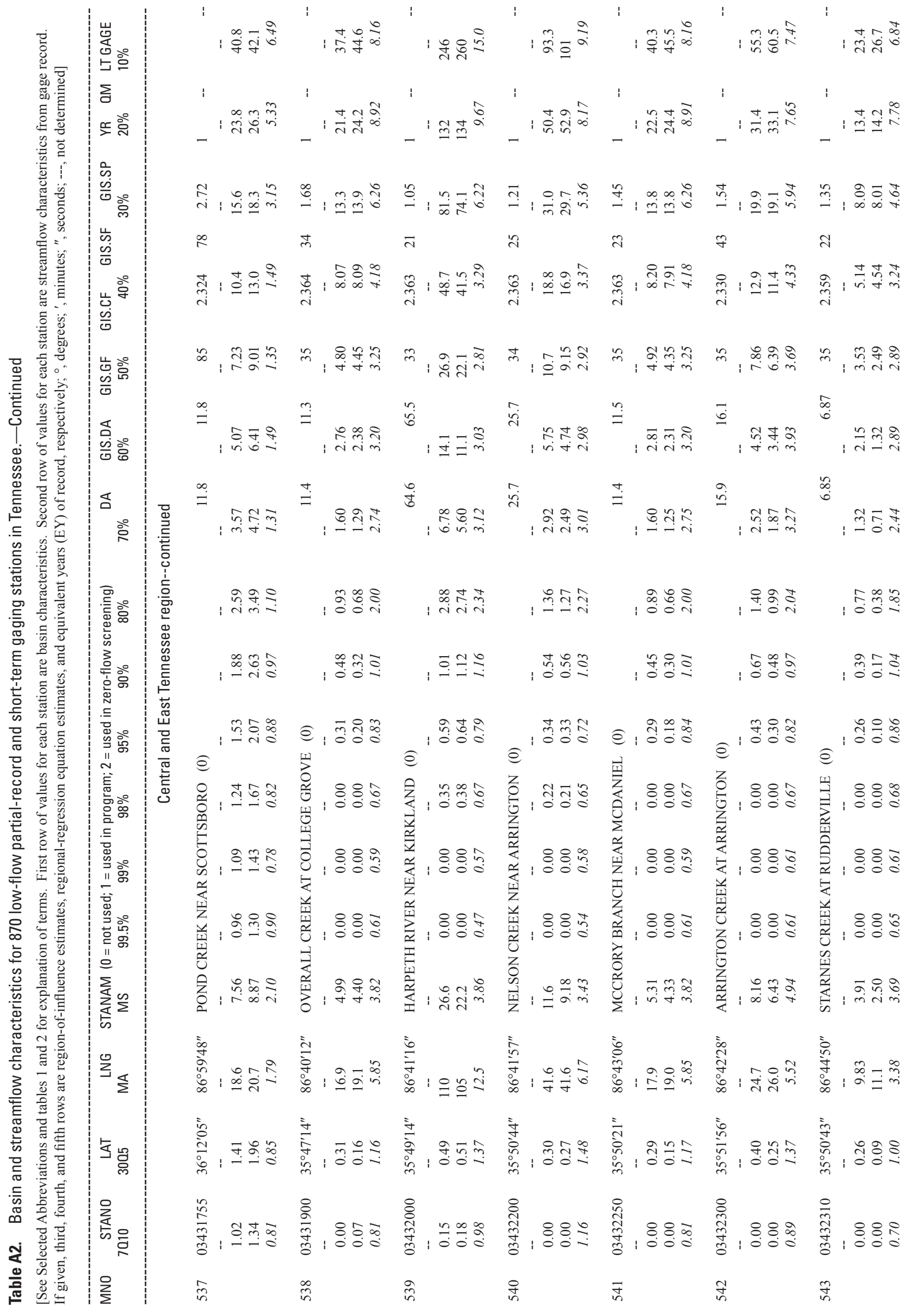




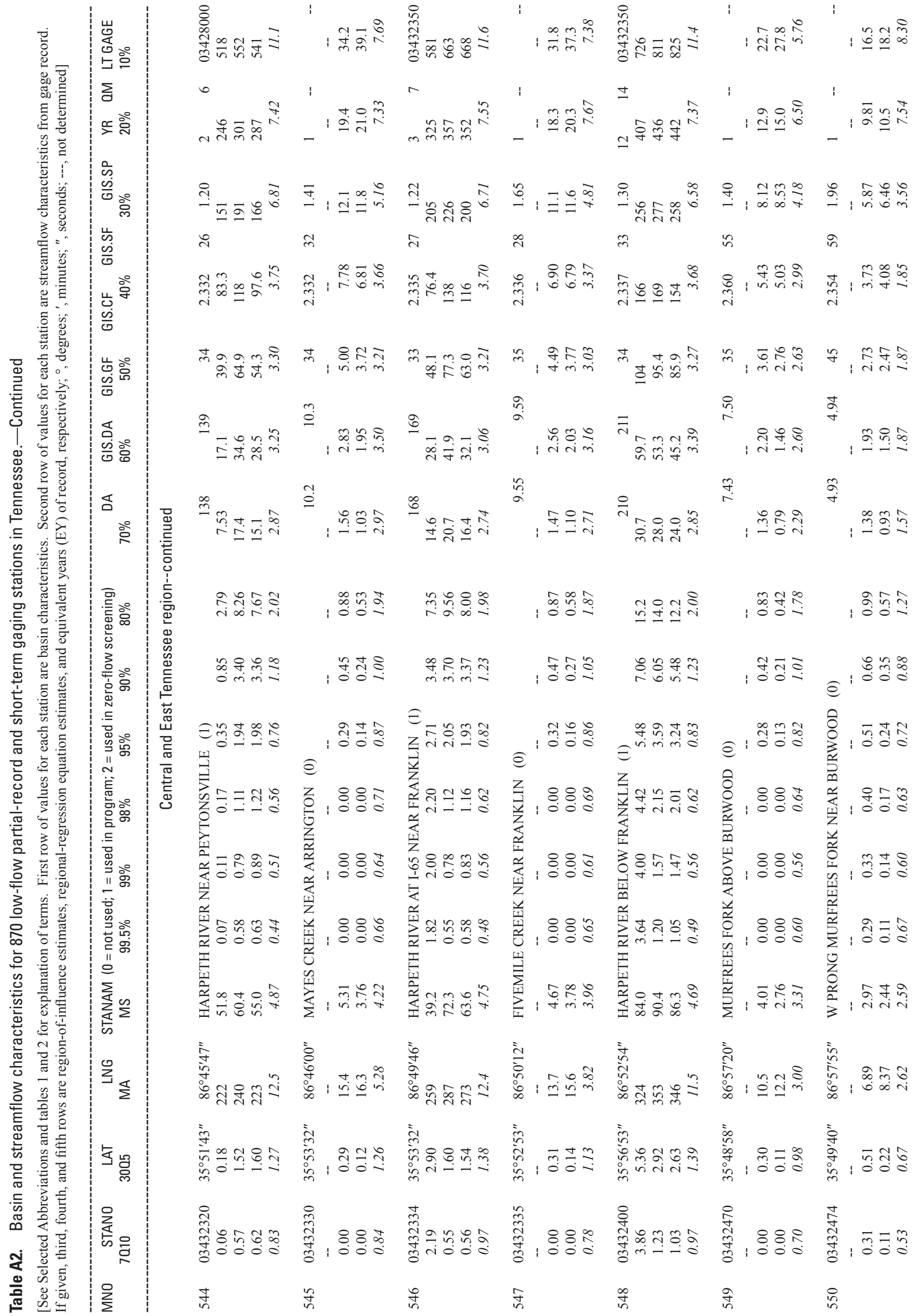




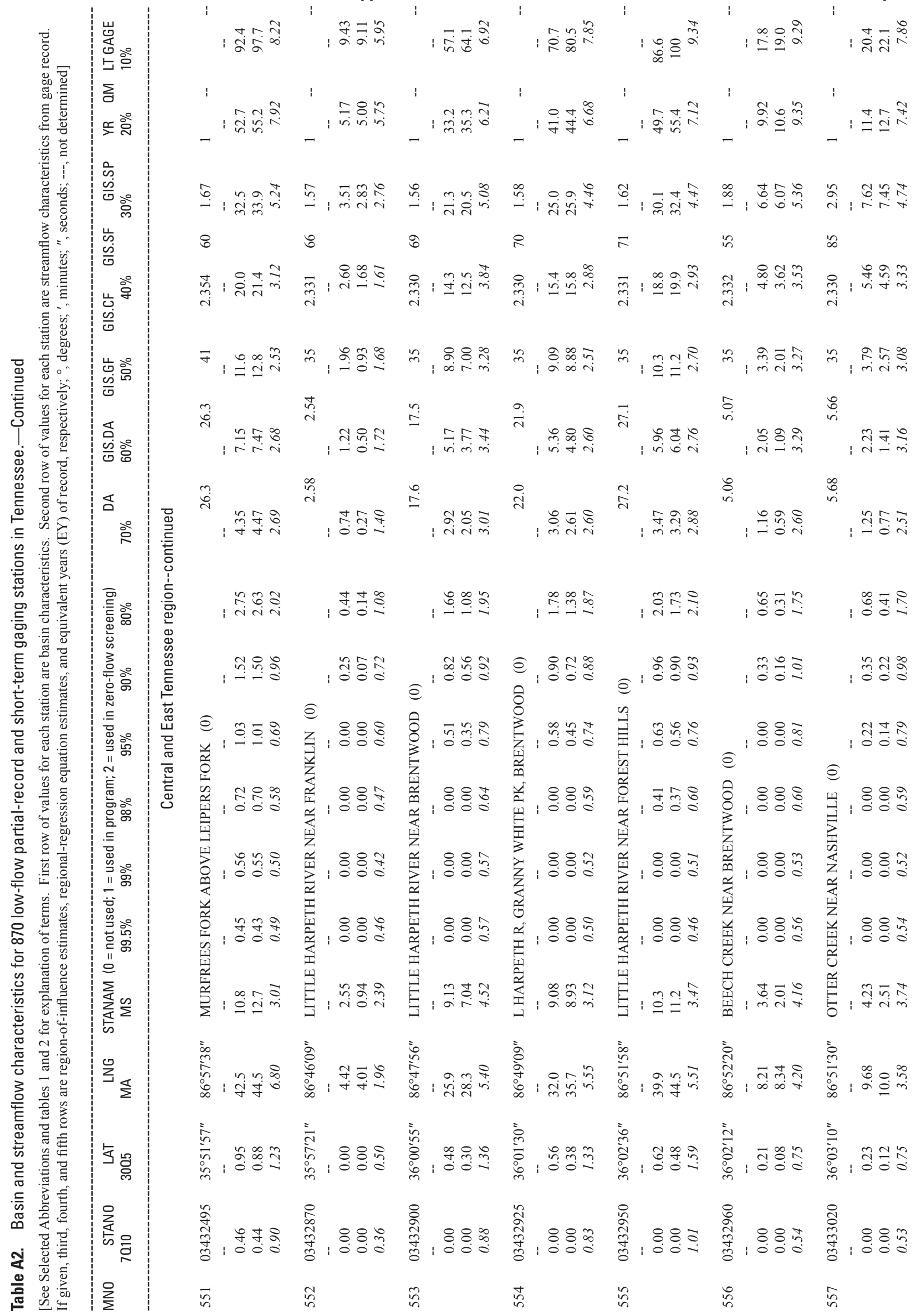




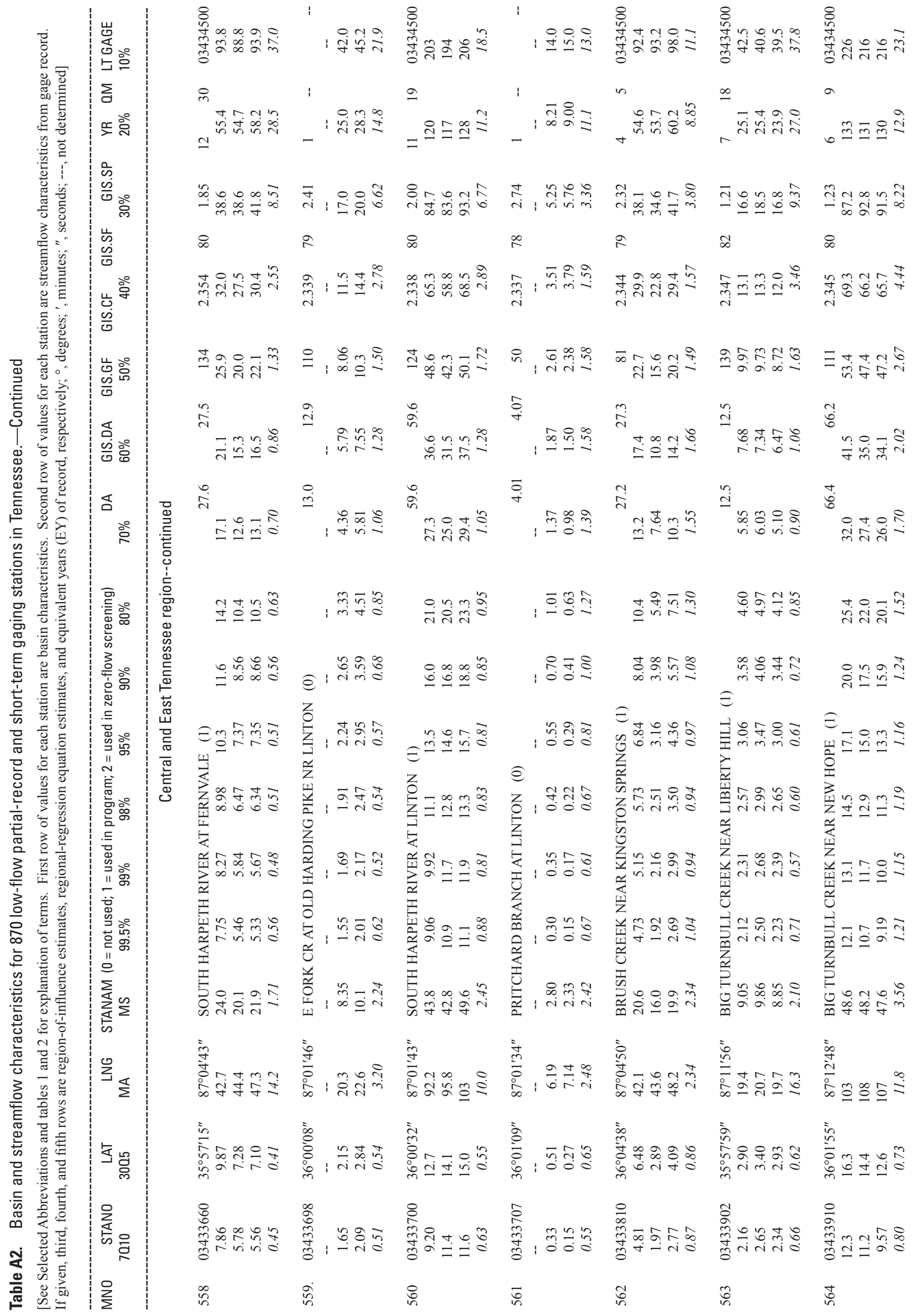




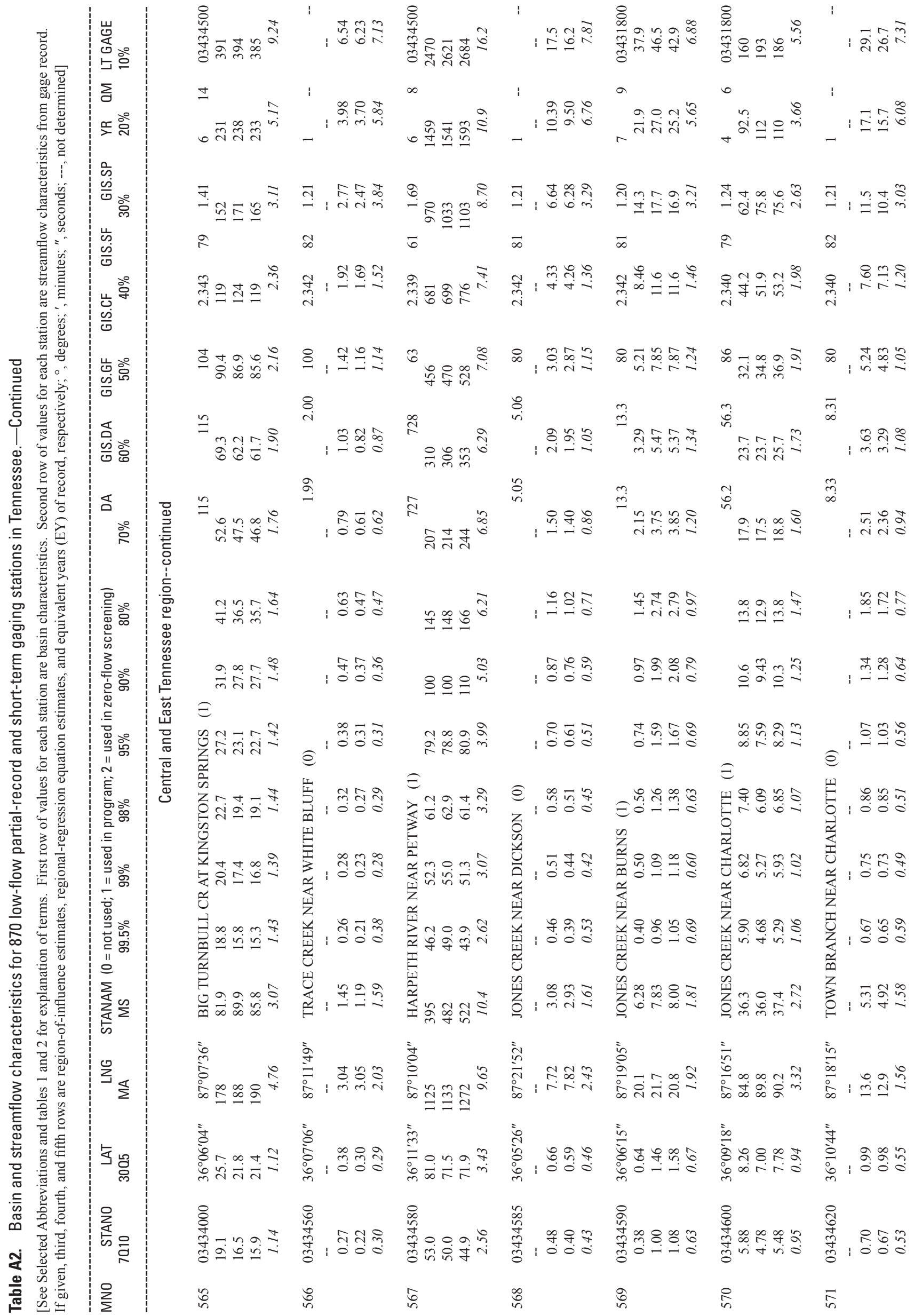




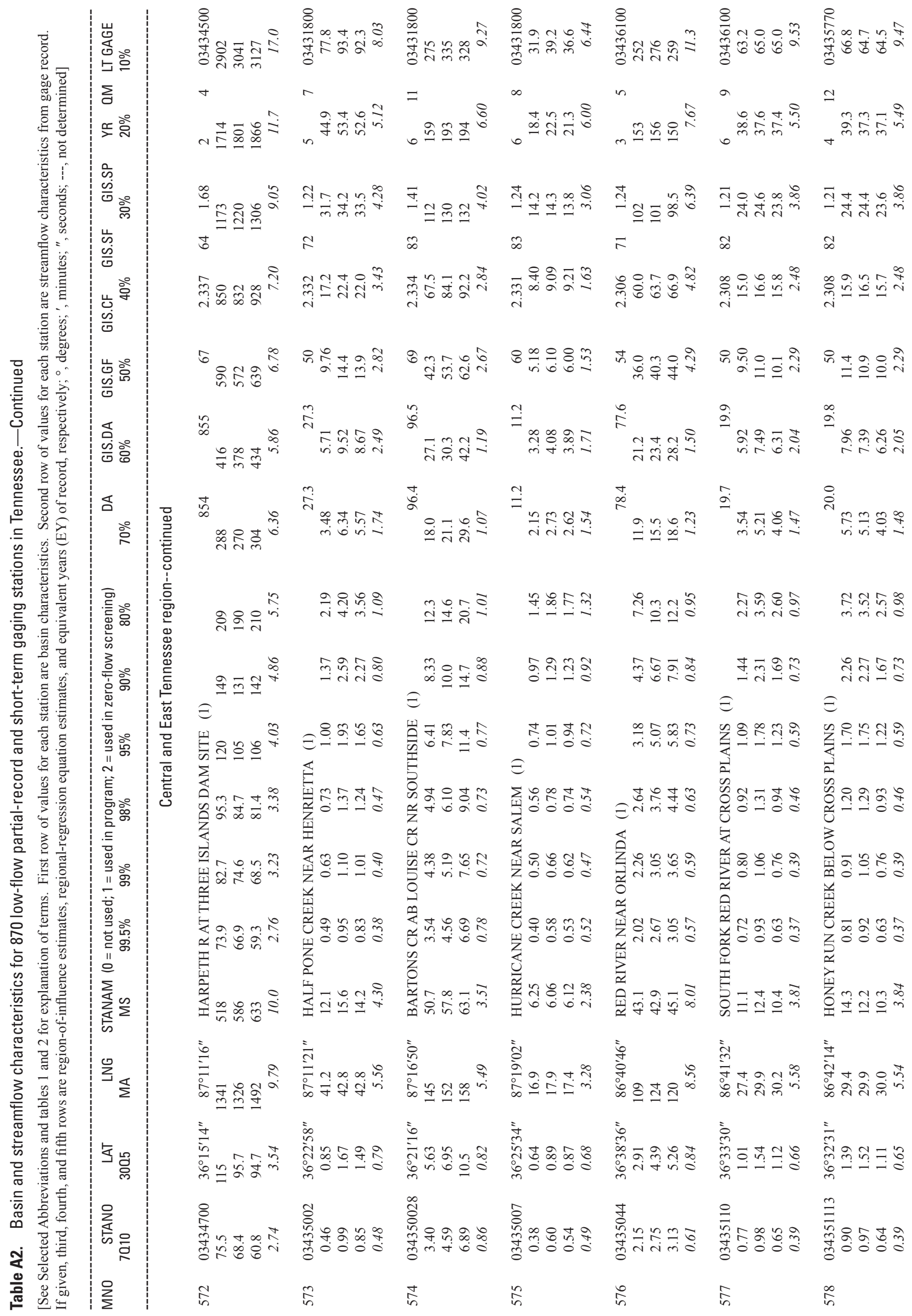




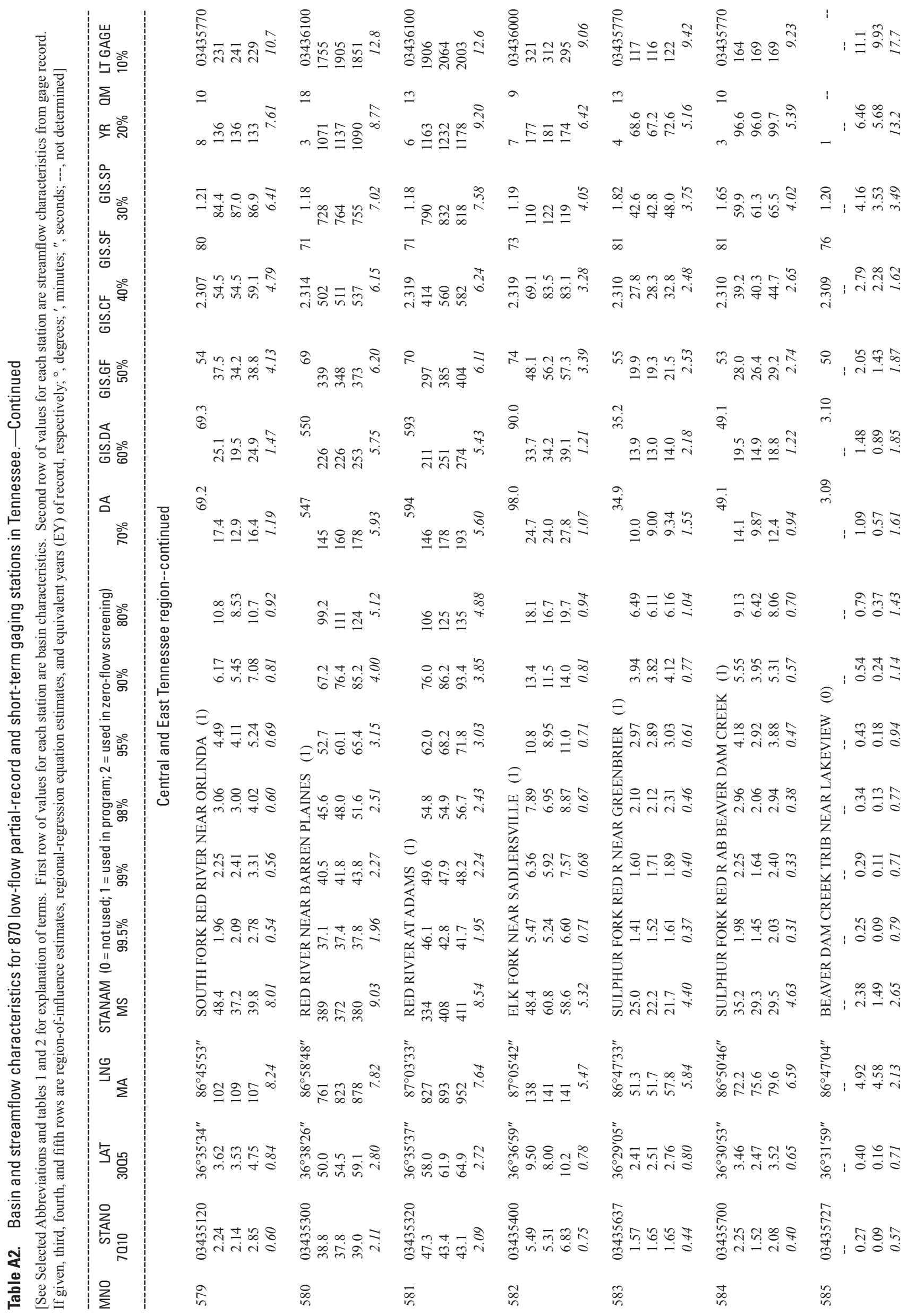




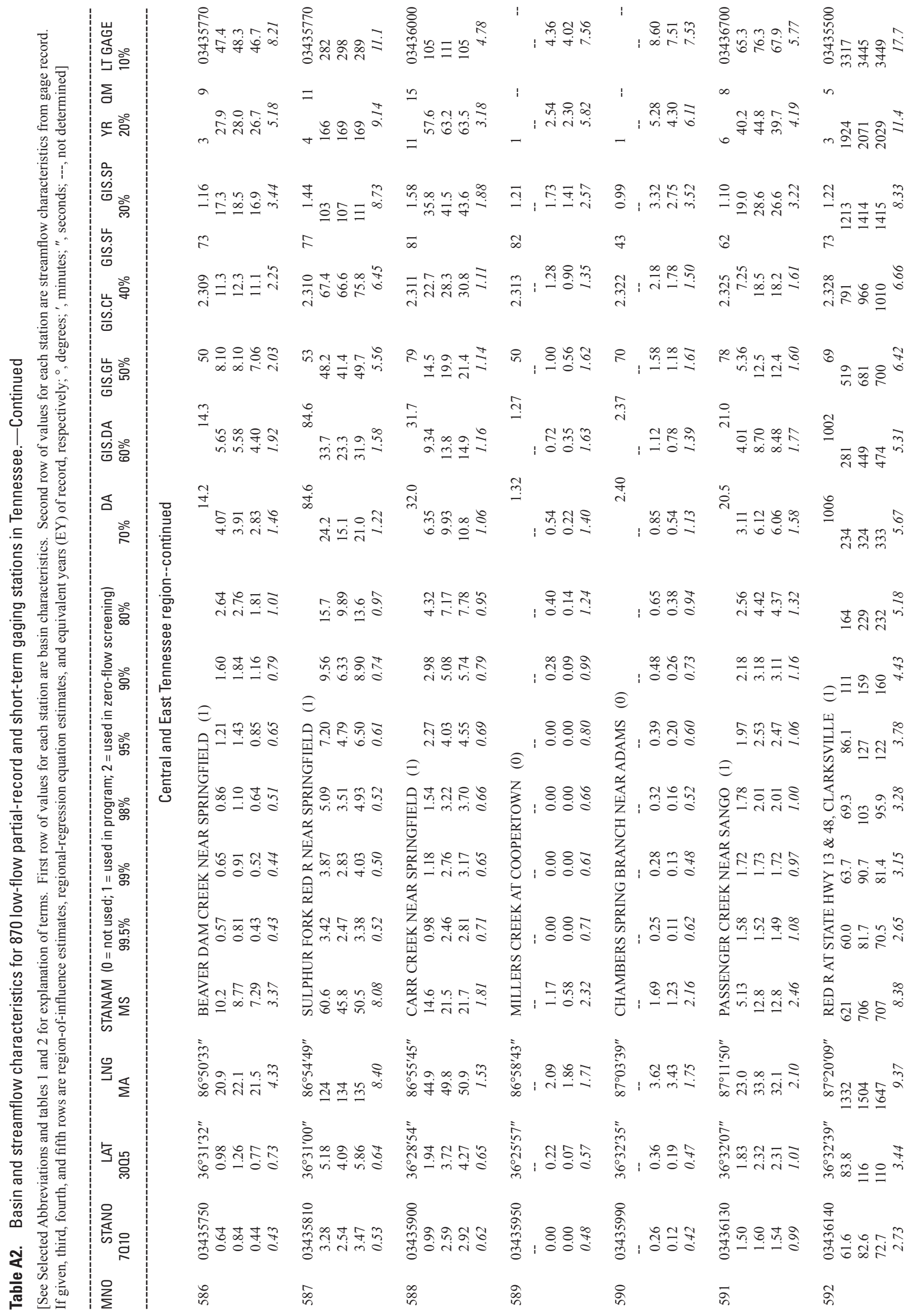


Appendix A. Basin and Streamflow Characteristics for Sites in This Report

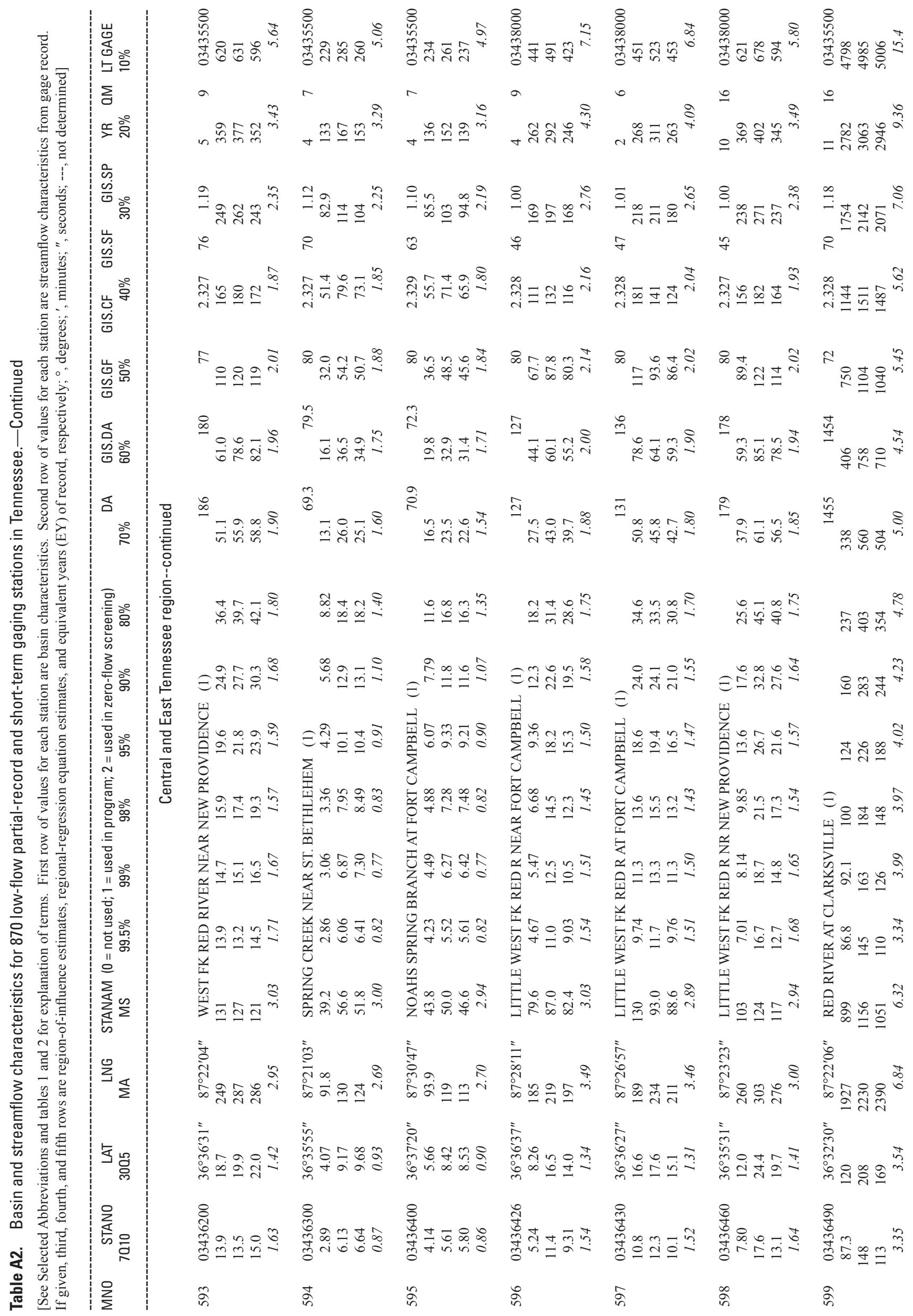




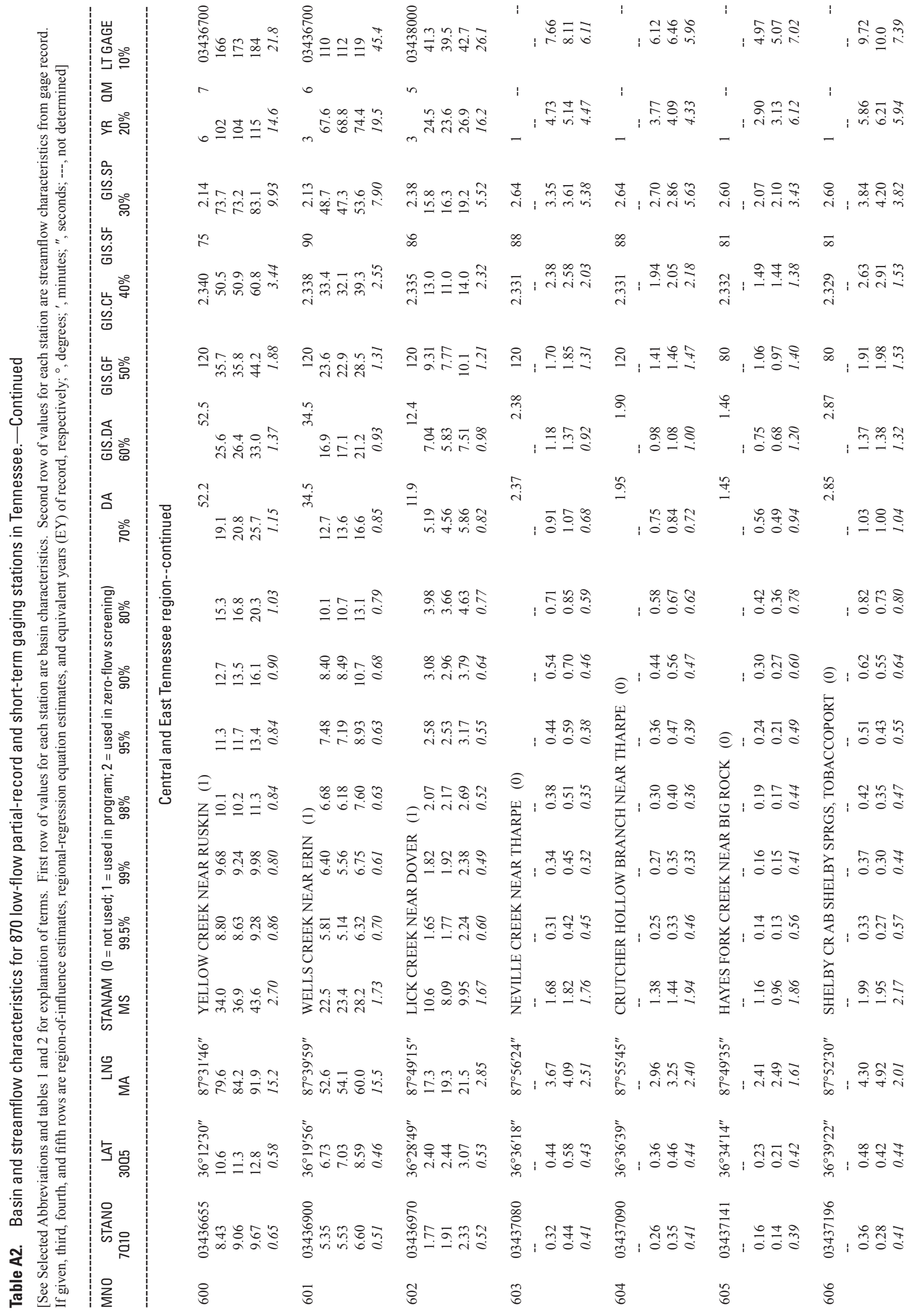




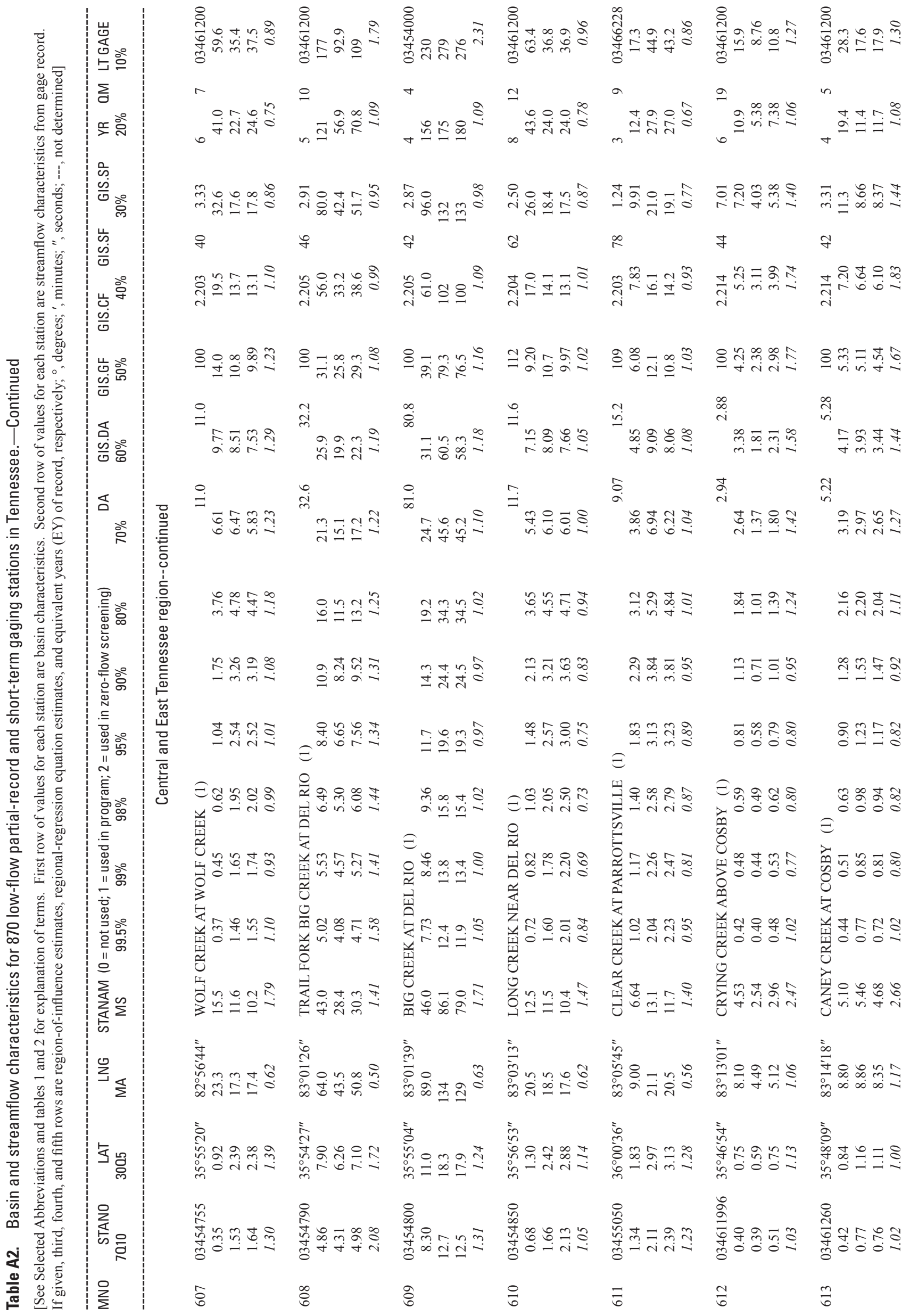




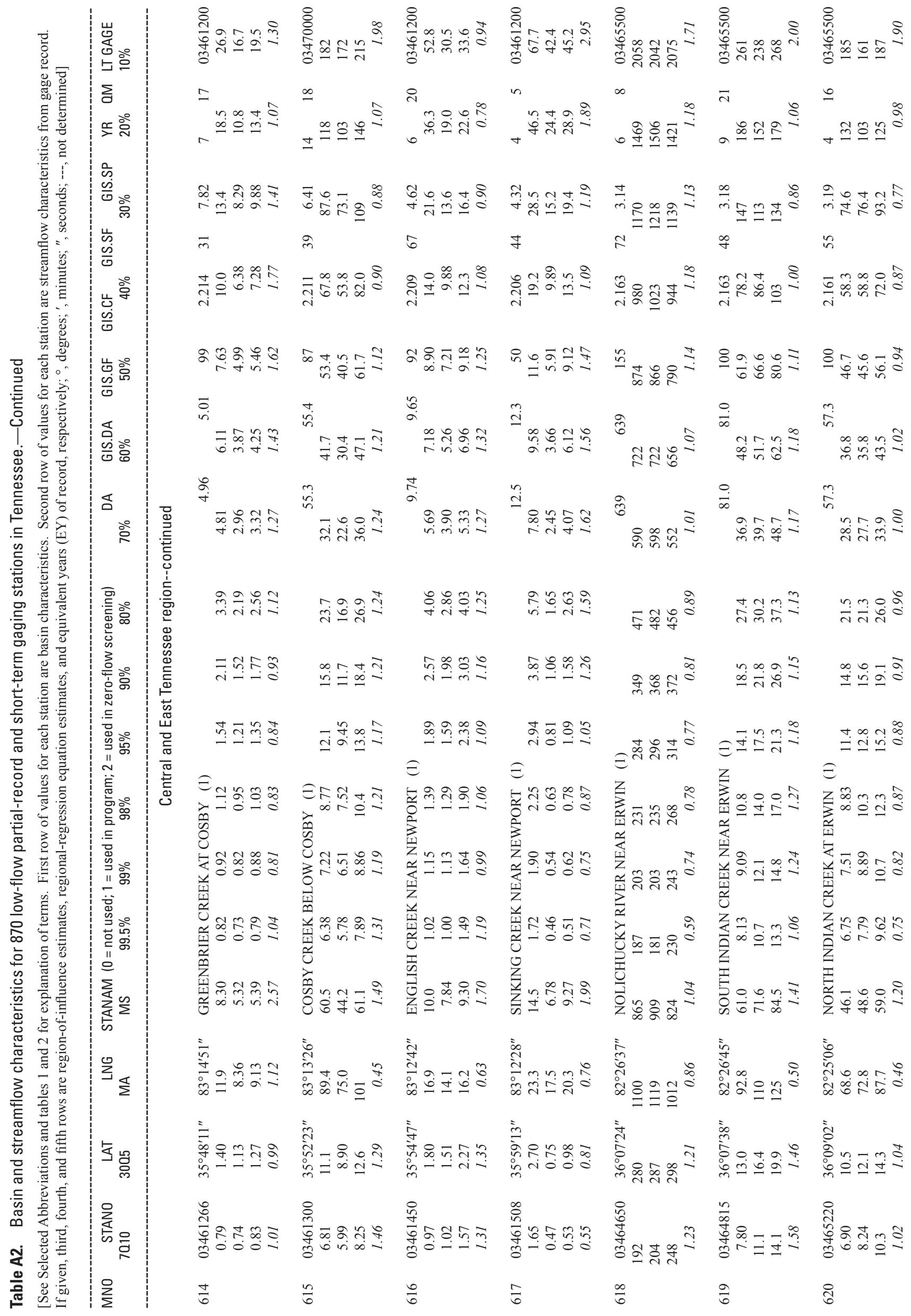




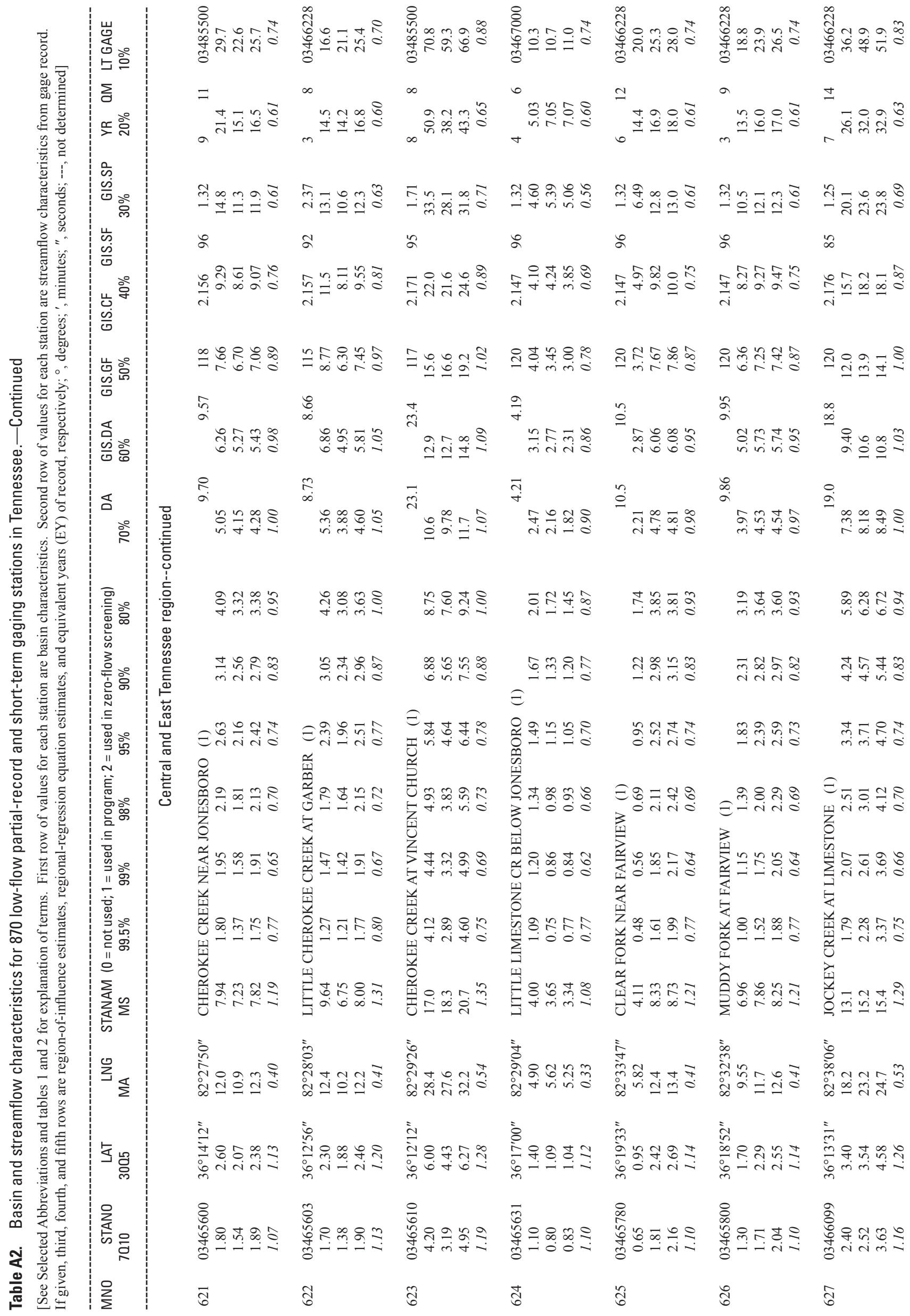




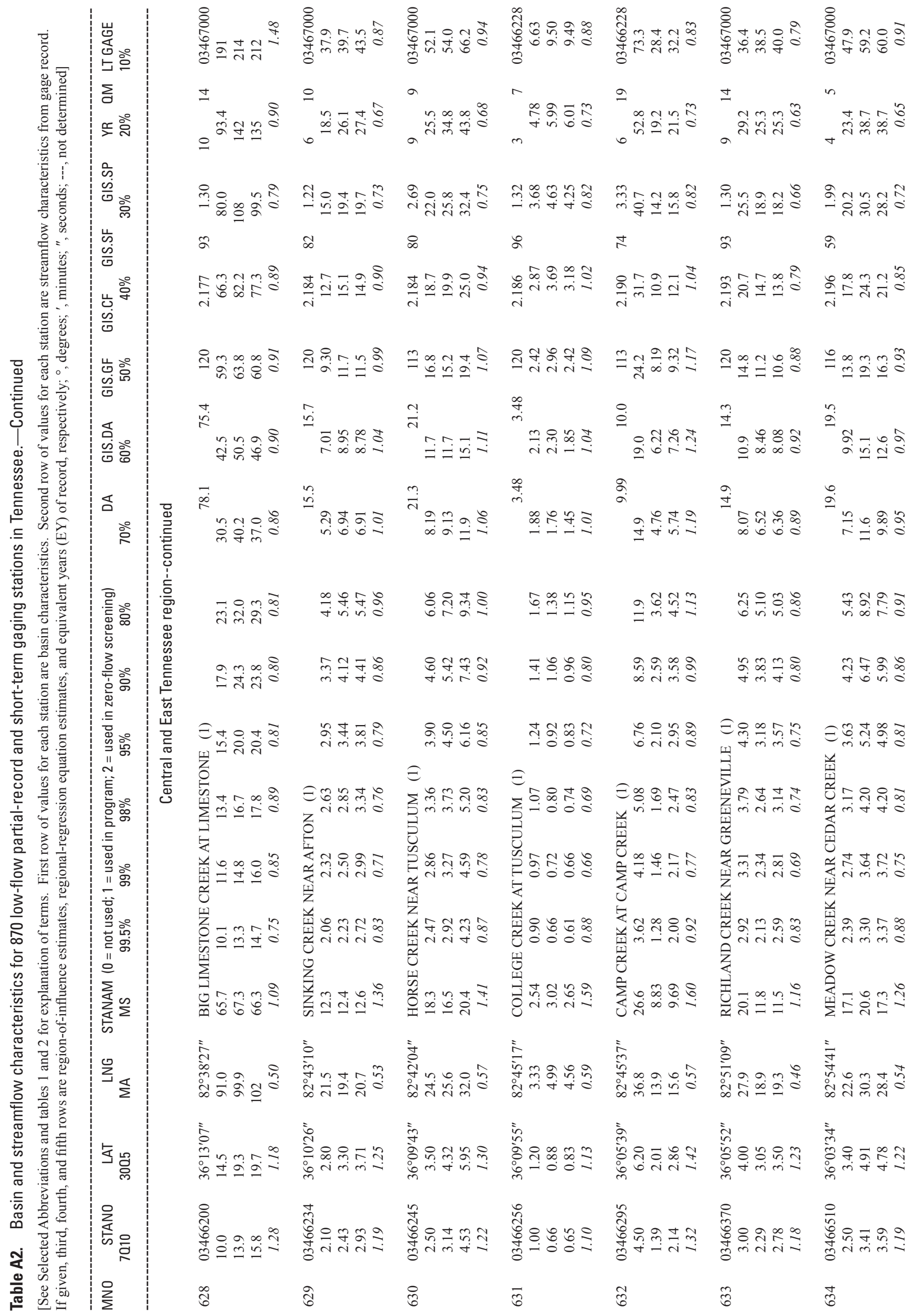




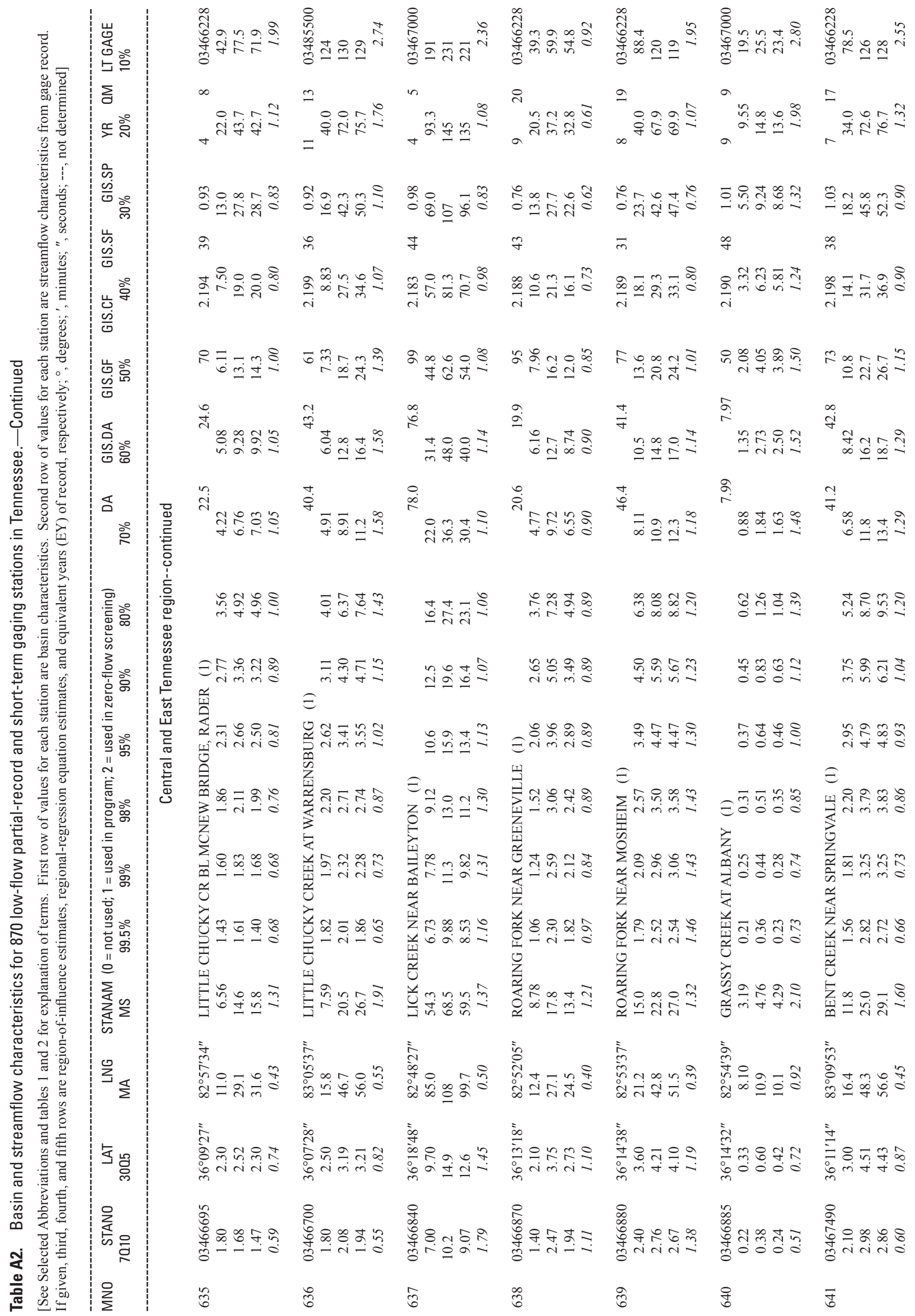




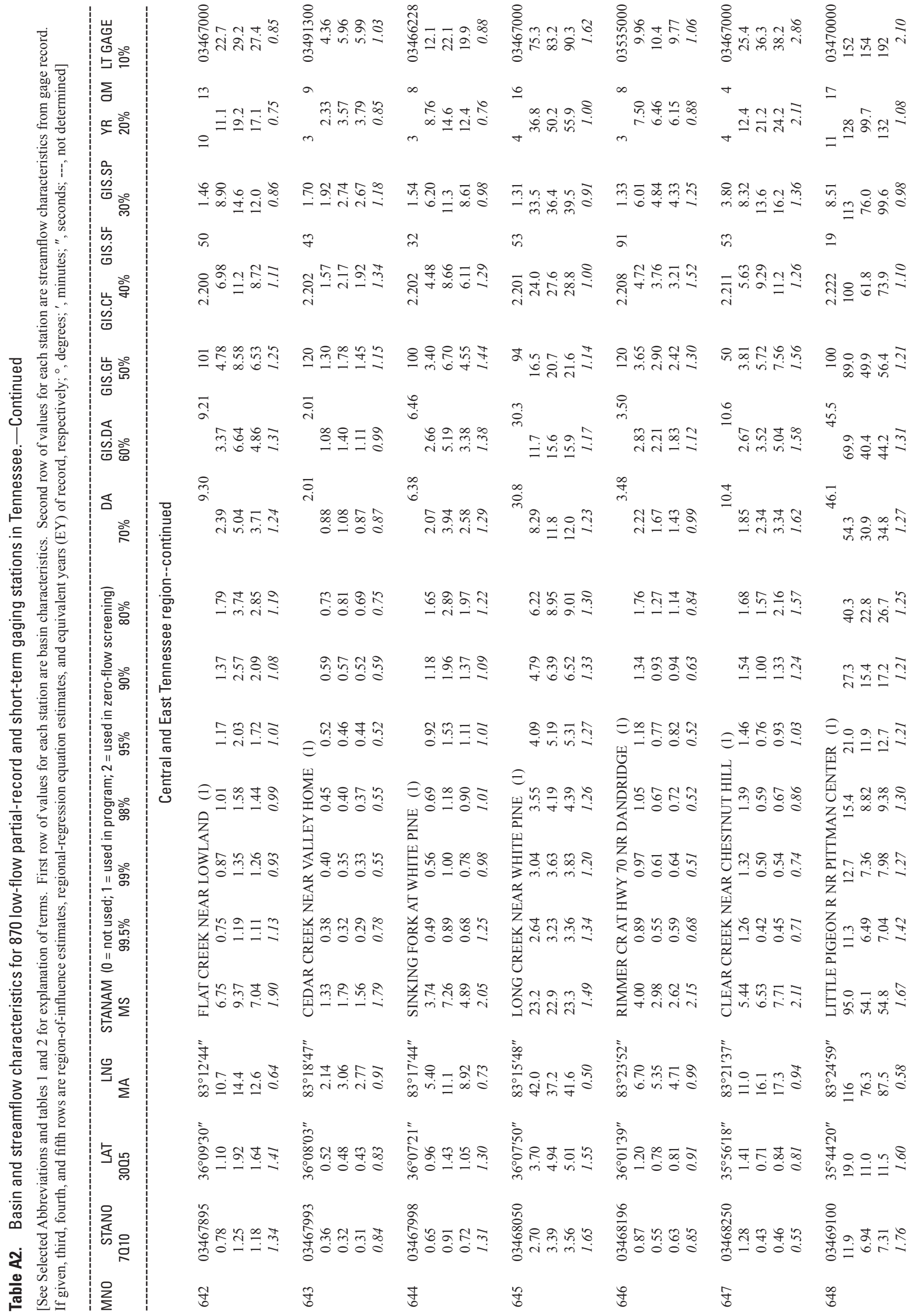




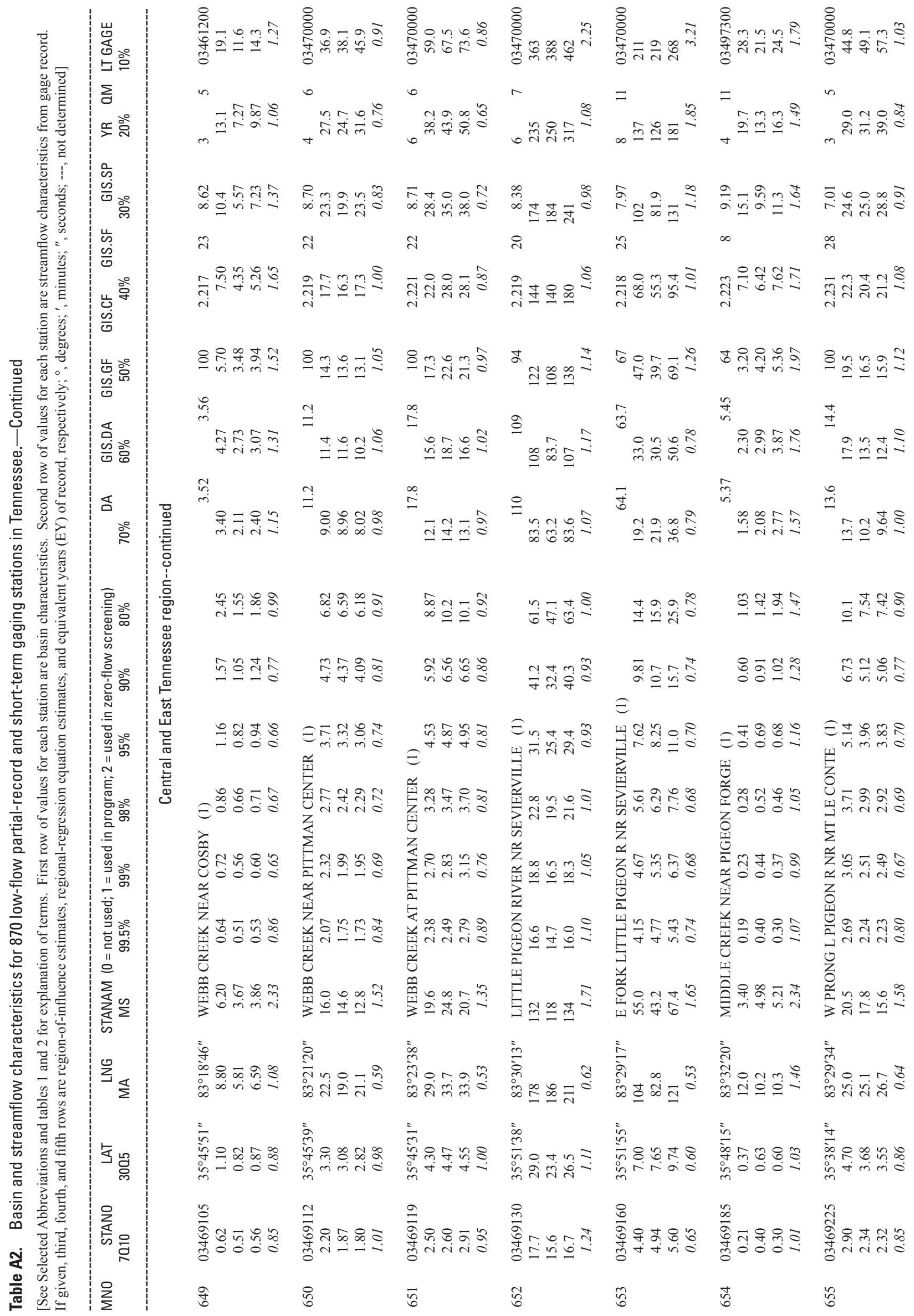




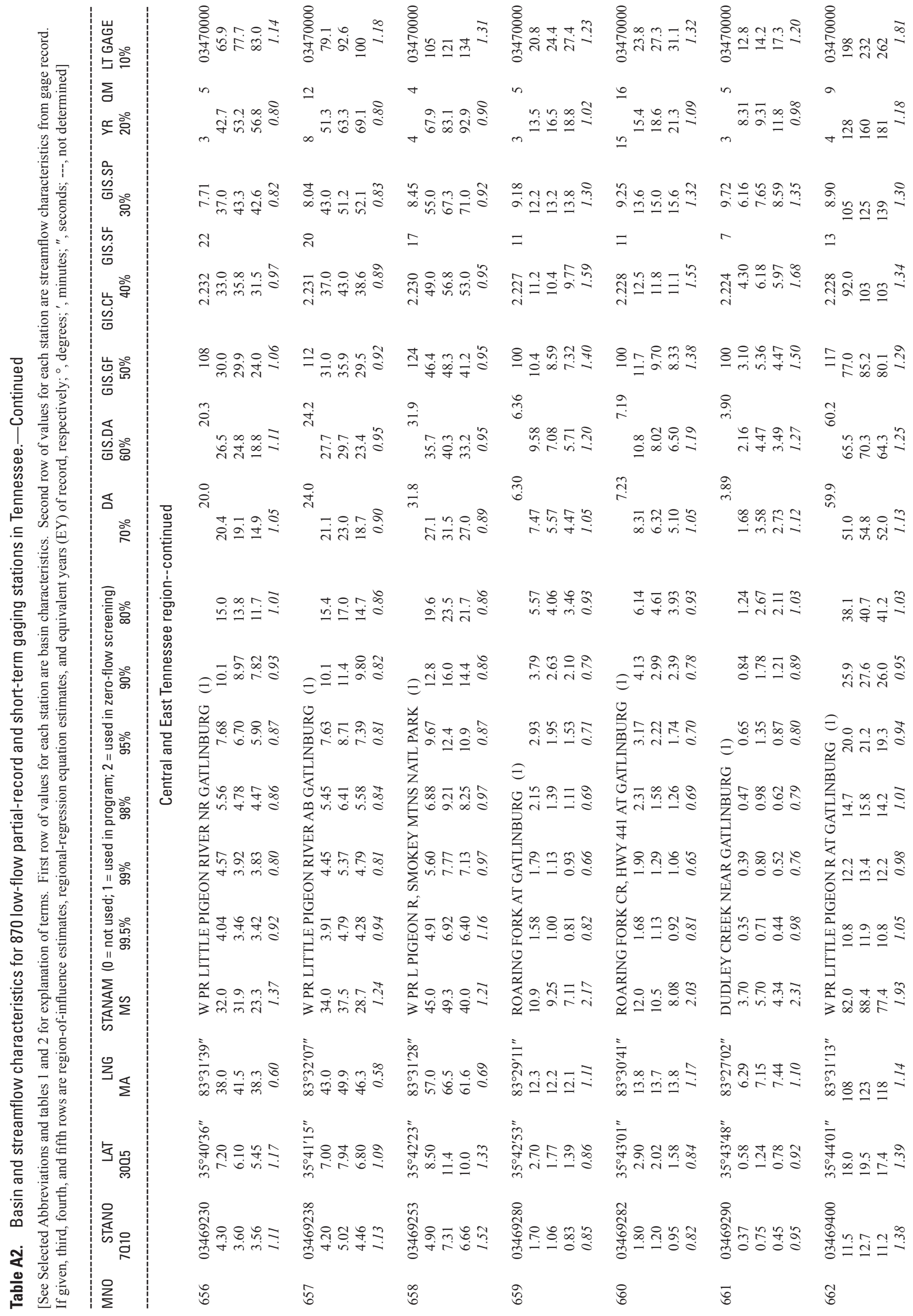




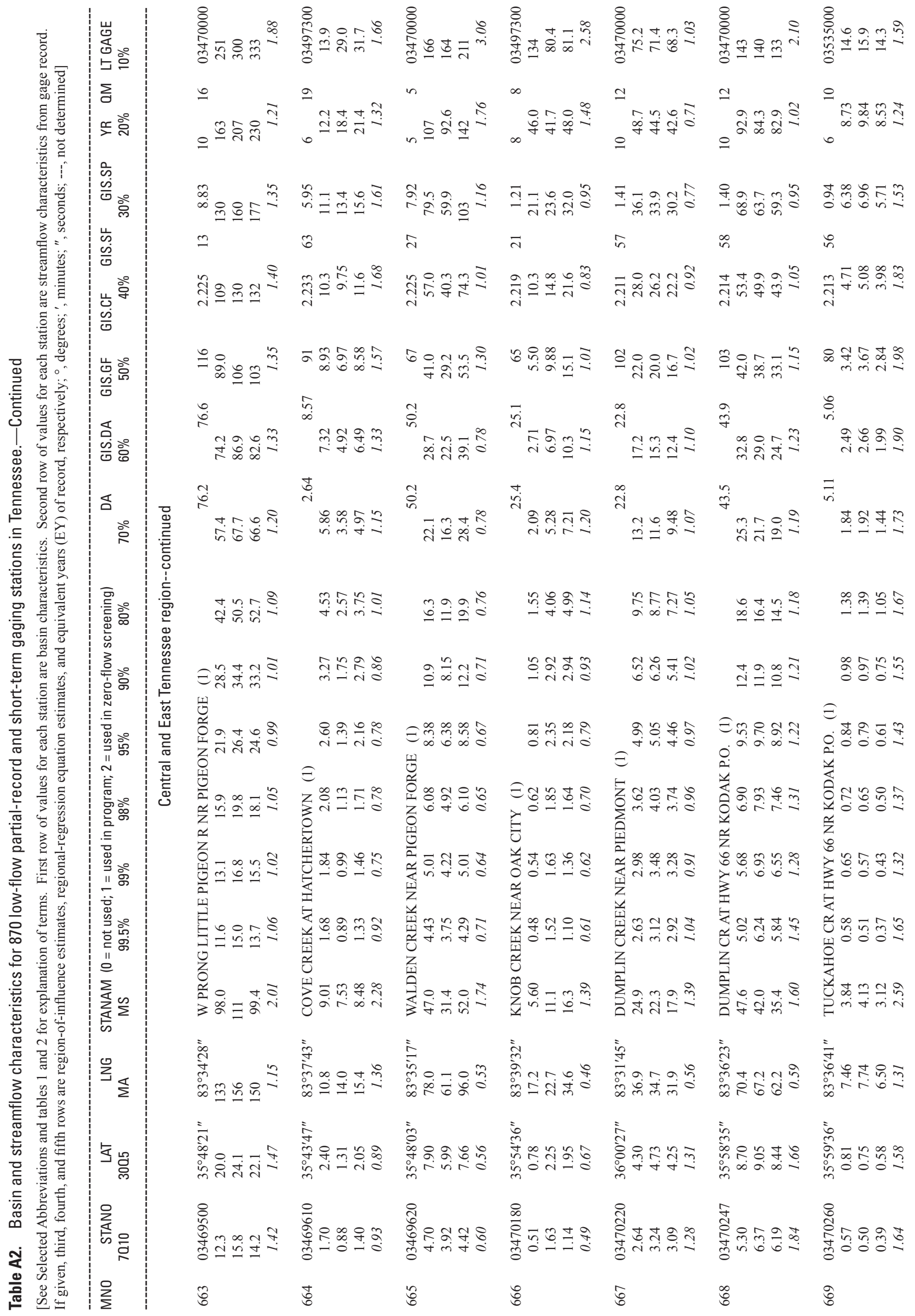




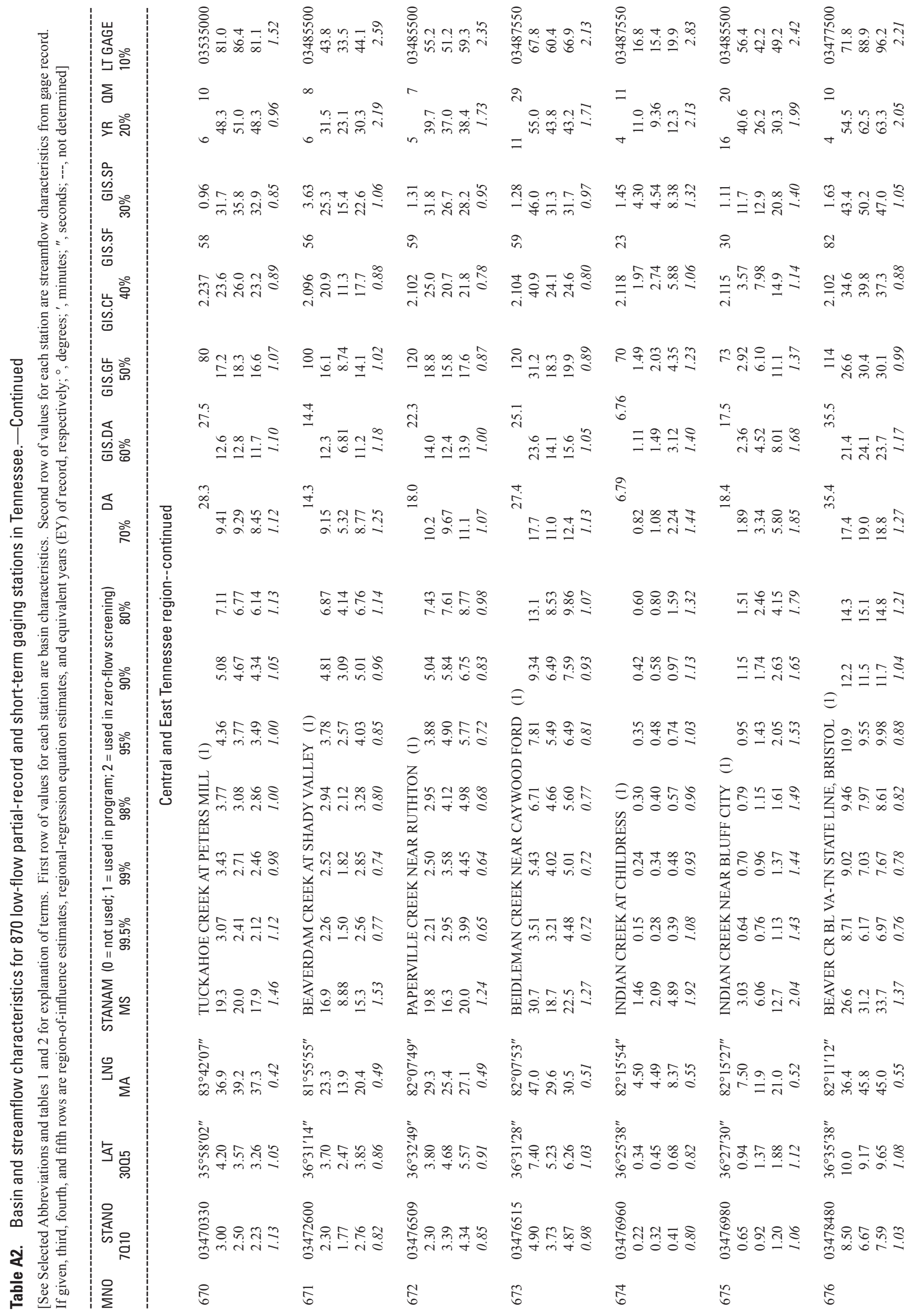




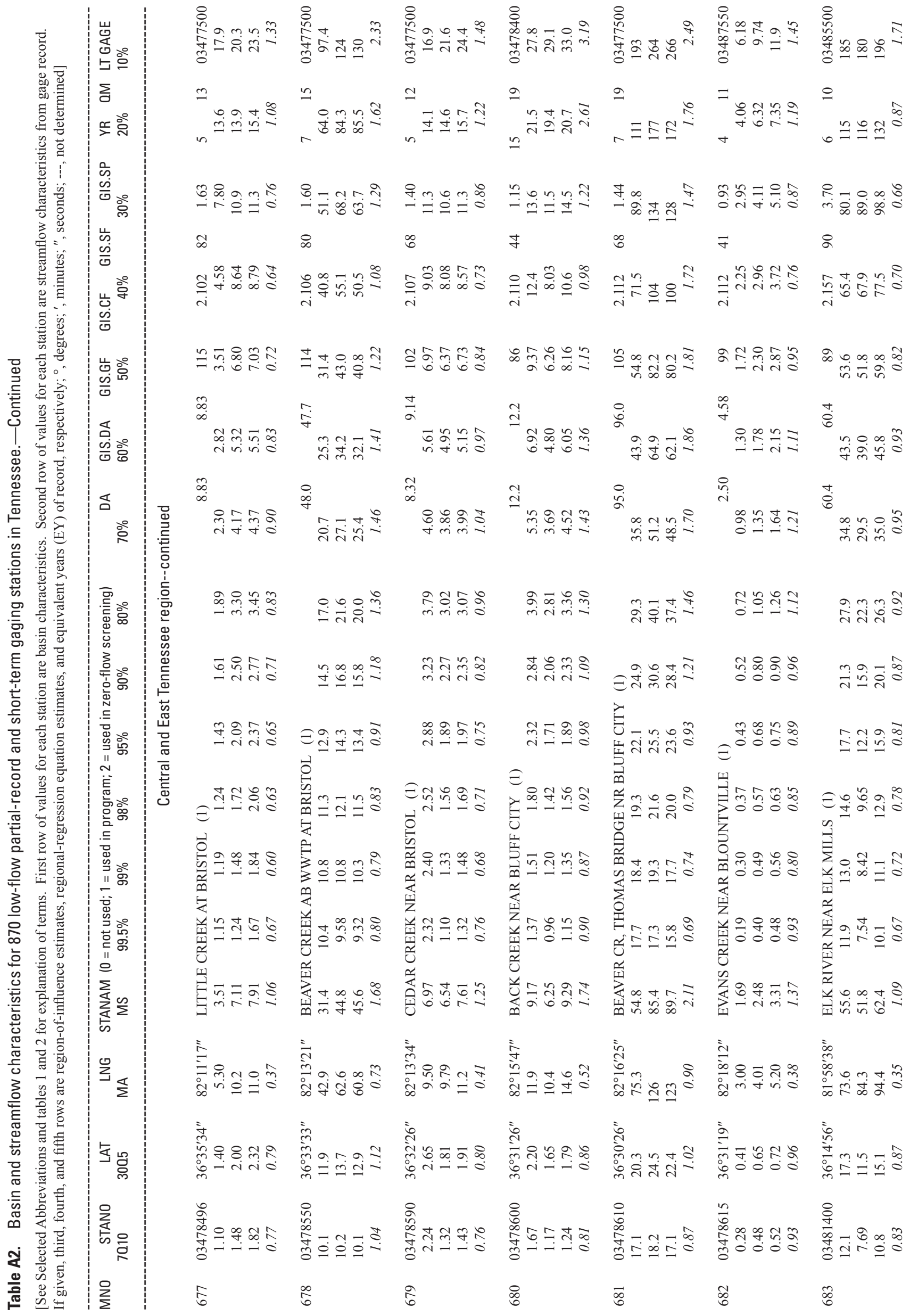




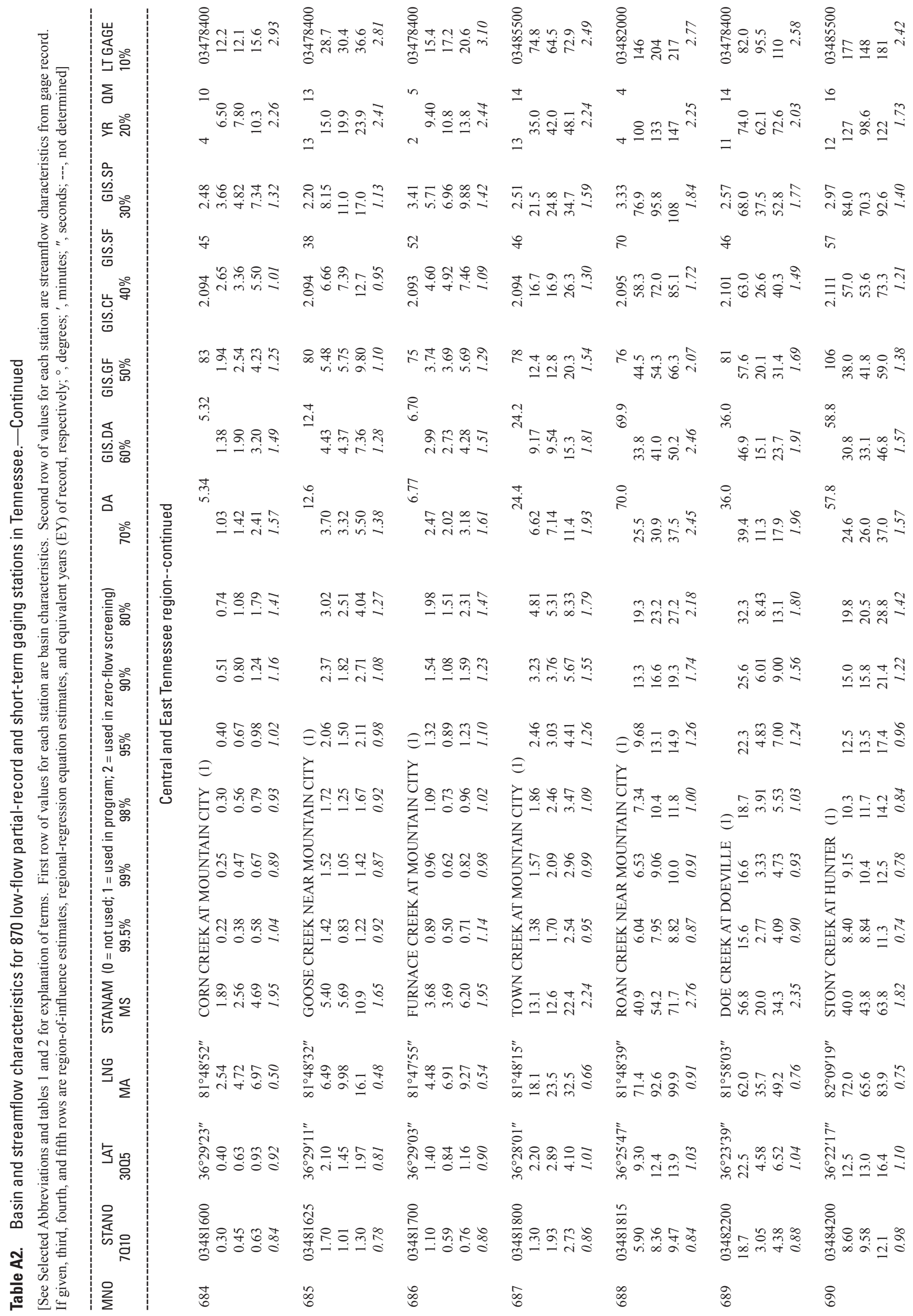




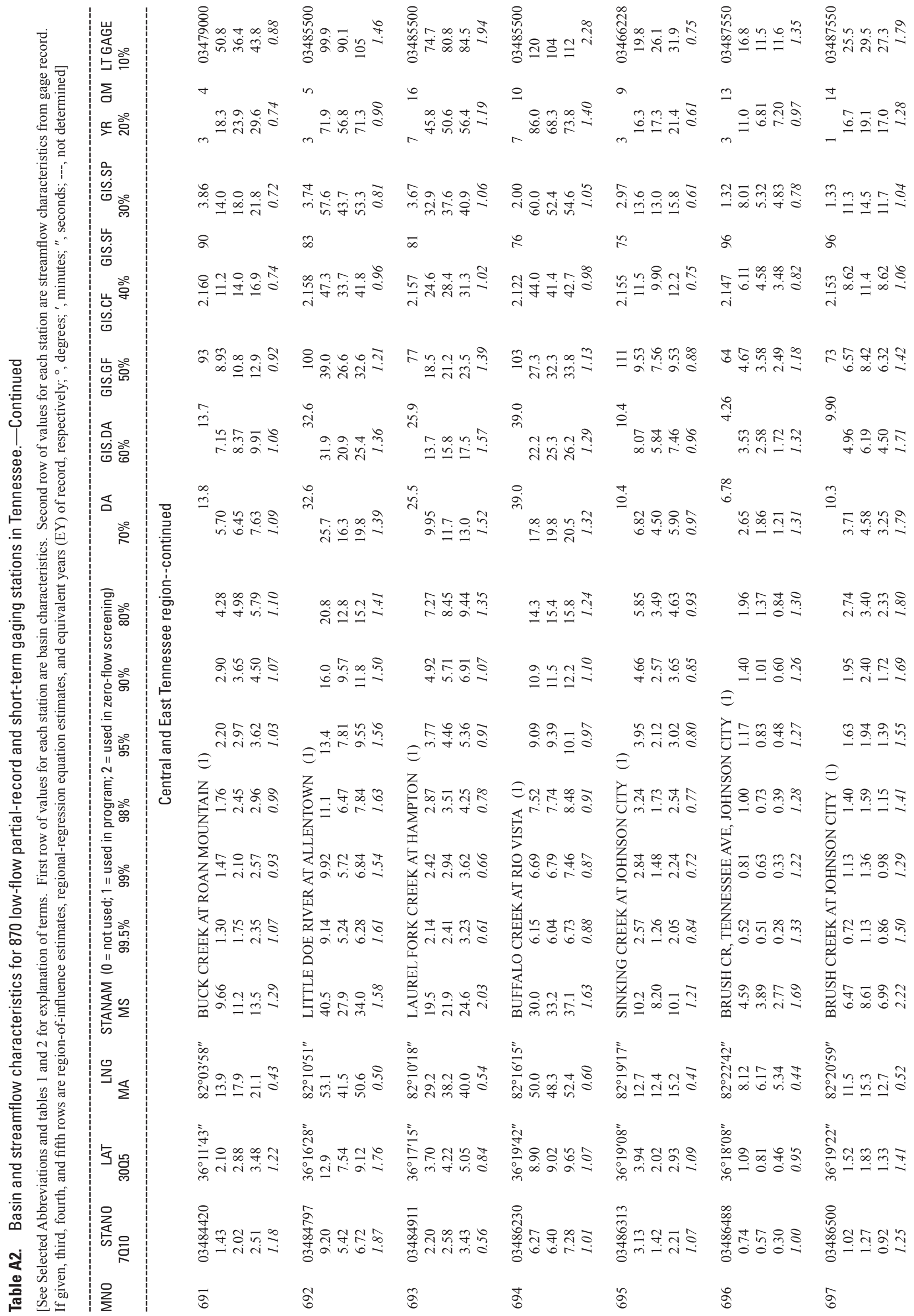




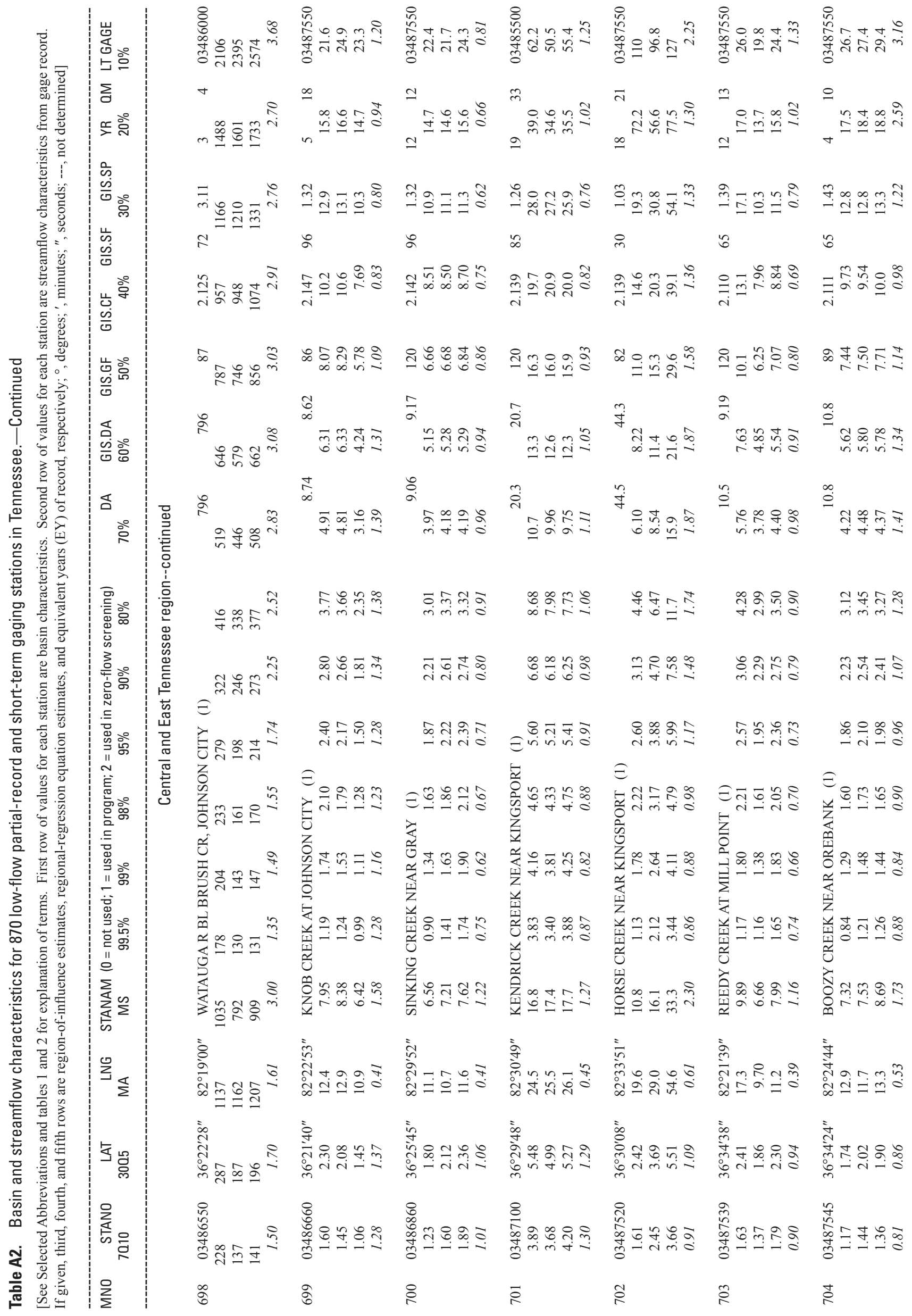


Appendix A. Basin and Streamflow Characteristics for Sites in This Report

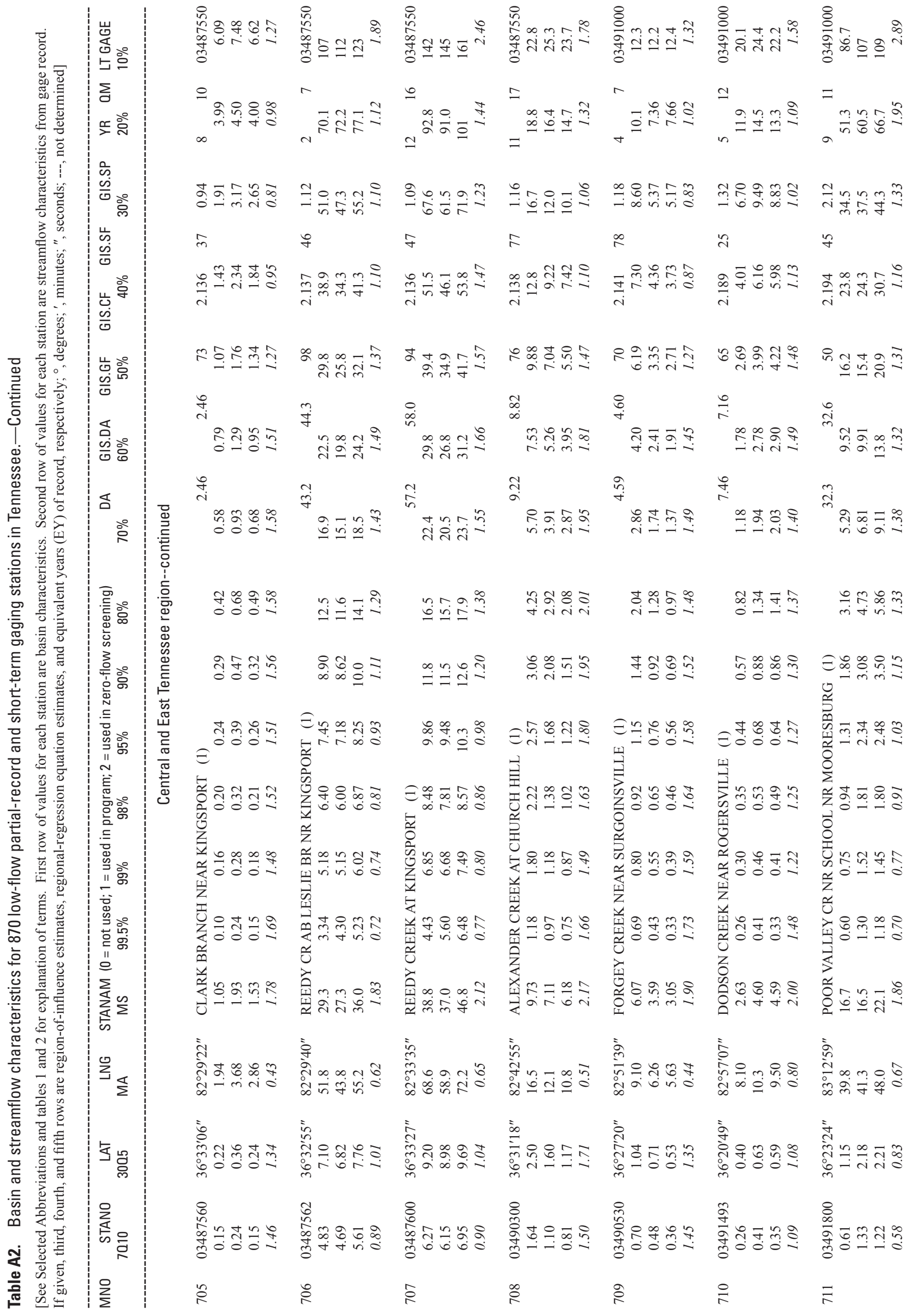




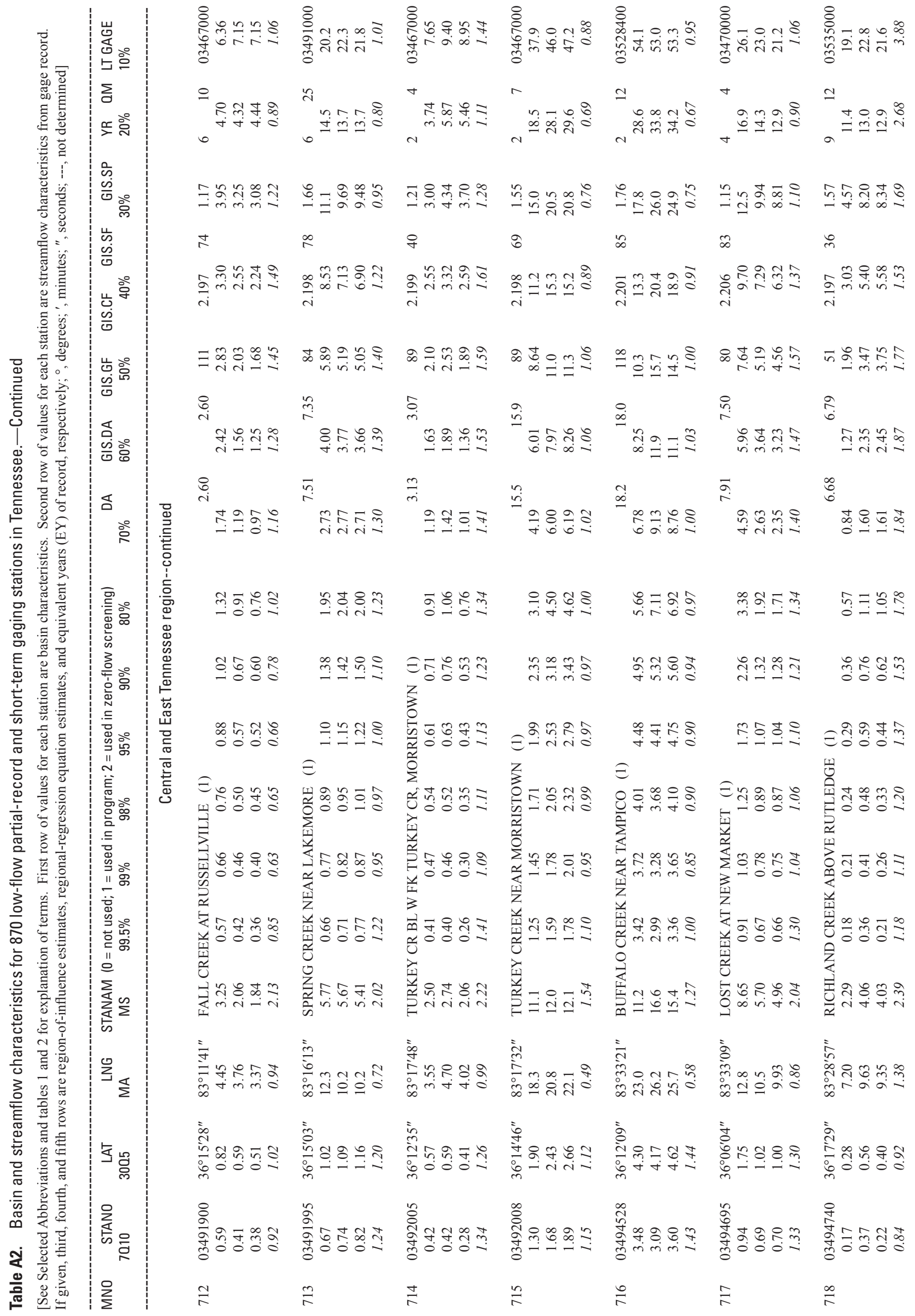




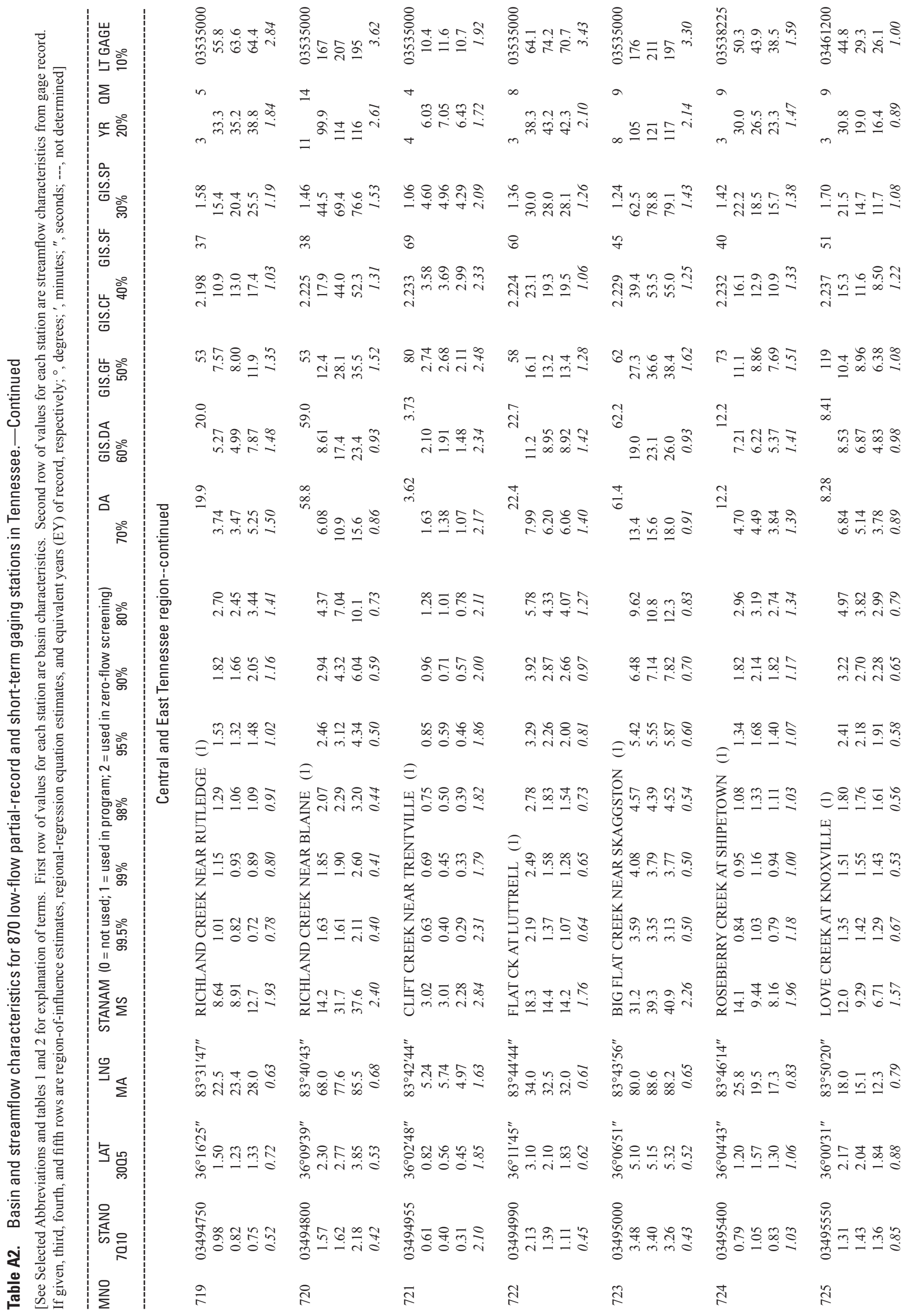




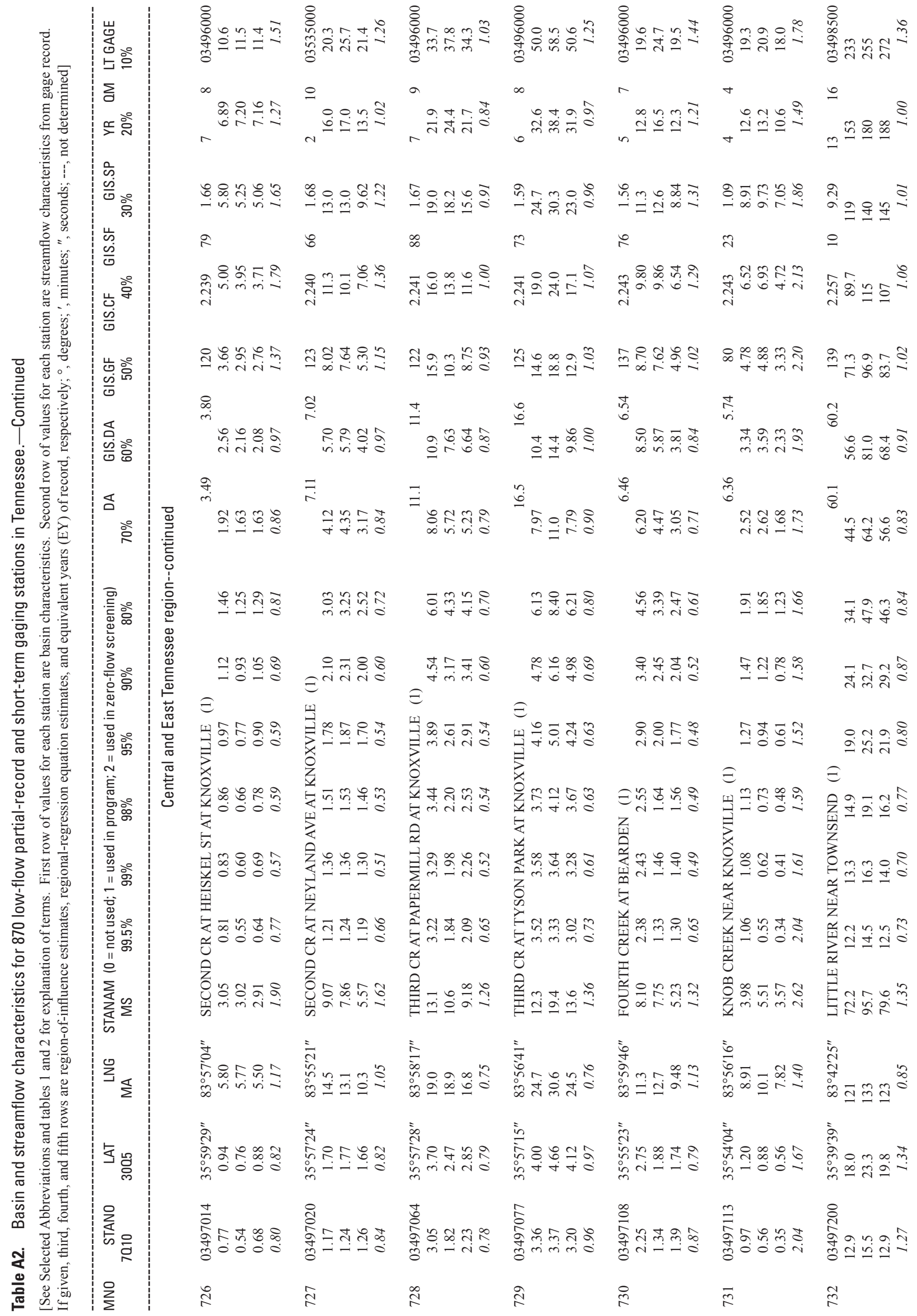




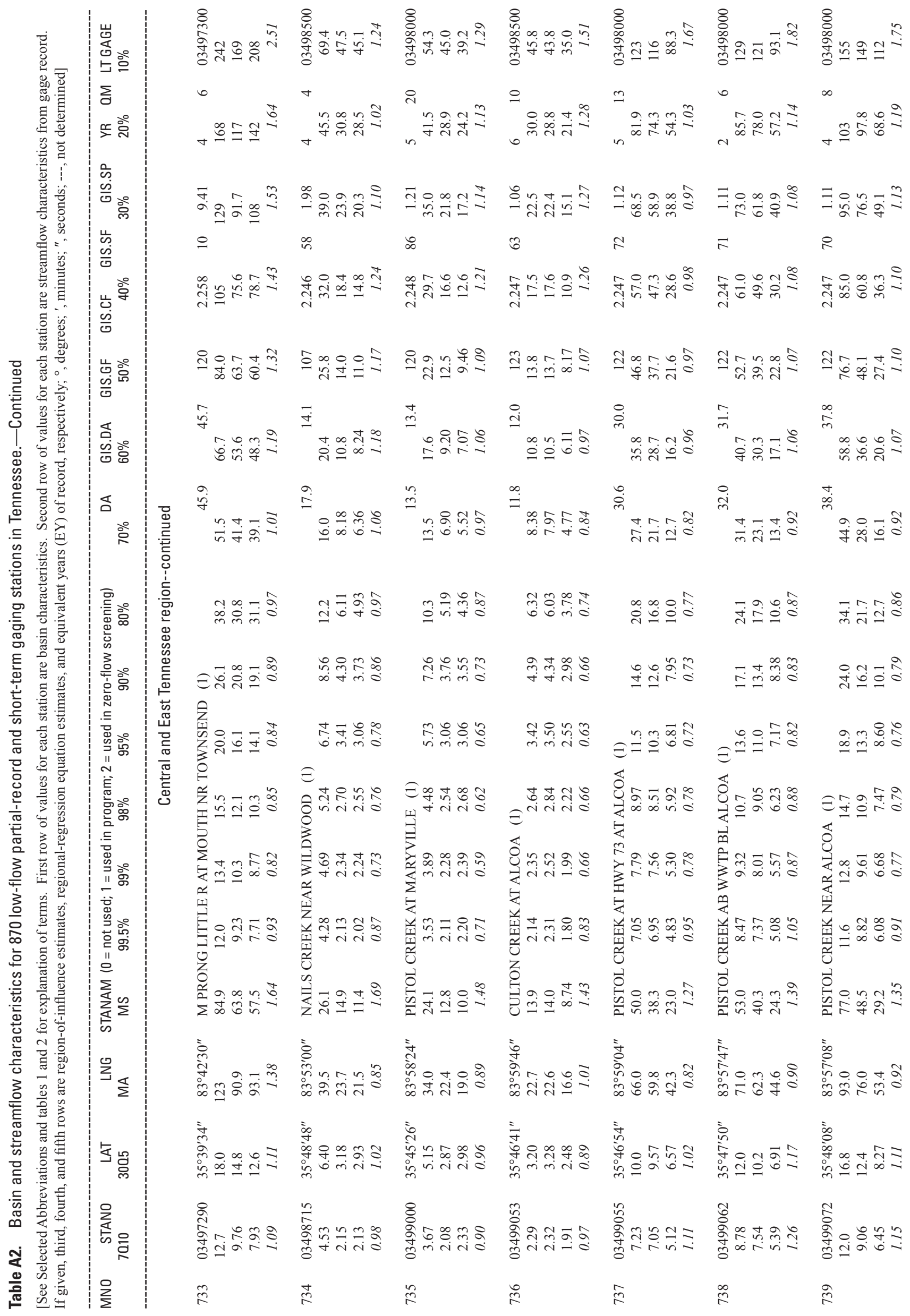




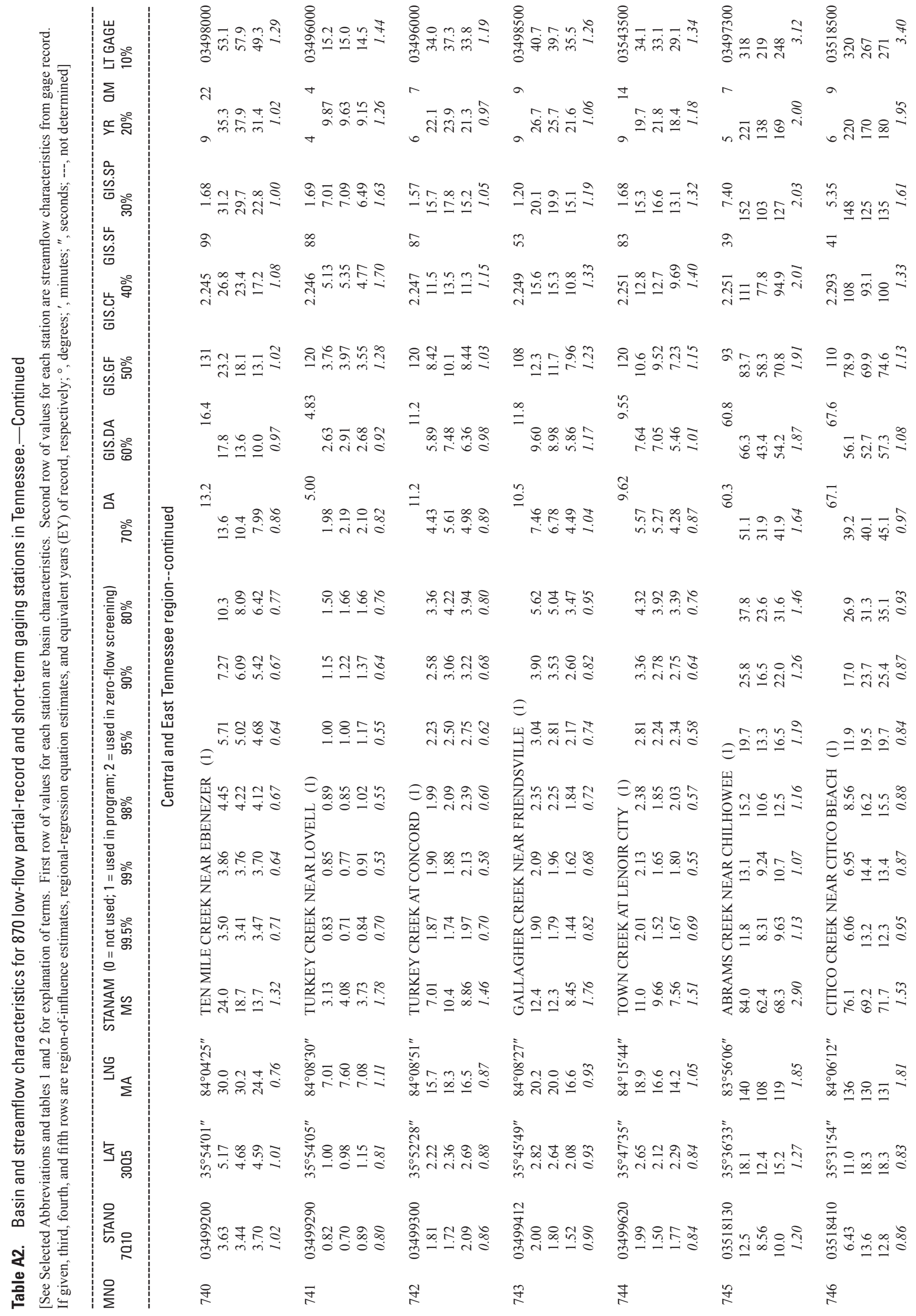




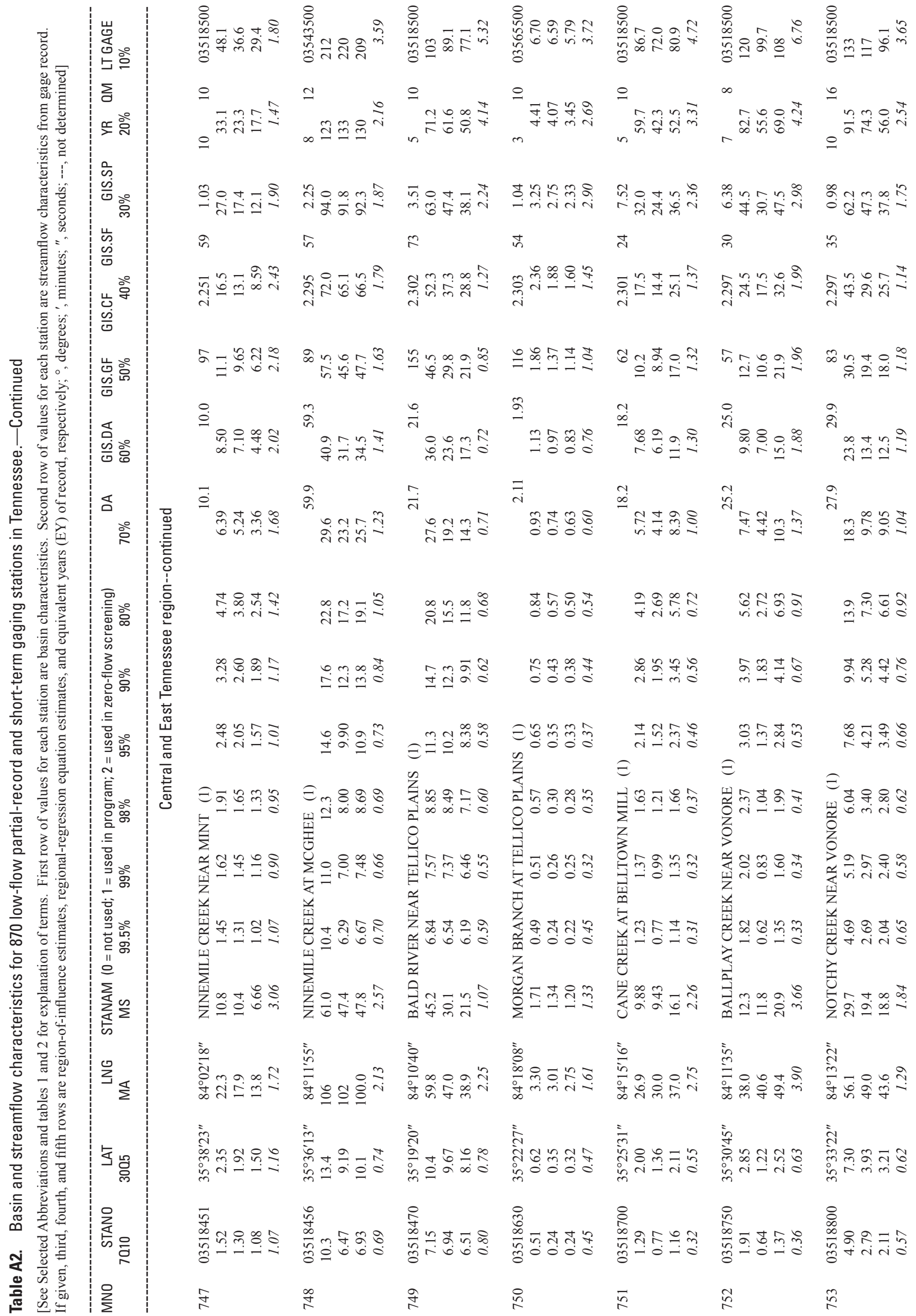




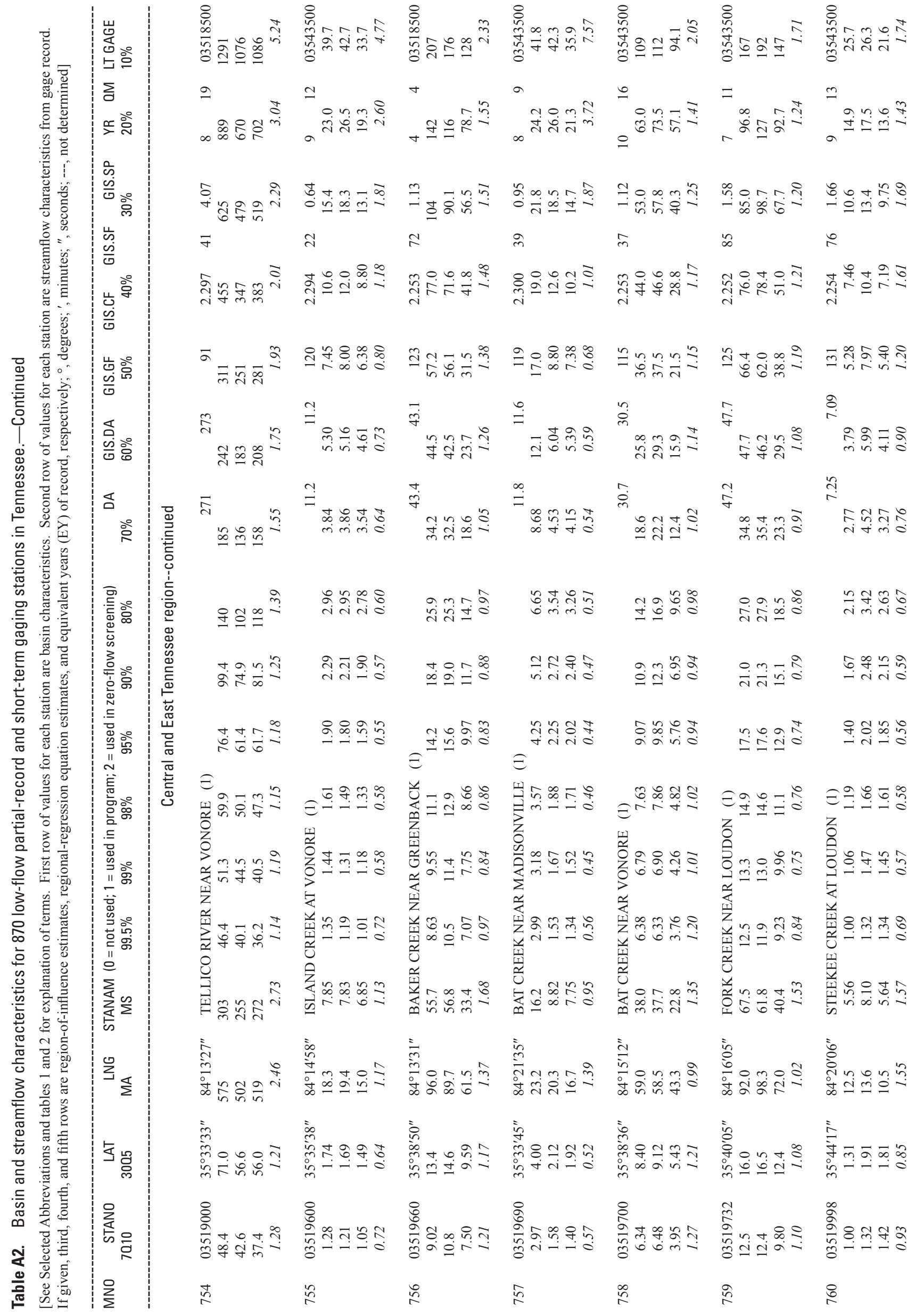




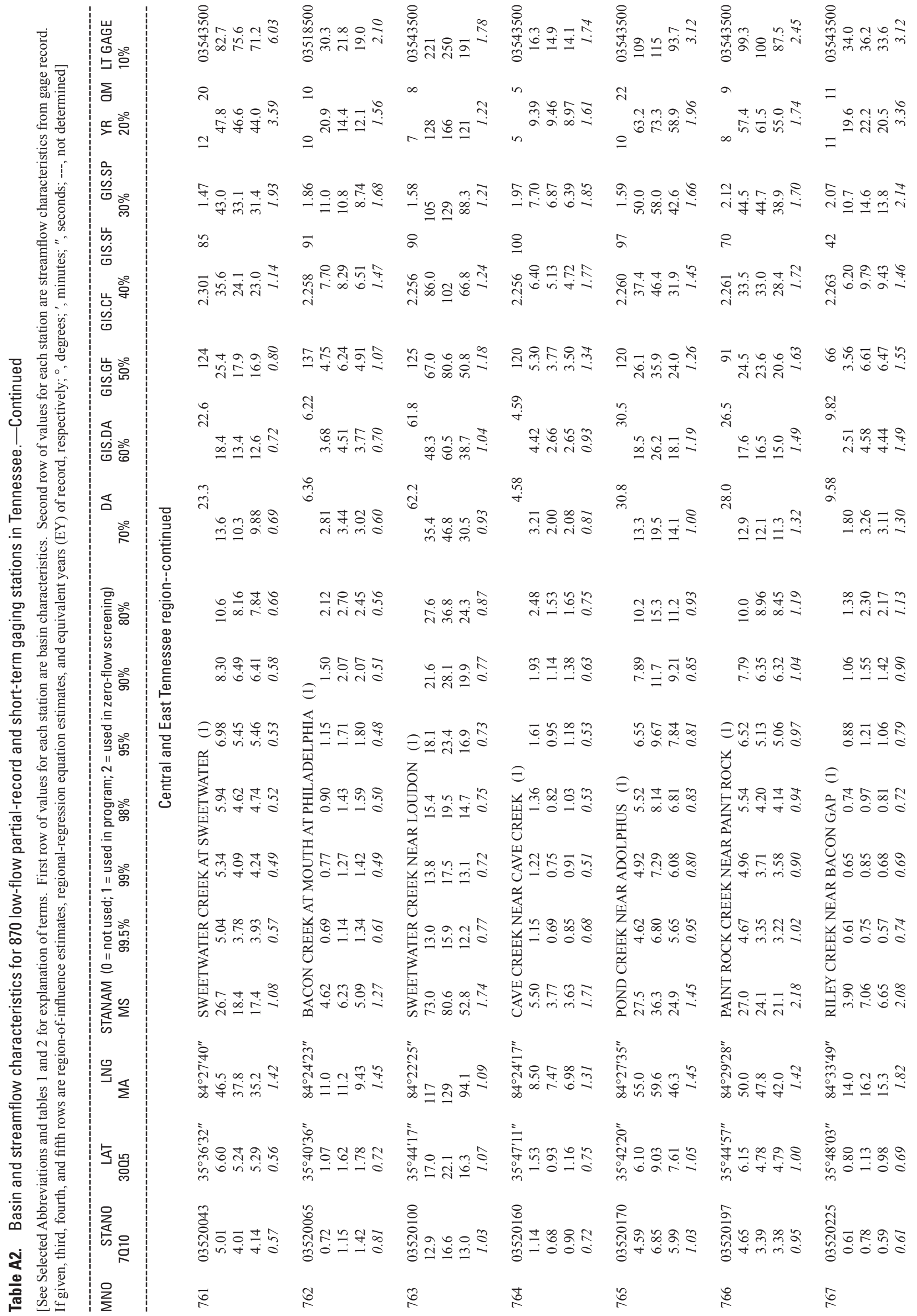




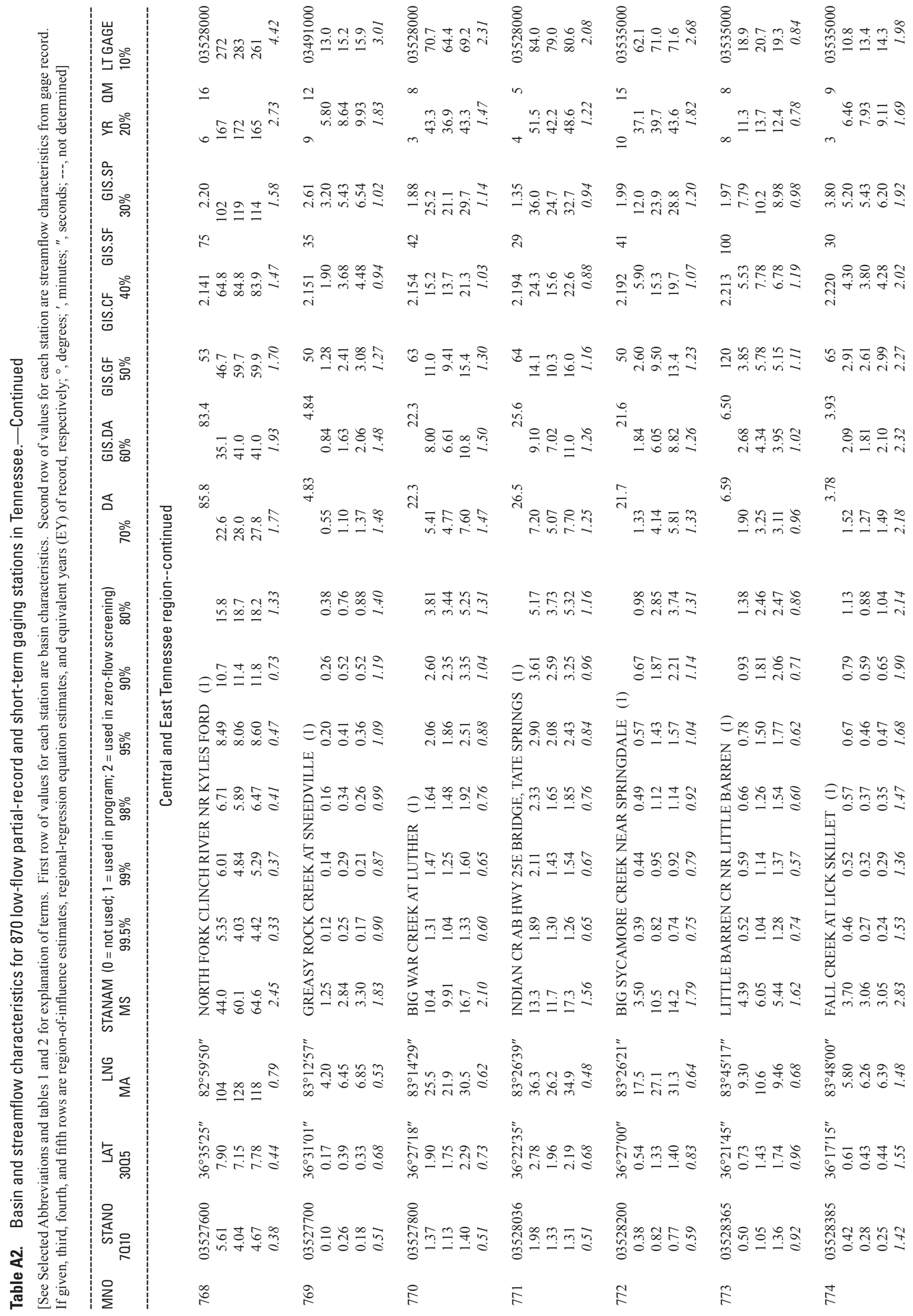


Appendix A. Basin and Streamflow Characteristics for Sites in This Report

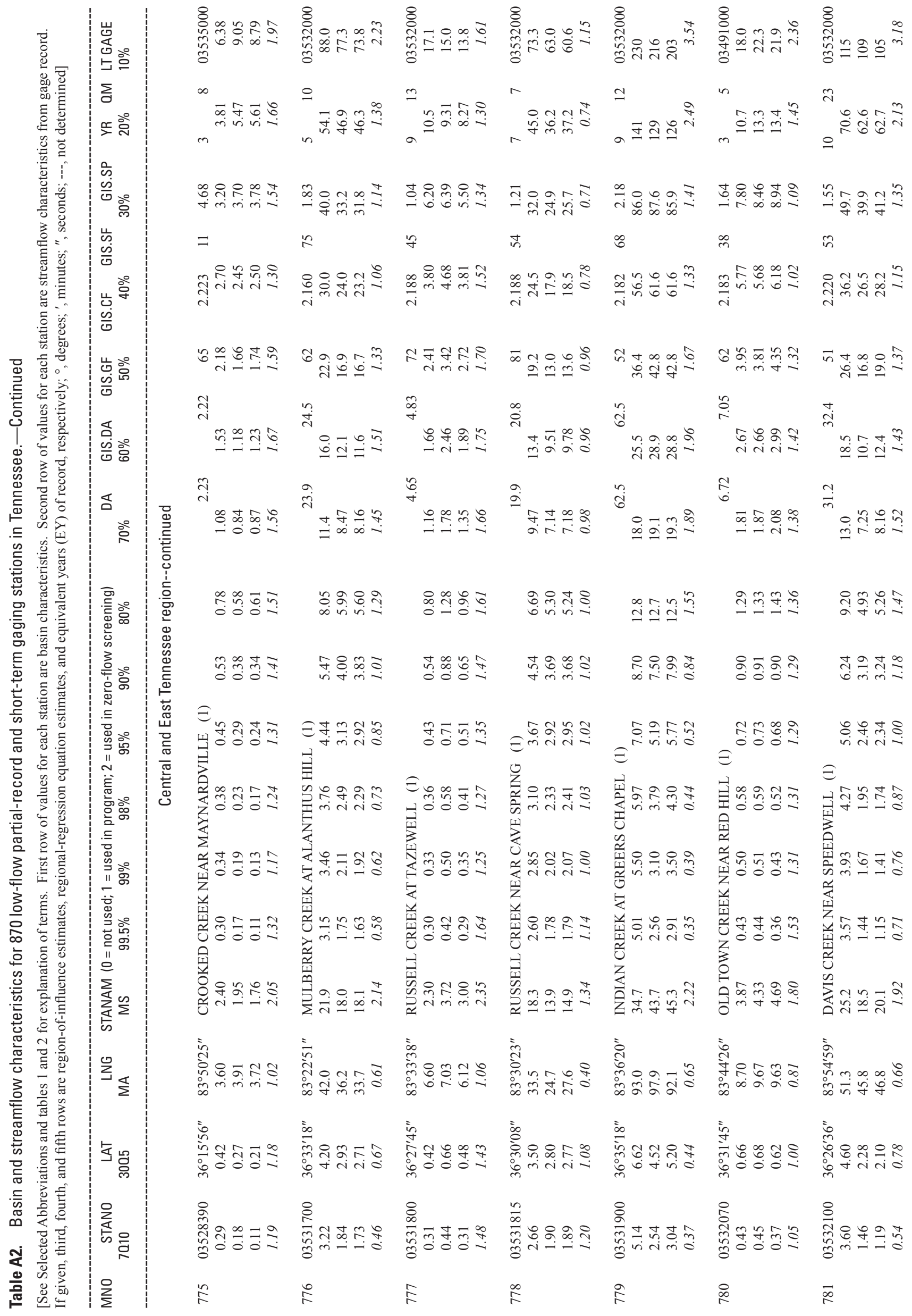




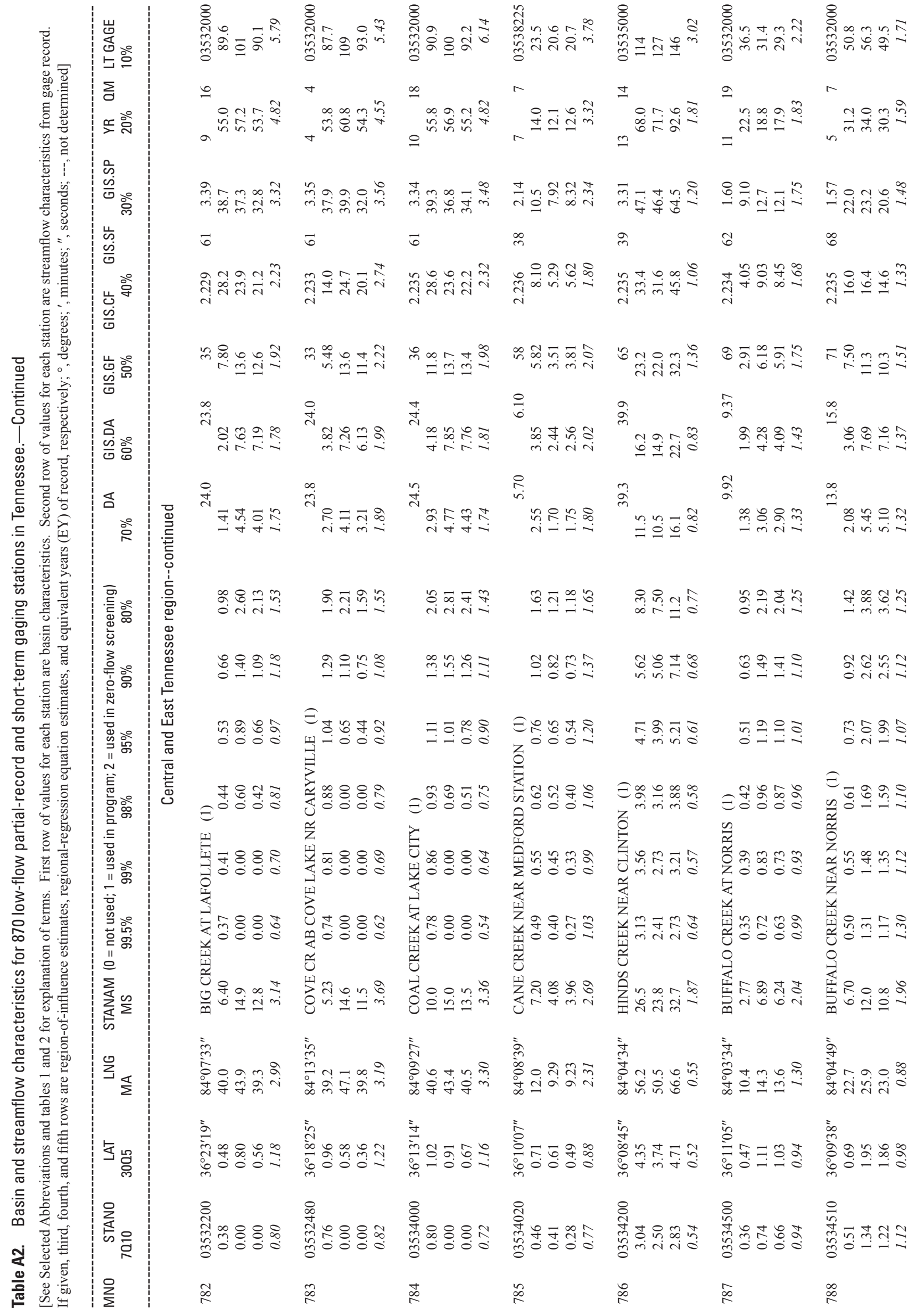




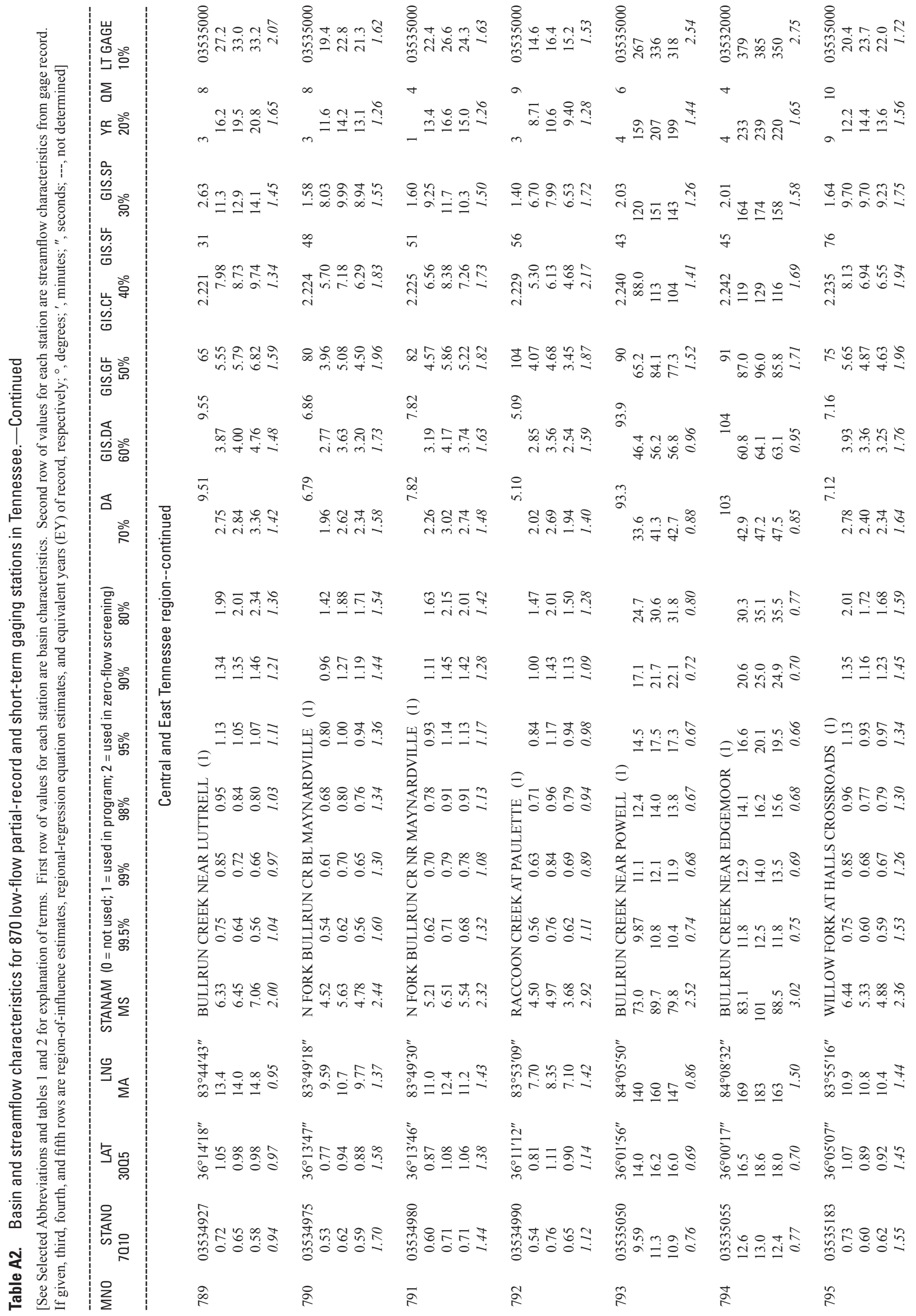




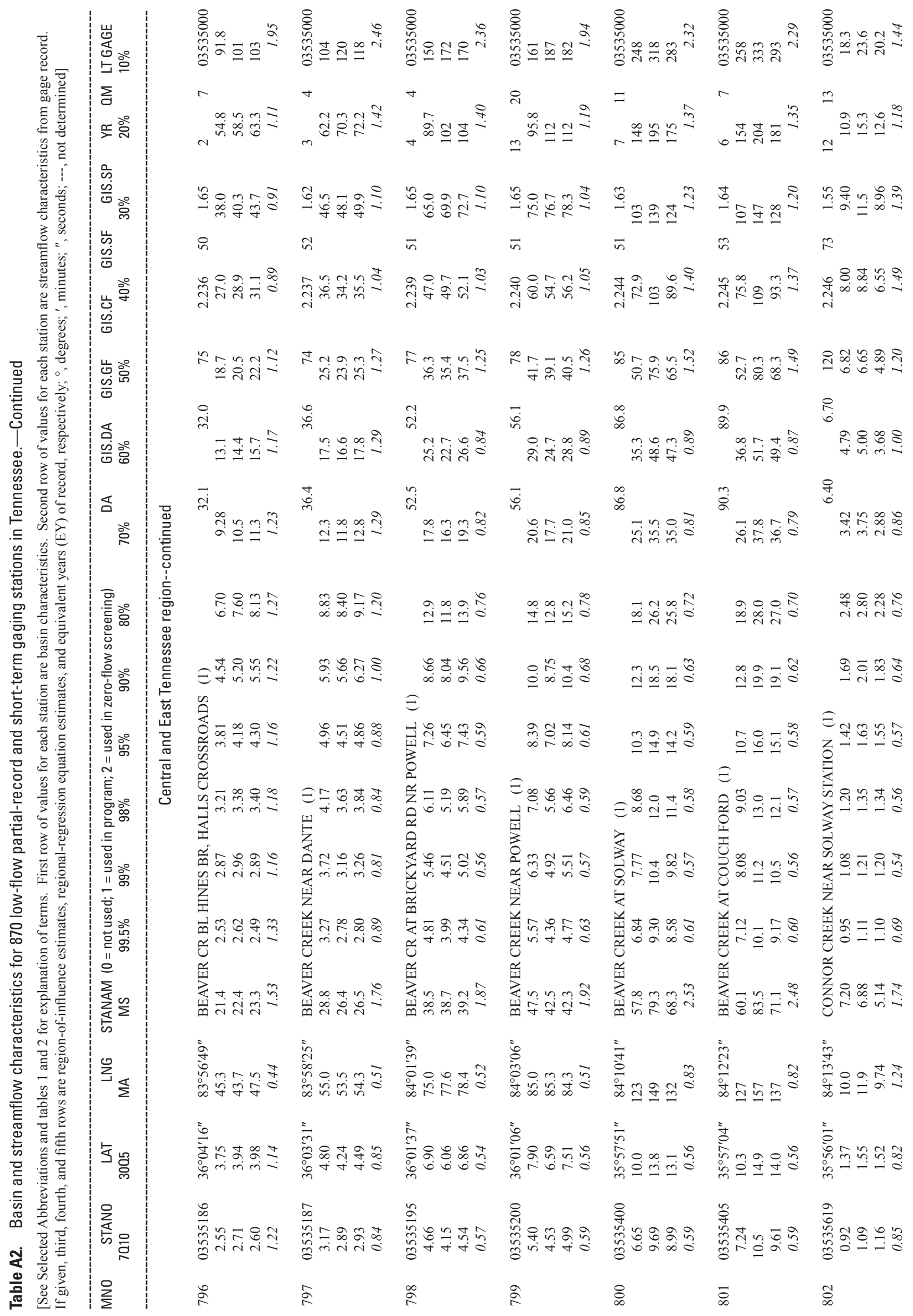




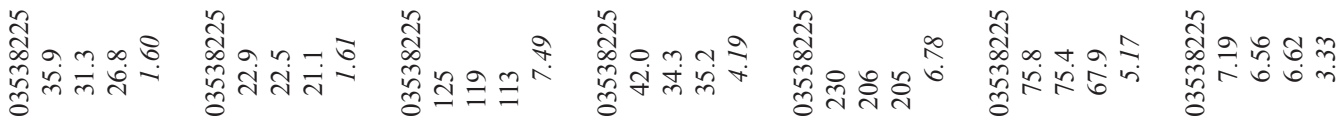

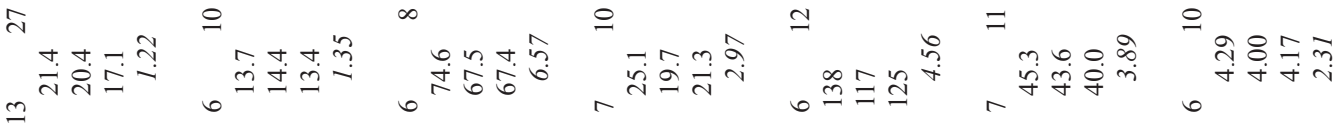

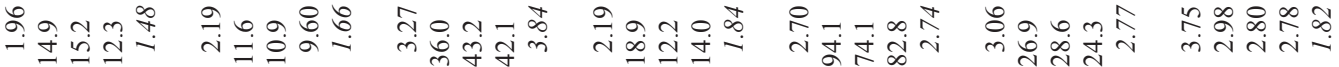

2 तु के के के उ

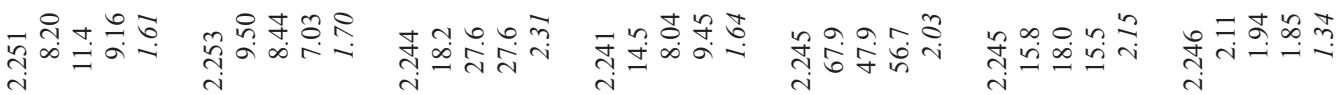

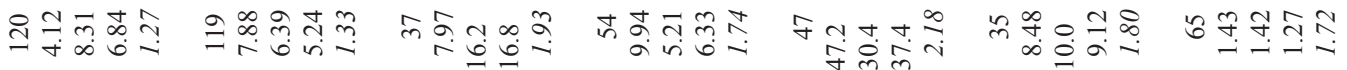

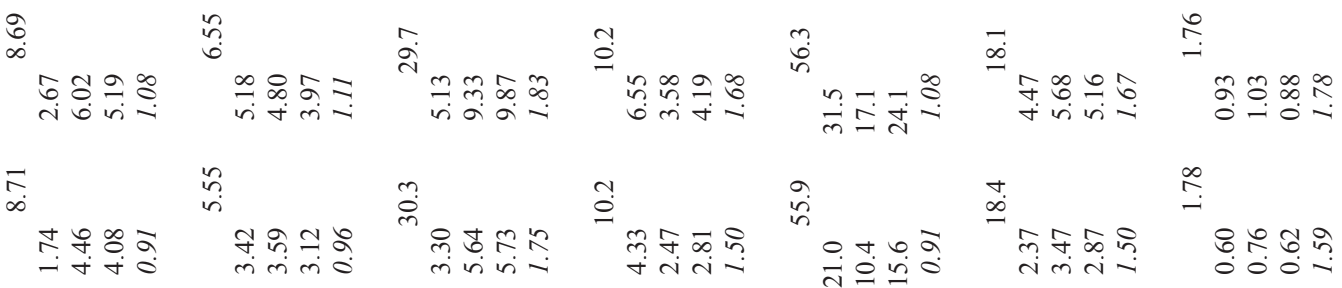

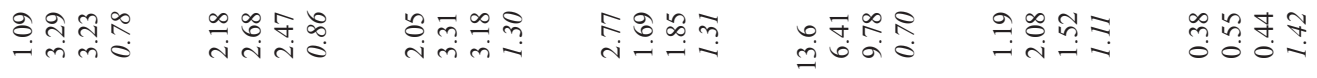

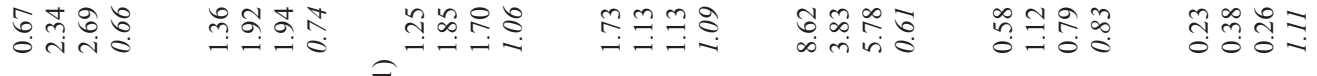

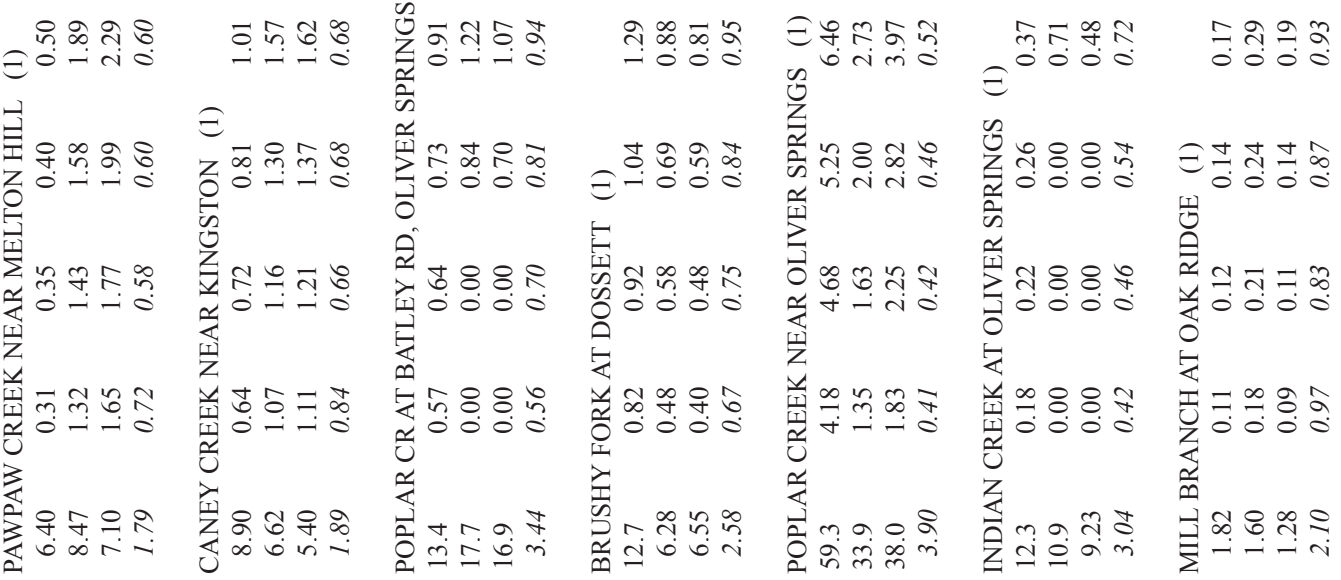

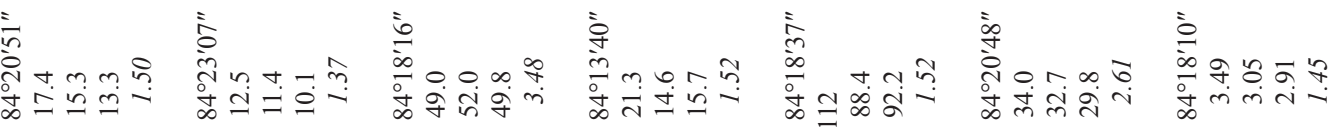

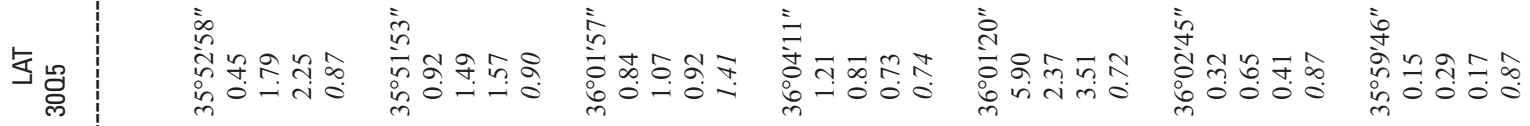

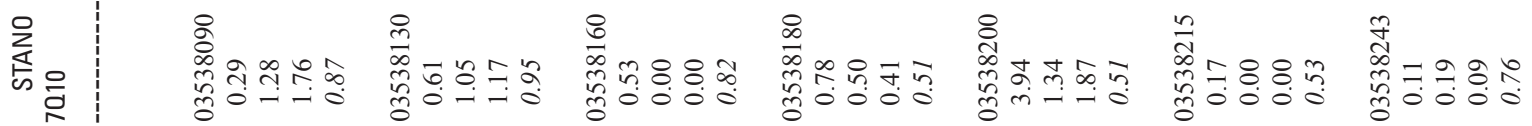

\begin{tabular}{l|l|l}
0 & 0 & 0 \\
$\Sigma$ & 0
\end{tabular}

$\underset{\infty}{+}$

$\stackrel{\circ}{\infty}$

$\stackrel{\circ}{\circ}$

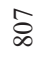

$\stackrel{\infty}{\infty}$

ڤे 


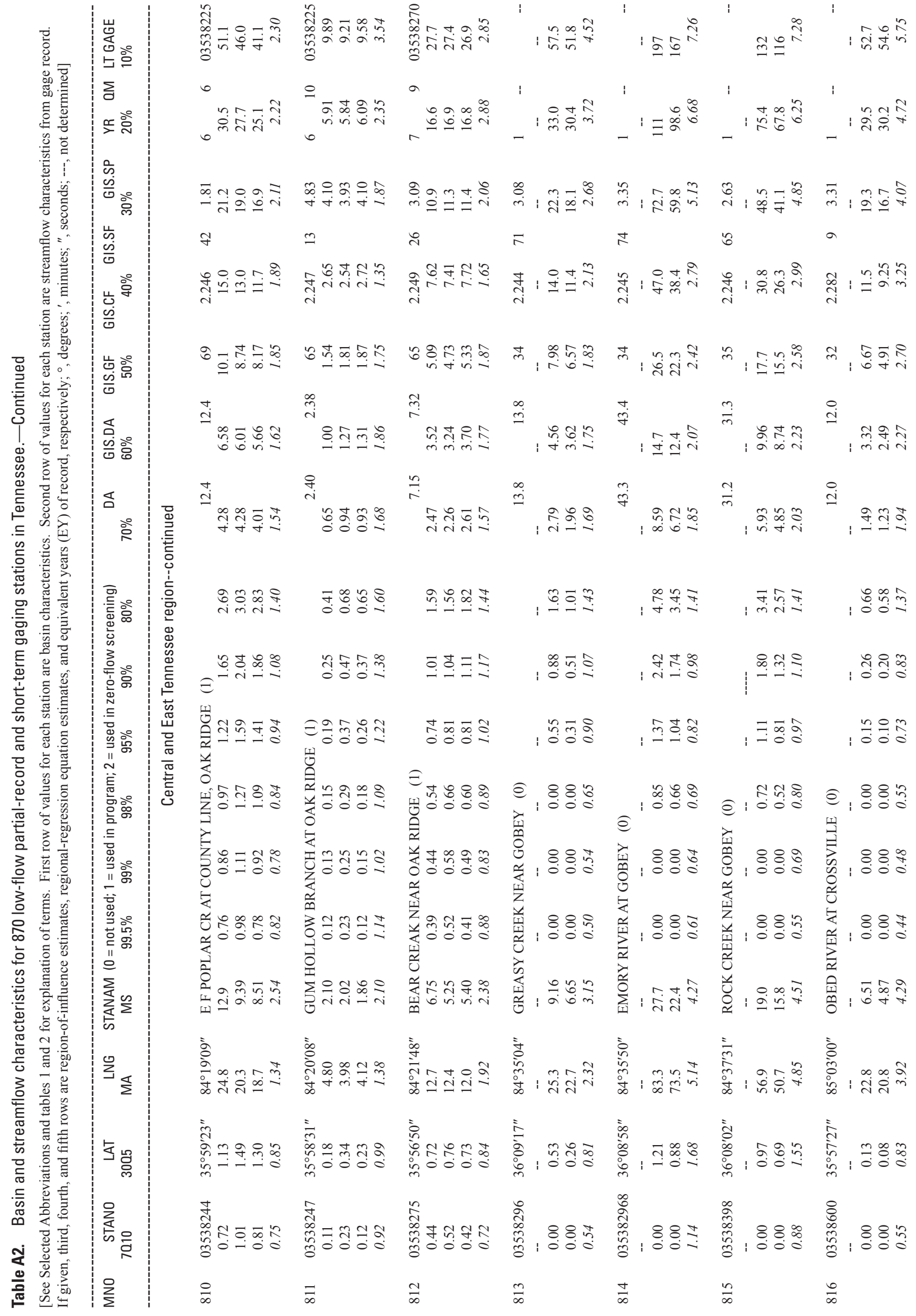




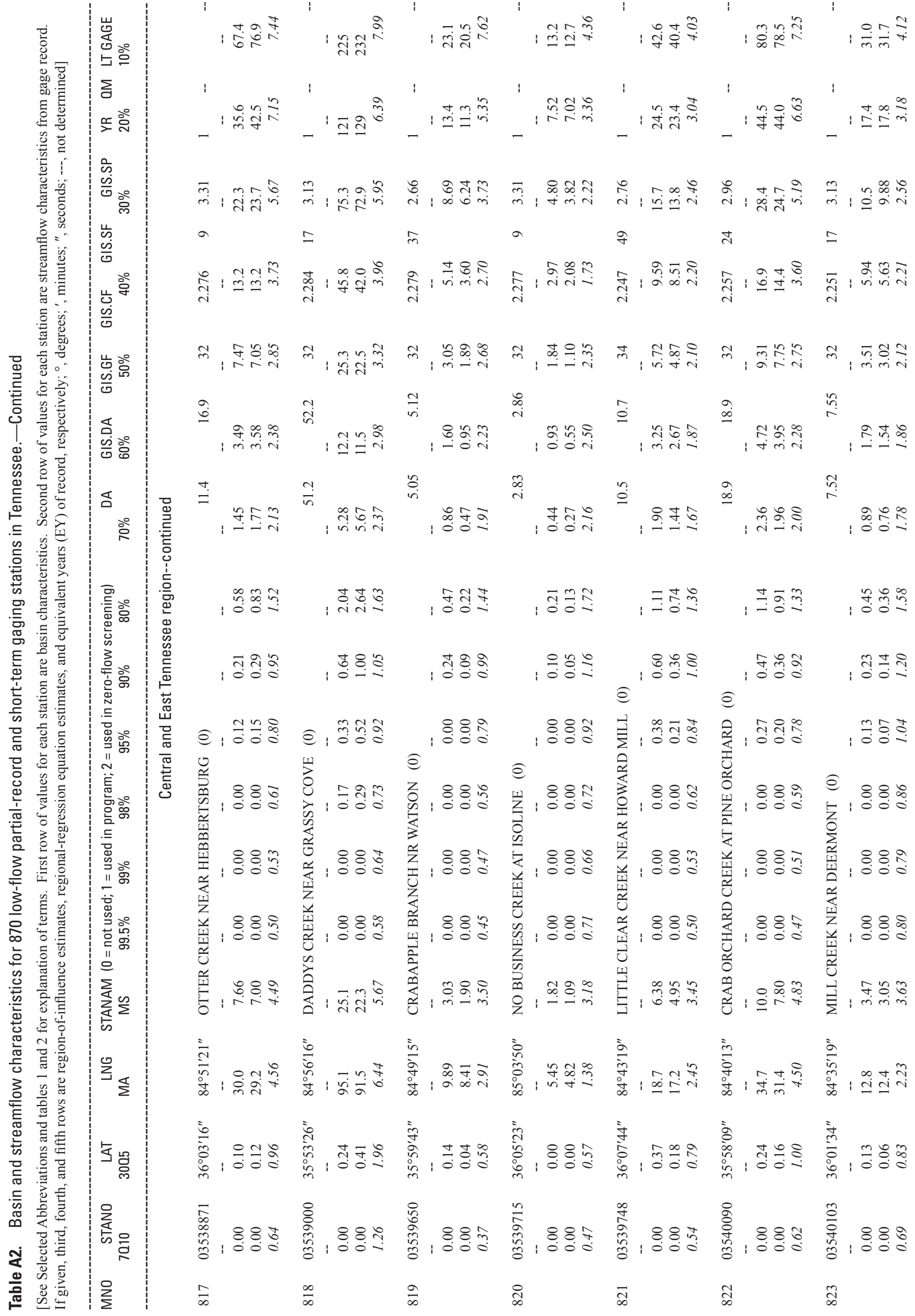




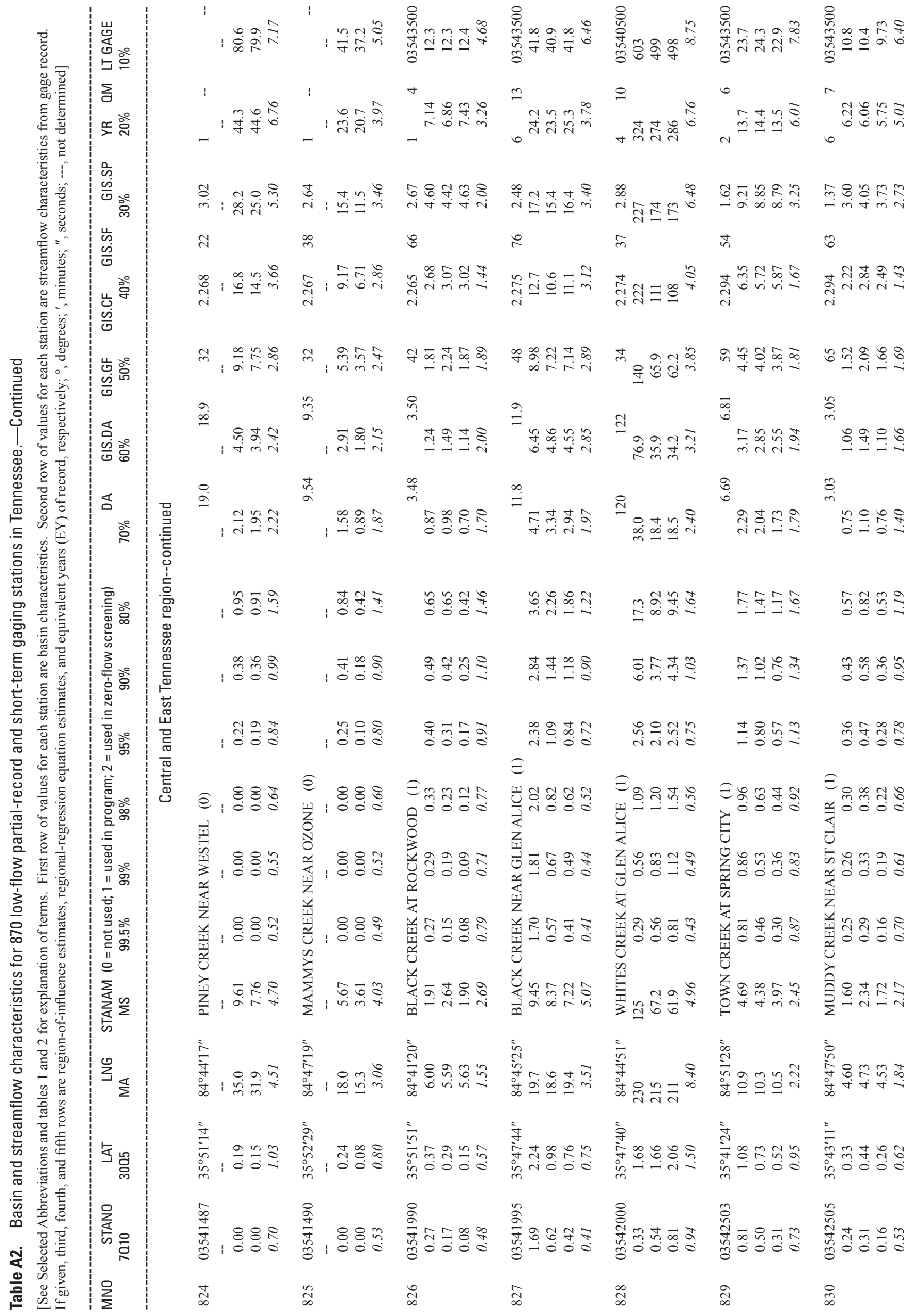




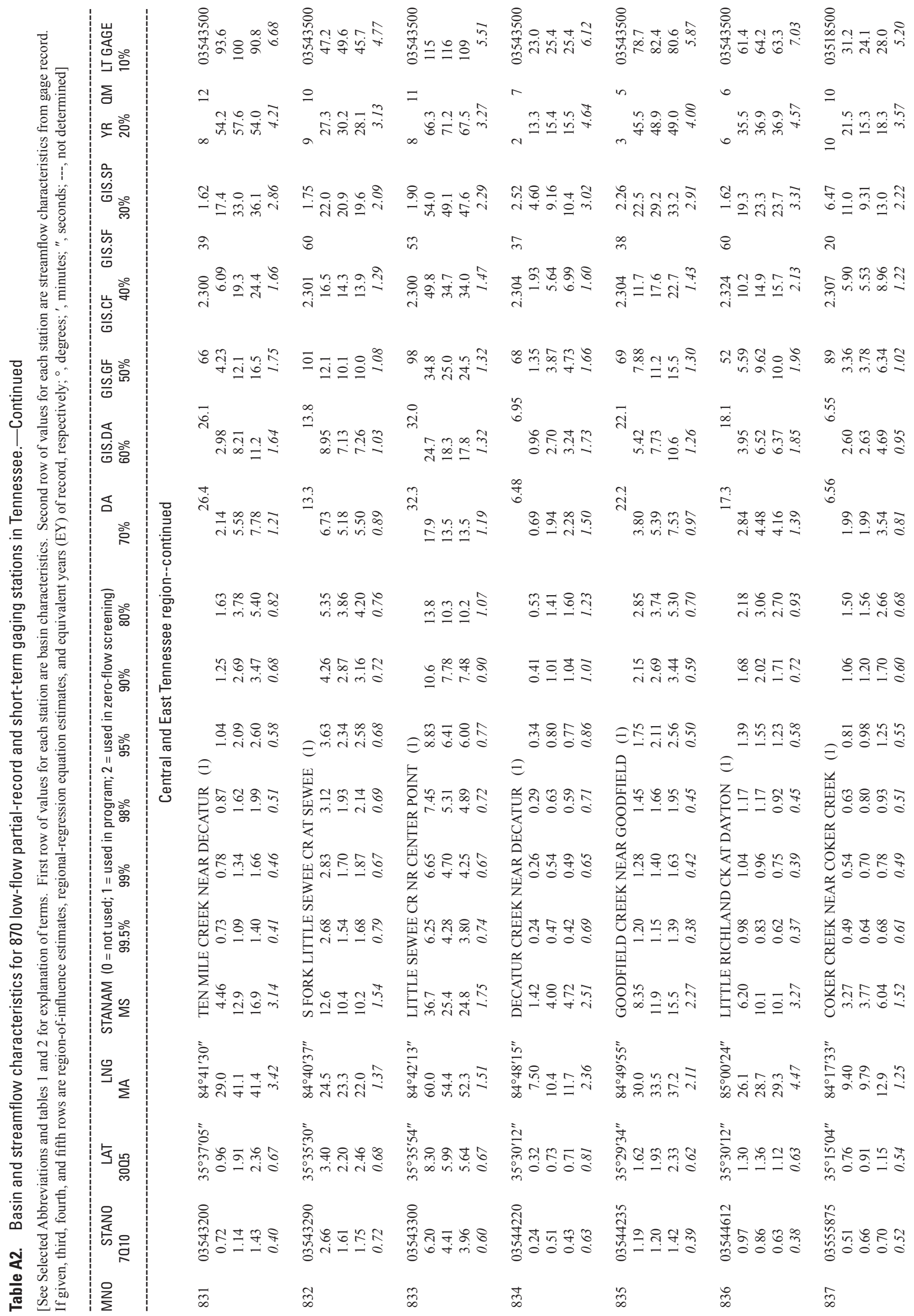




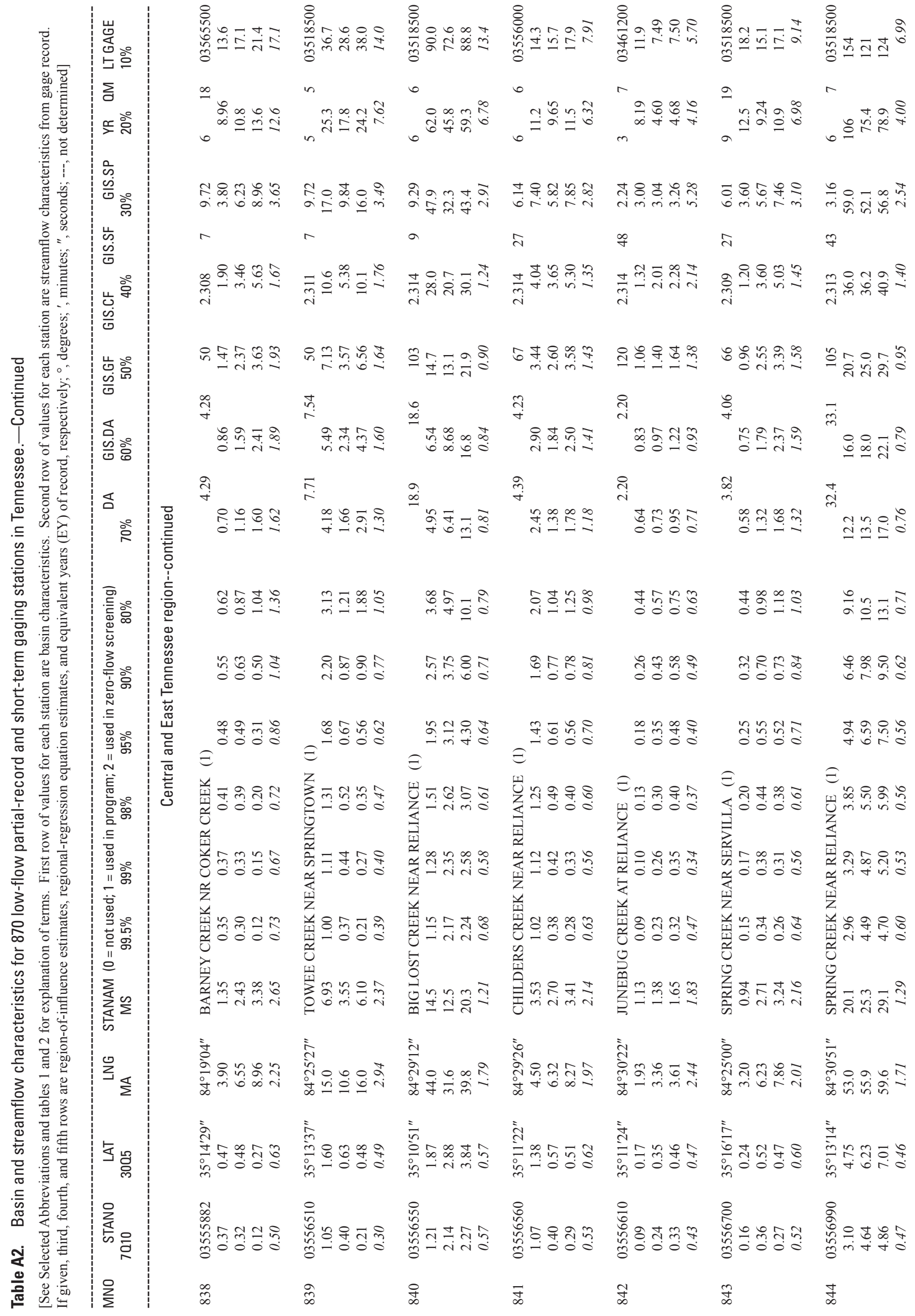




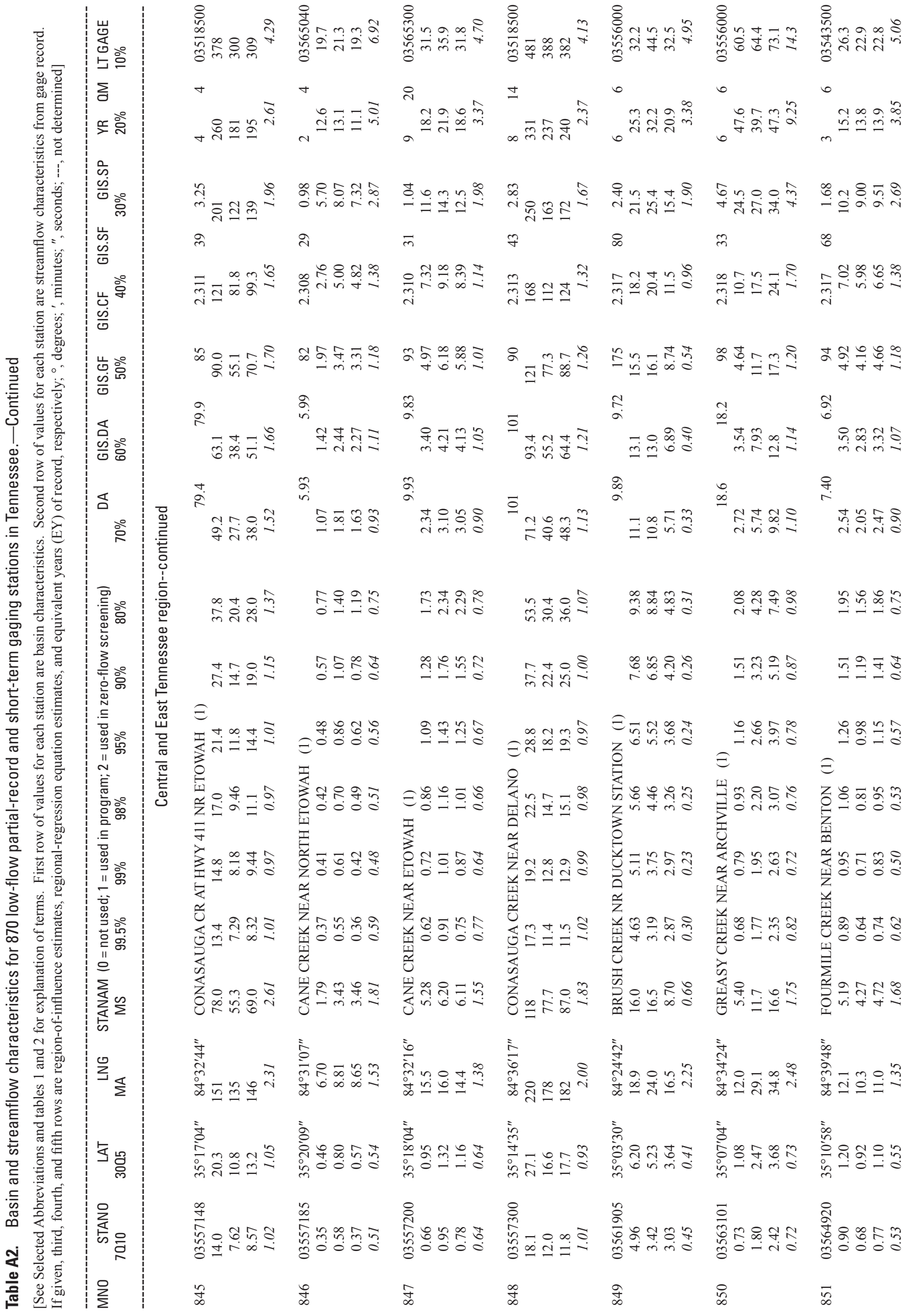




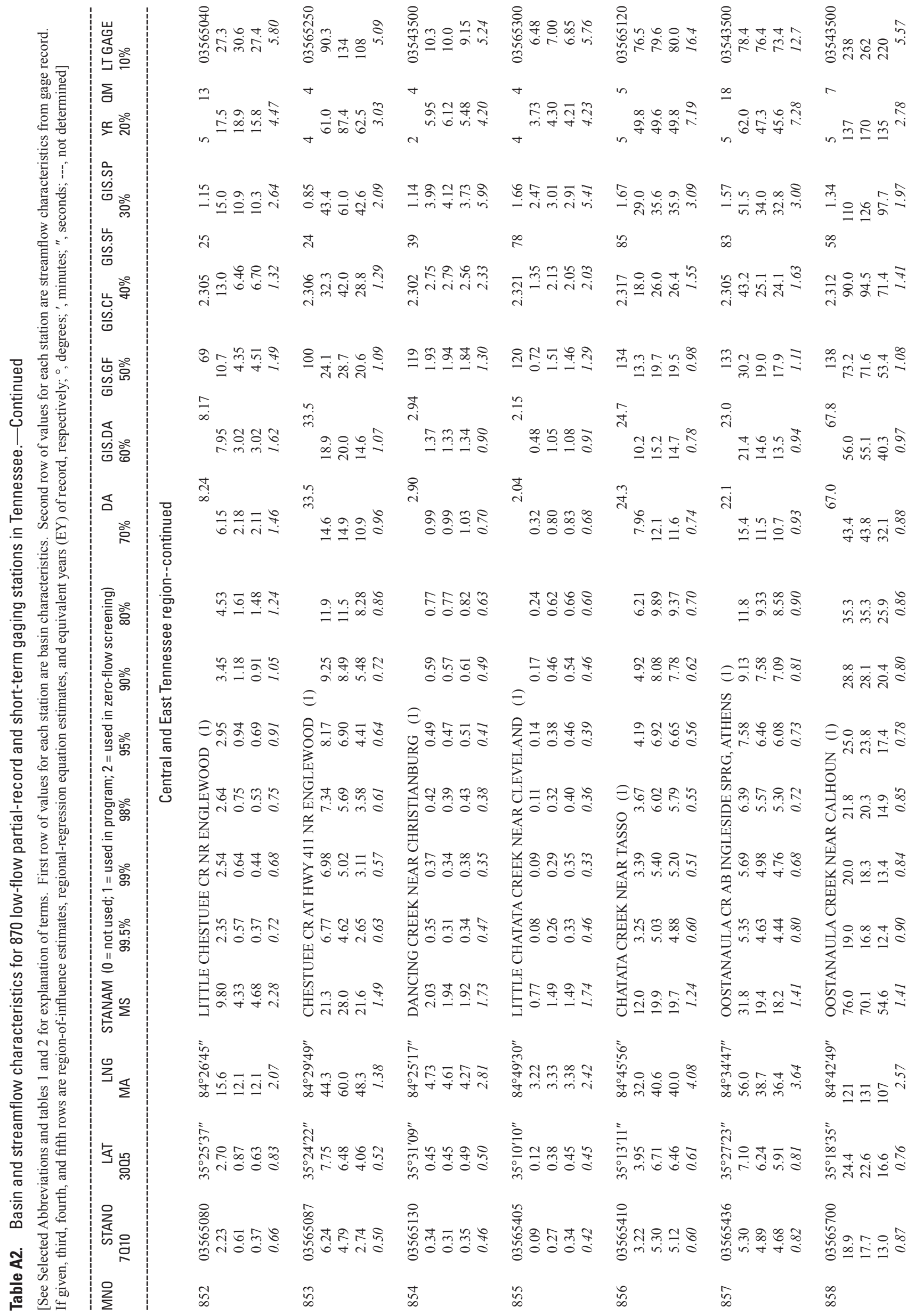




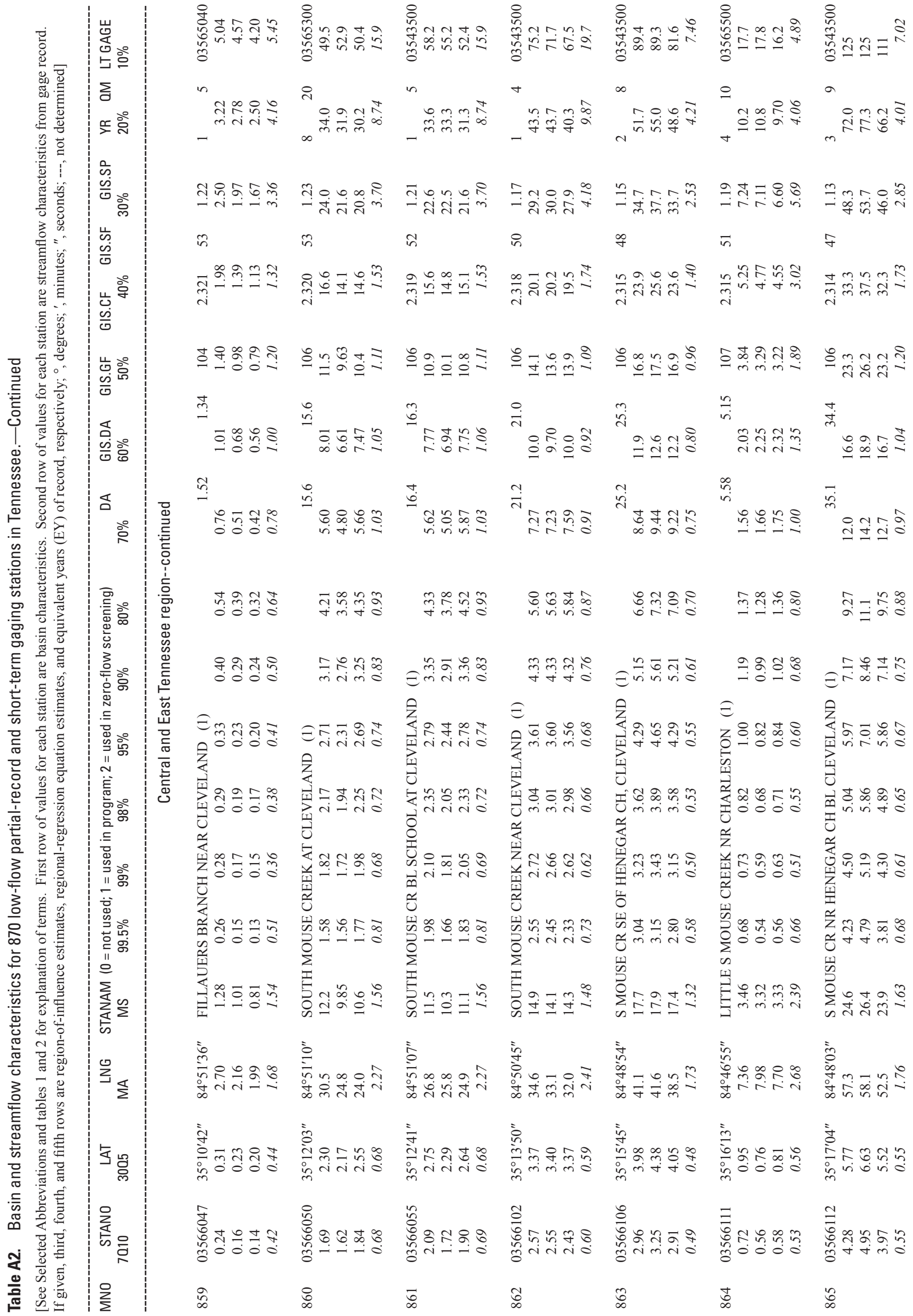




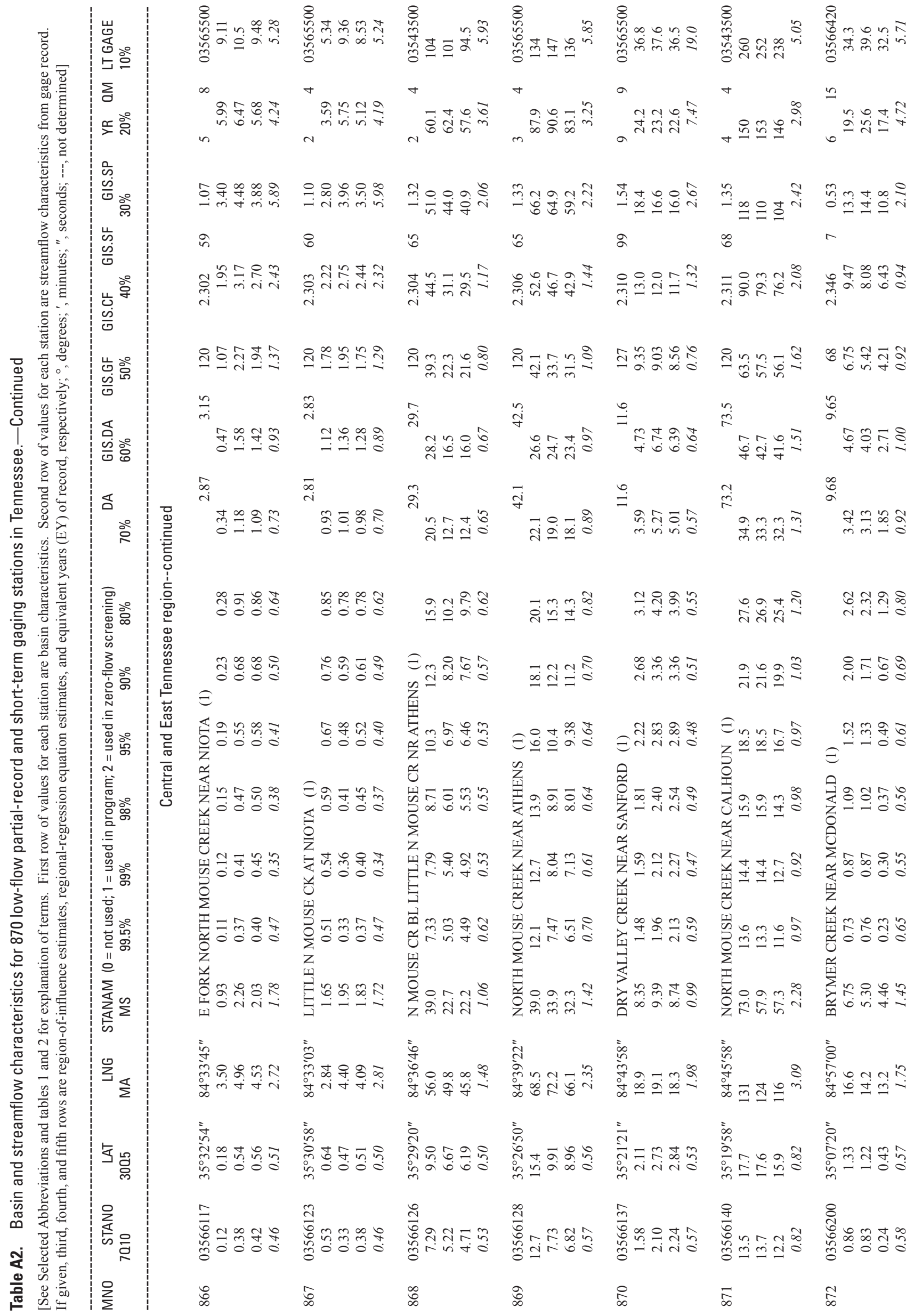




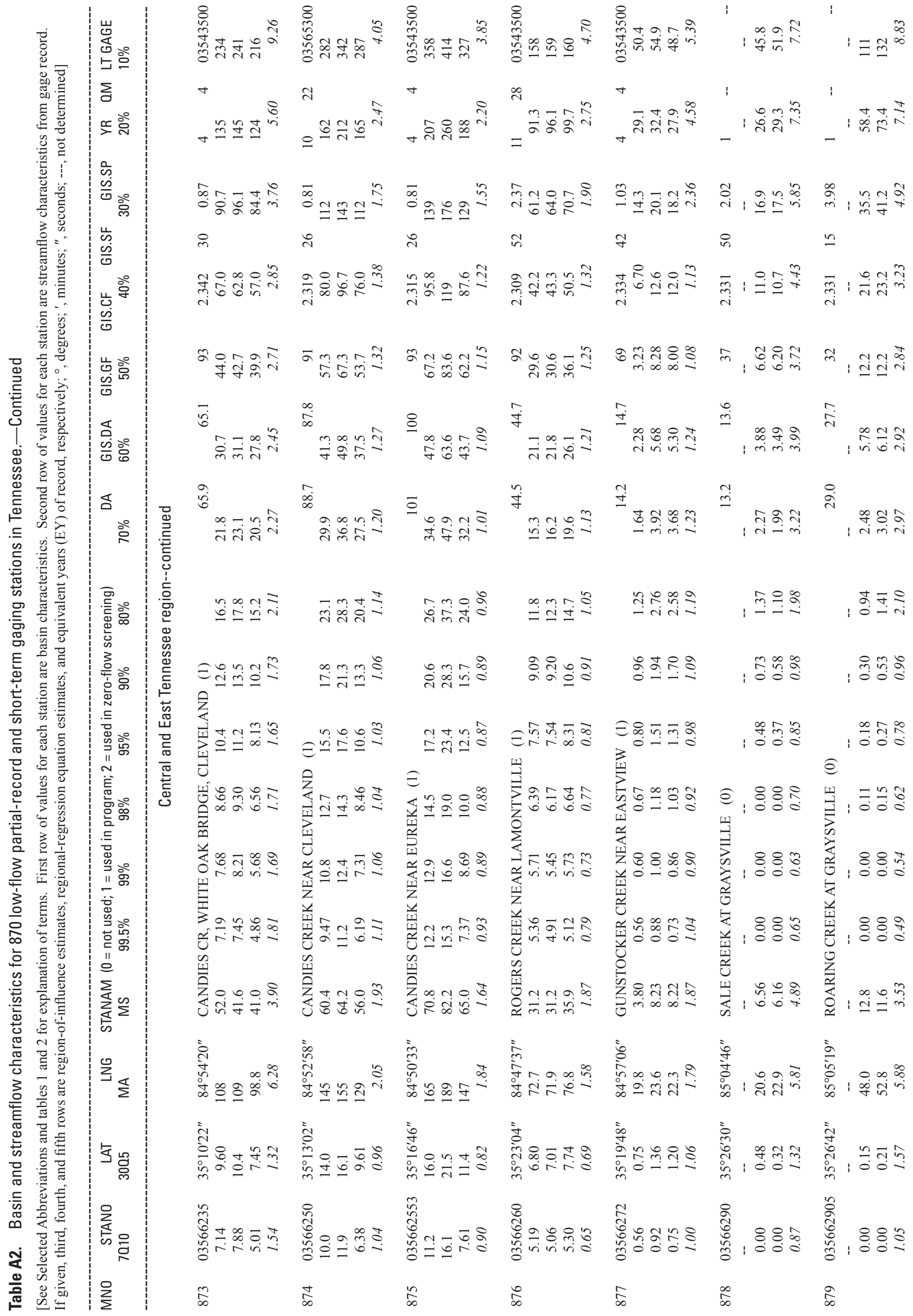




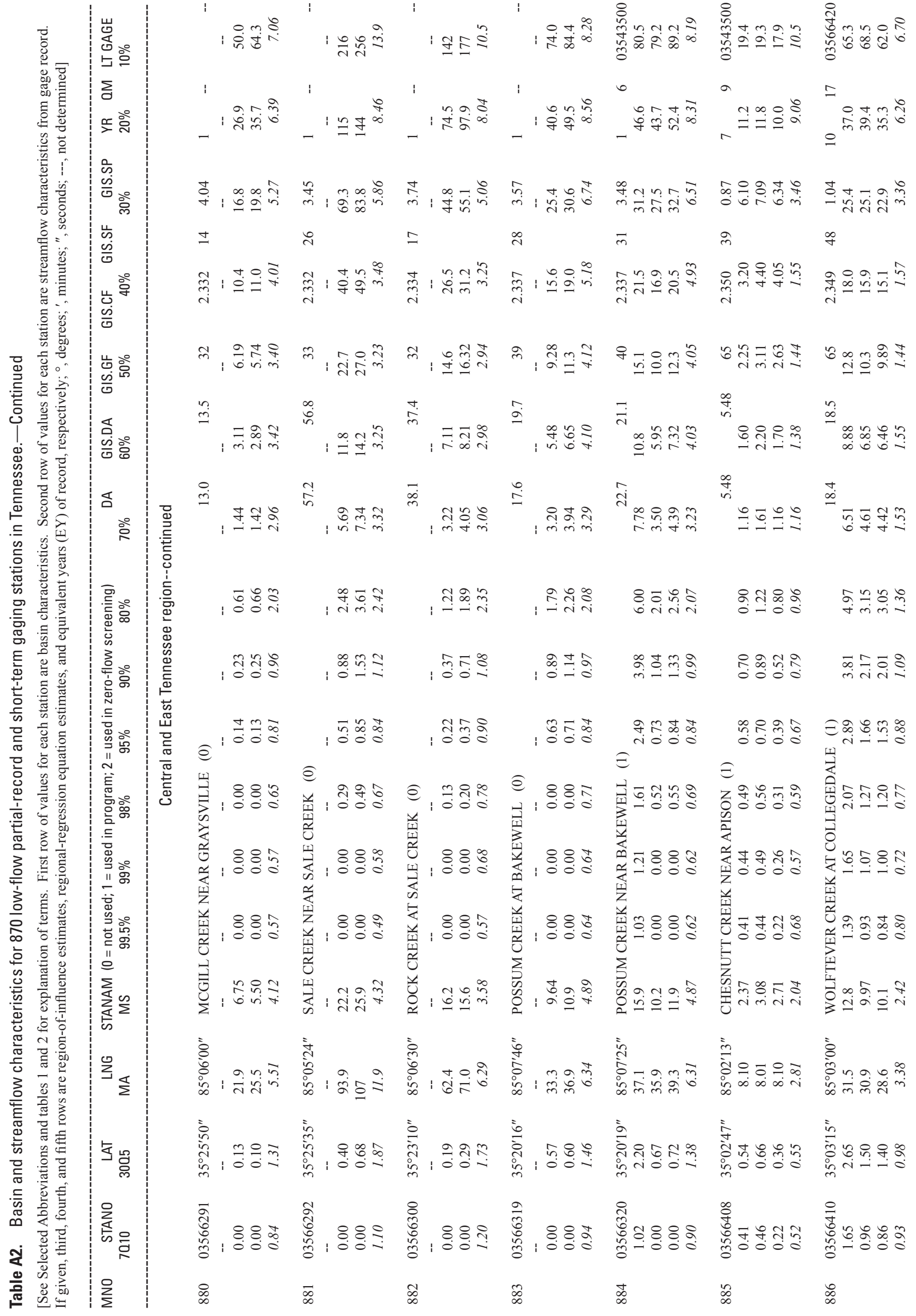




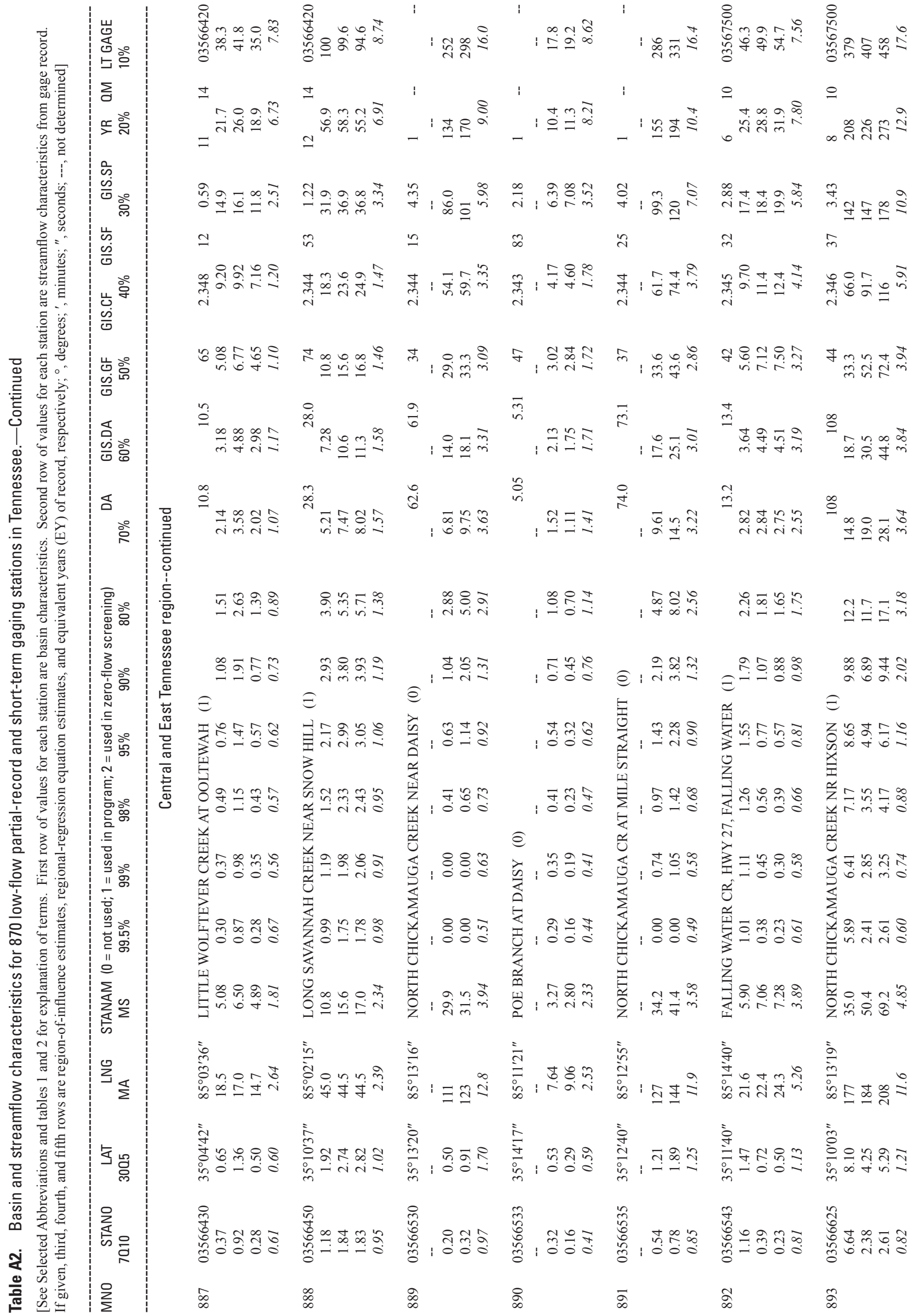




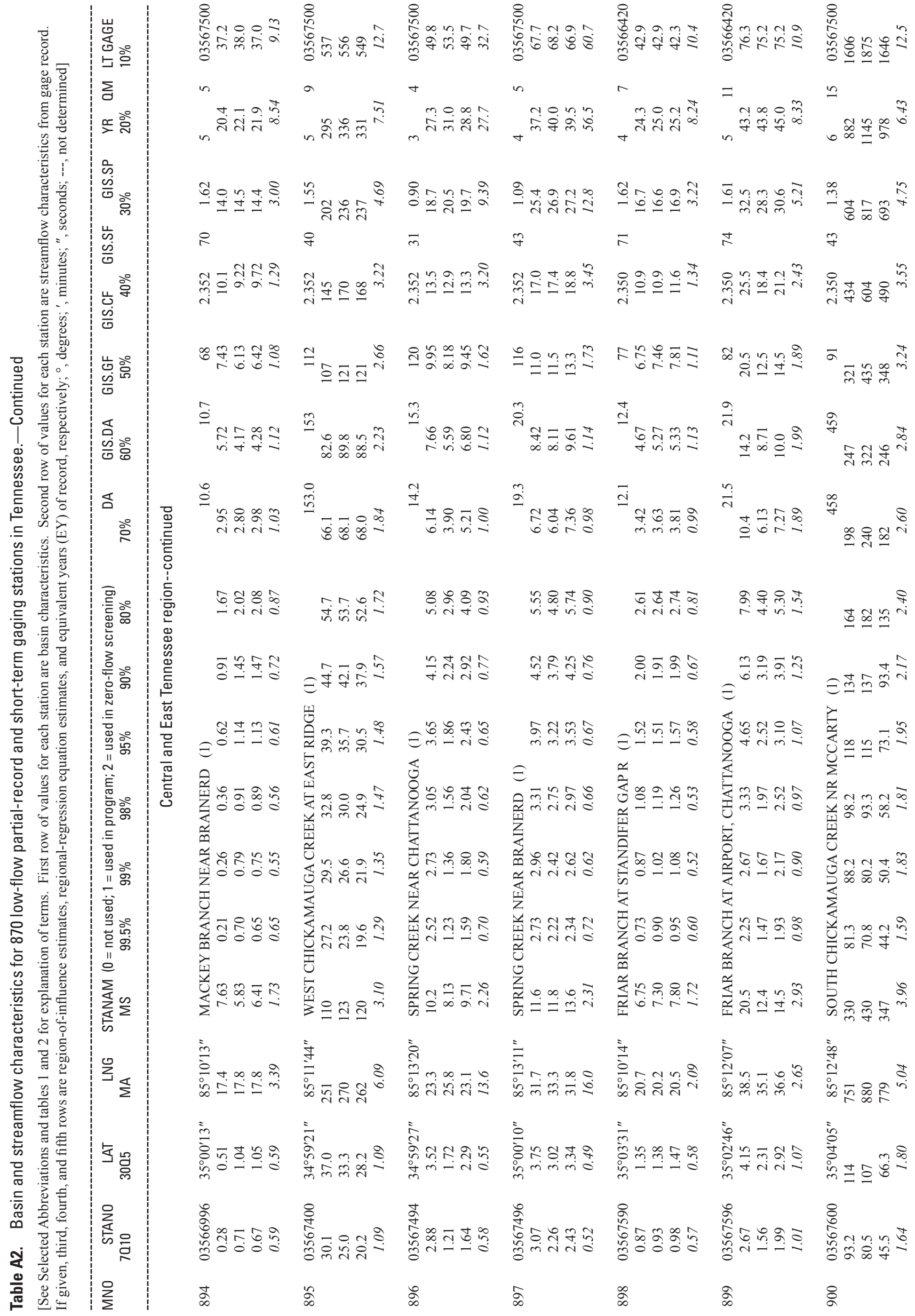




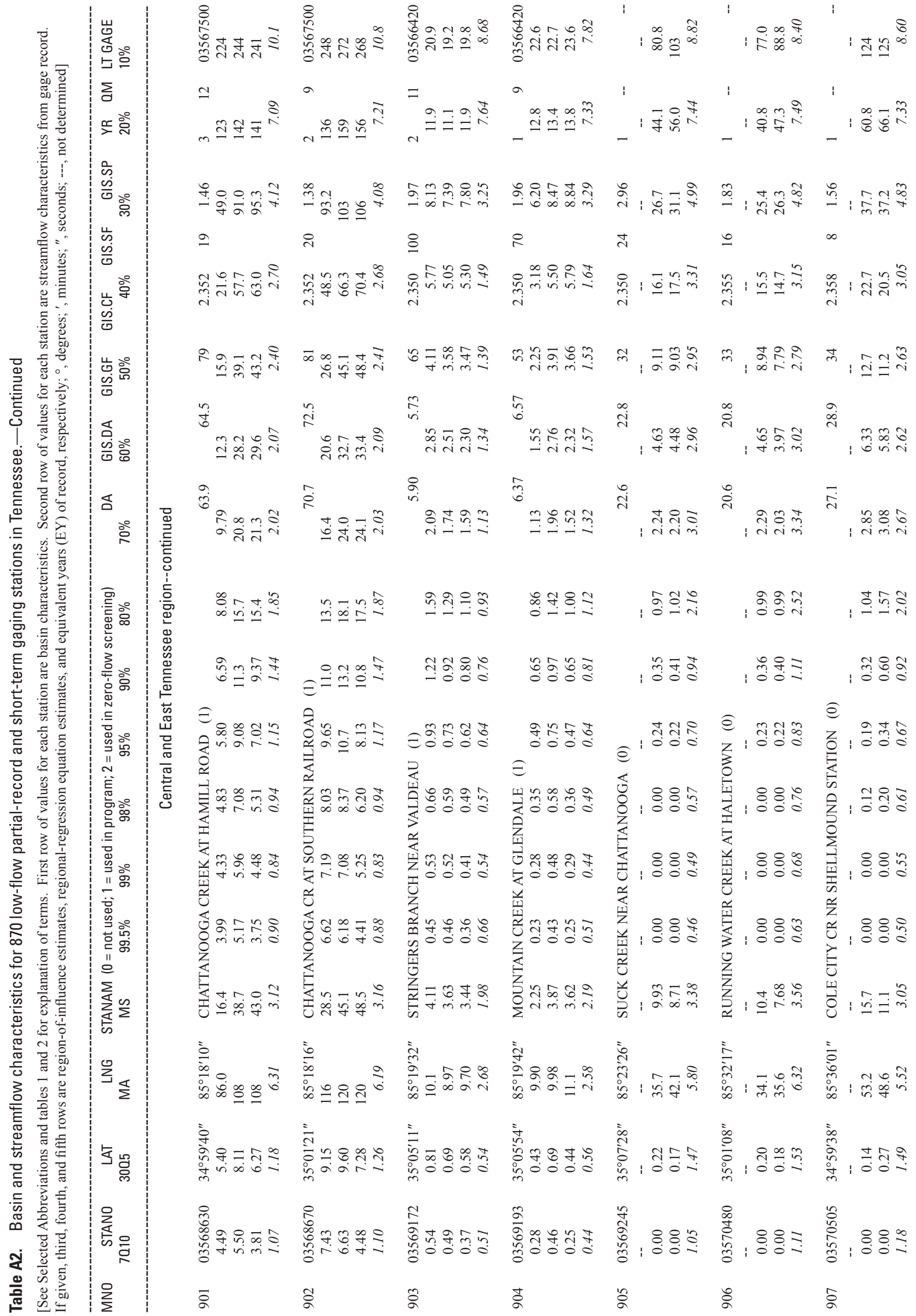




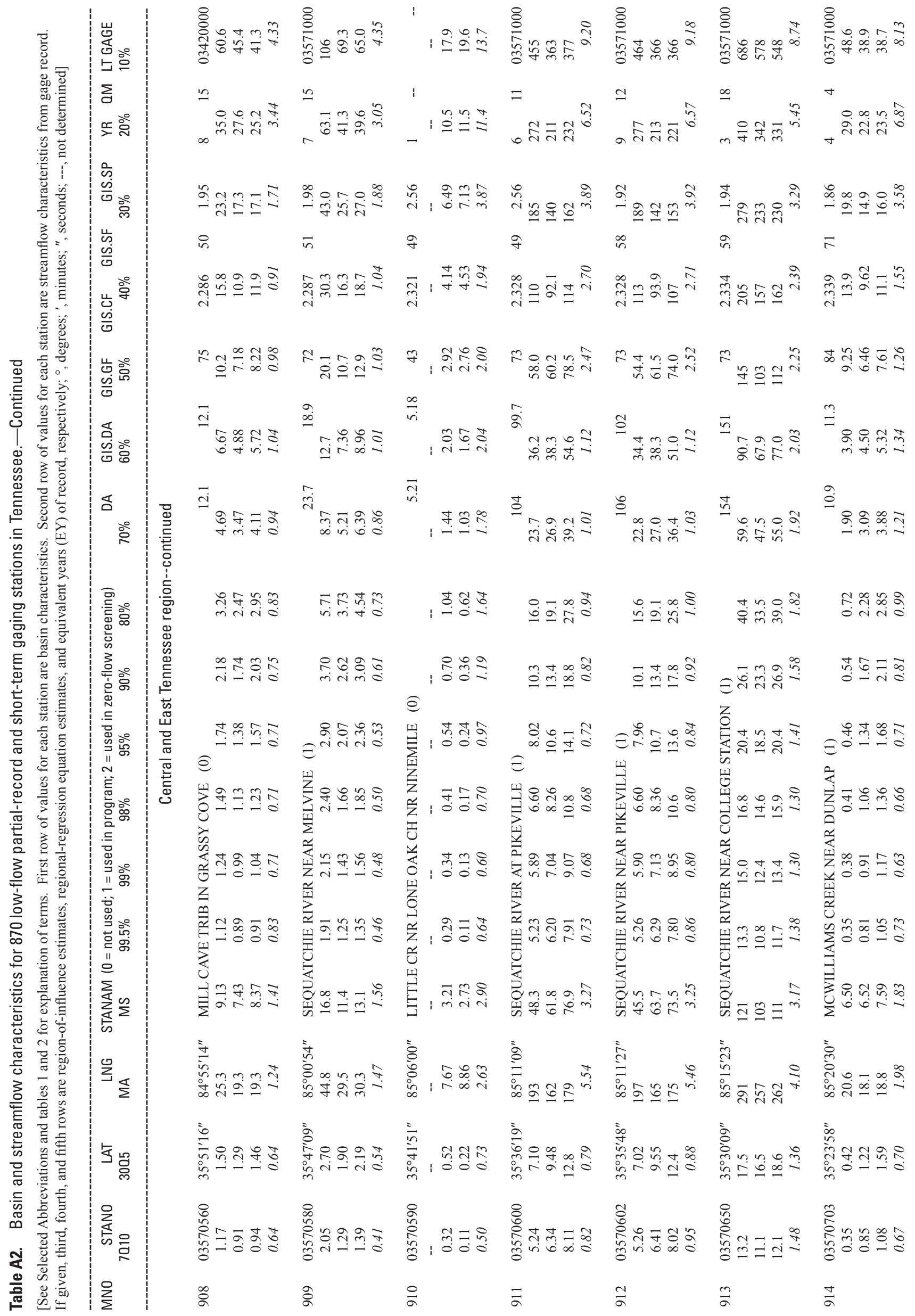




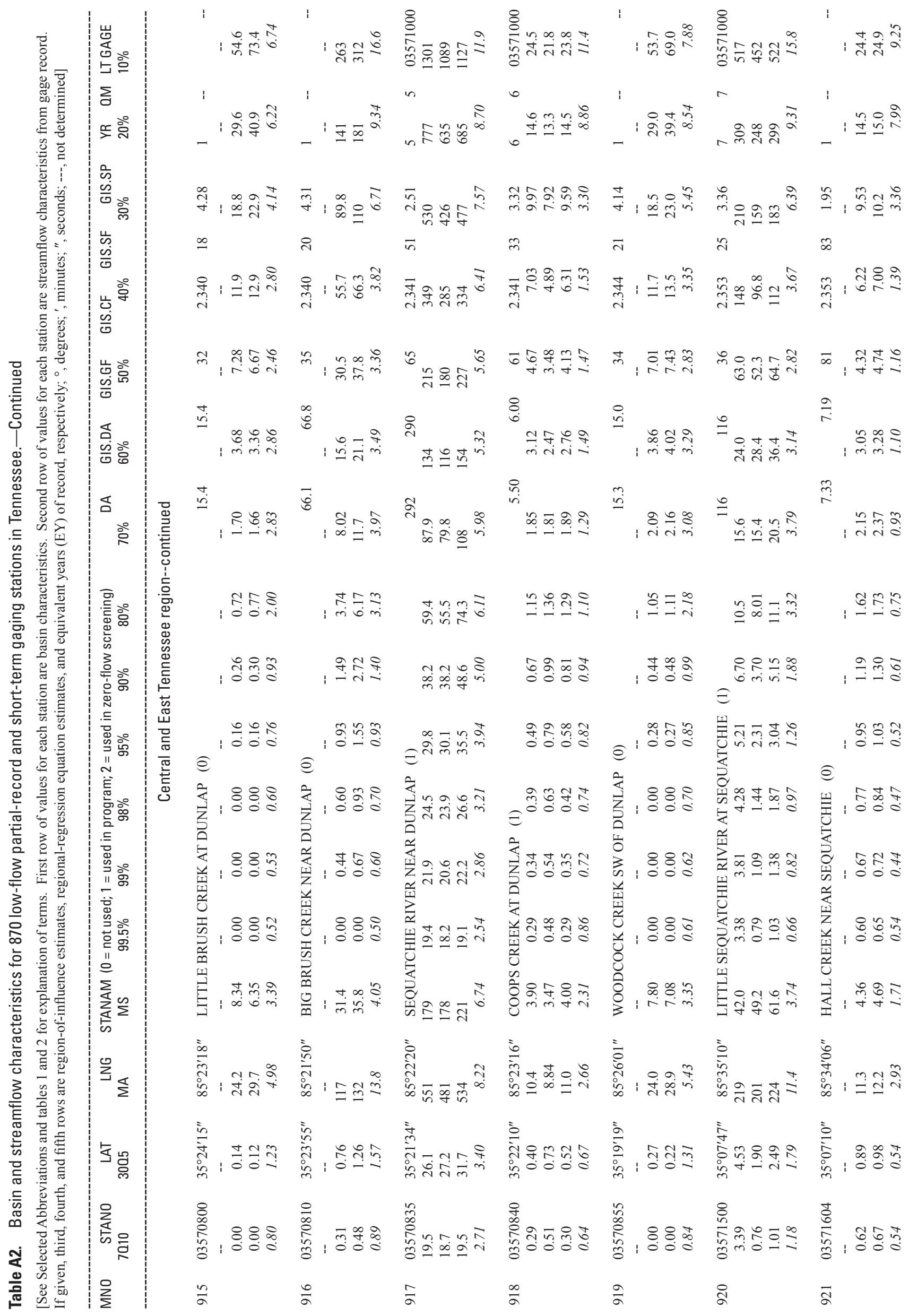




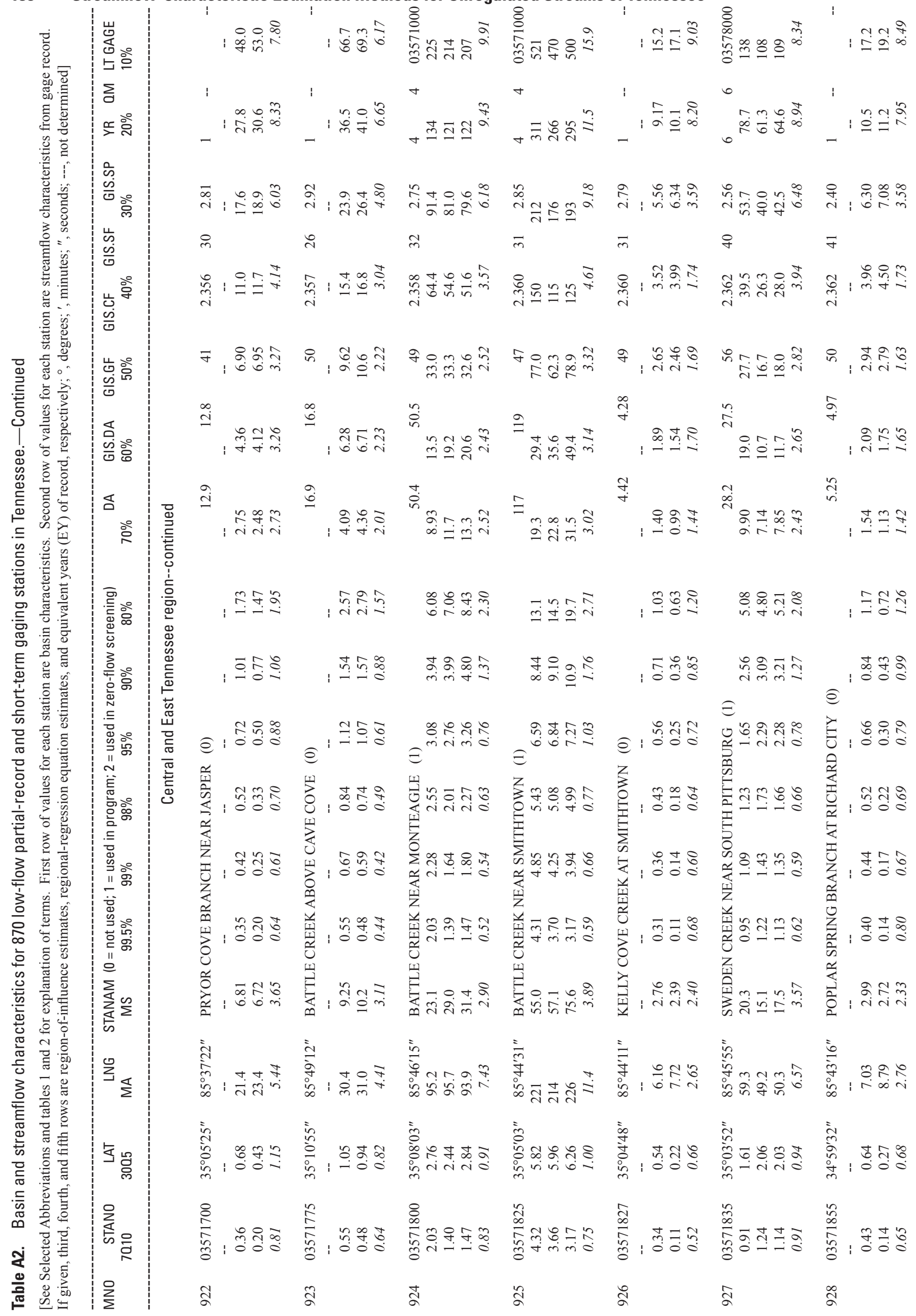




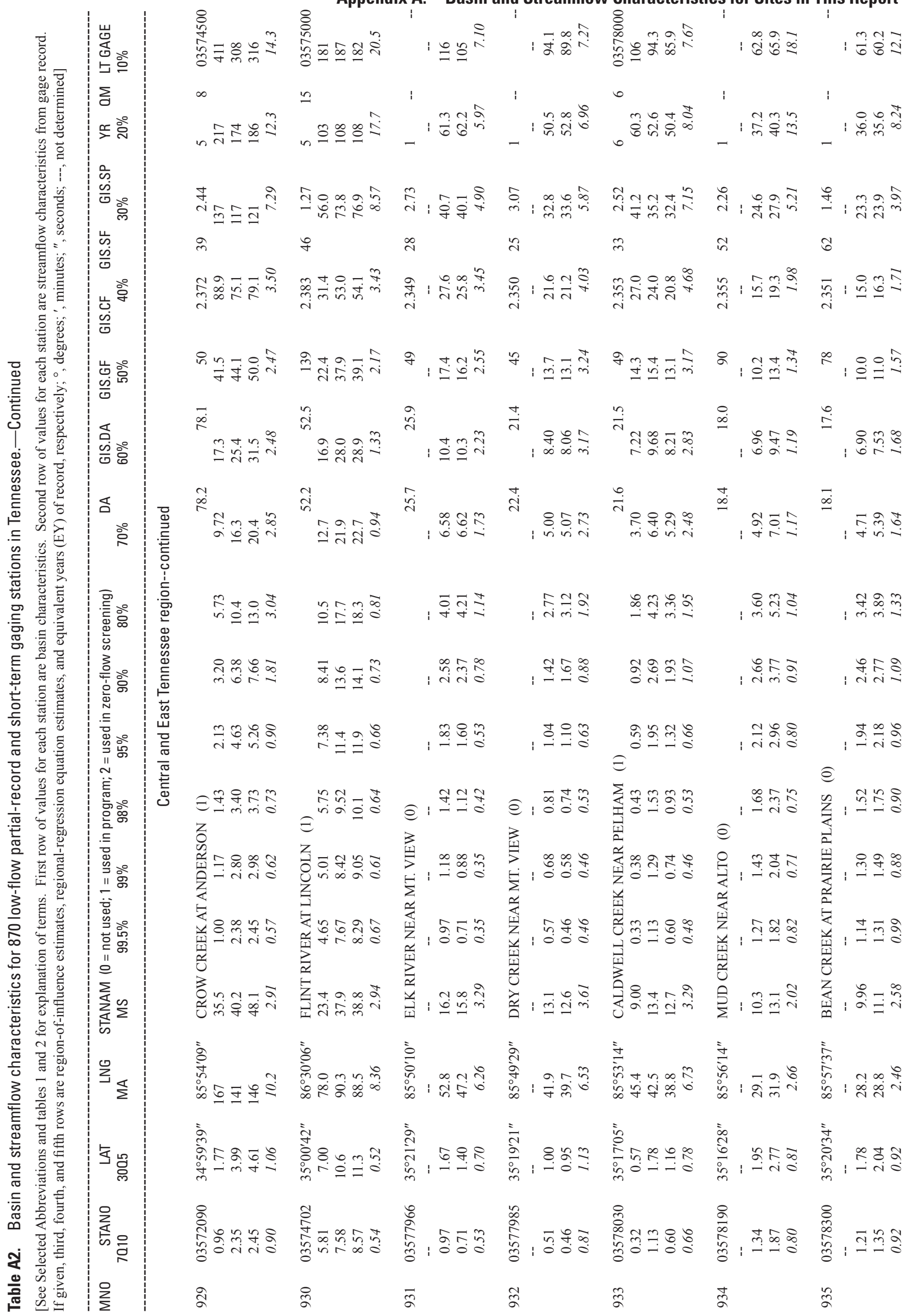




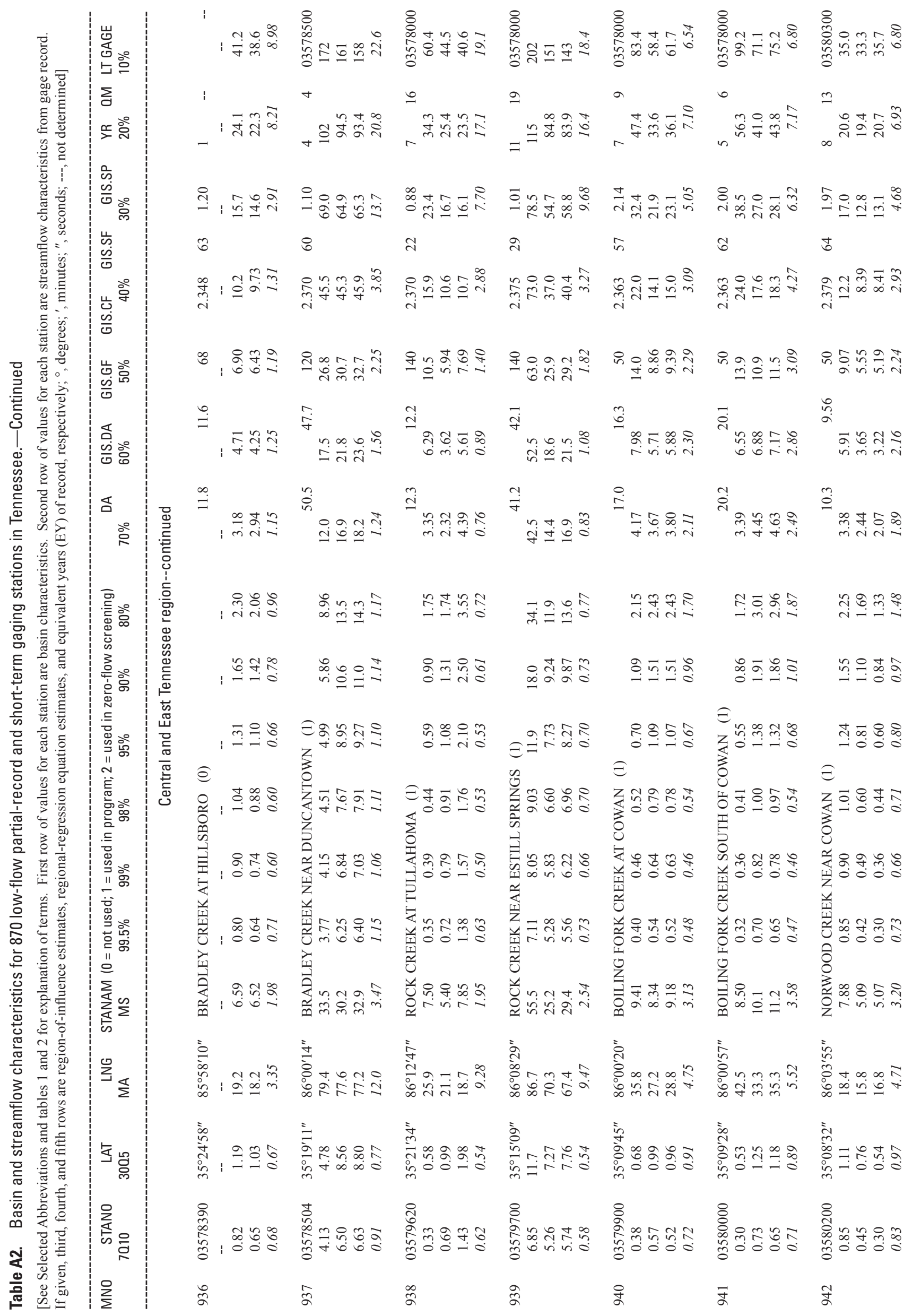


Appendix A. Basin and Streamflow Characteristics for Sites in This Report

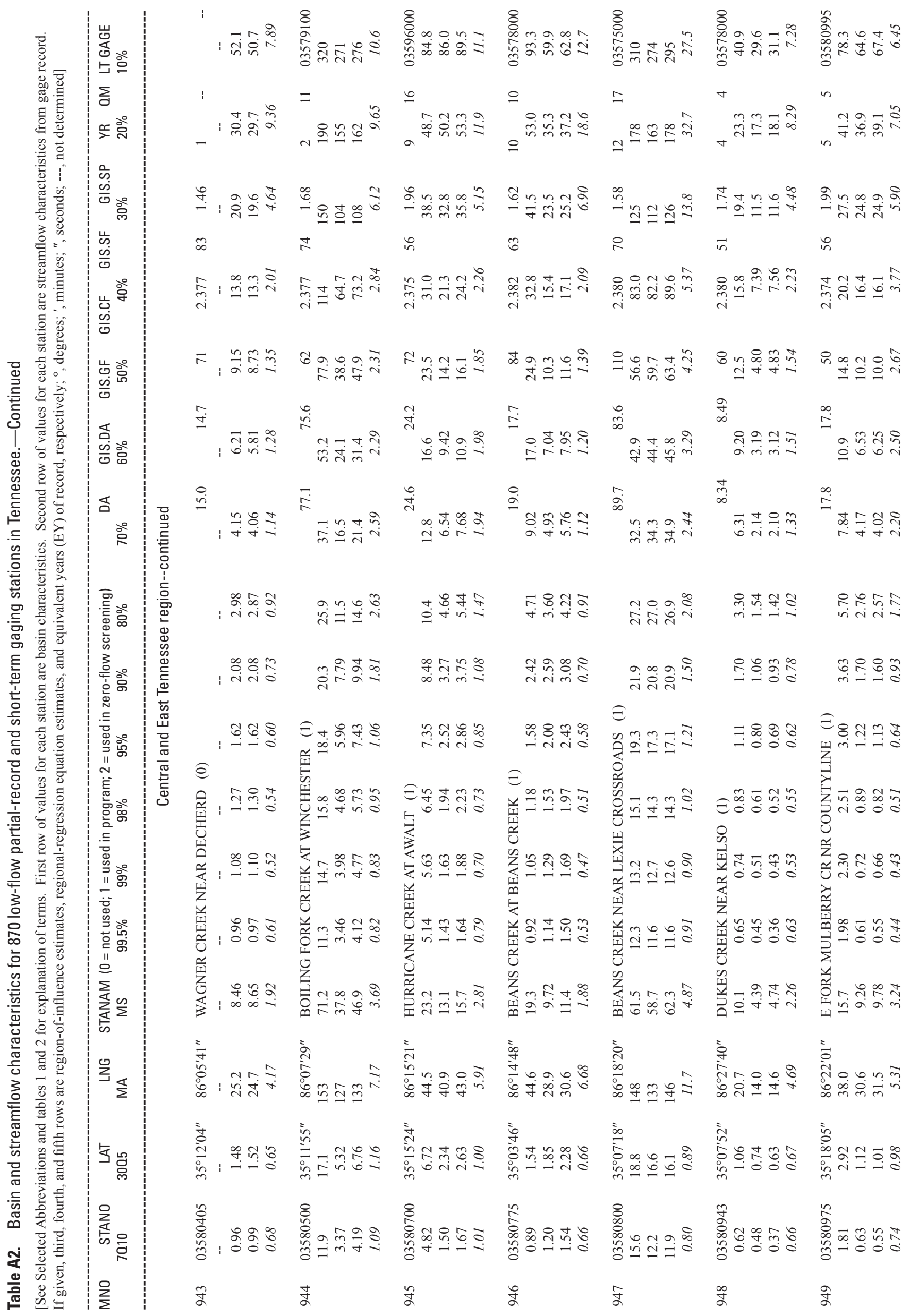




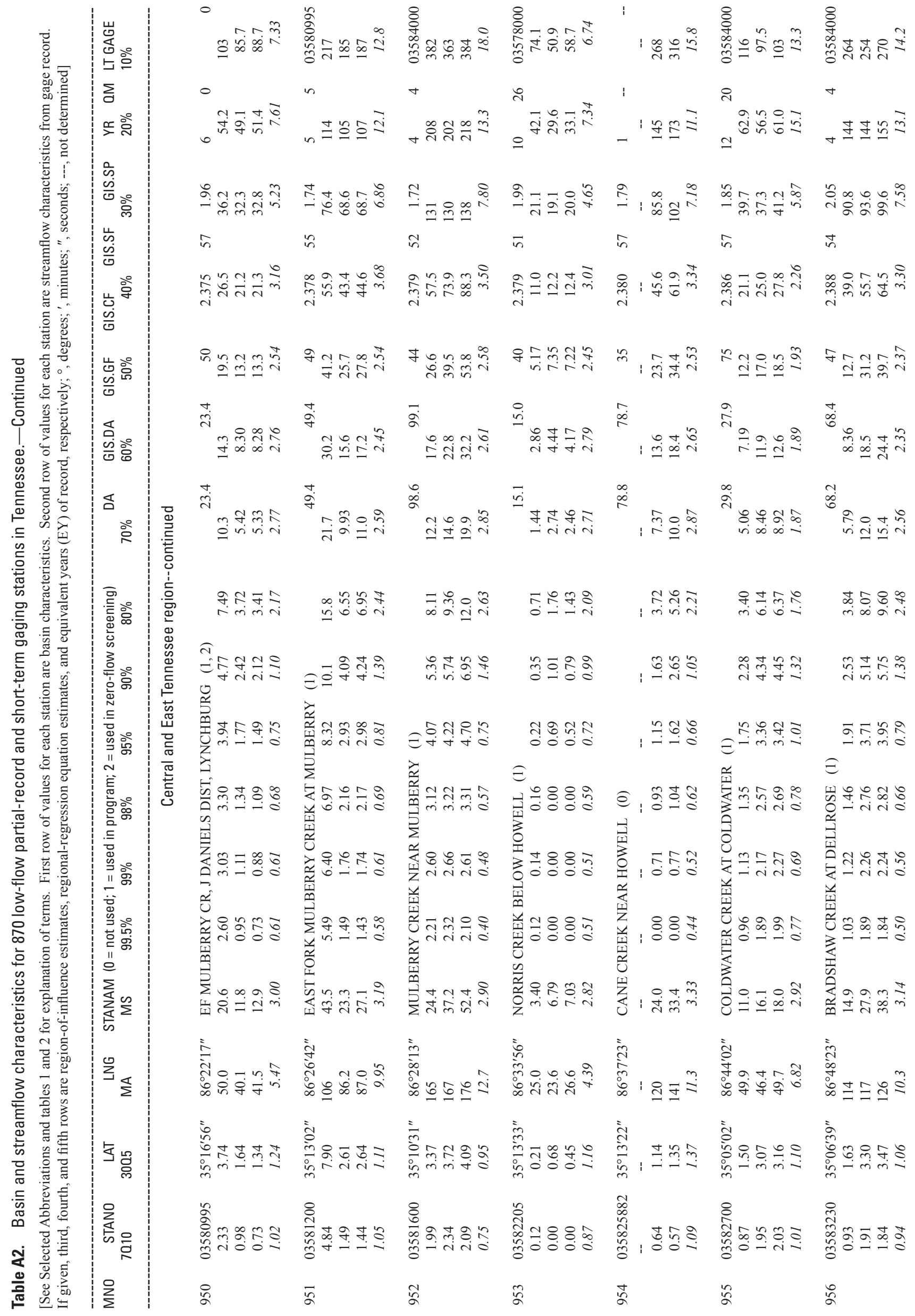




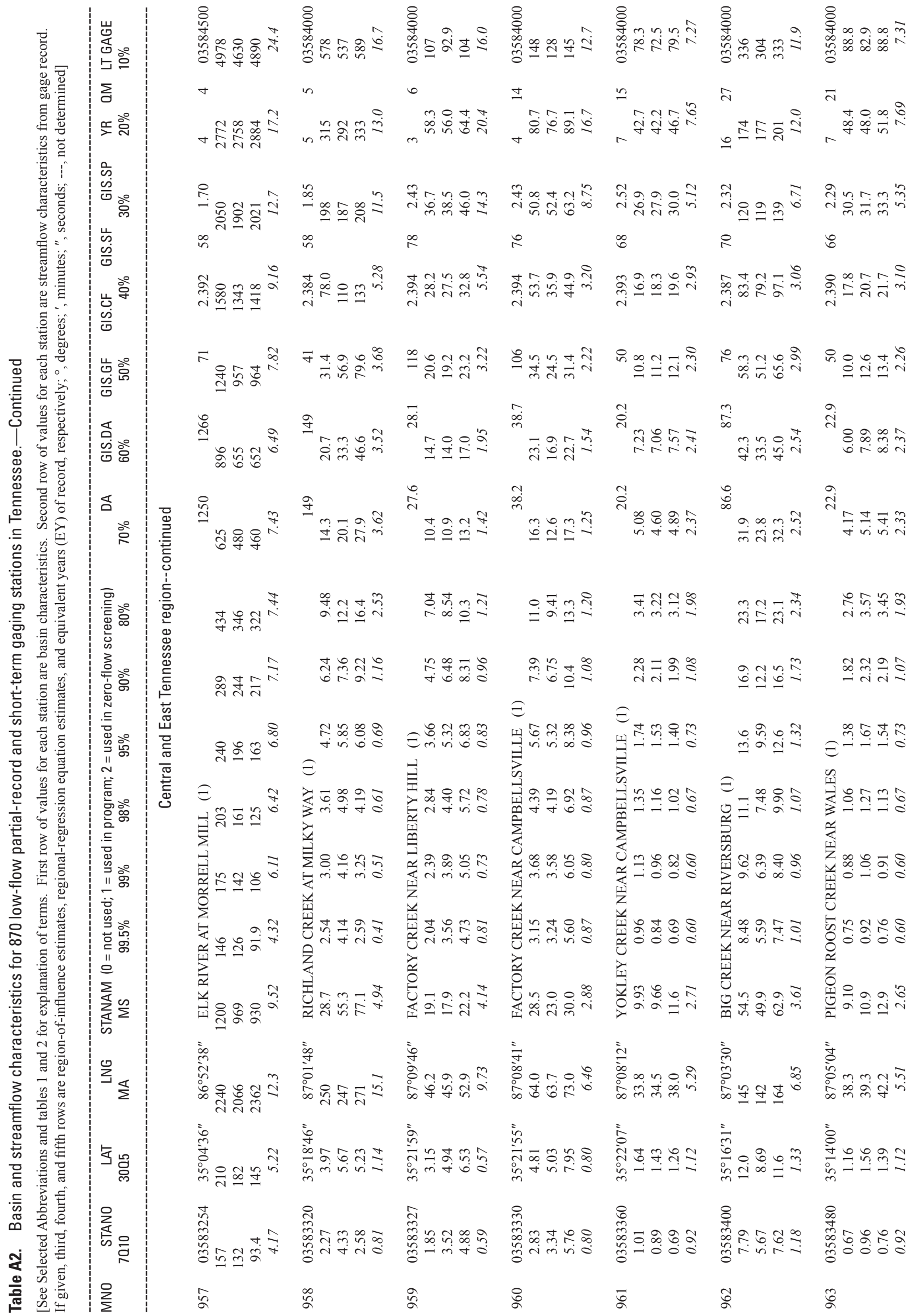




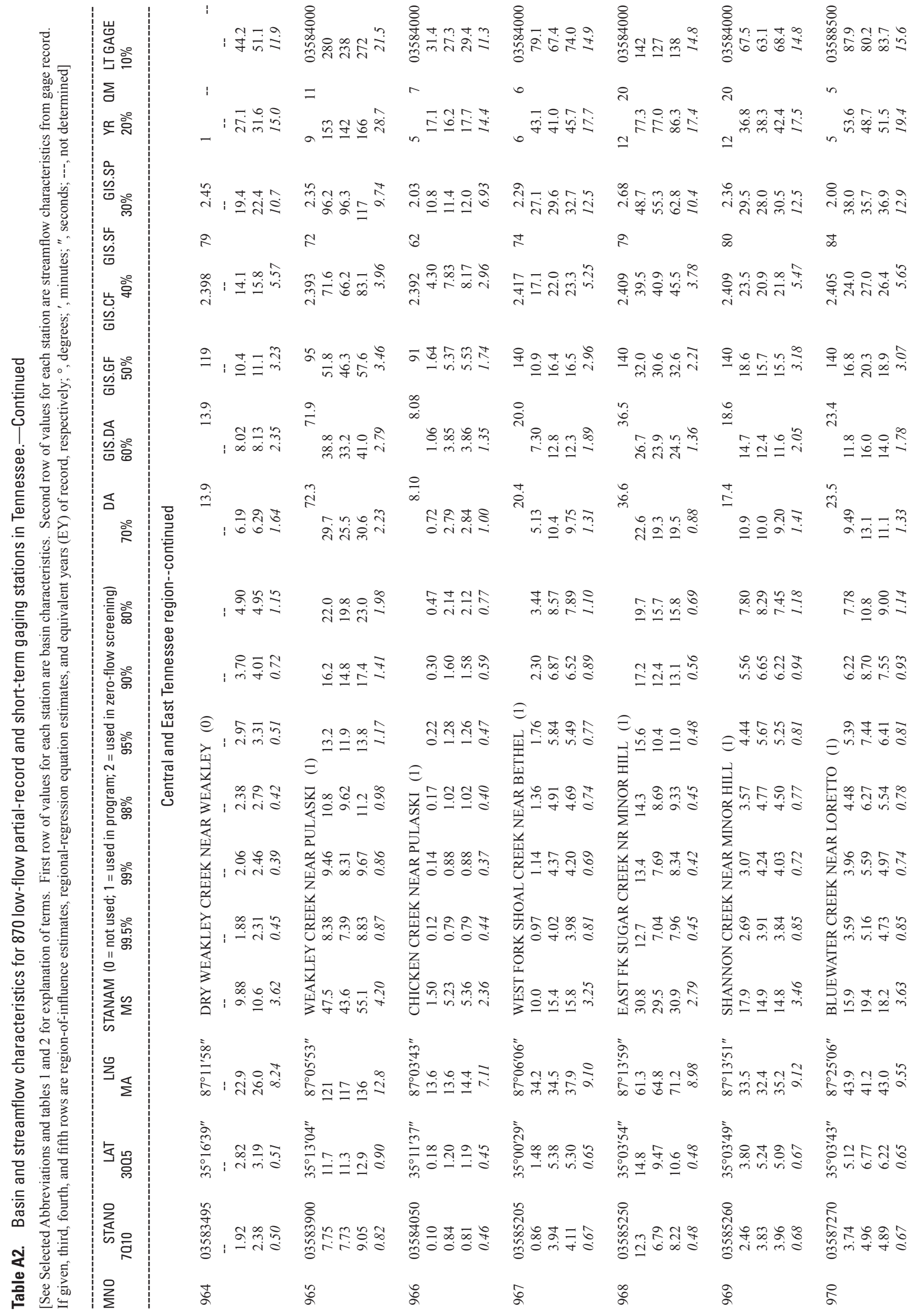




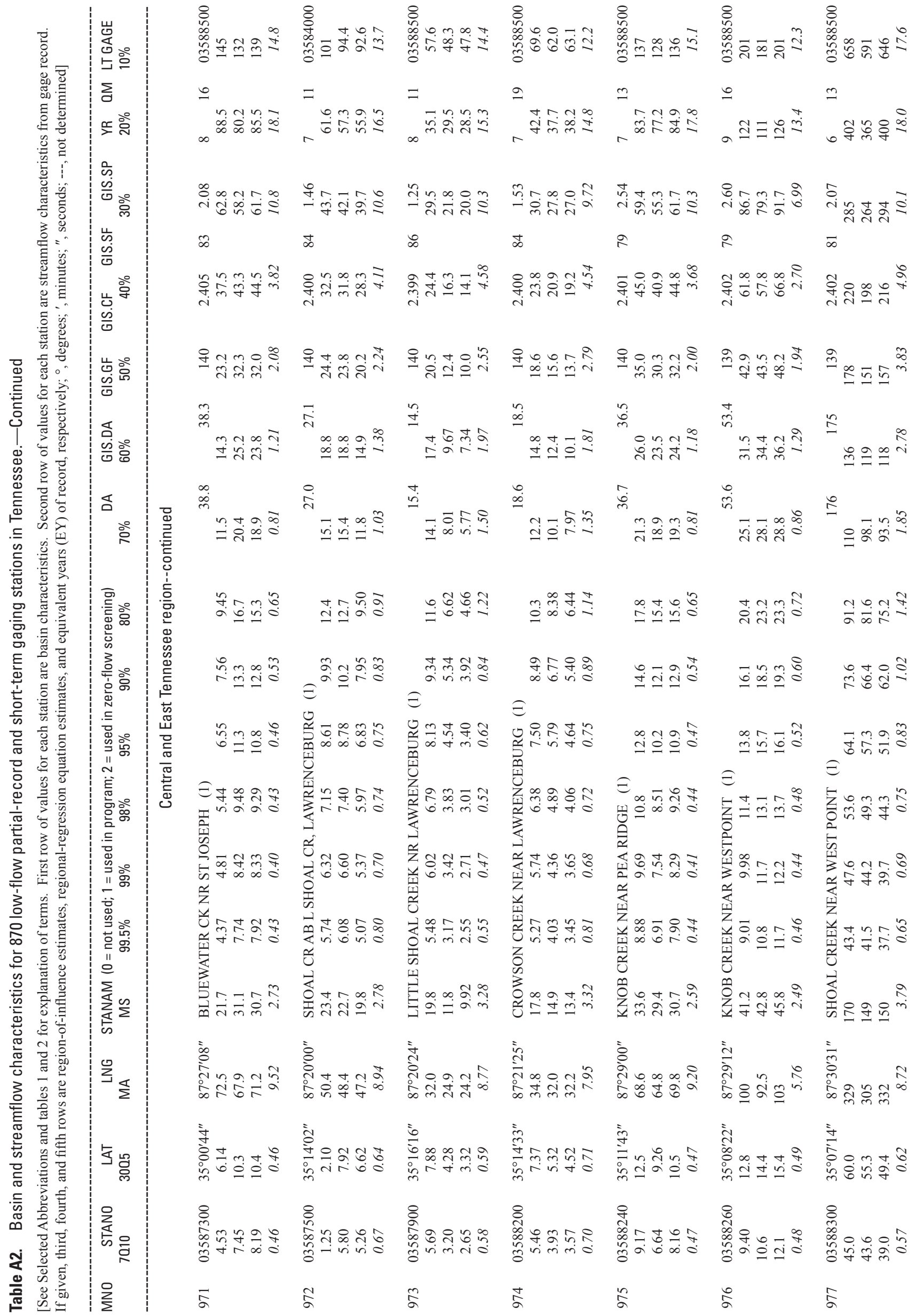




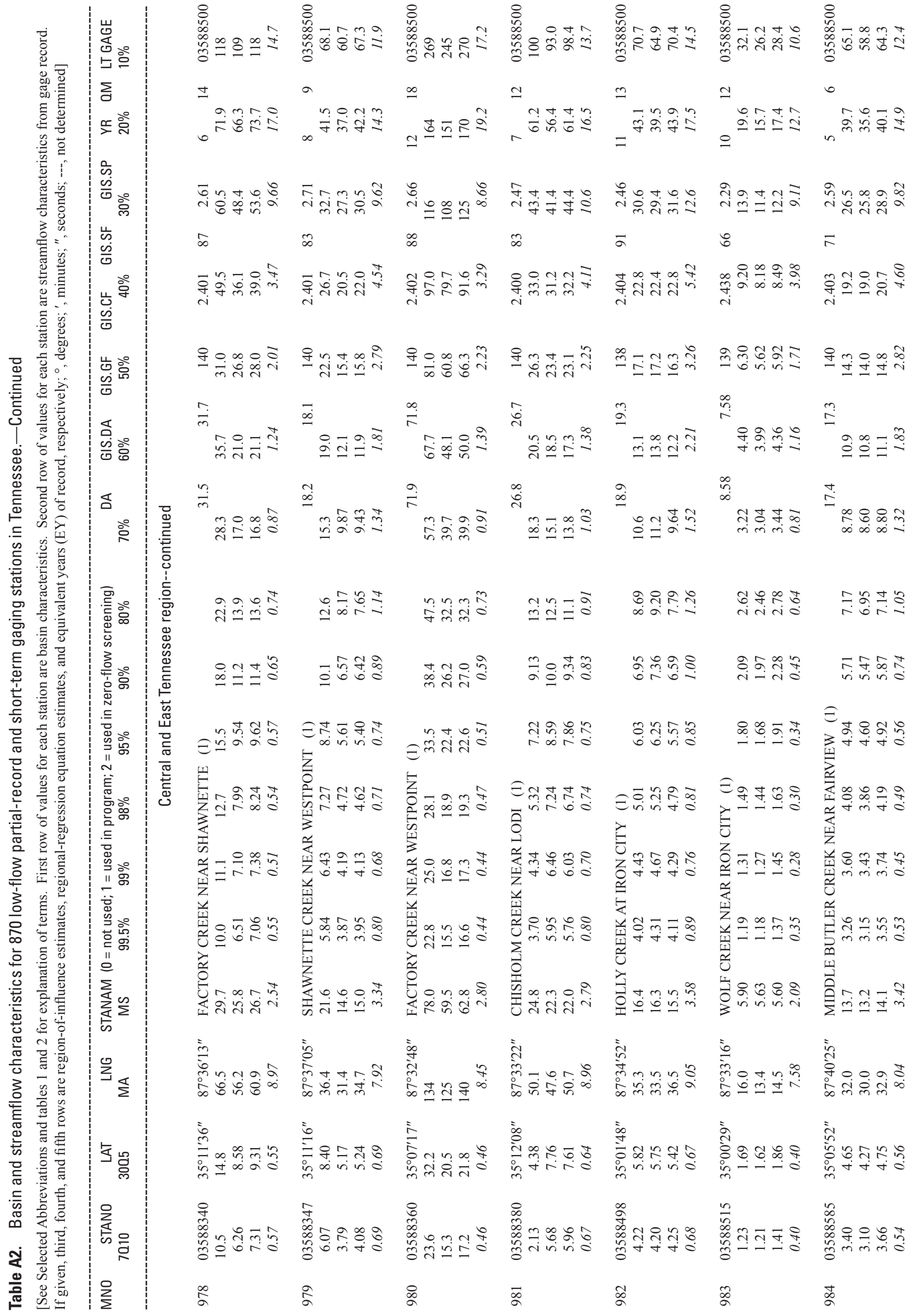




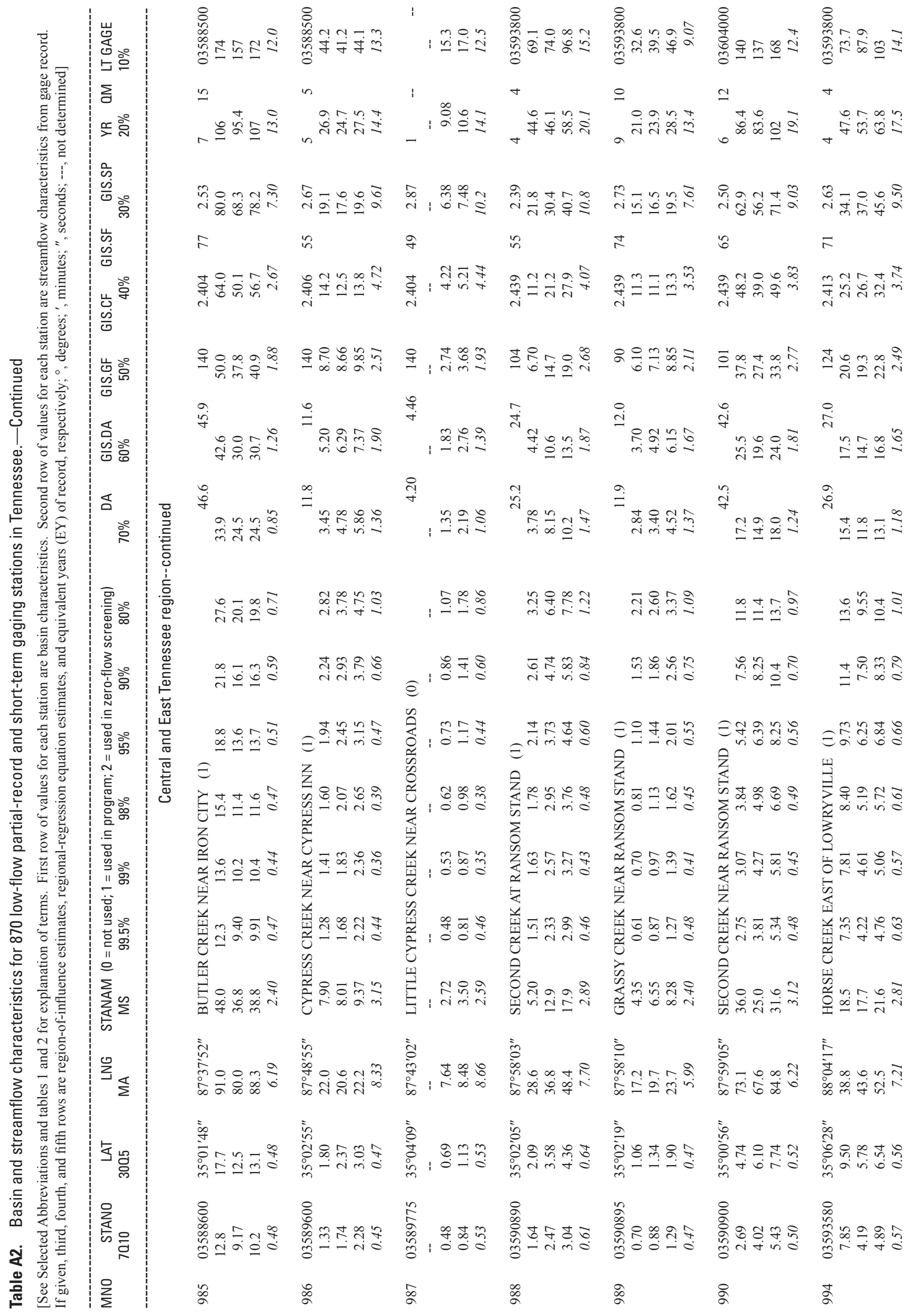




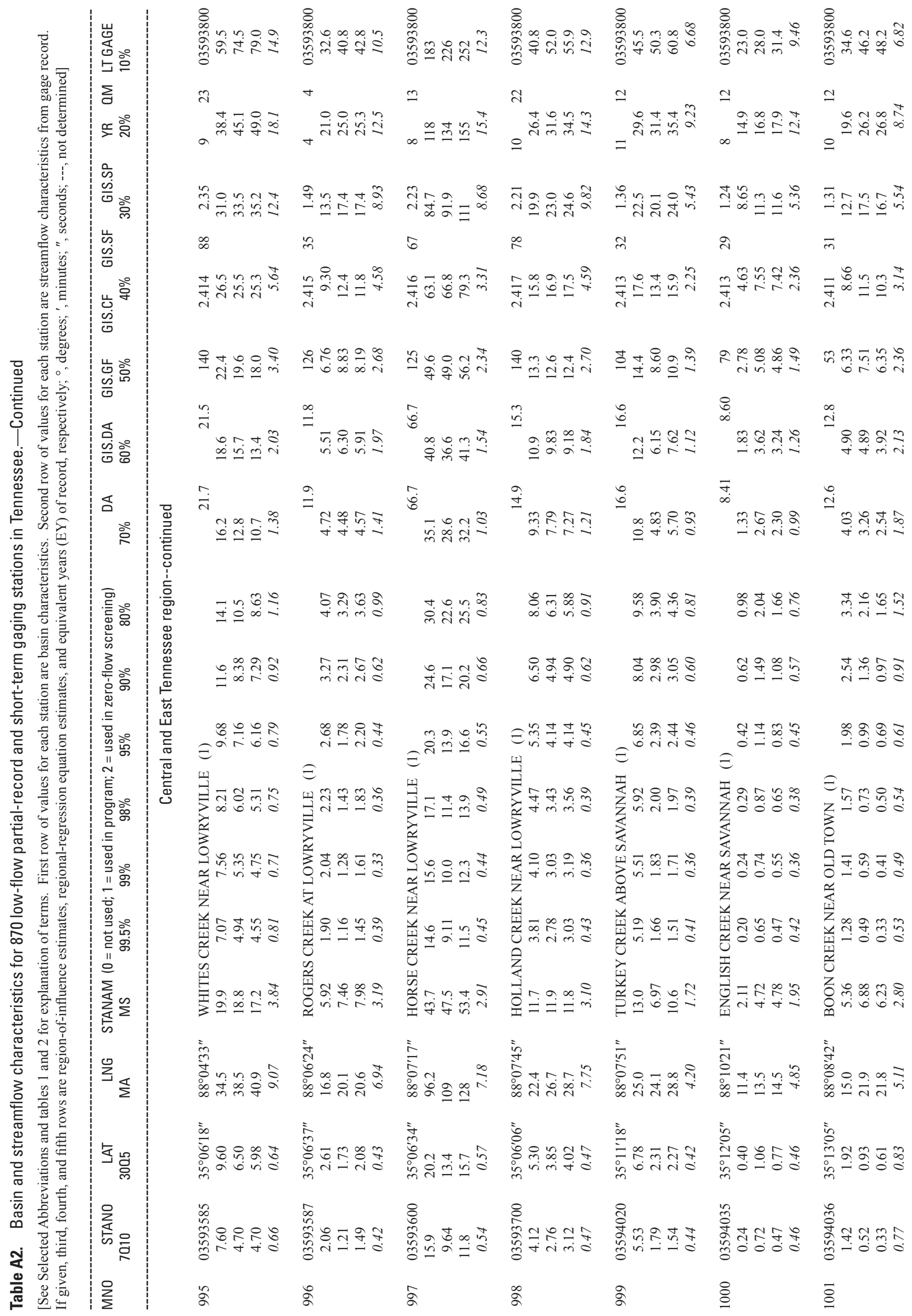




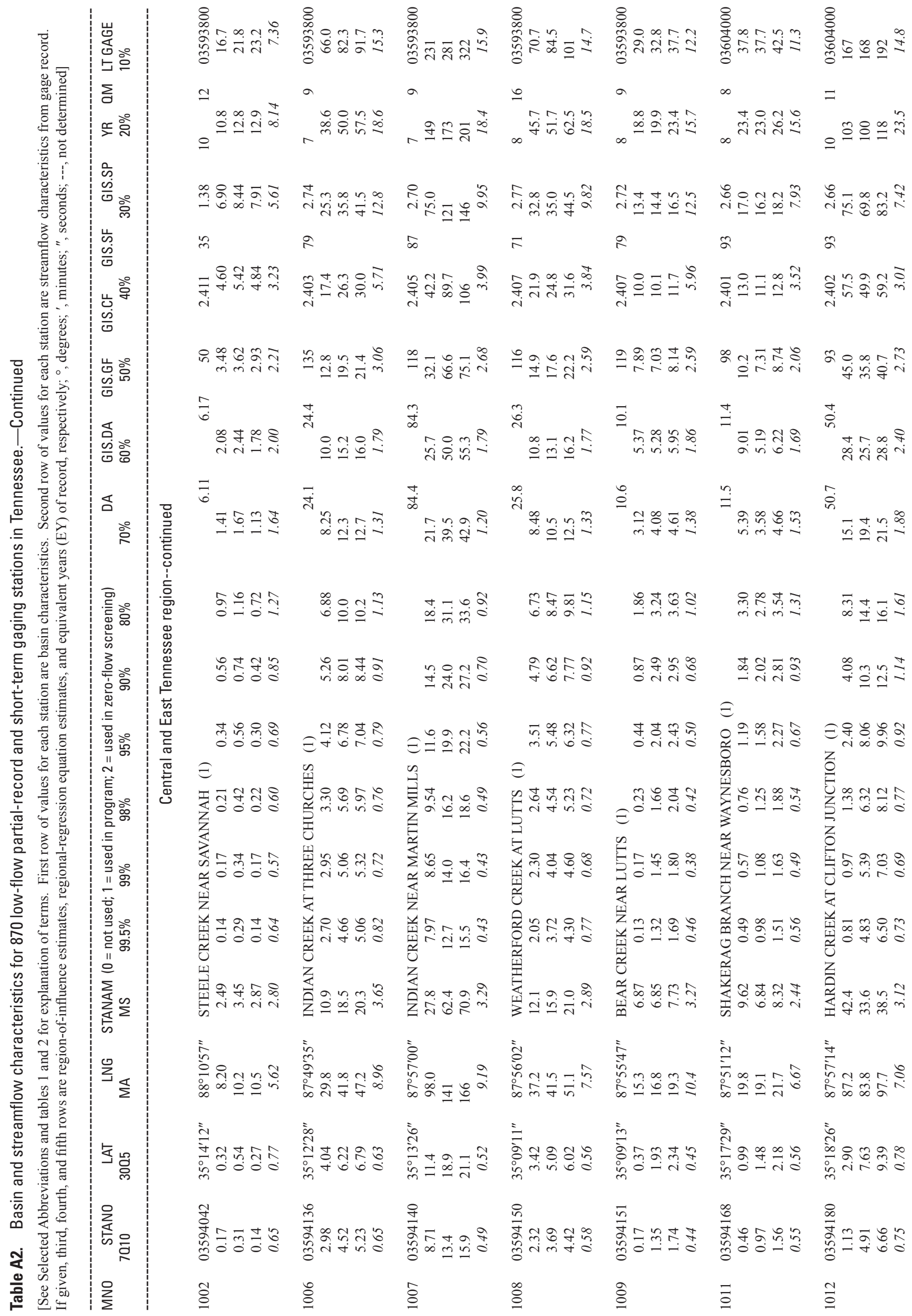




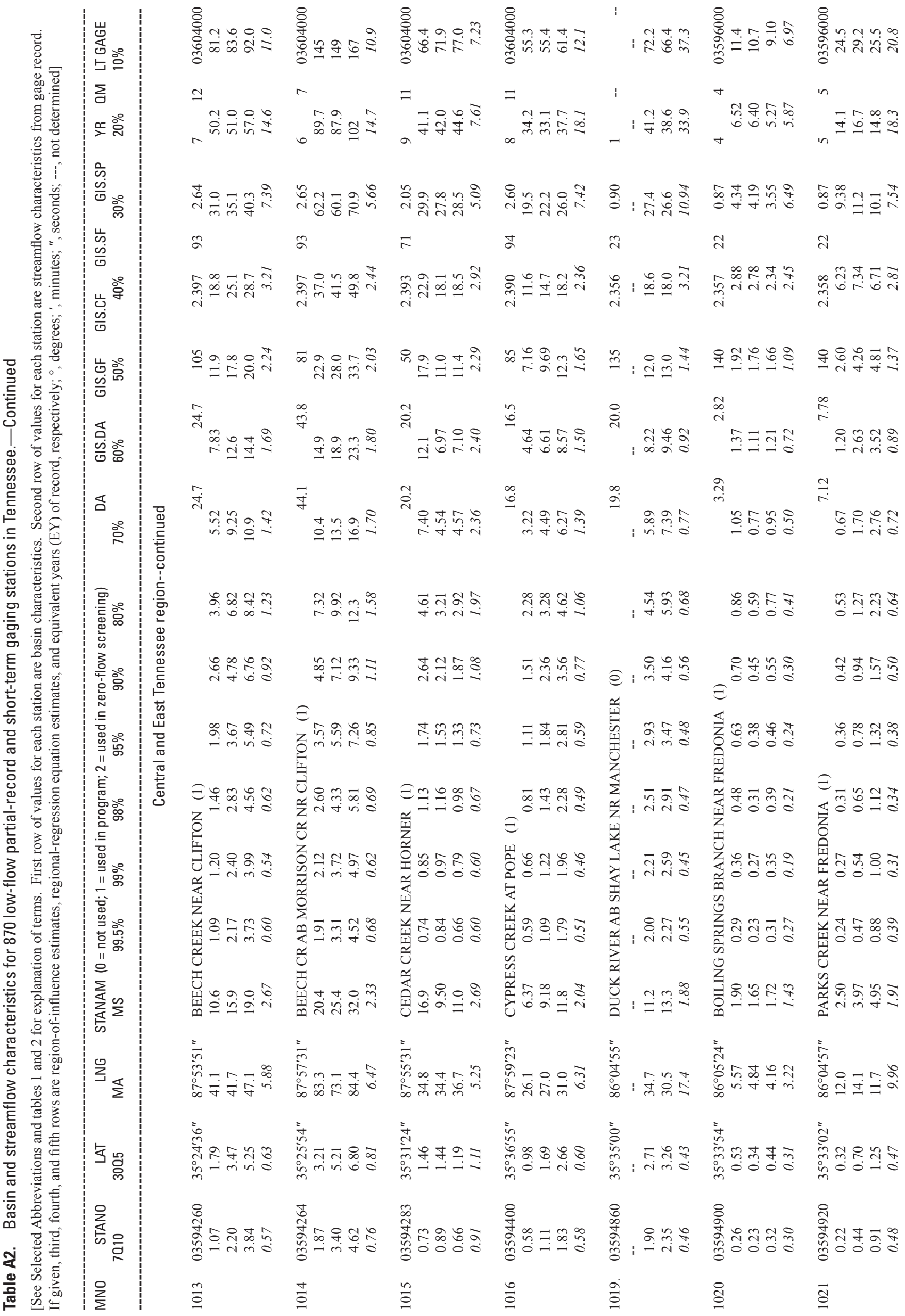




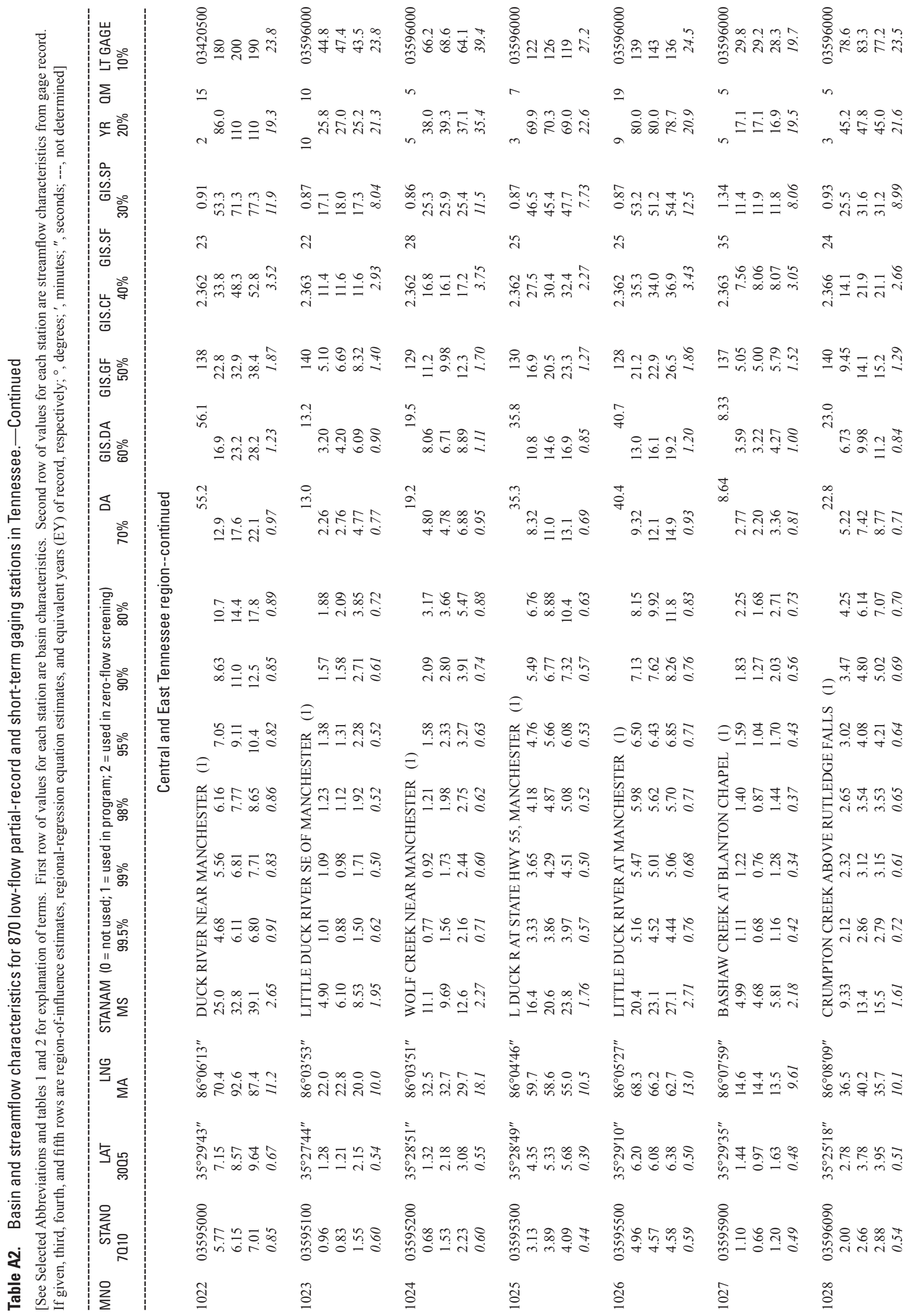




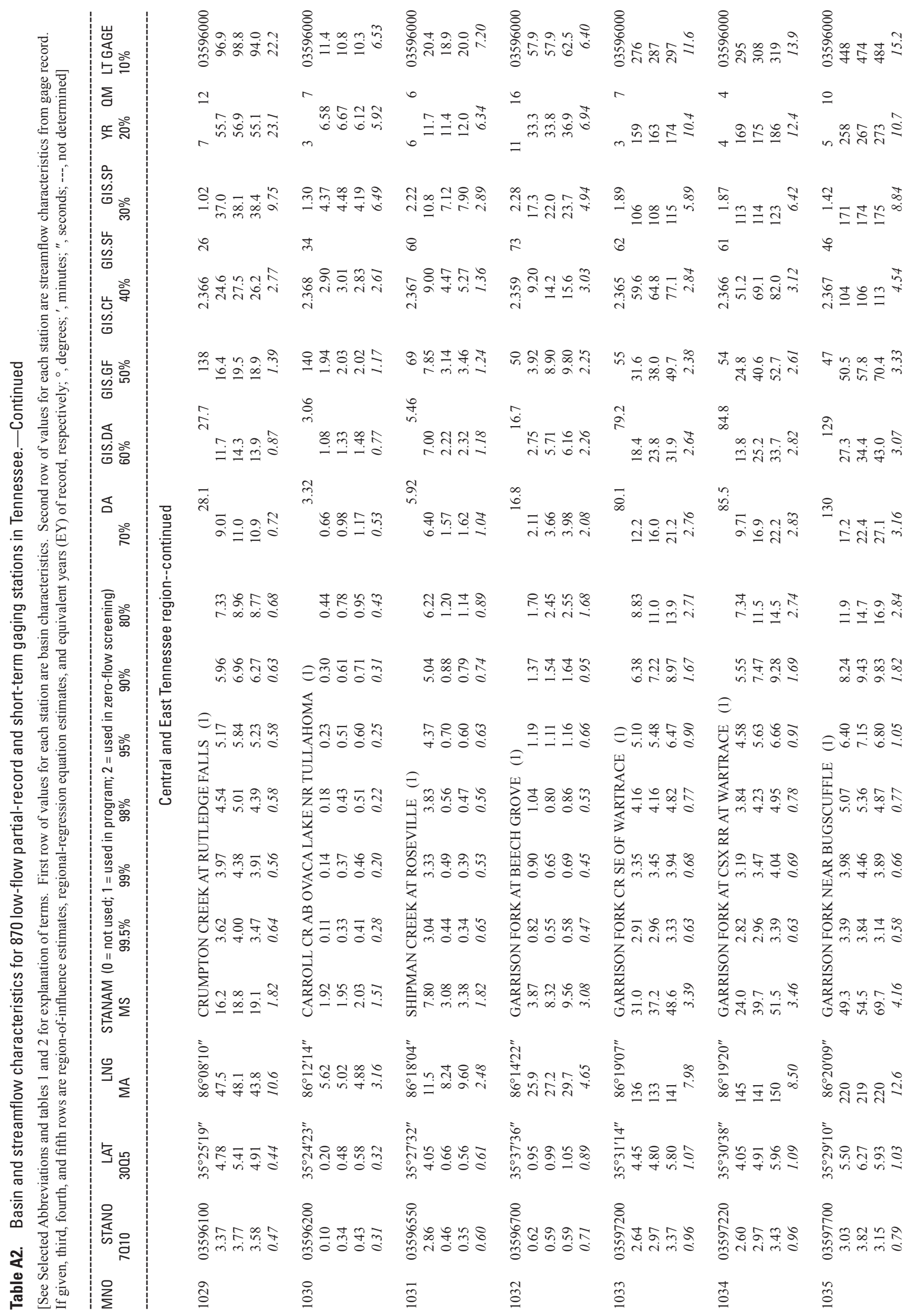




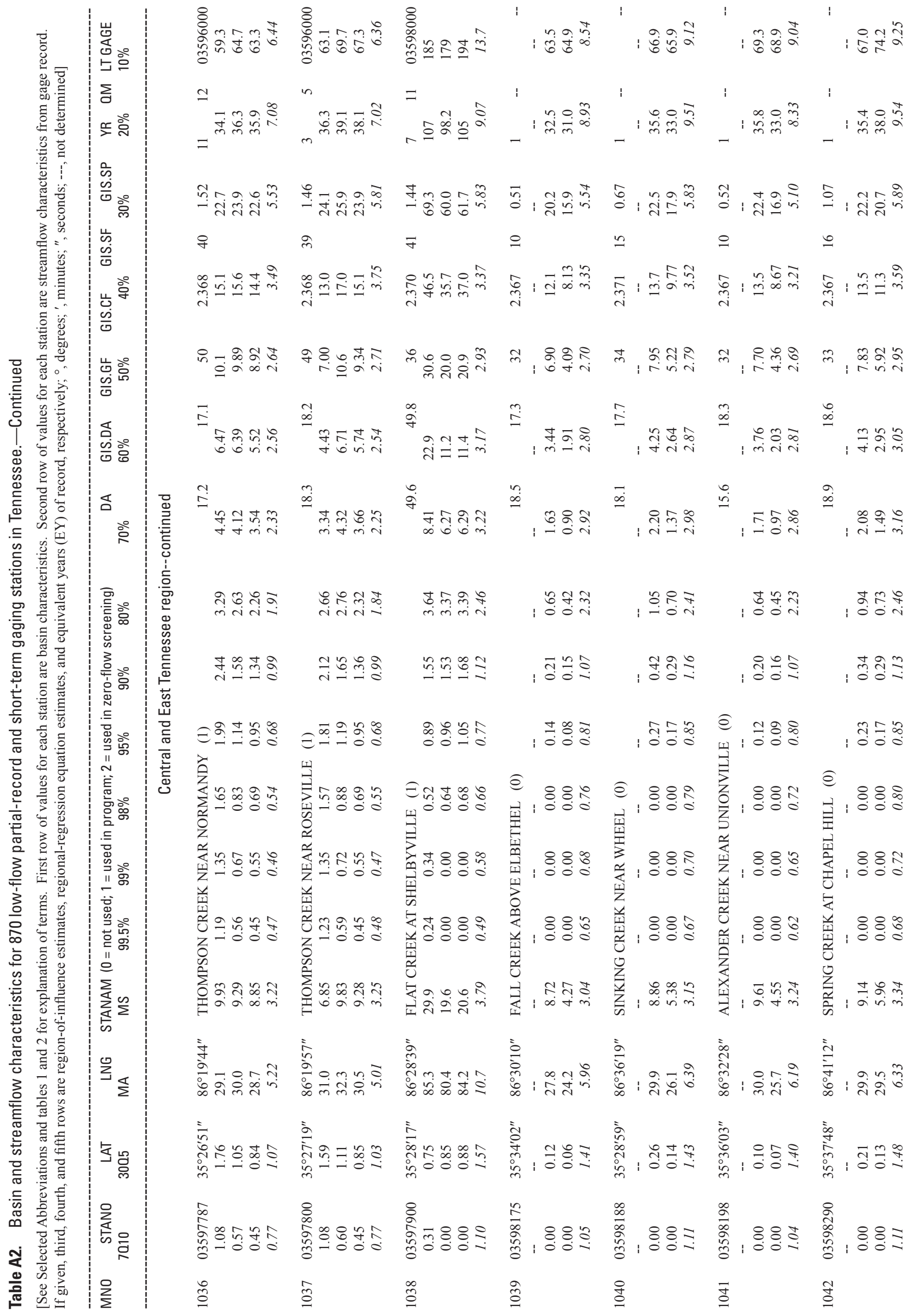




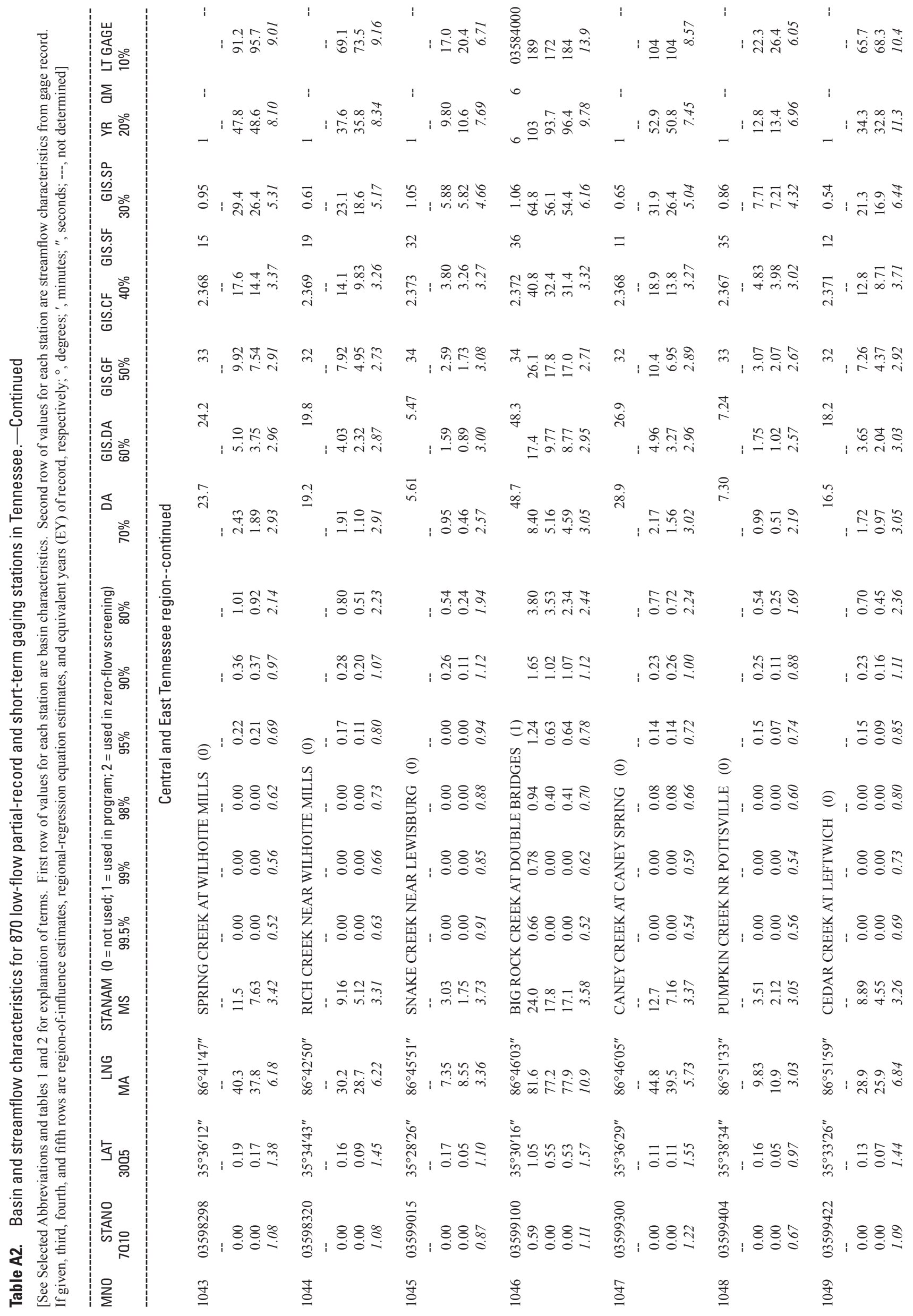




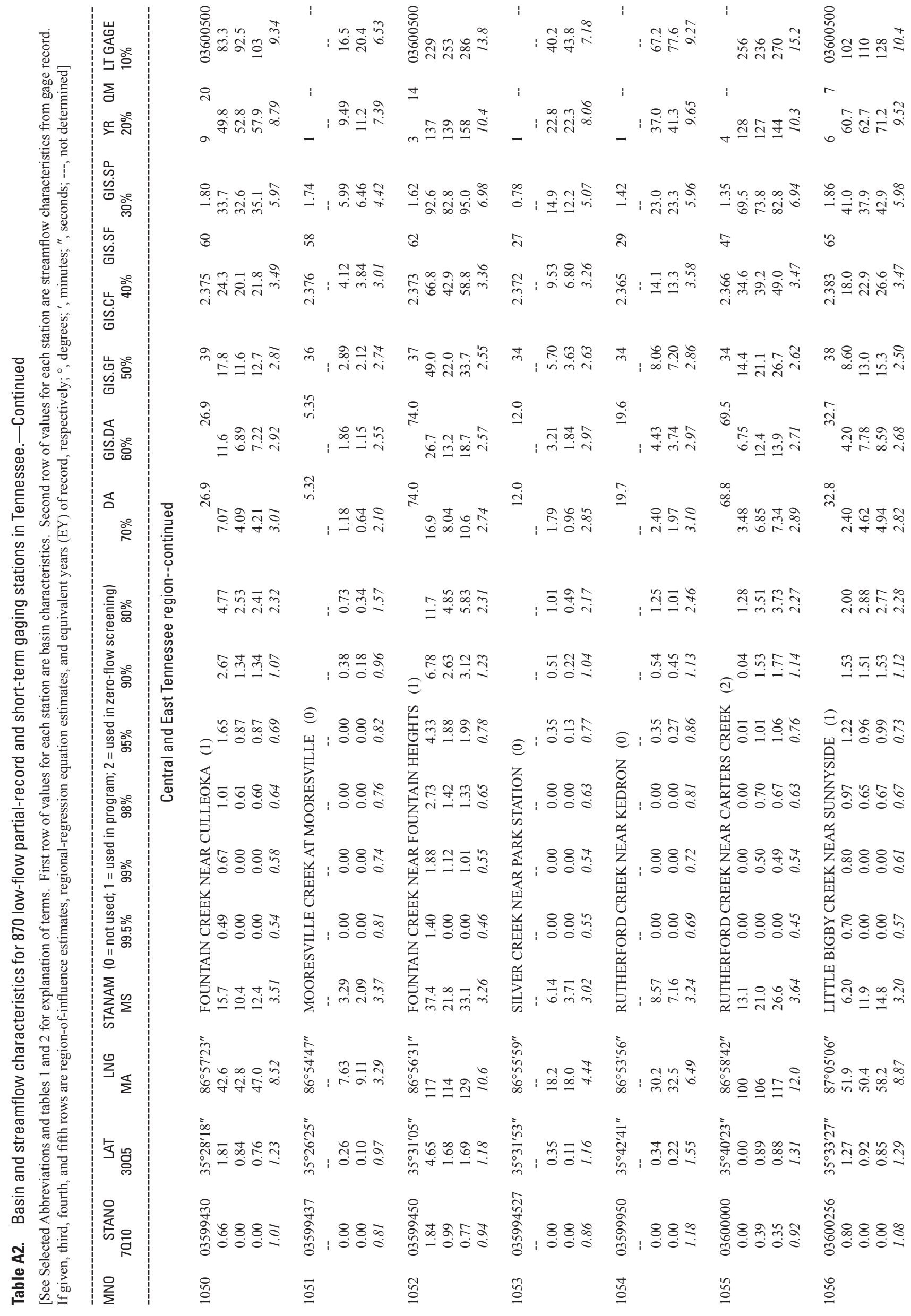




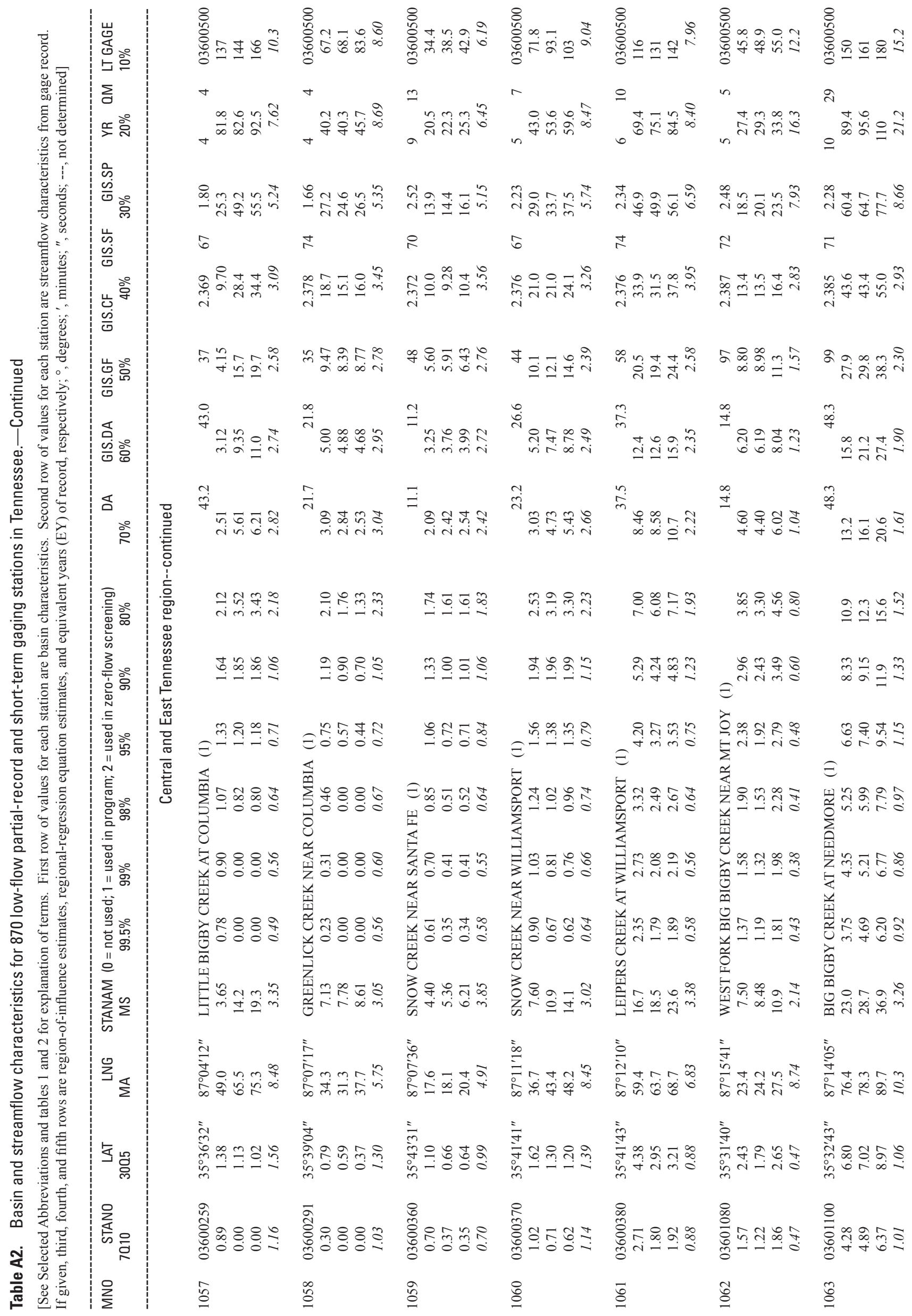


Appendix A. Basin and Streamflow Characteristics for Sites in This Report

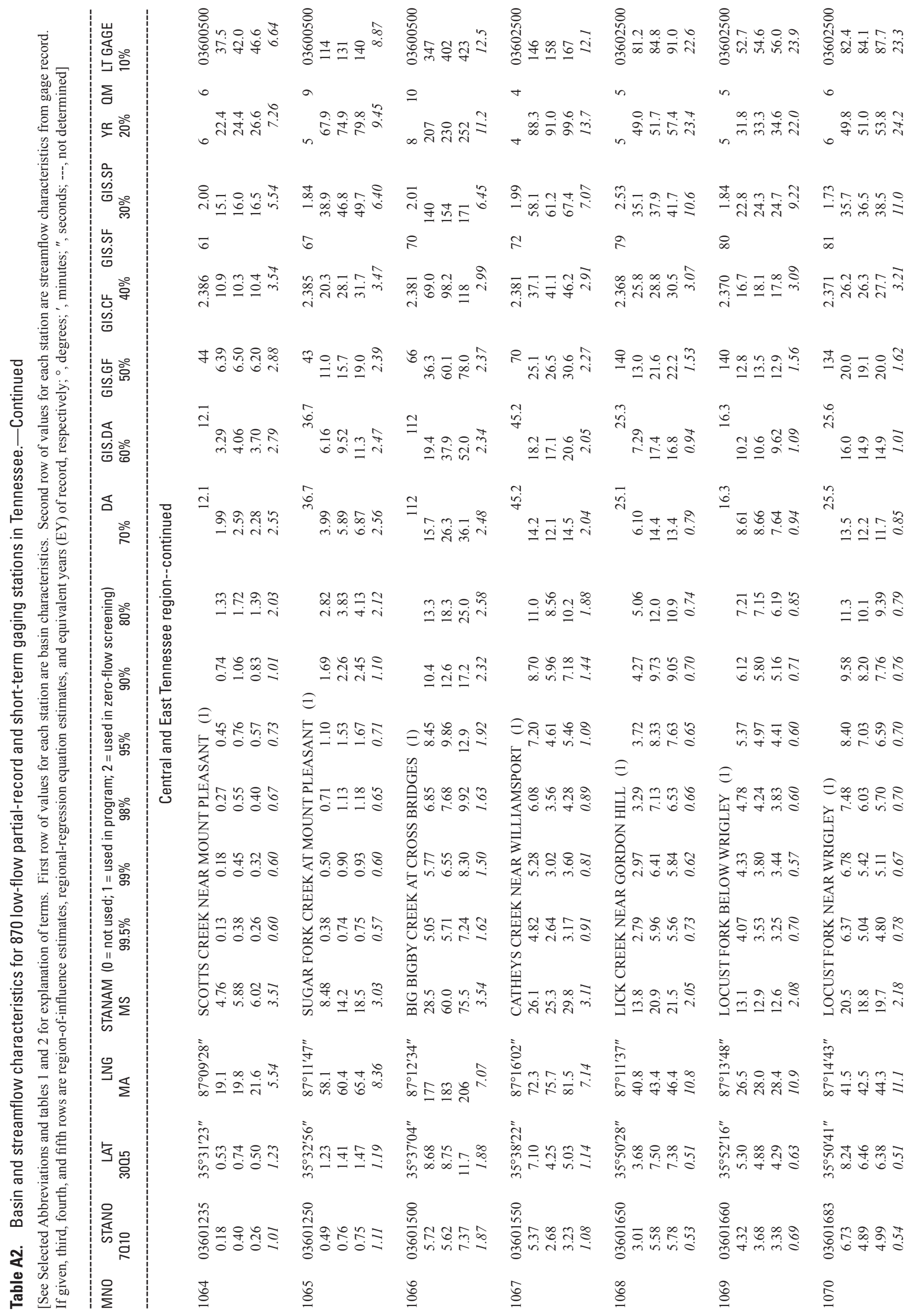




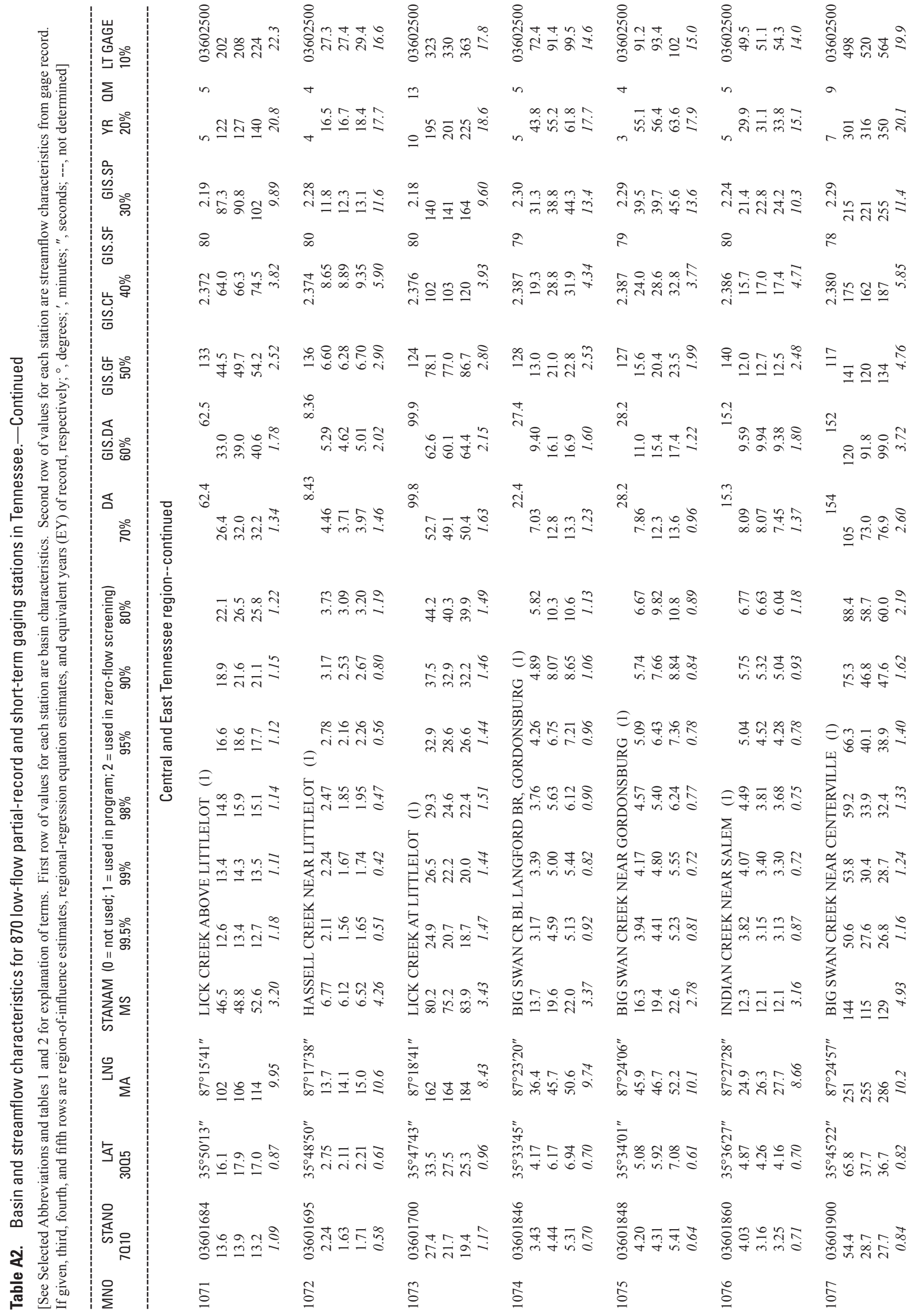




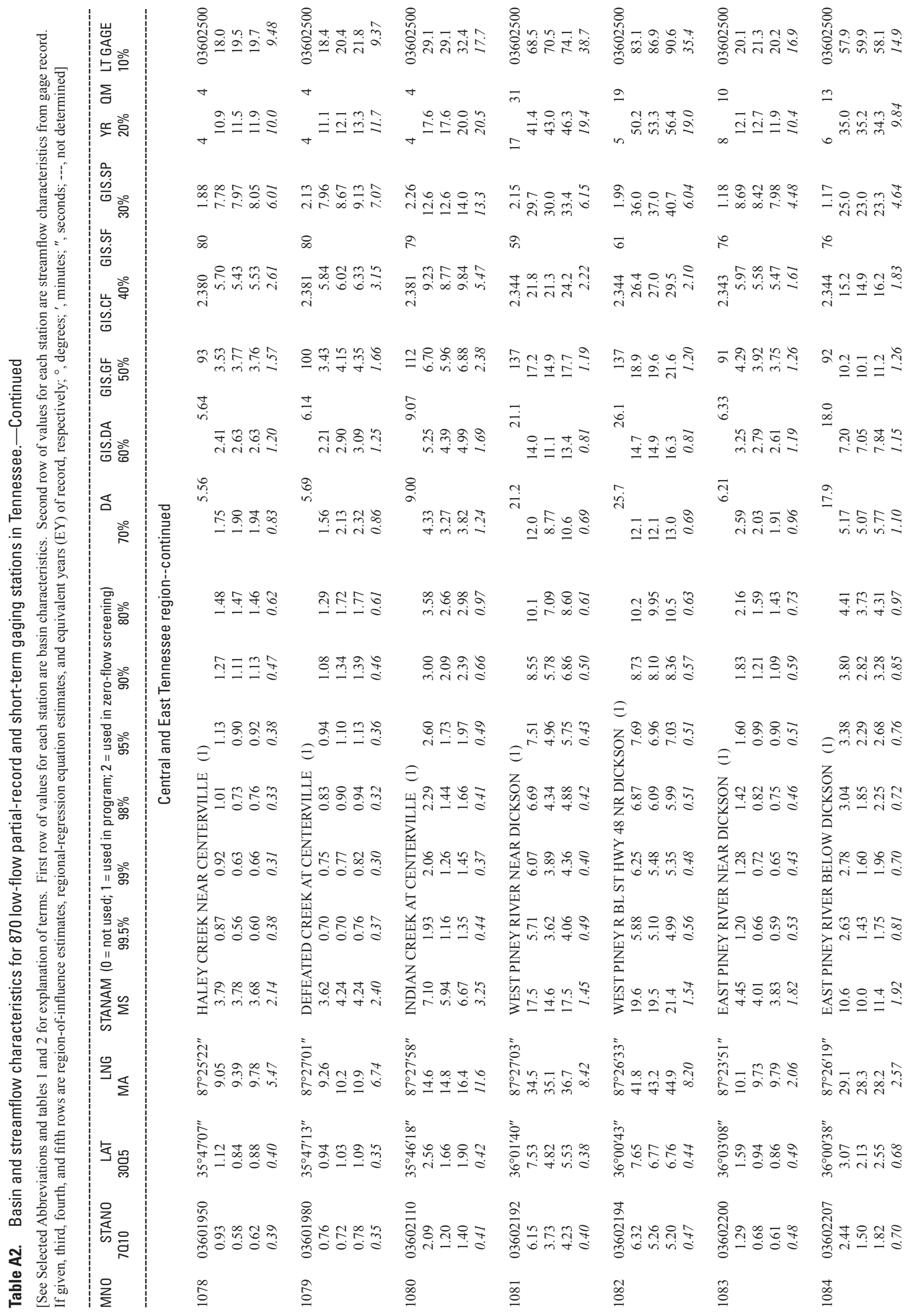




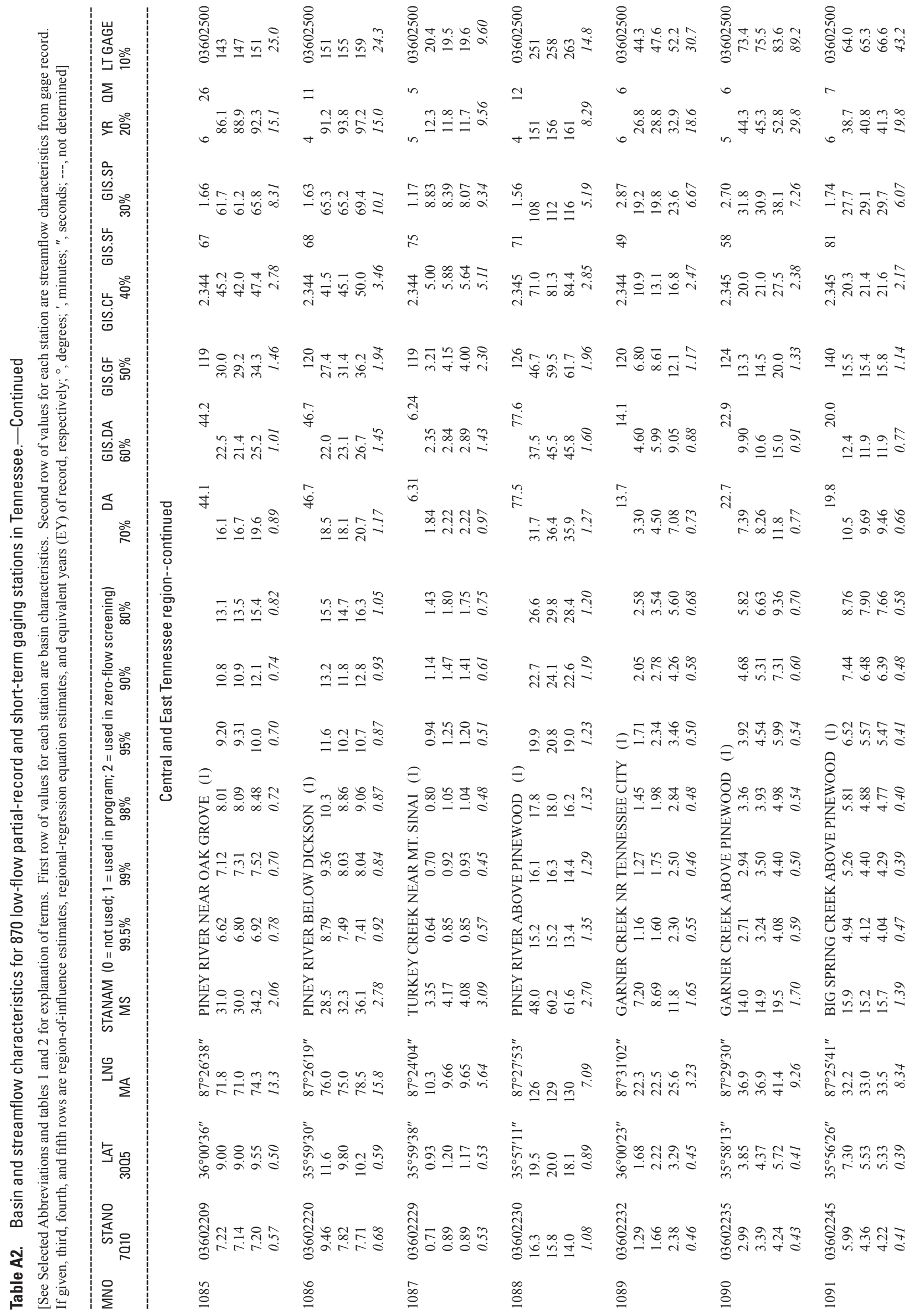




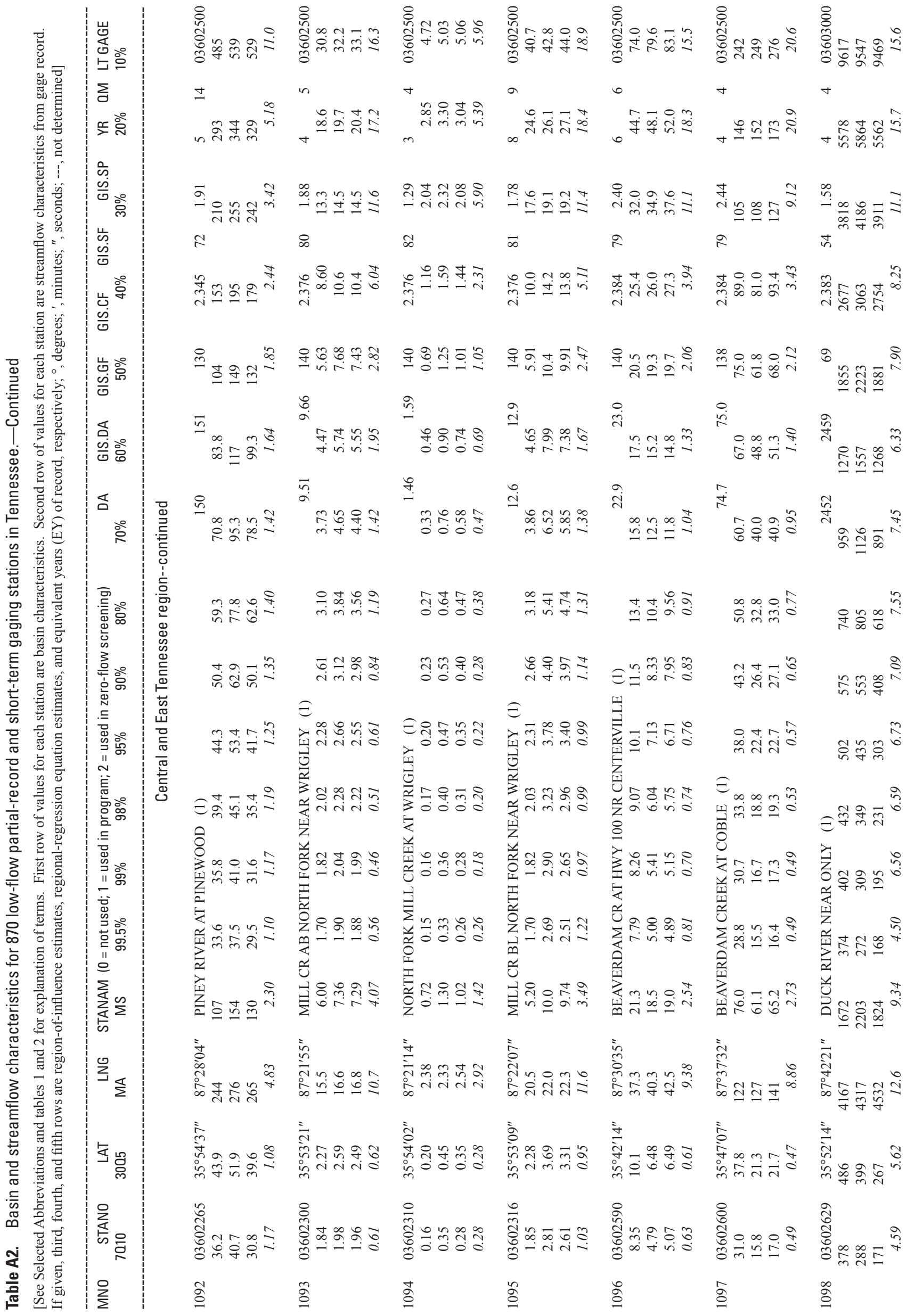




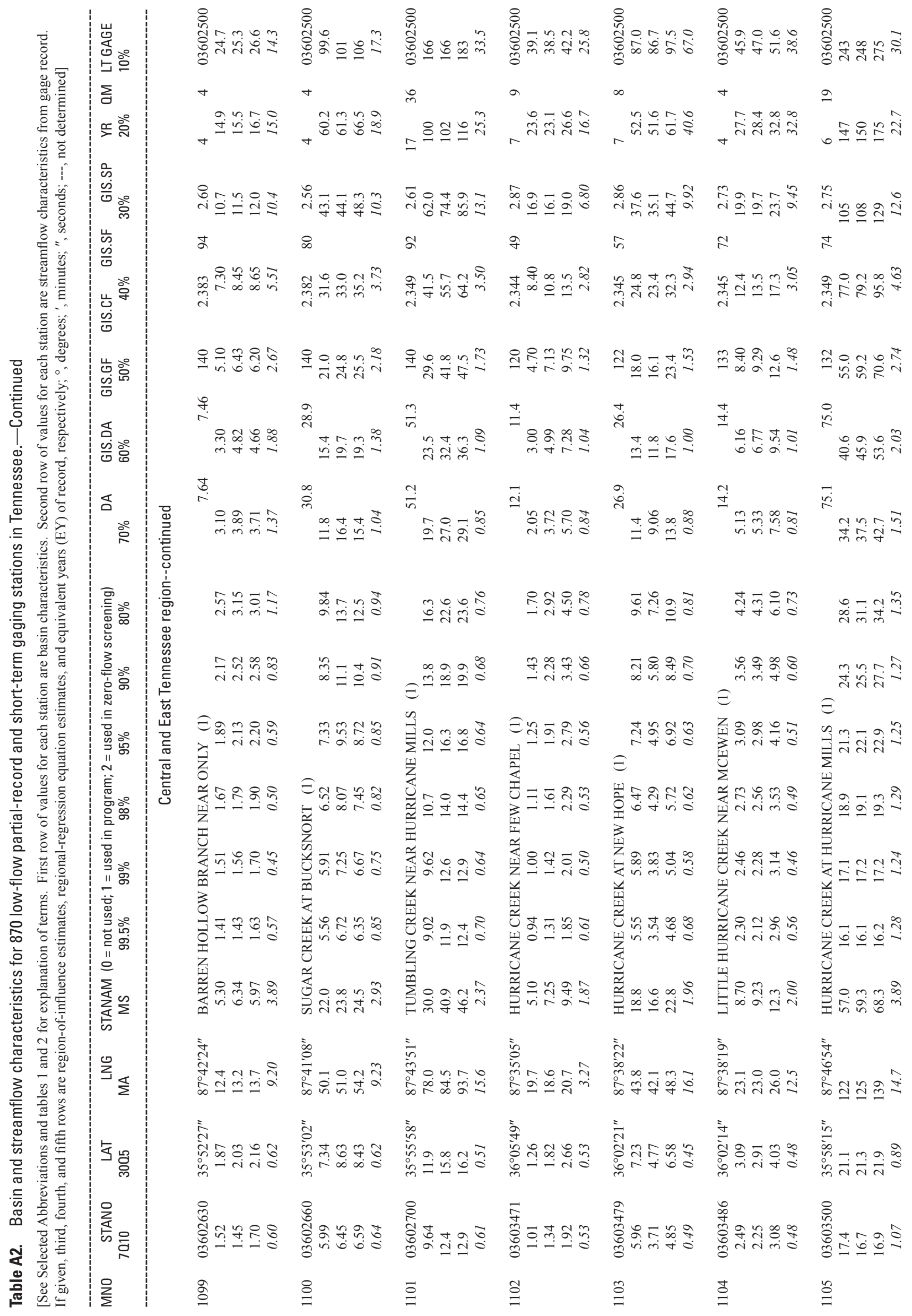




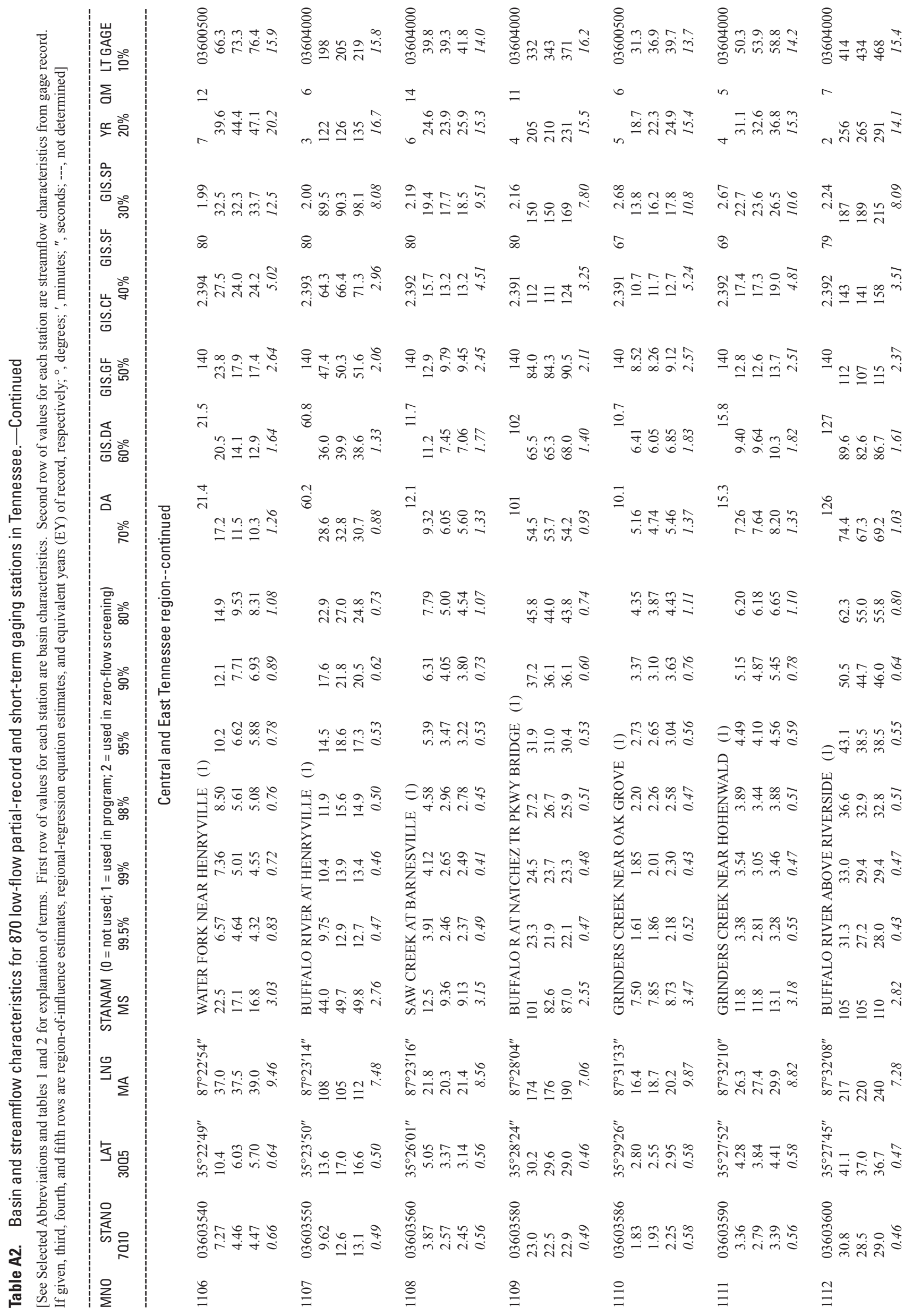




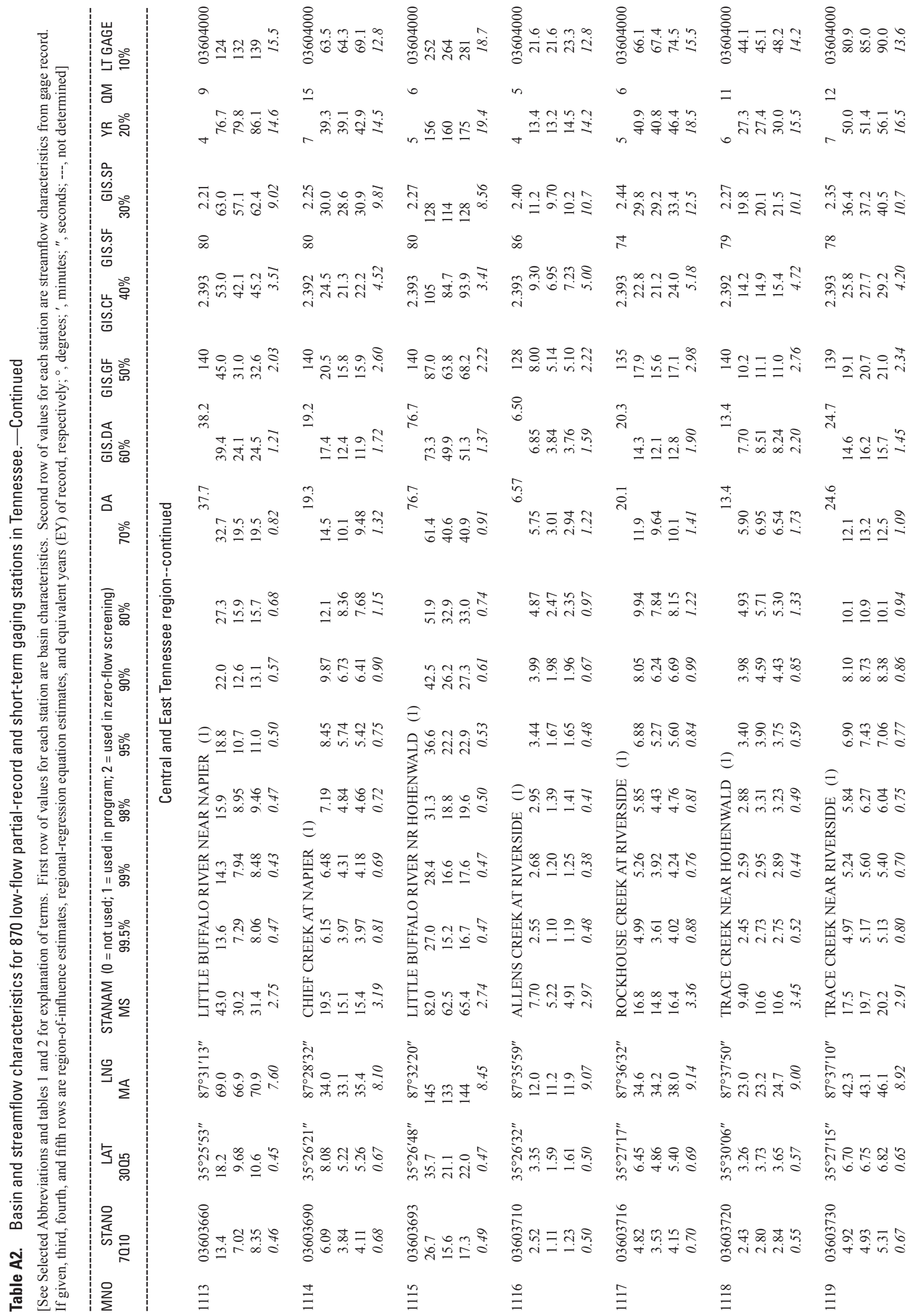




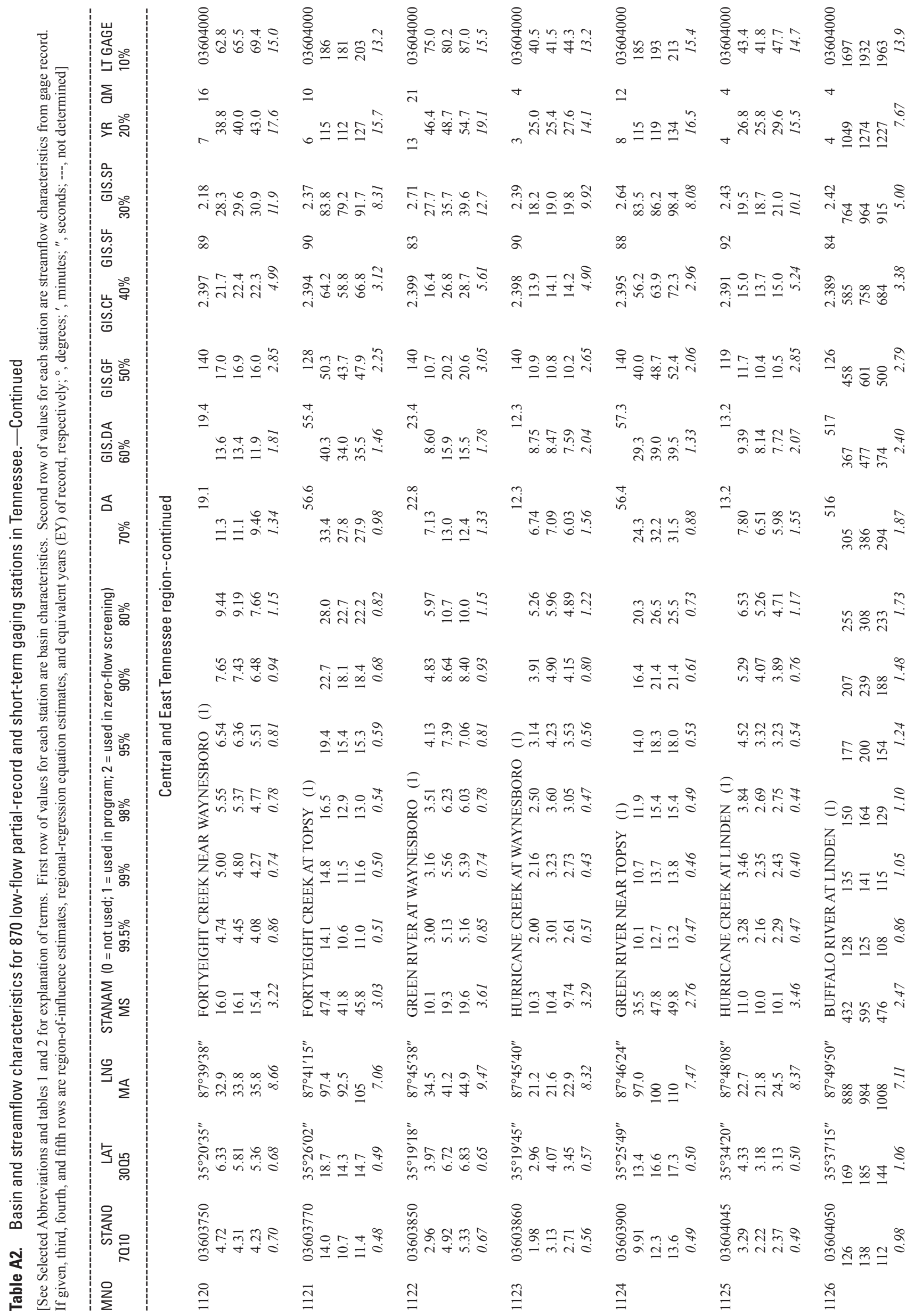




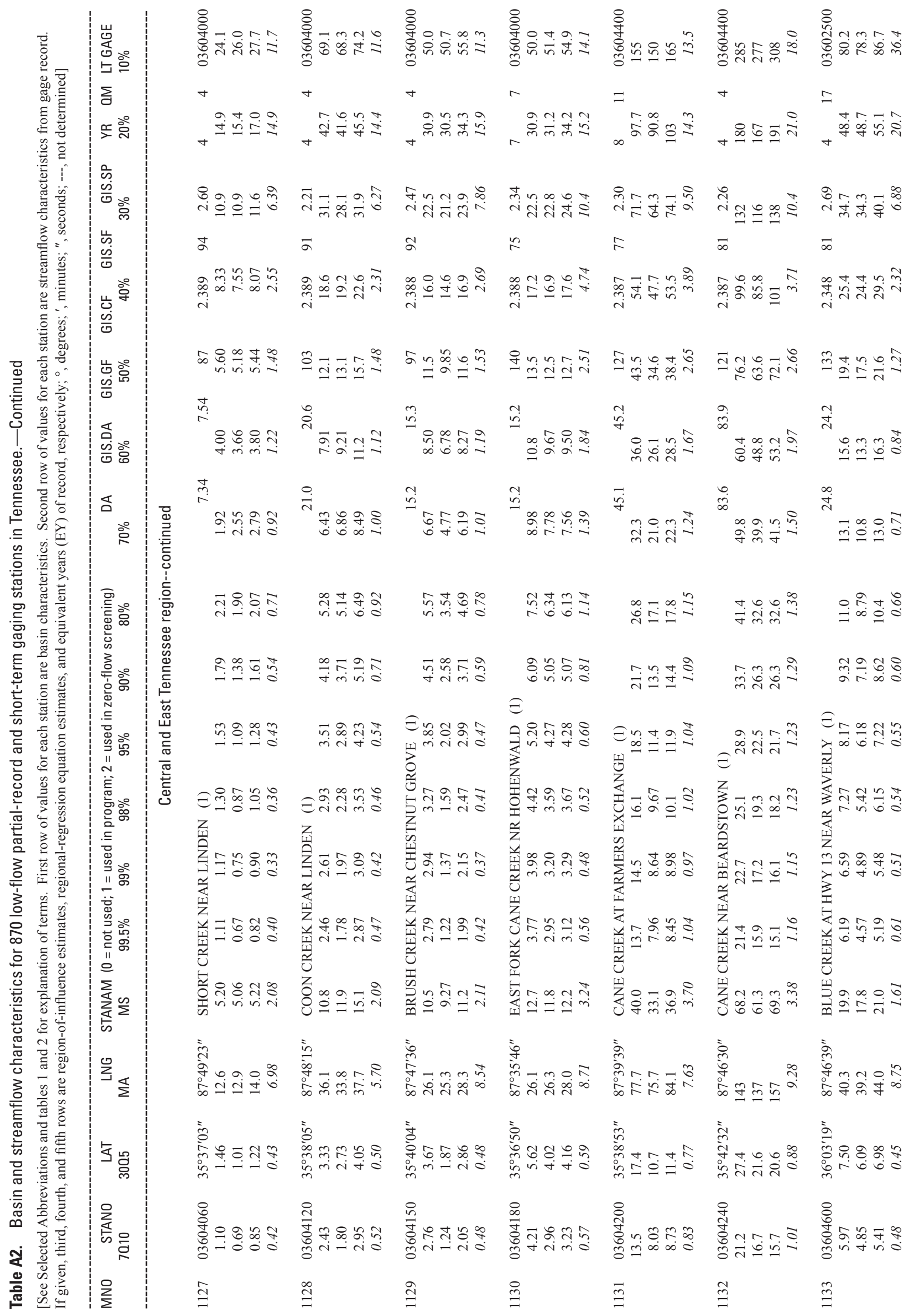




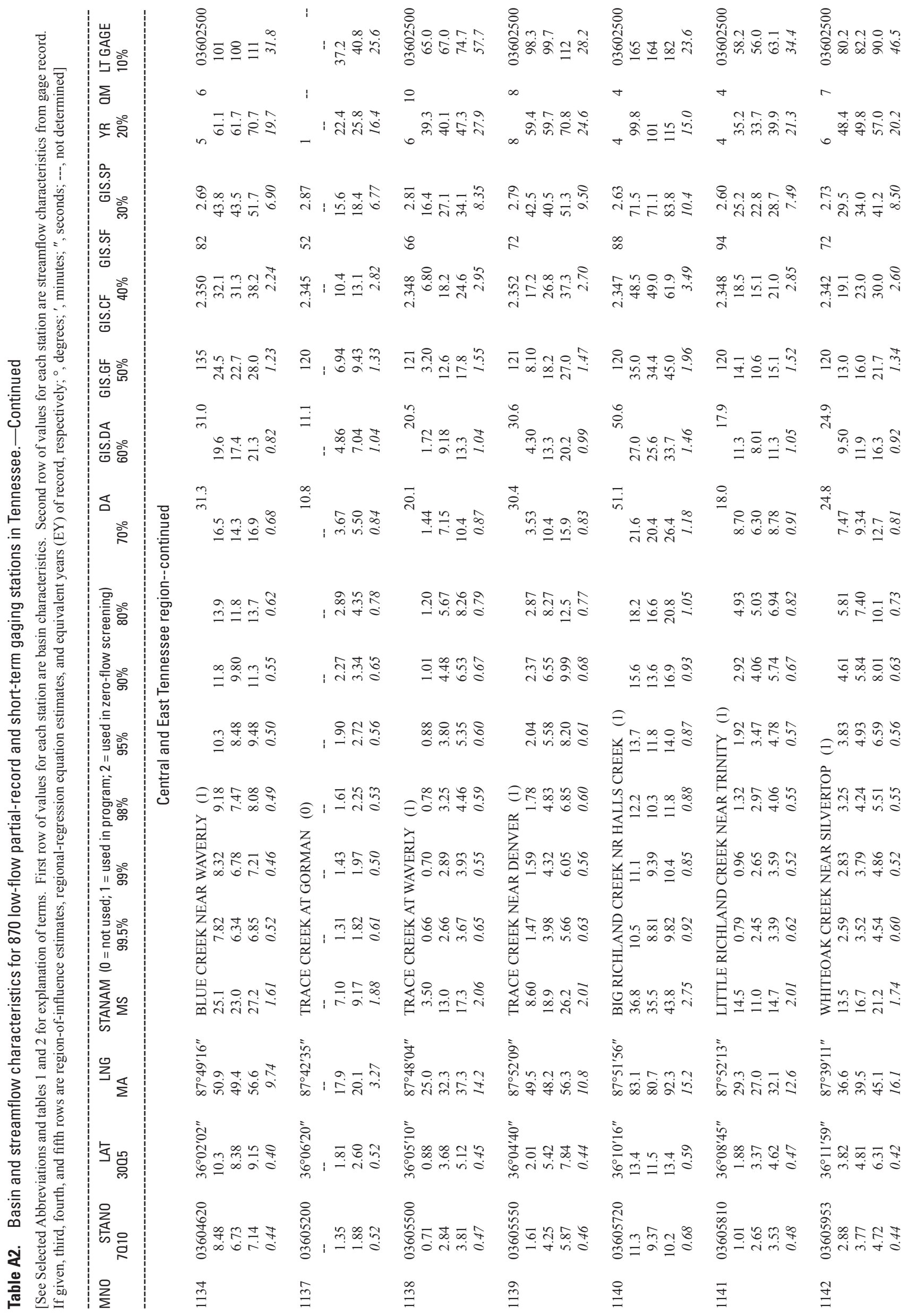




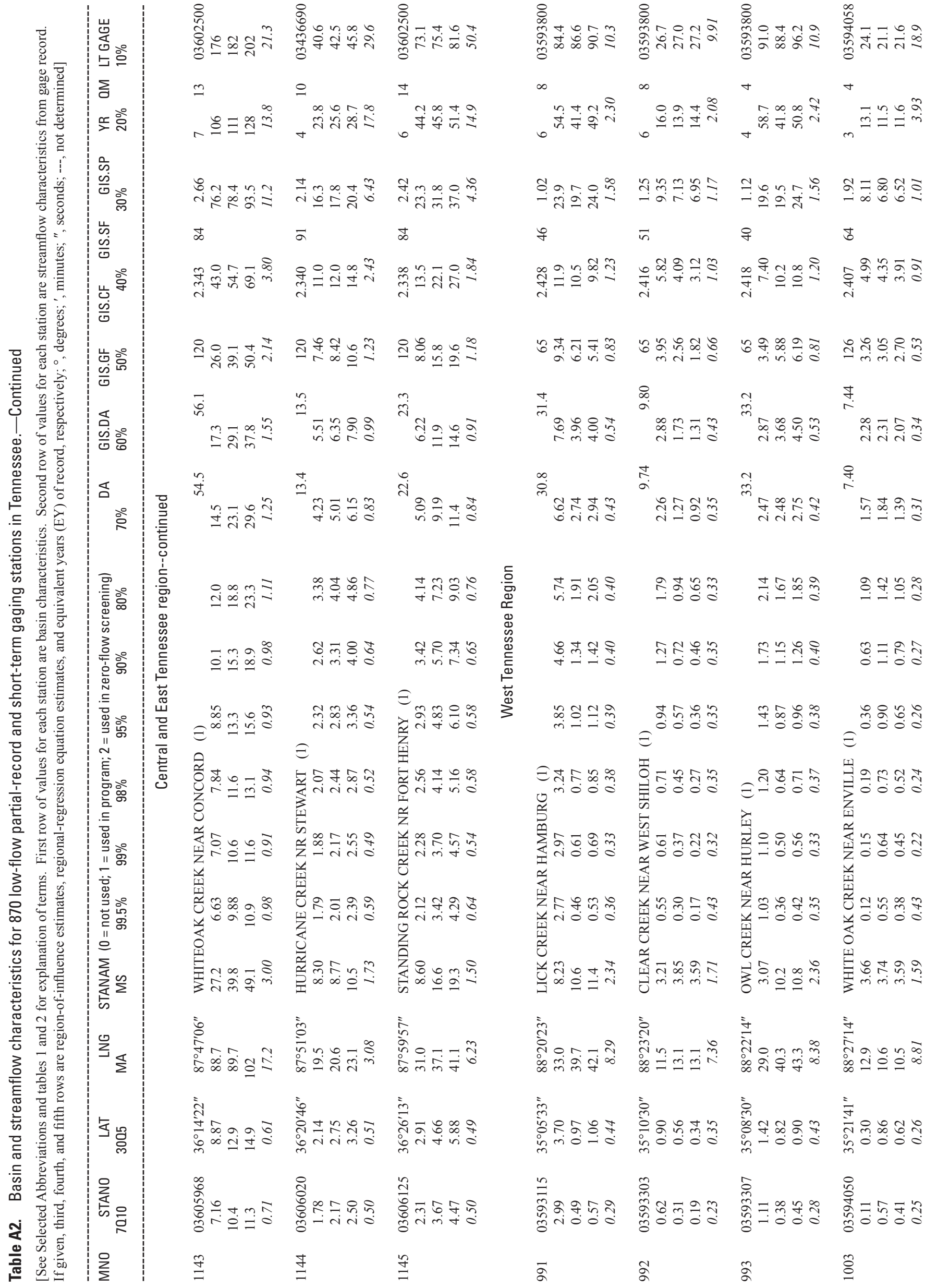




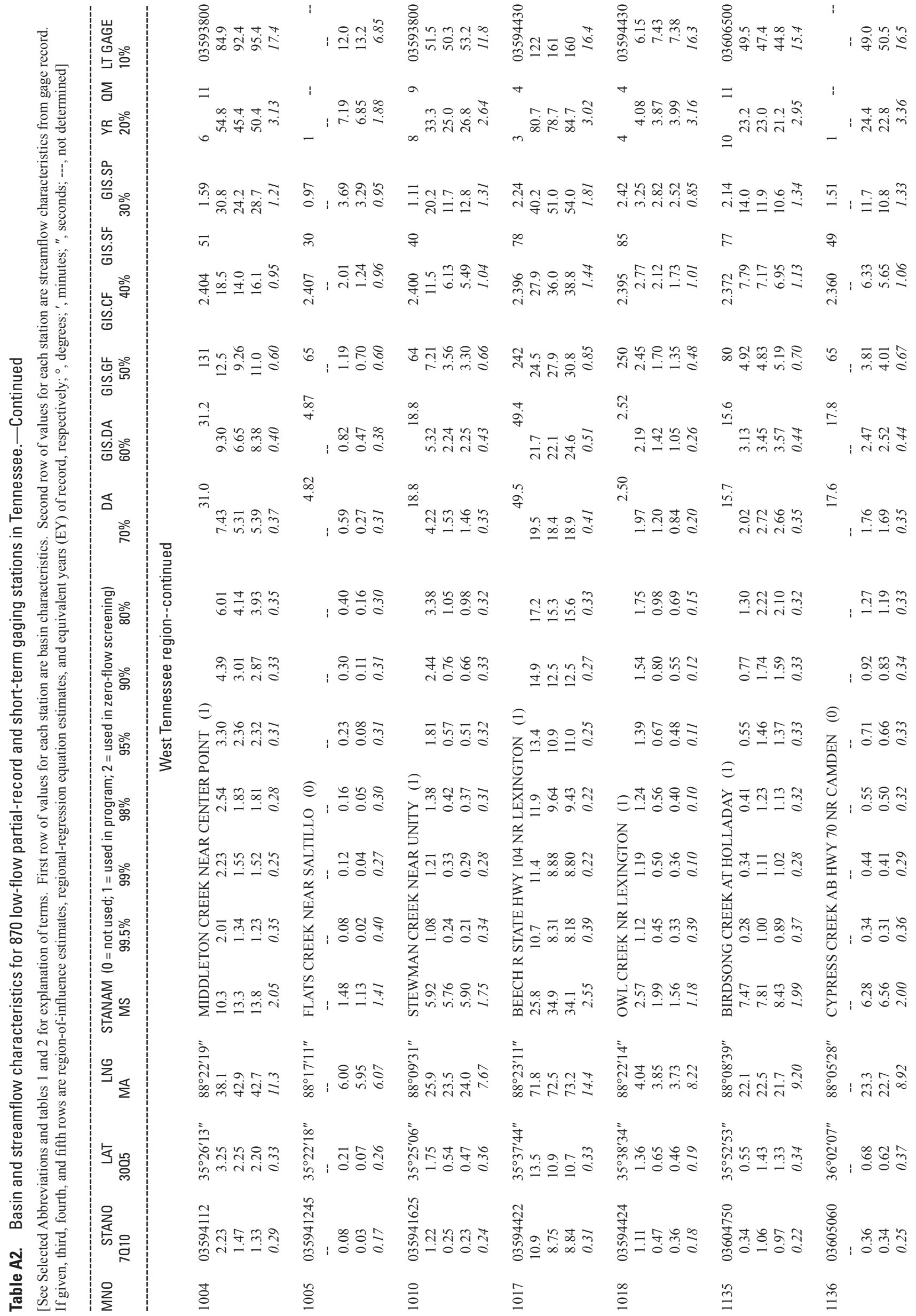




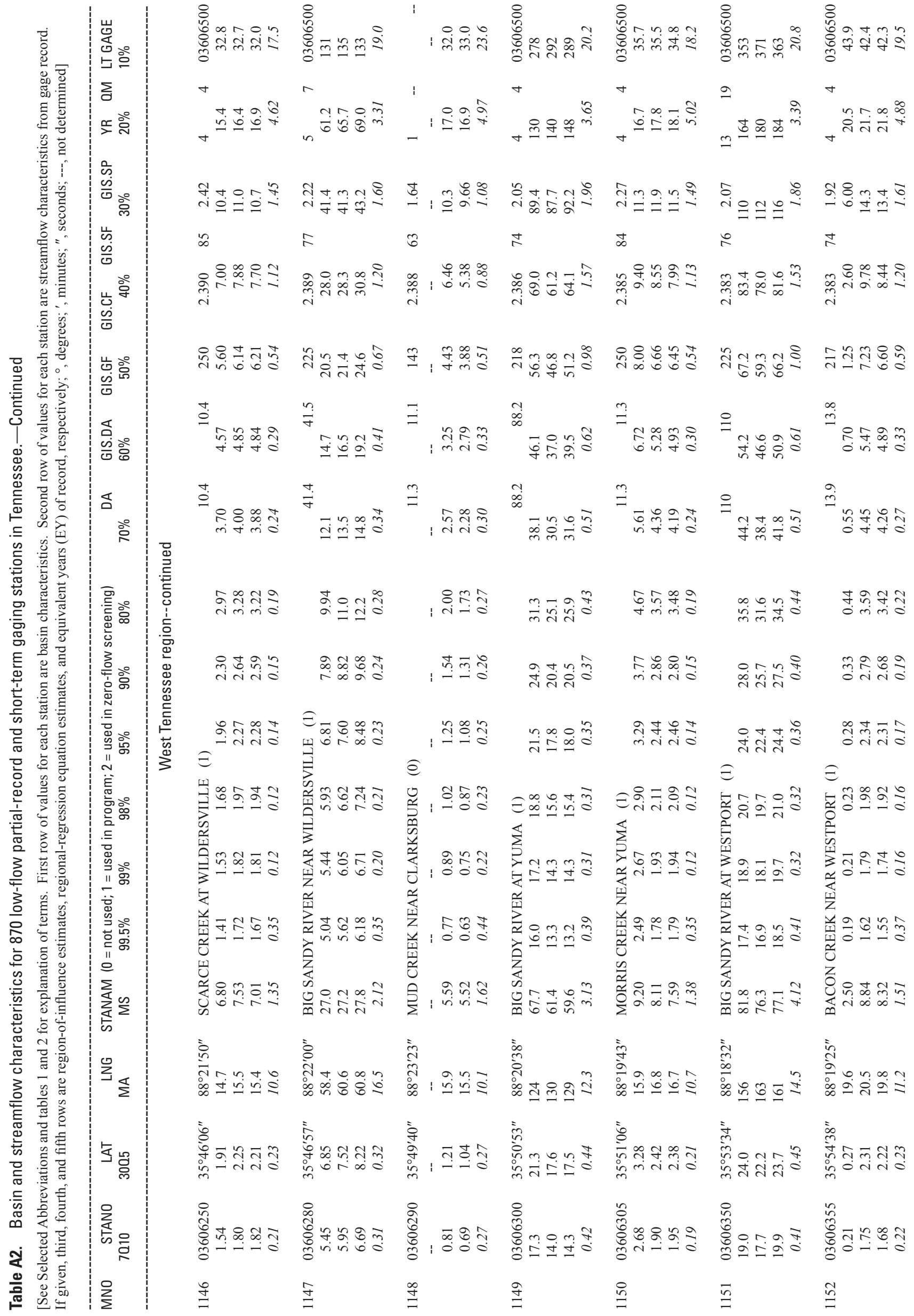




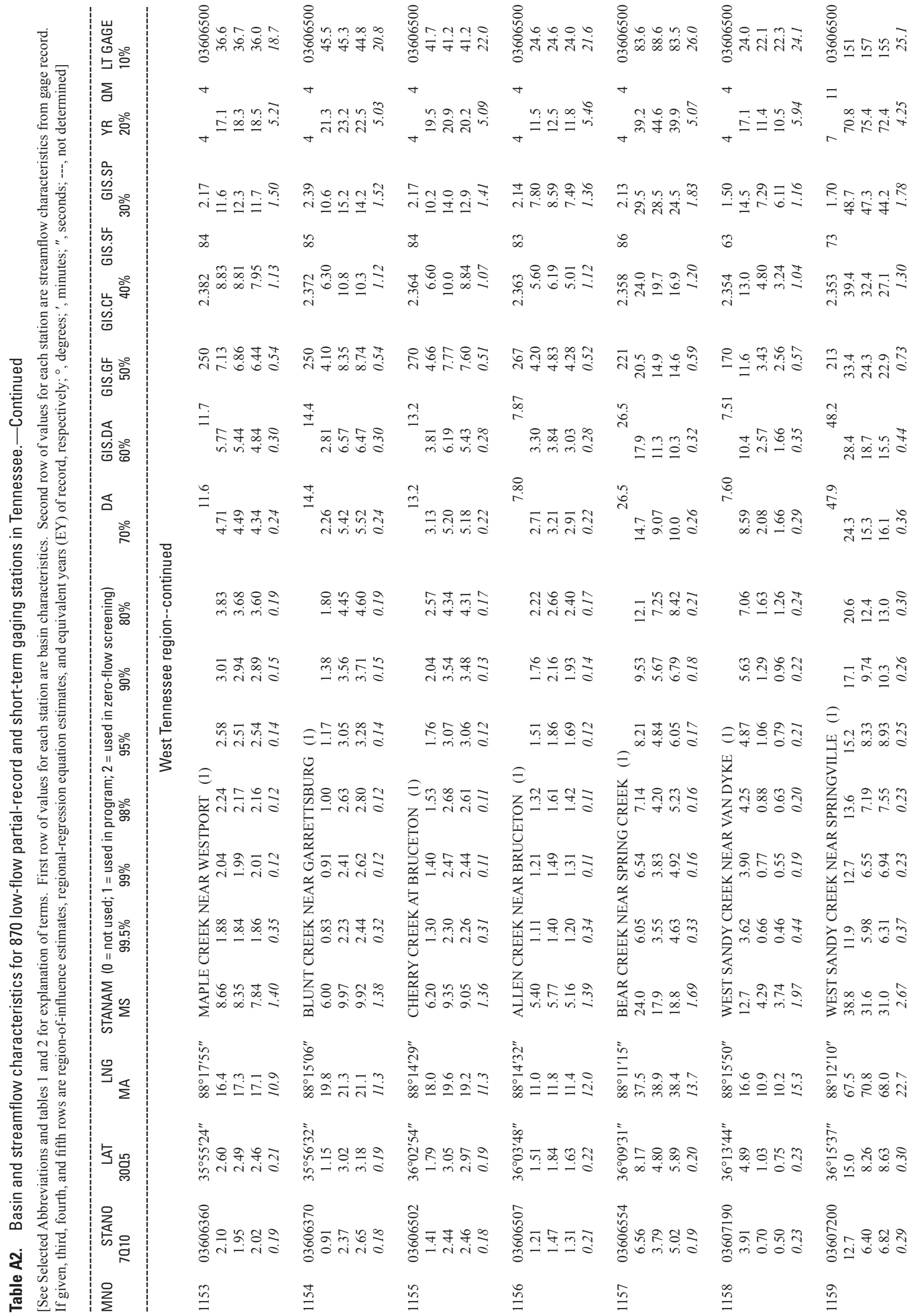




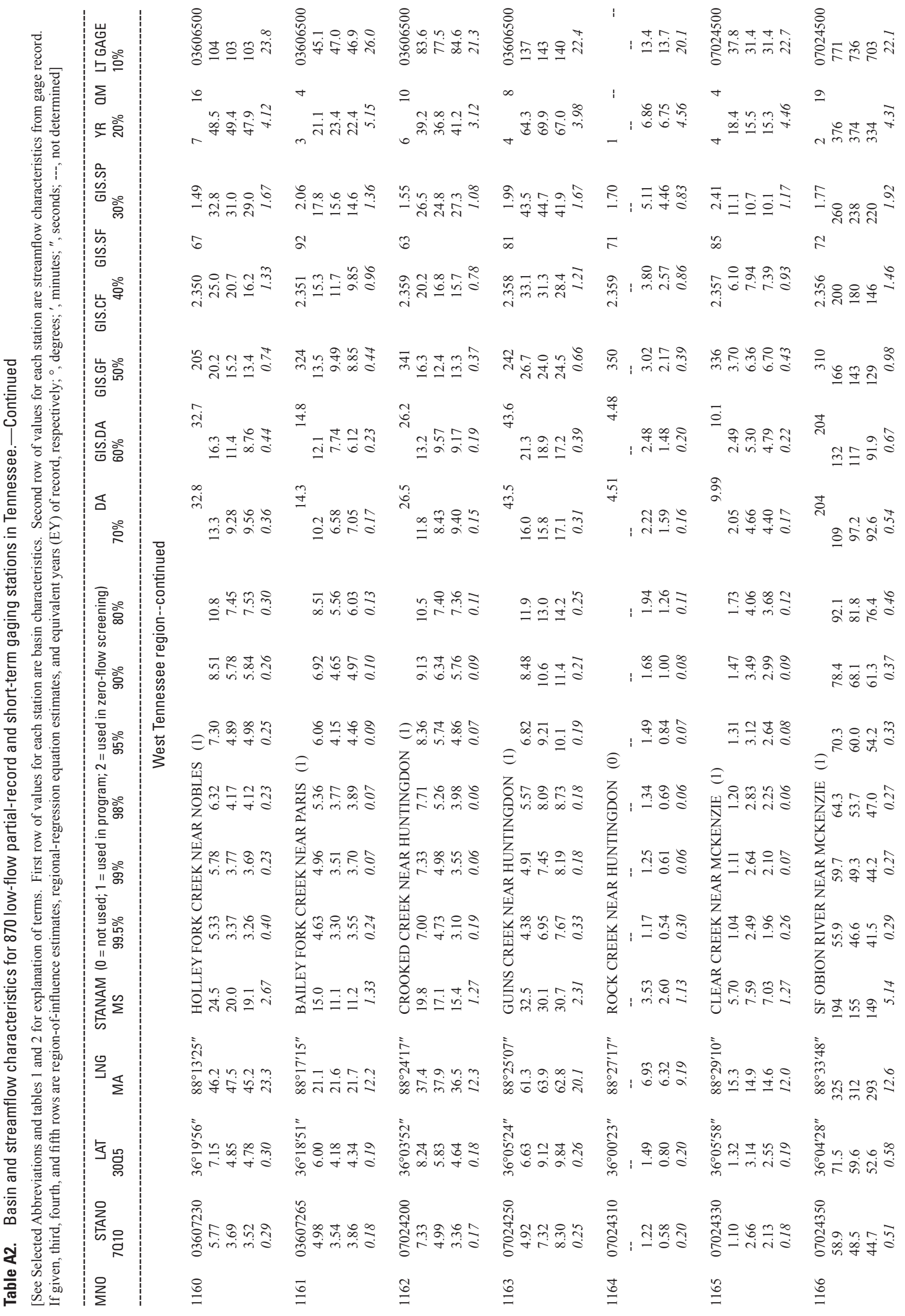




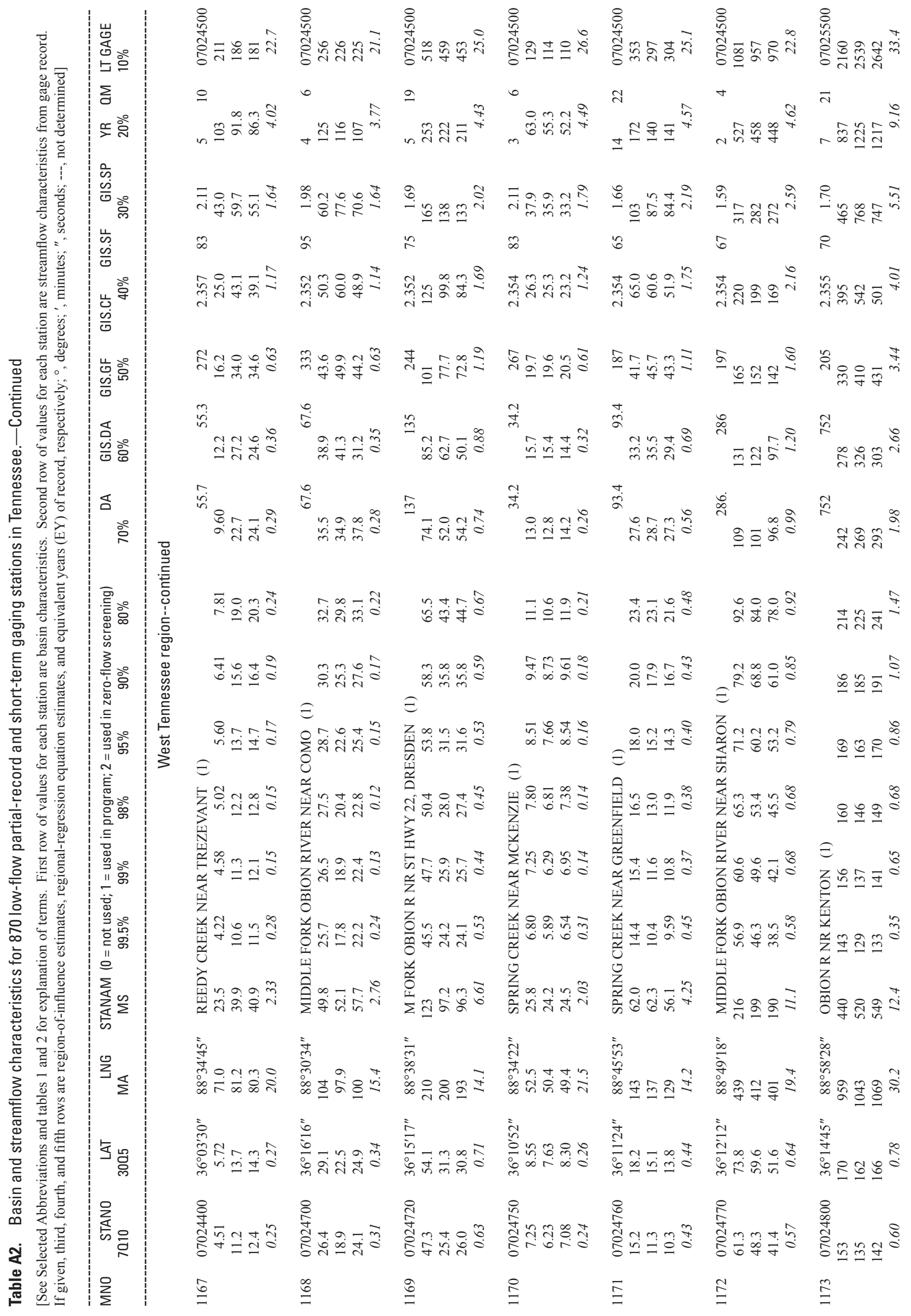




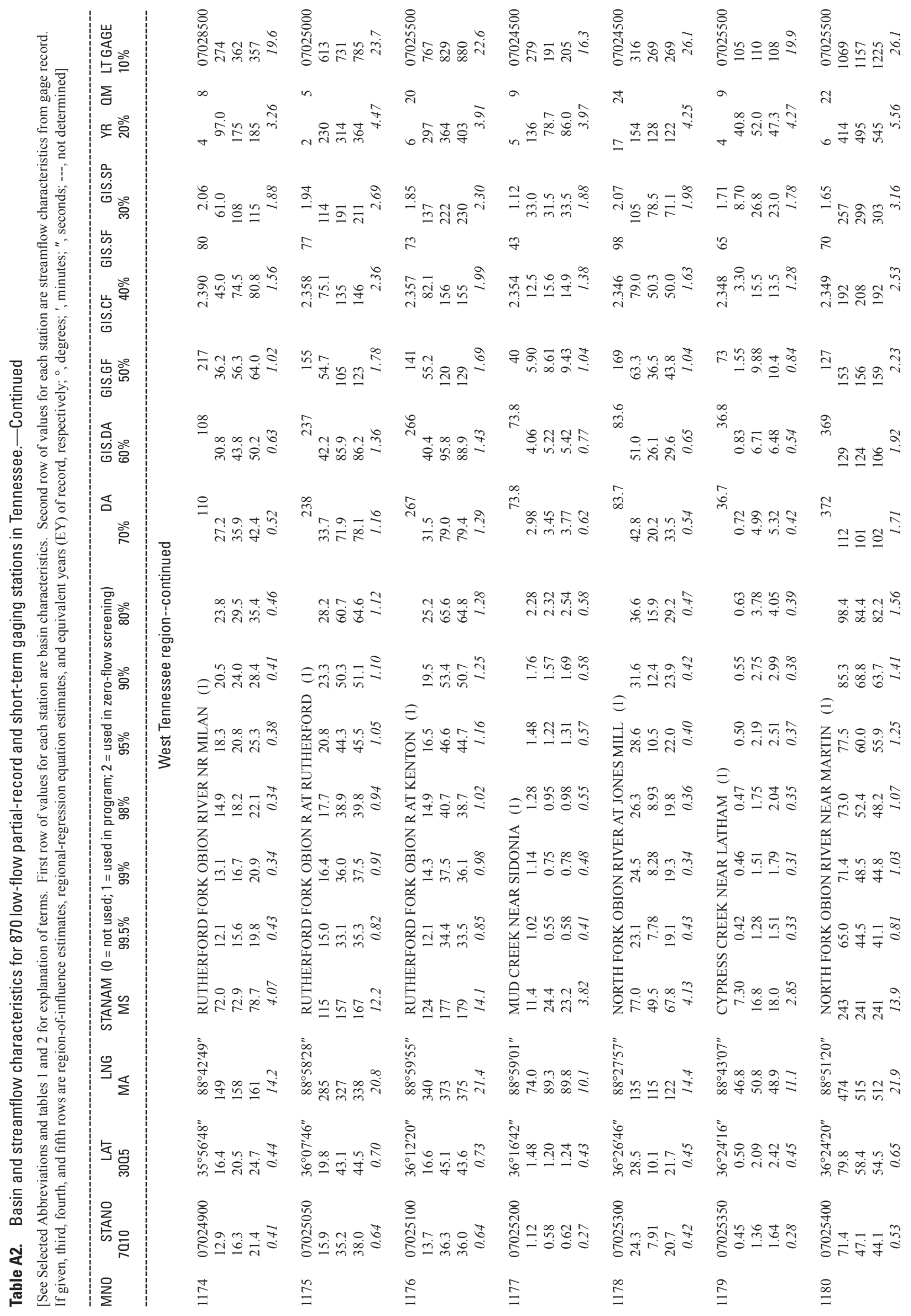




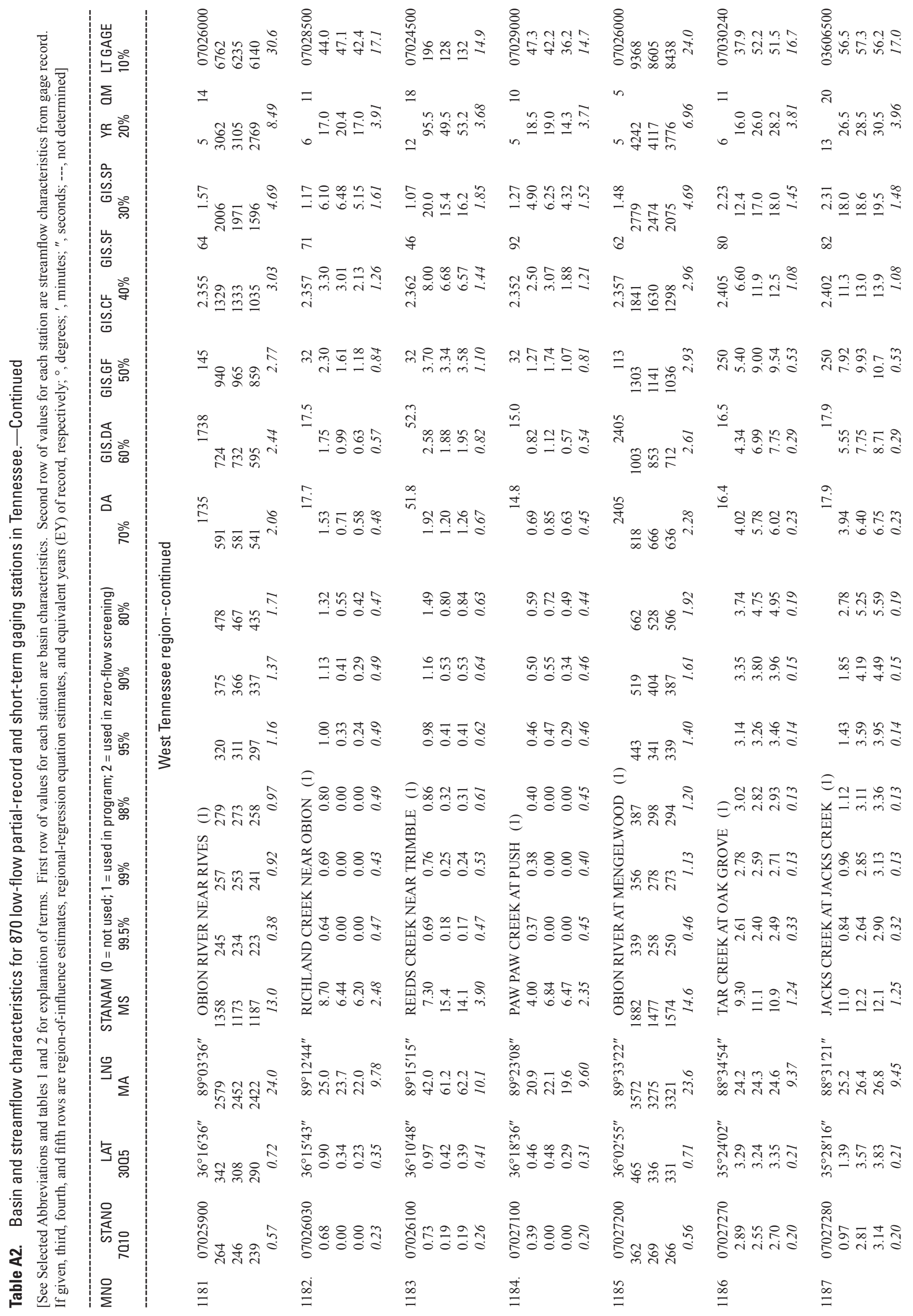




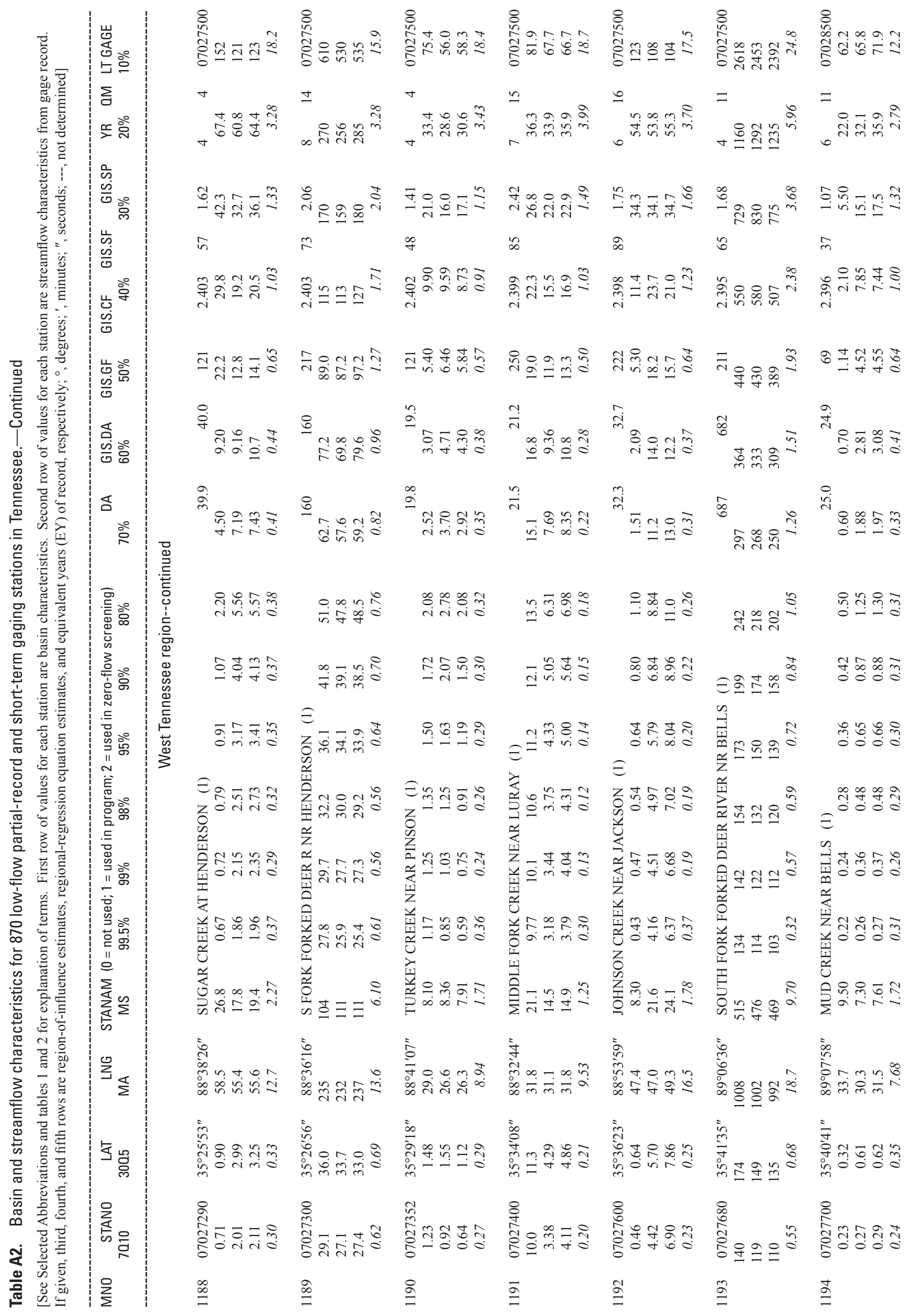




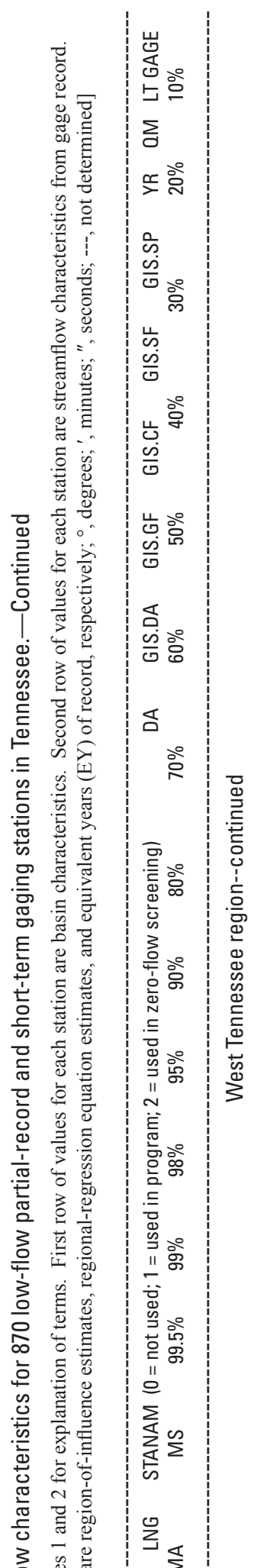

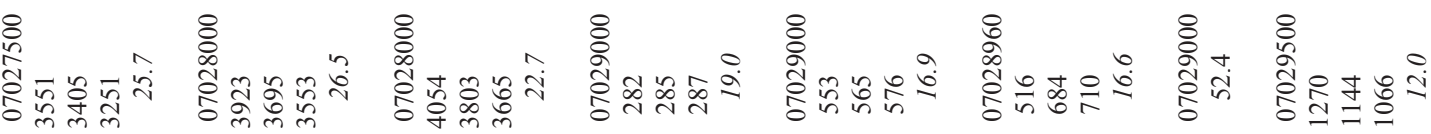

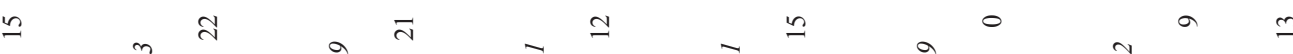

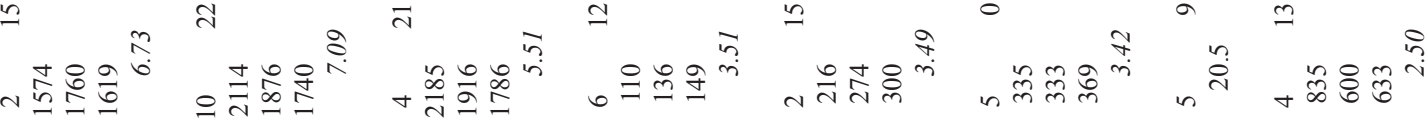

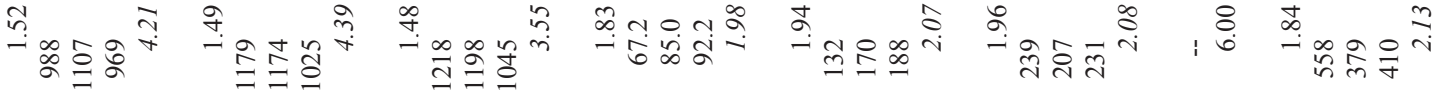

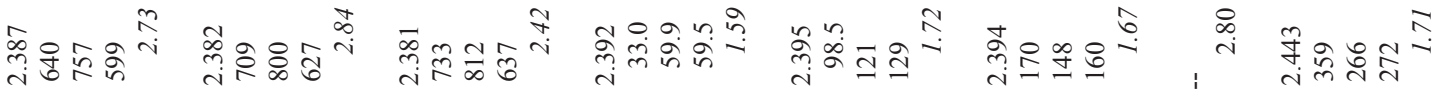

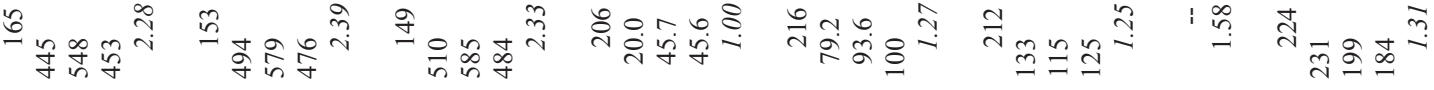

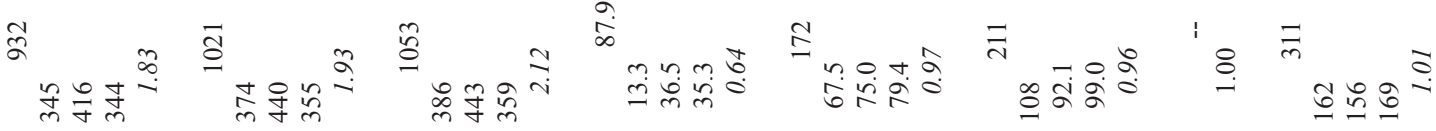

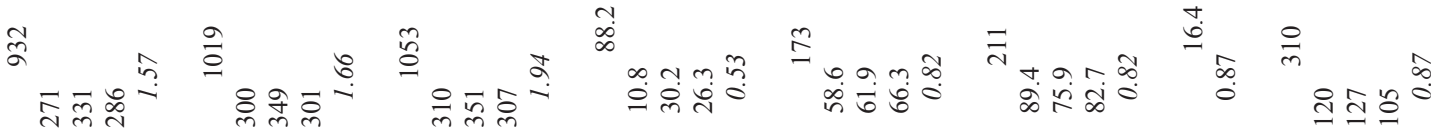

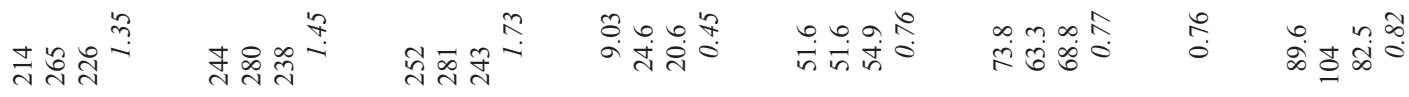

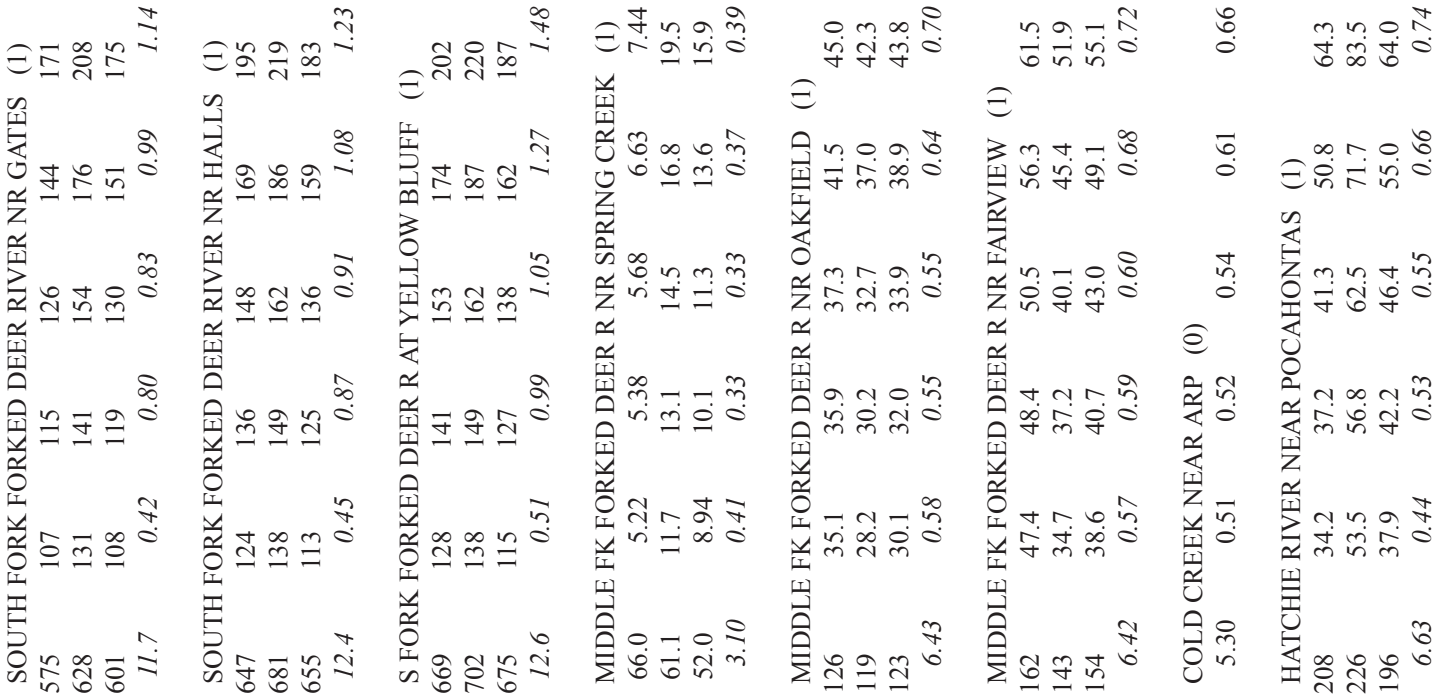

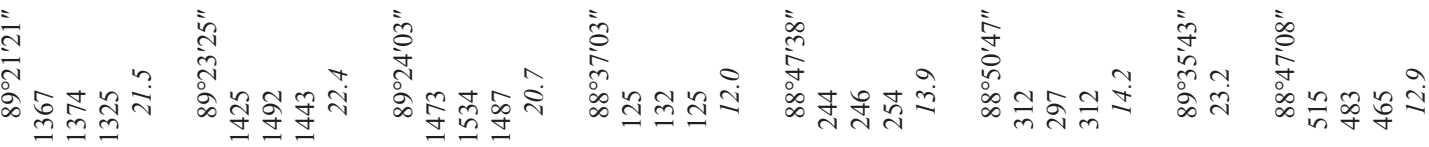

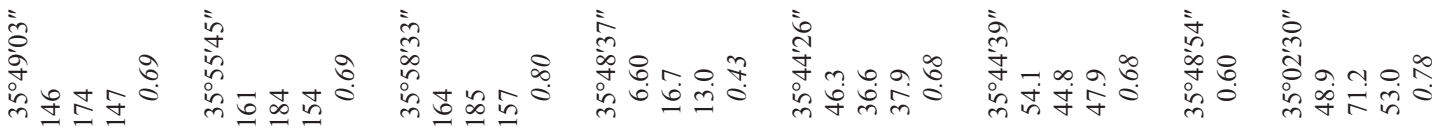

安题

窟

농음

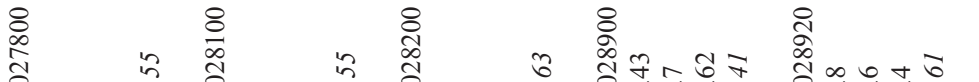

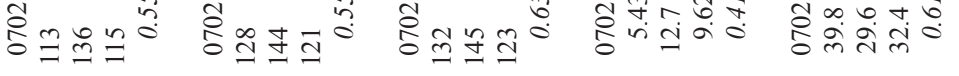

$\stackrel{\varrho}{=}$

$\stackrel{5}{\underline{9}}$

$\stackrel{\infty}{\rightrightarrows}$

$\stackrel{\partial}{=}$

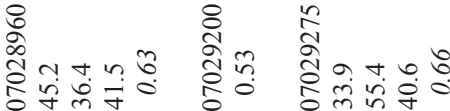




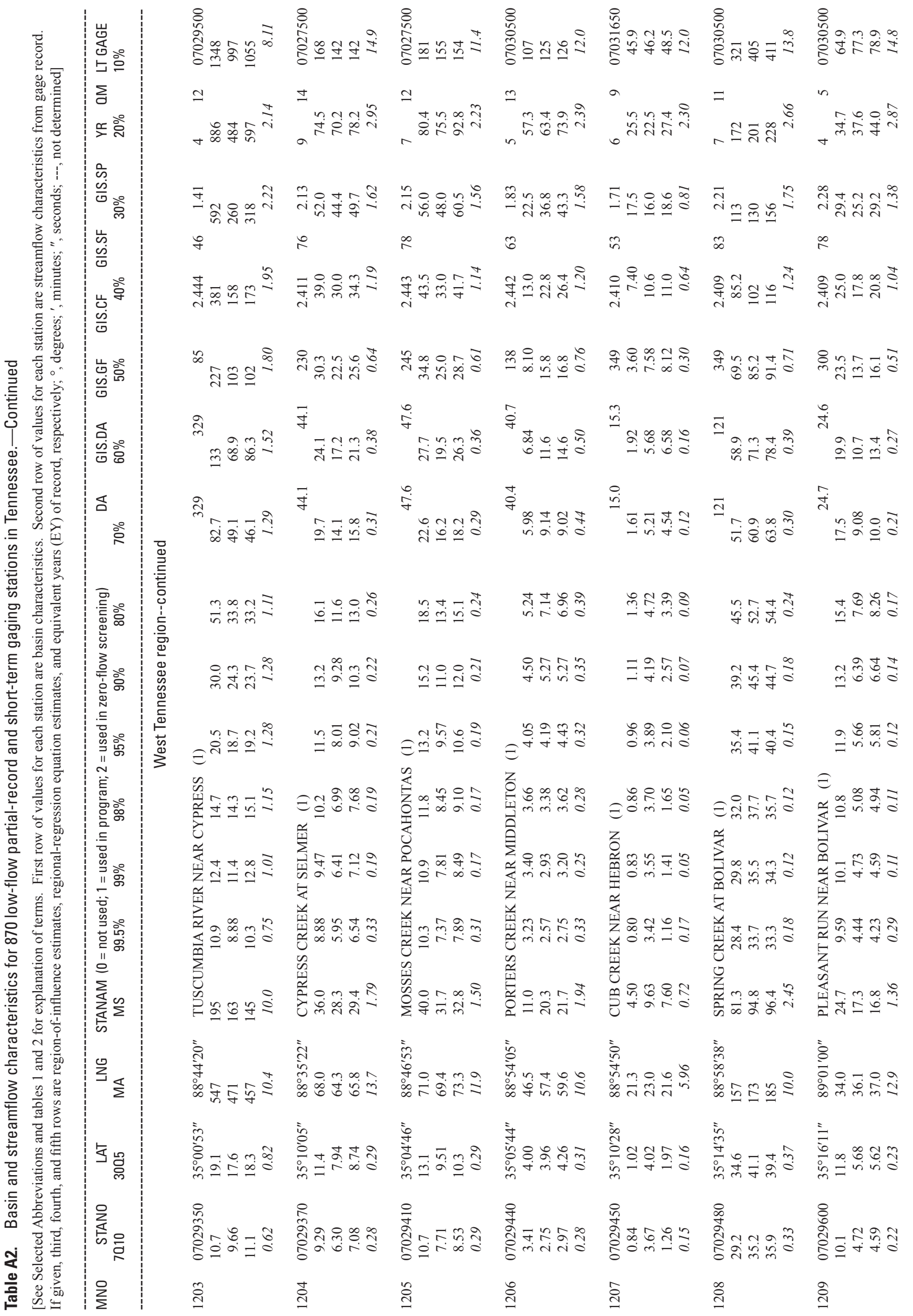




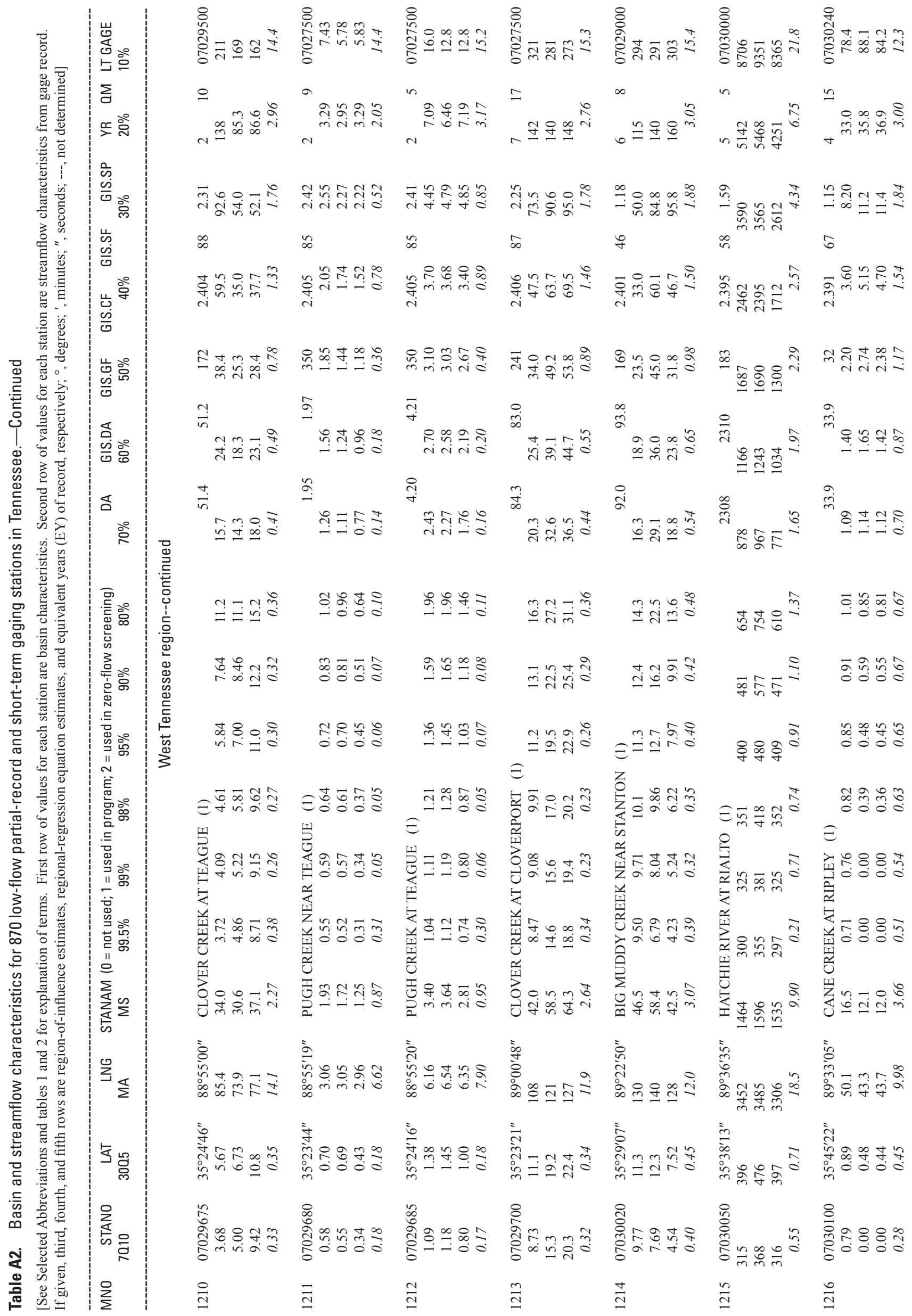




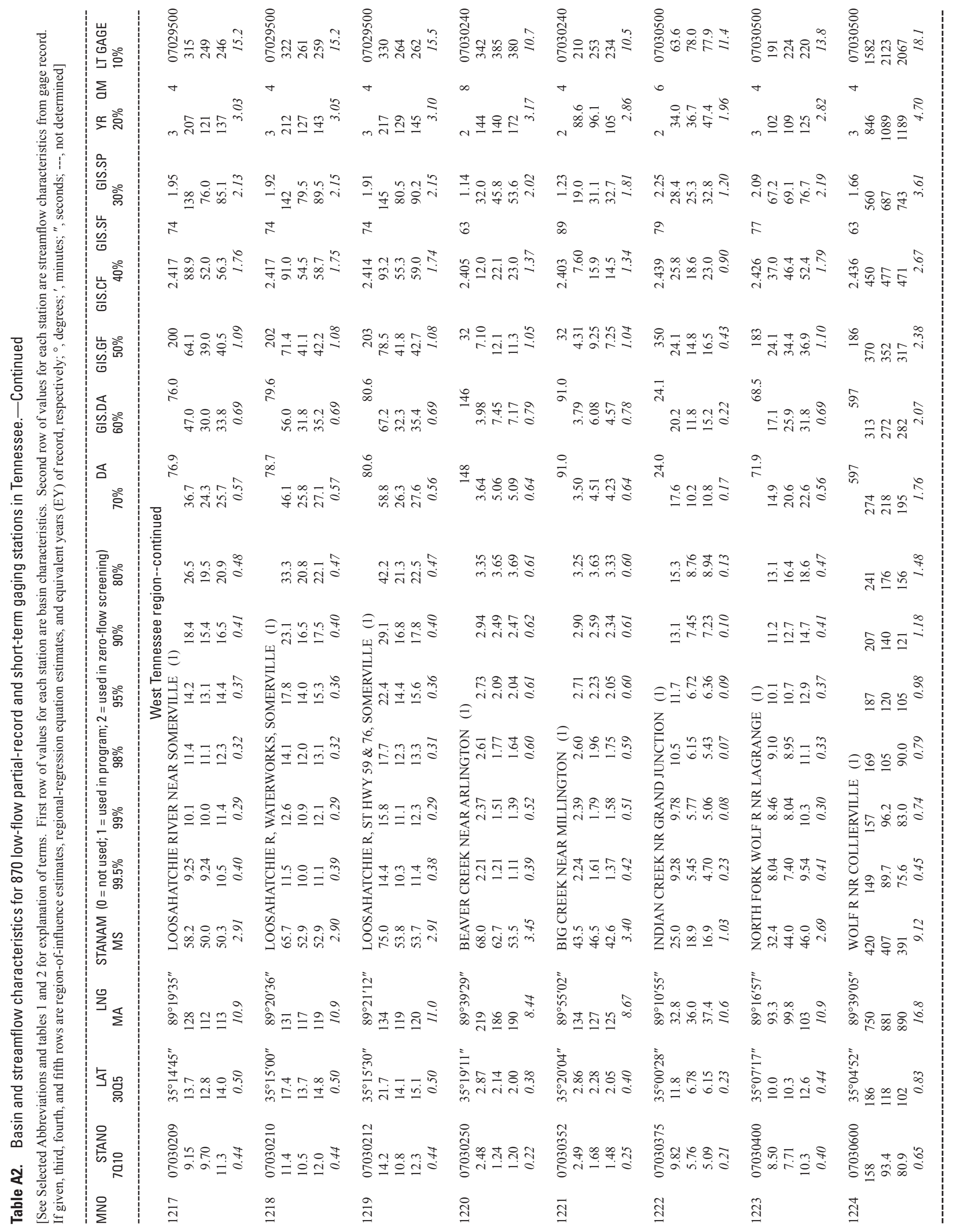




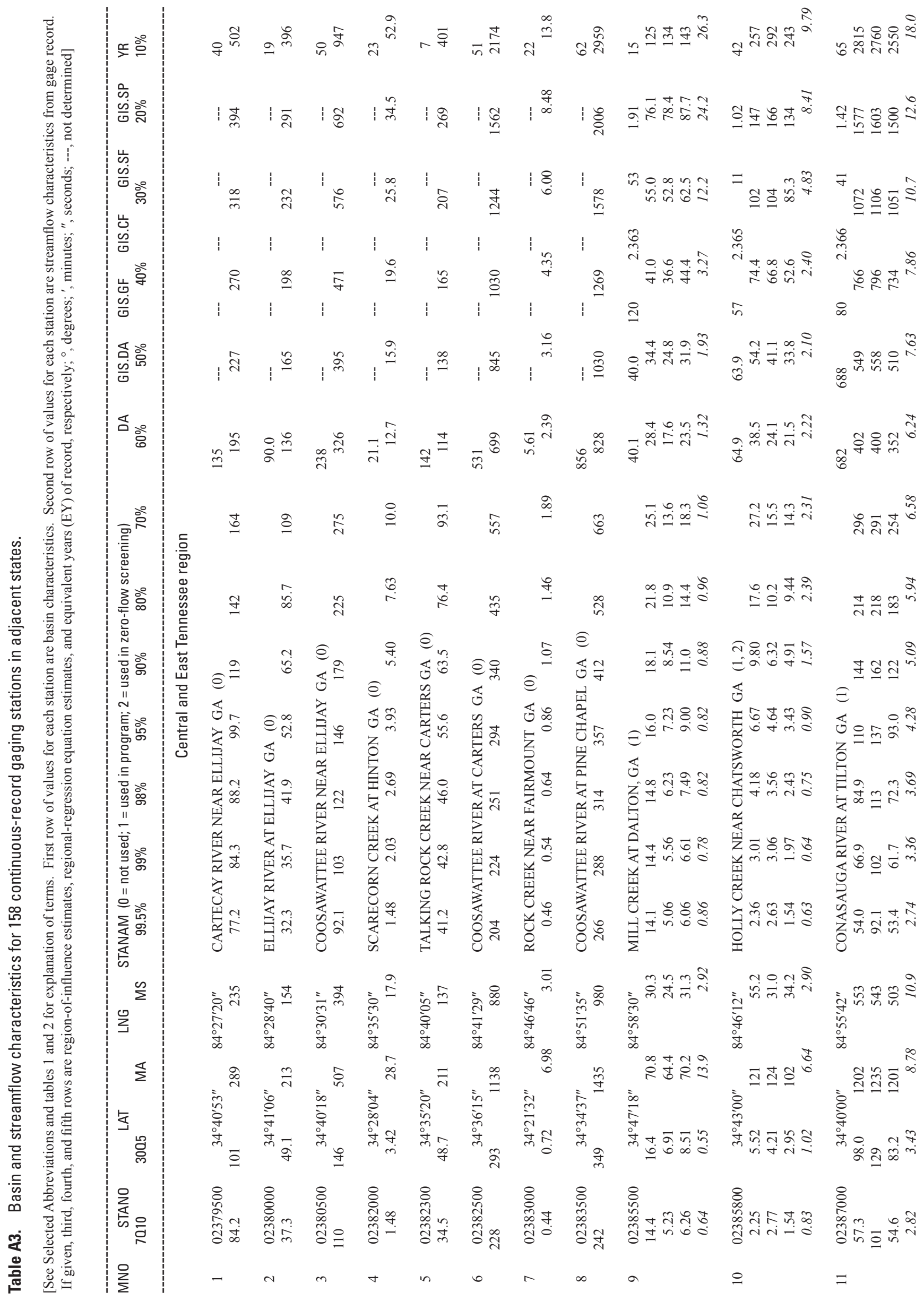




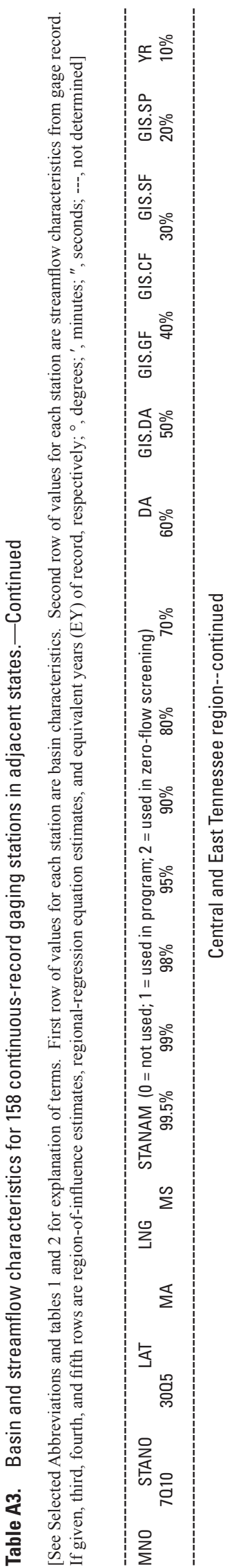

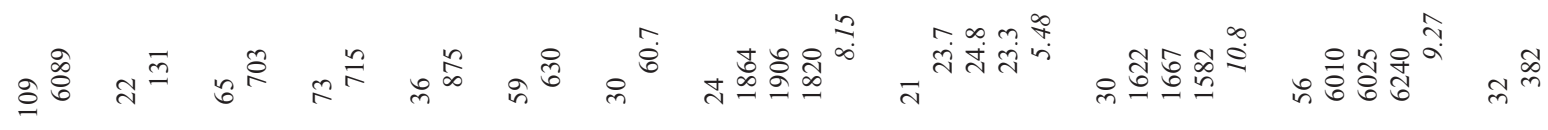

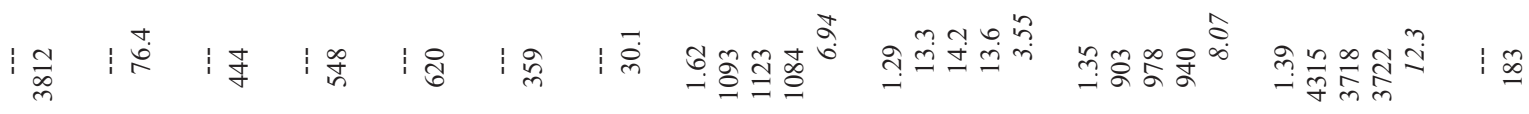

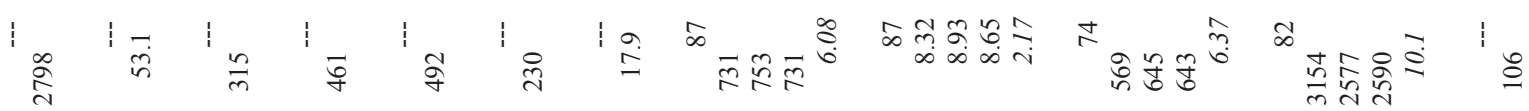

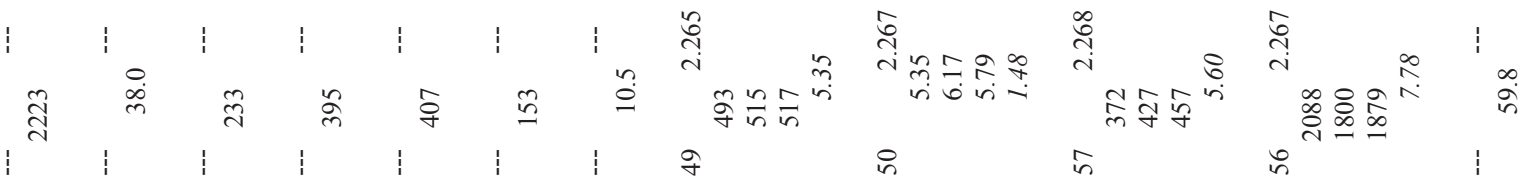

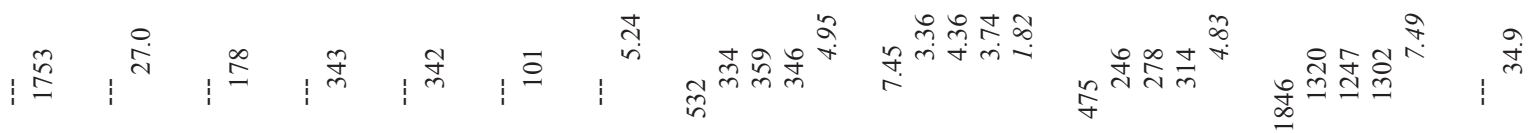

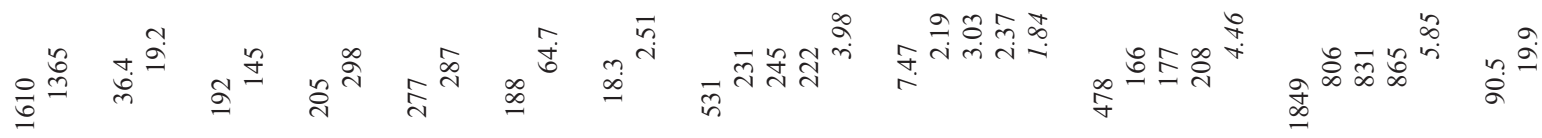

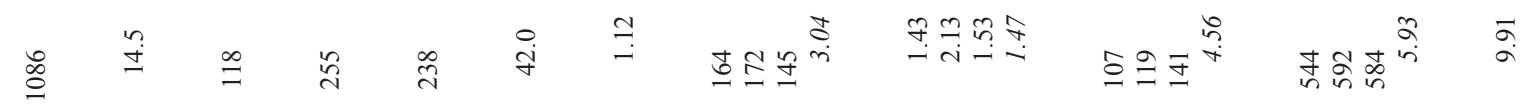

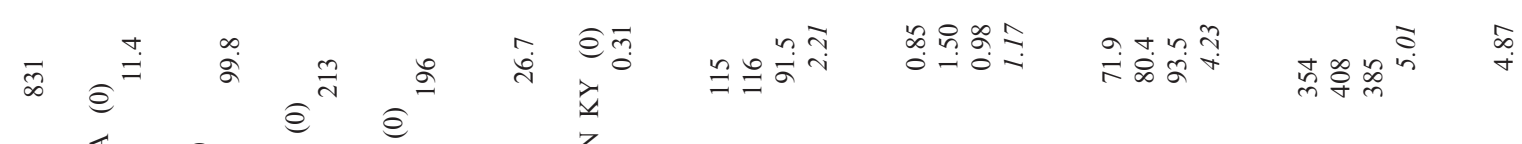

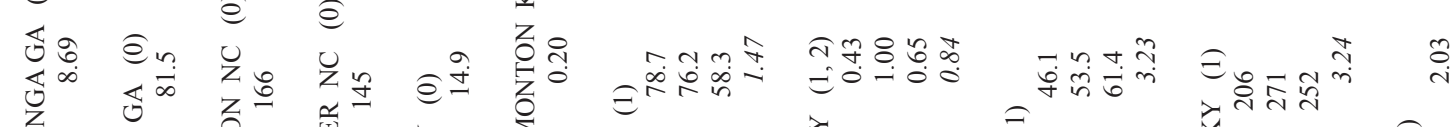

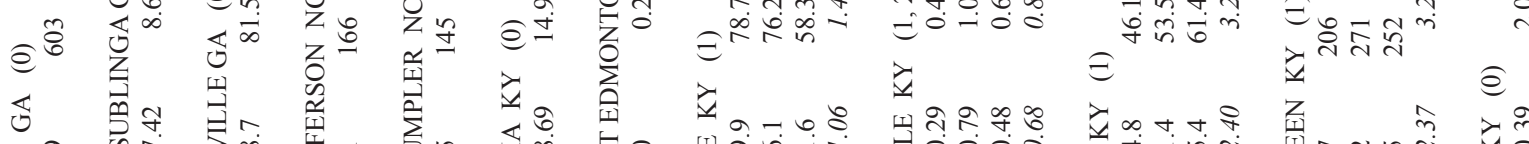

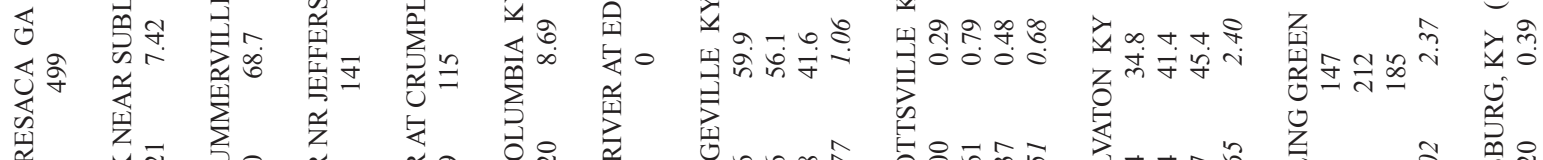

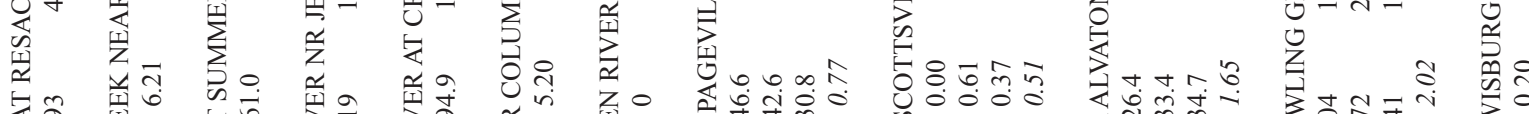

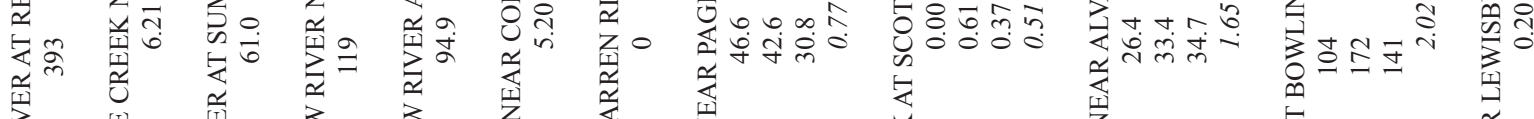

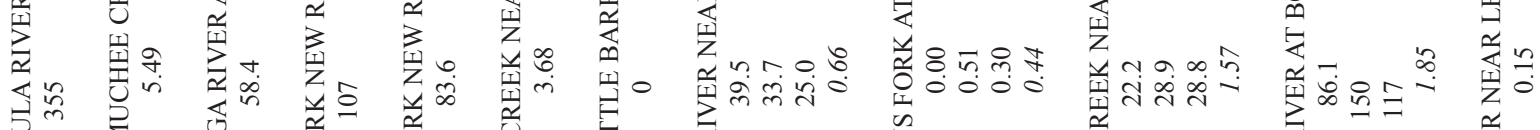

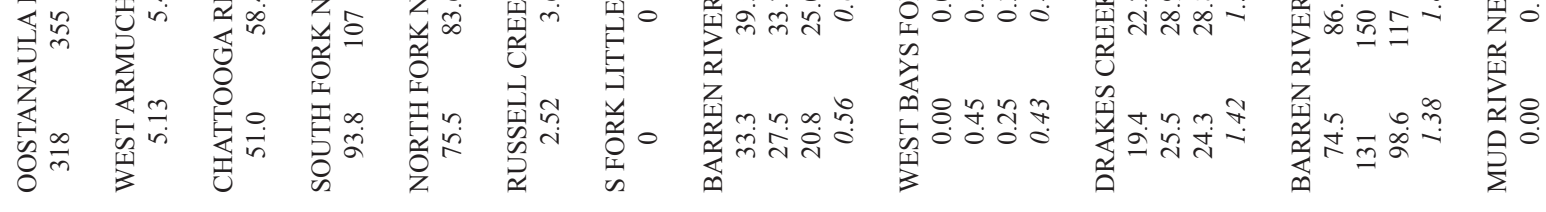

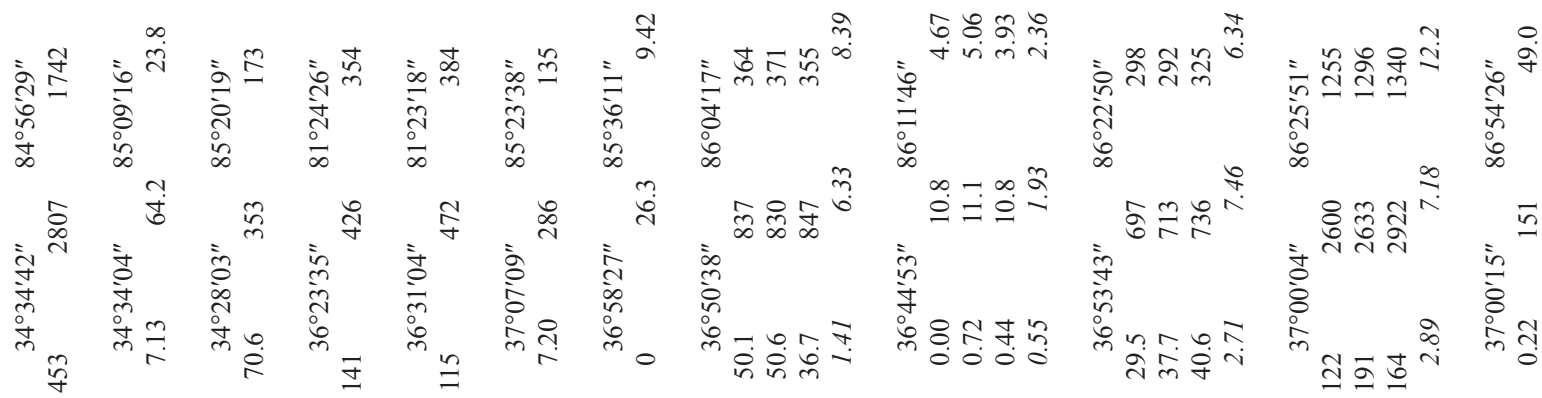

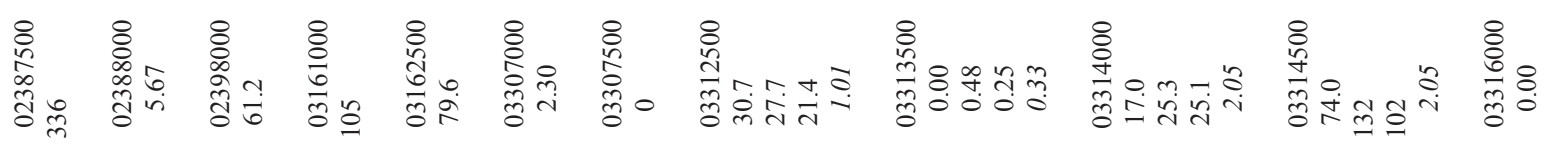

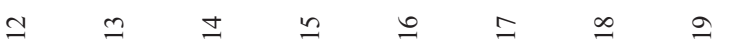
ำ $\vec{\sim}$ สี ก 


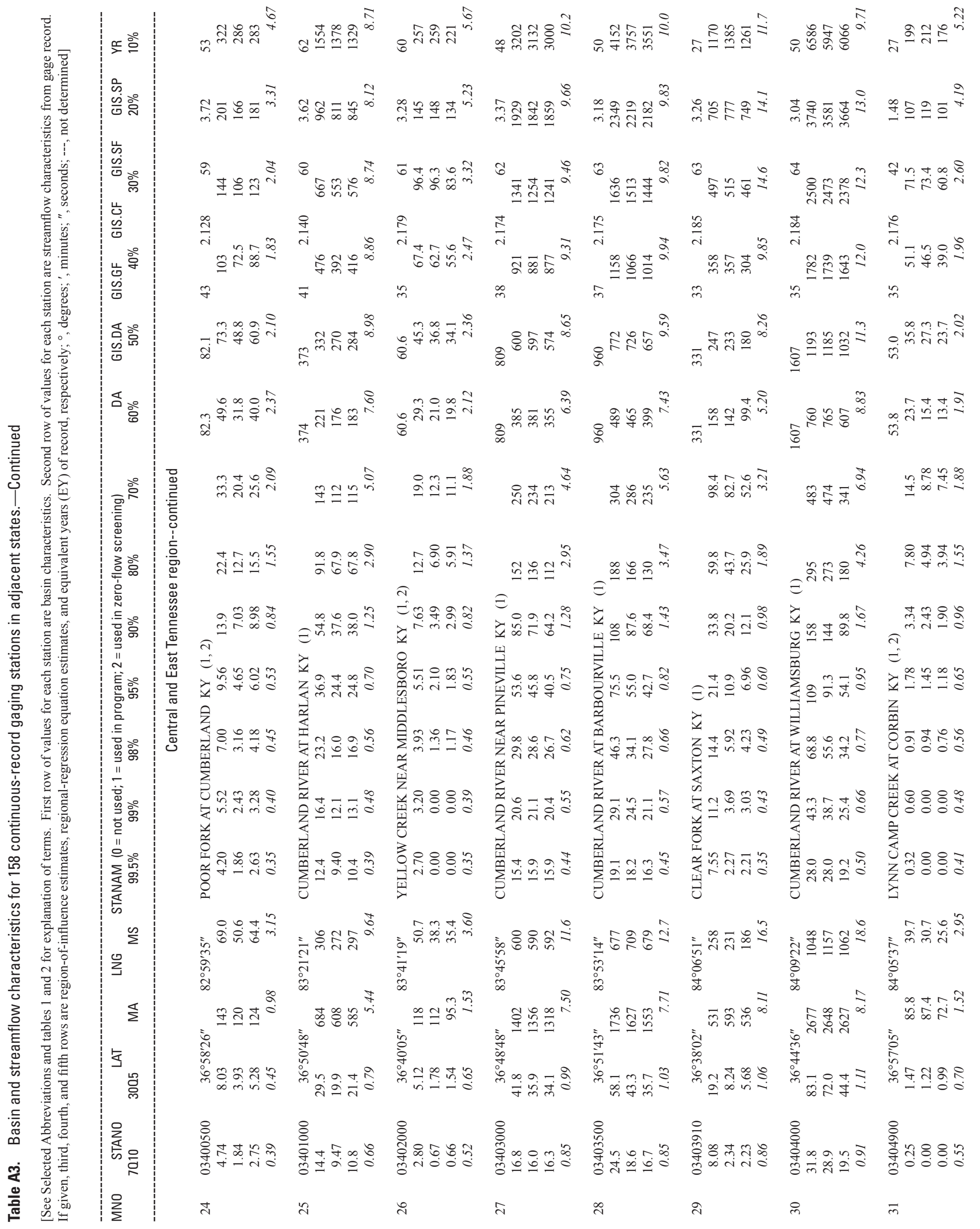




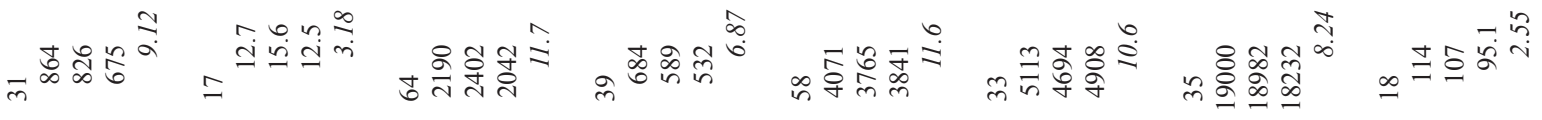

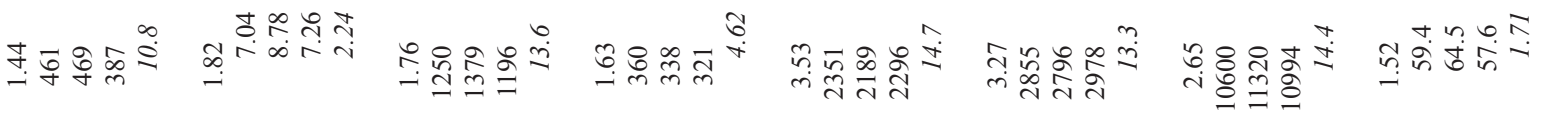

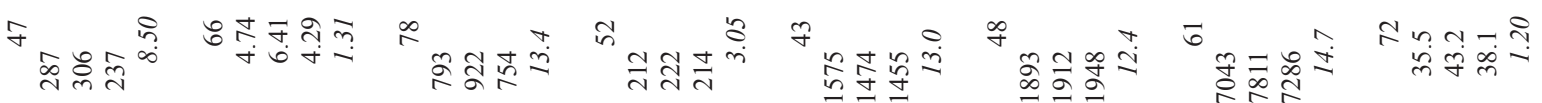

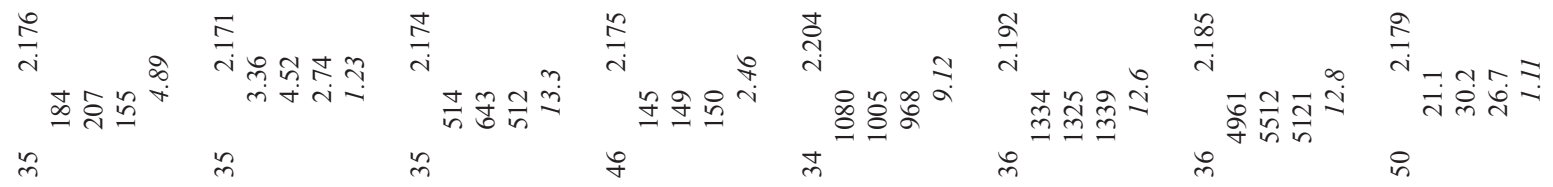

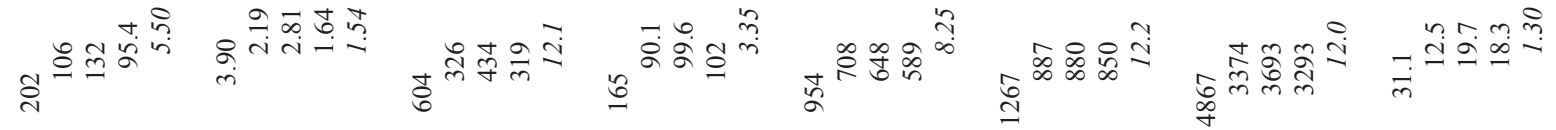

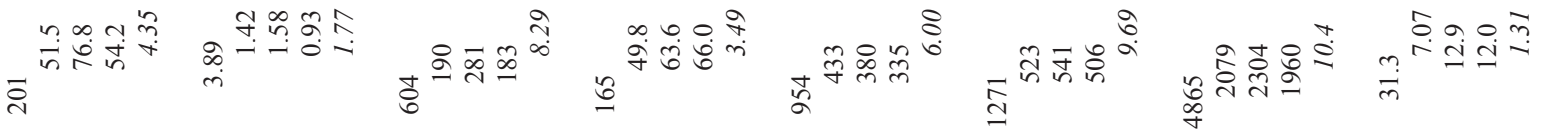

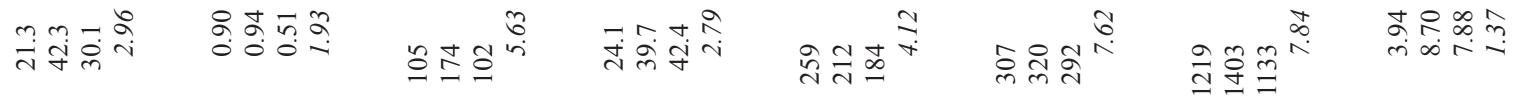

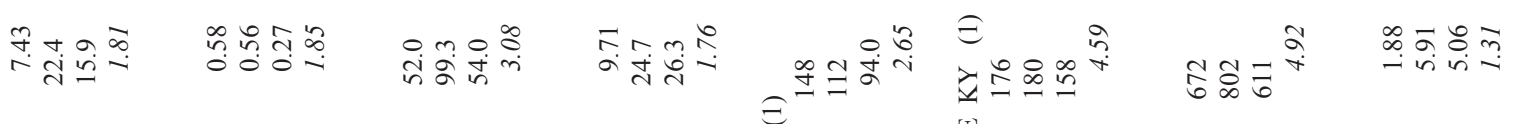

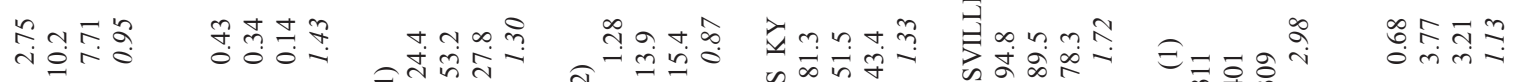

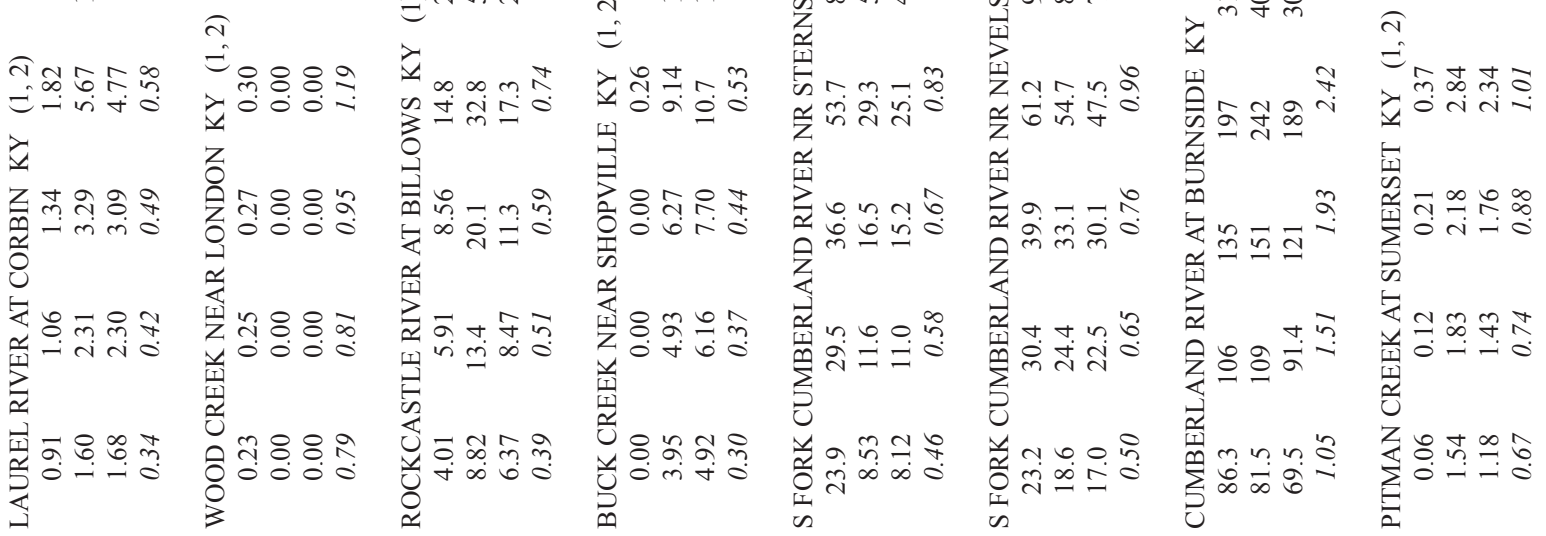

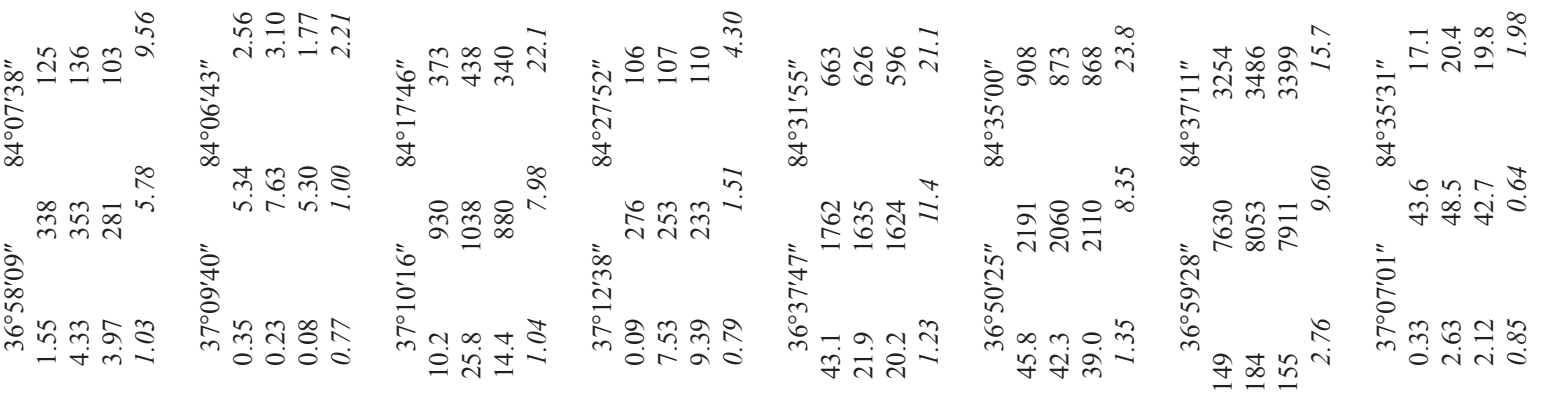

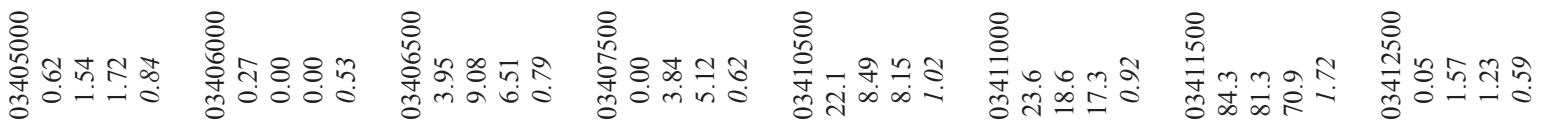
กี $m$ मे $\stackrel{m}{m}$ 우 


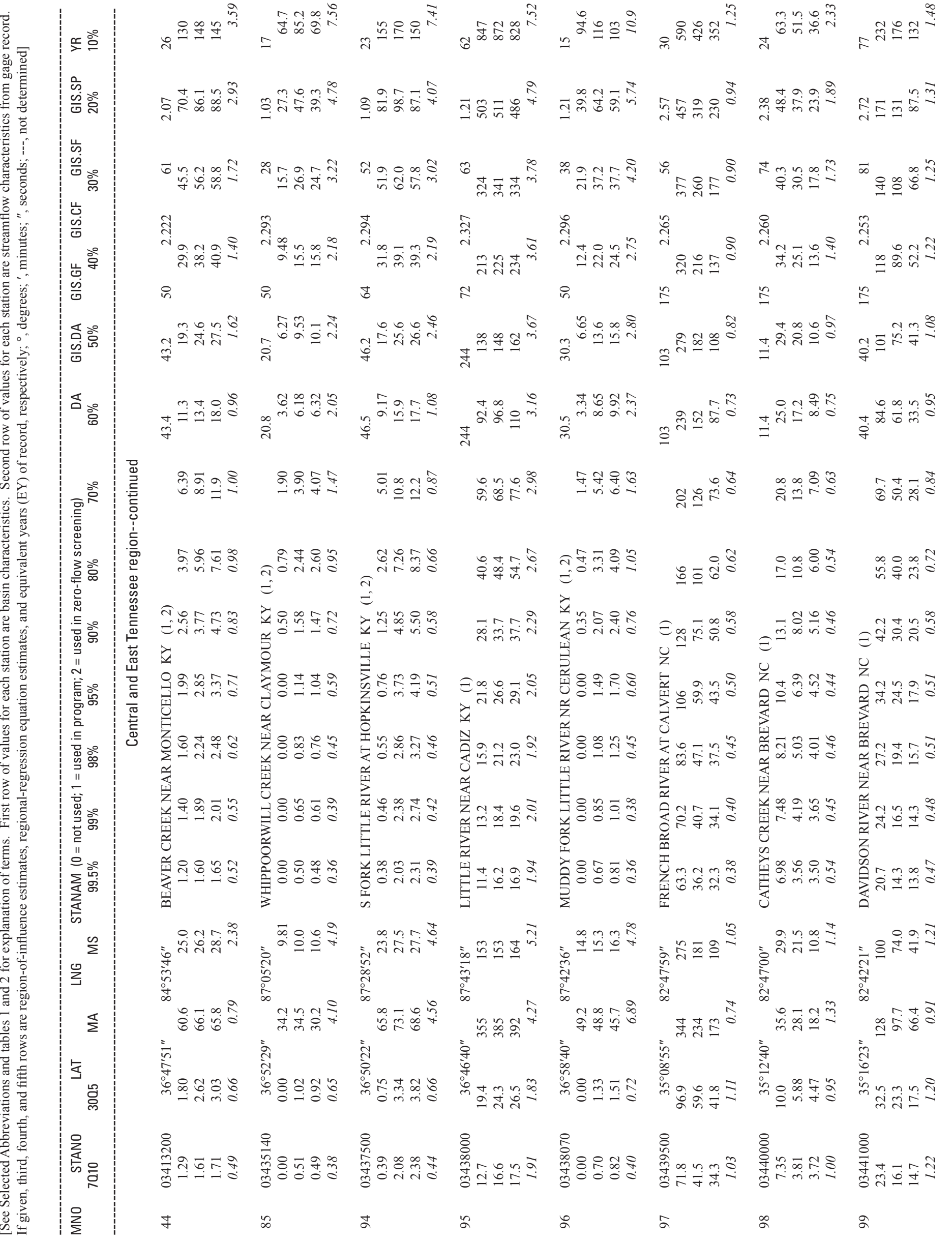




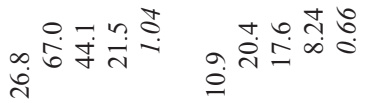

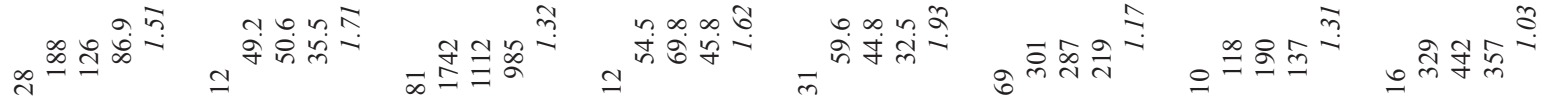

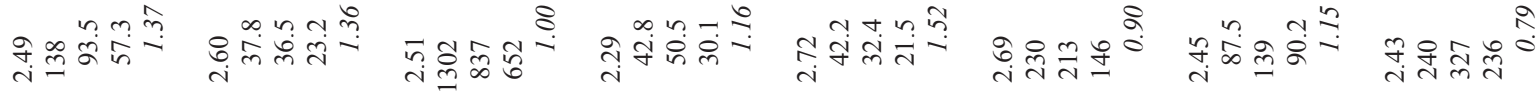
$\stackrel{2}{\exists} \stackrel{0}{\circ}$

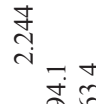
$\stackrel{n}{=}$

o $m n$ कोंशु 를 त्ते

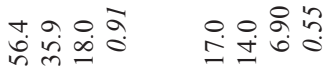

की

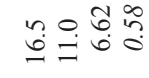

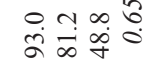

कूते तू के 르용

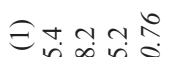

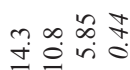
ㅇํำㅇํㅇ

ํํำ

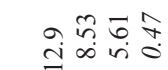

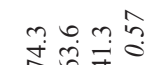

t.

$\vec{\infty}+\frac{m}{0} \stackrel{0}{0}$

Z 0.0 .9

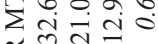

ำ

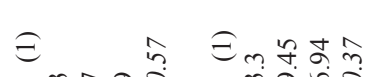

$\widehat{\exists}: \infty \infty m$

至

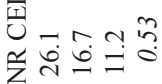

$=+\dot{0}$ ํํํ유.

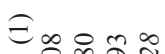

때

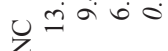

要0 0 的

震

舟为

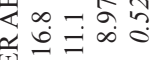

$\sum^{1}$

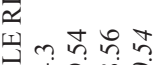

Z

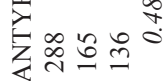

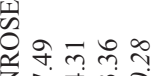

要

$\infty$

띵 농

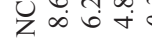

黛

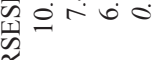

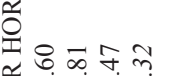

幽

$\approx$

西

出

毘

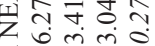

黄

岁势

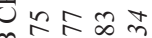
造

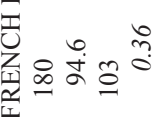

ज्ञ तै क⿺辶一

z

四。敒。

ง. กำ

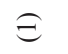

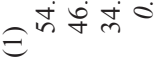

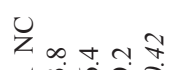

चै

品

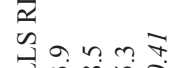

安的舟

商

झ户े

药-n-a

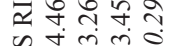
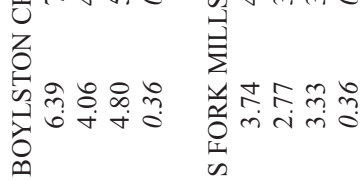

वें तुं

$\sum^{1}$

जैnra

勿

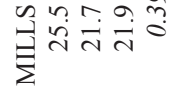

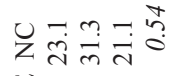

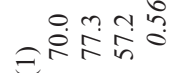

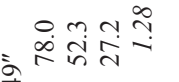

=

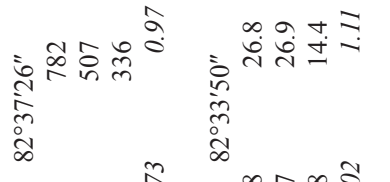

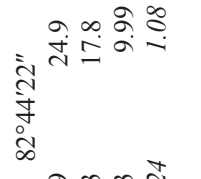

ป ํํㅇㅎํ

(1)

$\S$

安

in

i i

ஓำㅇํㅇ

लंख्य

产

总

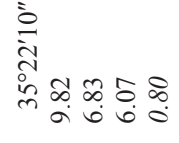

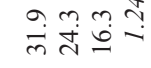

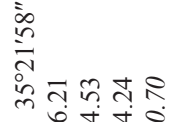

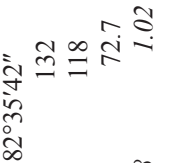

$\sum_{\ln } \ln$

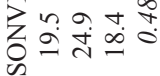

留

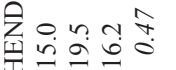

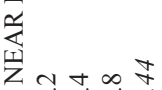

过苞㐫

된

近ㅇㅝㅂㅀำ

$\mathrm{z}$

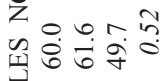

文

ț

त

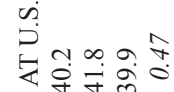

苍

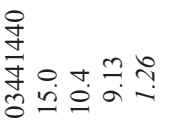

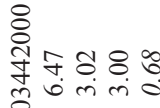

咅

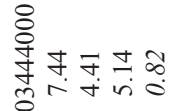

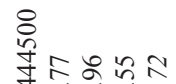

(1)

妾음

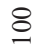

s

ऽิ

$\stackrel{m}{9}$

$\stackrel{t}{\circ}$

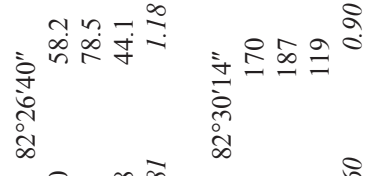

응

离

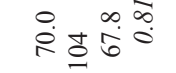

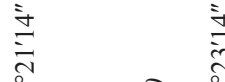

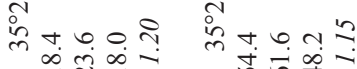
fं nूल

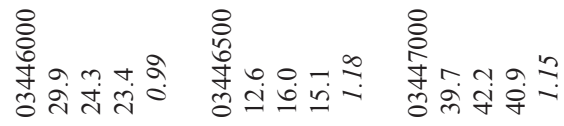
$\stackrel{\circ}{\varrho}$

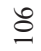

의 


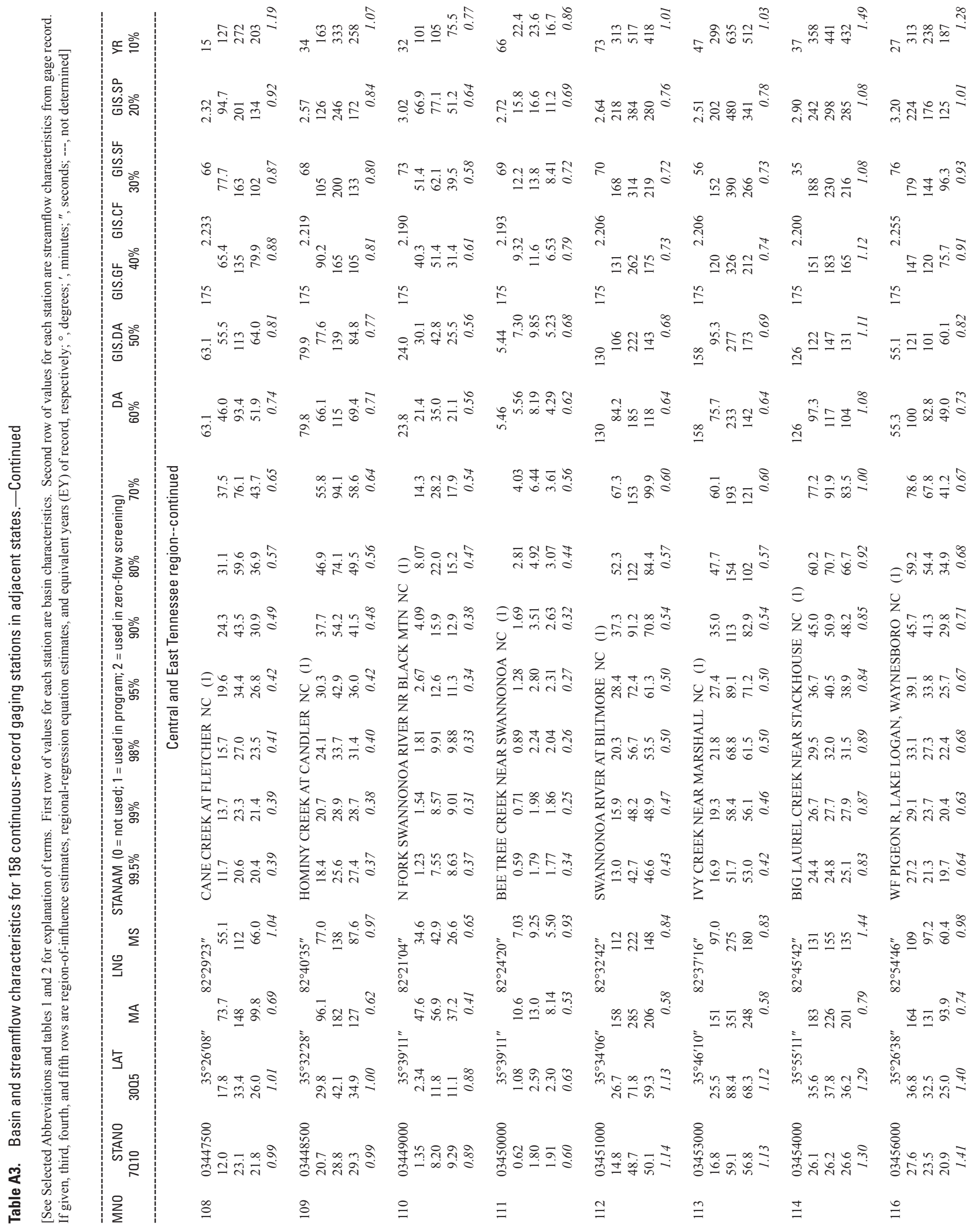




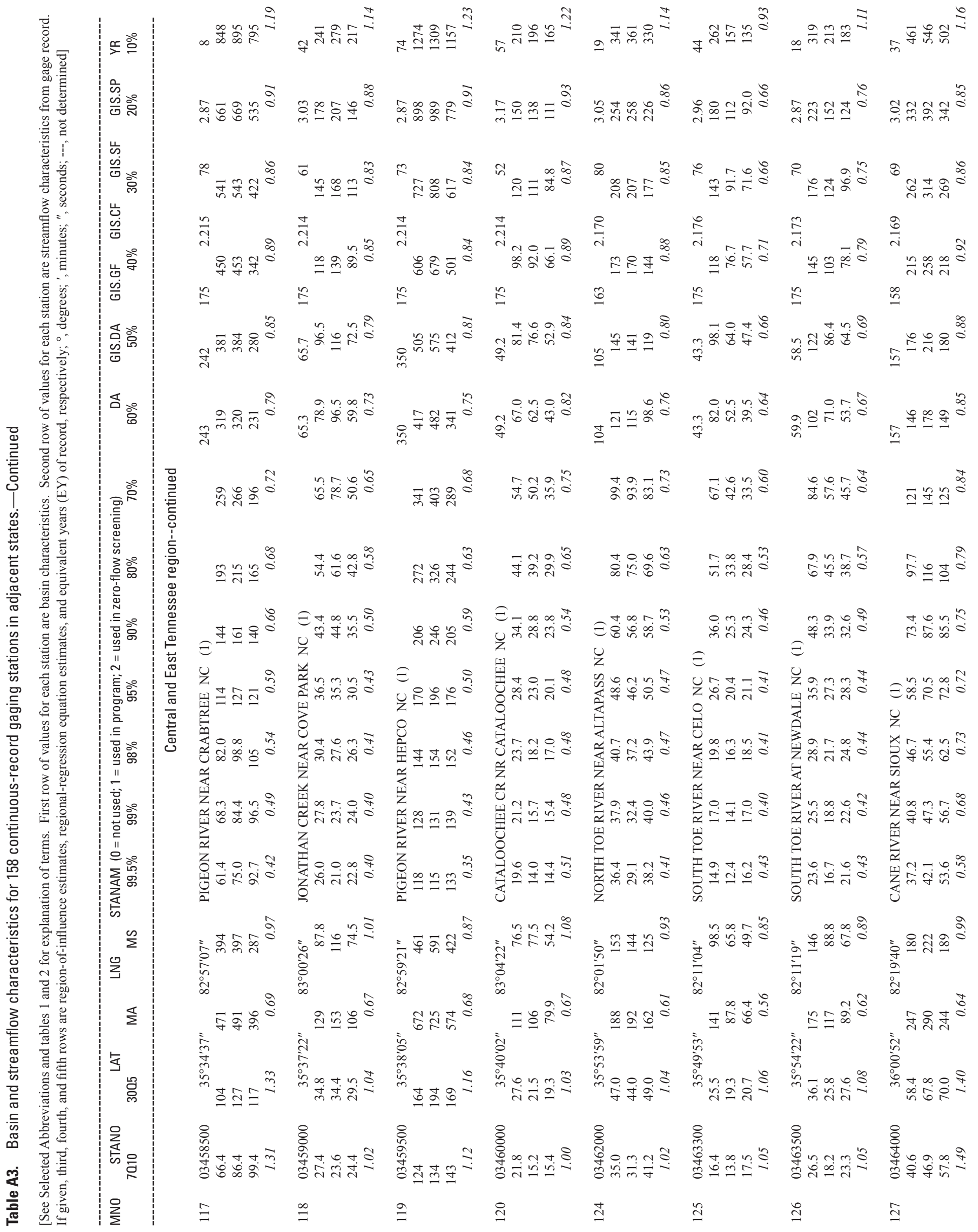




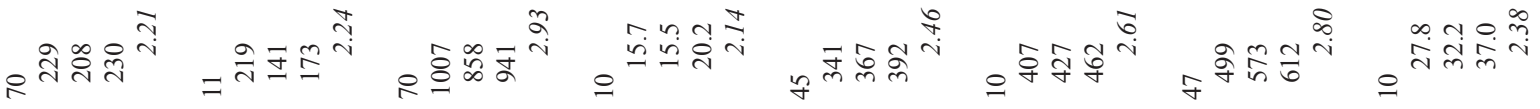
के

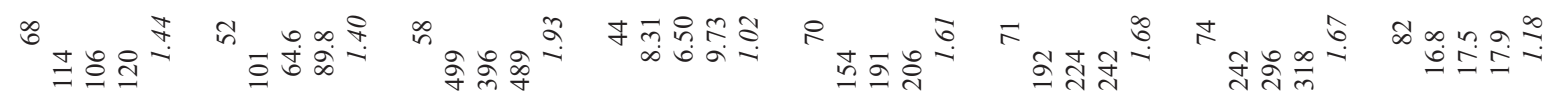

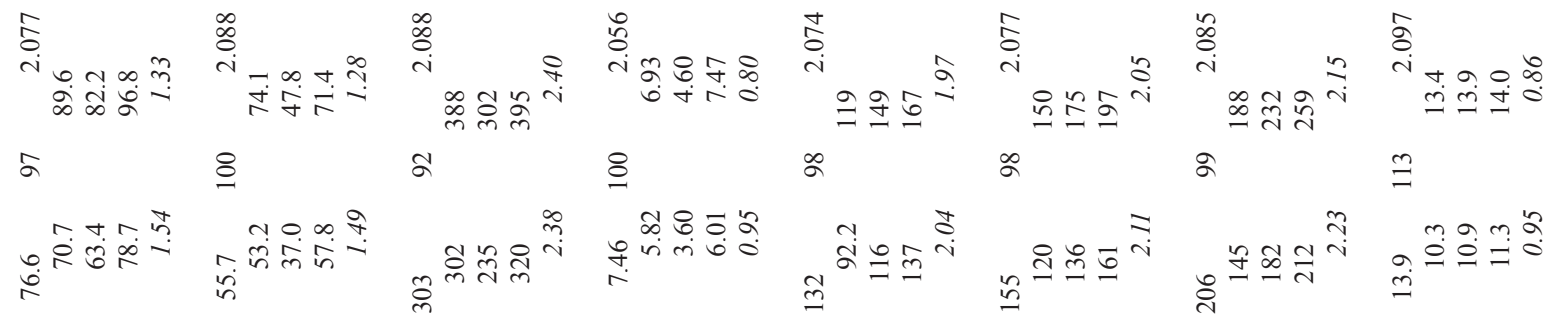

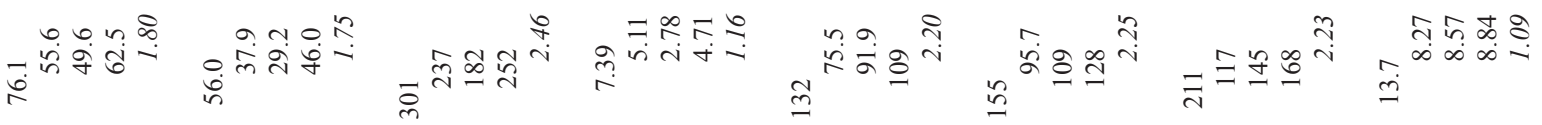

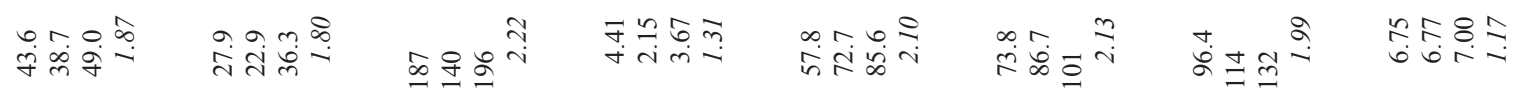

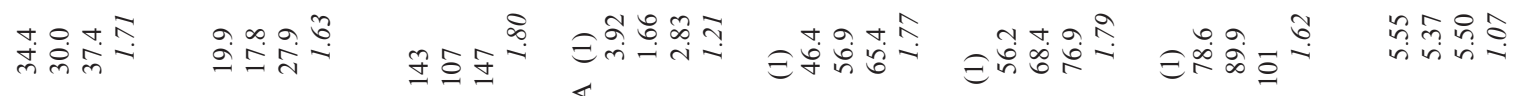

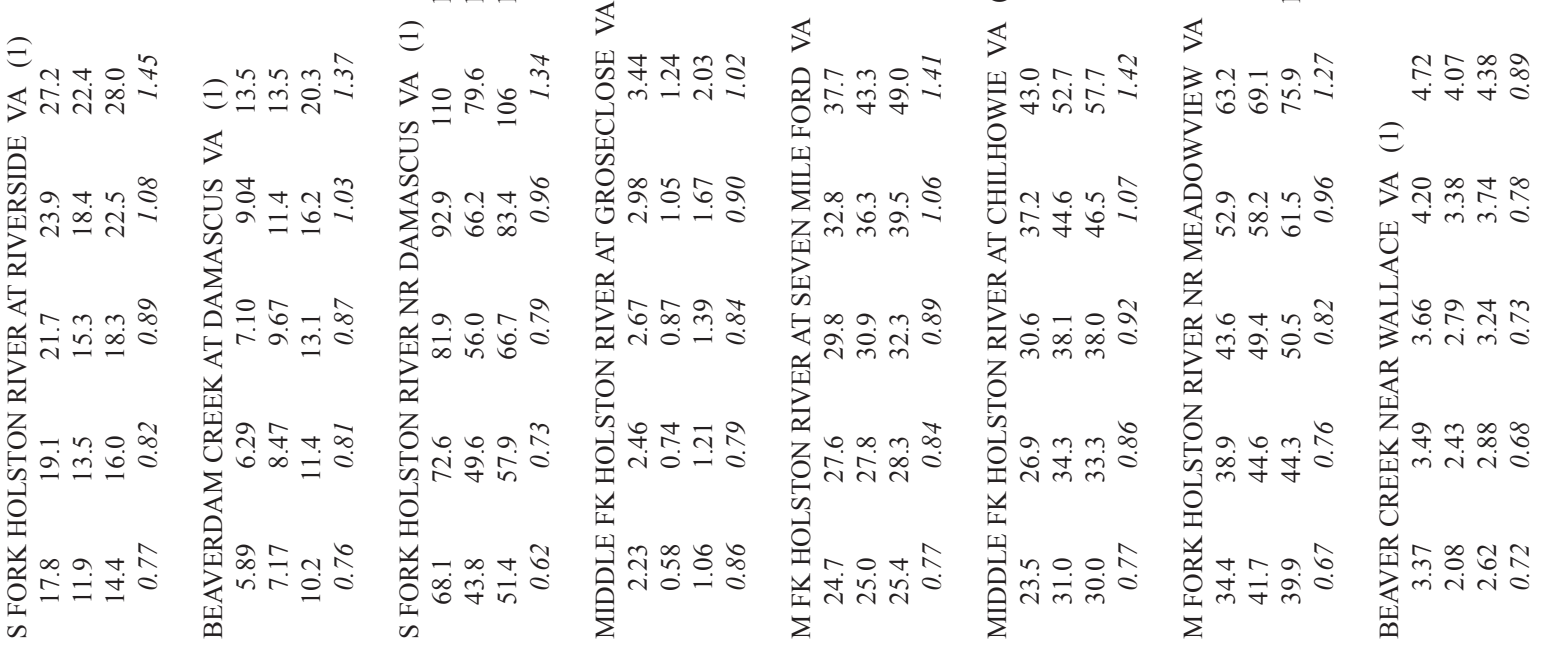

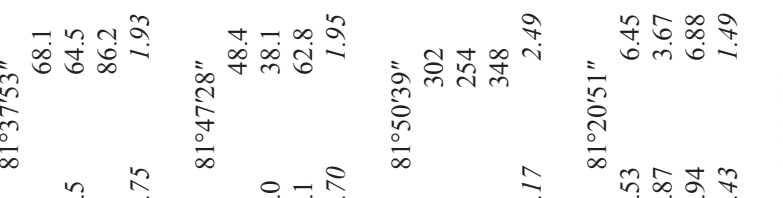

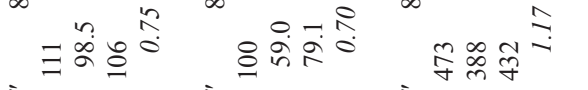

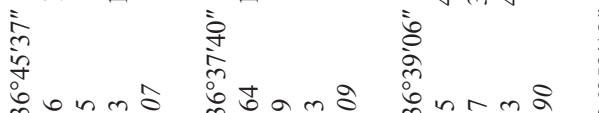

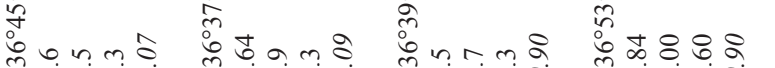
ते $\infty$ 으कोंर्ष०

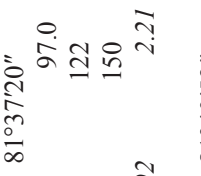

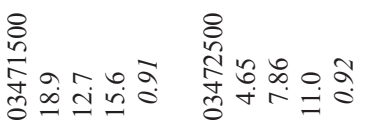

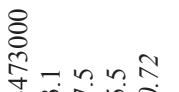

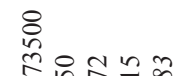
ธ도용

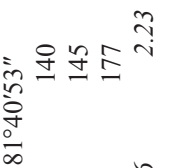

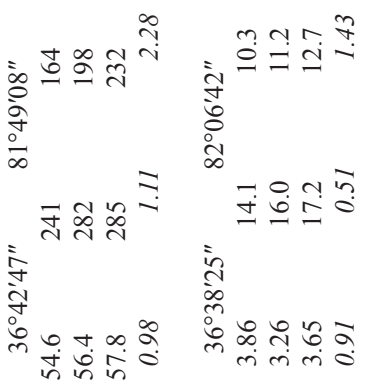
$\stackrel{\infty}{\oplus}$ m 요 $\exists$

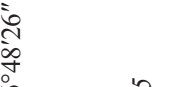
din 0,2 is

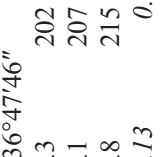
लिंक्षं लिभुष

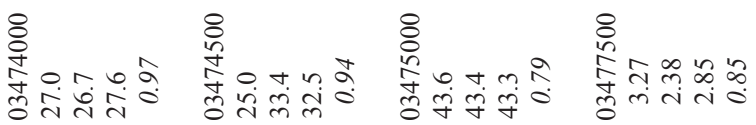
I 孚 专 


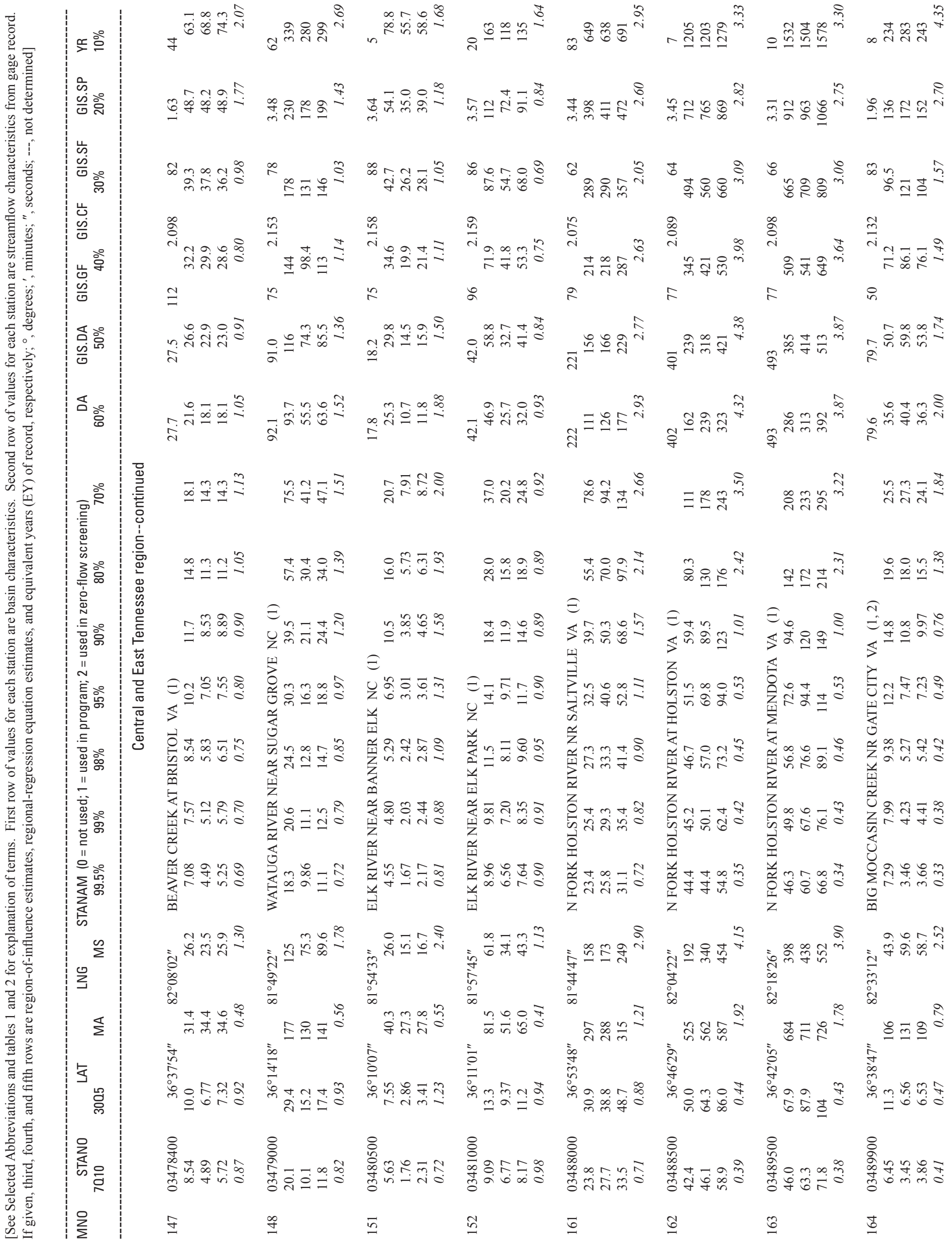




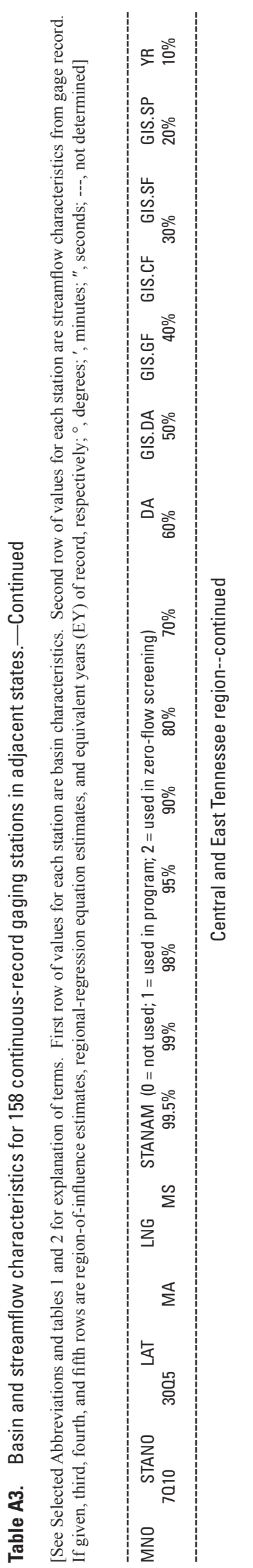

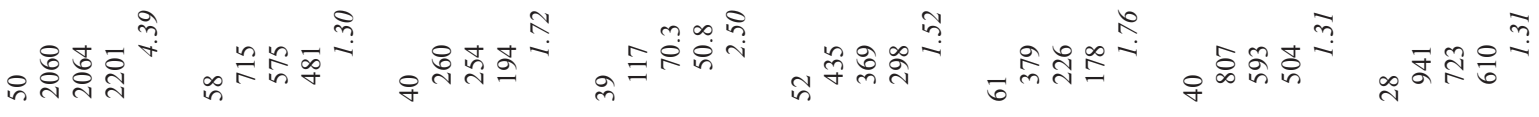

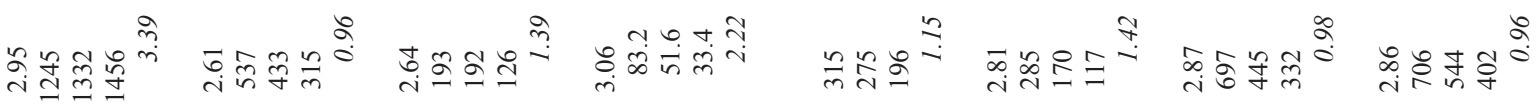

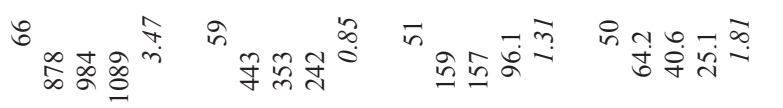

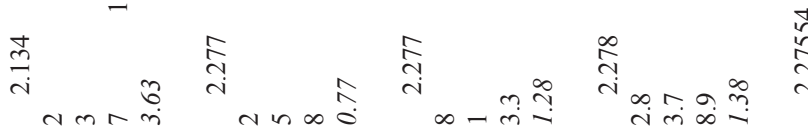

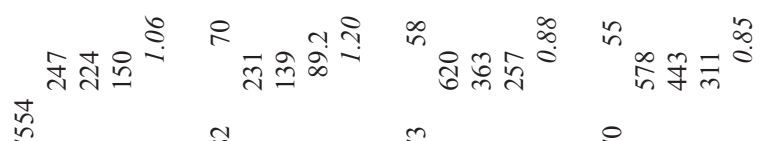

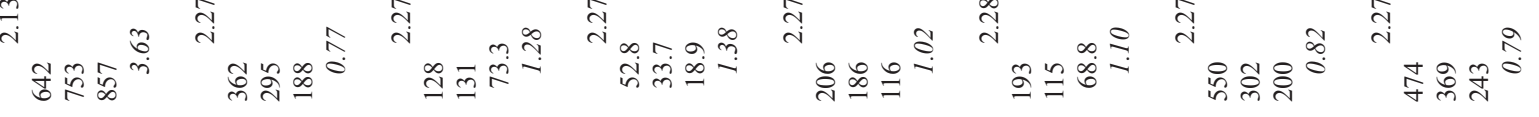

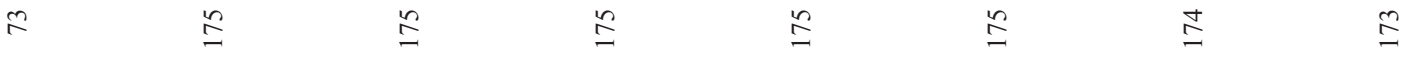

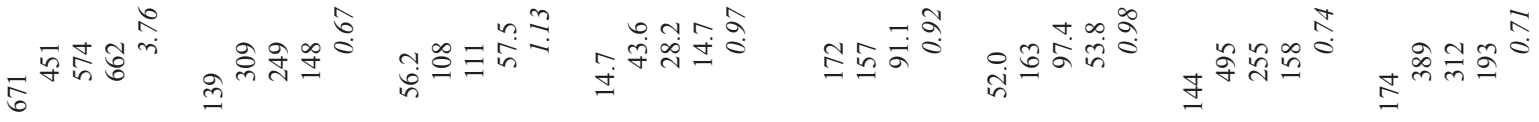

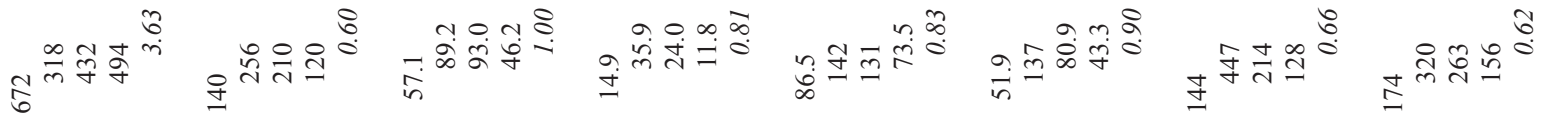

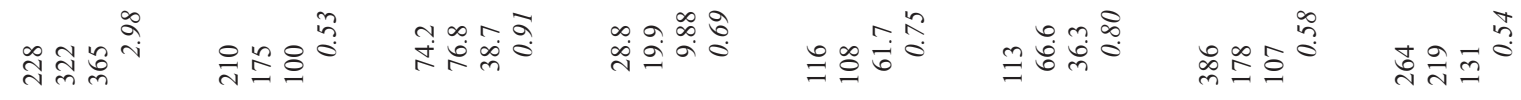

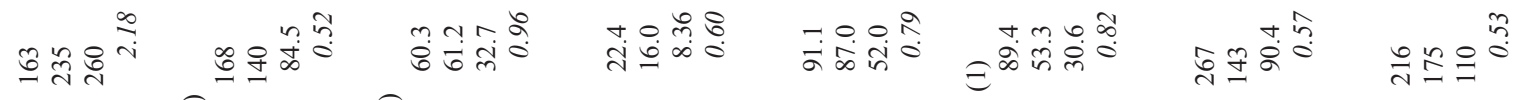

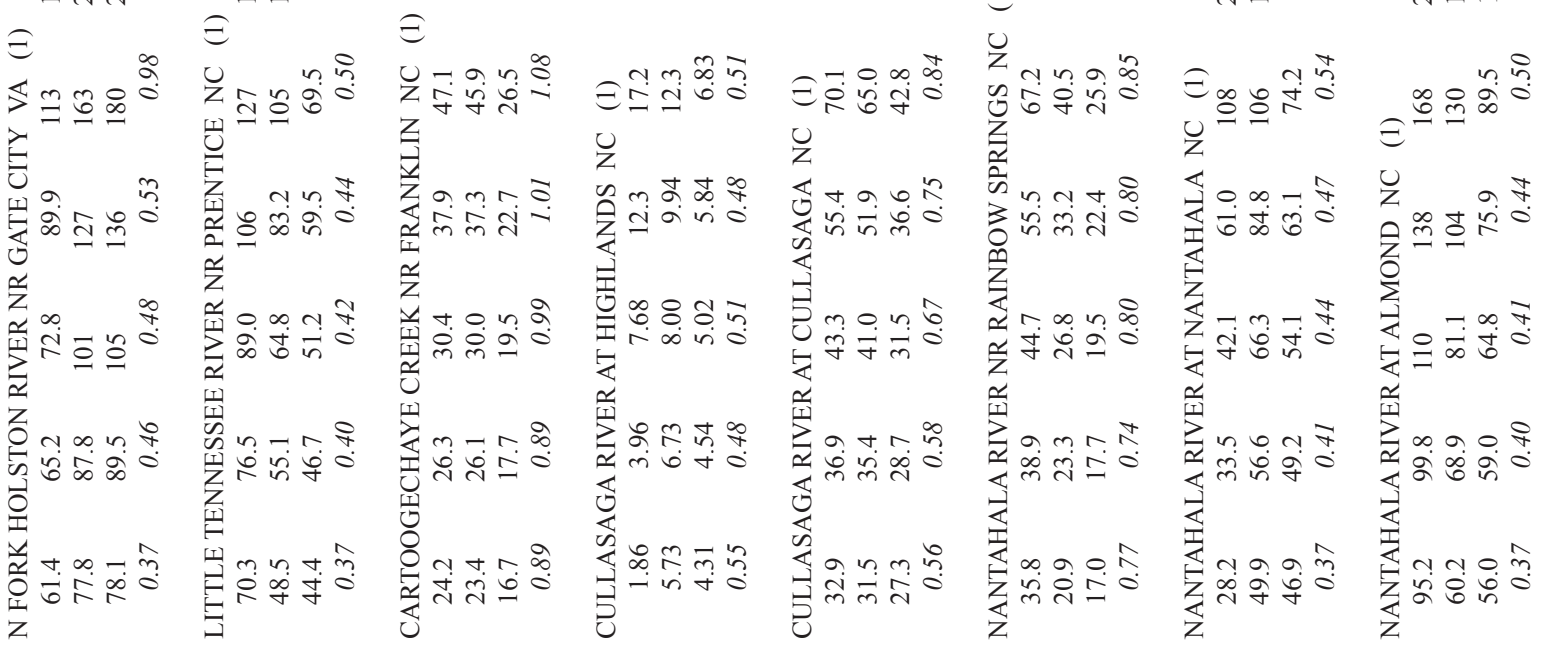

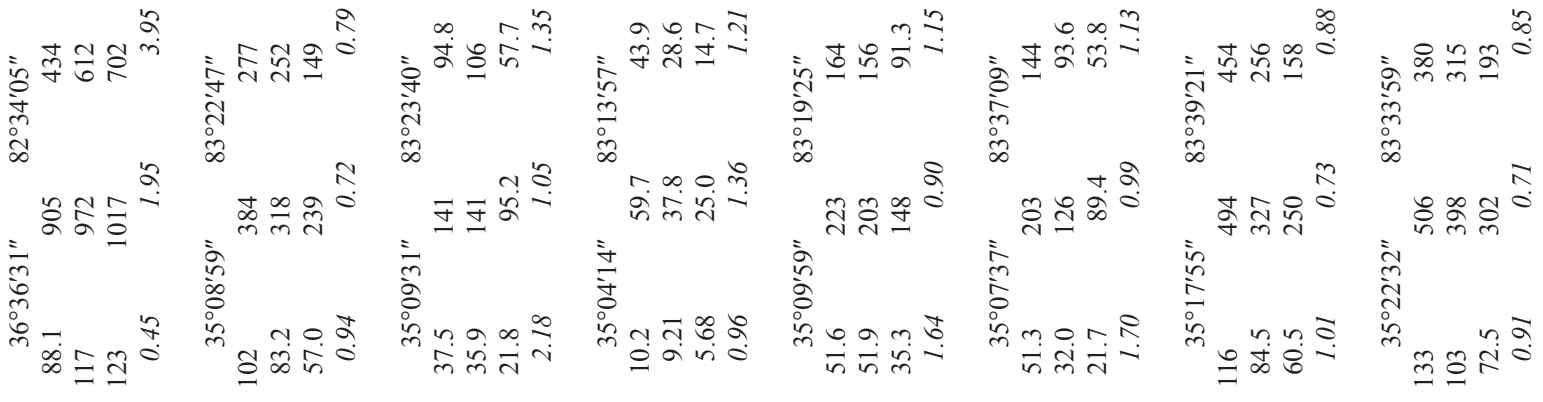

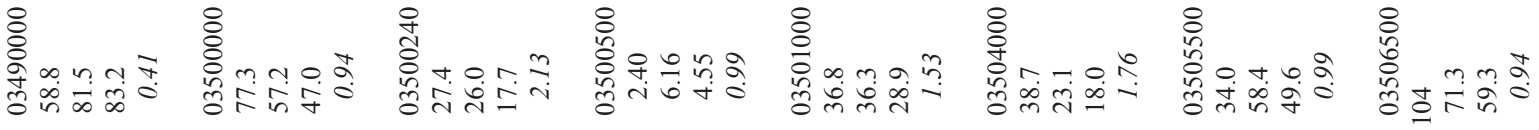
$\ddot{b}$ $\stackrel{-1}{-10}$ $\stackrel{\infty}{9}$

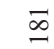
$\stackrel{\infty}{\infty}$

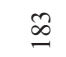
$\stackrel{+}{\Phi}$ $\stackrel{\infty}{\infty}$ 


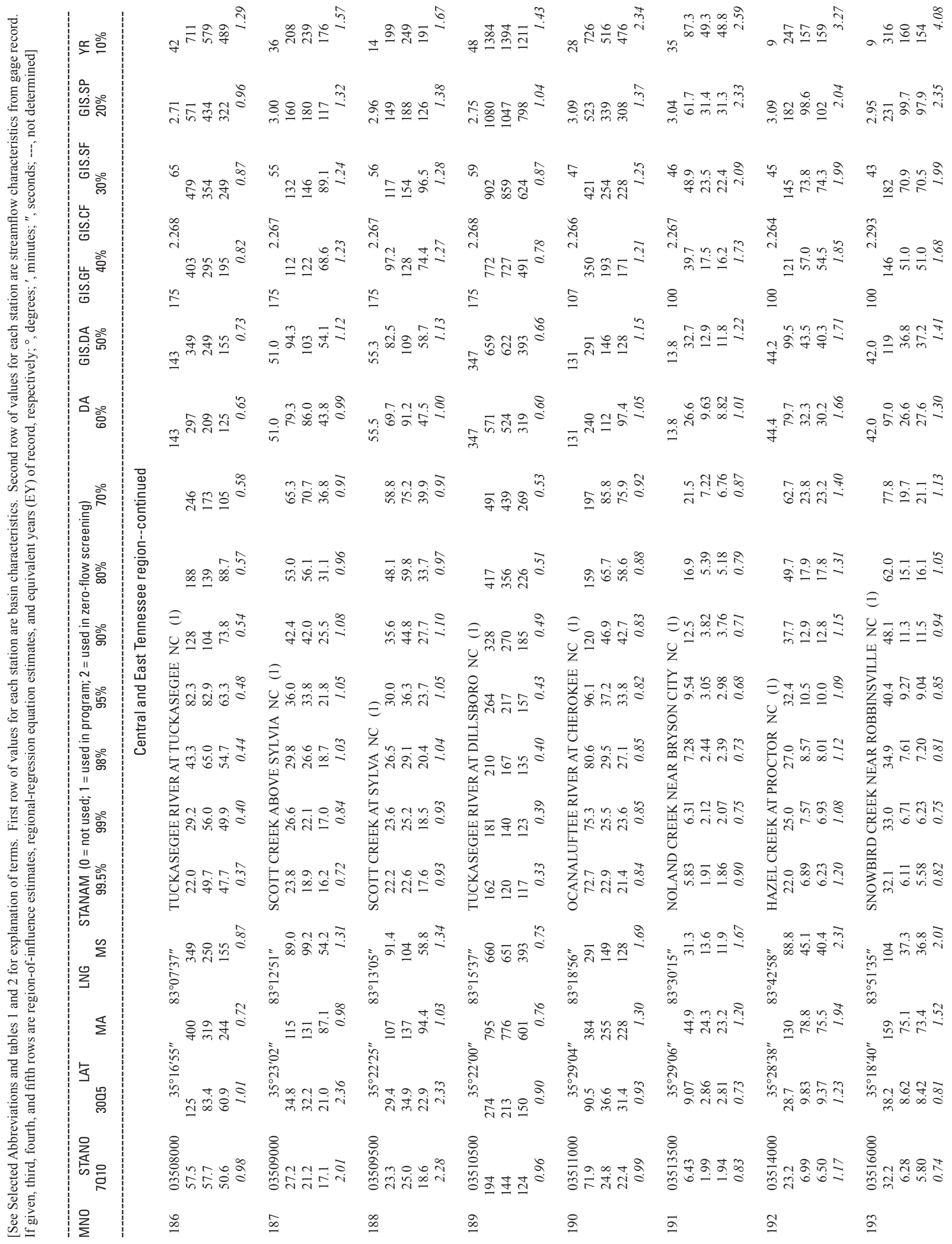




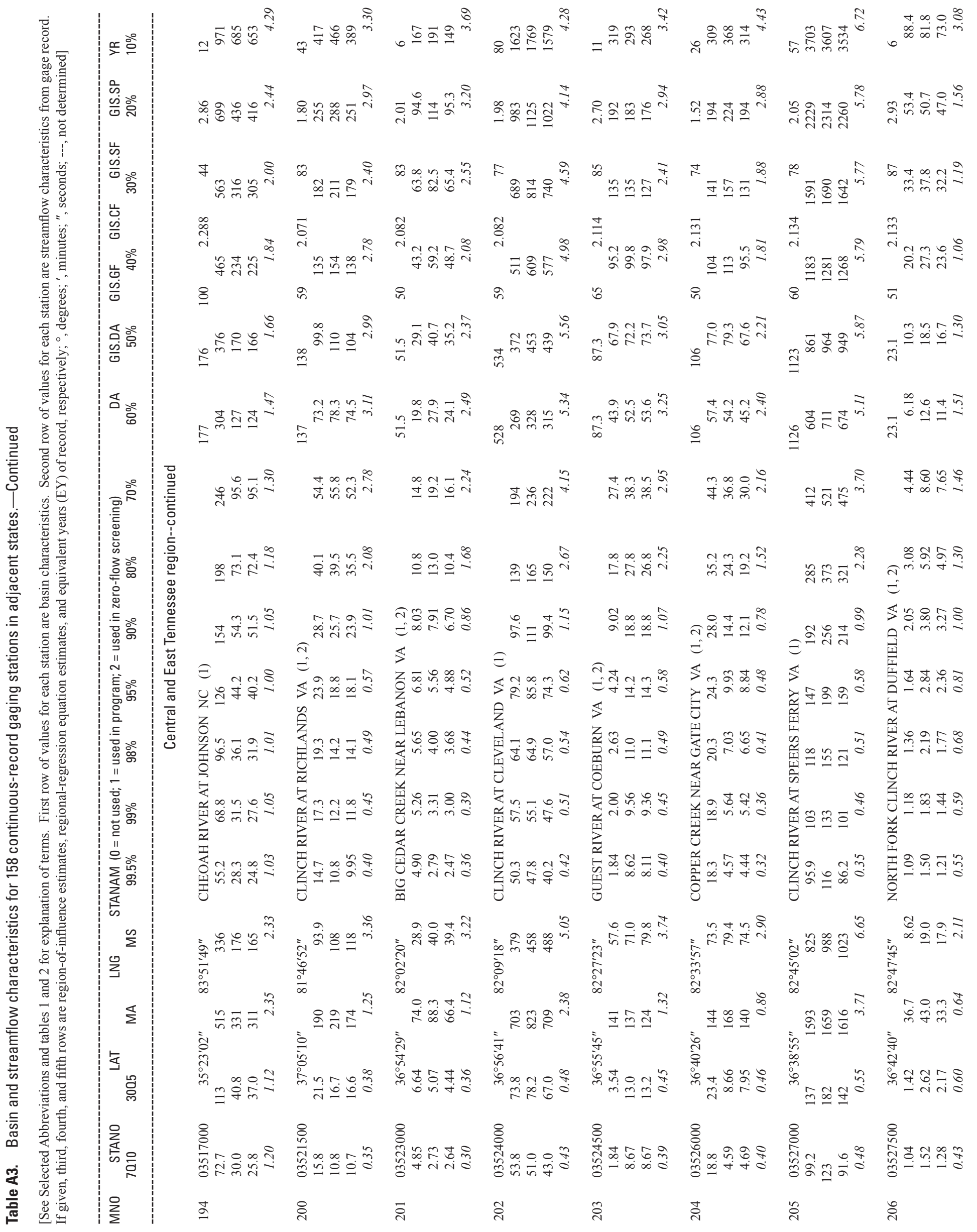




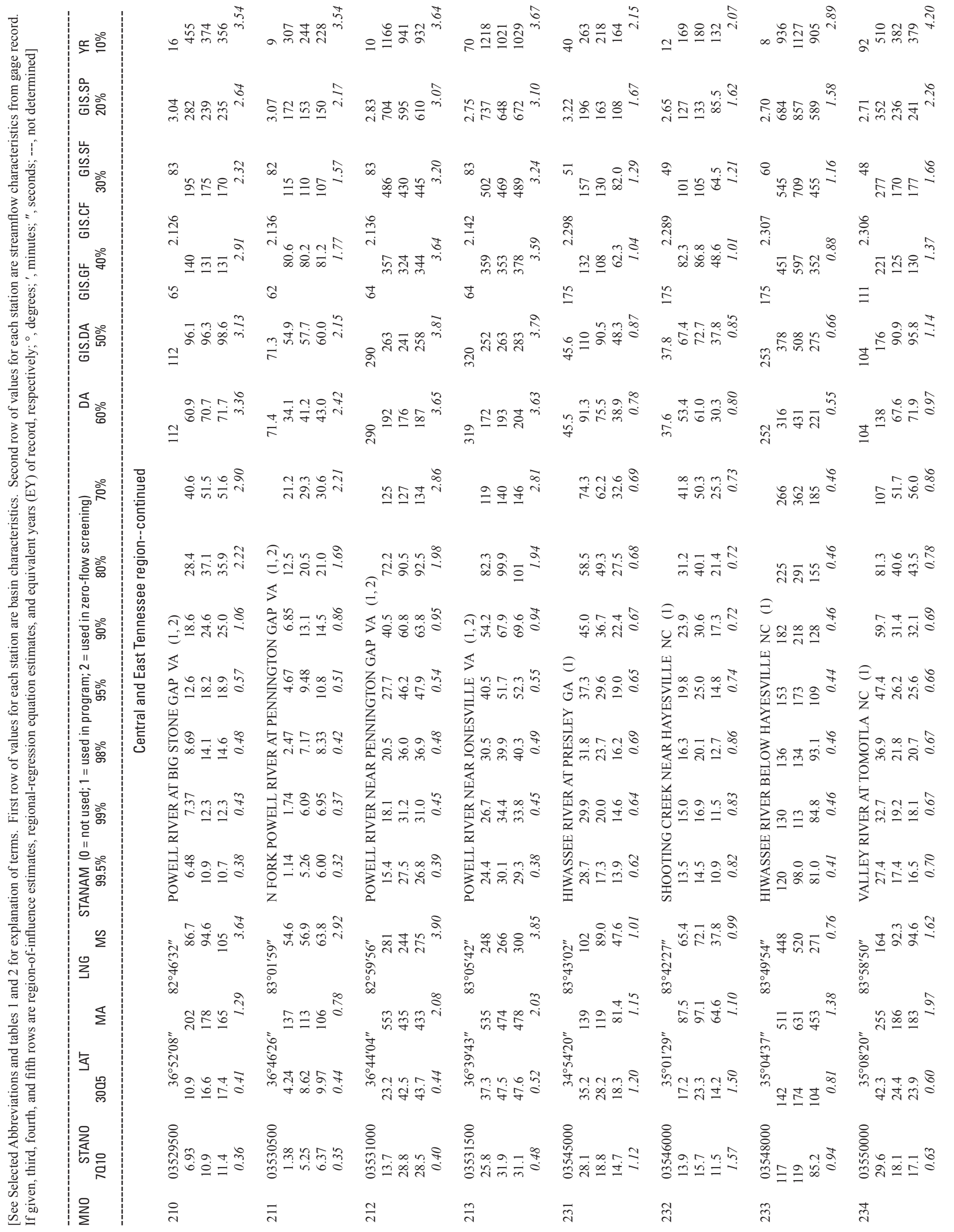




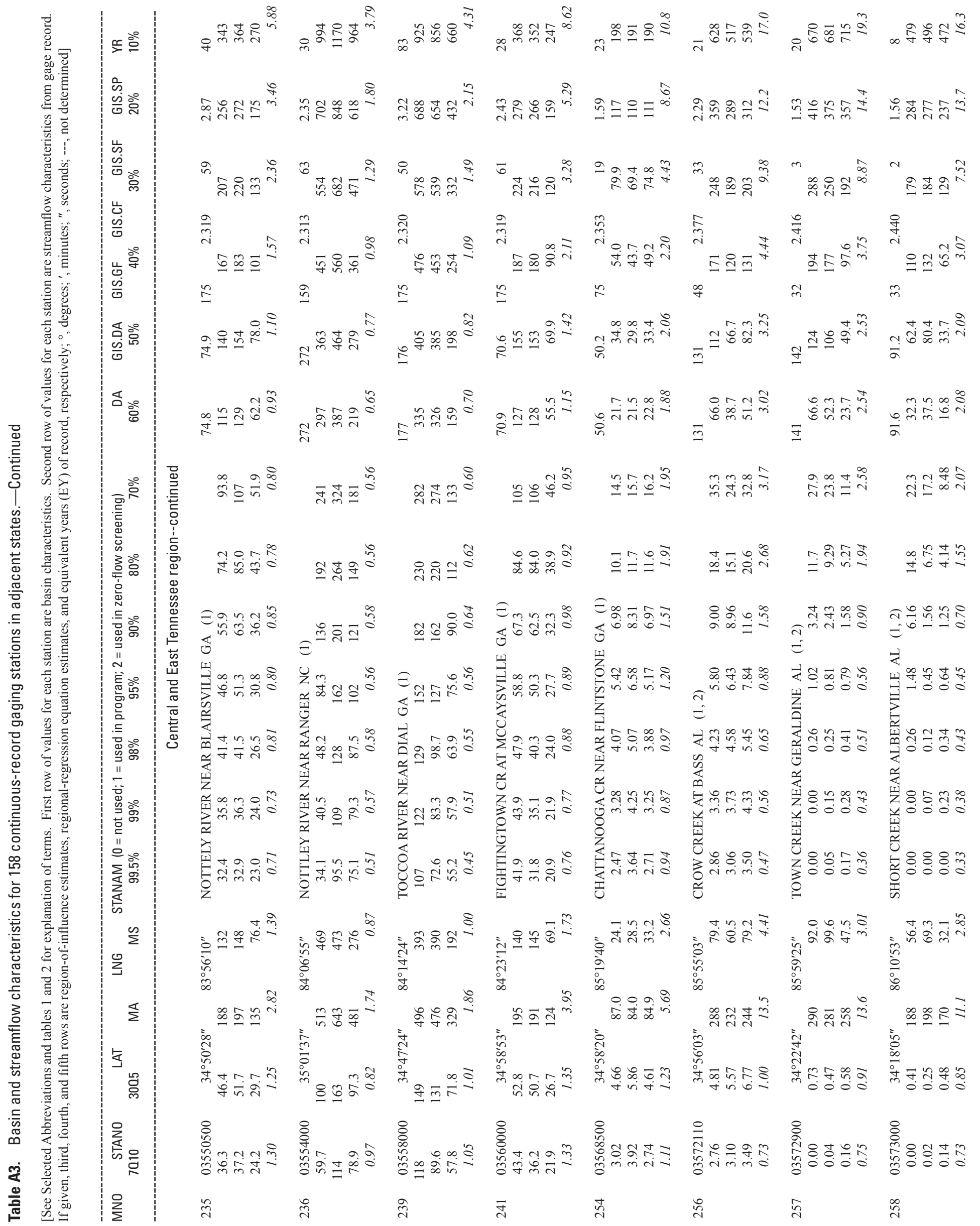




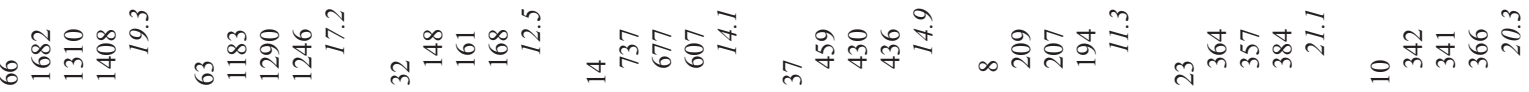

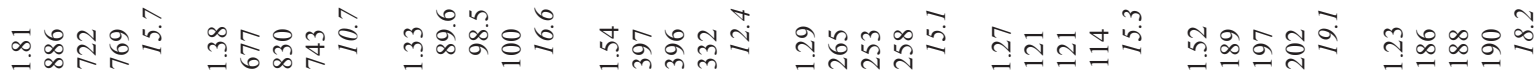

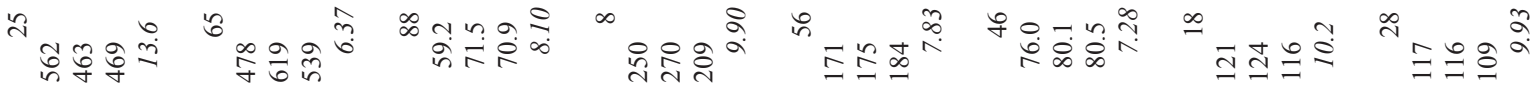

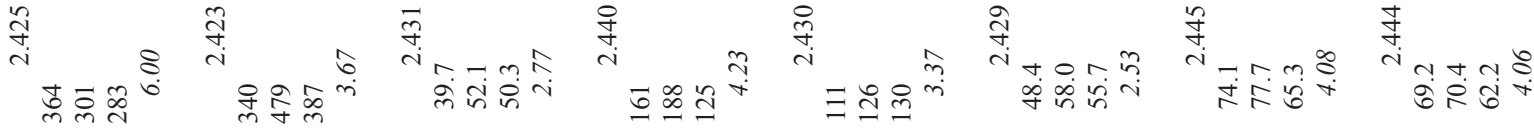

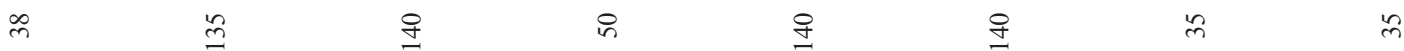

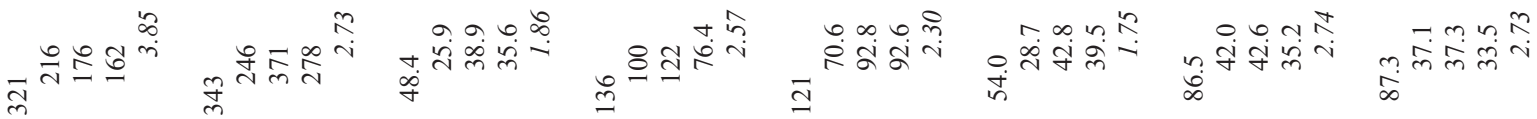

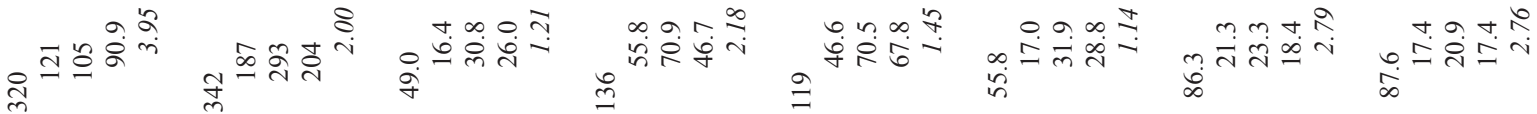

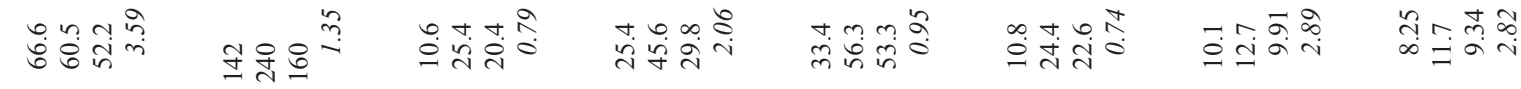

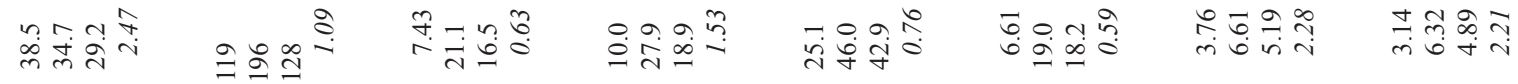

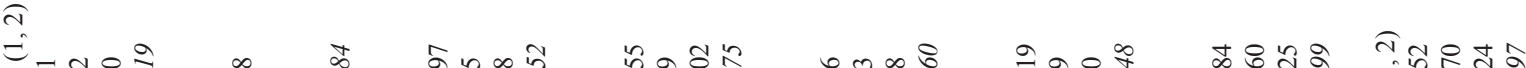

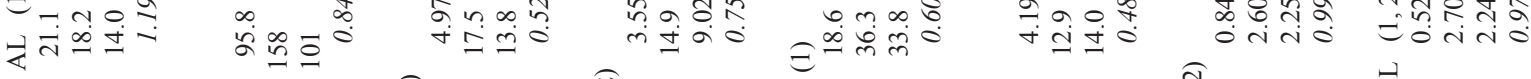

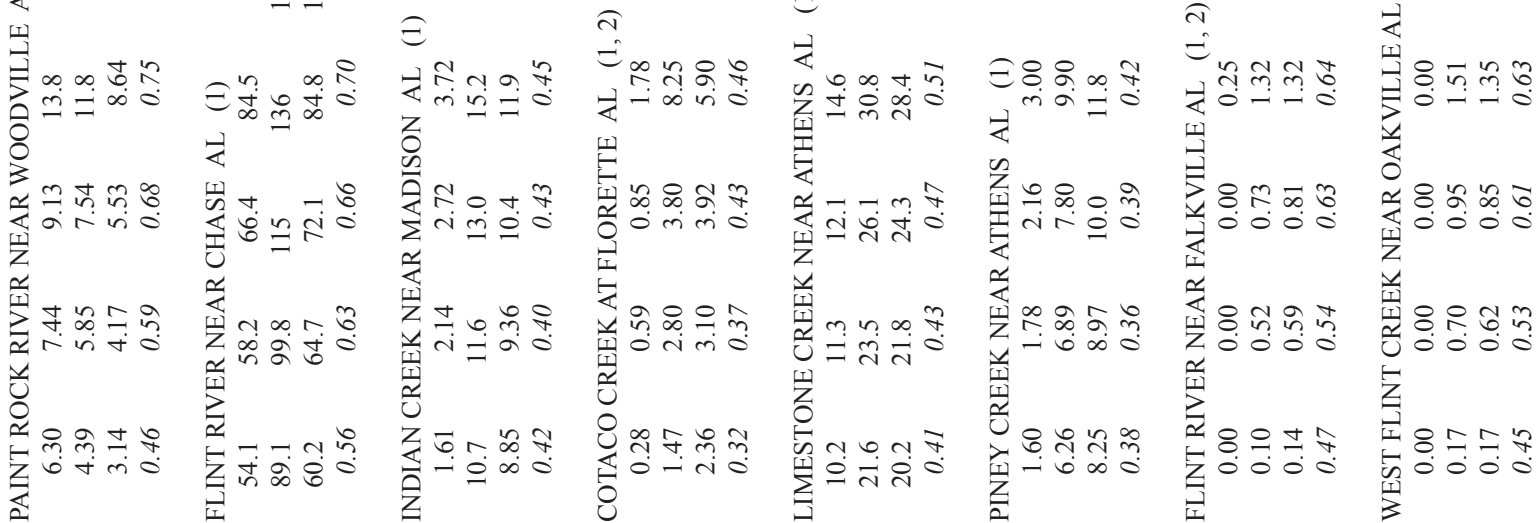

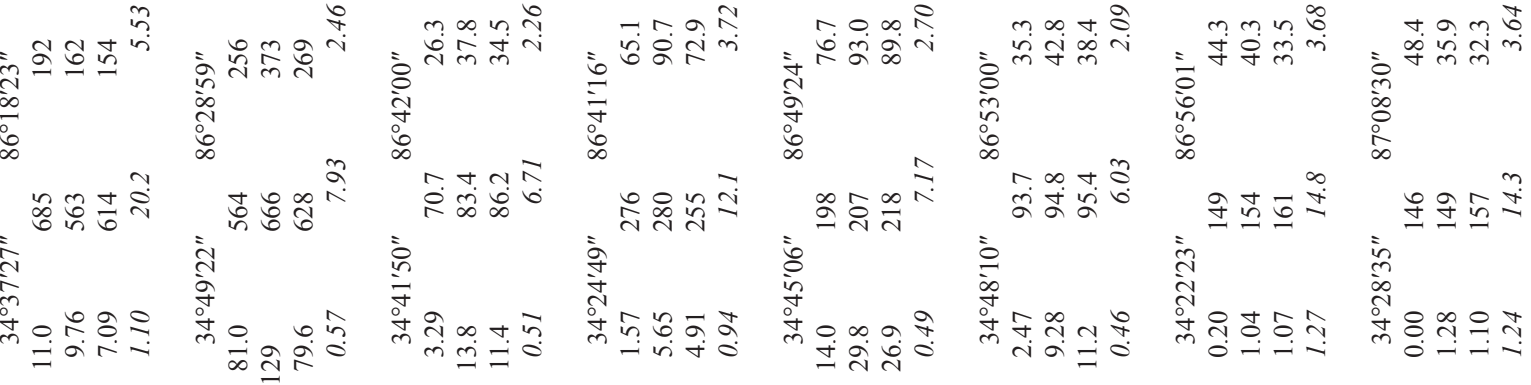

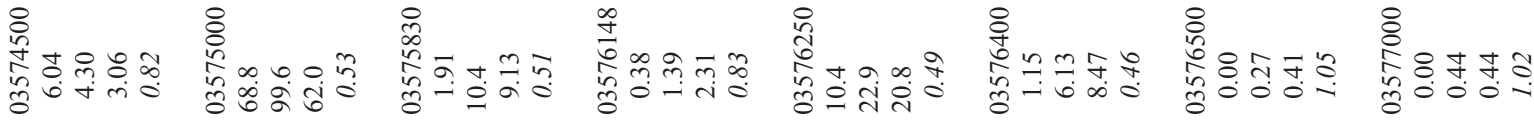




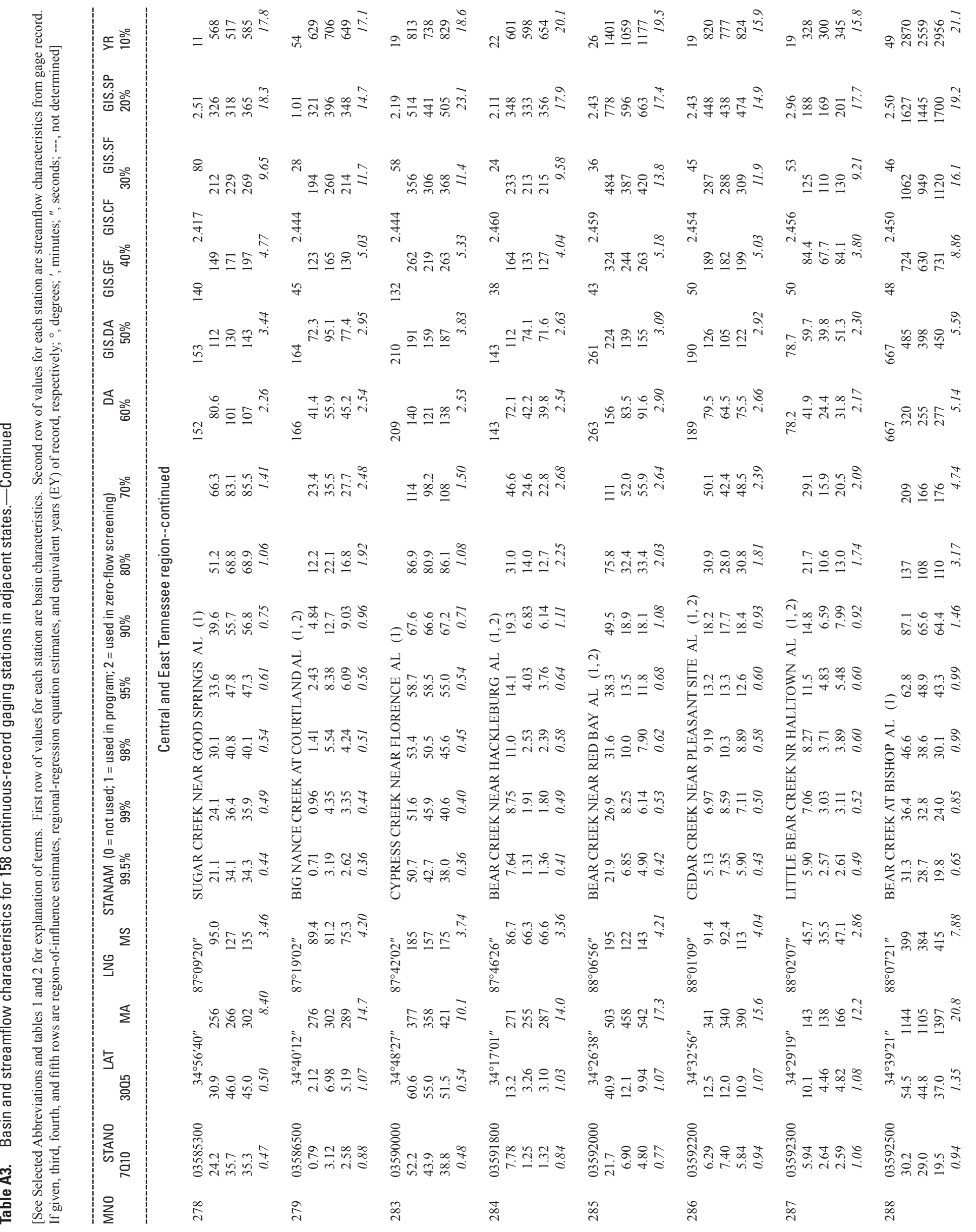




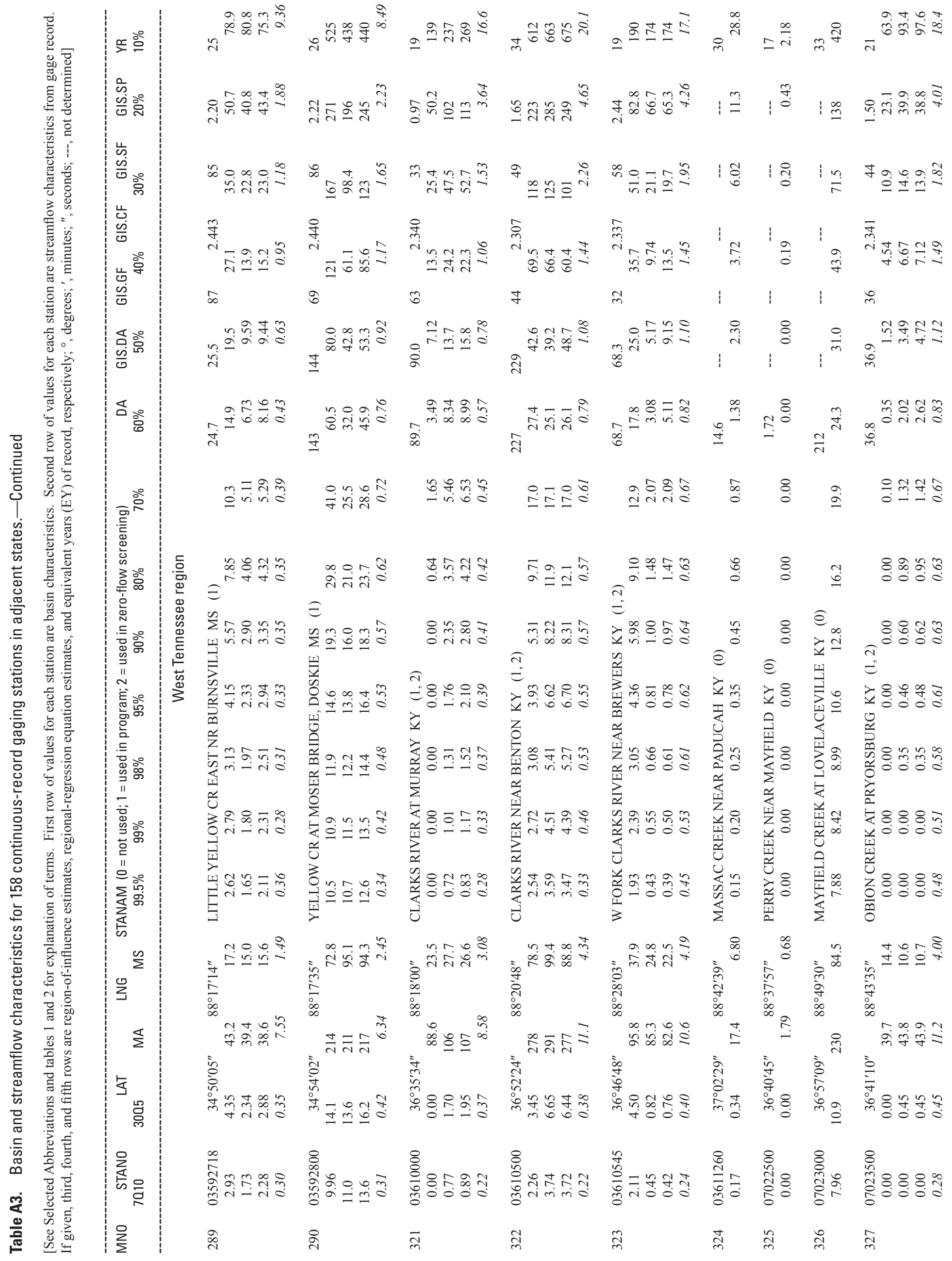




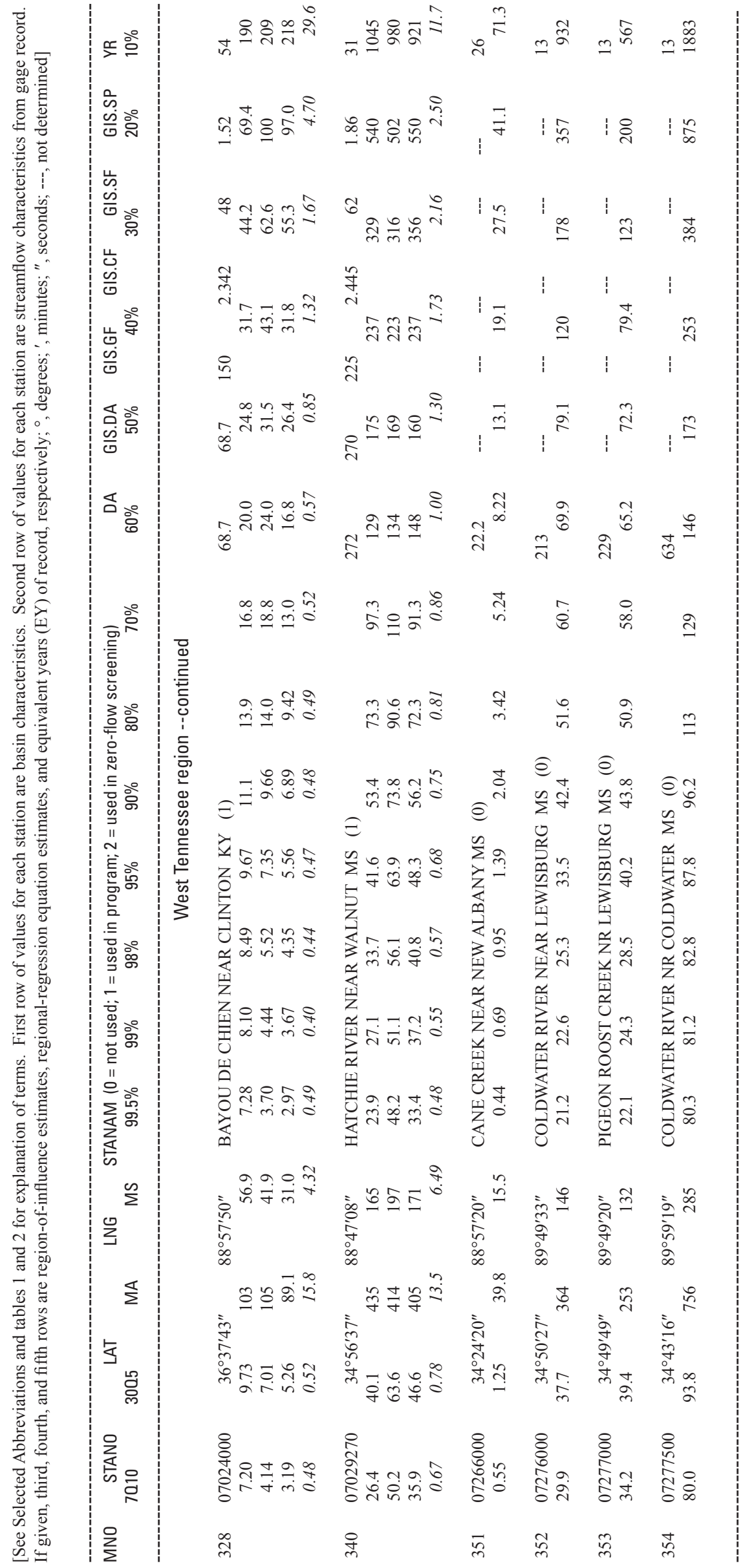





\section{Appendix B. Instructions for Use of the Stand-Alone Version of the Low-Flow Frequency and Flow-Duration Computer Program (TDECv301) for Tennessee}

The stand-alone low-flow and flow-duration (LFFD) computer program for Tennessee (TDECv301) includes five files. One is the executable program file named TDECv301.exe (423 kilobytes) and dated 28FEB2009 on the opening screen. The other files are required data files described as follows: DATWv303.txt (40 kilobytes), DATMv303.txt (288 kilobytes), NAMWv203.txt (10 kilobytes), and NAMMv203.txt (69 kilobytes). These files must be located in a common directory for the computer program to work properly. The computer program and data files can be downloaded from the World Wide Web at http://pubs.usgs.gov/ sir/2009/5159.

Prior to running the Tennessee LFFD program (TDECv301), go to the World Wide Web at http://water.usgs.gov/osw/ streamstats/index.html and use StreamStats to compute basin characteristics for the site. If justified, manual methods can be used to compute basin characteristics. After computing the required basin characteristics, run the computer program. The following opening screen will appear:

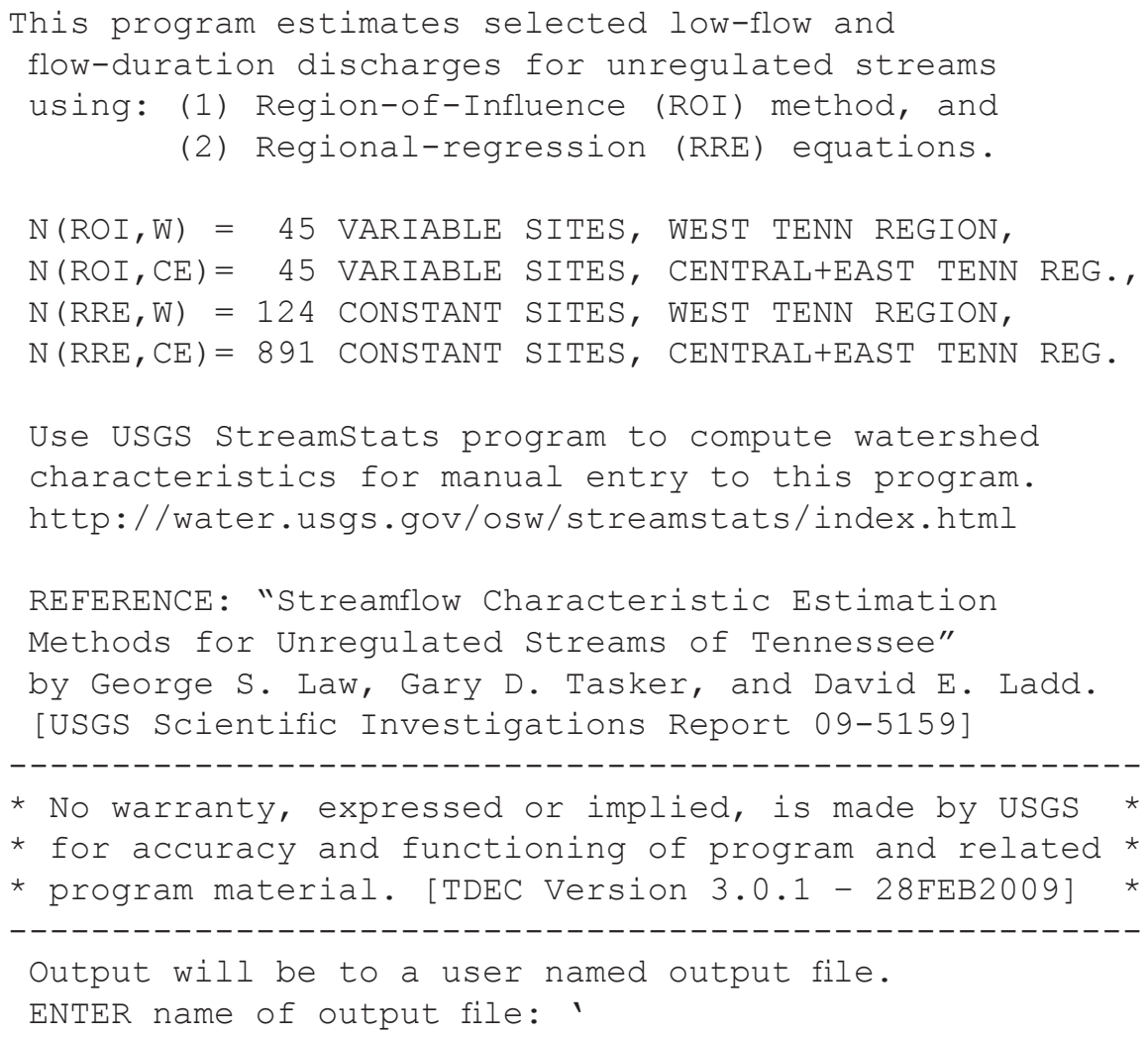

Type the output file name and press the ENTER key. The following question will appear:

Is site in West or Central+East Region of Tennessee?

ENTER 1 for West Region

ENTER 0 for Central+East Region

:

Type 0 or 1 and press the ENTER key. The following statement will appear:

ENTER name for site

:

Type the site name and press the ENTER key. The following statement will appear:

ENTER site latitude (dd $\mathrm{mm}$ ss): 
Type the site latitude and press the ENTER key. The following statement will appear:

ENTER site longitude as a positive no. (dd mm ss):

Type the site longitude and press the ENTER key. The following statement will appear:

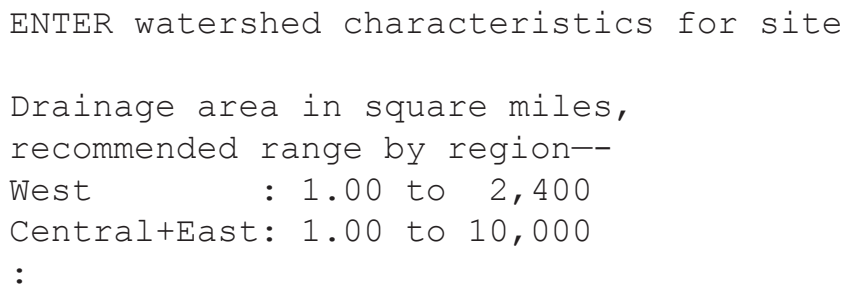

Type the drainage area and press the ENTER key. The following statement will appear:

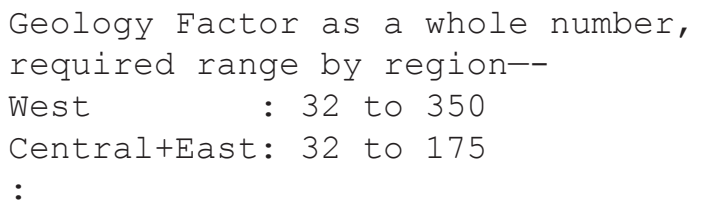

Type the geology factor and press the ENTER key. The following statement will appear:

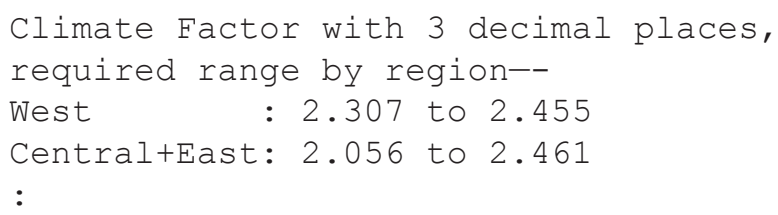

Type the climate factor and press the ENTER key. The following statement will appear:

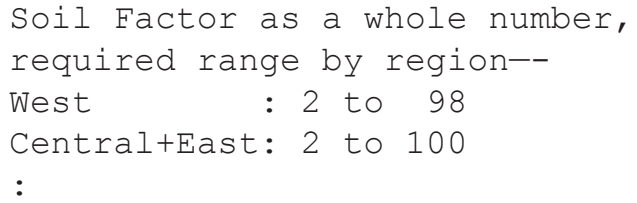

Type the soil factor and press the ENTER key. The following statement will appear:

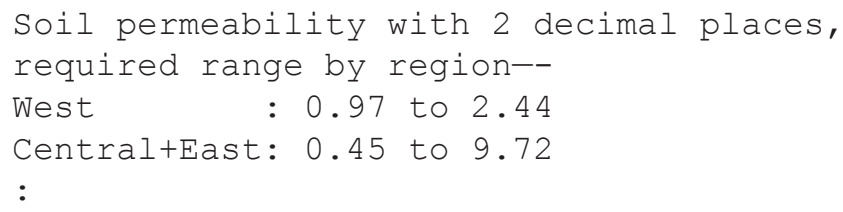

After entering soil permeability, the program writes results to the computer screen and to the user named output file (Appendix C). This completes the execution of the Tennessee LFFD computer program. 


\section{Appendix C. Description of Output From the Stand-Alone Version of the Low-Flow Frequency and Flow-Duration Computer Program (TDECv301) for Tennessee}

After entering the site name, latitude, longitude, drainage area, geology factor, climate factor, soil factor, and soil permeability for a site of interest, the low-flow and flow-duration computer program, TDECv301, produces a user-named output file. Tables $\mathrm{C} 1$ and $\mathrm{C} 2$ provide examples of the output file for a gaged site in the West-region and Central+East-region of Tennessee, respectively. After listing the basin characteristics of the site of interest and providing the method specifications, the output file gives a listing of the 45 gaged sites in the regionof-influence (ROI) for the site of interest. If the site of interest is a gaged site, the region-of-influence includes the gaged site. For the examples provided in tables $\mathrm{C} 1$ and $\mathrm{C} 2$, the site of interest is also the first site listed in the region-of-influence. For each gaged site in the region-of-influence, the output file gives map number (MNO; plate 1; Appendix A), station number (STANO), latitude (LAT), longitude (LNG), drainage area (DA), geology factor (GF), climate factor (CF), soil factor (SF), soil permeability (SP), and the station location. The location is abbreviated because each row has a maximum width of 80 characters.

After a list of the data sites in the region-of-influence, the output file lists the zero-flow probabilities, and the regionof-influence (ROI) method and regional regression (RRE) equation streamflow-characteristic estimates for the site of interest. For each streamflow characteristic, referred to as "Rv" in the output file, the program gives the ROI estimated value and the 90-percent PREDICTION INTERVAL for the ROI estimated value, equivalent years of record (EY) of the ROI value, and the region regression (RRE) equation estimated value. Prediction intervals are for a two-tailed confidence level of 10 percent, and $t$ critical is 1.682 for $\alpha$ of 0.10 and 43 degrees of freedom.

Next, for each streamflow characteristic, the program gives the intercept (CONSTANT) and slopes $[\log (\mathrm{DA})$, $\log (\mathrm{GF}-30)$, and $\log (\mathrm{SF})]$ of the logarithmic form of the ROI estimation equation. Following this information, the program lists the results of a test for the existence of a relation in the regression equation. In addition the program lists the standard error of the regression coefficient (SE), the student's $t$ value $(\mathrm{T}: \mathrm{BETA}=0)$ that measures the strength of the relation of the regression, and the probability (p-value) there is no relationship in the regression. The ROI method uses a full model fit to eliminate the possibility of inconsistent streamflow characteristic estimates that can occur when dropping insignificant explanatory variables from the equations. 
Table C1. Low-flow frequency and flow-duration estimates for a West region site (see Selected Abbreviations and tables 1 and 2 for explanation of terms; see fig. C1 for location of region-of-influence stations).

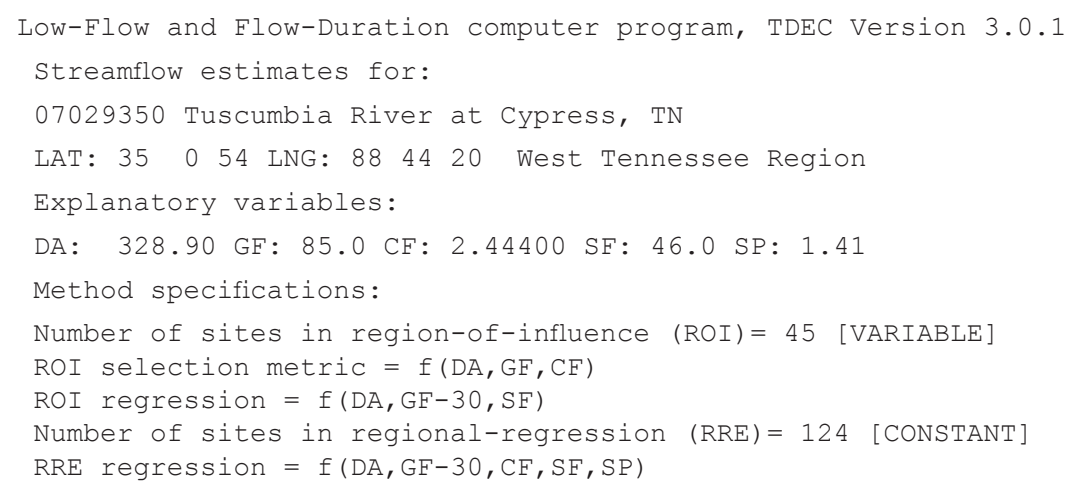

\begin{tabular}{|c|c|c|c|c|c|c|c|c|c|}
\hline MNO & STANO & LAT & LNG & DA & GF & $\mathrm{CF}$ & $\mathrm{SF}$ & SP & LOCATION \\
\hline 1203 & 7029350 & 35.015 & 8.739 & 328.9 & 85 & 2.444 & 46 & 1.41 & TUSCUMBIA R CYPRESS TN \\
\hline 0346 & 7030280 & 35.281 & 89.766 & 504.9 & 83 & 2.405 & 56 & 1.24 & LOOSAHATCHIE R BRSWCK TN \\
\hline 0290 & 3592800 & 34.901 & 88.293 & 143.8 & 69 & 2.440 & 86 & 2.22 & YELLOW CR DOSKIE MS \\
\hline 0345 & 7030240 & 35.310 & 89.640 & 211.8 & 145 & 2.406 & 56 & 1.40 & LOOSAHATCHIE $R$ ARLGTN TN \\
\hline 0342 & 7029400 & 35.056 & 88.799 & 838.2 & 148 & 2.4 & 53 & 1.60 & HATCHIE R POCAHONTAS TN \\
\hline 0348 & 7031650 & 35.116 & 89.801 & 697.1 & 164 & 2.4 & 61 & 1.58 & WOLF R GERMANTOWN TN \\
\hline 349 & 7031700 & 35.2 & 89.9 & 770.7 & 151 & 2.4 & 62 & 1.54 & WOLF R RALEIGH TN \\
\hline 0338 & 7029000 & 35.8 & 89.067 & 370.7 & 169 & & 68 & 1.70 & MF FKD DEER R ALAMO TN \\
\hline 0339 & 7029 & 36. & 89.3 & 938.9 & 94 & & 59 & 1.43 & NF FKD DEER R DYRSBRG TN \\
\hline 1224 & 703 & 35. & 89.6 & 597.0 & 186 & 2. & 63 & 1.66 & WOLF R COLLIERVILLE TN \\
\hline 0332 & 7025 & 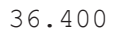 & 88.9 & 425.2 & 117 & & 66 & 1.56 & NF OBION R UNION CITY TN \\
\hline 180 & 7025 & 36. & 88.8 & 368.9 & 127 & 2.3 & 70 & 1.65 & N FK OBION R MARTIN TN \\
\hline 176 & 7025 & 36. & 88.9 & 266.0 & 141 & & 73 & 1.85 & RTHF FK OBION R KENTN TN \\
\hline 0347 & 7030 & 35. & 89.5 & 503.6 & 209 & & 67 & 1.77 & WOLF R ROSSVILLE TN \\
\hline 1175 & 7025 & 36.129 & 88.974 & 236.9 & 155 & 2.3 & 77 & 1.94 & RTHF FK OBION R RTHFD TN \\
\hline 0341 & 7029380 & 35.066 & 88.655 & 94.9 & 160 & 2.4 & 62 & 1.82 & CYPRESS CR RAMER TN \\
\hline 1202 & 70292 & 35.042 & 88.786 & 311.2 & 224 & 2.4 & 61 & 1.84 & HATCHIE R POCAHONTAS TN \\
\hline 0340 & 7029270 & 34.944 & 88.786 & 270.0 & 225 & 2.4 & 62 & 1.86 & HATCHIE R WALNUT MS \\
\hline 0336 & 7028000 & 35.862 & 89.348 & 972.0 & 159 & 2.3 & 60 & 1.50 & SF FKD DEER R CHNT BL TN \\
\hline 195 & 7027800 & 35.818 & 89.356 & 932.0 & 165 & 2.3 & 61 & 1.52 & SE FKED DEER R GATES TN \\
\hline 196 & 7028100 & 35.929 & 89.390 & 020.6 & 153 & 2.3 & 61 & 1.49 & SF FKED DEER R HALLS TN \\
\hline 197 & 7028200 & 35.976 & 89.401 & 1053.4 & 149 & 2.381 & 61 & 1.48 & SE FKED DEER R YLW BL TN \\
\hline 200 & 7028960 & 35.744 & 88.846 & 210.7 & 212 & 2.394 & 77 & 1.96 & MF FKED DEER R FAIRVW TN \\
\hline 337 & 7028500 & 35.980 & 88.926 & 72.7 & 123 & 2.388 & 83 & 2.19 & NF FKD DEER R TRENTON TN \\
\hline 1214 & 7030020 & 35.485 & 89.381 & 93.8 & 169 & 2.401 & 46 & 1.18 & BIG MUDDY CR STANTON TN \\
\hline 331 & 7025000 & 36.053 & 88.878 & 201.0 & 176 & 2.3 & 81 & 2.07 & RTH FK OBION R BRDFRD TN \\
\hline 1189 & 7027300 & 35.449 & 88.604 & 159.9 & 217 & 2.403 & 73 & 2.06 & SF FKED DEER R HNDRSN TN \\
\hline 1193 & 7027680 & 35.693 & 89.110 & 682.3 & 211 & 2.395 & 65 & 1.68 & SF FKED DEER R BELLS TN \\
\hline 1199 & 7028920 & 35.740 & 88.794 & 172.0 & 216 & 2.395 & 76 & 1.94 & MF FKED DEER R OAKFLD TN \\
\hline 0335 & 7027500 & 35.594 & 88.814 & 495.1 & 231 & 2.399 & 66 & 1.81 & SF FKD DEER R JACKSON TN \\
\hline 0299 & 3594445 & 35.624 & 88.273 & 114.7 & 198 & 2.395 & 70 & 2.07 & BEECH R CHESTERFIELD TN \\
\hline 0291 & 3593300 & 35.220 & 88.427 & 50.2 & 100 & 2.413 & 42 & 1.42 & SNAKE CR ADAMSVILLE TN \\
\hline 1172 & 7024770 & 36.203 & 88.822 & 286.1 & 197 & 2.354 & 67 & 1.59 & M FK OBION R SHARON TN \\
\hline 1220 & 7030250 & 35.320 & 89.658 & 145.5 & 32 & 2.405 & 63 & 1.14 & BEAVER CR ARLINGTON TN \\
\hline 0294 & 3594058 & 35.372 & 88.384 & 46.7 & 98 & 2.407 & 54 & 1.63 & WHITE OAK CR MLLEDGV TN \\
\hline 0320 & 3607000 & 36.238 & 88.097 & 391.2 & 200 & 2.348 & 73 & 1.90 & BIG SANDY R BIG SANDY TN \\
\hline 0321 & 3610000 & 36.593 & 88.300 & 90.0 & 63 & 2.340 & 33 & 0.97 & CLARKS R MURRAY KY \\
\hline 0343 & 7029500 & 35.275 & 88.977 & 1480.0 & 182 & 2.409 & 57 & 1.65 & HATCHIE R BOLIVAR TN \\
\hline 1223 & 7030400 & 35.121 & 89.283 & 68.5 & 183 & 2.426 & 77 & 2.09 & $\mathrm{~N}$ FK WOLF $\mathrm{R}$ LAGRANGE \\
\hline 0295 & 3594120 & 35.416 & 88.361 & 46.1 & 110 & 2.405 & 42 & 1.39 & MIDDLETON CR MLLEDGV TN \\
\hline 1218 & 7030210 & 35.250 & 89.343 & 79.6 & 202 & 2.417 & 74 & 1.92 & LOOSAHTCHE R 2 SOMRV TN \\
\hline 1219 & 7030212 & 35.258 & 89.353 & 80.6 & 203 & 2.414 & 74 & 1.91 & LOOSAHTCHE R 3 SOMRV TN \\
\hline 1174 & 7024900 & 35.947 & 88.714 & 108.3 & 217 & 2.390 & 80 & 2.06 & RTHF FK OBION R MILAN TN \\
\hline 1217 & 7030209 & 35.246 & 89.326 & 76.0 & 200 & 2.417 & 74 & 1.95 & LOOSAHTCHE R 1 SOMRV TN \\
\hline 0319 & 3606500 & 36.039 & 88.228 & 205.3 & 234 & 2.364 & 79 & 2.08 & BIG SANDY R BRUCETON TN \\
\hline
\end{tabular}


Table C1. Low-flow frequency and flow-duration estimates for a West region site (see Selected Abbreviations and tables 1 and 2 for explanation of terms; see fig. C1 for location of region-of-influence stations).-Continued

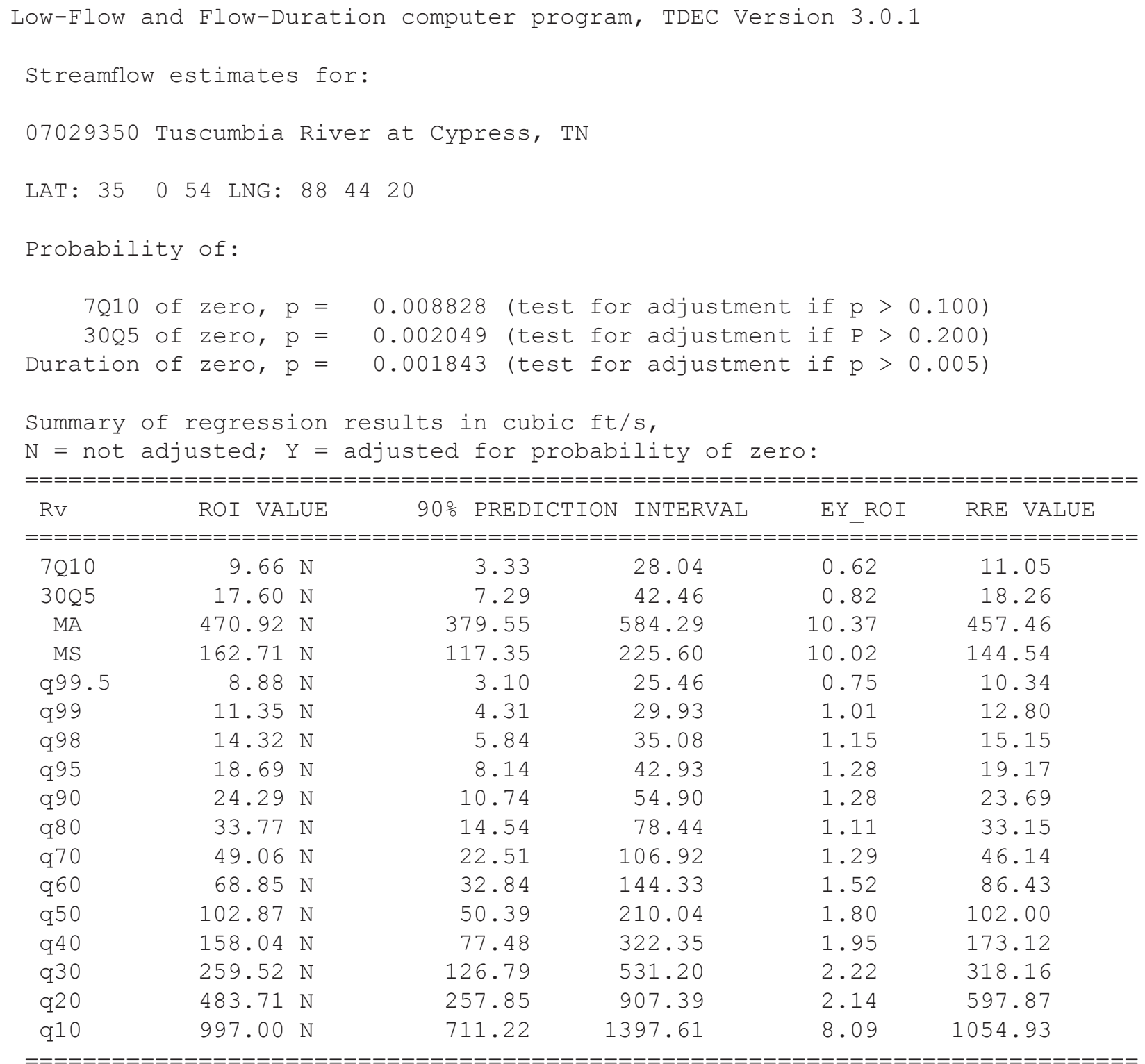


Table C1. Low-flow frequency and flow-duration estimates for a West region site (see Selected Abbreviations and tables 1 and 2 for explanation of terms; see fig. C1 for location of region-of-influence stations).- - Continued

\begin{tabular}{|c|c|c|c|c|c|}
\hline Rv & PARAMETER & COEFFICIENT & SE & $\mathrm{T}: \mathrm{BETA}=0$ & P-VALUE \\
\hline \multicolumn{6}{|c|}{------------------------------------------------------------} \\
\hline \multirow[t]{4}{*}{$7 Q 10$} & CONSTANT & -8.3342 & 0.8637 & -9.6496 & 0.0001 \\
\hline & $\log (\mathrm{DA})$ & 1.4184 & 0.0956 & 14.8433 & 0.0001 \\
\hline & $\log (G F-30)$ & 0.5089 & 0.1284 & 3.9626 & 0.0003 \\
\hline & $\log (\mathrm{SF})$ & 2.9248 & 0.4867 & 6.0094 & 0.0001 \\
\hline \multirow[t]{4}{*}{$30 Q 5$} & CONSTANT & -6.0949 & 0.7139 & -8.5371 & 0.0001 \\
\hline & $\log (D A)$ & 1.2742 & 0.0790 & 16.1321 & 0.0001 \\
\hline & $\log (G F-30)$ & 0.5309 & 0.1062 & 5.0010 & 0.0001 \\
\hline & $\log (\mathrm{SF})$ & 1.9299 & 0.4023 & 4.7971 & 0.0001 \\
\hline \multirow[t]{4}{*}{$\mathrm{MA}$} & CONSTANT & 0.1751 & 0.1748 & 1.0014 & 0.3225 \\
\hline & $\log (\mathrm{DA})$ & 0.9883 & 0.0193 & 51.1029 & 0.0001 \\
\hline & $\log (G F-30)$ & 0.0135 & 0.0260 & 0.5177 & 0.6075 \\
\hline & $\log (S F)$ & -0.0080 & 0.0985 & -0.0807 & 0.9360 \\
\hline \multirow[t]{4}{*}{ MS } & CONSTANT & -1.4937 & 0.2648 & -5.6403 & 0.0001 \\
\hline & $\log (\mathrm{DA})$ & 1.0579 & 0.0293 & 36.1064 & 0.0001 \\
\hline & $\log (G F-30)$ & 0.1031 & 0.0394 & 2.6168 & 0.0124 \\
\hline & $\log (\mathrm{SF})$ & 0.5190 & 0.1492 & 3.4773 & 0.0012 \\
\hline \multirow[t]{4}{*}{ q99. 5} & CONSTANT & -8.5973 & 0.8539 & -10.0680 & 0.0001 \\
\hline & $\log (\mathrm{DA})$ & 1.4327 & 0.0945 & 15.1644 & 0.0001 \\
\hline & $\log (G F-30)$ & 0.5096 & 0.1270 & 4.0135 & 0.0002 \\
\hline & $\log (S F)$ & 3.0386 & 0.4812 & 6.3146 & 0.0001 \\
\hline \multirow[t]{4}{*}{ q99 } & CONSTANT & -7.6129 & 0.7856 & -9.6911 & 0.0001 \\
\hline & $\log (\mathrm{DA})$ & 1.3824 & 0.0869 & 15.9056 & 0.0001 \\
\hline & $\log (G F-30)$ & 0.5087 & 0.1168 & 4.3545 & 0.0001 \\
\hline & $\log (\mathrm{SF})$ & 2.5880 & 0.4427 & 5.8461 & 0.0001 \\
\hline \multirow[t]{4}{*}{ q98 } & CONSTANT & -6.7045 & 0.7262 & -9.2321 & 0.0001 \\
\hline & $\log (\mathrm{DA})$ & 1.3231 & 0.0803 & 16.4675 & 0.0001 \\
\hline & $\log (G F-30)$ & 0.5164 & 0.1080 & 4.7816 & 0.0001 \\
\hline & $\log (\mathrm{SF})$ & 2.1839 & 0.4092 & 5.3365 & 0.0001 \\
\hline \multirow[t]{4}{*}{ q95 } & CONSTANT & -5.8279 & 0.6740 & -8.6469 & 0.0001 \\
\hline & $\log (D A)$ & 1.2503 & 0.0746 & 16.7667 & 0.0001 \\
\hline & $\log (G F-30)$ & 0.5390 & 0.1002 & 5.3781 & 0.0001 \\
\hline & $\log (\mathrm{SF})$ & 1.8129 & 0.3798 & 4.7732 & 0.0001 \\
\hline \multirow[t]{4}{*}{ q90 } & CONSTANT & -5.0817 & 0.6610 & -7.6885 & 0.0001 \\
\hline & $\log (\mathrm{DA})$ & 1.1972 & 0.0731 & 16.3716 & 0.0001 \\
\hline & $\log (G F-30)$ & 0.5548 & 0.0983 & 5.6452 & 0.0001 \\
\hline & $\log (\mathrm{SF})$ & 1.4963 & 0.3725 & 4.0174 & 0.0002 \\
\hline \multirow[t]{4}{*}{ q80 } & CONSTANT & -4.3313 & 0.6830 & -6.3414 & 0.0001 \\
\hline & $\log (\mathrm{DA})$ & 1.1441 & 0.0756 & 15.1396 & 0.0001 \\
\hline & $\log (G F-30)$ & 0.5714 & 0.1016 & 5.6262 & 0.0001 \\
\hline & $\log (\mathrm{SF})$ & 1.1942 & 0.3849 & 3.1026 & 0.0035 \\
\hline q70 & CONSTANT & -3.2675 & 0.6314 & -5.1754 & 0.0001 \\
\hline & $\log (D A)$ & 1.0968 & 0.0699 & 15.7019 & 0.0001 \\
\hline & $\log (G F-30)$ & 0.5848 & 0.0939 & 6.2287 & 0.0001 \\
\hline & $\log (\mathrm{SF})$ & 0.7095 & 0.3558 & 1.9943 & 0.0528 \\
\hline 960 & CONSTANT & -2.5104 & 0.5998 & -4.1851 & 0.0001 \\
\hline & $\log (D A)$ & 1.0830 & 0.0664 & 16.3179 & 0.0001 \\
\hline & $\log (G F-30)$ & 0.5857 & 0.0892 & 6.5659 & 0.0001 \\
\hline & $\log (\mathrm{SF})$ & 0.3628 & 0.3380 & 1.0731 & 0.2895 \\
\hline q50 & CONSTANT & -1.7520 & 0.5785 & -3.0287 & 0.0042 \\
\hline & $\log (\mathrm{DA})$ & 1.0741 & 0.0640 & 16.7819 & 0.0001 \\
\hline & $\log (G F-30)$ & 0.5130 & 0.0860 & 5.9640 & 0.0001 \\
\hline & $\log (\mathrm{SF})$ & 0.1010 & 0.3260 & 0.3098 & 0.7582 \\
\hline 940 & CONSTANT & -1.0663 & 0.5777 & -1.8458 & 0.0722 \\
\hline & $\log (D A)$ & 1.0694 & 0.0639 & 16.7317 & 0.0001 \\
\hline & $\log (G F-30)$ & 0.4549 & 0.0859 & 5.2958 & 0.0001 \\
\hline & $\log (\mathrm{SF})$ & -0.1313 & 0.3255 & -0.4034 & 0.6888 \\
\hline q30 & CONSTANT & -0.5364 & 0.5805 & -0.9240 & 0.3609 \\
\hline & $\log (D A)$ & 1.0610 & 0.0642 & 16.5202 & 0.0001 \\
\hline & $\log (G F-30)$ & 0.3430 & 0.0863 & 3.9733 & 0.0003 \\
\hline & $\log (\mathrm{SF})$ & -0.1907 & 0.3271 & -0.5828 & 0.5632 \\
\hline q20 & CONSTANT & -0.1256 & 0.5098 & -0.2464 & 0.8066 \\
\hline & $\log (D A)$ & 1.0757 & 0.0564 & 19.0698 & 0.0001 \\
\hline & $\log (G F-30)$ & 0.1445 & 0.0758 & 1.9060 & 0.0637 \\
\hline & $\log (\mathrm{SF})$ & -0.0895 & 0.2873 & -0.3114 & 0.7571 \\
\hline q10 & CONSTANT & 0.0916 & 0.2737 & 0.3345 & 0.7397 \\
\hline & $\log (D A)$ & 1.0663 & 0.0303 & 35.2072 & 0.0001 \\
\hline & $\log (G F-30)$ & 0.0789 & 0.0407 & 1.9392 & 0.0594 \\
\hline & $\log (\mathrm{SF})$ & 0.0517 & 0.1543 & 0.3349 & 0.7394 \\
\hline
\end{tabular}

END PROGRAM 


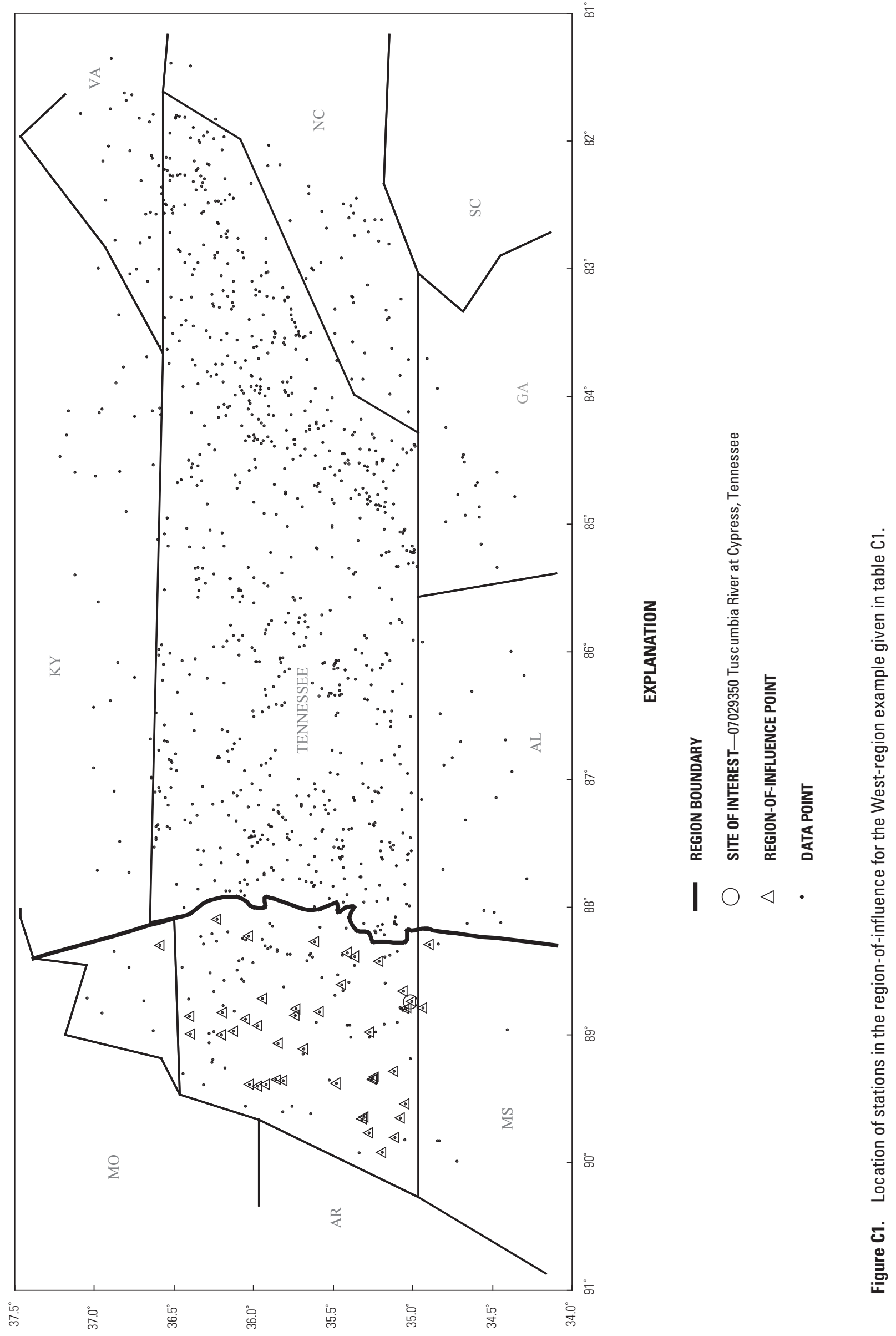


Table C2. Low-flow frequency and flow-duration estimates for a Central+East region site (see Selected Abbreviations and tables 1 and 2 for explanation of terms; see fig. C2 for location of region-of-influence stations).

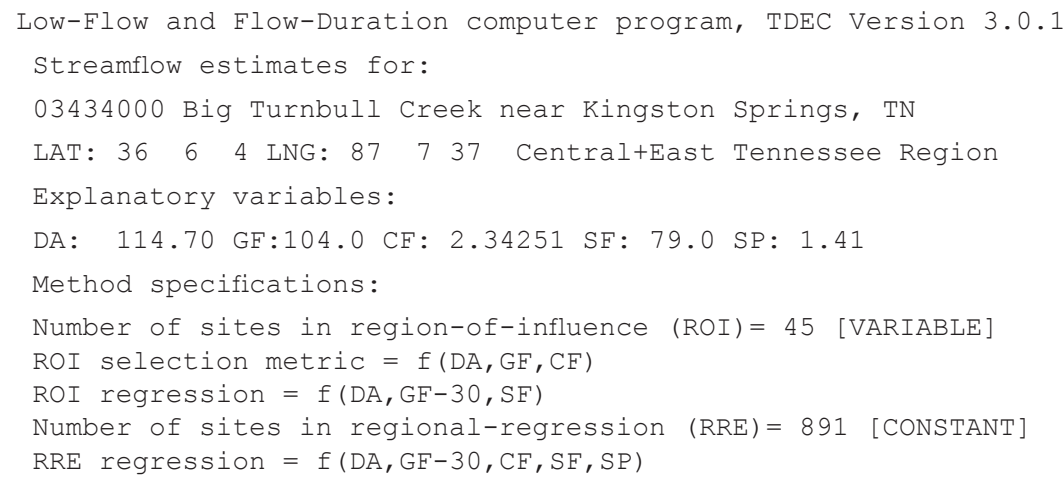

Region-of-influence stations and data:

\begin{tabular}{|c|c|c|c|c|c|c|c|c|}
\hline MNO & STANO & LAT & LNG & DA & GF & $\mathrm{CF}$ & $\mathrm{SF}$ & LOCATION \\
\hline & & & & & & & & \\
\hline 0565 & 3434000 & 36.101 & 87.127 & 114.7 & 104 & 2.343 & 79 & 1.41 B TURNBLL CR KSTN SPR TN \\
\hline 079 & 3431800 & 36.320 & 87.051 & 97.7 & 97 & 2.333 & 80 & SYCAMOR CR ASHLND CTY TN \\
\hline 895 & 3567400 & 34.989 & 5.196 & 153.4 & 112 & 2.352 & 40 & $1.55 \mathrm{~W}$ CHICKAMAUG CR E RDG TN \\
\hline 93 & 3436700 & 36.349 & 37.539 & 123.7 & 120 & 2.336 & 83 & 1.97 YELLOW CR SHILOH TN \\
\hline 92 & 3436690 & 36.311 & 87.554 & 103.0 & 120 & 2.338 & 82 & 2.04 YELLOW CR ELLIS MILLS TN \\
\hline 248 & 3565250 & 5.282 & 4.609 & 113.6 & 112 & 2.312 & 32 & 0.90 CHESTUEE CR DENTVILLE TN \\
\hline 375 & 553 & 5.279 & 4.843 & 100.2 & 93 & & 26 & 0.81 CANDIES CR EUREKA TN \\
\hline 64 & 3433 & 36.032 & 87.213 & 66.2 & 111 & 2.3 & 80 & 1.23 B TURNBLL CR NEW HOPE TN \\
\hline 374 & 3566 & 35.217 & 84.883 & 87.8 & 91 & 2.3 & 26 & 0.81 CANDIES CR CLEVELAND TN \\
\hline 73 & 35 & 35.173 & 4.906 & 65.1 & 93 & & 30 & 0.87 CANDIES CR US CLEVLND TN \\
\hline 38 & 355 & 35.243 & 605 & 101.3 & 90 & & 43 & 2.83 CONASAUGA CR DELANO TN \\
\hline 88 & 360 & 35.953 & 87.465 & 77.6 & 126 & 2. & 71 & 1.56 PINEY R 1 PINEWOOD TN \\
\hline 92 & 65 & 35.910 & 37.468 & 150.7 & 130 & 2. & 72 & 1.91 PINEY R 2 PINEWOOD TN \\
\hline 234 & 0 & 35.139 & 3.9 & 103.5 & 111 & & 48 & 2.71 VALLEY R TOMOTLA NC \\
\hline 01 & 0 & 35.471 & 86.122 & 112.2 & 130 & & 26 & 0.98 DUCK R MANCHESTER TN \\
\hline 437 & 3420 & 35.658 & 85.803 & 133.3 & 80 & 2. & 68 & 1.38 HICKORY CR MCMINNV TN \\
\hline 47 & 00 & 35.122 & 6.306 & 83.6 & 110 & & 70 & 1.58 BEANS CR LEXIE CRSRDS TN \\
\hline 96 & 0 & 35.362 & 4.279 & 117. & 115 & & 51 & 5.37 TELLICO R TELICO PLNS TN \\
\hline 73 & 00 & 35.795 & 87.311 & 99 & 124 & 2. & 80 & 2.18 LICK CR 2 LITTLELOT TN \\
\hline 96 & 26 & 36.610 & 7.470 & 127.4 & 80 & 2 . & 46 & 1.00 L WEK RED R 1 FT CAMP TN \\
\hline 97 & 343 & 36.608 & 7.449 & 36. & 80 & & 47 & 1.01 L WEK RED R 2 FT CAMP TN \\
\hline & 0 & 35. & 6.257 & 8 & 113 & & 3 & 1.38 DUCK R NORMANDY TN \\
\hline 054 & 342 & 35.667 & 85.882 & 25.6 & 138 & 2 . & 37 & 0.98 BARREN FK TROUSDALE TN \\
\hline 077 & 360 & 35.756 & 87.416 & 152.2 & 117 & 2 . & 78 & 2.29 BIG SWAN CR CENTERV TN \\
\hline & 36 & & 87.7 & & 132 & & 7 & 2.75 HURRICANE CR HCANE ML TN \\
\hline 871 & 356 & 35.333 & 84.766 & 73 & 120 & 2 . & 68 & $1.35 \mathrm{~N}$ MOUSE CR CALHOUN TN \\
\hline 60 & 343 & 36.009 & 87.029 & 59. & 124 & 2 . & 80 & $2.00 \mathrm{~S}$ HARPETH R LINTON TN \\
\hline & 36 & & 7.7 & & 120 & & 84 & 2.66 WHITEOAK CR CONCORD TN \\
\hline & & 35. & 4 & 72 & 81 & & 2 & 1.38 CHATTANOOGA CR 2 CHAT TN \\
\hline 94 & 343 & 36.599 & 87.351 & 79.5 & 80 & 2.327 & 70 & 1.12 SPRING CR ST. BETHLHM TN \\
\hline 45 & 355 & 35.284 & 4.546 & 79.9 & 85 & & 39 & 3.25 CONASAUGA CR ETOWAH TN \\
\hline & & & & 178 & 80 & & 4 & 1.00 L WFK RED R NEW PRVD TN \\
\hline 95 & 00 & 36.622 & 87.513 & 72.3 & 80 & 2 . & 63 & 1.10 NOAHS SPR BR FT CAMP TN \\
\hline 600 & 3436 & 36.208 & 87.529 & 52.5 & 120 & 2.340 & 75 & 2.14 YELLOW CR RUSKIN TN \\
\hline 570 & 343 & 36.155 & 87.281 & 56. & 86 & & 9 & 1.24 JONES CR CHARLOTTE TN \\
\hline 32 & 40 & 35.709 & 87.775 & 83. & 121 & & 81 & 2.26 CANE CR BEARDSTOWN TN \\
\hline 1140 & 3605 & 36.171 & 87.866 & 50.6 & 120 & 2.347 & 88 & 2.63 B RICHLAND CR HLLS CR TN \\
\hline 434 & 3420 & 35.678 & 85.952 & 65.3 & 138 & & 33 & $0.95 \mathrm{~S}$ PR BARREN FK TRSDLE TN \\
\hline 01 & 356 & 34.994 & 85.303 & 64. & 79 & & 19 & 1.46 CHATTANOOGA CR 1 CHAT TN \\
\hline 93 & 3436 & 36.609 & 87.368 & 179.6 & 77 & 2.327 & 76 & 1.19 WF RED R NEW PRVDNCE TN \\
\hline 086 & 3602 & 35.992 & 87.439 & 46.7 & 120 & & 68 & 1.63 PINEY R DICKSON TN \\
\hline 912 & 3570602 & 35.597 & 85.191 & 101.8 & 73 & 2.328 & 58 & 1.92 SEQUATCHIE R 2 PIKEV TN \\
\hline 0911 & 357 & 35.605 & 85.186 & 99.7 & 73 & 2.328 & 57 & 1.92 SEQUATCHIE R 1 PIKEV TN \\
\hline 0913 & 3570650 & 35.503 & 85.256 & 150.8 & 73 & 2.334 & 59 & 1.94 SEQUATCHIE R COLL STA TN \\
\hline 438 & 3420900 & 35.673 & 85.759 & 302.6 & 112 & 2.337 & 57 & 1.19 BARREN FK MCMINNV TN \\
\hline
\end{tabular}


Table C2. Low-flow frequency and flow-duration estimates for a Central+East region site (see Selected Abbreviations and tables 1 and 2 for explanation of terms; see fig. C2 for location of region-of-influence stations).-Continued

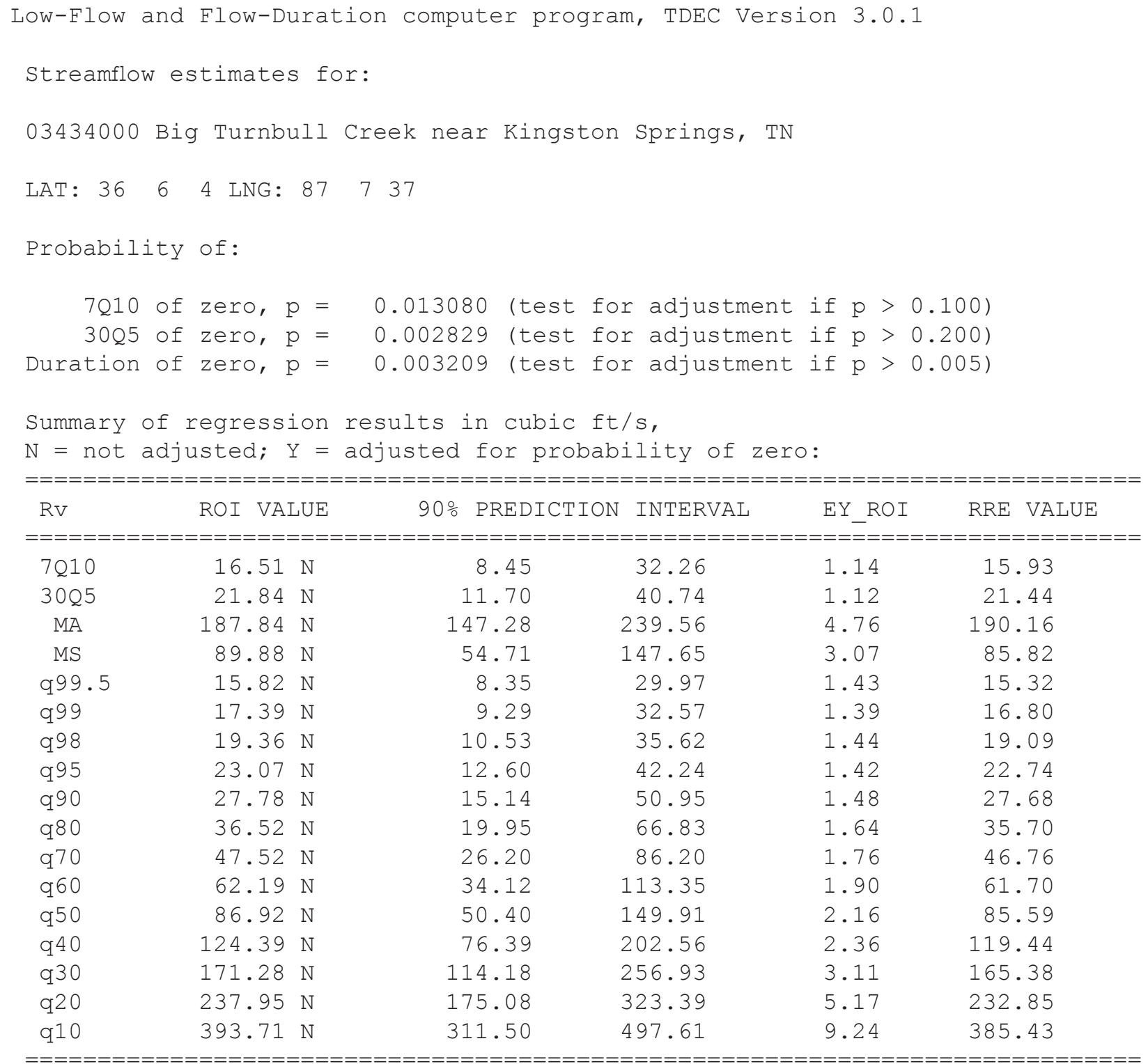


210 Streamflow-Characteristic Estimation Methods for Unregulated Streams of Tennessee

Table C2. Low-flow frequency and flow-duration estimates for a Central+East region site (see Selected Abbreviations and tables 1 and 2 for explanation of terms; see fig. C2 for location of region-of-influence stations).-—Continued

\begin{tabular}{|c|c|c|c|c|c|}
\hline Rv & PARAMETER & COEFFICIENT & $\mathrm{SE}$ & $\mathrm{T}: \mathrm{BETA}=0$ & P-VALUE \\
\hline \multirow[t]{4}{*}{ 7Q10 } & CONSTANT & -4.2491 & 0.5354 & -7.9364 & 0.0001 \\
\hline & $\log (\mathrm{DA})$ & 1.1487 & 0.1462 & 7.8563 & 0.0001 \\
\hline & $\log (G F-30)$ & 1.6496 & 0.2095 & 7.8736 & 0.0001 \\
\hline & $\log (S F)$ & 0.0093 & 0.1427 & 0.0648 & 0.9486 \\
\hline \multirow[t]{4}{*}{$30 Q 5$} & CONSTANT & -3.8307 & 0.4986 & -7.6835 & 0.0001 \\
\hline & $\log (D A)$ & 1.1547 & 0.1362 & 8.4810 & 0.0001 \\
\hline & $\log (G F-30)$ & 1.4834 & 0.1951 & 7.6034 & 0.0001 \\
\hline & $\log (\mathrm{SF})$ & 0.0099 & 0.1329 & 0.0746 & 0.9409 \\
\hline \multirow[t]{4}{*}{ MA } & CONSTANT & -0.0386 & 0.1944 & -0.1985 & 0.8436 \\
\hline & $\log (\mathrm{DA})$ & 1.0689 & 0.0531 & 20.1333 & 0.0001 \\
\hline & $\log (G F-30)$ & 0.1162 & 0.0761 & 1.5271 & 0.1344 \\
\hline & $\log (S F)$ & -0.0560 & 0.0518 & -1.0816 & 0.2858 \\
\hline \multirow[t]{4}{*}{ MS } & CONSTANT & -1.4649 & 0.3968 & -3.6918 & 0.0006 \\
\hline & $\log (D A)$ & 1.2503 & 0.1084 & 11.5381 & 0.0001 \\
\hline & $\log (G F-30)$ & 0.3148 & 0.1553 & 2.0274 & 0.0492 \\
\hline & $\log (\mathrm{SF})$ & 0.1344 & 0.1058 & 1.2710 & 0.2109 \\
\hline \multirow[t]{4}{*}{ q99. 5} & CONSTANT & -4.1317 & 0.5107 & -8.0902 & 0.0001 \\
\hline & $\log (D A)$ & 1.1061 & 0.1395 & 7.9308 & 0.0001 \\
\hline & $\log (G F-30)$ & 1.6127 & 0.1999 & 8.0697 & 0.0001 \\
\hline & $\log (S F)$ & 0.0201 & 0.1361 & 0.1478 & 0.8832 \\
\hline \multirow[t]{4}{*}{ q99 } & CONSTANT & -4.0554 & 0.5013 & -8.0895 & 0.0001 \\
\hline & $\log (\mathrm{DA})$ & 1.1275 & 0.1369 & 8.2361 & 0.0001 \\
\hline & $\log (G F-30)$ & 1.5706 & 0.1962 & 8.0062 & 0.0001 \\
\hline & $\log (S F)$ & 0.0199 & 0.1336 & 0.1487 & 0.8825 \\
\hline \multirow[t]{4}{*}{ q98 } & CONSTANT & -3.9169 & 0.4871 & -8.0406 & 0.0001 \\
\hline & $\log (\mathrm{DA})$ & 1.1366 & 0.1330 & 8.5439 & 0.0001 \\
\hline & $\log (G F-30)$ & 1.5290 & 0.1906 & 8.0207 & 0.0001 \\
\hline & $\log (S F)$ & 0.0026 & 0.1298 & 0.0199 & 0.9842 \\
\hline \multirow[t]{4}{*}{ q95 } & CONSTANT & -3.6199 & 0.4834 & -7.4881 & 0.0001 \\
\hline & $\log (\mathrm{DA})$ & 1.1550 & 0.1320 & 8.7488 & 0.0001 \\
\hline & $\log (G F-30)$ & 1.3963 & 0.1892 & 7.3810 & 0.0001 \\
\hline & $\log (S F)$ & -0.0031 & 0.1288 & -0.0238 & 0.9811 \\
\hline \multirow[t]{4}{*}{ q90 } & CONSTANT & -3.3639 & 0.4848 & -6.9383 & 0.0001 \\
\hline & $\log (\mathrm{DA})$ & 1.1760 & 0.1324 & 8.8816 & 0.0001 \\
\hline & $\log (G F-30)$ & 1.2595 & 0.1897 & 6.6385 & 0.0001 \\
\hline & $\log (S F)$ & 0.0165 & 0.1292 & 0.1279 & 0.8989 \\
\hline \multirow[t]{4}{*}{ q80 } & CONSTANT & -2.8806 & 0.4831 & -5.9630 & 0.0001 \\
\hline & $\log (D A)$ & 1.2009 & 0.1319 & 9.1031 & 0.0001 \\
\hline & $\log (G F-30)$ & 1.0041 & 0.1890 & 5.3115 & 0.0001 \\
\hline & $\log (S F)$ & 0.0489 & 0.1287 & 0.3801 & 0.7059 \\
\hline \multirow[t]{4}{*}{ q70 } & CONSTANT & -2.4551 & 0.4760 & -5.1578 & 0.0001 \\
\hline & $\log (D A)$ & 1.2204 & 0.1300 & 9.3879 & 0.0001 \\
\hline & $\log (G F-30)$ & 0.7819 & 0.1863 & 4.1973 & 0.0001 \\
\hline & $\log (S F)$ & 0.0828 & 0.1269 & 0.6527 & 0.5176 \\
\hline \multirow[t]{4}{*}{$q 60$} & CONSTANT & -2.0887 & 0.4798 & -4.3534 & 0.0001 \\
\hline & $\log (\mathrm{DA})$ & 1.2534 & 0.1310 & 9.5659 & 0.0001 \\
\hline & $\log (G F-30)$ & 0.6270 & 0.1878 & 3.3394 & 0.0018 \\
\hline & $\log (S F)$ & 0.0680 & 0.1279 & 0.5320 & 0.5976 \\
\hline q50 & CONSTANT & -1.5312 & 0.4356 & -3.5149 & 0.0011 \\
\hline & $\log (D A)$ & 1.2393 & 0.1190 & 10.4171 & 0.0001 \\
\hline & $\log (G F-30)$ & 0.3775 & 0.1705 & 2.2142 & 0.0324 \\
\hline & $\log (S F)$ & 0.1119 & 0.1161 & 0.9639 & 0.3407 \\
\hline$q 40$ & CONSTANT & -0.9492 & 0.3897 & -2.4357 & 0.0193 \\
\hline & $\log (D A)$ & 1.2145 & 0.1064 & 11.4116 & 0.0001 \\
\hline & $\log (G F-30)$ & 0.1832 & 0.1525 & 1.2016 & 0.2364 \\
\hline & $\log (S F)$ & 0.1055 & 0.1039 & 1.0156 & 0.3158 \\
\hline q30 & CONSTANT & -0.1593 & 0.3241 & -0.4914 & 0.6257 \\
\hline & $\log (D A)$ & 1.1166 & 0.0885 & 12.6159 & 0.0001 \\
\hline & $\log (G F-30)$ & 0.0317 & 0.1268 & 0.2503 & 0.8036 \\
\hline & $\log (\mathrm{SF})$ & 0.0178 & 0.0864 & 0.2066 & 0.8373 \\
\hline q20 & CONSTANT & 0.4128 & 0.2452 & 1.6833 & 0.0999 \\
\hline & $\log (D A)$ & 1.0691 & 0.0670 & 15.9643 & 0.0001 \\
\hline & $\log (G F-30)$ & -0.0708 & 0.0960 & -0.7382 & 0.4646 \\
\hline & $\log (S F)$ & -0.0557 & 0.0654 & -0.8528 & 0.3987 \\
\hline q10 & CONSTANT & 0.7498 & 0.1872 & 4.0056 & 0.0003 \\
\hline & $\log (\mathrm{DA})$ & 1.0540 & 0.0511 & 20.6175 & 0.0001 \\
\hline & $\log (G F-30)$ & -0.1040 & 0.0733 & -1.4196 & 0.1633 \\
\hline & $\log (S F)$ & -0.0691 & 0.0499 & -1.3841 & 0.1738 \\
\hline
\end{tabular}

END PROGRAM 


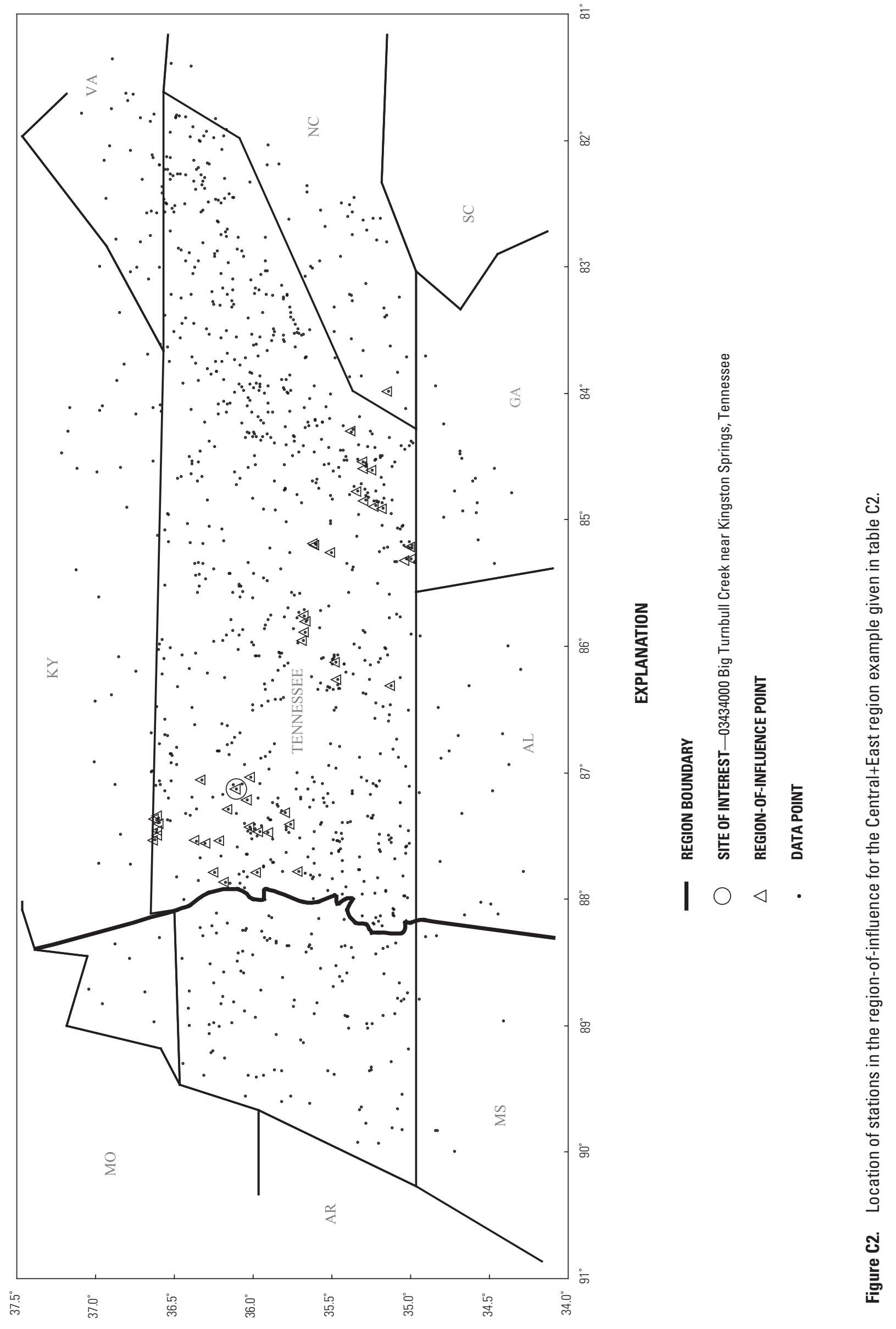


Prepared by: USGS Publishing Network

Raleigh Publishing Service Center

3916 Sunset Ridge Road

Raleigh, NC 27607

For additional information regarding this publication, contact:

George S. Law, Hydrologist

USGS Tennessee Water Science Center

640 Grassmere Park, Suite 100

Nashville, TN 37211

email: gslaw@usgs.gov

Or visit the USGS Tennessee Water Science Center Web site at: http://tn.water.usgs.gov/ 

